UNIVERSIDADE DE SÃO PAULO

ESCOLA DE COMUNICAÇÕES E ARTES

LUCI FERRAZ DE MELLO

Educomunicação e as Práticas Pedagógico-Comunicacionais da Avaliação Formativa no Ensino Básico

São Paulo

2016 


\title{
Educomunicação e as Práticas Pedagógico-Comunicacionais da Avaliação Formativa no Ensino Básico
}

\begin{abstract}
Tese apresentada ao Programa de PósGraduação em Ciências da Comunicação da Escola de Comunicações e Artes da Universidade de São Paulo, como requisito parcial para a obtenção do título de Doutora em Ciências da Comunicação, na área de concentração Interfaces Sociais da Comunicação.
\end{abstract}

Orientador: Prof. Dr. Ismar de Oliveira Soares

São Paulo

2016 
Autorizo a reprodução e divulgação total ou parcial deste trabalho, por qualquer meio convencional ou eletrônico, para fins de estudo e pesquisa desde que citada a fonte.

Catalogação na publicação

Serviço de Biblioteca e Documentação

Escola de Comunicações e Artes da Universidade de São Paulo

Mello, Luci Ferraz de

Educomunicação e Práticas Pedagógico-Comunicacionais da Avaliação

Formativa no Ensino Básico: Vol. I e II / Luci Ferraz de Mello. -- São Paulo:

L.F.Mello, 2016.

$2 \mathrm{v}$ : il.

Tese (Doutorado) - Programa de Pós-Graduação em Ciências da Comunicação Escola de Comunicações e Artes / Universidade de São Paulo

Orientador: Prof. Dr. Ismar de Oliveira Soares

Bibliografia

1. Educomunicação. 2. Práticas pedagógico-comunicacionais.

3. Avaliação Formativa 4. Ensino básico 5. Ecossistema Educomunicativo I. Soares, Ismar de Oliveira II. Título.

CDD 21.ed. - 302.2 
Nome: Luci Ferraz de Mello

Título: Educomunicação e Práticas Pedagógico-Comunicacionais da Avaliação Formativa no Ensino Básico

Tese apresentada ao Programa de PósGraduação em Ciências da Comunicação, da Escola de Comunicações e Artes da Universidade de São Paulo, como requisito parcial para a obtenção do título de Doutora em Ciências da Comunicação, na área de Interfaces Sociais da Comunicação.

Banca Examinadora:

Presidente: Prof. Dr. Ismar de Oliveira Soares

Julgamento: Assinatura:

1. Prof. Dr. Adilson Odair Citelli Instituição: ECA/USP

Julgamento:

Assinatura:

2. Prof. Dr. Claudia Lago

Instituição: ECA/USP

Julgamento: Assinatura:

3. Prof. Dr. Adriana B. Azevedo Instituição: Universidade Metodista de São Paulo Julgamento: Assinatura:

4. Prof. Dr. Patricia Horta Alves Instituição: Universidade Federal de Pernambuco Julgamento: Assinatura:

Resultado: São Paulo, 29 de março de 2016. 


\section{Dedicatória}

Dedico esta tese aos meus amores:

À minha mãe, Iulisca Vargas de Mello (in memoriam), cujo sonho não realizado foi ser professora de ensino fundamental.

Ao meu pai, Oswaldo Ferraz de Mello (in memoriam), cujo maior sonho foi ter um filho "doutor".

Ao Elói Marcos de Barros, meu namorado, amigo, companheiro, que me apoiou e motivou durante a realização desta.

Aos meus queridos Bhagdro, Sophie e Xamã, que nos momentos intensos me ajudaram na manutenção do foco para a concretização desta. 


\section{Agradecimentos}

Agradeço ao Prof. Dr. Ismar de Oliveira Soares, meu orientador, por todo conhecimento compartilhado, todas as reflexões propostas, todas as discordâncias desafiadoras, e principalmente pela paciência em meus momentos de angústia e voz forte nos momentos de desânimo. Com certeza, fez toda a diferença! Foi uma honra tê-lo como meu orientador e inspirador, para este doutorado, e o será para toda a vida!

Agradeço ao Prof. Dr. Adilson Odair Citelli e à Prof. Dra . Adriana Barroso de Azevedo, pelo empenho em me orientarem durante a qualificação sobre diversos ajustes, e pelas reflexões promovidas, que foram essenciais para o resultado desta tese. Às Prof. Dr ${ }^{\mathrm{a}} \mathrm{s}$. Claudia Lago, Patricia Horta Alves e Rita Maria Lino Tarcia, pelas reflexões metodológicas e epistemológicas.

Agradeço aos professores do CCA, da Escola de Comunicações e Artes, que sempre me inspiraram e me desafiaram: Maria Cristina Castilho Costa, Maria Cristina Mungioli, Maria Immacolata Vassallo Lopes, Roseli Fígaro, Solange Martins Couceiro.

À Secretaria Municipal de Educação de São Paulo, nas pessoas da Prof. Fátima Aparecida Antônio, Diretora da Coordenadoria Pedagógica (CODEP), e da Prof. Joane Vilela Pinto, exSecretária Municipal de Educação Substituta de São Paulo, gestão do prefeito Fernando Haddad, que autorizou a realização desta pesquisa de campo sobre projetos desenvolvidos nos Laboratórios de Informática Educativa de unidades escolares da Rede Municipal de Educação de São Paulo. Aos membros da Informática Educativa, da Secretaria Municipal de Educação de São Paulo, que me ajudaram com todo compartilhamento de ideias, práticas, documentos de registro dos alunos e deles próprios, o que propiciou a realização desta tese, nas pessoas de (coloco em ordem alfabética, para não incorrer em injustiças, pois todos foram de fundamental importância para a realização deste estudo): Professora Cristina Barroco Massei Fernandes; Professor Douglas Tomé; Professora Mestre Gislaine Batista Munhoz; Professora Jane Reolo da Silva; Professor José Rosemberg; Professora Margarete Gimenes Stalberg; Professora Nádia Melzer. À atual equipe coordenadora do Núcleo de Informática Educativa: Professora Regina Célia Fortuna Broti Gavassa, Professora Isabela Machado, Professor Silvio Luiz Caetano, Conceição Fernandes. Absolutamente nada disso seria possível sem todo compartilhamento de saber que me propiciaram ou mesmo de toda ajuda com aspectos 
administrativos!! Espero ter conseguido mostrar o maravilhoso trabalho de todos vocês, por uma educação melhor no Brasil!

Aos pesquisadores do Núcleo de Comunicação e Educação (NCE), Escola de Comunicações e Artes (ECA), Universidade de São Paulo (USP), que em vários momentos me auxiliaram com aspectos teóricos e procedimentais, além do apoio e incentivo necessários à realização da tese: Mestre Antonia Alves Pereira, Doutor Claudemir Edson Vianna, Doutor Claudio Messias, Doutor Marciel Consani, Doutor Richard Romancini.

À equipe da ECA/USP: Aparecida Florizete Machado dos Santos, Daniel de Oliveira Pires, Dario Aparecido Custódio, Elaine Pereira, João Carlos de Souza Megale, Maria de Lourdes Ferreira da Silva, Maristela Amaral Martins, Mirian Zarate Villalba, Regina Luiza da Rocha Garcia, Rosely Vieira de Souza, Tiago Muniz Garcia.

À Mestre Maria Salete Prado Soares, pelo trabalho de revisão do texto, por todos os alertas, considerações e reflexões feitas.

Aos meus familiares e amigos: Alan Bruce, Alexandra Correia Fochi, Ana Carolina Altieri Soares, Arlete dos Santos Petry, Claudio do Nascimento, Claudia Benjamin, Cristiana Mattos Assumpção, Dacio Augusto de Barros Filho, Edson Costa, Eliane Schlemmer, Erika Fernandes, Fábio Morais, Fátima Cecília Passos de Barros, Francisco Tupy, João Paulo Veríssimo, Juliana Veríssimo, Kelly Sinhorini, Leda Matayoshi, Lucia Helena Paz, Marcia Duarte Carvalho, Maria Helena Farinha Veríssimo, Maria Laura Passos de Barros, Paula Carolei, Patricia Paz, Raimundo Nonato Almeida, Renata Jesus Barbosa Rodrigues, Sandra Alonso Caixeta, Tatiana Paz, Walmir Aparecido Baptista.

Ao Prof. Dr. Cesar A. A. Nunes, por ter me apresentado as premissas da avaliação formativa de Dylan Wiliam e a proposta adotada nos laboratórios de informática educativa das unidades educacionais da SME-SP.

Aos alunos da Especialização em Educomunicação e da Licenciatura em Educomunicação, que em muitos momentos me colocaram questões sobre a avaliação as quais resultaram em ricas reflexões a partir de outros olhares.

Finalmente, agradeço ao Elói Marcos de Barros, meu namorado e amigo, por toda paciência, apoio, incentivo e compreensão durante minhas ausências para pesquisar e escrever, pela ajuda na revisão desta tese, bem como por todo amor a mim dedicado em meus momentos de incerteza, reflexões e angústias, que me permitiram desenvolver e finalizar este estudo. 


\section{Epígrafe}

"Educar o adolescente em instância de liberdade é abri-lo para si mesmo, conduzindo-o à autodescoberta e provocando a autodeterminação.

Mas, para que sua liberdade seja fonte de felicidade, será preciso que sua educação o conduza a abrir-se para os outros. " 


\title{
RESUMO
}

\begin{abstract}
MELLO, Luci Ferraz. Educomunicação e as Práticas Pedagógico-Comunicacionais da Avaliação Formativa no Ensino Básico. São Paulo, 2016. Tese (Doutorado) - Escola de Comunicações e Artes, Universidade de São Paulo.
\end{abstract}

A presente tese, formulada no âmbito da linha de pesquisa Comunicação e Educação, do Programa de Pós-Graduação em Ciências da Comunicação, da Escola de Comunicações e Artes, Universidade de São Paulo, teve como objetivo verificar se a abordagem de avaliação formativa adotada nas práticas dos laboratórios de informática educativa (LIE), ligados ao Núcleo de Informática Educativa (NIE), da Diretoria de Orientações Técnicas (DOT), Secretaria Municipal de Educação de São Paulo (SME-SP), se estrutura a partir de aspectos educomunicativos, principalmente por meio da adoção de práticas pedagógicocomunicacionais que caracterizam o campo emergente da Educomunicação. Para tanto, a pesquisa tomou como objeto de estudo o mapeamento dos possíveis pontos em comum entre os elementos definidores do paradigma da Educomunicação e a abordagem de avaliação para a aprendizagem (avaliação formativa) implementada, a partir de 2011, pela Secretaria Municipal de Educação (SME-SP) nos LIE de suas unidades educacionais. Inicialmente, foram definidos indicadores educomunicativos referentes às ações aqui nomeadas como práticas pedagógico-comunicacionais e às ditas competências educomunicativas, tendo como base a perspectiva defendida pelo Núcleo de Comunicação e Educação (NCE), Universidade de São Paulo (USP). Na sequência, foram destacadas as características conceituais da abordagem de avaliação dialógica e formativa adotada nos projetos desenvolvidos nos espaços dos LIE, sob coordenação do NIE, da DOT/SME-SP. Buscou-se, ao final, identificar os possíveis pontos comuns entre esses dois universos. A pesquisa de campo concentrou-se no estudo de oito casos vivenciados nos LIE, sendo que os dados coletados foram estudados principalmente com base na análise de conteúdo. Foram considerados: (a) a estrutura dos projetos; (b) os processos comunicacionais de elaboração e validação das rubricas enquanto instrumentos de avaliação formativa; (c) as trocas reflexivas entre os participantes dos projetos durante as fases de cada projeto, levando-se em conta o depoimento dos Professores Orientadores de Informática Educativa (POIE), bem como as conclusões das avaliações finais (autoavaliações e avaliações entre pares). Os resultados obtidos confirmaram a hipótese norteadora da tese ao sinalizarem para a existência de pontos de aproximação entre a proposta de avaliação formativa adotada nos LIE da Rede Municipal de Ensino de São Paulo (Rede-SP) e o paradigma da Educomunicação, com ênfase para o aspecto que se refere à necessária estruturação fortemente dialógica da referida proposta de avaliação para sua ocorrência. Isso nos fez concluir sobre a existência de práticas Educomunicativas nos laboratórios de informática educativa em diferentes estágios, contexto esse que chamamos de Educomunicação Possível. As informações coletadas nos sinalizaram ainda para a forte dependência de processos comunicacionais pela abordagem de avaliação formativa adotada. Ou seja, dependendo da intensidade e características das práticas de natureza dialógica e da oferta de espaços para o exercício do protagonismo por parte das crianças e jovens alunos envolvidos no processo, observamos diferentes fases de implementação das ações estratégicas de avaliação formativa.

PALAVRAS-CHAVE: Educomunicação; práticas pedagógico-comunicacionais; diálogo; protagonismo; avaliação formativa; informática educativa; ecossistema educomunicativo. 


\title{
ABSTRACT
}

\author{
MELLO, Luci Ferraz. Educommunication and Pedagogical-Communicational Practices \\ of Formative Assessment in Basic Education. São Paulo, 2016. Thesis (Doctorate Degree) \\ - Escola de Comunicações e Artes, Universidade de São Paulo.
}

This thesis was developed in the framework of Communication and Education research line, at PPGCOM-ECA / USP. It aimed to verify if the formative assessment approach adopted by the Educational Computer Labs projects, from public basic schools, Municipal Secretariat of Education of São Paulo (SME-SP) presents aspects of Educommunication Paradigm, mainly with the adoption of pedagogical-communicational practices. Therefore the field research study object was the mapping of possible commonalities among the defining elements of the Educommunication paradigm and stratetig actions of formative assessment approach (evaluation to learning) adopted for Educational Computer Labs projects at public basic schools of São Paulo city since 2011. Initially, the indicators of action and educomunicative skills were defined, based on the approach advocated by NCE / USP here named as pedagogical-communicational practices. Then characteristics of dialogical and formative assessment approach adopted in the projects developed in the Educational Computer Labs practices, coordinated by the Educational Computing Center (Municipal Secretariat of Education of São Paulo) were highlighted. The analysis focused on the study of eight educatinal projects developed at different Educational Computer Labs from public basic schools in Sao Paulo. Topics analysed: (a) the structure of the projects; (b) the communicatin processes for development and validation of rubrics as formative assessment tools and (c) the reflective exchanges between project participants, taking into account the testimonials of the Guiding Teachers on Education mediated by Techonologies (POIE), and the conclusions of final evaluations (self-assessments and peer reviews). The results confirmed the main hypothesis of the thesis by pointing the existence of common aspects between the formative assessment approach adopted by educational computer labs from public basic schools of the Municipal School of São Paulo and the paradigm of Educommunication, with emphasis on the adoption of a strongly dialogic structure by the formative assessment approach for its occurrence. This made us conclude on the existence of educommunicative practices in educational computer labs at different stages - what is called the possible Educommunication by NCE - ECA/USP. The information collected pointed to a strong dependence of communication processes - dialogue occurrence - for formative assessment approach adopted. That is, the successful implementation of this formative assessment approach came to depend on the intensity and characteristics of the dialogic nature of practices as well as the communicational spaces offered to the students involved in the process to really make the dialogic practices happen and make the social transformation for the empowerment.

Keywords: Educommunication; pedagogical-communicational practices; dialogue; leadership; formative assessment; technologies for learning; educommunicative ecosystem. 


\section{LISTA DE FIGURAS}

Figura 01 Evolução dos Tipos de Participação 57

Figura 02 A Escada de Participação do Jovem 58

Figura $\quad$ A Escada de Participação do Jovem (Legendas dos Degraus) 59

$02 \mathrm{~A}$

Figura 03 A Espiral de Roger Hart 60

Figura 04 Árvore das Teorias de Avaliação 98

$\begin{array}{ll}\text { Figura } 05 \text { Definição de Competências } & 130\end{array}$

Figura 06 Organograma da Secretaria Municipal de Educação de São Paulo 140

Figura 07 Mapa das Subprefeituras da Cidade de São Paulo 153

Figura 08 Programa POIE 2012 (Tela do ThinkQuest) 155

Figura 09 Projeto B.1: Vídeo Final (disponibilizado no Prezi) 163

Figura 10 Projeto B.2 - Tela de Abertura Produto Final, no Prezi 164

Figura 11 Projeto B.2 - Alunos desenvolvendo projeto no LIE 165

Figura 12 Projeto B.2 - Tela com Slide do Trabalho, no Padlet 166

Figura 13 Projeto B.2 - Tela de Planejamento no Popplet 167

Figura 14 Projeto B.3 - Tela com critério de rubrica, para autoavaliação, no 169 ThinkQuest

Figura 15 Projeto B.4 - Tela de Abertura do site repositório dos Jogos do 171 Riva

Figura 16 Programa POIE 2012 - Trocas reflexivas entre POIE no encontro 198 Presencial

Figura 17 Programa POIE 2012 - Trocas reflexivas entre POIE no encontro 199 presencial

Figura 18 Programa POIE 2012 - autoavaliações nos encontros presenciais $\quad 200$

Figura 19 Programa POIE 2012 - autoavaliações nos encontros presenciais 200 


\section{LISTA DE QUADROS}

$\begin{array}{lll}\text { Quadro } 01 \text { Debate / Discussão X Diálogo } & 73\end{array}$

Quadro 02 Funções de Avaliação, segundo o seu papel na sequência da ação de formação

Quadro 03 Abordagens Teóricas de Ensino e Aprendizagem 104

Quadro 04 Tipos de Estratégias de Avaliação Formativa 114

Quadro 05 Exemplo de Rubrica de Colaboração com uso de Ferramentas 121 Virtuais

Quadro 06 Exemplo de Problemas de Falta de Gestão da Comunicação para o Diálogo

Quadro 07 Competências do Século XXI, por Vários Autores

Quadro 08 Competências do Século XXI, do ATCS

Quadro 09 Indicadores Educomunicativos

Quadro 10 Projetos Grupo A - Programa POIE $2012 \quad 158$

$\begin{array}{lll}\text { Quadro } 11 & \text { Projetos Grupo B } & 161\end{array}$

Quadro 12 Temas e Subtemas para Análise de Conteúdo 173

$\begin{array}{lll}\text { Quadro } 13 \text { Descritivo resumido dos projetos estudados } & 179\end{array}$

Quadro 14 Elaboração das Rubricas: quando e como 181

Quadro 15 Projetos A.2; B.1; B.2: Análise de Conteúdo / Rosemberg - 183 rubrica

Quadro 16 Projeto A.4: Análise de Conteúdo / Nádia - autoavaliação dos 184 alunos

Quadro 17 Projeto A.1: Análise de Conteúdo / Margarete - indicadores e níveis de rubricas

Quadro 18 Projeto B.3: Análise de Conteúdo / Maria Helena - níveis de rubrica

Quadro 19 Análise de Conteúdo - critérios das rubricas Programa POIE 2012

Quadro 20 Programa POIE 2012 - Análise das Avaliações dos POIE e Gestores 
Quadro 21 Projeto B.4 - Análise de Conteúdo / Critérios

Quadro 22 Análise de Conteúdo / Rosemberg - relações em sala de aula

Quadro 23 Análise de Conteúdo / Rosemberg - relações em sala de aula 


\section{LISTA DE TABELAS}

Tabela 01 Projeto A.3 (POIE Douglas) - Questionários dos Alunos 186

Tabela 02 Projeto A.3 (POIE Douglas) - Questionários dos Alunos 186

Tabela 03 Projeto B.1 (POIE Rosemberg) - Questionários dos Alunos 187

Tabela 04 Projeto B.1 (POIE Rosemberg) - Questionários dos Alunos 187 


\section{LISTA DE SIGLAS}

$\begin{array}{ll}\text { AVA } & \text { Ambiente Virtual de Aprendizagem } \\ \text { DOT } & \text { Diretoria de Orientações Técnicas } \\ \text { ECA } & \text { Escola de Comunicações e Artes } \\ \text { EUA } & \text { Estados Unidos da América } \\ \text { INTERCOM } & \begin{array}{l}\text { Sociedade Brasileira de Estudos Interdisciplinares da } \\ \text { Comunicação }\end{array} \\ \text { LIE } & \text { Laboratórios de Informática Educativa } \\ \text { NCE } & \text { Núcleo de Comunicação e Educação } \\ \text { NIE } & \text { Núcleo de Informática Educativa } \\ \text { NOR } & \text { Núcleo Nas Ondas do Rádio } \\ \text { POIE } & \text { Professor(es) Orientador(es) de Informática Educativa } \\ \text { PPGCOM } & \text { Programa de Pós-Graduação em Ciências da Comunicação } \\ \text { Rede-SP } & \text { Rede Municipal de Ensino de São Paulo } \\ \text { SME-SP } & \text { Secretaria Municipal de Educação de São Paulo } \\ \text { TIC } & \text { Tecnologia(s) da Informação e Comunicação } \\ \text { USP } & \text { Universidade de São Paulo }\end{array}$




\section{SUMÁRIO}

\section{Volume I}

\section{INTRODUÇÃO}

A. Angústias, reflexões e diálogos da pesquisadora com a

Educomunicação: definindo o problema da pesquisa

B. Objetivos

C. Hipóteses Norteadoras

D. Justificativa quanto à relevância e originalidade

E. Aspectos da Pesquisa

F. Estrutura do Trabalho

\section{EDUCOMUNICAÇÃO}

1.1 Emergência e Fortalecimento do Campo

1.2 Reflexões Teóricas sobre as Interfaces Comunicação-Educação

1.3 Aspectos Educomunicativos e Áreas de Intervenção

1.3.1 Protagonismo, Tipos de Participação e Empoderamento

1.3.3 Algumas Áreas de Intervenção: Leitura Crítica dos Meios, Gestão da Comunicação nos Espaços Educativos, Práticas PedagógicoComunicacionais

A.Leitura Crítica dos Meios e Gestão da Comunicação nos Espaços Educativos

B.Práticas Pedagógico-Comunicacionais

2. PRÁtICAS PEDAGÓGICO-COMUNICACIONAIS $\quad$ DA 94 AVALIAÇÃO PARA A APRENDIZAGEM 
$\begin{array}{ll}2.3 \text { Ações Estratégicas de Avaliação Formativa } & 113\end{array}$

2.3.1. A definiçãa compartilhada de rubricas para a orientação das ações $\quad 118$

$\begin{array}{ll}\text { 2.3.2 Reflexão Crítica a partir do Diálogo } & 121\end{array}$

$\begin{array}{ll}\text { 2.3.3 O feedback do professor } & 124\end{array}$

2.3.4 Alunos enquanto parceiros ou monitores de aprendizagem para seus $\quad 126$ pares

$\begin{array}{ll}\text { 2.3.5 Avaliação entre Pares / Autoavaliação } & 127\end{array}$

$\begin{array}{ll}2.4 \text { Competências Educomunicativas } & 129\end{array}$

2.5 Educomunicação e Práticas Pedagógico-Comunicacionais da 136 Avaliação Formativa: reflexões sobre aproximações teóricas possíveis

\section{OS PROJETOS DE INFORMÁTICA EDUCATIVA (DOT/SME-SP) 139}

3.1 Diretrizes dos Laboratórios de Informática Educativa, da SME-SP, e a 140 Avaliação Formativa

$\begin{array}{ll}\text { 3.2 Dois Tipos de Amostra para um universo diversificado } & 148\end{array}$

3.3 Estudos de Caso dos Laboratórios de Informática Educativa da SME- 151 SP

3.3.1 Grupo A - Programa POIE 2012 / DRE Campo Limpo 152

$\begin{array}{ll}\text { 3.3.2 Grupo B } & 161\end{array}$

4. PRÁTICAS PEDAGÓGICO - COMUNICACIONAIS 172 APROXIMANDO EDUCOMUNICAÇÃO E A AVALIAÇÃO FORMATIVA

4.1. Pressupostos Educomunicativos nos Documentos Oficiais da 174 SME_SP

4.2 Práticas Pedagógico-Comunicacionais nos Laboratórios de 178 Informática Educativa

4.2.1 Sobre as rubricas: quando e como elaborar, e com qual finalidade $\quad 180$

4.2.2 Autoavaliação, com base nos conteúdos das rubricas 192 
4.2.3 Novas relações, práticas reflexivas e o feedback: construindo ecossistemas educomunicativos nos Laboratórios de Informática Educativa

\section{SUMÁRIO}

\section{Volume II}

$\begin{array}{ll}\text { ANEXOS } & 222\end{array}$

Anexo A - Sugestão de Aula do Projeto EducomJT 225

Anexo B - Rubricas DRE Campo Limpo (Inclui rubrica POIE 2012) 226

Anexo C - Relatório Final das Autoavaliações dos POIE 237

Anexo D - Respostas dos Alunos, aos Questionários Aplicados 257

Anexo E - Descritivo Técnico dos Projetos Estudados 280

Anexo F- Rubricas do Projetos 298

Anexo G - Trechos de entrevistas dos POIE (ilustração) 311

Anexo H - Categorias dos Temas e Subtemas: aproximações conceituais 376 possíveis

Anexo I - Autorizações 


\section{INTRODUÇÃO}

\section{A. Angústias, reflexões e diálogos da pesquisadora com a Educomunicação: definindo o problema de pesquisa}

Iniciei meus estudos em Educomunicação em 2004, após finalizar o curso de especialização em Gestão de Organizações de Terceiro Setor. Nessa época uma das professoras do curso, a Dra. Leda Matayoshi, trouxe-me à Escola de Comunicações e Artes (ECA), Universidade de São Paulo (USP), para apresentar a linha de pesquisa Comunicação e Educação ligada ao Programa de Pós-Graduação em Ciências da Comunicação (PPGCOM - ECA/USP).

É, pois, desde 2004, que me dedico à pesquisa sobre o paradigma da Educomunicação e à práxis de projetos com abordagem educomunicativa. Em 2006, passei a integrar o Núcleo de Comunicação e Educação (NCE) ligado à ECA/USP, o que propiciou uma intensificação e maior aprofundamento nesse universo. E, em 2008, iniciei o mestrado na linha de pesquisa Comunicação e Educação, do PPGCOM da ECA/USP, finalizado em 2011.

No segundo semestre de 2007, participei da mesa redonda Gestão da Comunicação - Terceiro Setor, Organizações Não Governamentais, Responsabilidade Social e Novas Formas de Cidadania, da INTERCOM ${ }^{1} 2007$ - XXX Congresso Brasileiro de Ciências da Comunicação, ocorrida em Santos, sob a coordenação da Prof. Dra. Maria Cristina Castilho Costa,

\footnotetext{
${ }^{1}$ INTERCOM: Sociedade Brasileira de Estudos Interdisciplinares da Comunicação
} 
organizadora do livro com o mesmo título da referida mesa redonda, livro esse que contém artigo escrito pelo Prof. Dr. Ismar de Oliveira Soares, em parceria comigo, intitulado Voluntários, Terceiro Setor e Gestão da Comunicação. Em 2009, fiz minha primeira palestra no curso de Especialização em Gestão da Comunicação, sobre Voluntariado e Comunicação no Terceiro Setor, o que deu origem a um convite para ministrar a disciplina Sustentabilidade e Voluntariado. Em 2011, o curso Gestão da Comunicação foi encerrado e substituído pela Especialização em Educomunicação. Desde então, houve três ofertas deste último durante as quais atuei como professora convidada, responsável pela disciplina Práticas de Comunicação em Rede. Além disso ministrei várias palestras para as disciplinas de Procedimentos Educomunicativos em Educação a Distância I e Educomunicação nas Organizações da Sociedade Civil, do curso de Licenciatura em Educomunicação, também da Escola de Comunicações e Artes, Universidade de São Paulo.

Minha trajetória profissional com projetos dessa abordagem, bem como a convivência com os alunos dos cursos da Licenciatura em Educomunicação e de Especialização me levaram por vários momentos a questionar os caminhos mais adequados para avaliar os projetos educomunicativos. De fato, as perguntas começaram a se intensificar no momento em que olhei mais detidamente o conceito de Educomunicação do Prof. Dr. Ismar de Oliveira Soares:

o conjunto de ações inerentes ao planejamento, implementação e avaliação dos processos, programas e produtos destinados a criar e a fortalecer ecossistemas comunicativos em espaços educacionais presenciais ou virtuais, assim como melhorar o coeficiente comunicativo das ações educativas, incluindo as relacionadas ao uso dos recursos da informação no processo de aprendizagem (SOARES, 2003, p. 43)

Ou seja, o próprio conceito prevê a avaliação dos processos, programas e produtos, mas à medida que mergulhava no universo desse novo paradigma da Educomunicação, eu refletia mais e mais sobre uma abordagem de avaliação que fosse coerente e que respeitasse as premissas essenciais desse paradigma.

A pergunta que me perseguia era, pois: como avaliar processos de gestão da comunicação coerentes com o paradigma da Educomunicação, quando aplicados a práticas educativas? Como verificar possíveis resultados de práticas que aqui denomino de "pedagógicocomunicacionais $^{2} "$, planejadas e desenvolvidas a partir dessa abordagem? Como acompanhar a construção e/ou fortalecimento de competências pessoais - como socioemocionais e comportamentais, dentre outras - em processos educativos que façam uso de tecnologias da

\footnotetext{
${ }^{2}$ Este conceito será explicitado posteriormente, no capítulo sobre Educomunicação.
} 
comunicação, que tenham sido desenvolvidas em práticas educativas de base educomunicativa? Como ter meios para traduzir mais claramente o que muitos educomunicadores querem dizer com as frases, como: "meus alunos estão mais felizes nas aulas"; "meus alunos estão mais motivados para aprender"; "meus alunos estão compreendendo os efeitos da adoção de tecnologias da comunicação em sua rotina diária”? Ou, ainda, "meus alunos estão entendendo e se empoderando de seu papel enquanto cidadãos responsáveis e reflexivos"?

Essas questões se tornaram mais relevantes quando percebi que, mesmo com a ampliação das pesquisas sobre a Educomunicação, pouco se avançou em relação à questão da avaliação desses processos e/ou produtos, como mencionados no conceito de Soares (1999).

Desde que o Núcleo de Comunicação e Educação da ECA/USP identificou a emergência desse campo (SOARES, 1999), cerca de cem pesquisas sobre a Educomunicação foram realizadas até o ano de 2012. Segundo a Dra. Rose Mara Pinheiro, o desenvolvimento de cada um desses estudos se deu por vários caminhos e cenários, sempre considerando uma ou mais das principais áreas de intervenção social ligadas a esse novo paradigma, quais sejam: gestão da comunicação para a educação, educação para os meios de comunicação (media education), mediações tecnológicas nos espaços educativos, práticas pedagógicas de abordagem educomunicativa ou pedagogia da comunicação, expressão comunicativa (artes) e reflexão epistemológica. (PINHEIRO, 2013)

Essas áreas de intervenção foram pesquisadas a partir de contextos como: políticas públicas, mediação do professor, gestão participativa, desenvolvimento de competências e habilidades comunicacionais, planejamento de práticas educomunicativas por projetos e interdiscursividade do novo campo, dentre outros.

A diversidade dos trabalhos desenvolvidos pelos pesquisadores que passaram pelo PPGCOM - ECA/USP e por outros 18 programas de pós-graduação em Comunicação ou em Educação, cujos trabalhos formaram o corpus da pesquisa de Pinheiro (2013), aponta para o fato de que, até o momento de apresentação oficial da proposta deste trabalho, nenhum deles tomou como foco de suas análises a natureza e as especificidades dos processos avaliativos na interface Comunicação-Educação, o que faz com que a proposta desta pesquisa seja inédita. 
Isso me animou a prosseguir por esse tema, mas apresentou outros desafios, posto que, como dito anteriormente, em função das características básicas das práticas educomunicativas, esse acompanhamento da gestão da comunicação para a educação ou mesmo o processo de desenvolvimento do que chamo de competências educomunicativas ${ }^{3}$, como a comunicação dialógica ou a leitura crítica dos meios de comunicação, deveria se realizar ao longo do processo de implantação de práticas pedagógico-comunicacionais ${ }^{4}$, e não apenas no início ou final de um período qualquer de estudo em ambientes educativos, tornando difícil exatamente a perspectiva da avaliação desse processo.

O primeiro desafio identificado foi quanto ao acompanhamento do processo comunicacional durante tais dinâmicas nos espaços educativos. Ou seja, tratava-se da verificação de uma abordagem que permitisse o acompanhamento e intervenção para eventuais ajustes já ao longo do processo comunicacional desenvolvido para a implementação das práticas pedagógicas nos espaços educativos.

Além disso, era necessário mapear a ocorrência e evolução de características específicas - ou de indicadores - ligadas à Educomunicação a partir das trocas comunicacionais realizadas entre todos os participantes (educador e educando) durante esse processo, de maneira a identificar como e quais delas contribuem significativamente para o resultado da prática nos ambientes educativos. Ou seja, quais delas seriam essenciais para o desenvolvimento e fortalecimento das competências educomunicativas, que sejam minimamente construídas e trabalhadas ao longo do processo comunicacional nesses espaços.

Outro aspecto que norteou minhas verificações preliminares foi uma das ações essenciais das práticas educomunicativas que deve ser adotada ao final de cada processo: a chamada roda de conversa $^{5}$. Por aproximadamente dezoito meses, de 2006 a 2008, participei do projeto Educom.Jt ${ }^{6}$. Ele foi desenvolvido pelo NCE - ECA/USP e o antigo Jornal da Tarde do grupo

\footnotetext{
${ }^{3}$ A serem definidas no Capítulo Dois, sobre Avaliação Formativa.

${ }^{4}$ A serem definidas no Capítulo Um, sobre Educomunicação.

${ }^{5}$ Roda de conversa: a roda de conversa é uma proposta de trabalho comumente adotada em atividades coletivas, com base nas ideias da Educação Popular, de Paulo Freire, a qual busca viabilizar o desenvolvimento de trocas dialógicas entre os participantes de uma determinada atividade, com o objetivo de criar oportunidades de produção e ressignificação conjunta de saberes - sentidos - sobre vivências desses membros. Maiores informações sobre esta abordagem podem ser verificadas na obra de Paulo Freire (Ex.: Educação como Prática da Liberdade; Educação e Mudança).

${ }^{6}$ O Projeto Educom.Jt, fruto de parceria entre o NCE - ECA/USP, e o Jornal da Tarde, do Grupo O Estado de S. Paulo, vigorou durante cerca de dezoito meses, de 2006 a 2008, sendo que as sugestões de aula eram desenvolvidas pelos membros da secretaria executiva do projeto, como: Luci Ferraz de Mello, Maria Salete de Prado Soares, Maria Isabel Leão e Carmen Gattás, dentre outros membros. Todas as aulas foram supervisionadas
} 
O Estado de S. Paulo, o qual consistia na publicação semanal de sugestões de aulas com abordagem educomunicativa sobre conteúdos diversos ligados ao ensino fundamental. A minha atuação como um dos membros da secretaria executiva do projeto consistiu em reescrever e ajustar as sugestões de aula, de um modelo tradicional para uma proposta de aula com base nas premissas educomunicativas.

Essas aulas eram originariamente desenvolvidas por especialistas em suas áreas de conhecimento, para que os membros da secretaria do Educom.Jt pudessem transformá-las em aulas com práticas de abordagem educomunicativa, sempre com foco no estabelecimento e fortalecimento de ecossistemas educomunicativos ${ }^{7}$ a partir do protagonismo e trocas dialógicas entre os participantes.

Era meu primeiro projeto no grupo e o que mais me chamou a atenção foi a orientação do Prof. Ismar de Oliveira Soares: ao final de toda prática proposta, devemos fazer uma roda de conversa com os participantes, visando o desenvolvimento de uma avaliação do projeto. Para essa etapa, a sugestão de aula deveria conter uma orientação para que no encerramento da atividade houvesse uma reflexão conjunta, mediada pelo professor, como indico no tópico de número 5 das etapas de desenvolvimento da atividade, sobre Avaliação, da sugestão de aula $\mathrm{O}$ Debate Político na Escola, publicado na coluna Pais \& Mestres, do Jornal da Tarde, de 24/09/2006 (vide Anexo A):

Em círculo, cada grupo deve apresentar suas sugestões. Depois promova uma avaliação das sugestões, tendo como critério a coerência do plano com as necessidades da região. Faça, então, uma votação secreta para escolher a proposta que mais atende às necessidades da comunidade. A proposta vencedora poderá ser encaminhada pelo diretor da entidade à autoridade política mais próxima à região considerada. (REHDER, 2006, p. 14A).

Apesar de não haver uma orientação clara para a realização de uma autoavaliação, a partir de indicadores previamente definidos para o desenvolvimento da atividade, já havia a preocupação para que os alunos fizessem uma reflexão conjunta sobre todos os projetos ao final desse processo, para que houvesse a conscientização de alguns caminhos trilhados e de eventuais conhecimentos adquiridos. Isso ficou gravado em minha mente: para mim, essa

pelo Prof. Dr. Ismar de Oliveira Soares, para, então, serem enviadas à redação do Jornal da Tarde, sendo que a finalização de cada sugestão de aula, para publicação, era feita pela então jornalista responsável Maria Célia Giudicissi Rehder, sob supervisão da editora chefe da coluna, a jornalista Ângela Crespo. O projeto teve mais de setenta e cinco aulas publicadas, sendo que os arquivos das mesmas se encontram disponíveis no site do NCE ECA/USP: www.usp.br/nce.

${ }^{7} \mathrm{O}$ termo ecossistema educomunicativo será definido no Capítulo Um, sobre Educomunicação. 
atividade poderia - e até deveria - ser desenvolvida a partir de parâmetros de avaliação mais claros que tivessem sido previamente definidos.

Ainda sobre a definição dos indicadores, refiro-me àqueles considerados por muitos pesquisadores, gestores de escola e professores, dentre outros atores ligados a esse contexto, como de conceituação até "subjetiva", o que tende a dificultar ainda mais a realização da avaliação em processos educomunicativos.

O grande desafio, contudo, foi a possibilidade de identificar uma proposta de avaliação que, a princípio, apresentasse já no seu planejamento e implementação, aspectos voltados à formação de um cidadão autônomo, empoderado e consciente de seus direitos e deveres.

Ou seja, dada toda base dialógica e altamente colaborativa da Educomunicação, perguntavame se seria possível identificar uma proposta de avaliação que fosse estruturada em um processo de participação conjunta de educadores e educandos, com ações dialógicas e colaborativas até mesmo quando da definição das ações e dos critérios avaliativos.

O problema de pesquisa envolveu, desse modo, também reflexões sobre o que seriam os aspectos básicos que deveriam estar contidos no próprio planejamento, desenvolvimento e acompanhamento desse processo de avaliação. Dessa forma, iniciei meus questionamentos e pesquisa buscando uma proposta teórica que contivesse os seguintes aspectos, os quais considero essenciais a uma proposta de avaliação para projetos desenvolvidos a partir do paradigma da Educomunicação:

a) Foco na formação da criança ou jovem adolescente enquanto cidadão responsável ${ }^{8}, \mathrm{crí}^{\prime}$ ico e empoderado de seus direitos e deveres junto à sociedade;

b) Adoção de uma pedagogia de projetos $^{9}$ desenvolvida principalmente com práticas protagonistas de todos seus participantes, centrada no desenvolvimento e fortalecimento de competências educomunicativas, incluindo a comunicação dialógica e a aprendizagem para a reflexão crítica sobre a realidade vivenciada.

\footnotetext{
${ }^{8}$ Termo utilizado por Célestin Freinet, o qual será explicado no Capítulo Um, sobre Educomunicação.

${ }^{9}$ Abordagem pedagógica adotada em vários dos projetos trabalhados pelos membros do grupo do NCE ECA/USP, sob supervisão do Prof. Dr. Ismar de Oliveira Soares, cuja origem trataremos no Capítulo 1, a partir das ideias do especialista em educação John Dewey (DEWEY, 1976a; 1976b), que defendia que a experiência educativa em sala de aula deve promover a reflexão sobre ocorrências da vida real, a partir da realização de projetos temáticos ligados a problemas da escola e do entorno da mesma.
} 
c) Acompanhamento da evolução das competências comunicacionais no contexto de ecossistemas comunicacionais, caracterizados por trocas intensas entre todos os participantes dos projetos educativos;

d) Viabilização de oferta de intervenções e orientações durante todo o processo comunicacional de um projeto educativo e não apenas no início ou final do mesmo.

e) Possibilidade de realização de rodas de conversas, ao final do processo, para desenvolvimento de reflexões analíticas e reflexivas pelos alunos, de forma individual e/ou grupal.

Iniciei a definição do corpus da presente pesquisa buscando no campo da Educação uma ou mais propostas de avaliação que atendessem os aspectos do contexto aqui apresentados. A partir desse olhar e de estudos sobre as propostas de avaliação, conheci a abordagem da avaliação para aprendizagem, a qual parecia atender a alguns dos aspectos "educomunicativos" aqui listados.

A proposta inicial dessa abordagem foi apresentada por Michel Scriven, em meados dos anos de 1960, sob o nome de avaliação formativa. Minha pesquisa bibliográfica mostrou que à época esse especialista listou as ideias gerais do que imaginava que seria essa avaliação. $\mathrm{O}$ desafio maior continuava sendo viabilizar a implementação da mesma ao longo do processo educacional. Isso porque apesar de propor uma avaliação durante o processo de maneira a auxiliar na construção da aprendizagem, de forma mais imediata e direta, esse especialista reconhecia que a implantação de práticas com esse objetivo ainda era difícil de ser realizada. Entretanto, desde então, vários estudos em diversas localidades do mundo, como Reino Unido e EUA, foram desenvolvidos nesse sentido.

Paralelamente à realização de experimentações de práticas de avaliação formativa, nos últimos anos, um novo fato veio auxiliar no planejamento e estruturação dessa proposta: surgimento, desenvolvimento e consequente adoção de inúmeras tecnologias de informação e comunicação (TIC) no processo educativo, nas salas de aula, em atividades curriculares e extracurriculares. Esse novo contexto permeado de aparatos digitais acabou por auxiliar na emergência e no fortalecimento da Educomunicação, por conta das interfaces pedagógico-comunicacionais que começaram a ser observadas mais claramente. Essas atividades mediadas por uma ou mais TIC têm viabilizado a realização de avaliações durante esse processo, posto que durante as 
mesmas ocorrem inúmeros registros das práticas dos alunos - da maioria, se não de todas exatamente por meio desses recursos.

Dessa forma, meu olhar foi direcionado para práticas educacionais com uso de TIC e, paralelamente à pesquisa teórica, comecei a buscar, principalmente na região da Grande São Paulo, onde resido, propostas educacionais desenvolvidas a partir de uma pedagogia de projetos, com orientações para ações de diálogo e protagonismo, e que tivessem um modelo de avaliação a partir dessa abordagem. Foi quando tomei conhecimento das práticas de avaliação formativa dos projetos desenvolvidos nas aulas dos Laboratórios de Informática Educativa (LIE) das escolas públicas da Rede Municipal de Ensino de São Paulo (Rede-SP), coordenados pelo Núcleo de Informática Educativa (NIE), da Diretoria de Orientação Técnica (DOT), Secretaria Municipal de Educação de São Paulo (SME-SP), desde o ano de 2011.

A confirmação da existência de projetos da referida área com tal abordagem motivou-me a definir como objeto deste estudo as dinâmicas comunicacionais realizadas durante o desenvolvimento das práticas pedagógicas de alguns projetos temáticos desenvolvidos nos LIE, da DOT/SME-SP, práticas pedagógicas essas que por sua vez foram estruturadas com base na abordagem de avaliação formativa de Wiliam (2011).

\section{B. Objetivos}

A definição do referido objeto de pesquisa deu origem a dois objetivos principais: (a) verificar se a abordagem de avaliação formativa adotada pelos LIE, da DOT/SME-SP, apresenta premissas de avaliação demandadas pela Educomunicação (apontadas no tópico A desta Introdução); (b) verificar a presença de aspectos educomunicativos norteadores das práticas dos LIE, da DOT/SME-SP, a partir das ações estratégicas da abordagem de avaliação formativa adotada.

A decisão de estudar se a referida abordagem de avaliação se estrutura a partir de características educomunicativas - protagonismo e diálogo -, deve-se ao fato que nas pesquisas teóricas preliminares identifiquei uma forte dependência da avaliação formativa, da instalação de espaços de trocas dialógicas para o atingimento dos resultados esperados. Além disso, a avaliação formativa se integra ao processo pedagógico das práticas adotadas e se a 
abordagem adotada pelos LIE se estrutura com base em características desse paradigma, há a possibilidade dessas práticas pedagógico-comunicacionais serem norteadoras das dinâmicas desses projetos. Daí eu ter decidido definir esses dois objetivos.

As práticas educomunicativas têm como principal foco a criação e fortalecimento de ecossistemas comunicativos de trocas reflexivas intensas em espaços educativos, considerando o uso de TIC nesse processo. Logo, para verificar esses dois objetivos, procurei mapear os procedimentos e intervenções comunicacionais desenvolvidos durante as ações estratégicas da abordagem de avaliação formativa dos projetos que compuseram o corpus da pesquisa, realizados no âmbito dos LIE, da SME-SP, verificando: a) como e se foram estabelecidos ecossistemas educomunicativos pautados por trocas dialógicas enquanto práticas estruturantes do processo de avaliação formativa; b) se essas ações estruturantes caracterizaram o que chamo neste estudo de práticas pedagógico-comunicacionais; c) se essa abordagem de avaliação formativa apresentou recursos que permitiram acompanhar e auxiliar no desenvolvimento das principais competências educomunicativas ligadas a práticas protagonistas - comunicação/diálogo, trabalho colaborativo em equipe e pensamento crítico pelos alunos participantes desse processo.

\section{Hipóteses Norteadoras ${ }^{10}$}

O desenvolvimento desta pesquisa foi norteado pelo fato de que eu acreditava que as dinâmicas da proposta de avaliação formativa com mediação tecnológica adotadas nos projetos dos LIE, da SME-SP, apresentavam forte relação de sinergia filosófica e metodológica com processos de natureza educomunicativa.

Como resultado dessas ideias norteadoras, imaginei que as ações estratégicas da referida abordagem se estruturariam a partir de premissas educomunicativas - como fortalecimento de ecossistema educomunicativo, trocas dialógicas, pensamento crítico e gestão da comunicação

${ }^{10}$ Guillermo Orosco Gómez (1997) reflete que não devemos fazer uso do conceito de hipóteses quando estamos trabalhando pesquisas qualitativas ligadas aos paradigmas hermenêutico e interacionista. Porém, dada a complexidade do tema em estudo, eu optei por definir algumas hipóteses norteadoras para estabelecer os parâmetros que me permitiram mais clareza na identificação das variáveis que deveriam ser adotadas e na análise dos dados apurados. Foi a partir desta perspectiva que eu utilizei aqui o termo hipótese. 
para educação - e que as práticas estruturantes dessa proposta de avaliação formativa seriam desenvolvidas necessariamente com base em processos comunicacionais com tais características entre todos os participantes do mesmo e mediante o protagonismo conjunto desses, as quais denomino de práticas pedagógico-comunicacionais.

Em função dessas perspectivas, pressupunha ainda que tal proposta de avaliação formativa com mediação de tecnologias comunicacionais apresentava muitos aspectos que poderiam ser adotados na estruturação, implementação e acompanhamento de projetos de abordagem educomunicativa, em sua concepção - planejamento e estruturação.

Dado que a avaliação formativa se integra à própria abordagem pedagógica das práticas, imaginei que, caso se confirmasse a primeira hipótese, dela ser estruturada nas práticas pedagógico-comunicacionais, isso indicaria que algumas das premissas educomunicativas já norteiam as práticas dos LIE, da DOT/SME-SP.

\section{Justificativa quanto à relevância e originalidade}

A justificativa quanto à relevância e originalidade deste estudo, bem como da minha escolha por desenvolver a pesquisa de campo nos projetos dos LIE passa necessariamente por uma explicação concisa sobre o histórico das atividades do mesmo e sobre alguns outros programas desenvolvidos pela própria SME-SP.

As primeiras ações por parte da referida Secretaria Municipal de Educação, no sentido de divulgar e disseminar as práticas de informática nas escolas de sua Rede Municipal de Ensino (Rede-SP), iniciaram em 1987, com a implementação de três projetos, sendo um voltado ao desenvolvimento de diversos trabalhos nas escolas, por meio da adoção da linguagem LOGO e processador de texto. Os outros dois possuíam ênfase profissionalizante.

Em 1989, ocorreu a mudança de gestão na prefeitura de São Paulo, com a posse da então eleita prefeita Luiza Erundina de Sousa, e do Prof. Paulo Freire, este último no cargo de Secretário Municipal de Educação de São Paulo. Uma das primeiras ações deste foi a revisão dos três projetos recém iniciados, os quais foram então descontinuados, principalmente em função do forte foco para a formação de trabalhadores para o mercado já no ensino fundamental. 
O então secretário defendeu a necessidade da revisão e reestruturação do projeto políticoeducacional dessa Rede, sendo que o Projeto Gênese de Informática Educativa, que tratava da temática de informática, foi pensado a partir de uma nova visão:

O indivíduo e a sociedade devem ser vistos na sua totalidade e nas suas possibilidades de "vir a ser", o que contraria, sobremaneira, o conceito fragmentado e pragmático de aquisição de habilidades profissionais estanques. Neste sentido, uma sociedade informatizada está passando a exigir homens com potencial de assimilar a "novidade" e a criar o novo, o homem aberto para o mundo, no sentido que lhe confere a teoria piagetiana quando se refere às assimilações mentais majorantes; da mesma forma, exige a presença do cidadão crítico e comunitário, onde os artefatos tecnológicos, especificamente o computador, possam ser ferramentas auxiliares para a construção de uma sociedade mais igualitária e justa. (SÃO PAULO, 1992, pg. 7) ${ }^{11}$

O referido projeto foi aprovado pelo Prof. Paulo Freire, em dezembro de 1989, e a instalação das quatro fases do projeto, que incluía os laboratórios de informática do Núcleo Central, dos subnúcleos e das escolas, foi desenvolvida dessa data até o final de 1991. Vale destacar que em 1991, o Prof. Paulo Freire foi substituído pelo Prof. Mario Sergio Cortella no cargo de Secretário Municipal de Educação, que deu prosseguimento à disseminação e fortalecimento do referido projeto. E foi a partir do ano de $1994^{12}$ que o termo informática educativa passou a ser adotado nas Portarias Municipais que regulamentam a referida prática.

Em 2001, com a aceleração da diversificação das tecnologias da comunicação, foi desenvolvido o Projeto A Cidade Que a Gente Quer, o qual vigorou até 2005, em 150 escolas. Ele objetivava o entendimento e empoderamento do uso das novas tecnologias digitais, linguagem de programação e o fomento à criatividade e autonomia na edificação do conhecimento, como seus principais objetivos. E foi o Projeto WebCurrículo, adotado de 2006 a 2012, que deu origem aos Laboratórios de Informática Educativa (LIE), nomenclatura esta adotada desde então.

Esse breve histórico sinaliza que muitas propostas e abordagens sobre o uso de tecnologias da comunicação nos espaços educativos dessa Rede foram sendo desenvolvidas, revisadas, atualizadas, ajustadas, renovadas e/ou substituídas.

Em 2010, houve uma reestruturação das práticas nesses espaços em função de uma nova avaliação que identificou a necessidade de atualização das orientações sobre o uso das TICs na educação e seu objetivo curricular junto às escolas da rede. Esse documento destacou

${ }^{11}$ Trecho retirado do material desenvolvido pela SME-SP, em 1992, sob o título Projeto Gênese - A Informática Chega ao Aluno da Escola Pública Municipal, disponível para acesso no link: http://issuu.com/iesme/docs/historico_2?e=5210261/2878575

${ }_{12}$ Decreto 34.160/1994, que instituiu o termo Informática Educativa em todas as unidades da Rede-SP. 
inúmeros aspectos que deveriam ser considerados nas dinâmicas dessas aulas, como as premissas das chamadas competências do século XXI, passíveis de serem trabalhadas também nessas práticas educacionais que fazem uso das TIC, bem como a indicação sobre como essas competências e respectivas práticas deveriam ser distribuídas nos anos de estudo do ensino fundamental, dentre outros (SÃO PAULO, 2010).

Foi também em 2010 que ocorreu uma aproximação das práticas dos LIE com os projetos do Núcleo Nas Ondas do Rádio (NOR) ${ }^{13}$. Ou seja, os formadores deste último passaram a oferecer cursos aos Professores Orientadores de Informática Educativa (POIE) e demais professores sobre o uso de várias mídias e suas respectivas linguagens (fotografia, áudio, vídeo, histórias em quadrinhos, fanzine, jornal impresso, jornal mural, games) na educação, para o desenvolvimento de tais competências.

Vale esclarecer que o NOR, com suas práticas e formações, foi planejado e desenvolvido com base em premissas educomunicativas desde sua origem. O Programa Nas Ondas do Rádio foi iniciado sob este nome em 2004, mas ele se originou do Projeto Educom.Radio ${ }^{14}$, desenvolvido de 2001 a 2004, por uma equipe multidisciplinar composta pelos membros do NCE/USP e por docentes e discentes da própria ECA/USP, dentre outros, sob coordenação geral do Prof. Dr. Ismar de Oliveira Soares. O objetivo principal do projeto do NCE/USP foi a redução da violência nas escolas da Rede, por meio do desenvolvimento de projetos voltados à formação de ecossistemas educomunicativos, estruturados a partir de ações protagonistas dos alunos e de trocas dialógicas intensas. E os POIE de várias unidades educacionais da Rede-SP são exatamente alguns dos responsáveis pela implementação e estruturação do Projeto Imprensa Jovem, ligado ao NOR, o qual reflete o Educom.Radio em seus primórdios: colocar os alunos enquanto protagonistas criadores e produtores de programas de rádio escolar.

Os cursos ministrados pelo NOR focam o planejamento e implementação das práticas educativas mediadas por uma ou mais tecnologias da comunicação, a partir de algumas das premissas educomunicativas destacadas pelo NCE - ECA/USP. A formação nessas práticas

\footnotetext{
${ }^{13}$ De 2004 a 2013, a terminologia adotada era Programa Nas Ondas do Rádio, mas isso foi modificado por portaria da SME-SP, de 2013, quando passou a ser denominado Núcleo Nas Ondas do Rádio. As práticas do NOR são regidas atualmente pela portaria 5792, de 2009.

${ }^{14}$ Alguns alunos do PPGCOM-ECA/USP, que desenvolveram suas pesquisas sob a linha de Comunicação e Educação, focaram seus estudos no entendimento dos processos educomunicativos desenvolvidos durante o Projeto Educom.Radio, sendo que essas pesquisas podem ser localizadas no site de teses da ECA/USP, com essa palavra-chave (Educom.Rádio). É o caso da tese de doutorado de Patricia Horta Alves, sob o título: Educom.Radio - uma política pública em Educomunicação. Disponível no link: http://www.teses.usp.br/teses/disponiveis/27/27154/tde-05072009-211722/pt-br.php Acesso em 10/06/2015.
} 
tem como objetivo a potencialização de ações protagonistas desses alunos, a partir do fortalecimento da competência de comunicação (SÃO PAULO, 2014c), dentre outras.

Desde então, as escolas da Rede-SP têm trabalhado com duas abordagens aparentemente diferentes, mas convergentes, de práticas educativas com uso de tecnologias comunicacionais: o NOR, com seu projeto Imprensa Jovem e as formações a partir de premissas da Educomunicação do NCE - ECA/USP, e os projetos dos LIE, cujas dinâmicas têm sido pensadas com base na pedagogia de projetos e ações estratégicas de avaliação formativa, as quais também são adotadas nos grupos de Imprensa Jovem desenvolvidos por POIE. Foi exatamente essa aparente convergência entre os dois programas que me motivou a conhecer e entender melhor as premissas dessa abordagem de avaliação dos laboratórios de LIE.

O descritivo desse contexto esclarece como as práticas de abordagem educomunicativa nos espaços escolares formais estão se disseminando dia a dia. Esse contexto descreve como os POIE passaram, de certa forma, a incorporar as premissas do paradigma da Educomunicação em suas práticas nos LIE, e quais foram as razões deles questionarem exatamente sobre como avaliar o processo de desenvolvimento dessas várias competências, até para justificar a sua adoção na própria SME-SP.

De fato, a falta de processos mínimos de acompanhamento dessas dinâmicas e avaliação dos processos desenvolvidos tem sido motivo de oposição à adoção dessas ações em dimensões educacionais mais amplas, inclusive em práticas que impliquem no trabalho integrado de disciplinas do currículo formal, ficando muitas dessas práticas desconectadas do cotidiano da sala de aula e restritas aos projetos fora do turno.

A própria reestruturação do currículo para essa Rede, que foi instituída pela SME-SP com a Portaria 5930/13, publicada em 14 de outubro de 2013, veio reforçar a necessidade da identificação e validação de uma abordagem de avaliação dos processos desenvolvidos durante os projetos dos LIE, especialmente aqueles do Terceiro Ciclo, sob a nomenclatura de Trabalho Colaborativo de Autoria (TCA), o qual deve focar "a construção do conhecimento, considerando o domínio das diferentes linguagens, a busca de resolução de problemas, a análise crítica e a estimulação dos educandos à autoria" (SÃO PAULO, 2013, Art. 5º, Inciso II, a.3). 
Além disso, como aponto no Capítulo Quatro deste estudo, a análise dessa portaria e das que normatizam as práticas do Núcleo de Informática Educativa me permitiu fazer algumas primeiras identificações de aspectos educomunicativos nessas orientações.

Ao optar por mapear as características educomunicativas da referida proposta de avaliação formativa, considerando os pontos de aproximação entre o paradigma educomunicativo e algumas das ações estratégicas de avaliação formativa adotadas nos projetos dos LIE nas escolas da Rede de São Paulo, espero ter contribuído para um melhor conhecimento das premissas do paradigma da Educomunicação nas práticas desenvolvidas nos LIE das referidas unidades escolares, bem como para um maior entendimento sobre como os processos comunicacionais estruturam tais ações estratégicas da avaliação formativa.

\section{E. Aspectos da Pesquisa}

Para desenvolver as reflexões sobre as possíveis aproximações entre o paradigma da Educomunicação e as ações estratégicas da proposta de avaliação formativa adotada pelo Núcleo de Informática Educativa (NIE), da DOT/SME-SP, realizei uma pesquisa de campo a partir dos dados coletados sobre oito estudos de casos, todos projetos educacionais mediados por tecnologias da informação e comunicação (TIC) desenvolvidos nos LIE da SME-SP.

Eu decidi analisar casos ocorridos na Rede-SP porque minhas pesquisas iniciais indicaram que os projetos desses espaços educacionais já faziam uso de algumas das ações estratégicas de avaliação formativa que eu pretendia estudar. Como detalho no capítulo três, eu estruturei esta pesquisa de campo com base na proposta de estudo de caso instrumental, de maneira a identificar os possíveis pontos de aproximação entre o paradigma da Educomunicação e abordagem de avaliação formativa, com um esclarecimento e/ou justificativa bem fundamentada dessa aproximação. Meu objetivo principal foi conhecer e entender detalhes sobre essa eventual aproximação, até para afirmar - ou negar - que as práticas pedagógicocomunicacionais estruturam as ações estratégicas da avaliação formativa e que consequentemente norteiam as práticas dos laboratórios de informática educativa (STAKE, 2009). 
Especificamente sobre os casos escolhidos, os mesmos foram definidos em conjunto com a então coordenadora do Núcleo de Informática Educativa, Prof. Jane Reolo da Silva. Isso porque nem todos os projetos desenvolvidos nos LIE das unidades educacionais dessa REDE chegaram a adotar essa abordagem de avaliação formativa de forma completa, com todas as ações estratégicas e etapas. Consequentemente, para que eu tivesse dados para serem investigados nesta pesquisa, optei por escolher projetos que eu já soubesse que tinham adotado a referida abordagem, lembrando que meu foco aqui nunca foi verificar, por exemplo, a eficácia da abordagem em termos de avaliação, mas principalmente conhecer os processos comunicacionais que estruturam a mesma para verificar exatamente a existência de pontos comuns entre a avaliação formativa e as práticas desenvolvidas a partir das premissas do paradigma da Educomunicação.

Logo, eu escolhi oito projetos e os dividi em grupos A e B. Os projetos do Grupo A foram desenvolvidos dentro de um programa maior - POIE 2012 - da Diretoria Regional de Educação (DRE) Campo Limpo, sob coordenação da gestora Cristina Barroco Massei Fernandes, durante o ano de 2012. A importância da verificação desses projetos deu-se em função de que ele estava diretamente ligado à formação sobre ações estratégicas de avaliação formativa da qual os Professores Orientadores de Informática Educativa (POIE) participaram no ano de 2012, o que me permitiu conhecer os processos comunicacionais adotados para a disseminação e formação desses docentes sobre a aplicação das ações estratégicas de avaliação formativa. Outro aspecto que reforçou a decisão para inclusão de projetos desse Programa foi o fato de que a Professora Cristina, então responsável pela formação desses POIE, tinha defendido sua monografia de especialização em Tecnologias na Aprendizagem, do SENAC, sobre tema ligado à Educomunicação.

Já os quatro projetos aqui classificados como Grupo B foram desenvolvidos sem qualquer ligação com o Programa POIE 2012, e isso me permitiu observar processos comunicacionais similares entre alguns deles. Um deles foi desenvolvido no mesmo ano que o programa mencionado, o que me possibilitou conhecer como ocorre alguns dos processos de disseminação de dados das formações do NIE para as escolas das diferentes DRE. Além disso, dois dos projetos deste Grupo B que foram desenvolvidos no ano de 2014, foram supervisionados por um mesmo POIE - José Rosemberg - responsável pela realização de um dos projetos analisados para o Programa POIE 2012. Com isso pude verificar como os fluxos comunicacionais na operacionalização dos projetos foram se desenvolvendo e resultando em 
um aprimoramento da aplicação das ações estratégicas de avaliação formativa por esse POIE. E o quarto projeto foi escolhido exatamente por fugir um pouco das orientações originais passadas pelo Núcleo de Informática Educativa, mas mantendo ainda assim a adoção de algumas das ações estratégicas da avaliação formativa.

Para coleta dos dados, eu optei por entrevistas com os POIE responsáveis por cada um dos projetos e por coletar dados dos projetos registrados durante a ocorrência dos mesmos em plataformas virtuais de aprendizagem, como ThinkQuest, Popplet e Prezi, entre outros. Aqui julgo importante esclarecer que os projetos foram todos presenciais, mas esses ambientes virtuais de aprendizagem foram adotados para registro das práticas feitas nessas atividades presenciais.

Para três dos projetos - um do Grupo A e dois do Grupo B - eu ainda entrevistei alguns dos alunos que participaram dos mesmos, o que novamente me permitiu confirmar como os POIE implementaram as ações estratégicas de avaliação formativa, principalmente quanto ao tipo de participações desses jovens e quanto aos aspectos comunicacionais estabelecidos durante esses processos educacionais. Finalmente eu entrevistei também a gestora da DRE Campo Limpo responsável pelo Programa POIE 2012 e pela formação dos POIE da referida DRE, a prof. Cristina, além da então coordenadora do NIE à época, a Prof. Jane Reolo da Silva.

O método principal que procurei seguir para verificar os dados coletados foi a Análise de Conteúdo, sendo que para isso, estabeleci como categoria alguns temas e estruturei um quadro com seus respectivos subtemas, para me nortear no mapeamento dos possíveis pontos de aproximação entre Educomunicação e a abordagem de avaliação formativa em estudo.

Então, à medida que tratava de cada ação estratégica da avaliação formativa, realizei as análises com base nos temas e subtemas definidos.

\section{F. Estrutura do Trabalho}

Para a estruturação deste trabalho, optei por esclarecer inicialmente os aspectos teóricos, que sustentam as ideias e os conceitos utilizados por mim, sobre Educomunicação e sobre Avaliação Formativa. Foi a partir destes que defini alguns indicadores, os quais adotei durante 
a realização da pesquisa empírica para estudar os projetos desenvolvidos nos LIE, da SMESP, principalmente nos anos de 2012 a 2014.

O Capítulo Um foi dedicado a apresentar os aspectos do paradigma da Educomunicação, como a sua emergência e fortalecimento, e as reflexões teóricas utilizadas para esclarecer as interfaces Comunicação-Educação. Na sequência, detalhei mais claramente algumas das premissas da Educomunicação e de suas áreas de intervenção. Dediquei-me ainda a especificar a qual protagonismo eu me referia e, para tanto, busquei esclarecer os tipos de participações passíveis de serem desenvolvidas nos projetos que considero como sendo educomunicativos, procurando sempre justificar com base nas conceituações sobre o tema. Apresentei também alguns esclarecimentos sobre o termo empoderamento e sua importância para a Educomunicação. E detalhei o entendimento por diálogo reflexivo aqui neste estudo, ao qual frequentemente me refiro, bem como procurei destacar os pontos de interface entre as práticas protagonistas e dialógicas.

Outro tema tratado nesse capítulo foi sobre as possíveis áreas de intervenção, com destaque para explicações sobre o que chamo neste trabalho de práticas pedagógico-comunicacionais. Finalizei com reflexões sobre quais seriam as características inerentes ao perfil do educomunicador.

Para o Capítulo Dois, sobre dialogicidade na avaliação formativa, discorri resumidamente sobre alguns dos principais questionamentos acerca da avaliação como um todo, para então apontar as abordagens de avaliação mais comumente utilizadas, como somativa e diagnóstica. Reforço que o objetivo aqui não foi me aprofundar na reflexão sobre a eficiência e aplicação de cada uma delas, mas principalmente para destacar as características dialógicas que me fizeram focar este estudo na proposta de avaliação para aprendizagem.

Apresentei, então as premissas das propostas de avaliação dialógica e da avaliação formativa, principalmente com base nas ideias de dois autores, a saber: José Eustáquio Romão e Dylan Wiliam. Pelo fato da SME-SP definir os indicadores utilizados em seus processos de avaliação formativa com base nas competências do século XXI, no penúltimo tópico desenvolvi algumas reflexões sobre a origem desse termo e ao entendimento dele no contexto da educação e da própria SME-SP. Encerrei esse capítulo com algumas reflexões sobre possíveis pontos de aproximação entre o paradigma da Educomunicação e as propostas de avaliação para aprendizagem apresentadas. 
O Capítulo Três foi dedicado a apresentar o tipo de pesquisa e as ferramentas adotadas para a coleta de dados, para depois detalhar os oitos projetos analisados na pesquisa empírica, bem como as razões deles terem sido escolhidos.

Destinei o Capítulo Quatro à apresentação dos indicadores utilizados e às análises realizadas, frente aos objetivos e hipóteses norteadoras que estipulei para o desenvolvimento desta pesquisa.

Encerrei com a apresentação das minhas considerações finais acerca das análises feitas. 


\title{
1. EDUCOMUNICAÇÃO
}

\begin{abstract}
Uma nação é democrática na medida que seus cidadãos estejam envolvidos, particularmente no âmbito comunitário. A confiança e competência para estar envolvido precisa ser gradualmente adquirida pela prática. É por essa razão que deveria haver gradualmente o aumento de oportunidades para as crianças participarem de qualquer processo aspirante de democracia e particularmente nas nações que já se convenceram que são democráticas. ${ }^{15}$ (HART, 1992, p. 04)
\end{abstract}

Este capítulo apresenta os principais aspectos teóricos da Educomunicação, com informações sobre sua emergência, áreas de intervenção, características básicas e competências educomunicativas.

\subsection{Emergência e Fortalecimento do Campo}

A identificação da Educomunicação enquanto um novo campo emergente se deu a partir da pesquisa temática realizada pelos membros do NCE/USP, durante os anos de 1997 e 1998, cujos resultados foram publicados em 1999. Esse estudo foi coordenado pelo Prof. Dr. Ismar de Oliveira Soares e contou com a participação de 176 especialistas, de 12 países da região

\footnotetext{
${ }^{15}$ Tradução livre da autora, do seguinte trecho, extraído do e-book Children's Participation: from Tokenism to Citizenship: "A nation is democratic to the extent that its citizens are involved, particularly at the community level. The confidence and competence to be involved must be gradually acquired through practice. It is for this reason that there should be gradually increasing opportunities for children to participate in any aspiring democracy, and particularly in those nations already convinced that they are democratic". (HART, 1992, p. 04)
} 
ibero-americana, vinculados a organizações de movimentos sociais, universidades e centro de pesquisas, envolvidos no esforço conjunto em favor do acesso e do uso solidário das tecnologias, por meio de projetos emancipatórios (SOARES, 2002).

Foi apenas após a análise dos resultados que o termo Educomunicação foi escolhido e ressignificado para nomeá-lo, de maneira que abrangesse e refletisse áreas de intervenção social passíveis de serem estudadas a partir das interfaces Comunicação-Educação.

Importante destacar que o objetivo desse novo campo em construção não é o de ocupar os campos atualmente conhecidos como Comunicação e Educação, mas de estudar as ocorrências de interface entre ambos e contribuir para o planejamento e implementação de novas práticas de ensino e aprendizagem que façam uso dos meios de comunicação disponíveis na sociedade a partir de determinadas premissas, entre as quais: o protagonismo dos sujeitos sociais, o diálogo e a gestão compartilhada dos processos de produção midiática.

O NCE/USP entende que a Educomunicação é um campo emergente, com paradigma próprio, e não apenas um conjunto de procedimentos e metodologias vinculados, por exemplo, à didática (do campo da Educação) ou às normas da produção midiática (do campo da Comunicação). A hipótese defendida pelo NCE/USP é a de que a prática denominada como educomunicativa ocorre, de forma transdisciplinar, na interface entre os tradicionais campos da Educação e da Comunicação, de lá extraindo seus referenciais. No caso, a Educomunicação pode dialogar com o campo da Comunicação, tanto quanto com o campo da Educação, como pressupomos esteja ocorrendo no caso do estudo em questão.

Sobre o tema do campo científico, Lopes se baseia em Pierre Bourdieu para esclarecer que:

o campo científico, enquanto sistema de relações objetivas entre posições adquiridas, é o lugar, o espaço do jogo de uma luta concorrencial pelo monopólio da autoridade científica definida de maneira inseparável, como capacidade técnica e poder político; ou, se quisermos, o monopólio da competência científica, compreendida enquanto capacidade de falar e de agir legitimamente, isto é, de maneira autorizada e com autoridade, que é socialmente outorgada a um agente determinado. Essa legitimidade é, portanto, reconhecida socialmente pelo conjunto dos outros cientistas (que são seus concorrentes), à medida que crescem os recursos científicos acumulados e correlativamente, a autonomia do campo. (LOPES, 2000, p. 48)

É justamente este o fenômeno que ocorre atualmente com o conceito e o campo da Educomunicação. Trata-se de um entendimento sobre os fenômenos que ocorrem na interface Comunicação-Educação, formulado a partir de uma competência científica, reconhecida socialmente por um conjunto de pesquisadores da área. 
Para iniciar as considerações sobre a Educomunicação e seu processo de consolidação enquanto campo, a partir do qual este estudo foi desenvolvido, apresento aqui alguns de seus aspectos básicos, vários deles já observados a partir de pesquisas científicas desenvolvidas nos últimos quinze anos, que começam a lhe conferir a tão buscada legitimidade destacada por Lopes (2000).

Educação se originou do termo "educare"16, o qual está conectado a "educere". Este consiste em um verbo de prefixo ex (fora) + ducere (conduzir, levar). Ou seja, a palavra educação consiste na ação de "conduzir para fora", ou de preparar para o mundo.

Quanto ao termo comunicação, David Bohm explica que deriva:

do latim commun, com o sufixo $e i$, que é semelhante a fie, que significa "fazer" ou "pôr em prática". Assim, um de seus significados é "fazer alguma coisa juntos", isto é, levar informações ou conhecimentos de uma pessoa para outra de maneira tão exata quanto possível” (BOHM, 2005, p. 29).

Já Bechara (2009, p. 216) o define como “... o processo de emitir, transmitir e receber mensagens com o objetivo de trocar conhecimentos...", sendo que tal palavra engloba ações de mensagem, informação, aviso, entendimento e diálogo, entre outros.

Com base em tais conceituações, poderia ser levada a pensar, por exemplo, em uma definição para o termo Educomunicação designando, com ele, uma "ação pedagógico-comunicacional conjunta de vários agentes para trabalhar o bem comum da sociedade". Porém, adotar tal definição representaria uma atitude muito simplista, posto que o entendimento do neologismo Educomunicação, ao menos por parte da pesquisa que ressemantizou o conceito, perpassa o que eventualmente indicaria seu mero significado etimológico para nomear algo mais amplo, como um novo campo de estudos, complexo e dinâmico, posto que consiste em um movimento político pedagógico-comunicacional com foco na transformação social. Por essas razões, adoto o significado postulado pela equipe do NCE/USP, segundo a qual a Educomunicação pode ser entendida como:

um conjunto das ações inerentes ao planejamento, implementação e avaliação de processos, programas e produtos destinados a criar e a fortalecer ecossistemas comunicativos, em espaços educacionais ou virtuais, assim como a melhorar o coeficiente comunicativo das ações educativas, incluindo as relacionadas ao uso de recursos da informação no processo de aprendizagem. Em outras palavras, a Educomunicação trabalha a partir do conceito de gestão comunicativa (SOARES, 2002, p. 24).

16 Significado localizado no Dicionário Etimológico On-line, cujo link é: http://www.dicionarioetimologico.com.br/educar/ Último acesso em: novembro/2015. 
O principal objetivo do referido campo é, pois, a promoção da transformação social por meio de uma ação comunicativa protagonizada por sujeitos sociais, incluindo as crianças, os adolescentes e os jovens, nos diferentes espaços sociais.

No caso do ambiente escolar, o resultado da ação educomunicativa pretendido é levar ao empoderamento os sujeitos que o coabitam - professores, estudantes e membros das comunidades educativas, enquanto cidadãos ativos e críticos da sociedade, a partir de práticas por eles protagonizadas, dentro e fora da sala de aula. Refiro-me aqui a práticas pedagógicas com grande influência socioconstrutivista e comunicacional, voltadas ao desenvolvimento e fortalecimento de competências diversas, necessárias à formação de cidadãos críticos e ativos junto a esta sociedade altamente tecnológica, como diálogo reflexivo e pensamento crítico, a partir de ações de pensar e construir juntos.

As práticas derivadas das premissas desse novo campo focam a interação dialética entre as pessoas e sua realidade, onde todos os agentes do processo são transmissores e receptores ao mesmo tempo (SOARES, 1999), sendo que ele se fundamenta em uma teoria de ação comunicativa, que enfatiza:

\footnotetext{
o conceito de comunicação dialógica; uma ética de responsabilidade social para os produtores culturais; uma recepção ativa e criativa por parte das audiências; uma política de uso dos recursos da informação de acordo com os interesses dos polos envolvidos no processo de comunicação (produtores, instituições mediadoras e consumidores da informação), o que culmina com a ampliação dos espaços de expressão (SOARES, 2002, p. 24-25).
}

Em que pese que já se tenham passado quase vinte anos do início da realização da pesquisa temática que identificou a emergência da Educomunicação enquanto um novo campo, há inúmeros aspectos apresentados por Soares (1999), ao final da pesquisa temática do NCE ECA/UP, ainda não desvelados e outros sendo descobertos até os dias atuais, garantindo ao campo a categoria de emergente ou em processo de consolidação.

\subsection{Reflexões Teóricas sobre as Interfaces Comunicação- Educação}

Como já mencionado na introdução deste trabalho, dezenas de pesquisas sobre as interfaces Comunicação-Educação foram realizadas desde a identificação do campo, em 1999. Rose 
Mara Pinheiro (2013), do NCE - ECA/USP destacou 97 pesquisas no mapeamento que apresentou em sua tese de doutoramento defendida junto ao PPGCOM da ECA/USP. Em seu estudo, a pesquisadora apontou as ideias de pelo menos dois autores que trabalharam na sustentação da emergência de um novo campo na interface Comunicação-Educação: Jorge Huergo e Ismar de Oliveira Soares. Retornaremos, nesse capítulo, a estes dois autores, bem como a um terceiro nome: Jesús Martín-Barbero.

Todos eles narram as tensões passíveis de serem identificadas no próprio campo da Comunicação, já a partir da discussão sobre o que é Comunicação e qual sua influência na sociedade atual, sendo que apresentam olhares diferentes sobre o campo da Comunicação e suas interfaces.

Jorge A. Huergo, argentino, falecido em janeiro de 2015, desenvolveu profundas reflexões sobre essa temática, admitindo a emergência do campo da Comunicação-Educação e traduzindo a transdisciplinaridade que perpassa as barreiras delimitadoras de cada um desses dois campos. O argentino não comungava da proposta de Ismar de Oliveira Soares de denominar o novo campo usando o neologismo Educomunicação por entender que esse termo já vinha sendo tradicionalmente empregado para designar uma ação específica da interface, que é a educação para a leitura crítica dos meios de comunicação.

Em suas análises, Pinheiro (2013) aponta que as ideias de Huergo (2000 apud PINHEIRO, 2013) coincidem, contudo, com as ideias de Ismar de Oliveira Soares no tocante ao ponto de partida para o reconhecimento de um novo campo na interface Comunicação-Educação, apontando que a prática latino-americana tem a criticidade e o diálogo como foco de sua abordagem durante a implementação das práticas pedagógicas. Esse é um pensamento que enfatiza o processo subjetivo e foca as relações que se estabelecem entre as pessoas nas ações comunicacionais. No caso, Huergo (2000 apud PINHEIRO, 2013) se refere a um modelo de comunicação em que as crianças e jovens participantes atuam como sujeitos que alternam os papéis de receptores e emissores constantemente, desenvolvendo um processo de trocas reflexivas, estimulados também por intervenções comunicacionais específicas com objetivos educacionais por parte do educador responsável.

Em sua ponderação sobre a ressignificação das práticas educacionais, ele propõe que adotemos um modelo transversal que considere as premissas da pedagogia crítica das mediações culturais, edificada criativamente, e dos estudos culturais da comunicação na 
educação. Uma das contribuições de Huergo (HUERGO, 2000 apud PINHEIRO, 2013) que interessa a esta pesquisa diz respeito à possibilidade de estudarmos esse novo campo com base em várias propostas pedagógicas utilizadas em sala de aula, que contam com o uso de tecnologias comunicacionais.

Ismar de Oliveira Soares, por sua vez, foi o supervisor da pesquisa temática do NCE/USP que identificou o surgimento de um novo campo na interface Comunicação-Educação, atribuindolhe a designação de Educomunicação. Enquanto Huergo (2000 apud PINHEIRO, 2013) preocupou-se com a natureza antropológica da interface, Soares volta-se para sua dimensão política, acreditando na necessidade de levar a herança do pensamento crítico latinoamericano em torno da comunicação dialógica e participativa para o âmbito das políticas públicas, em trabalho com as crianças e jovens. São suas considerações:

A questão da relação entre ensino, a juventude e o mundo da comunicação encontrase no centro deste processo formativo, por natureza transformador, bem como no centro dos sonhos dele decorrentes, entre os quais o pleno acesso das novas gerações ao mundo da comunicação e de suas tecnologias, colocado a serviço do bem comum e da prática da cidadania. (SOARES, 2011, p. 15)

Em alguns de seus textos, Soares aproxima o conceito da Educomunicação do universo escolar, afirmando que:

Uma comunicação essencialmente dialógica e participativa, no espaço do ecossistema comunicativo escolar, mediada pela gestão compartilhada (professor/aluno/comunidade escolar) dos recursos e processos da informação, contribui essencialmente para a prática educativa, cuja especificidade é o aumento imediato do grau de motivação por parte dos estudantes, e para o adequado relacionamento no convívio professor/aluno, maximizando as possibilidades de aprendizagem, de tomada de consciência e mobilização para a ação. (SOARES, 2011, p. 17)

Para melhor compreender o ambiente escolar, aqui entendido como um "ecossistema comunicativo", esclarece que:

O ecossistema comunicativo constitui, na verdade, o entorno que nos envolve, caracterizado por ser "difuso" e "descentrado". Tal ecossistema é difuso porque é formado por uma mistura de linguagens e de saberes que circulam por diversos dispositivos midiáticos intrinsecamente interconectados; é descentrado porque os dispositivos midiáticos que o conformam vão além dos meios que tradicionalmente vêm servindo a educação, a saber: escola e livros. (SOARES, 2011, p.43)

A Educomunicação não restringe sua atuação à educação formal, como também não é sinônimo de tecnologias da educação ou TIC: “Com relação às tecnologias, o que importa não é a ferramenta disponibilizada, mas o tipo de mediação que elas podem favorecer para ampliar os diálogos sociais e educativos" (SOARES, 2011, p. 18). Nessa linha - para o pesquisador - a ocorrência das TIC, por exemplo, deve estar prevista como meio de estabelecer, fortalecer e 
dinamizar ecossistemas comunicativos nos espaços educativos, de maneira disciplinar e transdisciplinar.

Jesus Martin-Barbero, é um terceiro autor comumente utilizado nas fundamentações teóricas sobre o surgimento do novo campo. Defende esse pensador espanhol radicado na Colômbia que a educação deve ser pensada em termos da transmissão da herança cultural, da capacitação demandada pelo mercado de trabalho da sociedade atual e da formação de cidadãos conscientes e ativos. Ele reconhece que:

\begin{abstract}
os meios de comunicação constituem hoje espaços-chave de condensação e intersecção de múltiplas redes de poder e de produção cultural, mas também alerta, ao mesmo tempo, contra o pensamento único que legitima a ideia de que a tecnologia é hoje o grande mediador entre as pessoas e o mundo, é a transformação da sociedade em mercado, e deste em principal agenciador da mundialização (MARTINBARBERO, 2003, p. 20).
\end{abstract}

Um de seus mais importantes questionamentos refere-se exatamente sobre como o sistema educacional pode, considerando a realidade midiática na qual a sociedade mundial está inserida, entender o atual sistema de meios de comunicação e suas inter-relações e convergências, no sentido de construir o que chama de ecossistemas comunicativos.

Ou seja, ele é um dos autores que alerta que um dos maiores prejuízos atuais na educação é exatamente a adoção de tecnologias da comunicação nos espaços educativos sem a mínima preocupação em se mudar o modelo de comunicação que sustenta esse ambiente escolar. Para ele, o modelo comunicativo-pedagógico das unidades escolares deve ser repensado antes da adoção em si das tecnologias da comunicação nesses espaços (MARTIN-BARBERO, 2011).

Ele ainda argumenta que um dos maiores desafios da atualidade é o estabelecimento de um ecossistema comunicativo que abranja essas experiências culturais diversificadas, o entorno das novas tecnologias da informação e comunicação (TIC), e que apresente a educação como o lugar onde se consegue um processo de aprendizagem que preserve seu encanto.

Martin-Barbero aponta que atualmente observamos dois tipos de dinâmicas que promovem as transformações na sociedade: "a de uma comunicação que se converte em ecossistema e a de uma forma de diversificação e descentralização do saber" (MARTIN-BARBERO, 2011, P. 127) -, as quais estão causando o que chama de esquizofrenia cultural. Ou seja, as pessoas acabam divididas entre um saber adquirido com a educação formal e que lhes confere inclusive um status, e outro saber construído em outros espaços de educação não formal ou até mesmo informal, que vai lhes permitir aprender a conviver em comunidade e a harmonizar. 
Ao refletir sobre as TIC no ambiente escolar, ele afirma que não há possibilidade de que elas produzam transformações nas estruturas, metodologias e práticas de aprendizagem sem que haja uma transformação da própria mentalidade escolar. Ele também busca em Paulo Freire as bases para sua proposta sobre a alfabetização para a comunicação, apontando que durante um longo processo de alienação estabelecido na sociedade, o opressor imprime ao oprimido valores e ideias que distorcem a percepção da realidade, sendo que a escola seria uma das poucas vias possíveis - se não for a única - para que esse oprimido volte a ter voz, ainda que emprestada.

O cidadão de hoje pede um sistema educativo que o capacite a ter acesso à multiplicidade de escritas, linguagens e discursos nos quais se produzem as decisões que o afetam, seja no campo de trabalho, seja no âmbito familiar, político e econômico. [...] Para tanto, necessitamos de uma escola na qual aprender a ler signifique aprender a distinguir, a tornar evidente, a poder e escolher onde e como se fortalecem os preconceitos ou se renovam as concepções que temos sobre política, família, cultura e sexualidade (MARTIN-BARBERO, 2011, p.130)

\subsection{Aspectos Educomunicativos e Áreas de Intervenção}

Para verificar a existência de sinergia filosófica e metodológica entre as práticas educomunicativas e a proposta de avaliação formativa, neste momento procuro definir mais claramente alguns aspectos importantes da Educomunicação, como qual o tipo de protagonismo e diálogo estou considerando enquanto educomunicativos neste estudo.

Soares (1999) afirma que a Educomunicação busca identificar, planejar e implementar práticas pedagógico-comunicacionais ${ }^{17}$ que promovam uma participação mais plena e ativa, que não se restrinja a uma manutenção da boa convivência humana no ambiente escolar, mas que viabilize e estimule a troca reflexiva efetiva para a construção de saberes ligados a conteúdos específicos nas práticas educativas mediadas por tecnologias da comunicação, desenvolvidas por meio de uma pedagogia de projetos transdisciplinares.

Ele esclarece que se trata de uma práxis social do diálogo enquanto pensar juntos, durante a qual o protagonismo desses participantes é um pressuposto básico para que todo esse ecossistema comunicativo de trocas intensas se desenvolva e se fortaleça. Ao nascer e se

\footnotetext{
${ }^{17}$ Considero que as práticas educomunicativas, que refletem as interfaces comunicação-educação são pedagógicocomunicacionais, também com o hífen propositadamente, pelo fato de que acredito que o resultado dessas práticas é muito maior que a mera soma das duas palavras. Esse termo será melhor detalhado mais adiante no item B do tópico 1.3.3.
} 
consolidar a partir da realização de práticas comunicativas voltadas à educação, a Educomunicação não se limita a reflexões teóricas e reforça a importância da vivência de atividades comunicativas dialógicas e críticas para o próprio desenvolvimento de competências ligadas à comunicação em si.

Essa complexidade foi identificada pela pesquisa temática do NCE/USP no momento em que constatou que o campo da Educomunicação - por sua natureza multidisciplinar - compreende práticas executadas em âmbitos laborais diversificados. Entre os entrevistados que formavam o corpo da pesquisa havia quem se preocupava com o planejamento de práticas comunicativas, os que desenvolviam projetos de educação midiática e os que faziam uso das tecnologias para o atendimento dos planos de suas comunidades. Todos, contudo, eram identificados pela convergência da maneira como procediam, pelas razões e fundamentos de suas metas. Reconhecer a diversidade das práticas realizadas sob um mesmo prisma teórico-metodológico, foi fundamental para se chegar ao conceito de áreas diversificadas de intervenção, no espaço de um único campo de conhecimento que emergia.

A expressão "intervenção" pode aparentar pouco nobre para um campo voltado à dialogicidade das ações humanas. No entanto, identifica justamente o que sua semântica propõe: mobilização coletiva em torno de mudanças profundas em realidades marcadas pelo imobilismo das práticas sociais. No caso, o que a pesquisa revelou foi que o novo campo se manifestava como espaço de falas, capaz de dar vida e transformar a realidade no cotidiano das diferentes práticas, em espaços específicos do exercício do trabalho humano. Portanto, as áreas de intervenção dizem respeito ao trabalho cotidiano do educomunicador.

Inicialmente, foram identificados quatro âmbitos de intervenção laboral onde era possível identificar a marca da prática educomunicativa, a saber: o âmbito da "gestão da comunicação em espaços educativos"; o âmbito das ações voltadas para a "educação para a comunicação" (media education); o âmbito do estudo e das ações envolvendo as "mediações tecnológicas" na educação e o âmbito da própria reflexão epistemológica, englobando as pesquisas e as sistematizações das ações em desenvolvimento.

Nos últimos anos, outros pesquisadores identificaram novas possíveis áreas de intervenção dos profissionais do referido campo. Um deles é o espaço da produção/educação artística (a área da expressão comunicativa por meio das artes). Outro é o espaço da didática (a área da pedagogia da comunicação). Um terceiro é o espaço da indústria cultural (a área da produção 
midiática voltada para a educação). No caso, estou falando, não mais em quatro, mas em sete áreas de intervenção social onde a Educomunicação se expressa como campo complexo e plural.

Vale esclarecer que o desenvolvimento desta pesquisa me fez refletir muito sobre todo esse contexto, e me fez considerar e propor a substituição do termo no espaço da didática para práticas pedagógico-comunicacionais. As ideias de Huergo (2005), Martin-Barbero (2005; 2011) e Citelli $(2004 ; 2011)$ foram consideradas para justificar essa proposta de modificação do termo, sobre a qual tratarei no item B do tópico 1.3.3.

\subsubsection{Protagonismo, Tipos de Participação e Empoderamento}

Ao afirmar que a Educomunicação tem como seu principal objetivo a transformação social das crianças e jovens para o empoderamento dos mesmos enquanto cidadãos dialógicos e críticos, a partir de atividades de participação protagonista, devo esclarecer o que estou considerando não apenas por protagonismo, mas também por participação e empoderamento.

O que vem a ser esse protagonismo do qual tanto falo aqui e qual a sua importância na práxis educomunicativa? Como se dá essa participação dos alunos enquanto atores sociais e como os procedimentos adotados podem promover uma transformação social que resulte no empoderamento dessas crianças e jovens? E o que vem a ser esse empoderamento? Por que a práxis?

Sobre a importância da adoção de atividades de práxis já nos espaços educativos, John Dewey (1859 - 1952), pedagogo e psicólogo norte-americano, defendia o que chamou de experiência educativa dos fatos da vida nos espaços escolares, sendo que alertava, porém para o fato de que nem toda vivência é educativa. Para ele, uma experiência educativa consistia em saber como trabalhar com os alunos experiências da vida real, fazendo uso dos conteúdos curriculares, para que esses vivenciassem e compreendessem a aplicação desses temas à realidade de suas vidas, bem como para que pudessem expandir essas experiências a partir de suas próprias referências. 
Dewey entendia a educação enquanto uma: "reconstrução ou reorganização da experiência, que esclarece e aumenta o sentido desta e também a nossa aptidão para dirigirmos o curso das experiências subsequentes"18 (1976a, p. 83).

Ao trabalhar a formação de professores a partir da integração curricular da proposta da escola progressiva, desenvolvida na The University of Chicago Laboratory School, durante cerca de oito anos (1896 - 1904), Dewey (1976a) considerou três aspectos tidos como essenciais: a vivência do aluno; as demandas de uma sociedade democrática e os conteúdos teóricos do currículo.

Ele explicava que a possibilidade de trabalhar a reflexão de conteúdos teóricos curriculares a partir da aplicabilidade dos mesmos a situações do dia a dia dessas crianças e jovens, permitiria orientar, direcionar e até qualificar a experiência desses atores. Porém ele destacou a importância do professor enquanto mediador, de forma que este último planejasse, propusesse, acompanhasse, orientasse e auxiliasse nas avaliações e deduções, sem impor suas próprias ideias, permitindo que seus educandos explorassem, refletissem, compreendessem e assimilassem o que estava sendo vivenciado em todo o processo de aprendizagem.

Uma experiência educativa tem que ser atrativa, com aspectos da vida real e conteúdos trabalhados pelo currículo da escola, para que esses novos significados sejam estruturados de uma forma mais realista pelos alunos. Essas crianças e jovens devem interagir com aspectos de suas realidades, sob a mediação de seu professor, no sentido deste último acompanhá-los, auxiliá-los e até orientá-los, sem, no entanto, direcioná-los para conclusões pré-concebidas.

A temática deve necessariamente estar ligada não a assuntos hipotéticos, mas a aspectos do dia a dia desses alunos, contextualizados a partir do conteúdo em estudo, que era utilizado como foco da dinâmica. E as reflexões fomentadas pelo educador devem provocar seus educandos de forma que eles conversem entre si, compartilhando e refletindo conjuntamente sobre experiências, sem qualquer tipo de barreira a essas trocas, em espaços democráticos.

Dewey (1976b) destacava também que isso precisa ser mediado e acompanhado para que essas trocas se mantenham dentro do foco previamente definido como objetivo para essas reflexões. Ele rechaçava a improvisação, defendendo que as aulas precisam ser preparadas já prevendo propostas e questionamentos que realmente estimulem a reflexão. Porém esse seria o

\footnotetext{
${ }^{18}$ Grifo do autor.
} 
mínimo a ser desenvolvido, sendo que por isso o professor precisa ter esse processo bem claro, para que possa mediar as trocas com sucesso:

É de responsabilidade do educador ter sempre em vista dois pontos: primeiro, que o problema surja em condições da experiência presente e esteja dentro da capacidade dos estudantes; e, segundo, que seja tal que desperte no aprendiz uma busca ativa por informação e por novas ideias (1976b, p.81-82)

Dewey (1976a) tinha como a base do seu pensamento o fato de que o processo de aprendizagem de um ser humano deve se desenvolver a partir de experiências reflexivas, que lhe permitam descobertas a partir de suas referências e das referências de seus pares, de maneira que esse processo não pode ser limitado ao que chamava de armazenamento de conhecimento construído por outras pessoas, a partir das vivências das mesmas.

Ou seja, analisando as ideias desse autor a partir do campo da comunicação em si, a mensagem pode até ser o estímulo do emissor ao receptor, mas o significado resultante desse processo passará por um processo único de recepção, que enquanto sujeito vai interpretar tal mensagem a partir de suas próprias referências internas, e não considerando apenas - se considerar - as referências do emissor em si.

Exatamente pelas referências internas de cada aluno, as eventuais ideias apresentadas como conhecimento pelos educadores acabam por ser quase que inúteis, sem ressonância para os alunos:

\footnotetext{
saber de segunda mão, saber que não nosso, mas dos outros, tende a tornar-se meramente verbal. Nada se objeta a que as informações sejam expressas com palavras; a comunicação opera-se necessariamente por meio de palavras. Mas na proporção em que o comunicado não possa ser incorporado à experiência existente de quem aprende, converteu-se em simples palavras isto é, estímulos sensoriais desprovidos de significação. (DEWEY, 1976a, P. 207) ${ }^{19}$
}

Além de pouco eficaz, essa abordagem mais verbalista acaba por tornar os educadores escravos dos próprios processos, uma vez que precisam se tornar verdadeiros recipientes de conteúdos a serem informados aos respectivos alunos.

Dewey (1976a) defendia a resolução colaborativa de um problema exatamente para que o enriquecimento do processo de construção do conhecimento a partir das trocas reflexivas conjuntas de um grupo de educandos, sendo que aos educadores - e até aos pais desses alunos - cabe o importante papel de estimuladores, apoiadores e orientadores desse processo conjunto de trocas de experiências e pontos de vista, mas esses não devem assumir, indicar e

\footnotetext{
${ }^{19}$ Grifos do autor.
} 
resolver o problema por seus educandos. Para ele, a aprendizagem só é passível de acontecer nesse contexto.

\begin{abstract}
isto não quer dizer que o docente fique de lado, como simples expectador, pois o oposto de fornecer ideias já feitas e matéria já preparada, ou de ouvir se o aluno reproduz exatamente o ensinado, não é inercia e sim a participação na atividade. Em tal atividade compartida, o professor é um aluno e o aluno é, sem o saber, um professor - e, tudo bem considerado, melhor será que, tanto o que dá como o que recebe a instrução tenha menos consciência possível de seu papel (DEWEY, 1976a, P. 176).
\end{abstract}

No tópico seguinte, quando trato do diálogo, identifico como a crítica deweyana influencia o pensamento de Freire (2002; 2005), no que se refere à educação tradicional ou bancária, como denominada por Freire (2002; 2005), enquanto uma "extensão" dos saberes que estão sendo informados, mas não necessariamente comunicados como pretendido. Nesse sentido, Dewey (1976a) e Freire $(2002,2005)$ apontam que nesse modelo tradicional a educação acaba por se tornar silenciadora e domesticadora.

Em suas reflexões sobre a democracia, que eram consideradas em sua proposta integradora, Dewey (1976a; 1976b) explicava que esta consistia em uma vivência construída conjuntamente, de forma colaborativa. Ele entendia que esse contexto participativo e cooperativo em sociedade teria uma melhor viabilização a partir da vivência de processos colaborativos reflexivos nas práticas de aprendizagem já nos espaços educativos durante a infância e adolescência.

Quanto às conversas alicerçadas no diálogo para a identificação de solução de problemas, essas devem se configurar como trocas de ideias e vivências entre os participantes de uma turma, em um espaço educativo, como um dos principais requisitos para dinâmicas focadas na solução de problemas. O papel do educador nesse processo é principalmente de mediador e orientador, mas tomando cuidado para não impor suas próprias ideias sobre um tema, para permitir a experimentação reflexiva conjunta pelos alunos, sobre um determinado tema.

Célestin Freinet (1896 - 1966) é outro dos autores, cujas ideias inspiram e norteiam a Educomunicação na adoção do protagonismo como um de seus pressupostos. Intitulada Pedagogia Freinet ou do Bom Senso, sua proposta sempre teve como principal objetivo a modernização da escola por meio de valores por ele chamados de bom senso, voltados a atender às necessidades de educação para todos e não apenas de uma minoria pertencente à elite das classes mais abastadas, a partir da modificação da relação professor-aluno. 
Para tanto, ele previa o desenvolvimento de práticas destinadas às reflexões entre alunos e deles com seus professores, de forma conjunta e igualitária, sobre conteúdos teóricos do currículo ou mesmo sobre aspectos da vida humana e do entorno comunitário em que vivem. Outra de suas premissas foi o respeito à individualidade dos jovens da forma como são sem tentar enquadrá-los em modelos preestabelecidos.

Freinet (1985) acreditava que os jovens poderiam se desenvolver de maneira plena por meio de uma cidadania ativa, e sua proposta pedagógica tem os seguintes princípios: foco no processo e não no produto final; conscientização progressiva, por meio da estruturação de várias etapas de participação desses jovens, com ações sempre ligadas à solução de problemas e necessidades da comunidade; envolvimento de todos os participantes da escola - gestores, coordenadores, professores, alunos; adoção de um plano de desenvolvimento de atividades para estruturação das práticas pedagógicas, com indicação inclusive de períodos e datas bem definidos.

Ele defendia a formação de seres humanos mais responsáveis a partir de práticas diferenciadas em sala de aula, com foco no fortalecimento de valores de convivência e no desenvolvimento de habilidades e competências, as quais lhes propiciassem as capacidades de agir e interagir ativamente em seu meio, para uma transformação social consistente. As práticas que desenvolveu ao longo de sua vida enquanto educador em sala de aula apontaram que esse processo demanda obrigatoriamente o estabelecimento do diálogo reflexivo pelos seus participantes, com questionamento constante das ideias ouvidas e postura de mente aberta para conhecer novos pontos de vista.

A Pedagogia Freinet tem como base práticas focadas no desenvolvimento e fortalecimento de algumas habilidades e competências importantes à prática da cidadania, como a cooperação, a comunicação e livre expressão, a educação do trabalho, e o que chamava de práticas experimentais para exercício da cidadania. Para tanto, já no início dos anos 1920, Freinet (1985) apresentava temas para serem discutidos e refletidos intensamente por seus alunos, sendo que seu papel era principalmente o de estimular as trocas dialógicas, críticas e reflexivas entre esses jovens.

Esses alunos se dividiam em grupos menores para que esse compartilhamento de ideias fosse mais aprofundado. Os resultados de tais reflexões cooperativas e conjuntas eram transformados em textos, que os próprios alunos escreviam e publicavam nos jornais da 
escola, sempre sob a orientação de Freinet (1985). Aos poucos, contudo, com a massificação da educação, os livros didáticos tradicionais foram substituindo essas publicações.

Ele foi um dos educadores que soube como trabalhar com seus alunos práticas de protagonismo nos espaços educativos para construção de saberes formais e não formais, ao solicitar e estimular que esses assumissem a responsabilidade pela solução de desafios e a redação e a edição de textos colaborativos entre eles. O próprio comprometimento desses jovens com o desenvolvimento de tais atividades foi um dos sinalizadores quanto à importância deles se apropriarem do processo comunicativo desses espaços educativos, ao atuarem como sujeitos produtores de significados.

Frente às ideias de Dewey e Freinet, vale resgatar Jean Piaget (1896-1980), cujas ideias mereceram e seguem merecendo vastos e profundos estudos, mas para efeito desta pesquisa destaco brevemente aspectos bem específicos sobre a importância do processo de aprendizagem em si vivenciado pelas crianças e jovens para a construção do conhecimento.

Piaget (1982) trabalhou com vários experimentos sobre os processos de lógica matemática e física, por exemplo, sendo que apresentou questões referentes a situações que podem ser extrapoladas para muitas outras. A prática mais comum é o educador - pai ou professor apresentar um modelo pronto, para que as crianças e jovens sigam o mesmo, repetindo o que é certo e errado em cada etapa, almejando que, dessa forma, a criança aprenda e saiba repetir o que foi dito ser certo e/ou errado.

Contudo os resultados desse estudioso apontaram que é essencial que a criança formule a pergunta e fantasie a resposta, para que crie minimamente em sua mente o modelo de resolução do problema a partir de suas perspectivas e não a partir do modelo pronto do adulto. Ele defendia que não adianta entregar a resolução de um tema a uma criança que não tem capacidade para entendê-la e assimilá-la, pois a apresentação tem que ser no nível de conhecimento da criança e não do adulto. E destaca que, para que haja compreensão, a criança precisa desenvolver seu próprio modelo para atingir um determinado resultado definido.

Para Piaget (1982), o estabelecimento de correspondências é a forma mais básica de interação com o mundo, posto que consiste no ato de estabelecer associações, ou seja, estabelecer funções. E apesar de toda associação ser assimilativa, nem toda assimilação é associativa, posto que o mediador é externo e pode ser independente. Aqui a base é a ação e a lógica é a linguagem operacional. Ao focar suas pesquisas no entendimento sobre as perspectivas da 
criança na relação com o mundo, ele constatou que essa estabelece o que chama de correspondências. Ou seja, ela junta duas coisas, realiza repetições das mesmas, para que possa reconhecer algo como mais uma vez e não como algo novo.

Ele destacava a necessidade de identificarmos semelhanças, para conseguirmos separar e transformar. As crianças aprendem fazendo comparações, reunindo os iguais, as diferenças, montando níveis de relações, integrando, estabelecendo relações. A vida se desenvolve a partir de relações, e o conhecimento se desenvolve do estabelecimento de relações. Ou seja, o ser humano está fadado ao contato, a trocas comunicacionais, posto que sem vículos não há vida.

Antônio Carlos Gomes da Costa (2006) é outro autor que dedicou muito de seu trabalho à implementação e acompanhamento de projetos de protagonismo juvenil, sendo que para esse autor:

A palavra "protagonismo" vem da junção de duas palavras gregas: protos, que significa principal, o primeiro, e agonistes, que significa lutador, competidor, contendor. Quando falamos de protagonismo juvenil, estamos falando, objetivamente, da ocupação pelos jovens de um papel central nos esforços para a mudança social. (COSTA, 2006, p. 150)

Agir como protagonista é atuar no papel principal, é ser o agente de uma ação qualquer que seja sua idade. Ao adotar o protagonismo juvenil, permite-se que crianças e jovens sintam e percebam a realidade que os cerca de uma forma experimental, mas a partir de uma abordagem que Costa (2006, p. 23) chama de "visceralmente contrária a qualquer tipo de paternalismo, assistencialismo e manipulação".

Esses atores sociais precisam vivenciar, aprender e internalizar o que é ser um cidadão ativo junto à sociedade, por meio de atividades reais junto ao entorno de sua escola, por exemplo, refletindo sobre problemas ligados a esse espaço com seus colegas, nas práticas de trocas reflexivas intensas, com o objetivo de identificar e buscar soluções para problemas dessa localidade.

A quantidade e qualidade das oportunidades de participação na resolução de situações reais postas ao alcance dos adolescentes influenciam de maneira decisiva nos níveis de autonomia e de autodeterminação que eles serão capazes de alcançar na vida familiar, profissional e cívica, quando atingida a idade adulta (COSTA,2006, p. 177).

Focar na implementação de práticas que tenham o protagonismo como pressuposto, como é o caso da Educomunicação, é permitir que os jovens adolescentes participem de projetos com 
ênfase no estímulo e fortalecimento de competências como criatividade, construção conjunta e solidariedade, junto com o que o autor chama de representantes do mundo adulto - educadores -, para superação de desafios reais da escola e da comunidade às quais estão ligados:

a participação do adolescente em atividades que extrapolam o âmbito de seus interesses individuais e familiares e que podem ter como espaço a escola, a vida comunitária (igrejas, clubes, associações) e até mesmo a sociedade em sentido mais amplo, através de campanhas, movimentos ou outras formas de mobilização que transcendem os limites de seu entorno sociocomunitário (COSTA, 2006, p. 176).

Ao tratar do termo participação, Costa (2006) reconhece que essa pode se caracterizar como a somatória de diversas ações integradas, as quais podem variar conforme as características do projeto, sendo que nem todas as formas de participação necessariamente são protagonistas.

Frente a isso, ele se baseou nas pesquisas do Prof. Dr. Roger Hart (1950 -) sobre os diferentes tipos de participação que podem ser adotados em atividades com crianças e adolescentes. Hart (2008) é um especialista em direitos desse público específico, sendo que atua academicamente nas áreas de Psicologia e Geografia, na University of New York City, além de ser diretor do Children's Environments Research Group. No documento da UNESCO, intitulado United Nations Convention on the Rights of the Child, de 1992, de cuja elaboração participou, ele define como "crianças" o público que abrange crianças e jovens adolescentes até dezoito anos, sendo que utilizo essa definição também para efeito do uso desse termo nesta pesquisa.

Hart $(2008$; 1992) reflete que tratar da questão da participação infanto-juvenil em projetos sobre temas ligados às comunidades gera grande debate entre os intitulados representantes desses. Isso porque há aqueles que defendem que as crianças e jovens devem ter uma adolescência tranquila para crescerem em um ambiente que chamam de positivo e sem ameaças, enquanto outros defendem que esses atores sociais podem e precisam participar de projetos que propiciem vivências para a estruturação e fortalecimento da sua cidadania responsável para uma gestão democrática. Ele enfatiza que as crianças e os jovens devem ser envolvidos em projetos de significados ligados às suas comunidades em cooperação com adultos e que esses adultos devem permitir que esses adolescentes sejam atores protagonistas do processo no qual essa figura mais velha assume uma postura mais de mediador.

Alguns aspectos que estão além ou são anteriores à práxis protagonista, posto que não basta planejar um projeto com práticas de premissas protagonistas se não envolver de fato o jovem nesse projeto, nessa proposta. Há inúmeras variáveis nesse contexto e algumas delas precisam ser consideradas obrigatoriamente para que consigamos a adesão completa desses jovens a 
ações como foco no protagonismo para atingir os objetivos previamente traçados para a referida atividade.

Hart $(2008$; 1992) cita inclusive trabalhos de protagonismo nas comunidades de baixa renda no Brasil, refletindo sobre a necessidade de iniciarmos com o desenvolvimento de pertencimento deles no grupo que está desenvolvendo um trabalho desse tipo, a partir inclusive de aspectos culturais. Isso porque a situação social de alguns jovens desses ambientes e sua baixa autoestima podem fazer com que eles precisem ser estimulados por meio de alguma atividade cultural comum aos membros do grupo, para se sentirem realmente pertencentes ao projeto, com direito a participar.

Esses projetos podem trabalhar inicialmente com a construção de expressões culturais dessa comunidade, com grande ênfase na música, dança e teatro: "ao criarem esses eventos, as crianças se veem cara a cara com a história de sua cultura e as raízes de sua pobreza e discriminação, um processo que resulta em conscientização, como chamado por Paulo Freire" ${ }^{20}$ (HART, 2008, pos. 1170) ${ }^{21}$.

Especificamente sobre o envolvimento desses jovens, há a necessidade de pensarmos atividades com variadas formas de participação e meios de expressão, que permitam que eles expressem suas competências aos demais, para fortalecer a autoestima.

Não basta trabalhar esses aspectos para a formação do cidadão crítico e ativo, pois é preciso que essas atividades também tragam em seu bojo aspectos que foquem a reflexão sobre o desenvolvimento social. Essa habilidade de participar socialmente, envolvendo-se com os desafios do grupo e trabalhando conjuntamente com os demais atores sociais na busca por soluções criativas, voltadas ao bem comum desse grupo, demanda que haja práticas voltadas à reflexão sobre os pensamentos e sentimentos dos outros. Esse é outro aspecto importante a ser considerado nas práticas protagonistas para que consigamos que a cooperação entre esses jovens, ao longo das atividades, ocorra de fato.

As crianças e jovens precisam aprender a trabalhar cooperativamente. Há que se prever atividades iniciais com mediações mais intensas de outros atores sociais, adolescentes ou

\footnotetext{
${ }^{20}$ Tradução livre da autora, do trecho: "In creating these events, the children face the history of their culture and the roots of their poverty and discrimination, a process that results in 'conscientization', as it is called by Paulo Freire" (HART, 2008, pos. 1170)

${ }^{21}$ Pos. 1170: no caso de e-books, não há páginas, mas “posições”. Daí quando a referência for de um e-book, será utilizado "pos."
} 
adultos, com conhecimentos mínimos sobre trocas reflexivas dialógicas para a cooperação. Atualmente já há diversos estudos destacando que essas dinâmicas promovem padrões consistentes de ação e interação, e não sequencias comportamentais meramente pontuais, como a execução de tarefas (ainda que seja mais de uma e que sejam integradas).

Crianças e adolescentes se tornam mais conscientes de suas próprias perspectivas e
das dos outros nas trocas com seus colegas e nas tentativas de convencer os outros,
bem como das diferenças de opinião que surgem nas discussões tópicas. Essas
habilidades reflexivas podem informar futuras interações sociais. (HART, 2008, pos.
$1267)^{22}$

Quanto à possibilidade de estruturar projetos que contem com a participação de jovens de diferentes idades, esses trabalhos permitem que eles desenvolvam habilidades de ensinar e aprender entre si, de dar e receber. Hart (2008) menciona Paulo Freire ao comentar sobre a questão das práticas educacionais tradicionais, em que o adulto se coloca no lugar de único detentor de saberes e trata o aluno como mero repositório. A abordagem protagonista deve permitir que os jovens testem seus próprios saberes atuando de igual para igual com pessoas de diferentes idades, nesse modelo.

Frente a todas essas considerações, entendo como necessários os seguintes aspectos quando do planejamento de projetos que tenham como pressupostos as práticas protagonistas: foco na diversidade e respeito às capacidades de desenvolvimento de cada jovem ao longo dos processos (devemos trabalhar variadas formas de envolvimento dos jovens, procurando envolver o maior número de jovens nesse processo); desenvolvimento de um senso de identidade comunitária; fortalecimento da autoestima e participação social por jovens de classes menos favorecidas; desenvolvimento social da comunidade de entorno; cooperação social; mistura de jovens de diferentes idades.

Retomando as ideias de Costa (2006), este defende a presença de um educador que faça a mediação nesses processos e destaca que, dada a situação de transição que especificamente o jovem adolescente se encontra, entre a fase infantil e adulta, a presença do educador se faz mais necessária ainda, para que esses jovens tenham uma referência norteadora, o que permitirá que realmente consigam trabalhar todas as competências desejadas. Ele explica que a fase de transição em que especificamente os adolescentes se encontram acaba reforçando a importância da adoção dessa abordagem, pois esses estão em um processo de:

\footnotetext{
${ }^{22}$ Tradução livre da autora do trecho: "Children and adolescents become more aware of their own and others perspectives in disputes with peers and attempts to convince others, as well as though differences of opinion which emerge in topical discussions. These reflective abilities can inform future social interactions." (HART, 2008, pos. 1267)
} 
travessia entre a heteronomia da infância e autonomia da idade adulta, entre o mundo da educação e o mundo do trabalho, entre a condição de filho e da possibilidade de fazer filhos. Passa por uma trajetória biográfica (estudo, trabalho, participação em grupos, entidades e movimentos de diversas naturezas) e por uma trajetória relacional (conjunto de relações interpessoais por ele estabelecidas ao longo de sua trajetória biográfica com o mundo adulto e com seus pares, outros adolescentes). (Costa 2006, p. 21)

Ele complementa que o protagonismo juvenil desenvolve esse jovem para a prática cidadã e para sua qualificação para o trabalho.

No campo do desenvolvimento pessoal (aprender a ser), a prática de protagonismo contribui para o desenvolvimento do senso de identidade, da autoestima, do autoconceito, da autoconfiança, da visão do futuro, do nível de aspiração vital, do projeto e do sentido da vida, da autodeterminação, da auto-realização e da busca de plenitude humana por parte dos jovens. No campo da capacitação para o trabalho (aprender a fazer), o protagonismo propicia ao jovem, através de práticas e vivências estruturantes, o desenvolvimento de habilidades de autogestão, heterogestão e cogestão, ou seja, ele aprende a lidar melhor com suas potencialidades e limitações (gerir a si mesmo), a coordenar trabalho de outras pessoas (atuar sobre a atuação de outros) e a agir conjuntamente com os outros adolescentes e adultos na consecução de objetivos comuns (trabalho em equipe). (COSTA, 2006, p.21-22)

O protagonismo tem como um de seus principais objetivos exatamente a edificação da autonomia da criança e do jovem a partir de ações práticas reais, críticas e democráticas na comunidade da qual fazem parte, com a coparticipação de adultos que atuam como norteadores, apoiadores ou mesmo orientadores na solução de problemas mais específicos.

Costa (2006) alerta que o termo participação pode se referir a diversos tipos de posturas e ações dessas crianças e jovens, sendo que se inspirou na proposta de Hart (2008; 1992), de oito tipos de participação para desenvolver um quadro orientador que detalha qual o envolvimento e o descritivo da participação desses jovens, dependendo do tipo de dinâmicas planejadas para serem desenvolvidas. Hart (1992) esclarece que o fato de uma criança ou adolescente participar de um determinado evento social, voltado à solução de problemas de uma determinada comunidade, não significa torná-lo protagonista desse processo. Para ele, à medida que vai aumentando o que chama de qualidade da participação do jovem no processo, esse protagonismo também vai se modificando e intensificando. 


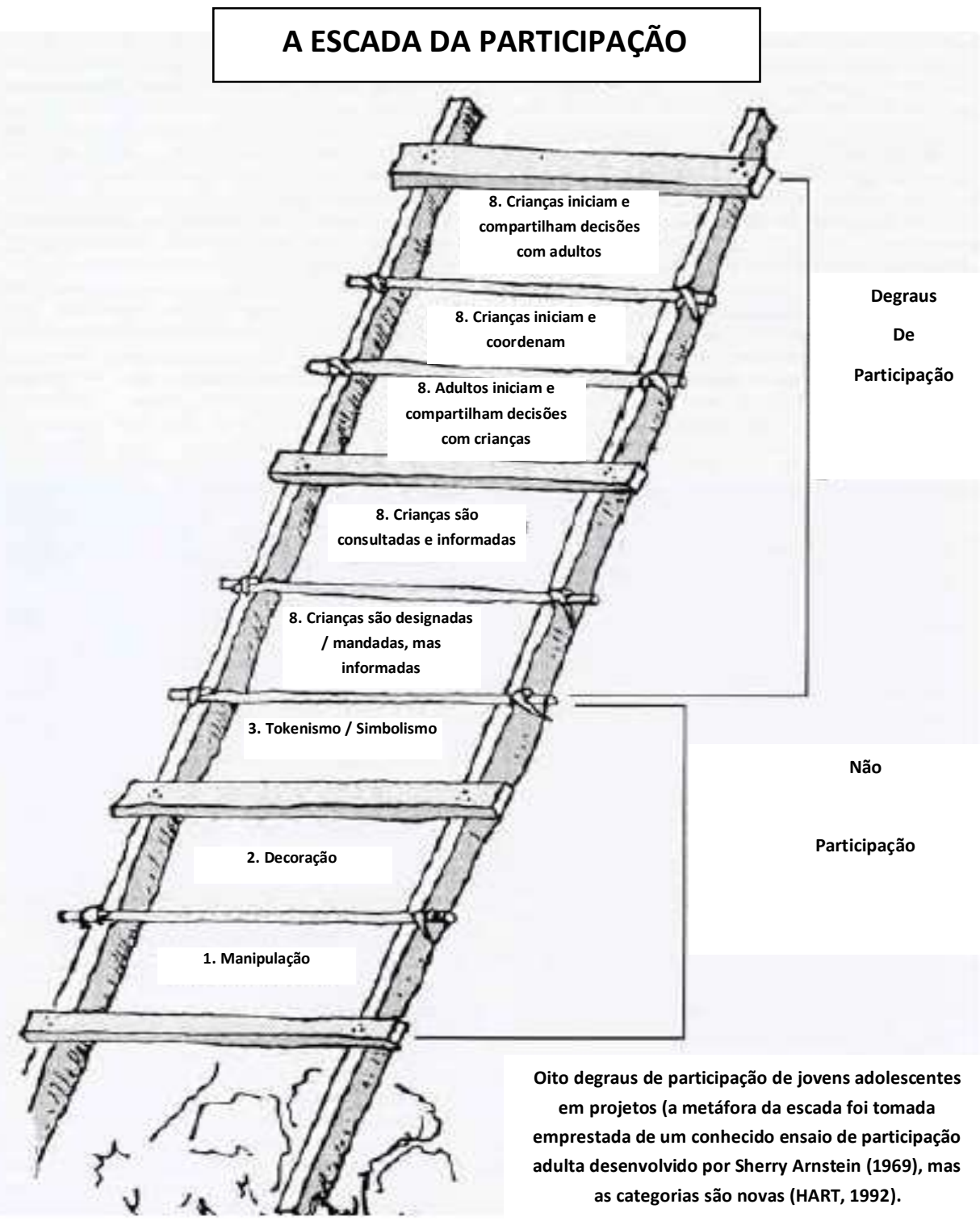

Figura 01: Evolução dos Tipos de Participação

Fonte: Roger Hart, 1992, p. $08^{23}$

A partir da definição desses oito tipos de participação, Hart (1992) conseguiu ilustrar mais claramente como trabalhar as diferentes participações de crianças e jovens com foco nas ações de protagonismo para empoderamento, o que viabilizou/facilitou também a identificação de quais as respectivas competências passíveis de serem trabalhadas com esses atores sociais. Segundo essa proposta, à medida que a participação vai sendo mais complexa, com a incorporação de competências mais específicas e o aumento da responsabilidade desses atores no processo como um todo, esse público vai se tornando cada vez mais protagonista (a partir 
do $5^{\circ}$ tipo). Vale destacar também que não necessariamente há a necessidade de seguir a ordem ascendente/crescente como sugere os degraus do desenho. A ideia dessa ilustração é mostrar que quanto mais responsabilidades são compartilhadas com esses jovens, mais consistente é o protagonismo deles, mas não necessariamente tem-se que seguir essa ordem quanto aos tipos de participação. Dependendo dos projetos, em um momento está-se trabalhando em uma participação do tipo 4 e na seguinte no tipo 7, para depois passar ao tipo 5 , por exemplo.

O planejamento de um processo de abordagem educomunicativa que resulte em transformação social a partir de práticas que considerem a participação protagonista de crianças e jovens, demanda uma definição de qual o tipo de participação desse público, sendo que a clareza sobre isso mostrará quais os tipos de ações eles realmente precisam desempenhar. Assim, há como estipular claramente quais competências poderão ser trabalhadas e fortalecidas ao longo dessas práticas.

Frente à realidade das situações de risco desses atores infantojuvenis no Brasil, Costa (2006) fez uma adaptação à proposta de Hart (1992), com a anuência deste último, no sentido de incluir mais dois tipos possíveis de participação, sendo que indico nesse quadro a partir de qual tipo de participação estou considerando como uma participação minimamente protagonista para efeito desta pesquisa.

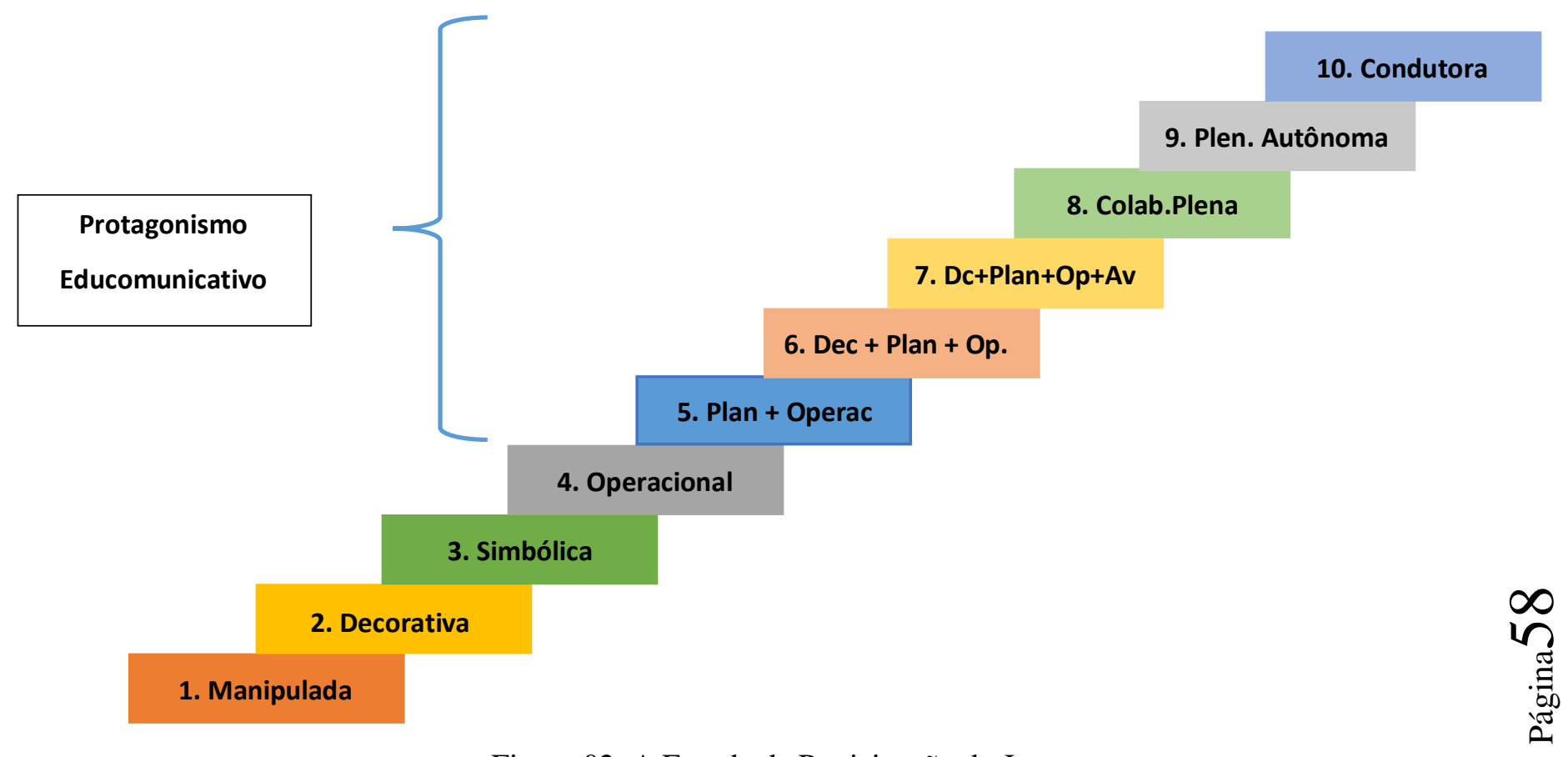

Figura 02: A Escada da Participação do Jovem

Fonte: COSTA, 2006, p.180-181 
1. Participação manipulada - Os adultos determinam e controlam o que os jovens deverão fazer numa determinada situação.

2. Participação decorativa - os jovens apenas marcam presença em uma ação, sem influir no seu curso e sem transmitir qualquer mensagem especial aos adultos.

3. Participação simbólica - A presença dos jovens em uma atividade ou evento serve apenas para mostrar e lembrar aos adultos que eles existem e que são considerados importantes. A participação é, ela mesma, uma mensagem.

4. Participação operacional - Os jovens participam apenas na execução de uma ação ou atividade.

5. Participação planejadora e operacional - Os jovens participam do planejamento e da execução de uma ação.

6. Participação decisória, planejadora e operacional - Os jovens participam da decisão de se fazer algo ou não, do planejamento e da execução de uma ação.

7. Participação decisória, planejadora, operacional e avaliadora - Os jovens participam da decisão, do planejamento, da execução e da avaliação de uma ação.

8. Participação colaborativa plena - Os jovens participam da decisão, do planejamento, da execução, da avaliação e da apropriação dos resultados.

9. Participação plenamente autônoma - Os jovens realizam todas as etapas.

10. Participação condutora - os jovens além de realizar todas as etapas, orientam a participação dos adultos.

Figura 02A: A Escada da Participação do Jovem (Legendas Degraus)

Fonte: COSTA, 2006, p.180-181

Ao refletir sobre as premissas anteriormente apontadas do campo emergente da Educomunicação, a partir das questões colocadas por Dewey (1976a; 1976b) quanto à importância da experimentação de aspectos da vida nos espaços educativos e dos conteúdos teóricos, para entender e me apropriar desse processo, e com base nas colocações de Hart (1992; 2008) e de Costa (2006) sobre o que é participação protagonista e quais seus desafios, passei a compreender - ao menos conceitualmente - as razões do protagonismo ser um pressuposto para as práticas educomunicativas. Consegui entender ainda como as ações educomunicativas a partir do protagonismo, podem contribuir para trabalhar inúmeras habilidades e competências inerentes à cidadania.

A própria análise dos tipos de participação, contudo, já sinaliza que nem toda participação é, de fato, protagonista, e que, considerando a transformação social enquanto objetivo principal da abordagem educomunicativa, a partir da adoção de um processo de prática reflexiva para a conscientização e empoderamento do cidadão responsável, apenas os tipos de participação 
descritos a partir do degrau número cinco da proposta de Costa (2006) refletem o que seria considerado como protagonismo educomunicativo.

Hart (1992) reflete que não necessariamente há como implementar atividades relativas ao degrau dez de imediato, pois a própria participação implica em um processo de aprendizagem que se desenvolve como que uma espiral.

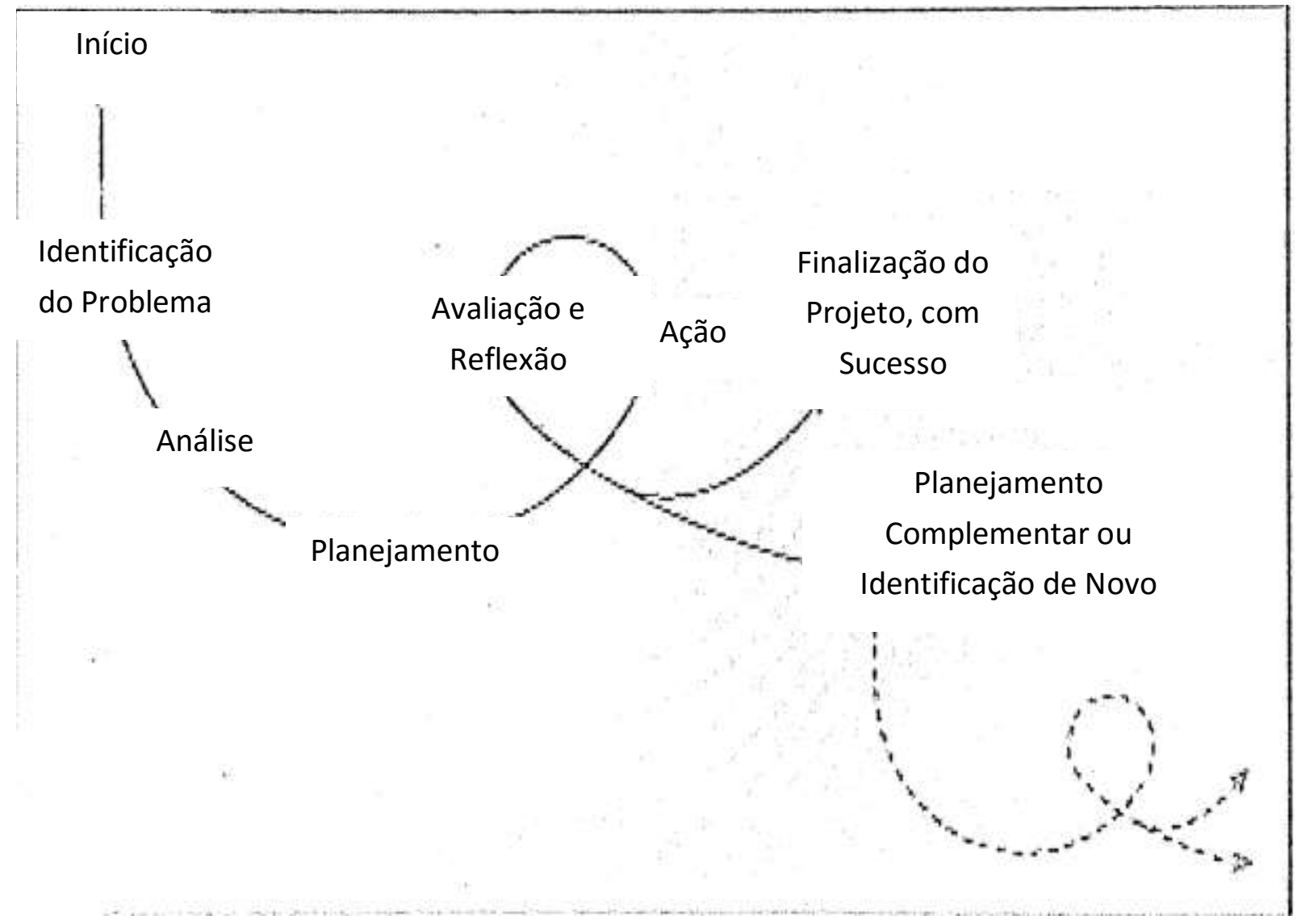

Figura 03: Espiral de Hart

Fonte: Roger Hart, 2008, pos. $2975^{24}$

Como as participações descritas a partir do degrau cinco não são tão comuns, mesmo por parte das crianças e jovens, as participações mais ativas com ênfase no protagonismo demandam um período de aprendizagem sobre como agir durante as mesmas, tanto pelos educadores mediadores dos processos, como pelos próprios alunos, para realmente compreenderem a importância dessa participação e apreenderem a experiência em todo seu significado.

Aprofundando a literatura sobre o protagonismo, localizei na atualidade outra especialista em práticas infanto-juvenis na pessoa da Prof. Dra. Malak Zaalouk, egípcia com formação em

\footnotetext{
${ }^{24}$ Tradução das legendas da espiral foram feitas por esta autora.
} 
Educação, Sociologia e Antropologia. Zaalouk atua como consultora sênior em educação para UNICEF, para as regiões do Oriente Médio e Norte da África. Zaalouk (2004). Foi uma das especialistas que acompanhou o processo de fundação de escolas comunitárias, do que resultou em uma consistente transformação social no Egito, entre os anos de 1990 e 2000: o empoderamento durante esse processo se desenvolveu a partir da adoção de práticas protagonistas dos alunos nas escolas das localidades de Asyut, Sohag e Quena, no Egito.

Há que se ter uma transformação profunda de entendimento sobre o que é aprendizagem já por parte dos gestores, coordenadores e professores envolvidos no processo, que precisam aprender e internalizar novos hábitos e crenças quanto ao que entendem por disciplina, controle, cooperação e cidadania ativa e crítica. Os alunos que vivenciam práticas que os auxiliam a estruturar e fortalecer um modelo de cidadania nessas bases acabam seguindo suas vidas com base no código de ética formulado nesse período. Nesse contexto:

\begin{abstract}
Equipes parceiras e cooperativas ajudam a criar esse ambiente. Os alunos são orientados para serem pacificadores. Nesse novo ambiente de aprendizagem os alunos aprendem como resolver seus próprios conflitos e também a mediar os conflitos entre seus colegas. Daí a disciplina em sala de aula e da escola ser baseada em desenvolver nos alunos as habilidades e competências necessárias para a resolução de seus conflitos interpessoais construtivamente. $\mathrm{O}$ foco é trabalhar para dentro, em vez de ser orientado para o exterior. O sistema disciplinar depende de os estudantes regularem suas próprias ações e ajudar seus colegas a fazerem o mesmo. (ZAALOUK, 2004, Pos 683)
\end{abstract}

Ao fazermos desaparecer as barreiras das hierarquias, permitimos que as pessoas se percebam enquanto colegas que podem compartilhar saberes para a construção de um bem maior para a comunidade. Esse contexto gera um ambiente de reflexão constante por parte de todos, sobre seus processos e suas conquistas, bem como um processo de busca constante para transformar a escola e a comunidade em melhores ambientes de convivência e aprendizagem.

O resultado desse processo é a formação de um novo perfil de líder comunitário, construtivo, que busca o atingimento de objetivos compartilhados por todos, pelo estímulo ao desenvolvimento de talentos criativos. O conhecimento é resultado de relações respeitosas criadas entre pessoas.

Essas relações formam um sistema social ecológico onde há interdependência, respeito, confiança mútua, e sempre, amor. A sustentabilidade desses sistemas confia 
na existência de uma construção conjunta de conhecimento e significado em torno de causas comuns. (ZAALOUK, 2004, pos. 744) ${ }^{25}$

Uma das propostas nas quais essa autora se baseia é a da Pedagogia da Libertação, de Paulo Freire, destacando que uma educação transformadora e libertadora só é viabilizada em ambientes dialógicos, estruturados a partir da revisão das relações e da criação de novas normas e significados sociais.

Lembro aqui que a proposta da Educomunicação emerge do desejo de um grupo de especialistas da comunicação e educação de promover a transformação social por meio de reflexões sobre os aspectos hegemônicos dessa região ibero-americana e para fazer resistência às influências culturais de países como EUA e Reino Unido, dentre outros, por conta da disseminação de ideias com o uso de inúmeros veículos de comunicação.

Sobre esse processo reflexivo quanto à educação para os meios de comunicação durante os anos de 1970, foram também as ideias resgatadas de Antônio Gramsci (1891 - 1937), filósofo marxista italiano, sobre hegemonia e ideologia, que deram sustentação a esse movimento. Gramsci (SIERRA, 2000) conferiu ao termo hegemonia um aspecto político ao defini-lo como o domínio de uma classe social sobre as outras, com o consentimento dessas. Ele apontou que consiste no poder que uma pessoa ou classe tem sobre outras, sendo que, considerando o contexto histórico em que vivia, ele se referiu especificamente ao domínio da burguesia sobre a classe trabalhadora. Ou seja, para esse filósofo italiano, quanto mais força tiver uma ideologia, mais firme será a hegemonia vigente e menor será a necessidade desse poder de fazer uso de recursos violentos para manter esse poder. Para ele, a hegemonia só se sustenta a partir da união da direção moral, intelectual e política.

Não pretendemos nos aprofundar no estudo específico das ideias desse filósofo, mas precisávamos resgatar as ideias sobre os termos hegemonia e ideologia que influenciaram Gramsci (SIERRA, 2000). Ele entendia a ideologia como um conjunto de ideias que norteiam uma sociedade, durante um determinado período de tempo, as quais são edificadas e disseminadas em nome do bem de todos, por um dado grupo. Quanto mais fortemente estabelecida e fortalecida for essa ideologia, mais forte será a dominação de uma classe social sobre as demais, maior será sua hegemonia.

\footnotetext{
${ }^{25}$ Tradução livre da autora do trecho: "Those relationships form an ecological social system where there is interdependence, respect, mutual trust, and often, love. The sustainability of such system relies on the existence of the joint construction of knowledge and meaning around common causes." (ZAALOUK, 2004, pos. 736)
} 
Gramsci (SIERRA, 2000) explicava que a hegemonia não deveria ser entendida como uma estratégia da burguesia, mas de uma classe qualquer que se organize para ter esse poder sobre as demais classes. Ou seja, para esse autor, a classe trabalhadora ou outras classes menos favorecidas também podem assumir esse poder, desde que considerem os interesses de outras forças e grupos sociais, com os quais possam integrar interesses comuns. Para que realmente ocorra uma mudança da estrutura desse poder para um modelo mais igualitário, é necessário que essas novas coalisões respeitem e permitam que cada grupo tenha sua própria participação ativa, com contribuições significativas e focadas no estabelecimento do bem comum da sociedade.

Ele refletiu também sobre o papel de crises orgânicas periódicas dos membros do grupo governante, que começavam a se desentender e a se desintegrar, o que propiciava a chance das demais classes se pronunciarem, por meio da criação de movimentos que desafiassem a ordem existente e hegemônica. Ele alertou, porém, que não necessariamente haveria uma mudança de poder, caso a oportunidade não fosse aproveitada por esses outros grupos, o que converge para as ideias de Paulo Freire, sobre a necessidade de cuidar para que o oprimido não se torne simplesmente o opressor e vice-versa, e para que outra - nova - estrutura de inter-relação seja desenvolvida e estabelecida entre todos na sociedade.

O empoderamento a partir da hegemonia nos permite entender seu objetivo maior, que consiste na conscientização dos membros da comunidade sobre o fato de que eles também podem ter poder nessa comunidade, e que podem e devem trabalhar conjuntamente com os demais membros da mesma, para o atingimento do bem comum.

Os aspectos básicos que caracterizam o processo de empoderamento são exatamente o poder e controle. Contudo, não estamos nos referindo à identificação específica sobre quem tem o poder e controle sobre uma maioria junto a uma comunidade, mas de trabalhar no sentido de mudar essa condição de controlador e controlado, para uma situação mais igualitária.

Ao refletir sobre a abordagem educomunicativa nos espaços educativos para trabalhar esse empoderamento, refiro-me a trabalhar processos junto ao público infantojuvenil dessas comunidades, de forma que esse se sinta pertencente a essas comunidades, bem como responsáveis, possibilitados de agir para o bem comum das mesmas. Trata-se de propiciar que eles vivenciem dentro dos próprios espaços escolares os desafios da comunidade da qual fazem parte, de maneira a se conscientizarem de que pertencem à mesma e que tem 
responsabilidades e direitos junto a ela. E que por isso devem assumir seus papéis de cidadãos juntamente com os demais membros dela.

O termo empoderamento passou a ser utilizado nos anos de 1970, em artigos sobre desenvolvimento sustentável, por acadêmicos das áreas de psicologia, sociologia, educação e pesquisas organizacionais. Está ligado a contextos que trabalham o desenvolvimento de soluções para situações de opressão versus oprimidos, controle e marginalização. Segundo Gutierrez (1990, apud FITZSIMONS ET AL, 2011, p. 5): "um processo de aumento de poder interpessoal ou político para que os indivíduos possam assumir ações para melhoria da sua situação de vida" 26 .

Considerando o que foi exposto sobre protagonismo, participação e empoderamento, apresento aqui alguns aspectos que considero como inerentes às práticas educomunicativas, os quais foram utilizados como indicadores em nossa pesquisa de campo:

a) tipo de participação: aquela em que o adolescente participa do planejamento, pelo menos, mas a qual pode chegar até o que Costa (2006) denomina de participação condutora - degraus seis a dez (COSTA, 2006);

b) temas trabalhados: temas que estejam ligados à realidade dos alunos, à escola e à sua comunidade de entorno;

c) públicos de interesse - stakeholders - envolvidos no processo: alunos, professores, gestores, funcionários das escolas e membros da comunidade de entorno.

\subsubsection{Diálogo e o Pensar Juntos}

Outro aspecto importante para a abordagem educomunicativa são as práticas dialógicas que permeiam os projetos protagonistas, e que contribuem inclusive para o enriquecimento do processo de aprendizagem. São exatamente essas dinâmicas de trocas reflexivas e críticas que, segundo Soares (1999), embasam o desenvolvimento e fortalecimento de ecossistemas comunicativos.

\footnotetext{
${ }^{26}$ Tradução livre desta autora, do trecho: “A process of increasing interpersonal or political power so that individuals can take action to improve their life situation" (GUTIERREZ, 1990, page 149, apud FITZSIMONS ET AL, 2011, p. 5)
} 
Daí dedicar este tópico ao esclarecimento do que chamo de diálogo reflexivo e crítico, passível de ser trabalhado nas práticas de abordagem educomunicativa. Para tanto, discorro sobre as ideias de Paulo Freire acerca do diálogo, para então finalizar com as reflexões e proposta metodológica de diálogo, de David Bohm.

Paulo Freire é considerado um dos principais educadores e filósofos brasileiros, cujas ideias são utilizadas na fundamentação da proposta do campo da Educomunicação. Uma de suas afirmações, que me faz refletir diretamente sobre as interfaces Comunicação-Educação, é exatamente a que ele afirma que educação é diálogo, é comunicação: “...não é transferência de saber, mas um encontro de sujeitos interlocutores que buscam a significação dos significados" (FREIRE, 2002, p. 69).

Freire (2005) contestava a comunicação que se realizasse fora das premissas dialógicas, principalmente quanto às supostas conversações cujo objetivo fosse a imposição da ideia de um grupo, não permitindo reflexão mais aprofundada voltada a superar o que chamava de "falsa consciência do mundo" (FREIRE, 2005, p. 86). De fato, ele fazia uma forte crítica à educação verbalista, refletindo que o fazer educativo:

[...] que se limite a dissertar, narrar, a falar algo, em vez de desafiar a reflexiva cognosciva dos educandos em torno de algo, além de neutralizar aquela capacidade cognosciva, fica na periferia dos problemas. Sua ação tende à "ingenuidade" e não à conscientização dos educandos (FREIRE, 2002, p. 86). ${ }^{27}$

Ele foi um dos autores que apontou a predominância do que denominava de ação antidialógica junto à sociedade, a qual foca exatamente o processo de conquista e manipulação dos oprimidos, para manutenção do controle de uma minoria sobre uma maioria, utilizando-se de processos comunicacionais diversos e até perversos em vários momentos. Para tanto, ele destacou que os representantes dessas minorias opressoras utilizam-se de práticas diferentes, "das mais duras às mais sutis. Das mais repressivas às mais adocicadas, como paternalismo" (FREIRE, 2005, p. 157).

O objetivo dessas práticas é exatamente conquistar pela manipulação, por meio de mensagens que influenciem as ideias de um grupo de oprimidos para proveito próprio desses opressores. Daí a adoção de abordagens adocicadas, para uns, ou mais duras, para outros, sempre buscando manipular todos esses, dividindo-os e enfraquecendo-os. A partir desse contexto, ele procura desvelar como esses opressores atuam no sentido de conquistar e manter o controle

\footnotetext{
${ }^{27}$ Grifo do autor.
} 
sobre tais oprimidos, fazendo com que muitos deles passem a ser defensores incontestáveis da proposta desses opressores, sem se aperceberem da manipulação contida nesse processo. Ele refletia que:

Todo ato de conquista implica um sujeito que conquista e um objeto conquistado. $\mathrm{O}$ sujeito da conquista determina suas finalidades ao objeto conquistado, que passa, por isto mesmo, a ser algo possuído pelo conquistador. Este, por sua vez, imprime sua forma ao conquistado que, introjetando-o, se faz um ser ambíguo. (FREIRE, 2005, p. 157)

O termo ação antidialógica surgiu exatamente pelo fato de que a construção de contextos com tais características se dá a partir da instauração de processos comunicacionais que inibem o diálogo, as trocas reflexivas e críticas sobre aspectos diversos da sociedade. Freire (2005) explicava que os opressores trabalham em várias frentes junto aos oprimidos, no sentido de aniquilar nestes últimos a capacidade de olhar para o mundo com atenção e de analisá-lo e criticá-lo propositadamente. A necessidade de conquista permeia toda essa ação antidialógica.

Foi exatamente para enfrentar esse modelo que ele apresentou sua proposta da Pedagogia da Libertação ou Emancipação, como uma opção para acabar com essa relação opressor oprimido. Para ele, o conhecimento consistente sobre algo se estrutura a partir de intensa reflexão conjunta sobre a solução para um problema acerca de um tema qualquer em estudo.

Freire (2005) defendia que, para que essa intensa reflexão conjunta ocorra em um determinado espaço escolar - ao qual chamamos aqui de ecossistema comunicativo de trocas dialógicas intensas -, faz-se necessário que educador e educando estabeleçam um processo comunicacional de igualdade, no qual as ideias e opiniões expressadas por todos sejam tratadas de forma igualitária quanto à sua relevância para a solução daquele problema. Todas essas ideias devem ser ouvidas e analisadas por todos conjuntamente para que a solução obtida defina ações para o bem comum. Ele defendia o que chamava de uma educação problematizadora:

o educador já não é o que apenas educa, mas o que, enquanto educa, é educado, em diálogo com o educando que, ao ser educado, também educa. Ambos, assim, se tornam sujeitos do processo em que crescem juntos e em que "os argumentos de autoridade" já não valem. Em que, para ser-se, funcionalmente, autoridade, se necessita de estar sendo com as liberdades e não contra elas $^{28}$. (FREIRE, 2005 P79)

Para esse autor, não há como apresentar uma situação problema a alguém e simplesmente colocar-se no papel de um mero expectador desse processo de problematização, principalmente porque, para Freire (2005), essa situação problema não deveria se caracterizar

\footnotetext{
${ }^{28}$ Destaque e grifo do autor.
} 
como um entretenimento intelectual fora do contexto da realidade daquele educando, numa tentativa quase de negar a sua realidade. Pelo contrário, ele defendia que esse enfretamento da realidade deveria ser praticado já na sala de aula, pela prática de reflexões conjuntas estabelecidas a partir de trocas dialógicas entre os participantes - educandos e educadores -, para uma real libertação e humanização, para um verdadeiro domínio da cultura e da história. Para ele, é exatamente nos processos reflexivos e criativos que reside a força da práxis enquanto fonte de conhecimento.

Vale destacar que essa é uma das suas afirmações, na qual identifico a influência das ideias deweyanas, sobre as quais comentei no tópico sobre protagonismo, o que aponta para a sua ideia de que esses processos de participação com foco no protagonismo são passíveis de serem instalados a partir exatamente das trocas dialógicas com reflexões intensas.

Ele enfatizava também a necessidade básica de adequação dos símbolos e sinais a serem adotados nesse processo, de maneira que ocorra o entendimento por todos os participantes sobre o que está sendo refletido. Era a isso que ele se referia ao mencionar a significação e ressignificação de significados por sujeitos interlocutores, e não apenas por um sujeito e seus objetos. Ou seja, trata-se de planejar e implementar dinâmicas nas quais educadores e educandos sejam, ao mesmo tempo, emissores oradores e receptores ouvintes e reflexivos, alternadamente, exatamente para a construção consistente de novos significados comuns a todos.

Ele apontou para a complexidade desse contexto, indicando que um dos aspectos a serem trabalhados é exatamente a mudança de postura do educador, de senhor detentor de todo saber, para uma figura até mais humana, falível, dialógica e desejosa de compartilhar seus saberes e aprender novos com os próprios educandos. Ele lembra que os alunos não são uma tábula rasa e que, mesmo considerando a capacidade deles de leitura do mundo por conta de suas respectivas faixas etárias, eles já trazem conhecimentos próprios sobre inúmeros contextos. Referências internas, saberes e experiências que devem ser considerados nas dinâmicas escolares.

Freire (2005) defendia que cada educador deve rever constantemente suas próprias práticas, para colocar-se mais como um mediador dos processos pedagógico-comunicacionais, e se afastar do papel de um transmissor de conteúdos, que oprime seus alunos com suas próprias 
leituras do mundo e pontos de vista, sem espaço para reflexões ou contribuições de e com terceiros.

Há, porém, o risco de implementação de falsas práticas dialógicas, que podem resultar na imposição de ideias e consequente manipulação dos participantes. Ele fala da necessidade de um diálogo real, que permita uma clara e consistente troca de ideias e impressões de todos os participantes, e a respectiva reflexão sobre as mesmas, sem indícios de imposição de ideias ou do que ele chama de ações do opressor sobre oprimidos.

Apesar de Freire (2002) ter sido o Secretário Municipal de Educação de São Paulo, que deu início ao processo de implantação dos primeiros laboratórios de informática desse município nas escolas da rede municipal de ensino, ele não chegou a viver para ver as transformações que a adoção da internet e dos recursos comunicacionais digitais têm provocado na sociedade e mesmo nos espaços escolares.

Contudo, já nos anos de 1980, ele começou a se interessar pelos efeitos que programas veiculados em televisão, rádio e cinema começavam a gerar nas crianças. Exatamente por se dar conta do significativo desenvolvimento e facilitação de acesso a esses recursos comunicacionais, bem como a consequente rápida disseminação desses meios pela sociedade, ele alertou para a necessidade crescente de trabalharmos nas escolas dinâmicas voltadas ao desenvolvimento de competências ligadas à leitura crítica desses meios de comunicação.

Ao contrário do que era feito por muitos professores que evitavam trabalhar com esses recursos alegando os danos que as mensagens divulgadas por meio deles poderiam causar à educação das crianças e jovens, Freire (2002) defendia que esses meios de comunicação fossem realmente adotados nas salas de aula, mas a partir de dinâmicas que fomentassem competências ligadas à leitura crítica dos meios nos alunos.

Ou seja, isso o levou a refletir sobre quais deveriam ser as habilidades a serem trabalhadas pelos educadores com seus educandos durante as práticas nos espaços escolares, para que então esses educadores pudessem planejar, implementar, mediar e avaliar esses processos educacionais com intensas trocas dialógicas, voltadas à leitura crítica dos meios. Foi com base nesse contexto, que Freire (2002) propôs o planejamento e implementação de atividades que transformassem as salas de aula em espaços dialógicos, as quais viabilizassem o 
desenvolvimento de trocas reflexivas intensas e do pensamento crítico, práticas essas que poderiam também trabalhar a questão da leitura crítica dos meios.

Estudo desenvolvido sobre a obra de Paulo Freire (TORRES \& MORROW, 2002) indica que ele destacava exatamente a complexidade de se trabalhar a sua proposta de Pedagogia da Libertação, visto que ele entende que os processos dialógicos reflexivos e críticos não são naturais do ser humano e precisam ser trabalhados, desenvolvidos e fortalecidos durante toda a vida humana. O olhar político desse autor destacava o interesse da minoria governanteopressora em manter as massas-oprimidos longe desse tipo de práticas, até para que eles não pudessem desenvolver esse olhar crítico em relação à sociedade e aos próprios processos de opressão aos quais estavam sendo submetidos.

Ao analisar estas ideias de Freire $(2002 ; 2005)$ enquanto algumas das bases de fundamentação teórica para a Educomunicação, passei a compreender mais claramente os objetivos desse campo emergente quanto ao empoderamento do processo comunicacional pelas crianças e jovens já nos espaços escolares, para formação de cidadãos responsáveis e críticos.

A proposta de trabalhar a práxis da gestão comunicacional integrada à práxis pedagógica, a partir das premissas da abordagem educomunicativa, parece permitir a viabilização do planejamento e implementação dos processos propostos por esse autor, exatamente por meio da adoção obrigatória de práticas protagonistas vivenciadas pelas crianças e jovens, focadas na vivência e no exercício dessas trocas dialógicas nos espaços escolares, sobre aspectos das comunidades de entorno desses locais.

David Joseph Bohm (1916-1992) é outro autor cujas ideias muito têm contribuído para a sistematização mínima e viabilização desses processos comunicacionais dialógicos, recentemente utilizados pelo movimento de Cultura da Paz, da UNESCO. Seus estudos e experiências científicas sobre Física Quântica o levaram a ter contato com as obras do filósofo indiano Jiddu Krishnamurti ${ }^{29}$, o que o fez refletir sobre a proximidade das suas próprias ideias científicas com as propostas filosóficas deste último. Tanto que em 1980, ele chegou a publicar texto que indicava as aproximações entre a física e a filosofia de Krishnamurti.

\footnotetext{
${ }^{29}$ Jiddu Krishnamurti (1895 - 1986) foi um educador e filósofo indiano, que trabalhou em suas reflexões temas sobre revolução psicológica, meditação, conhecimento, liberdade, relações humanas, a natureza da mente, a origem do pensamento e a realização de mudanças positivas na sociedade global.
} 
Essa sua experiência levou Bohm (2005) a questionar diversos aspectos da sociedade, como o próprio estado de sua fragmentação, e a propor uma técnica hoje conhecida como Diálogo de Bohm, a qual atualmente tem sido utilizada em práticas de movimentos ligados à cultura da paz, como destacado anteriormente, em vários países na Europa e mesmo no Brasil.

Ele refletia sobre as dificuldades que os indivíduos encontram nos dias atuais de se comunicarem, mesmo com todo desenvolvimento de aparatos comunicacionais que já estavam em curso no final dos anos de 1980. A internet já dava seus primeiros passos e acadêmicos de seu meio já começavam a traçar estimativas de usos e consequências desses aparatos.

Ao analisar essa fragmentação da sociedade como um todo, Bohm (2005) apontava que esse contexto ocorre porque durante uma conversa, as pessoas estão mais preocupadas em defender suas próprias ideias e conteúdos, do que ouvir as fundamentações e argumentações dos outros, para criação de propostas novas, originadas de um processo comunicacional de pensar juntos. Ele apontava a postura da grande maioria, de acusar o outro de ser surdo e preconceituoso às suas ideias e reflexões, sem se preocuparem de eles mesmos ouvirem atenta e cuidadosamente as proposições desse "outro". E que esse seria um dos grandes obstáculos à concretização da cooperação e colaboração entre os indivíduos que atuam em uma comunidade.

Bohm (2005) refletia que cooperar consiste na estruturação de grupos de pessoas para trabalharem conjuntamente na criação de algo novo ou mesmo na solução de problemas em uma comunidade, com o objetivo do bem comum. Ele explicava que a técnica de diálogo que ele propunha não era algo intuitivo e imediato, mas que demandava prática, observação e cuidado de todos os participantes durante o desenvolvimento desse processo dialógico.

Sua proposta nasce da palavra diálogo, que tem sua origem no termo em grego dialogos (dia = através; $\operatorname{logos}=$ palavra ou significado da palavra):

\footnotetext{
O retrato ou imagem sugerido por essa derivação é o de uma corrente de significados que flui de nós e por nosso intermédio; que nos atravessa, enfim. Esse fato tornará possível o fluxo de significados na totalidade do grupo, e daí podem emergir compreensões novas. [ ... ] Esse significado compartilhado é a "cola" ou amálgama que mantém juntas as pessoas e as sociedades. (BOHM, 2005, p. 34)
}

Segundo Bohm (2005), o diálogo pode ocorrer mesmo com uma só pessoa que apresente essa prática dialógica consigo próprio, quando do seu contato com novas ideias.

Para esse autor, o processo dialógico consiste em um encontro direto entre indivíduos que procuram pensar juntos temas diversos, inclusive a resolução de problemas, durante o qual 
esses participantes não buscam vencer uns aos outros, mas encontrar soluções conjuntas com as quais todos vençam: “o diálogo é mais uma participação, na qual não jogamos uns contra os outros, mas com cada um deles" (BOHM, 2005, p. 35).

Um grupo de indivíduos que se reúne para trabalhar juntos, a partir do diálogo, sobre um determinado tema referente à sua comunidade de interesse, até busca esse objetivo. Contudo, esse grupo tem um grande desafio que é superar sua própria vivência comunicacional de negociação de trocas, prática essa que acaba limitando esse grupo de colaboradores e levandoos a não praticarem o diálogo que ele define como pleno, de pensarem, refletirem e agirem conjuntamente.

Sua abordagem defende o fato de que os participantes precisam cuidar para que não haja uma autoridade que conduza as ideias e discussões do grupo, para uma conclusão de seu interesse e ponto de vista, para que não haja uma limitação das pessoas a meros ouvintes. Esse autor refletia que as pessoas estão muito acostumadas a praticar o trade-off, que são negociações, ao longo das quais há inúmeros choques de opiniões, tendo como resultado a vitória e imposição das ideias e propostas do mais forte. E alerta para a dificuldade que cada um tem de passar dessas práticas para o diálogo enquanto pensar juntos.

Um aspecto que conta muito para a viabilização desses processos dialógicos é o número de pessoas que compõem o grupo, pois quanto menos pessoas, mais simples e fácil são as trocas reflexivas. Porém quando estamos tratando de grupos maiores, as divergências entre os participantes tendem a se acentuar e o processo fica cada vez mais difícil.

Ele alertava para o fato de que pensar juntos é diferente de pensar igual. Ou seja, o processo dialógico de pensar juntos implica em ouvir as ideias do outro - que normalmente diferem das suas próprias -, refletir sobre as mesmas com base nas suas referências internas e apresentar nova devolutiva, sobre elas, agora considerando também seu próprio contexto, para que o outro realize esse mesmo procedimento reflexivo.

Exatamente pelo fato de estarmos mais acostumados a discutir e negociar, que há a necessidade de encararmos a implementação de um processo dialógico em fases, nas quais os participantes iniciam com discussões, mas aos poucos, com a ajuda de um mediador, eles vão modificando a postura, no sentido de ouvirem e realmente refletirem sobre o que está sendo 
apresentado pelos demais participantes. Observe que falo em um mediador e não em líder, com um objetivo específico, diferente da busca de um senso comum.

Muitos desses processos iniciam com esses procedimentos de trade-off, mas aos poucos, com a ajuda de um mediador experiente, os participantes começam a ser instigados a reverem seus pressupostos e a desejarem realmente conhecer e entender o que está na mente dos demais. As premissas do Diálogo de Bohm (BOHM, 2005) alertam para o fato de que os pressupostos de alguns dos participantes podem se chocar com os pressupostos de outros, sendo que esse choque pode gerar irritação e confrontos que podem comprometer o desenvolvimento do processo dialógico, caso isso não seja cuidado. As pessoas devem se manter abertas a novos olhares e evitar se irritarem com esse tipo de colocações: "a negociação implica encontrar uma forma comum de prosseguir" (BOHM, 2005, p. 52)

Essa postura remete a uma nova fase: a de escuta. Ou seja, após um instante de negociações, com a ajuda desse mediador, os participantes passam a um estado de ouvirem, assistirem e observarem mais uns aos outros. Nesse momento, eles começam a se atentar para o processo real do pensamento reflexivo que vai se desenvolvendo à forma e ordem em que ele ocorre. Falo aqui de modificar a atitude imediata, de provocar mudanças, para prestar atenção a tudo que está sendo dito e feito.

As dificuldades de expressão das pessoas quanto às suas ideias ou mesmo dos conflitos entre as argumentações de cada um promove o pensar colaborativa e coletivamente para o entendimento mútuo. Bohm (2005) coloca que no diálogo enquanto pensar juntos o compartilhamento de opiniões deve ser feito sem hostilidade, para o desenvolvimento de um exercício mais complexo:

Temos que compartilhar nossa consciência e nos capacitarmos para pensar juntos, para fazer o que for necessário de uma forma inteligente. Se enfrentarmos o que ocorre num grupo de diálogo, compreenderemos o núcleo do que acontece no todo da sociedade. Sozinho, você perde muito de tudo isso; mesmo em duplas, não se consegue realmente chegar ao ponto central. (BOHM, 2005, p. 47)

É preciso aprender a sair do que o autor chama de automatismo concordo-discordo e se permitir conhecer e considerar outros olhares e possibilidades. Exatamente por reconhecer e entender a dificuldade da prática dialógica enquanto pensar juntos foi que ele propôs o quadro abaixo, o qual apresenta uma síntese dos aspectos que devem ser cuidados quando de uma prática comunicacional, para que os participantes dessa atividade realmente consigam passar de um contexto de discussão para um contexto verdadeiramente dialógico. 
Na prática as ações apresentadas no quadro, que caracterizam o debate e o diálogo, acabam por se mesclar e em alguns momentos as características apontadas para ambos se entremeiam e alternam. Porém é a falta da escuta e da reflexão sobre o que ouve e tendência a não se preocupar em entender o ponto de vista do outro, por exemplo, que acabam fazendo com que as pessoas debatam mais frequentemente e muito raramente dialoguem. Até porque é do processo de trade-off em si que as trocas reflexivas nascem e podem evoluir e passar ao diálogo. Porém dada a dificuldade das pessoas se aperceberem disso e tenderem a permanecer mais no debate é que ele estruturou o quadro 01, exatamente para deixar claro às pessoas sobre essas diferenças, para que consigam passar do debate para o diálogo com mais frequência.

\begin{tabular}{|c|c|}
\hline DISCUSSÃO / DEBATE & DIÁLOGO \\
\hline Visa fechar questões & Visa abrir questões \\
\hline Convencer & Mostrar \\
\hline Demarcar posições & Estabelecer relações \\
\hline Defender ideias & Compartilhar ideias \\
\hline Persuadir e ensinar & Questionar e aprender \\
\hline Explicar & Compreender \\
\hline Visa as partes em separado & Vê a interação partes / todo \\
\hline Descarta as ideias "vencidas" & Faz emergir ideias \\
\hline Busca acordos & Busca pluralidade de ideias \\
\hline
\end{tabular}

Neste momento resgato as ideias apresentadas aqui com base nos dois autores e nas premissas da Educomunicação para refletir especificamente sobre o que seria, então, o processo de trocas reflexivas que deveria ser instalado para observarmos práticas dialógicas nos ambientes educativos. E aponto alguns indicadores ligados a esta temática e o que estou considerando como práticas dialógicas de abordagem educomunicativa para a realização desta pesquisa de campo:
a) tipos de trocas comunicacionais reflexivas para o diálogo e seus momentos de escuta do outro;

b) definição dos critérios de avaliação das atividades desenvolvidas durante o desenvolvimento do projeto (rubrica); 
c) realização da avaliação entre pares ou autoavaliação, com base na rubrica do projeto (a qual possa ter sido desenvolvida ou não em conjunto, por todos os participantes do projeto - educandos e educador responsável);

d) definição das etapas do projeto;

e) distribuição e realização de tarefas entre os membros do grupo.

\subsubsection{Algumas Áreas de Intervenção: Leitura Crítica dos Meios, Gestão da Comunicação nos Espaços Educativos, Práticas Pedagógico-Comunicacionais}

Apresentei, então, que atualmente já foram identificadas sete possíveis áreas de intervenção social. Ao refletir sobre quais seriam as possíveis áreas de intervenção, a partir das quais poderia verificar pontos comuns entre a Educomunicação e uma proposta de avaliação formativa, focada no processo, considero que há pelo menos duas possibilidades: leitura crítica dos meios e gestão da comunicação nos espaços educativos. Frente a isso, dedico este tópico a explicar algumas das razões delas serem consideradas como possíveis áreas de intervenção por meio de práticas educomunicativas.

Além disso, nas minhas pesquisas teóricas e no campo identifiquei aspectos que me levaram a uma releitura sobre como podem e devem ocorrer as práticas educomunicativas no espaço da didática, a qual vem sendo nomeada de pedagogia da comunicação. Admito que já apresentava questionamentos e certa resistência em aceitar tal denominação, por considerar que, de certa forma, ela limita a abrangência dessa área de intervenção. Com as observações e verificações feitas neste estudo, eu acabei convencida que o termo práticas pedagógicocomunicacionais parece mais apropriado do que pedagogia da comunicação, sendo que no item B deste tópico, eu apresento as justificativas para essa colocação.

A sociedade atual apresenta um cenário caracterizado pela existência de sujeitos assumindo os papéis de atores e receptores simultaneamente e fazendo uso das TIC, principalmente das disponíveis na internet para emitirem suas informações e ideias. Mais do que isso, aumenta a 
cada dia a dificuldade de verificação da veracidade da informação obtida, principalmente pelo excesso de canais pelos quais ela é disseminada.

Esse contexto altamente tecnológico tem gerado questionamentos e transformações profundos também por conta da dificuldade que vínhamos encontrando quanto ao entendimento sobre a ocorrência dos processos comunicacionais, sendo que Adilson Citelli (2006), doutor em Literatura Brasileira, especialista na inter-relação Comunicação-Educação, e livre docente na ECA/USP, destaca que:

[...] o discurso elaborado resulta de um ponto de vista, foco de visão, compreensão, ideologia, acerca das diferentes circunstâncias objetivas e subjetivas, materiais e imateriais, intuitivas e racionais que matizam a vida e a experiência dos sujeitos enunciadores. Eis o motivo pelo qual a linguagem, a seu modo, evidencia a fabricação/construção/reelaboração de um conjunto de eventos, experiências, percepções, de quem se envolve na produção dos textos. Neste âmbito, o "real" disponibilizado por um autor é uma forma de relato, sobre o qual o leitor/ouvinte/interlocutor/co-enunciador estabelece os seus próprios procedimentos intelectivos, suas formas de ver e perceber os enunciados que lhes chegam. Os discursos, quando entram em circulação social, e para ganharem sentido, acabam cruzando duas instâncias internectivas: uma que deriva dos processos de apreensão promovidos pelos enunciadores, outra, dependente dos destinatários. Isto é, juntamente com a montagem do texto advém não apenas um assunto ou tema, mas, de mesmo modo, irrompem mecanismos de subjetivação das heterogeneidades que irão produzir o fato discursivo, estejam momentaneamente, ocupando o lugar de "autores" ou de "leitores". Como se percebe, os termos autoria e leitura são intercambiáveis indicando sujeitos em ação sobre a linguagem, que elaboram/negociam a construção de campos de sentidos. ${ }^{30}$ (CITELLI, 2006, p. 171)

Há um aspecto que se torna cada vez mais preocupante, que é o resultado que cada uma dessas disseminações de mensagem pode gerar a partir da forma como uma dessas linguagens foi utilizada para significar e ressignificar uma determinada mensagem.

A adoção intensa de diversos aparatos comunicacionais em várias áreas da sociedade tem gerado uma preocupação quanto ao uso das mesmas e respectivos efeitos que essa utilização pode ocasionar. Alertar para esse fato não é tarefa fácil, pois não se trata de simplesmente apontar essa necessidade em um livro ou palestra, mas de realmente conseguir fazer com que os usuários desses aparatos entendam, aprendam e desenvolvam o hábito de realizar a leitura crítica quanto aos objetivos inseridos nas transmissões de informações diversas por meios desses inúmeros canais de comunicação (SOARES, 2011).

Todos esses aspectos que vim trazendo até este momento me fazem deduzir que o desenvolvimento de leitura crítica dos meios a partir de práticas educomunicativas implica em

\footnotetext{
${ }^{30}$ Destaques em haspas feitos pelo autor.
} 
estruturar atividades focadas no protagonismo, as quais permitam que esses atores sociais possam vivenciar minimamente planejamento, implementação, acompanhamento e avaliação dos processos necessários ao desenvolvimento de um projeto temático que faça uso de mídias convergentes. Todas essas várias habilidades e competências $^{31}$, por sua vez, estão ligadas diretamente ao processo de formação do cidadão responsável e crítico, sobre como uma mensagem pode ser trabalhada e manipulada - por meio do uso de símbolos, signos e linguagens diversas -, visando um objetivo prévio.

Esses espaços educativos apontam para a necessidade de dinâmicas que permitam aos alunos registrarem suas contribuições e reflexões em várias linguagens, por meio do uso de mídias diversas, de maneira a já desenvolverem e fortalecerem o que chamo de competência de leitura crítica dos meios de comunicação.

Essas dinâmicas permitem não apenas que as crianças e jovens aprendam o uso instrumental dessas tecnologias, mas principalmente que se deem conta dos objetivos contidos em cada mensagem transmitida pelos diferentes canais de comunicação. Essas atividades de produção e transmissão de mensagens, por meio de linguagens e mídias diversas, permitirão que esses atores sociais se apropriem, se conscientizem e desenvolvam uma criticidade quanto à forma como esses aparatos podem ser utilizados e como uma mensagem pode ser trabalhada, para que ela seja recebida e entendida pelo receptor, com um significado o mais próximo possível do que o emissor pretendia que fosse entendida.

Aqui eu me refiro exatamente ao que Freire $(2005$; 2002) falava quanto a permitir que os indivíduos voltem a olhar para o mundo e a refletir criticamente sobre o que está se desenvolvendo ao seu redor.

Soares (2009) alerta para o aspecto político do ato de trabalharmos o planejamento e implementação de uma comunicação, qualquer que seja seu conteúdo. Para ele, todo plano comunicacional é desenvolvido a partir do objetivo de quem emite a mensagem, que justifica sua elaboração. Ou seja, dependendo de qual ideia um determinado grupo deseja não simplesmente informar, mas principalmente comunicar a um público específico, será a partir da mesma que se trabalhará toda a gestão do processo comunicacional, muitas vezes independentemente das desigualdades ou manipulações sociais que possam estar contidas nesses objetivos.

\footnotetext{
${ }^{31}$ Conceito que será melhor esclarecido no Capítulo Dois.
} 
O entendimento sobre a importância desta área de intervenção passa pela conscientização de que atualmente vivemos um problema sério de incomunicação (WOLTON, 2006). Esse contexto demanda uma reflexão sobre a diferença entre os conceitos de Informação e Comunicação, dentre outros.

O aumento da facilidade de acesso ao uso dessas mídias e disponibilização de peças desenvolvidas em várias linguagens tem contribuído consideravelmente para o isolamento de algumas pessoas. Alguns autores, como Dominique Wolton, apontam que corremos um grande risco de estarmos nos comunicando muito menos até do que antes do surgimento de tais tecnologias. Ele reflete que esse contexto mostra a "fragilidade da comunicação que vai além de seu próprio triunfo" (WOLTON, 2006, p. 125).

Há uma complexidade muito maior na comunicação do que na informação, por conta de três razões: o ato de comunicar pressupõe o estabelecimento de uma relação nossa com o outro; há uma grande valorização da informação e um quase descaso com a comunicação, o que se caracteriza como uma contradição, posto que na prática nós buscamos nos relacionarmos/nos comunicarmos melhor com nossos pares; é a definição de um processo comunicacional que permite que a informação seja transmitida, interpretada e assimilada.

O direito à comunicação sempre foi um tema polêmico, principalmente durante o final do século XIX e ao longo do século XX. O surgimento de veículos de comunicação como rádio, televisão e cinema e o uso deles para diversos fins junto à sociedade como um todo, foi muito questionado por vários filósofos desses períodos, em função do controle de seus conteúdos estar concentrado nas mãos de uma minoria. Daí vários estudiosos sobre o tema terem feito estimativas de que o surgimento da internet viabilizaria uma grande conquista democrática da comunicação. De fato, atualmente os diversos canais ali existentes apresentam meios de trocas comunicacionais com total liberdade de expressão e de acesso à informação.

Ainda assim, Wolton (2006) observa que o processo da incomunicação entre as pessoas parece estar se instalando dia a dia. $\mathrm{O}$ advento da internet e todos os recursos comunicacionais disponíveis principalmente nas redes sociais, viabilizou e intensificou a possibilidade de expressarem e defenderem suas ideias e posições em comunidades com interesses cada vez mais específicos, com posições bem rígidas em alguns casos, o que tem resultado em uma segregação e não em uma integração, como vários supunham que ocorreria. Somos solicitados a fazer uma escolha entre o que esse autor aponta como identidade cultural refúgio, 
estruturada no entrincheiramento, e como identidade cultural relacional, que se permite dialogar com outras culturas que a cercam, para uma revisão e atualização constante das ideias frente às transformações que ocorrem na sociedade.

Pensar essas possibilidades a partir da Educomunicação é refletir sobre a opção de trilhar o percurso da identidade cultural relacional, e esse autor destaca exatamente as dificuldades da vivência da mesma pela sociedade como um todo. Isso porque a escolha dessa opção implica em ouvir e refletir sobre um excesso de informações, com grande possibilidade de maiores confrontos, o que tem resultado no conformismo.

A sociedade vivencia atualmente um momento paradoxal, posto que, apesar de uma maior disseminação de informação, o desconhecimento sobre como se comunicar e dialogar reflexiva e criticamente tem feito com que as pessoas prefiram se acomodar nos nichos e comunidades com cujas ideias se identificam, deixando de lado a vivência de uma maior diversidade.

A própria velocidade com que a informação tem que ser propagada pela rede tem provocado uma superficialidade sobre como as pessoas lidam ela. A intensa demanda pela agilidade faz com que a complexidade dessa informação seja desconsiderada e muitos fatos importantes sejam descartados, fomentando a desinformação e intolerância.

Wolton (2006) postula que a disponibilização excessiva de informações, em termos de canais e conteúdos - o que ele chama de onipresença da informação -, torna o desenvolvimento do processo comunicacional mais difícil de ser concretizado. $\mathrm{O}$ atual grande desafio é fazer exatamente a gestão do referido processo por meio do uso das diferentes linguagens, religiões, políticas, filosofias e culturas, para que esses vários receptores assimilem a informação que desejamos.

Informação consiste em conteúdo e dados a serem transmitidos a um ou mais receptores. Comunicação pressupõe o estabelecimento de relações, compartilhamento de ideias, convencimento e sedução entre duas ou mais pessoas. A Comunicação pressupõe ainda a negociação, posto que cada receptor tem seu entendimento do mundo e novas ideias e informações precisam ser avaliadas e negociadas a partir das referências internas - culturais, sociais, psicológicas - desses receptores. 
Wolton (2006) reflete que a incomunicação surge exatamente neste momento, como resultado desse processo de comunicação entre duas ou mais pessoas. Em um universo onde a grande maioria imagina que tudo está desvelado e aberto nesse espaço e que, consequentemente, todos sabem tudo, a pessoas acabam se tornando rígidas quanto às posições em relação às das pessoas ao seu redor, configurando essa incomunicação. Isso tem gerado uma convivência que deveria buscar a tolerância, mas que reflete esse contexto de não comunicação, não diálogo, não relação.

Há necessidade da busca da coabitação, a partir do respeito às e entre as diversas identidades culturais, por meio do diálogo. E alerta que essa coabitação não pode ser decretada, posto que não se trata de uma mera decisão política, mas de uma ação de toda sociedade, uma postura verdadeiramente cultural por parte de todos os envolvidos. Ou seja, há que se pensar nessa gestão da comunicação em diversos espaços públicos, para que o diálogo enquanto pensar juntos ocorra: "deve-se pensar hoje o universalismo em termos de diversidade cultural, de coabitação cultural e multiculturalismo" (WOLTON, 2006, pág. 214).

A adoção das tecnologias pode auxiliar de alguma forma vários processos de comunicação, mas essas por si só não resolvem a questão desse contexto de incomunicação humana e pode até amplia-lo.

As ideias de Wolton (2006) aqui apresentadas reforçam a necessidade de conhecer todo o processo comunicacional passível de ser desenvolvido nos espaços educativos, incluindo os aspectos sobre como e quais as influências que agem sobre o aluno quando esse está refletindo acerca de um determinado conteúdo. Isso permitirá planejar, implantar e avaliar ações comunicacionais que auxiliem na minimização e, em alguns casos, na neutralização dessa incomunicação humana a partir de negociações, de trocas dialógicas e reflexivas intensas, para que o ensino e aprendizagem de um determinado conteúdo realmente se concretize.

\section{A) Leitura Crítica dos Meios e Gestão da Comunicação nos Espaços}

\section{Educativos}

Sobre a leitura crítica dos meios, trata-se de defender a colocação das crianças e jovens como produtores de conteúdos diversos, de forma que eles aprendam como trabalhar a leitura crítica 
do tema em estudo em todo um processo de gestão da comunicação com o qual trabalharão. De fato, em 1999, os resultados do estudo do NCE indicaram que a gestão da comunicação nos espaços educativos é a área de intervenção social que permite estudar os aspectos de "planejamento, execução e avaliação das atividades destinadas a criar e manter ecossistemas comunicativos, entendidos como ambientes regidos pelo princípio da ação do diálogo comunicativo" (SOARES, 1999, p. 40).

Por outro lado, ao defender o trabalho de competências específicas em espaços educativos, eu me refiro a um outro aspecto da gestão da comunicação para a educação. Os educadores responsáveis pela formação dessas crianças e jovens devem atuar como mediadores dessas ações focadas no protagonismo, para promoverem e acompanharem as reflexões desses alunos e para ajustarem o foco quando e caso estes últimos se percam, para que não sejam direcionados e tolhidos em seus processos criativos.

As salas de aula presenciais nos dias atuais ainda apresentam boa parte de seus professores adotando práticas de aprendizagem tradicionais, do tipo "bancária", os quais não admitem serem questionados sobre o tipo de comunicação que realmente ocorre nesses espaços educativos. A possibilidade de registrar as contribuições dos alunos e as próprias intervenções dos educadores enquanto mediadores do processo de aprendizagem, por meio do uso de diversas linguagens, tem apontado para as dificuldades desse processo, inclusive quanto à clareza com que os professores se expressam nesses espaços educativos, e como isso impacta o resultado educacional almejado.

Anteriormente apontei que a Educomunicação tem como objetivo o empoderamento dos alunos quanto ao seu papel de cidadãos, por meio de vivências de práticas pedagógicocomunicacionais que se desenvolvem em ecossistemas comunicativos de trocas intensas, estruturados no diálogo e protagonismo dos mesmos. A gestão da comunicação nos espaços educativos mediados por tecnologias a partir dessas premissas busca também garantir o exercício pleno da comunicação entre os membros de uma determinada comunidade, e desta com os demais setores da sociedade, de maneira desenvolver e fortalecer a criatividade de todos os envolvidos e sob a orientação de educadores devidamente qualificados.

Castells (2013) é um dos filósofos da atualidade que tem se dedicado ao estudo da importância de dominarmos o processo comunicacional, uma vez que na sociedade altamente tecnológica em que vivemos, comunicação é poder: 
O processo de construção de significado opera num contexto cultural que é simultaneamente global e local e é caracterizado por uma grande diversidade. Há, no entanto, uma característica comum a todos os processos de construção simbólica: são em grande parte dependentes de mensagens e dos quadros criados, formatados e difundidos em redes de comunicação multimídia. Apesar de cada mente individual humana construir o seu próprio significado, interpretando os materiais comunicados nos seus próprios termos, este processamento mental é condicionado pelo ambiente de comunicação.

Além disso, neste novo mundo da autocomunicação de massa e de audiência altamente segmentada existem poucos casos de partilha de mensagens mediáticas em massa simultâneas, sendo que o que é amplamente compartilhado consiste em uma cultura de partilha de mensagens de media de vários emissores/receptores. Isso porque o novo sistema de comunicação é tão versátil, diversificado e aberto, e integra mensagens e códigos de tantas fontes, que abarca a maioria da comunicação socializada nas suas redes multimodal e multicanal. Portanto, se as relações de poder são construídas em grande parte na mente humana e se a construção de sentido na mente humana é essencialmente dependente dos fluxos de informação e das imagens processadas nas redes de comunicação, seria lógico concluir que o poder reside nas redes de comunicação e nos seus proprietários empresariais (CASTELLS, 2013, p. 548).

Esse autor fala sobre a necessidade de entendermos como funciona a disseminação da informação nessas redes e, com base nisso, de sermos capazes de antecipar possíveis efeitos que essa mensagem pode causar às mentes dos diferentes públicos de interesse. Ele não trata especificamente da educação, mas alerta para a importância de considerarmos tais aspectos dos usos das TIC na educação, no sentido de trabalharmos o tema nos espaços escolares.

Castells (2013) fala sobre as relações de poder existentes nas redes sociais, reconhecendo o que chama do poder dominante e um contrapoder, fazendo resistência à dominância, sendo que sua ideia converge com as colocações de Freire $(2005 ; 2002)$. E alerta para o fato de que a sociedade vive um momento em que o poder se traduz a partir de inúmeras relações, e, por meio dessas influencia valores e interesses, algo que Castells (2013) chama de batalha para dominar mentes. O poder é construído nas mentes das pessoas e saber trabalhar os processos comunicacionais para manter o poder e influenciar as pessoas de sua relação nessas redes é saber construir e fortalecer o poder.

Como destaquei, esse contexto de opressor e oprimidos não é um tema novo, posto que Freire (2005) já apontava a necessidade de trabalhar dinâmicas em sala de aula na qual todos tenham direito a verbalizar suas ideias e pensamentos e onde fossem ouvidos por todos esses participantes também, para que o grupo possa intervir colaborativamente para o bem comum da comunidade junto à qual vivem.

Sobre as práticas de gestão educomunicativa, considerando a visão e proposta do NCE, da ECA/USP, o compromisso do gestor da comunicação com a sociedade deve ser de: 
primeiro, que, ao planejar, tenha como referência a própria sociedade e suas necessidades à luz daquilo que o debate público em torno da realidade permite perceber; e, segundo, que crie mecanismos que lhe permitam ouvir audiências, garantindo uma maior participação possível dos interessados tanto na produção quanto na recepção das mensagens ou dos resultados de seu trabalho (SOARES, 2009, p. 37).

A gestão da comunicação nesses espaços educativos tem que focar na ampliação das “mediações sociais no ato de comunicar" (SOARES, 2009, p.37) ao longo dos procedimentos comunicacionais, para o atingimento dos objetivos de aprendizagem almejados.

Os alunos precisam vivenciar em seus espaços escolares práticas de produção e implantação de processos comunicacionais mediados por tecnologias, para que eles próprios entendam e apreendam como se dá esse processo de gestão da comunicação sobre temas diversos ligados à comunidade de entorno e à sociedade. Tais ações permitem o desenvolvimento de um olhar mais crítico e reflexivo em relação às mensagens que circulam por meio de tais aparatos, principalmente os digitais.

O empoderamento desses alunos quanto ao ato de se assumirem com direito a enviar mensagens por eles produzidas ou mesmo a responderem e/ou questionarem mensagens enviadas por outros utilizando meios de comunicação diversos nessas comunidades, passa por várias etapas de implantação, para que consigam desnudar e refletir sobre os objetivos até mesmo político das mesmas. Essas permitem também que eles reflitam e compreendam principalmente os aspectos ligados à dimensão e abrangência dos efeitos que essas práticas podem ter na sociedade.

Além disso, o educador responsável por acompanhar e mediar tais projetos com grupos de alunos deve ser ele próprio um gestor da comunicação nesses espaços, de maneira a ser capaz de atuar no fortalecimento das relações interpessoais entre seus alunos, para a construção de novos saberes, por meio da implementação de práticas pedagógico-comunicacionais, que façam uso de uma ou mais tecnologias da comunicação. Ele próprio precisa ser capaz de fazer as intervenções comunicacionais adequadas, no sentido de estimular a formação de ecossistemas comunicativos (SOARES, 1999).

Para Soares (2011), no contexto da Educomunicação, a gestão comunicativa de um ambiente educacional é estruturada com a interação dialética e dialógica entre as pessoas e a sua realidade, sendo que em todo esse processo os participantes assumem os papéis de emissores e receptores simultaneamente. 
Refiro-me aqui não ao mero uso instrumental das tecnologias, mas de uma interação orgânica dos alunos com os processos comunicacionais, por meio do uso de tais aparatos digitais, de maneira que aprendam o conteúdo principal em estudo enquanto desenvolvem outras importantes competências, como capacidade de comunicação eficiente, realização de trabalhos colaborativos e de diálogos reflexivos em equipe, dentre outras.

Anteriormente mencionei que a adoção da abordagem educomunicativa foca dinâmicas nas quais os jovens criam, planejam, implementam e avaliam todo processo comunicacional utilizado para transmitir um conteúdo qualquer, o qual vai ser desenvolvido e apresentado por meio de uma ou mais ferramentas de comunicação. Consequentemente, eles precisam pensar não apenas o conteúdo e a lógica da transmissão da mensagem que querem transmitir, mas também precisam considerar os sujeitos que as receberão e as influências culturais que mediarão tais recepções, dentre outros aspectos (SOARES, 2011).

Ao serem expostos a tais práticas, o objetivo é que esses alunos possam se apropriar da utilização dessas TIC, ao serem solicitados a planejar uma produção simbólica, voltada à transmissão de um conteúdo específico, que gere reflexão e promova a construção do conhecimento do mesmo. Além disso, os temas dos projetos são sempre ligados a desafios enfrentados pela comunidade de entorno do espaço escolar que necessitam de solução, de maneira a envolver o maior número possível de atores dessa comunidade, até para uma revisão conjunta dos valores de convivência que regem e estruturam a mesma.

\section{B) Práticas Pedagógico-Comunicacionais}

Como destaquei no início deste tópico, estou adotando o termo práticas pedagógicocomunicacionais em substituição ao que vem sendo denominado como pedagogia da comunicação para trabalhar as práticas educomunicativas no espaço da didática. Chamo aqui de práticas pedagógico-comunicacionais aos procedimentos comunicacionais que considero que devam ser adotados nos espaços educativos com mediação de TIC para a concretização e atingimento dos objetivos educacionais. Ou seja, planejamento das dinâmicas em sala de aula deve necessariamente considerar aspectos não apenas pedagógicos, mas principalmente comunicacionais para o seu desenvolvimento, sempre considerando a integração entre esses dois contextos. 
O que inicialmente me chamou a atenção sobre o tema foi a leitura de algumas das ideias de Jesus Martin-Barbero e de Adilson Citelli, sobre os processos comunicacionais que se desenvolvem entre os professores e seus respectivos educandos, durante o desenvolvimento de um determinado projeto.

Ou seja, exatamente sobre essa relação professor- aluno, Martin-Barbero reflete que:

O modelo predominante é vertical, autoritário na relação professor-aluno e linearmente sequencial no aprendizado. Introduzir nesse modelo meios e tecnologias modernizantes é reforçar ainda mais os obstáculos que a escola tem para se inserir na complexa e desconcertante realidade de nossa sociedade. Ao colocar como ponto de partida as mudanças que são necessárias à escola para que ela possa interagir com o país, e não simplesmente para a utilização dos meios de comunicação, estou enfrentando um mal-entendido que o sistema escolar não parece interessado em desfazer: a obstinada crença de que os problemas da escola podem ser solucionados sem que se transforme o seu modelo comunicativo-pedagógico, isto é, com uma simples ajuda do tipo tecnológico. E isso é um autoengano. Enquanto permanecer a verticalidade na relação docente e a sequencialidade no modelo pedagógico, não haverá tecnologia capaz de tirar a escola do autismo em que vive. Por isso, é indispensável partir dos problemas de comunicação antes de falar sobre os meios (MARTIN-BARBERO, 2011, p. 123).

O professor precisa, pois, transformar os processos comunicacionais da sala de aula a partir da instalação do que denomina de ecossistemas comunicativos, os quais se estruturam com base em dois tipos de dinâmicas:

... uma transformação nos modos de circulação do saber é uma das mais profundas transformações que podem sofrer uma sociedade. E é aí que se situa a segunda dinâmica que configura o ecossistema comunicativo no qual estamos imersos: o saber é disperso e fragmentado e pode circular fora dos lugares sagrados nos quais estava circunscrito e longe das figuras sociais que antes o administravam (MARTINBARBERO, 2011, P. 127).

Barbero (2011) explica como ele imagina que os processos comunicacionais deveriam ser modificados nos espaços educacionais de maneira a definir processos mais horizontais, o que implica uma mudança nas relações entre os próprios alunos e deles com seus docentes durante as atividades para a construção do conhecimento dentro e fora da sala de aula.

Na relação entre Educação e Comunicação a última quase sempre é reduzida à sua dimensão puramente instrumental. É deixado de fora o que é justamente estratégico pensar: que é a inserção da educação nos complexos processos de comunicação da sociedade atual, ou falando de outro modo, pensar no ecossistema comunicativo que constitui o entorno educacional difuso e descentrado em que estamos imersos. Um entorno difuso, pois está composto de uma mescla de linguagens e saberes que circulam por diversos dispositivos mediáticos, mas densa e intrinsecamente interconectados; e descentrados pela relação com dois centros: escola e livro que há vários séculos organizam o sistema educacional... (MARTIN-BARBERO, 1998, P. 215). 
Ao analisar a colocação desse autor frente às características básicas do paradigma da Educomunicação aqui já apontadas, e à colocação de Soares (2011) sobre a práxis social do diálogo enquanto pensar juntos, eu entendo que um espaço escolar pode ser definido como um ecossistema educomunicativo quando esse ambiente educacional - formal, não formal e informal - mediado por tecnologias da informação e comunicação se edifica por meio de ações de protagonismo dos sujeitos da educação, principalmente dos discentes envolvidos, estruturadas no diálogo enquanto pensar juntos, a partir de um consistente e intenso processo comunicativo de escuta, reflexão e devolutivas entre seus participantes com foco principal na construção e fortalecimento do conhecimento e pensamento crítico acerca do tema trabalhado, para a formação de cidadãos empoderados, ativos e propositivos.

Ou seja, aqui constato que não há tão somente uma indicação da necessidade de utilização instrumental das TIC, mas principalmente da criação de um novo ecossistema educomunicativo -, o qual somente emergirá e se fortalecerá com a criação de um ambiente mais dialógico e reflexivo, como também defendido por Soares (2011). Novamente, importante destacar que ao imaginar espaços com tais características, considero a mudança na própria forma como o próprio professor se comunica e interage com seus alunos nesses espaços.

A Prof. Dra. Maria Aparecida Baccega ${ }^{32}$ (2011) reflete sobre o fato de que as tradicionais esferas de socialização - escola e família - passaram a competir de certa forma com os meios de comunicação, que começa a se configurar como uma outra dessas esferas, no próprio espaço de estruturação e fortalecimento de valores dos sujeitos, influenciando na definição dos sentidos sociais. E esclarece que o embate se desenvolve exatamente nesse campo da Educomunicação, o qual busca o estabelecimento de uma relação dialógica entre todas essas esferas.

Ao falar em criar ecossistemas comunicativos para a educação em diversos espaços educação formal, não formal e informal - e pensar que são nesses ambientes que se

\footnotetext{
${ }^{32}$ Livre Docente em Comunicação, pela ECA/USP, está docente, pesquisadora e orientadora do Programa de Mestrado Comunicação e Práticas de Consumo, da Escola Superior de Propaganda e Marketing SP (ESPM-SP), desde 2003, do qual foi coordenadora adjunta de 2003 a 2007. Enquanto professora e pesquisadora da ECA/USP, ministrou graduação e pós-graduação stricto e lato sensu, além de ter sido chefe do Departamento de Comunicações e Artes (CCA), de 1992 a 1996, entre outros cargos. Fundadora e editora da revista Comunicação \&Educação (USP; Paulinas) de 1994 a 2003 da qual segue como membro do Conselho Editorial e da Comissão de Publicação. Coordenou a equipe fundadora do Curso de Gestão da Comunicação, tendo sido sua coordenadora, além de docente e orientadora, de 1993 a 2003.
} 
desenvolve o cidadão ativo, crítico e consciente de seus direitos e deveres, estou considerando trabalhar todo um processo comunicacional no ambiente escolar que vai muito além do que observamos hoje enquanto prática pedagógica em si.

Vale reforçar que me refiro aqui não a aspectos problemáticos da definição da ação pedagógica em si, mas aos procedimentos de implementação e vivência da mesma, os quais acabam por influenciar diretamente nos objetivos de aprendizagem atingidos, provocando muitas vezes a redução dos mesmos por depender exatamente de processos comunicacionais muito subjetivos e individualizados, inerentes a cada docente. Ou seja, uma mesma proposta pedagógica acaba por obter diferentes resultados em função da própria prática - ou ausência dela - de gestão da comunicação de cada docente durante a implementação da mesma.

Mais do que isso, estamos falando de uma "educação para a vida, do sabor da convivência, da construção da democracia, da valorização dos sujeitos, da criatividade, da capacidade de identificar para que serve o conjunto de conhecimentos compartilhados através da grade escolar". (SOARES, 2011, p. 45)

\begin{abstract}
A tecnologia também garante aos meios sua presença não só na edição do mundo, mas também a presença dessa edição nos contextos sociais dos alunos, professores, cidadãos em geral, independentemente de eles possuírem ou não aparelhos de mídia, uma vez que essa edição está presente nos interstícios da cultura que ela própria ajuda a construir, resultando novas possibilidades. Para dar conta dessa complexidade, o campo comunicação-educação obriga a inclusão de temas como mediações, criticidade, informação e conhecimento, circulação das formas simbólicas, ressignificação da escola e do professor, recepção, contextualização sociocultural da realidade, consumo/consumidor, entre muitos outros. (BACCEGA, 2011, p. 32)
\end{abstract}

A evolução e adoção intensa das diversas mídias está causando transformações profundas nessas interações e influenciando diretamente os comportamentos dos indivíduos, especialmente porque esses aparatos permitem uma imensa produção de significados compartilhados de uma forma jamais vista anteriormente. E isso, somado à pluralidade desses sujeitos, o que implica necessariamente na mudança das relações dentro dos próprios espaços educativos, entre todos os seus participantes, no sentido de preparar esses alunos enquanto cidadãos, para atuarem nesses novos contextos sociais.

Esse processo comunicacional precisa estar integrado com as premissas das ações pedagógicas adotadas, mas precisa ter um planejamento e escopo que transcendam as fronteiras dessas práticas e consigam prever inclusive possíveis desdobramentos de seu processo, considerando um contexto muito mais amplo, complexo e dinâmico que a própria prática pedagógica, que 
até então vem sendo praticada, propõe e abarca. Trata-se do que Paulo Freire colocava como “estar no mundo e com o mundo”. É papel da Educomunicação: “[...] levar a saber ler e interpretar o mundo que, metonimicamente, nos é passado como sendo a totalidade e conseguir reconfigurar essa totalidade, partindo da sua materialidade, e não a partir de nossos desejos, por mais nobres que sejam”. (BACCEGA, 2011, p. 36).

Citelli (2004) já alertava para essa nova necessidade, que identificou nas pesquisas realizadas em espaços educativos. Ele fala de um "espaço de passagem” nesses ambientes educativos (CITELLI, 2004, p. 210), no qual há várias mudanças ocorrendo em termos de busca por um novo modelo de escola, mas que ainda não foi claramente identificado, dada a complexidade do contexto educacional e do número de variáveis envolvidas, provenientes de diversas áreas.

Tanto Citelli (2004), como Martin-Barbero (2005), Baccega (2011) e Soares (2011) apontam o fato de que os educadores identificam o surgimento desses novos canais de fontes para o conhecimento, que não se limitam mais aos espaços escolares, reconhecem a necessidade de modificarem sua abordagem em sala de aula, mas encontram grandes desafios para transformar tal contexto, que implica em inúmeras variáveis, como o próprio conhecimento sobre como lidar com todos esses aspectos comunicativos que passam a influenciar esse ambiente educativo.

Aqui destaco as reflexões a partir de John Dewey, Paulo Freire, Célestin Freinet, Antônio Carlos Costa e Roger Hart, dentre outros, sobre a necessidade de planejamento e implementação de práticas pedagógicas que sejam executadas paulatinamente para que todos os participantes - alunos e professores, no contexto da educação formal, por exemplo aprendam por meio da vivência, sobre como trabalhar práticas colaborativas dialógicas e reflexivas, sobre um ou mais temas em estudo.

Percebo que a execução do planejamento pedagógico depende direta e totalmente dos procedimentos comunicacionais adotados nesse processo de implementação, o que me sinaliza para a necessidade também de um planejamento da gestão desses procedimentos comunicacionais de forma integrada ao primeiro, uma gestão que foque exatamente na viabilização de processos mais reflexivos a partir do desenho de atividades que permitam exatamente as mudanças de relações nesses espaços. 
Apesar de atualmente vislumbrar inúmeros exemplos de experiências voltadas a definir um novo modelo de escola, ainda há uma questão básica:

[...] O sujeito-educador, saído de um instituto superior ou de algum curso para o magistério que se resumiu a prepara-lo para o trabalho com o texto verbal, está, agora, diante de uma nova rede discursiva e de desafios práticos que lhe sugerem problemas com os quais não está em condições de operar. Com a clareza de quem enfrenta a estrada fechada em dia de nevoeiro, o docente busca encontrar o caminho. (CITELLI, 2004, p. 222)

Mais do que destacado por Martin-Barbero (2003), sobre a necessidade desses professores entenderem a adoção dessas TIC nesses espaços educativos como uma dimensão estratégica da cultura, Citelli aponta que devemos considerar também um outro lado dialógico da interação:

[...] caberá à escola olhar com lentes crítico-analíticas os significados e implicações das mensagens e dos sistemas informático-comunicacionais. As salas de aula não devem ser, em nosso entendimento, simples lugares de ancoragem das culturas mediáticas, mas espaços onde os sentidos neles aportados encontram grandes unidades semânticas geradas pelas dinâmicas e práticas do próprio universo escolar. Eis, em seu desenho sumário, o jogo que tensões que pode provocar fraturas naquela vontade centralizadora de produzir significados únicos que costuma acompanhar os media. Trata-se, neste caso, de estabelecer um conceito de educação como instância que tanto impregna o tecido social como é por ele impregnado. Em uma palavra: o termo ressignificação deve ser resgatado em sua dimensão plena, dialética, de algo que se modifica ao se modificar. (CITELLI, 2004, P.240)

Citelli (2004) prossegue refletindo sobre o papel social da escola enquanto espaço voltado ao trabalho de atividades que permitam o desenvolvimento e fortalecimento de habilidades para a formação de um cidadão pleno, o que implica a apreensão de inúmeras formas de estruturação do conhecimento. Isso parece passar necessariamente por uma aproximação da comunicação e educação, não para atender a modismos passageiros, mas para estabelecer e fortalecer essas relações professor-alunos:

[...] uma relação crítica entre os vários núcleos produtores de sentidos visando a tornar aparente aquilo que já está latente nas salas de aula: uma cultura em cujo interior podem ser lidas as marcas da ampla reorientação nos modos de ver, sentir, conhecer e saber que singularizam os processos formadores no mundo contemporâneo. Como em nossa frente o que existe e interessa são as razões humanos: Travessia. (CITELLI, 2004, p.241).

Para complementar essa breve aproximação, refletindo sobre esse contexto com base nas características básicas da Educomunicação (protagonismo, diálogo e pensamento crítico) e nas ideias de Freire (2009) e Dewey (1976a), considero que o professor pode propor projetos que promovam momentos de trocas dialógicas sobre aspectos da própria comunidade escolar, para depois, estimulá-los a desenvolverem uma avaliação geral final da atividade como um todo. 
Trata-se do estabelecimento de novas e diversas relações entre alunos e com o próprio professor, por meio de trocas reflexivas, negociações e seduções, para a apresentação e revisão de posições. É preciso resgatar o objetivo principal das práticas educomunicativas, que é a educação de cidadãos conscientes e críticos para a vida, para atuarem em nossa atual sociedade tecnológica.

Essa abordagem propõe um redimensionamento e reconfiguração da instituição escolar, focando processos educacionais: "se queremos formar o cidadão crítico, temos que nos preocupar, portanto com as relações que seremos capazes de estabelecer com os meios. Buscar compreender seus mecanismos...” (BACCEGA, 1997, p. 8). É preciso que o raciocínio e cognição, bem como a afetividade e criatividade sejam trabalhados e desenvolvidos a partir de práticas dialógicas problematizadoras, construídas por meio do estabelecimento de relações interpessoais entre os alunos participantes, como proposto por Freire (2002). E esse processo deveria ser mediado por uma ou mais dessas ferramentas comunicacionais.

Tania Maria Esperon Porto, doutora em Educação, pela Faculdade de Educação, da Universidade de São Paulo, define que:

O homem, como ser de relações (não só com pares, mas com as situações, as informações, os objetos), vive processos de reciprocidade, de comunicação. No entender de Freire, a comunicação gira em torno de um significado. Dessa forma não há sujeitos passivos. [...] a característica da comunicação é que ela envolve diálogo. (PORTO, 2001, p. 24).

Ela complementa que exatamente em função das áreas da cultura, lazer e prazer, dentre outras, estarem altamente impregnadas com o uso da TIC, há uma demanda crescente do uso das mesmas nos processos de aprendizagem. Aqui é interessante observar que as premissas que Dewey (1976a, 1976b) defende como essenciais às práticas em sala de aula, a partir de situações ligadas à realidade dos alunos, agora estão sendo demandadas pelos próprios alunos, que querem estar em espaços educativos que utilizem as tecnologias da comunicação, mas que também permitam que eles interajam e decidam, como ocorre nos ambientes de lazer ancorados pelas TIC, por exemplo.

Porto (2001) prossegue refletindo que os alunos precisam estar preparados para atuarem como sujeitos ativos dos processos de educação e de comunicação. E define pedagogia da comunicação:

Não é uma pedagogia sobre os meios de comunicação. É uma pedagogia que estabelece comunicação escolar com os conhecimentos, com os sujeitos, 
considerando os meios de comunicação. Dialoga-se com os meios e suas linguagens, em vez de falar dos meios. (PORTO, 2001, p. 29)

A definição aponta para esse novo contexto, sendo que não estou alegando que o mesmo seja improcedente, principalmente quanto à ocorrência da mesma a partir da área da didática. Contudo ao analisar essa afirmação e refletir sobre algumas das colocações dos autores aqui mencionados e sobre os comentários feitos por alguns dos entrevistados durante a realização da etapa da pesquisa de campo, acabo por me convencer da limitação desse termo.

Apesar de alguns especialistas da própria Educomunicação aceitarem e utilizarem o termo pedagogia da comunicação, entendo, como muito bem destacado por Huergo (2000), que se trata de um processo comunicacional que demanda ser pensado à parte e além da educação, apesar de ser com base e integrado às práticas pedagógicas. Falar em uma pedagogia da comunicação, a meu ver, limita significativamente as possibilidades de desenvolvimento dessas práticas comunicacionais para o atingimento dos objetivos educacionais.

Isso porque entendo, neste momento, que não se trata de uma pedagogia específica nascida nos espaços formais da educação, que considera uma transformação dos processos comunicacionais das práticas nos espaços educativos. Não me parece tampouco que seja uma pedagogia nascida da comunicação. Falo de um processo que não é oriundo exclusivamente de um ou outro desses dois campos, mas exatamente dessa inter-relação comunicaçãoeducação, a qual demanda novas práticas que sejam planejadas a partir dessa inter-relação, que parece ser muito mais ampla e sinaliza para eventuais resultados muito mais consistentes de aprendizagem para formação de cidadãos responsáveis.

\footnotetext{
Para obter êxito nesse desafio, é fundamental levar o sujeito a ter consciência de como se processam (nos seus vários âmbitos) as práticas midiáticas que nos envolvem e que colaboram tão fortemente para a configuração de nossa identidade. Em outras palavras: conhecer que comunicação e cultura são inseparáveis, dois lados de uma mesma moeda. Conhecer a cultura, as mediações que advêm das práticas culturais, os traços da tradição e da modernidade que balizam a práxis social são tarefas da comunicação/educação. Só a intersecção que se forma entre as ciências humanas e sociais em sua interação poderá dar conta ((BACCEGA, 2011, p. 40).
}

Daí que aqui proponho a substituição do termo pedagogia da comunicação para o termo práticas pedagógico-comunicacionais para a referida área de intervenção social, prevendo o planejamento de práticas pedagógicas integradas a ações comunicacionais específicas que auxiliarão na construção e fortalecimento desses espaços de ecossistemas educomunicativos, nos quais se dará o desenvolvimento de saberes específicos e de competências para a vida, às 
quais chamo aqui de competências educomunicativas, que se integram e transcendem as próprias competências ligadas aos conteúdos teóricos trabalhados em sala de aula.

Os aspectos aqui indicados também foram utilizados para a análise dos pontos de aproximação entre Educomunicação e avaliação formativa, sendo que acredito que a conscientização sobre a necessidade dessa mudança nas relações nos espaços educativos, entre gestores, coordenadores, professores e alunos, dentre outros, e a promoção da mesma, a partir das práticas que chamo de pedagógico-comunicacionais, com base nas premissas da Educomunicação, permitirão:

[...] levar os alunos a uma produção que valorize aspectos da cultura em que vivem, que abra discussões sobre a dinâmica da sociedade, sua inserção na totalidade do mundo, conhecendo-o para modificá-lo - reformando-o e/ou revolucionando-o, numa nova linguagem audiovisual, num novo mundo (BACCEGA, 2011, p. 41).

\subsection{Educomunicador}

Ao discorrer sobre o discurso do professor nos espaços educativos, Citelli (2004) destaca a necessidade de revisão e atualização do currículo das instituições de ensino que ofertam cursos de formação para esses profissionais, para que esses possam ser melhor preparados para atuarem nesses novos contextos educativos altamente midiatizados.

No tópico anterior, tratei de algumas das áreas de intervenção social, como a gestão da comunicação, leitura crítica dos meios e o que chamo de práticas pedagógicocomunicacionais. Ou seja, um profissional que pretenda adotar a abordagem educomunicativa em suas práticas precisa apresentar algumas novas competências ${ }^{33}$ específicas, que consistem em um conjunto de habilidades e conhecimentos sobre como planejar e implementar as ações de intervenção nesses ambientes mediados por novas tecnologias.

Soares (2011) aponta que o educomunicador enquanto gestor da comunicação deve atuar como um facilitador nesses espaços educativos, ao assumir a responsabilidade pela definição, implementação, acompanhamento e avaliação de projetos que apresentem dinâmicas, recursos e TIC, os quais se estruturem a partir de práticas protagonistas - que permitam que os próprios alunos planejem, implementem, coordenem, tomem decisões, solucionem problemas, se

\footnotetext{
${ }^{33} \mathrm{O}$ conceito do termo competências será detalhado no capítulo 3, sobre avaliação formativa.
} 
autoavaliem e avaliem seus pares -, sempre considerando a ocorrência de trocas dialógicas em todo esse processo de desenvolvimento do projeto.

Para ele, esse profissional precisa ser capaz de orientar os educandos sobre como definirão os meios de comunicação, de que farão uso durante o desenvolvimento do projeto, sempre destacando para esses alunos a importância da decisão dessas adoções, de maneira que esse processo de aprendizagem otimize o atingimento dos seus objetivos educacionais, principalmente os que seguem aqui relatados: capacitação desses participantes sobre o manejo desses aparatos comunicacionais; reflexão sobre a recepção organizada, ativa e crítica das mensagens massivas; atuação colaborativa e cooperativa em equipe; reflexão sobre os aspectos da vida real na comunidade de entorno para solução de problemas, a partir dos temas que estão sendo trabalhados na prática; desenvolvimento de determinadas competências cognitivas ligadas aos conteúdos em estudo.

Para conseguir trabalhar a partir de tais premissas, ele precisa saber utilizar vários tipos de TIC (e suas respectivas linguagens) e ainda apresentar conhecimentos sobre as chamadas teorias de recepção, dentre outras, de maneira que possa pensar as interações dialógicas específicas necessárias à construção de inúmeras competências definidas no objetivo de um determinado curso (MELLO \& SOARES, 2015).

Deve também refletir sobre seu próprio papel e respectivas obrigações, para trabalhar práticas que permitam pelo menos que os alunos tomem decisões quanto a fazer algo ou não, desde o planejamento até a operacionalização dessas ações. Lembro que o tipo de participação que trabalharia mais competências ligadas às etapas do empoderamento é a que Costa (2006) chamou de participação condutora, na qual os jovens realizam todo o processo de produção de algo e ainda orientam a participação dos adultos durante a execução do mesmo.

Trata-se de orientar esses jovens por um processo de apropriação do direito de fazer e intervir conjuntamente com os demais cidadãos de uma sociedade para um bem comum. Para tanto, esse educomunicador precisa entender que deve deixar de ser o centro das atenções e a principal e única fonte de informação e conhecimento nesses espaços educativos, para ser um mediador responsável pela facilitação do processo pedagógico-comunicacional que tenha a instalação de intensas trocas reflexivas entre seus alunos e o aprofundamento do pensamento crítico destes últimos. Sobre a complexidade desses ambientes altamente mediatizados: 
A questão central, quando se busca alcançar politicas emancipatórias e de vida ambas vinculadas e interdependentes, no compósito de construção identitária e autorrealização-, tendo em mira o amplo quadro educativo em suas interfaces com a comunicação, e sobretudo, no caso por nós destacado, das formas de presença do jovem docente seja no interior das salas de aula, seja na vivência cotidiana, está em atualizar as relações entre os sujeitos/agentes professores e alunos, atentando para as mediações patrocinadas pelas múltiplas circunstâncias comunicacionais que os circundam. (CITELLI, 2011, pag. 75)

A cada dia, ganham força as colocações feitas por Martin-Barbero (2005), Citelli (2011) e Soares (2011), sobre considerar atividades voltadas à formação de aspectos específicos nessas formações, que permitam preparar os futuros profissionais que liderarão os processos de aprendizagem nos espaços educativos, para atuarem no sentido de estabelecerem novas relações com seus alunos. Essa transformação parece não ser limitada à definição e implementação de novas dinâmicas, mas reforçamos que eles parecem apontar para uma transformação real das relações não apenas entre alunos, mas entre esses e o professor em si.

Falo aqui de uma modificação de entendimento do atual cenário quanto à necessidade de uma nova postura interna do próprio educador, que se assume um educomunicador, competente para exercer a gestão da comunicação nesses espaços, a partir da orientação para essas crianças e jovens sobre como fazer isso nos projetos que deles solicitar, bem como das próprias relações que estabelecerá com esses alunos.

A descrição desse novo contexto aparenta ser algo simples quando dito, mas a concretização dessa transformação da forma como esses profissionais entendem os espaços educativos, como destacado por Martin-Barbero (2005), por conta de não entenderem ou de se negarem a aceitar que precisam passar a atuar a partir de uma proposta mais dialógica e transdisciplinar, que é a Educomunicação. 


\section{PRÁTICAS}

\section{PEDAGógICO-}

\section{COMUNICACIONAIS}

\section{DA AVALIAÇÃO PARA}

\section{A APRENDIZAGEM}

Dedico este capítulo à apresentação das bases conceituais da "avaliação formativa", levando em conta a hipótese de que esta se estrutura a partir de processos comunicacionais específicos, os quais indicam relações de proximidade com o paradigma da Educomunicação, identificadas quando do desenvolvimento da fase teórica desta pesquisa. Reforço que o foco do presente trabalho é, justamente, a verificação dos pontos de contato entre a referida abordagem de avaliação e os pressupostos educomunicativos. Ou seja, não pretendo aqui qualificar as abordagens como melhor ou pior, eficiente ou ineficiente, mas tão somente cotejar o quanto os dois conceitos podem caminhar juntos. 
Meus estudos iniciais mostraram que as propostas de avaliação surgiram da necessidade de verificação da eficácia dos processos de ensino e aprendizagem largamente adotados, constituindo-se em ferramentas de poder e controle, até mesmo político - em vários dos contextos -, além de serem modelos estruturados e implementados considerando inúmeros aspectos da sociedade atual.

Não à toa, a avaliação tem sido um dos temas de maior atenção nos últimos anos no Brasil e em vários outros países, inclusive Inglaterra e EUA, principalmente quando da apresentação dos programas políticos e de resultados de gestão pública, visando eleição ou mesmo reeleição nos vários âmbitos do executivo (federal, estadual e municipal).

A proposta educacional e seus respectivos indicadores de avaliação acabam por sofrer forte pressão por parte dos interesses políticos ou mesmo mercantis da sociedade em que é implementada, levando os programas de ensino à reprodução do modelo social vigente, nitidamente de caráter conservador e autoritário. Daí Cipriano Carlos Luckesi (2011a) destacar que o entendimento sobre as intenções de uma determinada avaliação adotada passa pela verificação de sua função para o atingimento dos objetivos de aprendizagem. Porém, para esse autor, seu objetivo maior é - e sempre foi - apenas um: o controle social.

Sobre o uso político dos resultados, constata-se que os planos de marketing dos sistemas de educação impõem a apresentação rápida, principalmente de resultados quantitativos que destaquem os eventuais ganhos de uma política educacional e, consequentemente, justifiquem a permanência da equipe política responsável pela mesma. A existência de tais indicadores tem fortalecido de certa forma a adoção de avaliações de aprendizagem do tipo somativa e/ou diagnóstica, que focam a aplicação administrativa, pontual, no início ou final de períodos específicos, de instrumentos de verificação de resultados de ensino e aprendizagem para a respectiva certificação (ex.: o índice do IDEB - Índice de Desenvolvimento da Educação Básica - aumentou em tais e tais escolas municipais, em função da nova gestão; o mesmo índice caiu em tais e tais escolas estaduais, em função da má gestão do governo anterior).

A definição dos indicadores está ligada diretamente aos interesses de cada instituição e ao perfil do público com o qual ela quer atuar. Vários aspectos de maior ou menor complexidade são considerados, como a disponibilidade de tempo para se dedicarem às leituras obrigatórias e pesquisas adicionais, sua formação prévia, a motivação para estudar, o entendimento que tem da importância da educação em sua vida, a estrutura familiar e local onde reside esse 
aluno, dentre outros. Quando o corpo de educadores se reúne para definir e/ou rever os critérios de avaliação da instituição de ensino onde atuam, precisa considerar não apenas o conteúdo que pretendem ministrar, mas também o grau de profundidade e reflexão que poderá ser cobrado desse estudante, por exemplo, em função de todos esses aspectos.

Para Dylan Wiliam (2011), especialista britânico em avaliação formativa, a adoção de diferentes linguagens utilizadas no desenvolvimento das atividades em espaços escolares, em função das várias possibilidades de uso de TIC, tem pressionado também para uma maior clareza nos critérios a serem considerados, até para que os próprios alunos consigam entender melhor o que é esperado deles durante e ao final de uma dada atividade, a qual utilize um ou mais recursos comunicacionais para seu desenvolvimento. Cada vez mais a definição clara e apresentação prévia desses indicadores, até mesmo para os alunos, demonstra clareza desses educadores em relação às suas práticas. Além disso, auxilia os alunos no entendimento quanto ao que se espera de suas construções de conhecimento.

Os sistemas de avaliação têm sido muito questionados pelos especialistas em educação, principalmente aqueles defensores de práticas educacionais voltadas exatamente à transformação social, e que têm como referência teóricos como Célestin Freinet, e sua Pedagogia do Bom Senso, e/ou Paulo Freire, com sua Pedagogia da Libertação, e/ou John Dewey, com sua defesa da prática educacional para a democracia, dentre outros (PERRENOUD, 2007) $)^{34}$.

Sobre as origens, alguns dos primeiros registros da avaliação enquanto área da educação indicam que a mesma passou a ser estruturada a partir do final século XVII, início do século XVIII, com a formação dos primeiros colégios europeus, em função de duas necessidades principais: investigação social sistemática e prestação de contas. Nesse momento, os alunos passaram a ser matriculados nessas instituições para trabalharem a construção de conhecimentos diversos, sendo que o foco era prepará-los para atuarem na sociedade da época, a partir da oferta de diversas disciplinas e cursos.

A formação dessas instituições fez surgir um cenário importante: como a falta de clareza quanto aos critérios de avaliação impossibilitava a própria comparação dos cursos oferecidos por tais instituições, passou-se a adotar um processo avaliativo tendo como base os objetivos

\footnotetext{
${ }^{34}$ Philippe Perrenoud é um sociólogo suíço, doutor em Antropologia, e especialista nos temas educação e educação por competências.
} 
de aprendizagem almejados ao final de um processo educacional, para viabilizar minimamente essa verificação (ALKIN \& CHRISTIE, 2004).

O aumento da busca por conhecimentos técnicos específicos teve como consequência a necessidade de desenvolvimento de aparatos que permitissem verificar a aprendizagem sobre um determinado conjunto de conteúdos. Aqui há a fragmentação das teorias em disciplinas e a adoção de diversos recursos de avaliação, ao final de períodos específicos de estudo, para que as instituições verificassem e justificassem a evolução dos alunos para estágios de aprendizagem mais avançados, com disciplinas mais complexas. Esse processo demandava a aplicação de instrumentos que comprovassem a assimilação desses temas estudados, com base em critérios de avaliação previamente definidos, os quais seriam utilizados para essa verificação.

Logo, aos alunos cabia atenderem às aulas, e aqueles que estudavam e conseguiam ser aprovados nas avaliações passavam para a etapa seguinte. Os critérios dessas avaliações eram definidos pelas instituições de ensino, mas sempre com base em seus objetivos e nas regras dos órgãos reguladores da Educação. Esses critérios eram pensados quase que à parte do processo educacional como um todo, e pelo fato de serem avaliações pontuais - início (avaliação diagnóstica) ou final (avaliação somativa) de períodos específicos do processo de ensino e aprendizagem -, de caráter principalmente administrativo, para certificação, seu planejamento não precisava estar atrelado diretamente às práticas pedagógicas escolhidas para serem desenvolvidas nesses espaços escolares (ALKIN \& CHRISTIE, 2004).

À época, esse tipo de acesso ao conhecimento era possível principalmente para uma minoria privilegiada em termos financeiros, sendo que a grande maioria dos próprios conteúdos estudados refletiam as ideias que essa minoria queria que fosse disseminada. Daí eu ter dito anteriormente que a avaliação pode ser utilizada para manter o status quo da sociedade vigente, com critérios voltados à afirmação e disseminação de ideias que se almeja propagar e reforçar.

À medida que foi se desenvolvendo, a temática avaliação foi se estruturando em três principais ramos - Uso (use), Métodos (methods) e Valorização (valuing), do que Alkin \& Christie (2004), especialistas no tema, chamam de Árvore das Teorias de Avaliação. Um breve olhar para a Figura 4, permite identificar que, para cada um desses ramos, há uma série de propostas teóricas apresentadas por diferentes especialistas. 


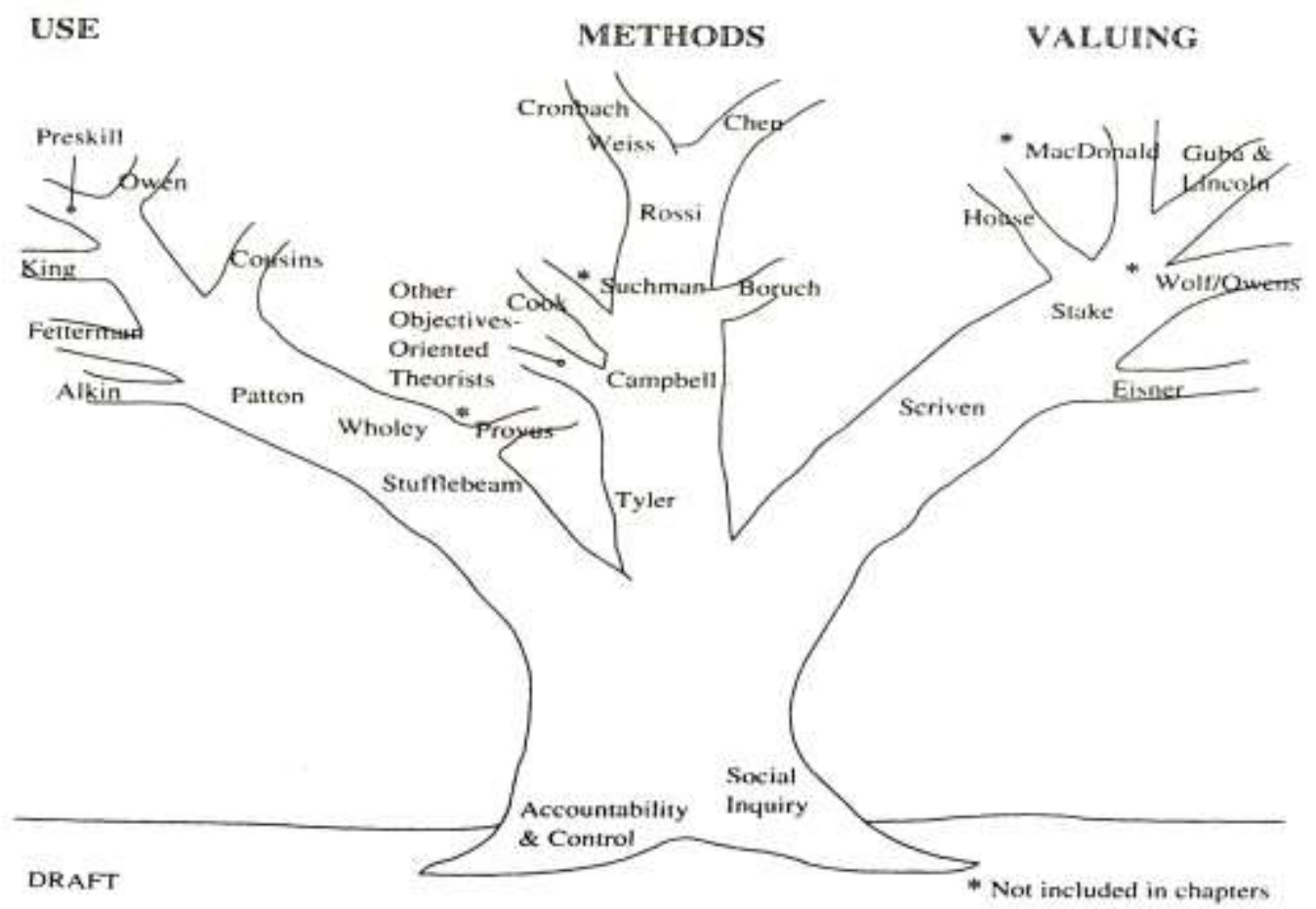

Figura 4 - Árvore das Teorias de Avaliação

Fonte: ALKIN \& CHRISTIE, 2004, p. 12

Essa Figura 4 mostra algumas referências básicas para cada um dos ramos. Os autores do ramo Método focam seus estudos sobre avaliação para a área de pesquisa, ou seja, dedicam-se a apresentar propostas iniciais sobre métodos de pesquisa para a construção do conhecimento científico. O ramo Valorização concentra-se no acompanhamento e na mensuração dos processos educativos em termos qualitativos e quantitativos, sendo que se trata especificamente da definição e atribuição de valores ou níveis de critérios a informações apuradas, para comprovação racional do processo de aprendizagem. Já os especialistas que atuam a partir do ramo Uso direcionam seus estudos sobre como os dados obtidos devem ou podem ser aplicados.

Essa ilustração orienta minimamente sobre como a área da avaliação se desenvolveu e segue se transformando nos dias atuais, frente às novas demandas e possibilidades de mensuração que surgem com as mudanças da própria sociedade. De fato, foram exatamente as transformações sociais que geraram as revisões e até redefinições dos objetivos de aprendizagem e respectivas demandas por novos tipos e instrumentos de avaliação, para que os contextos atuais de conhecimento e novas competências pudessem ser verificados adequadamente. 
Especificamente sobre o ramo Valorização, da Figura 3, há três abordagens mais comumente adotadas pelas instituições de ensino nos dias atuais, quais sejam: diagnóstica, somativa, e formativa.

Charles Hadji (1994), doutor em Educação, Letras e Ciências Humanas, especialista em avaliação, que atua como professor do Departamento de Ciências da Educação da Universidade Pierre Mendès - France Grenoble 2, distingue essas três abordagens de avaliação com base no papel que cada uma terá no processo formativo.

Quadro 02: Funções da Avaliação, segundo o seu papel na sequência da acção de formação ${ }^{35}$

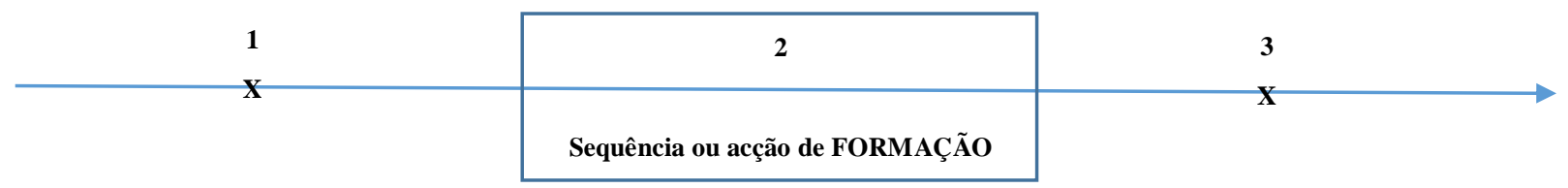

\begin{tabular}{|c|c|c|}
\hline $\begin{array}{l}\text { Em (1): ANTES DA ACÇÃO } \\
\text { DE FORMAÇÃO }\end{array}$ & Em (2): DURANTE A ACÇÃO & $\begin{array}{l}\text { Em (3): DEPOIS DA ACÇÃO } \\
\text { DE FORMAÇÃO }\end{array}$ \\
\hline $\begin{array}{l}\text { Avaliação: } \\
\text { - Diagnóstica } \\
\text { - Prognóstica } \\
\text { - Preditiva }\end{array}$ & $\begin{array}{l}\text { Avaliação: } \\
\text { - Formativa } \\
\text { - Progressiva }\end{array}$ & $\begin{array}{l}\text { Avaliação: } \\
\text { - Sumativa } \\
\text { - Terminal }\end{array}$ \\
\hline $\begin{array}{l}\text { Função: } \\
\text { - Orientar } \\
\text { - Adaptar }\end{array}$ & $\begin{array}{l}\text { Função: } \\
\text { - Regular } \\
\text { - Facilitar } \\
\text { (a aprendizagem) }\end{array}$ & $\begin{array}{l}\text { Função: } \\
\text { - Verificar } \\
\text { - Certificar }\end{array}$ \\
\hline $\begin{array}{l}\text { Centrada: } \\
\text { No produtor e nas suas } \\
\text { características (Identificação) }\end{array}$ & $\begin{array}{l}\text { Centrada: } \\
\text { Nos processos e nas atividades de } \\
\text { produção }\end{array}$ & $\begin{array}{l}\text { Centrada: } \\
\text { Nos produtos }\end{array}$ \\
\hline
\end{tabular}

A avaliação diagnóstica, também conhecida como prognóstica ou preditiva, destina-se ao mapeamento de um conhecimento específico, antes de se iniciar um determinado processo educacional. Trata-se de avaliações aplicadas, por exemplo, quando da entrada em uma instituição de ensino, para fins de verificação sobre qual o conhecimento prévio de um conteúdo a ser estudado. Um exemplo dessa avaliação são as provas aplicadas pelas escolas de idioma, para identificação do nível que um aluno poderá ser alocado, em função do que já conhece ou não sobre o idioma em questão (LUCKESI, 2011a).

\footnotetext{
${ }^{35} \mathrm{O}$ texto do quadro está escrito em português de Portugal, pois ele foi retirado de um livro cuja tradução para o português foi feita em Portugal. (Sumativa = Somativa)
} 
A avaliação somativa é atualmente a mais adotada pelo maior número de instituições educacionais no Brasil e na maioria dos demais países, para verificação de seus processos de aprendizagem, a qual é realizada ao final de períodos específicos de apresentação de conteúdos. Dependendo do tempo de duração do curso, ela pode ser realizada apenas uma vez ao final do curso, ou em dois momentos diferentes, durante um curso de um semestre, por exemplo.

Para esse segundo contexto, o professor pode trabalhar determinados conteúdos em cerca de dois meses, e ao final desse período opta por aplicar um instrumento de verificação, que pode ser uma prova discursiva. O resultado final do processo de aprendizagem será a somatória de todas as verificações realizadas, em momentos específicos, sempre para verificar o quanto os alunos aprenderam sobre o conteúdo apresentado/trabalhado durante um período específico (LUCKESI, 2011a).

Já a avaliação formativa, sobre a qual apresentarei mais detalhes na sequência, se caracteriza por ter: “[...] uma finalidade pedagógica, o que a distingue da avaliação administrativa, cuja finalidade é probatória ou certificativa. A sua característica essencial é a de ser integrada na acção de formação, de ser incorporada no próprio acto de ensino". (HADJI, 1994, p.63)

Ao tratar especificamente das funções da avaliação formativa, Hadji (2003) destaca que essa abordagem apresenta algumas funções complementares: fortalecimento da confiança do aluno em si próprio; apoio para o progresso dos alunos, com a definição de etapas claras a serem cumpridas; feedbacks propositivos e rápidos aos alunos, sempre com base nos critérios que estão sendo utilizados; estabelecimento de relação dialógica entre professor e aluno, com transparência do processo de avaliação.

Perrenoud (2007) e Wiliam (2011), dentre outros especialistas em avaliação, consideram a avaliação diagnóstica e a somativa como sendo $d e^{36}$ aprendizagem, posto que focam a verificação do quanto um aluno aprendeu sobre um determinado tema, mas a aplicação dos instrumentos de avaliação se dá apenas após as aulas sobre o mesmo. Ou seja, uma avaliação sobre o que o aluno conseguiu aprender de um tema, apresentado durante um período específico de aulas.

\footnotetext{
${ }^{36}$ Grifo da pesquisadora, para destacar um aspecto.
} 
Até os anos de 1940, as categorias de avaliação eram mais simples e incipientes quando comparadas aos complexos sistemas de avaliação hoje vigentes no Brasil e no mundo (LUCKESI, 2011b). Foi a partir de 1942, que Ralph Tyler (1902-1994), educador norteamericano especialista em avaliação e valorização ${ }^{37}$, cujo nome é mencionado na base do ramo Método, da Árvore das Teorias da Avaliação, propôs um processo de avaliação focado na identificação racional dos objetivos curriculares definidos previamente para um processo de ensino aprendizagem (ALKIN \& CHRISTIE, 2004). Nessa proposta, as verificações eram feitas em momentos específicos, com base no modelo de soma dos resultados obtidos a cada verificação realizada (avaliação somativa).

A evolução das pesquisas de Tyler (ALKIN \& CHRISTIE, 2004) sobre avaliação e a identificação dessa necessidade motivou a Associação de Psicologia Americana a encomendar a um grupo de estudiosos, à época influenciados pelas propostas desse pesquisador, a elaboração de uma lista do que seriam esses objetivos educacionais, a qual ficou conhecida como Taxonomia de Bloom ${ }^{38}$, em 1956.

O surgimento de novas abordagens educacionais com propostas mais dialógicas e colaborativas, muitas delas focadas no desenvolvimento do pensamento crítico dessas crianças e jovens, independentemente de sua classe social, fez surgir a necessidade de novas abordagens de avaliação. O processo de avaliação não poderia mais se restringir a aprovar ou reprovar o aluno, como resultado de verificação sobre o quanto o mesmo havia aprendido de um determinado conteúdo.

A evolução dessas reflexões conceituais fomentou a necessidade de acompanhamento dos alunos ao longo do processo de construção do conhecimento, momento a momento. $\mathrm{O}$ objetivo era reforçar o conhecimento desenvolvido de forma correta, e de intervir e ajudar o educando no processo de ajuste do seu processo de aprendizagem mais direta e rapidamente, para os temas que necessitassem maiores esclarecimentos.

\footnotetext{
${ }^{37}$ Em inglês, os especialistas utilizam dois termos diferentes para tratar desse tema, quais sejam: assessment, que se refere à avaliação; evaluation, que se refere à mensuração e/ou valorização de um processo educativo.

${ }^{38} \mathrm{O}$ nome de tal classificação deve-se ao fato de que o desenvolvimento da mesma foi feito pelo especialista Benjamin Bloom e sua equipe de colaboradores. A publicação dessa primeira proposta no Brasil foi feita em 1972. Em 2001, outro grupo de estudiosos do tema, agora composto por um dos colaboradores do primeiro grupo - PhD. D. Krathwohl -, também a partir de um convite da Associação de Psicologia Americana, revisou e atualizou a referida proposta, de 1956 .
} 
Foi Michael John Scriven (1928 -), especialista britânico em avaliação educacional, quem, em 1967, apresentou a primeira proposta de avaliação formativa, termo por ele cunhado. Suas primeiras ideias discorriam sobre quais as características que uma avaliação voltada à construção da aprendizagem do aluno deveria ter, e enfatizavam a necessidade de pensarem novas formas e instrumentos para aplicação de tal tipo da avaliação (ALKIN \& CHRISTIE, 2004).

Nesse novo contexto, os dados obtidos deveriam ser analisados e tratados pelo professor de uma forma diferenciada, para que ele efetivamente auxiliasse seu aluno na construção do próprio conhecimento, indicando seus pontos fracos e como melhorá-los, estimulando-o e orientando-o sobre como assumir a responsabilidade pela construção de sua própria aprendizagem.

Outro aspecto dessa proposta refere-se ao planejamento em si da avaliação. Como destaquei anteriormente, a avaliação diagnóstica e a somativa, mais corriqueiramente adotadas, desenvolvem verificações no início ou final de cada processo de aprendizagem, respectivamente, sendo que os instrumentos de mensuração utilizados são pensados separadamente do plano das práticas pedagógicas. A necessidade de pensarem instrumentos de verificação para o processo de ensino e aprendizagem os fez refletir sobre o planejamento de instrumentos de avaliação, com a finalidade de auxiliarem na construção do conhecimento, quando da definição de cada uma das atividades em sala de aula.

Surgiu, então, a necessidade de uma estrutura de avaliação composta por ações estratégicas, as quais deveriam ser pensadas de forma integrada e convergente ao plano pedagógico de um curso. E as técnicas de avaliação para a aprendizagem deveriam ser implementadas em momentos específicos, em todo o processo de ensino e aprendizagem (WILIAM, 2011).

Popham (1975 apud ALKIN \& CHRISTIE, 2004) reflete que a proposta de avaliação formativa se estrutura com base em um conjunto de ações que devem ser planejadas e organizadas de forma clara e detalhada, em um processo coletivo entre professor e alunos participantes do referido processo. E esclarece que há instrumentos de avaliação que podem ser utilizados tanto para a abordagem somativa como para a formativa.

Lembro que, independente do país, já à época da apresentação dessa proposta por Scriven (ALKIN \& CHRISTIE, 2004), os professores já se mostravam pressionados pela quantidade 
de conteúdos que deviam ministrar durante um determinado período letivo. E apesar de reconhecerem a necessidade da mudança dos processos de avaliação, receavam a inviabilidade de implantação de instrumentos de verificação nesse processo, sob risco de terem que realizar inúmeros ajustes em suas práticas, que resultassem inclusive na necessidade de aumento de número de horas de dedicação à preparação e aplicação desses processos.

Antes de prosseguir, esclareço que não tenho como afirmar aqui se essas classificações sobre ser de ou para aprendizagem sejam absolutamente corretas, e que principalmente a avaliação diagnóstica e somativa não possam ser classificadas como para aprendizagem. Trata-se de um aspecto ainda em estudo pelo campo da educação, sobre o qual não nos cabe opinar aqui neste estudo. Esse aspecto só foi apontado por ser a forma como Perrenoud (2007) e Wiliam (2011) explicam o aspecto formativo ao longo do processo de construção do conhecimento.

Foram exatamente esses dois primeiros aspectos da avaliação formativa, o de permitir o acompanhamento do processo de aprendizagem, e sua classificação inicial como sendo uma avaliação para aprendizagem, exatamente por focar no apoio à construção do conhecimento dos alunos já nesse processo, que nos fizeram propor como objetivo deste estudo a verificação da estruturação dessa proposta, principalmente com base nas premissas do paradigma da Educomunicação, a saber, o diálogo e protagonismo.

\subsection{Teorias de Ensino e Aprendizagem e as Abordagens de Avaliação}

O surgimento de novas teorias de ensino e aprendizagem em função das transformações sociais ocorridas principalmente nas últimas décadas, tem destacado a necessidade da identificação de novas propostas de avaliação que sejam adequadas para aplicação nos espaços educativos que adotam práticas definidas com base nessas novas teorias.

A crítica aos modelos de avaliação ditos "quantitativos" se dá principalmente pelos defensores da adoção de práticas pedagógicas nascidas e/ou voltadas exatamente à transformação social, sobre a qual tratamos no Capítulo Um, sobre Educomunicação. E a escolha por uma dessas avaliações - diagnóstica, somativa ou formativa - deriva da definição das propostas teóricas de ensino e aprendizagem adotadas em cada escola. Logo, neste tópico explico de forma 
resumida a relação entre as bases de algumas das principais teorias de ensino e aprendizagem, com as avaliações aqui mencionadas.

Para tanto, escolhi utilizar a nomenclatura adotada pela Prof. ${ }^{\text {a }}$ Maria da Graça Nicoletti Mizukami (1986). Para essa pedagoga e doutora em Ciências Humanas, professora titular da Universidade Federal de São Carlos, todas as transformações sociais, filosóficas e psicológicas, que o ser humano vivencia constantemente, fazem com que as teorias de ensino e aprendizagem estejam em constante questionamento, revisão, atualização e até inovação.

Ela classificou e trabalhou em sua pesquisa de doutorado o que denominou de cinco principais abordagens teóricas de ensino e aprendizagem: tradicional, comportamentalista, humanista, cognitivista e sociocultural $^{39}$. Esse estudo teve como objetivo apurar e entender a aparente desarticulação ocorrida entre as teorias mais lembradas e defendidas pelos docentes, e as abordagens práticas mais adotadas pelos mesmos em suas salas de aula.

Os descritivos resumidos me permitiram refletir brevemente sobre a relação das abordagens de avaliação com essas teorias. Percebi, por exemplo, que os modelos tradicional e comportamental, a princípio, focam mais na avaliação de aprendizagem, optando por avaliações diagnósticas e/ou somativas, com verificações antes ou após períodos específicos (LUCKESI, 2011b; PERRENOUD, 2007).

Quadro 03: Abordagens Teóricas de Ensino e Aprendizagem ${ }^{40}$

\begin{tabular}{|c|c|}
\hline $\begin{array}{c}\text { ABORDAGEM } \\
\text { TEÓRICA }\end{array}$ & DESCRITIVO RESUMIDO \\
\hline Tradicional & $\begin{array}{l}\text { Os objetivos educacionais obedecem à sequência lógica dos conteúdos. Os conteúdos } \\
\text { são baseados em documentos legais, selecionados a partir da cultura universal } \\
\text { acumulada. Predominam aulas expositivas, com exercícios, leituras-cópias. }\end{array}$ \\
\hline Comportamentalista & $\begin{array}{l}\text { Os objetivos educacionais são operacionalizados a partir de classificações: gerais } \\
\text { (educacionais) e específicas (instrucionais). Ênfase nos meios: recursos audiovisuais, } \\
\text { instrução programada, tecnologias de ensino, ensino individualizado (módulos } \\
\text { instrucionais), "máquinas de ensinar", computadores, hardwares, softwares. Os } \\
\text { comportamentos desejados serão instalados e mantidos nos alunos por condicionantes e } \\
\text { reforçadores. }\end{array}$ \\
\hline Humanista & $\begin{array}{l}\text { Objetivos educacionais obedecem ao desenvolvimento psicológico do aluno. Os } \\
\text { conteúdos programáticos são selecionados a partir dos interesses dos alunos. "Não } \\
\text { diretividade". A avaliação valoriza aspectos afetivos (atitudes) com ênfase na }\end{array}$ \\
\hline
\end{tabular}

\footnotetext{
${ }^{39}$ Nomenclatura adotada por Mizukami (1986) quando da publicação de sua tese de doutoramento em Ciências Humanas, pela Pontifícia Universidade Católica do Rio de Janeiro (PUC-RJ).

${ }^{40}$ Os textos dos descritivos resumidos de cada uma das cinco abordagens teóricas deste quadro foram retirados do quadro resumido que Santos (2005) elaborou em seu próprio estudo, sobre as ideias de Mizukami (1986).
} 
autoavaliação.

Cognitiva $\quad$ Desenvolve a inteligência, considerando o sujeito inserido numa situação social. A inteligência constrói-se a partir da troca do organismo com o meio, pelas ações do indivíduo. Baseado no ensaio e no erro, na pesquisa, na investigação, na solução de problemas, facilitando o "aprender a pensar". Ênfase nos trabalhos em equipe e jogos.

Sociocultural Os objetivos educacionais são definidos a partir das necessidades concretas do contexto histórico-social no qual se encontram os sujeitos. Busca uma consciência crítica. O diálogo e os grupos de discussão são fundamentais para o aprendizado. Os "temas geradores" para o ensino devem ser extraídos da prática de vida dos educandos.

Fonte: Mizukami (1986, apud Santos, 2005, p. 30)

A própria mudança de papel dos professores nos espaços educativos, a partir das novas propostas de aprendizagem, me faz refletir também sobre a necessidade de uma avaliação que acompanhe o processo de aprendizagem em si. Foi exatamente por conta desse novo contexto que surgiu a proposta de avaliação para aprendizagem ou formativa, a qual vem sendo estudada e testada por vários especialistas, como Wiliam (2011), que já dedica cerca de trinta anos de sua vida acadêmica pesquisando sobre uma proposta de avaliação mais consistente e eficiente com base nessa abordagem. Ele tem verificado práticas dessa avaliação desenvolvidas em contextos educativos do Reino Unido e EUA, as quais foram estruturadas a partir de práticas pedagógicas desenvolvidas sob as premissas das três teorias mais recentes, destacadas por Mizukami (1986), a saber: a humanista, cognitiva e sociocultural, buscando uma sistematização mínima da mesma.

Sobre os resultados da pesquisa de Mizukami (1986), eles indicaram a existência de uma significativa desarticulação entre o conteúdo estudado - e em teoria, aprendido, pelos professores enquanto atendiam suas formações ao longo dos anos - e a prática pedagógica que eles adotam no dia a dia de suas salas de aula:

Esta possível desarticulação sugere a necessidade de se repensar cursos de formação dos professores. Sugere igualmente a necessidade de análise dos conteúdos usualmente veiculados em disciplinas pedagógicas, especialmente daqueles que analisam abordagens do processo ensino-aprendizagem, procurando articulá-los com a prática pedagógica, em suas diferentes manifestações, possibilitando assim uma compreensão cada vez mais abrangente e significativa do real. (MIZUKAMI, 1986, p. 100)

Lembro que a referida pesquisa foi desenvolvida nos anos de 1984 - 1985, sendo que esses resultados já sinalizavam a dificuldade dos professores na adoção de novas práticas pedagógicas pensadas a partir de abordagens mais dialógicas e interativas, como a cognitiva, sociocultural e humanista. Mizukami (1986) pode ter identificado uma possível dificuldade dos professores quanto ao planejamento, implementação e acompanhamento de atividades 
mais dialógicas, mas infelizmente, em seu trabalho ela não chega a avançar quanto ao esclarecimento sobre as possíveis causas.

Não localizei uma sequência do referido estudo, mas resgatei esta pesquisa para explicar resumidamente essas três abordagens - cognitiva, sociocultural e humanista - e seus aspectos dialógicos passíveis de serem identificados no processo de aprendizagem, o que permite entender mais claramente a necessidade de identificação de uma proposta avaliativa que atenda a essa necessidade.

A própria leitura desses resumos me fez refletir sobre qual seria o processo avaliativo mais adequado a cada uma dessas abordagens, em função de suas características dialógicas e reflexivas. Exatamente o aspecto dialógico das mesmas parece demandar uma opção que viabilize o acompanhamento ao longo do processo, sendo que esse foi, como disse anteriormente, um dos motivos pelos quais escolhi verificar os aspectos comunicacionais da avaliação para aprendizagem, a partir do mapeamento dos pontos comuns com os pressupostos da abordagem educomunicativa.

Especificamente sobre a adoção das tecnologias digitais nos espaços escolares e sobre as recentes demandas por formações específicas para esse uso, tais cursos têm sido indicados ou solicitados pelos próprios professores, para que entendam como planejar dinâmicas pedagógicas com tais aparatos comunicacionais, as quais apresentem reais ganhos para a aprendizagem dos alunos.

Esse cenário indica que os contextos identificados nos estudos de Mizukami (1985) ainda parecem existir, apesar de já terem se passado vários anos da realização da pesquisa. De fato, vários professores ainda hoje parecem demonstrar dificuldades em pensar o uso pedagógico e comunicacional de tais recursos midiáticos, principalmente quando são demandados a abandonarem o uso instrumental desses aparatos, para pensarem práticas pedagógicas mais dialógicas e protagonistas, a serem desenvolvidas por meio do uso de tais recursos, como as defendidas pelas teorias humanista, cognitiva, sociocultural, por exemplo. 


\subsection{A Avaliação Dialógica}

Como apresentei no histórico sobre o surgimento da abordagem da avaliação formativa, ela foi formulada principalmente para atender às necessidades de acompanhamento dos processos de aprendizagem caracterizados por trocas dialógicas entre seus participantes, planejadas a partir das premissas de teorias de aprendizagem mais recentes, como a humanista, cognitiva e sociocultural.

Consequentemente, essas características dialógicas foram exatamente o aspecto comum principal considerado por em minha pesquisa de campo, para verificar os possíveis pontos de aproximação entre uma abordagem de avaliação para aprendizagem e os paradigmas educomunicativos.

Durante meus estudos iniciais, identifiquei a proposta da avaliação formativa de Wiliam (2011) e uma proposta denominada avaliação dialógica, nascida das bases da Pedagogia da Libertação, proposta por Freire (2005). Dado que as bases referenciais da proposta adotada nas aulas dos LIE, da SME-SP, são de Wiliam (2011), e que as da Educomunicação têm em Freire (2005) um de seus principais autores, optei por apresentar aqui a fundamentação conceitual de ambas as propostas, para mapear os indicadores que poderiam ser utilizados na pesquisa de campo.

Para iniciar, apresento a proposta de avaliação nascida das próprias ideias de Freire (2002), a avaliação dialógica. Lembro que dentre suas ideias, está a defesa de, por exemplo, o professor adequar sua fala à realidade dos alunos ao apresentar qualquer conteúdo, de maneira que esses tenham uma melhor compreensão sobre o que está sendo tratado em aula. Para ele, o educador precisa considerar a subjetividade dos participantes de uma turma, para que esses vivenciem os processos de produção de sentidos e de construção de seus próprios significados.

Ao defender uma Pedagogia de Libertação estruturada no diálogo entre as partes envolvidas, dentre outros aspectos, Freire (2002) refletiu também sobre como deveria ser uma avaliação dialógica isenta de aspectos punitivos, de reprovação, derivada da concepção burocrática e bancária da escola. Essa abordagem deveria adotar a colaboração e diálogo desde a definição de suas premissas até sua própria implementação. E os critérios a serem considerados deveriam ser definidos por um colegiado de professores e coordenadores, além de ser transdisciplinar, posto que deve acompanhar a evolução da construção de conhecimento 
considerando também os pontos de integração entre as diversas disciplinas em estudo. Nessa abordagem, a avaliação passa a ter o papel de fomento da transformação social de todos seus participantes, inclusive no que se refere à própria forma como o erro é tratado.

José Eustáquio Romão (2011) preocupou-se em aprofundar a proposta da avaliação dialógica com base nas ideias de Freire (2002). Um dos primeiros aspectos que ele destaca é quanto aos desafios de se implantar a referida abordagem em função de uma cultura escolar fortemente arraigada em uma prática de avaliação majoritariamente somativa do processo de aprendizagem, com forte ênfase no acerto e erro, norteadores da aprovação ou reprovação. Vale destacar que o modelo de avaliação com base nas ideias de Freire (2002) deve sustentar ações voltadas à transformação das estruturas das relações e vínculos entre alunos, professores, instituição de ensino e comunidade, as quais devem ser mais flexíveis e horizontais.

A escola deve resgatar seu papel principal de formação de cidadãos, a partir do que ele denomina uma escola cidadã, que trabalhe os conteúdos obrigatórios integrados com dinâmicas que permitam também a construção de competências específicas necessárias às práticas de cidadania. Essa estruturação transdisciplinar dos processos de aprendizagem proposta por Freire (2002) demanda uma avaliação mais dialógica, com novas formas de acompanhamento e registro das dinâmicas em sala de aula, bem como que a avaliação desses registros e respectivos retornos aos alunos sejam feitos de maneira mais ágil, objetiva, construtiva e propositiva.

A verificação da aprendizagem não deve se restringir à elaboração de uma dissertação ou trabalho escrito, para que o professor possa analisar o desenvolvimento da construção de conhecimento por cada aluno, e muito menos para a identificação dos erros cometidos. Ao contrário disso, além de práticas dialógicas ao longo de todo o processo de aprendizagem, essa proposta deve prever, ainda, como atividade final, uma reflexão problematizadora coletiva - a chamada roda de conversa -, a qual é desenvolvida com e por todos os alunos, enquanto que ao professor cabe apresentar feedbacks objetivos, com base nos conteúdos trabalhados e objetivos almejados, pontuando aos alunos o que e como pode ser ajustado ou corrigido, para que eles tenham uma aprendizagem mais consistente. Aqui se instala o que Romão (2011, p. 107) chama de "verdadeiro círculo de investigação do conhecimento e dos processos de abordagem do conhecimento". 
Como destacava Paulo Freire ao longo de sua obra e, mais especificamente, na última que publicou em vida, Pedagogia da Autonomia (1997), o homem, como ser incompleto, inacabado e confuso que é, só inicia o processo de plenificação, de acabamento e de auto conclusão de sua humanidade no momento em que toma consciência de sua incompletude. $O$ processo de desalienação inicia-se, então, com a consciência dos próprios limites ou com a apreensão crítica da própria realidade alienada. Essa conscientização nada mais é do que um profundo processo de autoavaliação, de verificação da própria ontologia, na medida em que a pessoa se debruça, diagnosticamente, sobre si mesma, na busca da superação dos próprios limites. (ROMÃO, 2011, p.149)

Observo aqui alguns aspectos que remetem às práticas educomunicativas, mais especificamente, ao Projeto EducomJt, mencionado no capítulo um. Como dito, apesar de não haver uma orientação clara sobre o que seriam os processos de avaliação dessas dinâmicas, um de seus principais pressupostos era de que, ao final de cada projeto, os alunos fizessem uma avaliação do que havia ocorrido ao longo do desenvolvimento do mesmo, a partir de uma roda de conversa.

Especificamente sobre o tratamento do erro na avaliação dialógica, ele passa a ter uma função não de reprovação, mas de indicador de necessidade de novas reflexões e eventuais explicações sobre um determinado conteúdo, para auxiliar os alunos que apresentam algum tipo de dificuldade no acompanhamento e desenvolvimento coerente da atividade. Nessa abordagem:

\begin{abstract}
é o registro e a análise dos insucessos como fonte de apreensão dos mecanismos de raciocínio que a eles presidiu, com vistas à reprogramação curricular - aqui entendido em seu sentido amplo. Se o equívoco e o insucesso deixam de ser fonte de julgamento e punição, é porque a visão de mundo de quem os aborda considera-os como "contingências necessárias" no processo de construção do saber. Não se trata de buscar o erro para que se possa construir o conhecimento, mas encará-lo como fonte de outros saberes - no caso da avaliação - didático-pedagógicos. Além disso, nem todo "insucesso" é na verdade insucesso, porque o é, na maioria das vezes, se nos colocamos na perspectiva do conhecimento que se pretende hegemônico. O pensamento conservador lê o mundo no viés do "certo / errado" - evidentemente considerando-se como monopolizador da primeira parte da dicotomia - porque tal "maniqueistização" lhe permite desideologizar seus próprios interesses. E esta sectarização do conhecimento não pode ter contrapartida a valorização absoluta do outro polo da dicotomia. (ROMÃO, 2011, p. 104)
\end{abstract}

Ele propõe uma estrutura mínima de implementação da avaliação dialógica, a partir de cinco etapas, quais sejam:

(1) definição dos critérios a serem verificados no processo;

(2) definição dos procedimentos de gestão da comunicação para o processo de avaliação, para definição dos pontos de intervenção, negociação e estabelecimento de padrões a serem trabalhados; 
(3) planejamento dos instrumentos de verificação e dos pontos onde eles serão aplicados;

(4) definição das ações estratégicas de verificação do desempenho e aplicação dos critérios previamente definidos;

(5) procedimentos de análises dos resultados, descrição das formas de feedback e definição das próximas ações, considerando esses resultados.

Especificamente sobre os objetivos de aprendizagem, esses devem focar "processos de reflexão e formulação coletiva com os demais membros da comunidade escolar, especialmente com os alunos, sobre o plano do curso a ser desenvolvido e os objetivos específicos a serem alcançados" (ROMÃO, 2011, p. 112).

Esse autor destaca os benefícios que todos os participantes de um determinado curso poderão ter com a adoção dessa estrutura de avaliação, apesar do desafio de implementá-la, e aqui lembro que atualmente as TIC têm papel essencial na facilitação da adoção dessa abordagem, posto que muitos dos registros podem ser feitos por meio do uso desses instrumentos.

A avaliação enquanto instrumento de auxílio para a construção da aprendizagem, com base na definição coletiva, objetiva e detalhada dos critérios de avaliação por todos os educadores envolvidos, torna o processo menos subjetivo, anulando o aspecto de poder que a avaliação apresenta. Outro aspecto que acaba sendo trabalhado é o desempenho dos próprios educadores com os estudantes, posto que a maior integração, principalmente entre esses participantes do processo, permite que eles se ajudem uns aos outros na definição e planejamento dos critérios e atividades, o que acaba elevando o desempenho de muitos deles.

Romão (2011) reflete que, ao propor a adoção dessa abordagem de avaliação dialógica, isso não deve ser feito de forma radical e súbita. Ele relembra que se trata de uma mudança de cultura escolar, que demanda tempo para assimilação e interiorização dessas práticas pelos próprios educadores. Consequentemente, a implementação dessa abordagem tem que ser feita paulatinamente, para depois passar à redução das práticas de outra abordagem mais pontual e quantitativa.

Uma educação cidadã e avaliação dialógica deve ser pensada e estruturada considerando tanto a abordagem de "educação e avaliação positivistas, que se desenvolvem com base na permanência, estrutura, estático, o existente e o produto, e as construtivistas, que reforçam a mudança, a mutação, a dinâmica, o desejado e o processo" (ROMÃO, 2011, p. 93). Isso porque só há reestruturação de processos quando se conhece detalhadamente suas bases. Além 
disso, é preciso conhecer o que já existe, para entender o processo atual e verificar o que pode e deve ser modificado em quais tempos.

Outro aspecto a ser cuidado refere-se à participação dos próprios alunos, tanto no planejamento e execução das atividades, como na própria validação dos critérios de avaliação definidos previamente pelos professores. Ou seja, antes de iniciarem qualquer atividade com os alunos de uma turma, é importante que o professor responsável pela mesma explique detalhadamente como eles serão avaliados e quais serão os critérios que serão considerados. Aqui os estudantes não apenas devem entender os mesmos, mas principalmente opinar quanto à validade ou não deles em relação às ações onde serão adotados.

Observei também um trabalho direto da competência de autonomia desses estudantes, os quais são estimulados a todo momento a entenderem e internalizarem a importância da construção contínua de novos conhecimentos para suas vidas enquanto cidadãos, de forma que eles se apropriem desse processo e passem a definir individualmente os rumos de sua própria aprendizagem ao longo da vida.

Este último se refere a um aspecto muito defendido por vários especialistas em avaliação, como é o caso de Hadji (2011) e Wiliam (2011), qual seja, a autorregulação. Esta será melhor explicitada na apresentação das ações estratégicas do modelo de avaliação formativa, de Dylan Wiliam, mas destacamos aqui que, mesmo para esse modelo da avaliação dialógica, com base nas ideias de Paulo Freire, a autorregulação também é considerada o principal objetivo ou objetivo maior de todo o processo de aprendizagem.

Essa proposta propõe a figura de um profissional que dê apoio ao planejamento dessas práticas, para auxiliar e fomentar a mudança de cultura escolar:

\footnotetext{
Oferecer diretrizes para o planejamento, com base em pesquisas de "temas geradores" ou "estruturas significativas" da "cultura primeira" da comunidade em que a escola atua; subsidiar a formulação do plano de curso com instrumentos, mecanismos e procedimentos que tenha estudado ou aplicado ao longo de sua experiência como professor; realizar pesquisas sobre procedimentos didáticopedagógicos praticados na escola; analisar, tecnicamente, os instrumentos de avaliação e seus resultados, devolvendo sugestões que orientem o replanejamento etc. (ROMÃO, 2011, p. 122)
}

Ele reflete sobre o nome que poderia ser dado a esse profissional, algo que tire um pouco do que chama de aspecto militarista e político, sugerindo "coordenador pedagógico" ou “animador pedagógico" (Romão, 2011, p.121). Eu sugiro educomunicador, por razões óbvias. 
Neste momento, vale analisar as atividades descritas desse educador e as dinâmicas pelas quais o educomunicador deve ser responsável, apresentadas no capítulo um, que permite observar pontos de aproximação entre a Educomunicação e Avaliação Dialógica.

A análise desse modelo de avaliação para aprendizagem aponta que a avaliação dialógica apresenta procedimentos comunicacionais tanto em sua estruturação como em sua implementação, sendo que, em todos esses momentos, as intervenções devem ser feitas de maneira planejada e cuidadosa, para que ao final os objetivos do processo de aprendizagem almejados sejam atingidos.

Trata-se do que chamo aqui de uma avaliação para $^{41}$ a aprendizagem, em função da própria definição apresentada por Perrenoud (2007) sobre esse termo. Há também vários pontos comuns entre a avaliação formativa, como descrita por Scriven (ALKIN \& CHRISTIE, 2004) e avalição dialógica, por Romão (2011), quais sejam: trocas dialógicas entre todos os participantes; o erro enquanto ferramenta de construção do conhecimento; formulação dos critérios de avaliação desenvolvida conjuntamente entre professor e alunos; acompanhamento ao longo do processo de aprendizagem; desenvolvimento de uma escola cidadã; mudança da relação professor-aluno (mais próxima, dialógica, respeitosa); e, objetivo maior é a transformação social.

Mais do que isso, essas primeiras reflexões permitem considerar a avaliação dialógica como sendo um modelo alinhado com os pressupostos do paradigma da Educomunicação, posto que uma das principais referências teóricas da Educomunicação é exatamente Paulo Freire.

Lembro que decidi apresentar esta proposta neste estudo para estruturar mais claramente quais seriam os aspectos de uma avaliação educomunicativa. Apesar disso, na sequência, apresento as ideias da avaliação formativa por Wiliam (2011), posto que se trata da abordagem adotada nas práticas dos LIE, da DOT/SME-SP, sobre as quais desenvolvemos nossa pesquisa empírica. Além disso, essa segunda proposta apresenta os instrumentos de avaliação, cuja elaboração Romão (2011) sugere que sejam definidos.

\footnotetext{
${ }^{41}$ Grifo desta autora, para destacar a característica dessa avaliação.
} 


\subsection{Ações Estratégicas de Avaliação Formativa}

A competência essencial do professor consiste, portanto, em saber criar as condições suscetíveis de permitir que os alunos construam seus próprios saberes. Em outras palavras, saber estruturar e organizar o ambiente, para que ele se torne um ambiente facilitador de aprendizagens. (HADJI, 2011, P. 5).

A adoção da avaliação para aprendizagem implica não apenas em um planejamento e aplicação de vários instrumentos de avaliação ao longo do processo de aprendizagem, mas de uma mudança da cultura educacional das instituições. Pensar a avaliação para aprendizagem formativa ou dialógica, qualquer que seja a nomenclatura utilizada - demanda uma mudança profunda na forma de criar, planejar e implementar um processo de ensino e aprendizagem como um todo, inclusive de todas as relações e interações passíveis de ocorrerem durante o mesmo.

Aqui resgato as ideias de Martin-Barbero (2011) sobre a necessidade de criação de ambientes educativos que propiciem a construção e fortalecimento de uma nova relação pedagógicocomunicacional entre os participantes desses espaços educativos, e de Baccega (2011) e Citelli (2011), que também destacaram a necessidade de modificação das relações e interações que ocorrem nos espaços educativos, a partir das transformações sobre como os processos comunicacionais se desenvolvem, focando em práticas mais dialógicas e interativas.

Há a necessidade de revisão e modificação dos procedimentos de responsabilidade dos professores, coordenadores e gestores dessas instituições, especialmente porque a referida proposta pressupõe como resultado um empoderamento e autorregulação do seu próprio processo de aprendizagem pelo aluno. Trata-se da conscientização da importância da educação na vida do ser humano, estado esse que se edifica e consolida por meio de uma série de processos dialógicos reflexivos, estruturantes da proposta de avaliação para aprendizagem.

Esse contexto remete também às reflexões de Roger Hart, apresentadas ao final do tópico sobre protagonismo, do Capítulo Um, quando destaco a necessidade da vivência de vários processos seguidos de diferentes tipos de participação, até para que as crianças e jovens alunos possam construir e reconstruir seus referenciais internos, seus conhecimentos e entendimentos, sobre as diferentes possibilidades de participação, e entender quais as implicações de cada uma delas. A autorregulação é um estado que tem que ser edificado, e um dos meios de fazê-lo é a adoção da avaliação formativa. 
A leitura das ideias desses autores - da comunicação e da educação - reforça a necessidade de retornarmos às práticas pedagógico-comunicacionais, descritas no Capítulo Um, por nós entendidas como sustentação necessária ao desenvolvimento das ações estratégicas da avaliação formativa ou para aprendizagem. E o que seriam, então, essas ações estratégicas?

As ideias de Wiliam (2011; 2015), de certa forma, convergem ainda mais com as ideias da avaliação dialógica de Freire (ROMÃO, 2011), quando se trata das ações estratégicas voltadas à implementação da avaliação de aprendizagem. O primeiro passo para pensar a estruturação de uma proposta de avaliação formativa é responder a três perguntas básicas: (a) onde o aluno quer chegar; (b) onde o aluno está neste momento; (c) como chegar onde deseja.

Quadro 04: Tipos de Estratégias de Avaliação Formativa

\begin{tabular}{|c|c|c|c|}
\hline & $\begin{array}{l}\text { Onde o aluno quer } \\
\text { chegar }\end{array}$ & $\begin{array}{l}\text { Onde o aluno está neste } \\
\text { momento }\end{array}$ & $\begin{array}{ccc}\text { Como chegar onde } \\
\text { deseja }\end{array}$ \\
\hline Professor & $\begin{array}{l}\text { Estratégia } 1-\mathrm{A} \text { : } \\
\text { Esclarecendo as intenções } \\
\text { de aprendizagem e os } \\
\text { critérios para sucesso }\end{array}$ & $\begin{array}{l}\text { Estratégia 2: Estruturar } \\
\text { discussões eficazes em } \\
\text { sala de aula e outros } \\
\text { desafios de aprendizagem } \\
\text { que evidencie o } \\
\text { entendimento do aluno } \\
\text { sobre o tema em estudo }\end{array}$ & $\begin{array}{l}\text { Estratégia 3: Oferecer } \\
\text { feedback/retorno que } \\
\text { motive o aluno a seguir } \\
\text { em frente }\end{array}$ \\
\hline Parceiro & $\begin{array}{lrr}\text { Estratégia } 1 & - & \text { B: } \\
\text { Entendendo } & \text { e } \\
\text { compartilhando } & \text { as } \\
\text { intenções } & \text { de } \\
\text { aprendizagem e } & \text { critérios } \\
\text { de sucesso } & & \end{array}$ & $\begin{array}{l}\text { Estratégia 4: Ativar/mob } \\
\text { recursos instrucionais para }\end{array}$ & $\begin{array}{l}\text { izar os alunos enquanto } \\
\text { s próprios alunos }\end{array}$ \\
\hline Aluno & $\begin{array}{l}\text { Estratégia } 1 \text { - C: } \\
\text { Entendendo as intenções } \\
\text { de aprendizagem e os } \\
\text { critérios de sucesso. }\end{array}$ & $\begin{array}{l}\text { Estratégia 5: Ativando/mo } \\
\text { donos de sua própria apren }\end{array}$ & $\begin{array}{l}\text { oilizando os alunos como } \\
\text { izagem }\end{array}$ \\
\hline
\end{tabular}

Fonte: Wiliam (2011, p. 5)

As informações referentes às respostas a essas três perguntas norteiam a definição das ações estratégicas de avaliação para aprendizagem, as quais serão adotadas para toda disciplina ou curso. E essas dinâmicas devem ser trabalhadas durante a aprendizagem, sempre de forma integrada às práticas pedagógicas, para que os objetivos educacionais sejam atingidos. 
Planejar as práticas a partir da avaliação para a aprendizagem implica na definição, implementação e acompanhamento de cinco tipos de intervenções: definição de rubricas; formulação de perguntas para promoção do pensamento reflexivo; feedback do professor aos alunos; mobilização dos alunos como fontes de conhecimentos para trocas com seus pares; e, ativação dos alunos como donos de seus próprios processos de aprendizagem. Dependendo do momento do processo, uma ou mais delas devem estar ocorrendo.

Esse modelo específico se estrutura pela definição e realização de diversos pontos de verificação da aprendizagem do aluno em relação a um determinado conteúdo e a realização dos respectivos feedbacks do professor nesses momentos de verificação, para que esse aluno possa já providenciar ajustes na construção do seu conhecimento durante o desenvolvimento do processo de aprendizagem, e não apenas ao final de um período específico, como ocorre na avaliação somativa, por exemplo.

Sobre essas dinâmicas de retorno ao aluno, Wiliam (2011) reconhece a existência de algumas dificuldades para a adoção de tal proposta, com base em diversas experimentações que desenvolveu durante suas pesquisas. A dinâmica de comentários sobre o desempenho desse aluno precisa ser desenvolvida com agilidade, para gerar eventuais processos até de revisão e reforço do processo de aprendizagem, caso haja algum aspecto que não esteja se desenvolvendo como o esperado.

A necessidade de um rápido encaminhamento quanto a eventuais ajustes no processo de aprendizagem de cada aluno, com ênfase em rápidas intervenções para orientação ou reorientação do aluno, demanda ações que implicam mais tempo do professor responsável na execução dessas dinâmicas, o que pode configurar como um desafio à adoção dessa proposta.

Esse desafio tem sido vencido aos poucos pela adoção de TIC nos ambientes educativos, cada vez mais apropriadas para os registros e verificações desse tipo de abordagem. Atualmente, já foram identificadas ferramentas midiáticas, cujo uso facilita a implementação de vários instrumentos de avaliação para aprendizagem, especialmente quanto ao registro, apuração e análise do desempenho dos alunos em períodos curtos de tempo. 
Algumas instituições de ensino passaram a fazer uso dos chamados ambientes virtuais de aprendizagem $^{42}$, inicialmente mais utilizados em cursos de educação a distância, para viabilizar a implementação e acompanhamento de processos comunicacionais também nos espaços presenciais, voltados ao desenvolvimento de competências específicas.

Tais ambientes são, em sua maioria, espaços multimidiáticos, com aparatos comunicacionais de diversas linguagens, como: área de fórum para troca de mensagens escritas assíncronas, promoção de reflexões colaborativas entre todos os membros da turma ou mesmo entre os membros de grupos pequenos, focados no desenvolvimento de uma ação específica; chat escrito para conversas ao vivo por escrito; mensagens particulares para contatos individualizados entre professor - aluno ou mesmo aluno - aluno; repositório de atividades com detalhamento das atividades a serem desenvolvidas em sala de aula presencial; repositório de materiais para disponibilização de conteúdos diversos, teóricos ou mesmo de práticas desenvolvidas na sala de aula presencial; outras.

Refiro-me aqui a espaços educativos mediados por TIC presenciais ${ }^{43}$, que permitem o desenvolvimento de inúmeras atividades pedagógico-comunicacionais, por meio do uso de computadores, tablets ou mesmo smartphones, e eventualmente até com acesso à internet para todos os participantes, de maneira a permitir o registro das diferentes participações dos alunos, em tempo real, com esses dispositivos digitais, as quais são acessadas, analisadas e rapidamente comentadas pelos professores responsáveis. Em alguns casos, até em tempo real.

Ou seja, um dos grandes desafios da proposta da implementação das práticas reflexivas é a própria práxis desse processo em sala de aula. Como pensar a dinâmica para uma turma de 30 - 40 - 50 alunos? Como estabelecer e fortalecer ecossistemas comunicativos de intensas trocas no sentido de "ouvirmos" e conhecermos as várias e diferentes reflexões e processos de aprofundamento do conhecimento sobre um determinado tema de todos os alunos da turma? Haveria realmente tempo para isso em meio a todo o conteúdo a ser trabalhado durante um período letivo?

Apesar dessa proposta, em teoria, atender diversas demandas das propostas mais recentes de ensino e aprendizagem, autores como Luckesi (2011), Perrenoud (2007) e Romão (2011),

\footnotetext{
${ }^{42}$ Exemplo: Moodle, EdModo, Brightspace, Blackboard, ThinkQuest/Oracle e até mesmo o Facebook, dentre outros.

${ }^{43}$ Para efeito desta pesquisa, estamos considerando especificamente o uso dessas TIC nos ambientes educativos presenciais, mas esse contexto também pode ser considerado para as modalidades a distância e híbrida.
} 
dentre outros, alertam para o grande desafio da implementação das mesmas, posto que, aliado à dificuldade de fazer os alunos refletirem mais profunda e criticamente sobre um determinado tema - prática essa para a qual em muitos casos nem os próprios docentes estão preparados para implementar -, está a limitação de tempo para conseguir realmente "ouvir" a grande maioria de alunos de uma turma, e para que o educador mediador responsável faça as respectivas devolutivas propositivas ao longo do processo.

Wiliam (2011) alerta ainda sobre a necessidade de envolvimento dos gestores, coordenadores, educadores e dos próprios alunos, o que demanda tempo e dedicação para o desenvolvimento de negociações constantes entre todas as partes envolvidas, para que ocorra de fato uma mudança de cultura escolar e a consequente viabilização da implementação da proposta de avaliação formativa. Trata-se de uma ponderação que já era feita pelo próprio Freire (2005; 2002) e por Romão (2011), ao desenvolver suas reflexões sobre o que seria a avaliação dialógica.

Retomando a questão das ações estratégicas, pensar a avaliação formativa não se resume apenas em planejar uma atividade qualquer em sala de aula, que utilize, por exemplo, um ambiente virtual de aprendizagem para o registro de alguns dos procedimentos ao longo desse processo. De fato, pensar a adoção de apenas algumas das ações estratégicas para esta proposta é tornar o processo limitado e até falho. O detalhamento das etapas permite a regulação clara do processo de avaliação para a aprendizagem. Ao defini-las e comunicá-las aos seus alunos antes de iniciar o desenvolvimento desse processo de aprendizagem, esse docente está informando como serão as regras dele, como o processo será regulado. E esse detalhamento permite ao aluno decidir sobre como será sua participação, permite assumir e trabalhar a sua autorregulação. (WILIAM, 2011; HADJI, 2011)

Outro aspecto que se destaca nesta proposta é o erro, posto que ele não indica a possibilidade de reprovação, mas assume o papel de norteador quanto aos aspectos que precisam de algum reforço, explicação adicional ou ajuste já ao longo do processo. Ele sinaliza o momento em que o aluno precisa de um esclarecimento específico ou até mesmo um acompanhamento mais próximo por parte do professor, para que consiga acompanhar os demais colegas da turma. Ou seja, o erro surge para lançar luz a uma dificuldade, para que uma ação positiva de apoio ao aluno seja providenciada já durante o processo, de forma assertiva e qualitativa. 
A seguir, trato exatamente desses cinco tipos de ações estratégicas, apresentadas no Quadro 4, para apontar os seus aspectos dialógicos.

\subsubsection{A definição compartilhada de rubricas para a orientação das ações}

O questionamento (a), proposto por Dylan (2011), refere-se ao objetivo que o aluno busca atingir ao se inscrever em um determinado curso, sendo que, para este modelo de avaliação formativa, são exatamente esses objetivos - do aluno - que embasam o desenho de um curso. Lembramos que esses objetivos não se restringem ao conteúdo teórico que possa ser oferecido, mas também a habilidades e competências ${ }^{44}$.

Para melhor explicitar os objetivos de aprendizagem é necessário que a comunidade educativa esteja atenta ao conjunto dos critérios utilizados para verificar o atingimento dos objetivos de aprendizagem, sendo que cada um dos quatro níveis de cada critério deve ser descrito detalhadamente. É o que Wiliam (2011) define como rubricas, como destaco mais adiante. Sobre a nomenclatura dos quatro níveis, eles podem receber nomes diferenciados que estimulem os alunos a se dedicarem mais ainda ao processo (ex: níveis dos critérios com nomes de pókemons, aves, ou animais ${ }^{45}$ ).

O termo rubrica confunde muitas pessoas, posto que ele está associado principalmente ao significado de "marca ou sinal que representa, por abreviação, a assinatura de alguém" (BECHARA, 2009, p. 792). Por isso, trazemos uma explicação sobre a origem do mesmo:

Terra vermelha, usada na cerâmica para dar a cor avermelhada. Era uso entre os copistas das Idade-Média escrever com tinta vermelha o nome e o número dos capítulos, tomando a pal. rubrica o significado de capítulo, assunto aí tratado. Da mesma forma, as partes explicativas dos livros litúrgicos, onde se davam as indicações das cerimônias, eram escritas com tinta vermelha, passando rubrica a significar por isso as regras segundo as quais devem ser feitas as cerimônias. Modernamente, na França, rubrique passou a designar coluna, a secção mantida por alguém nos jornais. Pelo fato de tais escritos serem assinados, rubrique, rubrica tomou também o significado de assinatura, de autenticação de um escrito. Daqui os livros rubricados, os documentos rubricados, isto é, que trazem a assinatura da autoridade competente ou da pessoa responsável. A palavra é portanto, de uso

\footnotetext{
${ }^{44}$ Trataremos do detalhamento destes termos ainda neste capítulo.

${ }^{45} \mathrm{Na}$ apresentação dos dados da pesquisa de campo, essa classificação dos quatro níveis com nomes de animais, ou pokemons foi mais detalhada e no Anexos B, há exemplos de rubricas desenvolvidas pela DRE Campo Limpo, para seus projetos de LIE, que apresentam nomes diferenciados para esses níveis, adequados aos contextos e perfis dos públicos aos quais se destinavam.
} 
literário e daqui vem que alguns dizem rubbrica, sendo a acentuação correta de acordo com o latim, rubrica (BUENO, 1974, p. 3589).

As primeiras ações voltadas à estruturação de rubricas enquanto instrumento de avaliação para aprendizagem datam dos anos de 1970, nos EUA, quando os professores do idioma inglês buscavam criar um novo recurso avaliativo que fosse formativo e auxiliasse no processo de alfabetização em inglês, para que não deixassem nenhum aluno reprovado. Eles buscavam a definição de padrões mínimos de qualidade para o desenvolvimento de redações dessas crianças e jovens, com indicação mais clara e detalhada de quais critérios já haviam sido cumpridos e quais os que faltavam cumprir, detalhando como fazer isso. Atualmente há inúmeras publicações, principalmente em inglês sobre o tema, e já foram desenvolvidos até aplicativos para tablets e celulares, que auxiliam na elaboração das rubricas ${ }^{46}$ (TILESTON, 2006). Logo, esta ação estratégica se deriva desse contexto.

Ao discorrer sobre os objetivos, refiro-me à definição das habilidades e competências que se espera que sejam trabalhadas nesses processos, sendo que na avaliação para aprendizagem, esses critérios não são quantitativos, mas qualitativos. Consequentemente, para definir esses indicadores, é preciso detalhar quais são as dinâmicas a serem implementadas. São exatamente ações como diálogo, colaboração em grupo, contribuições nas ideias do grupo, execução das atividades em grupo, dentre outras, que devem ser acompanhadas, para verificar como elas serão desenvolvidas.

Como muitas dessas dinâmicas são tidas como subjetivas - mesmo os professores divergem entre si quanto ao que esperam em cada uma dessas atividades -, é preciso identificar e listar os procedimentos principais que se espera que sejam adotados pelos alunos durante o desenvolvimento dessas práticas. A partir desse detalhamento, deve-se dividir a execução em quatro classificações, da possibilidade de execução mais básica ou simples, à mais complexa.

Ou seja, com base nos indicadores definidos como essenciais para serem trabalhados, montase uma tabela na qual são descritos como poderá ocorrer o desenvolvimento das mesmas, de maneira a apresentar níveis e classificações diferentes para os mesmos. Normalmente trabalha-se com 4 estágios e descreve-se detalhadamente o que se espera que o aluno faça para cada nível daquele critério.

\footnotetext{
${ }^{46}$ Alguns desses aplicativos podem ser baixados por meio da Apple Store, tais como: Rubrics, MyRubrics.
} 
No caso específico da avaliação para aprendizagem, Wiliam (2011) reflete que essa fase tem que ser desenvolvida de forma totalmente colaborativa e participativa, de maneira que os alunos também se comprometam com o processo de aprendizagem a ser desenvolvido. Ele propõe que os professores de uma determinada disciplina definam com seus pares a rubrica do projeto ou disciplina, com esse detalhamento de indicadores, para depois os mesmos serem compartilhados com os alunos logo no início do processo. O que se almeja aqui é que essas crianças e jovens conheçam, entendam e validem essas premissas do curso que estão iniciando, bem como todas as competências previstas para serem trabalhadas por eles - e de que forma. Aqui é considerada ainda a possibilidade dos próprios alunos desenvolverem a rubrica da atividade, sendo que esse tipo de prática foi identificado em nossa pesquisa de campo.

Após a aprovação e ciência desses critérios, o professor inicia o processo de aprendizagem, sendo que ao final, ele vai retomar a rubrica, para realização das ações estratégicas finais, sobre as quais trataremos mais adiante.

A importância do conceito e da prática das rubricas reside no fato de que elas especificam claramente para os alunos o que é esperado deles durante o processo, desde os aspectos que envolvem sua participação mais simples até a mais completa, tornando claro para eles os ganhos que têm à medida que se empenham mais o desenvolvimento das tarefas.

Esse descritivo detalhado passa a ser um grande recurso para aprendizagem, posto que durante o desenvolvimento das atividades e o acompanhamento do professor e sua observação das posturas e respostas dos alunos às suas intervenções reflexivas, é possível identificar mais claramente em que nível o aluno se encontra para cada um dos critérios. Mais do que isso, permite que o próprio aluno perceba sobre o que ele pode fazer para melhorar ainda mais a qualidade do seu próprio processo de aprendizagem. Com isso, o aluno pode rever suas "respostas" e providenciar ajustes em sua reflexão e participação, sempre destacando os ganhos de aprendizagem que esse aluno tem ao decidir fazer esses ajustes indicados.

Para entender mais claramente o conceito atribuído ao termo rubrica, apresento um exemplo da mesma, com o Quadro 5: 
Quadro 5 - Exemplo de Rubrica de Colaboração com uso de Ferramentas Virtuais ${ }^{47}$

\begin{tabular}{|c|c|c|c|c|}
\hline Critério & Nível 1 = D & Nível 2 = C & Nível 3 = B & Nível 4 = A \\
\hline $\begin{array}{l}\text { RESOLUÇÃO DE } \\
\text { PROBLEMA }\end{array}$ & $\begin{array}{l}\text { Não tento solucionar } \\
\text { problemas ou ajudar } \\
\text { os demais a fazê-lo. } \\
\text { Deixo que os demais } \\
\text { façam o trabalho. }\end{array}$ & $\begin{array}{l}\text { Não sugiro ou refino } \\
\text { soluções, mas estou } \\
\text { aberto a testar as } \\
\text { soluções sugeridas } \\
\text { pelos demais. }\end{array}$ & $\begin{array}{lr}\text { Refino } & \text { soluções } \\
\text { sugeridas } & \text { pelos } \\
\text { outros. } & \end{array}$ & $\begin{array}{lr}\text { Busco } & \text { participar } \\
\text { ativamente } & \text { e sugiro } \\
\text { soluções } & \text { para os } \\
\text { problemas. } & \end{array}$ \\
\hline FOCO NA TAREFA & $\begin{array}{l}\text { Raramente foco na } \\
\text { tarefa e no que } \\
\text { precisa ser feito. } \\
\text { Deixo que os demais } \\
\text { executem o trabalho. }\end{array}$ & $\begin{array}{l}\text { Foco na tarefa e no } \\
\text { que precisa ser feito } \\
\text { em alguns momentos. } \\
\text { Outros membros do } \\
\text { grupo precisam me } \\
\text { cutucar em alguns } \\
\text { momentos, para me } \\
\text { fazer agir. }\end{array}$ & $\begin{array}{l}\text { Foco na tarefa e no } \\
\text { que precisa ser feito } \\
\text { na maior parte do } \\
\text { tempo. } \\
\text { membros do grupo } \\
\text { podem contar com } \\
\text { essa pessoa. }\end{array}$ & $\begin{array}{l}\text { Permaneço } \\
\text { consistentemente } \\
\text { focado na tarefa e no } \\
\text { que precisa ser feito. } \\
\text { Sou muito bem focado } \\
\text { e auto-direcionado. }\end{array}$ \\
\hline $\begin{array}{l}\text { RESPEITO } \\
\text { MÚTUO }\end{array}$ & 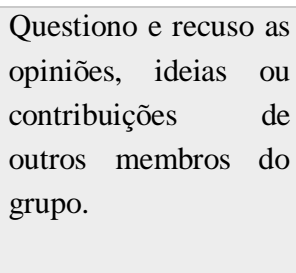 & $\begin{array}{l}\text { Reconheço o valor } \\
\text { das opiniões, ideias } \\
\text { ou contribuições de } \\
\text { outros membros do } \\
\text { grupo. }\end{array}$ & $\begin{array}{l}\text { Incorporo algumas } \\
\text { das opiniões, ideias } \\
\text { ou contribuições de } \\
\text { outros membros do } \\
\text { grupo no projeto em } \\
\text { andamento. }\end{array}$ & $\begin{array}{lr}\text { Busco ativamente } \\
\text { incorporar as opiniões, } \\
\text { ideias } & \text { ou } \\
\text { contribuições } & \text { de } \\
\text { outros membros do } & \text { grupo. }\end{array}$ \\
\hline $\begin{array}{lll}\text { VALOR PARA } & \text { O } \\
\text { GRUPO } & & \end{array}$ & $\begin{array}{l}\text { Raramente ofereço } \\
\text { ideias úteis quando } \\
\text { participo em grupo ou } \\
\text { nas discussões em } \\
\text { classe. Em alguns } \\
\text { momentos, até me } \\
\text { recuso a participar. }\end{array}$ & 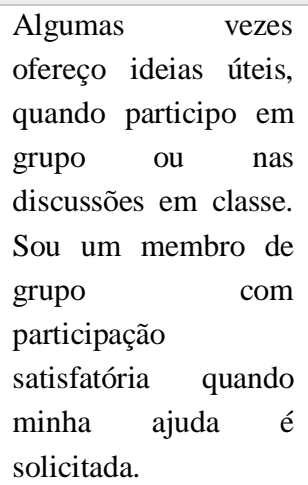 & $\begin{array}{l}\text { Normalmente ofereço } \\
\text { ideias úteis, quando } \\
\text { participo em grupo ou } \\
\text { nas discussões em } \\
\text { classe. Sou um forte } \\
\text { membro de grupo } \\
\text { quando me esforça } \\
\text { em participar. }\end{array}$ & $\begin{array}{l}\text { Rotineiramente } \\
\text { ofereço ideias úteis } \\
\text { quando participo em } \\
\text { grupo ou nas } \\
\text { discussões em classe. } \\
\text { Sou um líder nato que } \\
\text { contribui com muita } \\
\text { dedicação. }\end{array}$ \\
\hline
\end{tabular}

Fonte: Exemplo desenvolvido a partir do quadro de Rubricas de Avaliação Formativa

(JOHNSON, 2011, p.31)

\subsubsection{Reflexão Crítica a partir do Diálogo}

Wiliam (2011) se baseia na pergunta (b) do Quadro 3 - onde o aluno está nesse momento -, para a estruturação do que classifica como o segundo tipo de ação estratégica da proposta, que ele denomina como a reflexão crítica.

Como pude identificar pelos estudos de Mizukami (1986), muitos professores ainda têm dificuldade em planejar e aplicar dinâmicas dialógicas que envolvam todos os participantes,

\footnotetext{
${ }^{47} \mathrm{O}$ texto deste quadro foi publicado originariamente em inglês, e foi traduzido, para este texto, por esta autora.
} 
em seus espaços educativos. O próprio Freire (TORRES \& MORROW, 2002) já alertava para a dificuldade das pessoas em se relacionarem dialogicamente. Logo, quando falo em adotar uma abordagem de avaliação para aprendizagem, edificada a partir de práticas dialógicas, esse é um dos aspectos a ser revisto e modificado, para que a construção do conhecimento a partir desse acompanhamento realmente ocorra.

Wiliam (2011) destaca este tema como uma ação estratégica por levar em conta que a gestão da comunicação dialógica para a reflexão crítica nos espaços educativos apresenta-se, ainda hoje, como uma questão problemática. É o que fica claro no Quadro 6, com exemplos extraídos do cotidiano das práticas educativas:

Quadro 6 - Exemplos de Problemas de Falta de Gestão Comunicação para o Diálogo

\begin{tabular}{|c|c|}
\hline PROCEDIMENTOS & RESULTADOS INADEQUADOS \\
\hline $\begin{array}{l}\text { O professor pede que alunos levantem } \\
\text { a mão para responder }\end{array}$ & Tal procedimento faz com que apenas uma minoria participe. \\
\hline Falta de roteiro de aula estruturado & $\begin{array}{l}\text { Essa conduta não permite uma adequada gestão da comunicação } \\
\text { para um diálogo reflexivo, sem o detalhamento claro da dinâmica } \\
\text { reflexiva. }\end{array}$ \\
\hline Tempo de reflexão e resposta & $\begin{array}{l}\text { Muitas vezes o professor apresenta a pergunta, aguarda uns poucos } \\
\text { segundos, para ele mesmo já apresentar a resposta. }\end{array}$ \\
\hline $\begin{array}{l}\text { Apresentação de perguntas com } \\
\text { respostas binárias }\end{array}$ & $\begin{array}{l}\text { Tal forma de propor perguntas leva a respostas simples (sim ou } \\
\text { não), sem possibilitar ou favorecer a reflexão. }\end{array}$ \\
\hline Falta de atenção às respostas & Professor não presta atenção à resposta do aluno \\
\hline Esclarecimento de dúvidas & $\begin{array}{l}\text { Nem sempre o professor apresenta uma explicação clara, que } \\
\text { elucida a dúvida do aluno e este não pergunta mais, para não se } \\
\text { expor. }\end{array}$ \\
\hline Questões que não estimulam a reflexão & $\begin{array}{l}\text { Não contém aspectos metacognitivos ou mesmo inferenciais, } \\
\text { limitando-se a caraterísticas básicas, literais. }\end{array}$ \\
\hline
\end{tabular}

Fonte: Wiliam $(2011)^{48}$

Esses exemplos de erros de abordagem de dinâmicas aqui apresentados, destacam a dependência que as práticas pedagógicas têm dos processos comunicacionais que as sustentam, apontando o quanto a forma como são gerenciados influenciam no sucesso ou fracasso do atingimento dos resultados traçados. E reforçam ainda mais a ideia de adoção do termo práticas pedagógico-comunicacionais enquanto uma área de intervenção da Educomunicaçao, ligada à didática, posto que não se trata de uma pedagogia (da

\footnotetext{
${ }^{48}$ Fonte: Quadro desenvolvido com base nas considerações de Dylan Wiliam sobre os problemas passíveis de ocorrerem, em função da falta de planejamento das práticas comunicacionais (WILIAM, 2011).
} 
comunicação), mas de um conjunto de práticas e intervenções comunicacionais que precisam ser planejadas para viabilizar o próprio processo pedagógico idealizado.

O físico Eric Mazur, ligado à University of Harvard, em palestra proferida na conferência da Association for Learning Technology 2012 (ALT-C 2012), ocorrida na University of Manchester, Inglaterra, discorreu sobre estudos que apontam para o fato de que os alunos ainda hoje são pouco reflexivos quanto ao conteúdo estudado nos espaços reflexivos. Ele refletiu que parece não haver a preocupação ou cuidado por parte da grande maioria dos docentes em planejar para suas aulas algumas ações específicas exatamente com foco no estímulo ao aprofundamento das reflexões dos alunos sobre o conteúdo em estudo.

A prática costumeira dos docentes é a de questionarem sobre a existência de dúvidas ao final de suas explanações teóricas (Ex.: alguém tem dúvida?). A ausência de dúvidas não significa necessariamente que os alunos entenderam, mas que, na maioria dos casos, eles sequer começaram a refletir sobre o tema tratado, posto que não foram questionados e estimulados adequadamente à reflexão crítica. Observe que não se trata de questionar o conhecimento desses professores, mas da capacidade deles de elaborarem perguntas reflexivas sobre o conteúdo em estudo, o que são duas coisas diferentes.

Ele apontou o quanto esse tipo de prática compromete, limita e prejudica a aprendizagem. Em sua fala no referido evento, ele defendeu e justificou exatamente a adoção de práticas comunicacionais que fomentem esse processo reflexivo dos alunos já nos espaços educativos, de maneira que o docente responsável possa esclarecer mais rapidamente as eventuais dúvidas ou entendimentos errados, e contribuir com melhor qualidade para o processo de aprendizagem de seus alunos. Perrenoud (2007) aponta que o professor deve atentar à evolução do desenvolvimento das reflexões de seus alunos, para conseguir identificar de maneira mais rápida e consistente as conclusões e até derivações de pensamentos a que seus alunos estão chegando sobre o que está expondo.

Para efeito deste estudo, destaco como indicadores de minha pesquisa os procedimentos comunicacionais que fomentam a reflexão crítica, mas não pretendo adentrar ao âmbito específico da formulação da pergunta, pois esse tema não está sendo tratado aqui.

Os aspectos aqui destacados mostram também como a gestão da comunicação para a educação precisa ser pensada enquanto parte do planejamento dessas práticas pedagógico- 
comunicacionais, para a construção consistente do conhecimento sobre um determinado tema. Ou seja, ao pensar o planejamento de aulas, tenho que entender, considerar e planejar minhas intervenções enquanto mediadora do processo dialógico para o aprofundamento da reflexão sobre um tema, de maneira que realmente consiga concretizar o processo comunicacional que julgo necessário para que os objetivos de aprendizagem que tracei realmente sejam atingidos.

Todas as reflexões apresentadas aqui permitem observar outro aspecto que passa necessariamente pelo fato de que a implementação de processos dialógicos para a construção social do conhecimento, bem como de práticas voltadas à resolução de problemas ou mesmo ao desenvolvimento reflexivo, deve prever uma formação específica dos próprios educadores, com grande ênfase na prática dos mesmos, os quais passam a atuar como mediadores e participantes ativos dessas dinâmicas, postura essa que pode ser bem diferente e até desafiadora para eles.

\subsubsection{O feedback do professor}

O feedback do professor aos alunos é a terceira ação a ser destacada como estratégica para a avaliação formativa, a qual se origina da pergunta (c): como chegar onde deseja. É exatamente com a apresentação de comentários sobre como está o desempenho do aluno, que este último poderá entender seu contexto de aprendizagem e fazer os ajustes necessários para seguir com a construção de seu conhecimento sobre uma prática.

De fato, todo tipo de avaliação - de ou para a aprendizagem - deve prever um momento desse tipo de devolutiva, para que os alunos conheçam e entendam onde erraram, para poderem focar seus estudos nos pontos fracos e para ajustarem/substituírem entendimentos errados. Mesmo para os casos em que essas crianças e jovens estejam atendendo às expectativas esboçadas na rubrica, é importante fazer o feedback propositivo, para reforçar esse contexto, para que as crianças e jovens também entendam que estão no caminho esperado e quais as premissas norteadoras. Contudo, ele alerta que há diferentes tipos de comentários, sendo que há aspectos específicos que devem ser considerados na devolutiva da avaliação formativa.

No processo avaliativo para aprendizagem, essa ação assume um novo papel, uma vez que o foco da mesma é o acompanhamento e assessoria aos participantes na construção do 
conhecimento em todo o processo de aprendizagem, o que faz com que esses comentários tenham que ser elaborados com foco no fortalecimento desse conhecimento.

A forma como o professor estrutura e apresenta esse retorno ao aluno vai afetar diretamente todo esse processo de construção de novos saberes. O educador precisa cuidar dos termos que utilizará para apresentar essa devolutiva, posto que ele precisa fazê-lo com clareza e objetividade, para que seus alunos realmente consigam entender o que e como podem esclarecer suas dúvidas e ajustar seus erros. (WILIAM, 2011)

Os comentários simples - de aprovação ou reprovação -, ou mesmo sentimentais (Ex.: seu trabalho está ótimo!), não se aplicam. Os alunos necessitam de comentários embasados nos indicadores dos objetivos de aprendizagem, para que eles entendam os acertos, os erros, ou mesmo os tópicos que precisam de ajustes no entendimento, para poderem retomar a construção do conhecimento.

A simples apresentação de pontos, grades ou níveis enquanto instrumentos de verificação de aprendizagem, raramente auxilia na melhoria qualitativa dos processos de aprendizagem. Pelo contrário, estudos de Wiliam (2011) apontam que a melhoria qualitativa da construção de novos saberes ocorre com devolutivas detalhadas elaboradas pelo professor, as quais fomentem nova reflexão nos alunos, para um melhor entendimento sobre seus processos, para que entendam como e se estão realmente evoluindo ou onde precisam fazer ajustes. Os comentários desse tipo agregam de forma construtiva principalmente quando desenvolvidos com base nos próprios indicadores contidos na rubrica da atividade, disciplina e/ou curso.

A questão do feedback, como os demais aspectos que envolvem o processo de avaliação, qualquer que seja o tipo adotado, é polêmica, dependendo das premissas consideradas e da forma como ele é apresentado aos alunos, como, por exemplo, a própria disciplina junto à qual ele será desenvolvido. Ou seja, a forma como é feita a gestão da comunicação desse retorno de desempenho, é que vai fazer com que o aluno entenda ou não as razões de ter errado um determinado exercício, focando a construção do seu conhecimento.

Novamente, a ação feedback foi destacada por sua importância na avaliação formativa, mas para efeito desta pesquisa especificamente, verifiquei apenas os procedimentos relativos à ocorrência dela - se ocorreu ou não -, e em quanto tempo isso foi realizado, como um indicador da gestão dessa comunicação para educação. Especificamente quanto à análise desse 
discurso, acredito que isso demandaria um estudo a partir das premissas da análise do mesmo, abordagem essa que não foi considerada nesta pesquisa.

\subsubsection{Alunos enquanto parceiros ou monitores de aprendizagem para seus pares}

A quarta ação estratégica consiste em pensar momentos em que os alunos possam se colocar como parceiros ou monitores de aprendizagem uns para os outros, para motivá-los a se envolverem mais nas práticas dedutivas. Trata-se de pensar atividades durante as quais os pares se auxiliam mutuamente, em eventuais dificuldades que estejam enfrentando, e que precisem ser trabalhadas, para que o resultado do grupo seja ainda mais aprimorado. Essa ação busca responder às perguntas (b) e (c): onde o aluno está neste momento e como chegar onde deseja.

Esta fase não se restringe a implementar reuniões dos alunos após o período normal de aulas, para que aqueles que tiveram um melhor desempenho possam ajudar seus colegas com maior dificuldade, ensinando conteúdos específicos, mas principalmente de planejar dinâmicas colaborativas para serem desenvolvidas durante o período de aula.

Wiliam (2011) reflete que essa prática propicia vários ganhos na aprendizagem e destaca que especificamente as dinâmicas colaborativas e cooperativas trabalham pelo menos quatro importantes competências, quais sejam:

(a) motivação: alunos se sentem instigados a apoiarem e ajudarem seus colegas, principalmente quando o docente responsável pela atividade discorre sobre os ganhos que essa prática promove para todos os envolvidos no processo;

(b) coesão social enquanto grupo: auxilia na estruturação e fortalecimento de vínculos entre os alunos, tornando o grupo mais coeso e fortalecido;

(c) personalização: o fato dos alunos participantes terem perfis muito similares, permite a realização de leituras e entendimentos mais claros da realidade que os cerca, e torna mais fácil para que eles apresentem explicações e exemplos de contextos teóricos ligados ao dia a dia do 
qual fazem parte e que melhor compreendem, o que ajuda na elucidação de uma dúvida, qualquer que seja ela; e,

(d) elaboração cognitiva: o processo de reflexão e elaboração de ideias e explicações desenvolvido pelos alunos, para poderem explicar situações e conceitos para seus colegas, promove um aprofundamento reflexivo mais rápido e consistente por parte desses atores envolvidos.

Esse tipo de ação implica no planejamento de atividades colaborativas, estruturadas com trocas reflexivas entre os participantes das atividades e norteadas pela rubrica do projeto.

Esta ação remete novamente às ideias de Freinet (1985), Freire (2002), Dewey (1976a), dentre outros, pois ela prevê a realização de dinâmicas com características de protagonismo por parte dos alunos, que assumem o papel de educadores, para ajudarem seus colegas no processo de aprendizagem.

Logo, em minha pesquisa de campo procurei verificar a ocorrência desse tipo de atividade nas práticas analisadas.

\subsubsection{Avaliação entre Pares / Autoavaliação}

Como quinta ação estratégica, há a avaliação entre pares ou autoavaliação, as quais são realizadas normalmente ao final do projeto, para uma análise mais detalhada de todas as competências trabalhadas e dos objetivos atingidos. Essa ação também busca responder às perguntas (b) e (c) - onde o aluno está neste momento e como chegar onde deseja.

A avaliação entre pares consiste nas considerações desenvolvidas por um aluno sobre o desempenho de outro colega seu, sempre com base nos critérios contidos na rubrica da atividade desenvolvida, que pode ser uma simples atividade ou um projeto. E a autoavaliação é aquela que cada um faz do desempenho de si próprio ao longo do desenvolvimento de um determinado projeto, por exemplo, sempre com base nos critérios que compõem a rubrica do mesmo.

Ocorre que nem sempre os alunos conseguem se autoavaliar logo da primeira vez que são apresentados a essa prática, sendo que vários acabam por fazer autoavaliações que não 
condizem com o que foi a realidade, sub ou supervalorizando seu desempenho. Logo, os professores responsáveis normalmente optam por iniciar com a avaliação entre pares, para que eles entendam como desenvolver a avaliação dos seus pares com base na rubrica validada no início do curso. Esse processo permite que se familiarizarem com esse procedimento, que não tem por finalidade a aprovação ou reprovação, mas uma conscientização reflexiva e construtiva sobre como evoluiu o próprio processo de construção do conhecimento ao longo da atividade. Wiliam (2011) destaca a importância dessa prática, para a conscientização sobre as competências trabalhadas e as dificuldades enfrentadas e suplantadas.

A dinâmica de avaliação entre pares pode ser adotada para atividades individuais de reflexão inicialmente para depois passar à avaliação dos pares, quando os alunos avaliarão o desempenho de seus colegas de grupo, apontando em qual dos níveis da rubrica eles se encontram (para cada critério) com a devida justificativa de sua avaliação. A apresentação dessa justificativa se faz essencial para a conscientização do aluno sobre seu processo de aprendizagem. Na pedagogia de projetos, quando o desenvolvimento do mesmo tem média a longa duração, essas duas dinâmicas - principalmente a avaliação entre pares - pode ser adotada mais vezes para verificar se estão evoluindo como esperado.

O processo de autoavaliação é uma das etapas para a construção da competência de autorregulação em si, que se configura como sendo: "um processo por meio do qual o sujeito é levado a ter um julgamento sobre a qualidade da execução do seu trabalho e das suas aquisições, o que exige que se tenha, de forma mais ou menos explícita, critérios de qualidade" (HADJI, 2011, p. 51). Trata-se da oportunidade do aluno analisar e refletir sobre o que acertou e/ou errou, com base nos critérios apresentados na rubrica, no sentido de entender mais claramente como foi a evolução do seu processo de aprendizagem. Daí a necessidade de ele entender o uso da rubrica, para a realização dessa ação. Exatamente por propiciar esse trabalho de desenvolvimento do empoderamento é que a autoavaliação é considerada como uma parte do processo da própria autorregulação.

Para o desenvolvimento da pesquisa de campo deste estudo eu foquei na verificação da ocorrência de pelo menos uma dessas duas possibilidades de avaliação - entre pares ou autoavaliação - e no modelo aplicado, com o descritivo das ações adotadas para o desenvolvimento da mesma. 


\subsection{Competências Educomunicativas}

O surgimento da palavra competência ocorreu na Idade Média, no final do século XV, com emprego especificamente na área jurídica, que designava o poder atribuído ao tribunal para julgar temas específicos. Foi a partir do século XVIII que o uso do termo começou a ser revisto e ampliado, passando a significar uma capacidade decorrente de notório conhecimento que alguém tem sobre um determinado tema.

Mais recentemente, em meados dos anos de 1980, as áreas de Recursos Humanos de diversas organizações passaram a adotar essa palavra, em função do surgimento de uma nova proposta de formação do ambiente corporativo, intitulada Educação Corporativa, a qual defende que os objetivos estratégicos de uma empresa, a médio e longo prazos, devem nortear a definição das formações dos seus colaboradores, principalmente quanto aos saberes comportamentais, técnicos e operacionais, para que consigam atingir os objetivos gerais e específicos definidos para cada uma de suas áreas (EBOLI, 2004).

Muitas corporações têm adotado essa nova proposta metodológica intitulada Educação Corporativa, desde o final do século XX, principalmente nos países do hemisfério norte, mas foi no início do século XXI que essa proposta começou a ganhar força no Brasil. Para Eboli (2004, p.48), a Educação Corporativa foca “o desenvolvimento e a instalação das competências empresariais e humanas consideradas críticas para a viabilização das estratégias de negócios".

Para Eboli (2004), o termo competências representa o imbricamento de três práticas atitudinais: a compreensão (Conhecimento), a aptidão (Habilidade) e a postura (Atitude). 


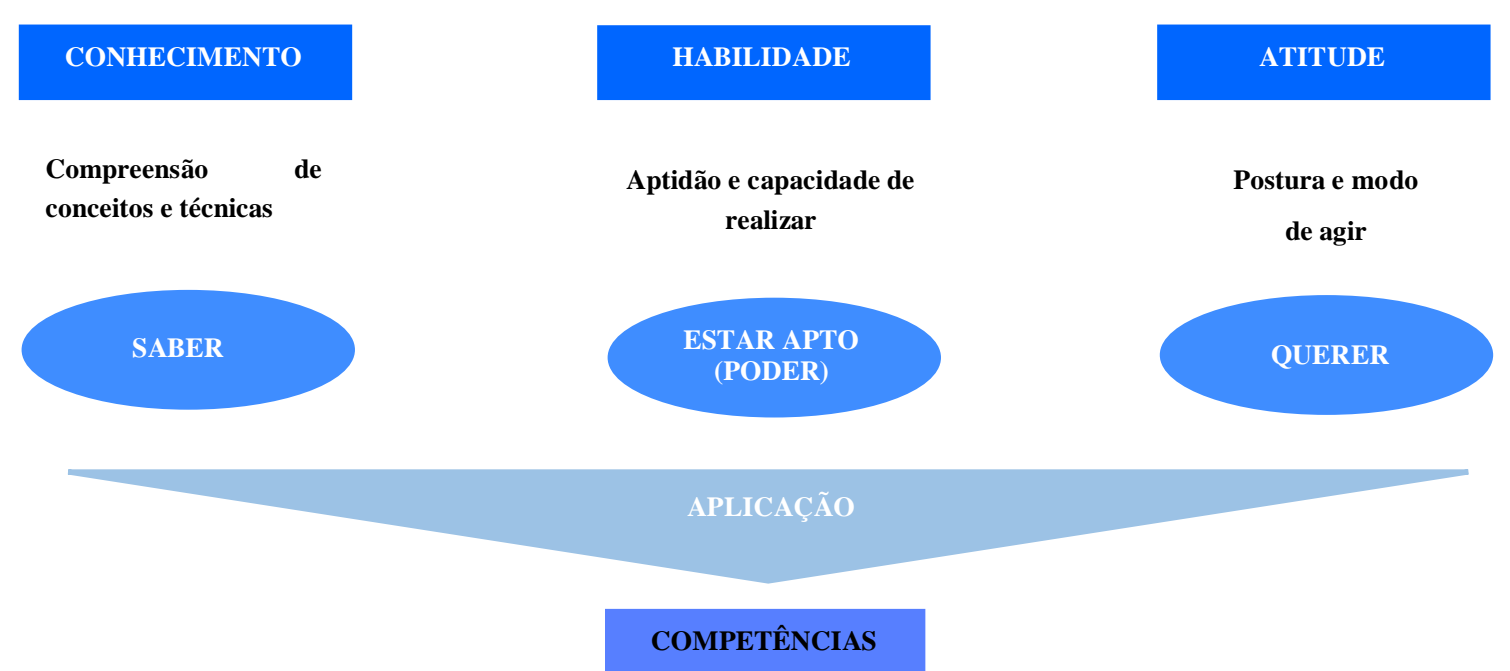

Figura 05: Definição de Competências

Fonte: EBOLI, 2004, p. 53

Investir em formações que trabalhem competências de uma pessoa, de maneira consistente e estruturada, implica, pois, em estruturar a aplicação dessa teoria com situações práticas e dinâmicas reflexivas, promovendo a conscientização sobre a importância de aplicar esse saber de forma correta e otimizada (EBOLI, 2004).

Antoni Zabala e Laia Arnau, especialistas sobre o tema competências na área de educação, reforçam essa definição de competências, ao afirmar que:

As competências são ações eficazes diante de situações e problemas de diferentes matizes, que obrigam a utilizar os recursos dos quais se dispõe. Para resolver os problemas que as situações apresentam, é necessário estar disposto a resolvê-los com uma intenção definida, ou seja, com atitudes determinadas. Uma vez mostrados a disposição e o sentido para a resolução dos problemas propostos, com atitudes determinadas, é necessário dominar os procedimentos, as habilidades e as destrezas que a ação que se deve realizar exige. Para que as habilidades cheguem a um bom fim, devem ser realizados sobre objetos de conhecimento, ou seja, fatos, conceitos e sistemas conceituais. Tudo isso deve ser realizado de forma inter-relacionada: a ação implica integração de atitudes, procedimentos e conhecimentos. (ZABALA \& ARNAU, 2010, 37-38)

Essa explicação sobre o desenvolvimento de competências nos remete às práticas de Célestin Freinet (1985), com sua Pedagogia do Bom Senso, e de John Dewey (1976a; 1976b), que defendiam que as reflexões teóricas deveriam ser desenvolvidas a partir de experiências da vida, para que os jovens reflitam sobre conceitos teóricos aplicados em situações reais e sobre a conscientização da participação ativa e responsável deles.

Quando da adoção mais recente desse termo pela área da educação, houve - e ainda há - uma certa resistência a isso por vários educadores desse campo, até em função de sua origem e seu 
prévio uso pelo setor empresarial. Perrenoud (2002), por exemplo, é um dos pesquisadores que, apesar de defender o uso das competências pela educação, alerta que a adoção pela educação dessa palavra e de toda proposta que ela traz consigo, deve ser feita com cuidado, para que não submeta a educação a algo focado na mera formação de mão de obra para o mercado e na produção de robôs bem formados.

Segundo ele:

O reconhecimento de uma competência não passa pela identificação de situações a serem controladas, de problemas a serem resolvidos, de decisões a serem tomadas, mas também pela explicitação dos saberes, das capacidades, dos esquemas de pensamento e das orientações éticas necessárias. Atualmente, define-se uma competência como a aptidão para enfrentar uma família de situações análogas, mobilizando de uma forma correta, rápida, pertinente e criativa, múltiplos recursos cognitivos: saberes, capacidades, microcompetências, informações, valores, atitudes, esquemas de percepção, de avaliação e raciocínio. (PERRENOUD, 2002, pag. 19)

A palavra competência apresenta diversos significados, a partir de várias áreas, até por causa da evolução do seu significado, sendo que esse termo já é melhor aceito por vários autores da própria educação, desde que considerados alguns cuidados.

Perrenoud utiliza o conceito de família de situações análogas ${ }^{49}$ (como vimos em Le Boterf) para se referir à aplicação de "saberes, capacidades, microcompetências, informações, valores, atitudes, esquemas de percepção, de avaliação e de raciocínio", de forma eficaz e flexível, ou seja, "rápida, pertinente e criativa". Os componentes que identifica nas competências poderiam ser agrupados em conhecimentos, capacidades e atitudes, como defendem a maioria dos autores nas definições que analisamos, no entanto, vai mais além ao acrescentar "microcompetências, informações, valores, atitudes esquemas de percepção, de avaliação e de raciocínio". Entendemos que esses novos elementos se referem, por um lado ao processo de atuação diante das situações análogas que descreve e, por outro, à atitude com a qual se atua em tais situações. (ZABALA \& ARNAU, 2010, p. 34)

Esses dois autores esclarecem que pensar o desenvolvimento de competências nos espaços educativos não é tarefa tão clara e simples, e fazem também uma proposta de esquema de competências, com base nas diferentes propostas analisadas sobre as competências e a adoção de suas premissas nesses espaços:

\footnotetext{
${ }^{49}$ Grifo do autor.
} 
Quadro 7 - Competências para o Século XXI, por Vários Autores

\begin{tabular}{|c|c|c|c|}
\hline Delors $^{50}$ & Projeto DeSeco ${ }^{51}$ & Currículo Básico ${ }^{52}$ & Monereo $^{53}$ \\
\hline Conhecer & Interatuar & Pensar e aprender & $\begin{array}{c}\text { Aprender a buscar a } \\
\text { informação e a aprender }\end{array}$ \\
\hline Fazer & $\begin{array}{l}\text { Atuar de forma } \\
\text { autônoma }\end{array}$ & Comunicar-se & Comunicar-se \\
\hline Ser & Utilizar as ferramentas & Conviver & Colaborar com outros \\
\hline Conviver & & $\begin{array}{c}\text { Ser autêntico; fazer e } \\
\text { empreender }\end{array}$ & $\begin{array}{c}\text { Aprender a participar na } \\
\text { vida pública }\end{array}$ \\
\hline
\end{tabular}

Fonte: ZABALA \& ARNAU, 2010, p. 77

A análise das propostas destacadas permite observar a forma como elas se aproximam, sendo que o aspecto comum a todas elas é o fato de que a concretização demanda necessariamente um movimento, para o que Zabala \& Arnau (2010) chamam de realidade concreta, ou seja, para trabalhar tais competências, qualquer que seja a idade, é preciso fazer isso a partir de fatos reais, situações problema ligadas à sua comunidade e ao seu dia a dia. Aqui identifico também pontos comuns com a própria abordagem protagonista das práticas educomunicativas, voltadas ao empoderamento das crianças e jovens adolescentes.

Se entendemos que a formação de todos os cidadãos deve estar direcionada a que sejam competentes para serem capazes de responder aos problemas que uma vida comprometida com a melhoria da sociedade e deles mesmos, as competências que deverão aprender podem se desenvolver nas seguintes dimensões: social, pessoal e profissional (ZABALA, 1999, apud ZABALA \& ARNAU, 2010,78).

Tais definições e alertas mostram a força que a proposta de adoção das competências como norteadoras da definição de objetivos nos espaços educativos está ganhando espaço crescente, a cada dia, na área da educação, pelo que optei por trazer este tópico ao presente estudo.

Ao buscar as características comuns entre o paradigma da Educomunicação e os fundamentos da avaliação formativa constatei que o conceito das competências começa a ser utilizado, atualmente, e cada vez com mais força, como base na definição de objetivos dos processos educacionais. Esta a razão de trazer este tópico como mais uma das possibilidades de definir os indicadores possíveis para os processos dialógicos e formativos do ato de avaliar.

\footnotetext{
${ }^{50}$ Jacques Delors. DELORS, 1996 apud ZABALA \& ARNAU, 2010)

${ }^{51}$ OCDE: Organização para Cooperação e Desenvolvimento Econômico. Sobre a referência: OCDE, 2002 ZABALA \& ARNAU, 2010)

${ }^{52}$ AA.VV., 2005 ZABALA \& ARNAU, 2010)

${ }^{53}$ C. Monereo, 2005 ZABALA \& ARNAU, 2010)
} 
Incluí assim ao presente capítulo a questão em análise para explicar a origem do termo que adotei neste estudo: competências educomunicativas.

As ponderações desses dois autores da educação (ZABALA \& ARNAU, 2010) convergem com as colocações de Mello \& Soares (2015), que alertam para o fato de que, ao pensar competências que sejam trabalhadas nos espaços escolares e que possam ser consideradas como educomunicativas, é preciso manter o foco na clareza do objetivo das práticas educomunicativas, que é a formação de cidadãos responsáveis e críticos, principalmente a partir das ideias colocadas por Freinet (1985), Freire (2002; 2005), Dewey (1976a; 1976b) e Soares $(1999 ; 2011)$.

O conceito das competências ganhou relevo na educação com o surgimento das novas TIC e de todo o ambiente digital que delas se originou, causando forte impacto sobre a sociedade, ao chamar a atenção de diversos atores ligados direta ou indiretamente às áreas de comunicação e educação, para os questionamentos sobre quais deveriam ser as habilidades e competências mais apropriadas para a formação de cidadãos e de mão de obra para uma sociedade altamente influenciada pelas tecnologias.

As chamadas competências do século XXI têm sido estudadas por diversas instituições, sendo que um dos mais antigos - se não for o mais antigo - é o Partnership for 21 st Century Skills ${ }^{54}$, o qual foi fundado nos Estados Unidos da América (EUA), em 2002. Consiste em um consórcio de instituições educacionais, corporativas e governamentais focadas no debate e definição sobre quais as competências que devem ser trabalhadas com as crianças e jovens no ensino fundamental desse país. Sua proposta de competências é resultado de anos de estudos feitos por várias organizações e educadores em todos os EUA.

De fato, em meados da década de 2010, esse contexto motivou as empresas Intel, Cisco e Microsoft a se juntarem para financiar uma pesquisa sobre quais seriam as competências que já deveriam ser trabalhadas nos espaços educativos - formal e não formal - desde os anos iniciais, para viverem nesse contexto altamente tecnológico e também estarem preparados para atuarem neles, enquanto mão de obra qualificada.

\footnotetext{
${ }^{54}$ www.21stcenturyskills.org
} 
Trata-se do projeto Assessment and Teaching of 21 st Century Skills (ATCS) ${ }^{55}$ que foi desenvolvido e coordenado por pesquisadores da área de educação da Universidade de Melbourne, na Austrália, de 2009 a 2012. Liderada pelo referido grupo de pesquisadores, essa iniciativa acabou envolvendo mais de sessenta universidades e mais de duzentos e cinquenta pesquisadores espalhados em diversos países ao redor do mundo. Seu objetivo maior foi a identificação dessas habilidades e competências.

Essa pesquisa apontou e destacou dez grupos de competências, os quais foram classificados e distribuídos em quatro categorias, apresentadas no quadro abaixo:

Quadro 8-Competências do Século XXI, do ATCS

\begin{tabular}{|l|l|}
\hline \multicolumn{1}{|c|}{ CATEGORIA } & \multicolumn{1}{|c|}{ COMPETÊNCIAS } \\
$\begin{array}{l}\text { Formas de Viver no } \\
\text { Mundo }\end{array}$ & $\begin{array}{l}\text { Cidadania (local e global) } \\
\text { Vida e Carreira } \\
\text { Responsabilidade pessoal e corporativa (incluindo consciência cultural e } \\
\text { competências) } \\
\text { Formas de Pensar }\end{array}$ \\
$\begin{array}{l}\text { Criatividade e inovação } \\
\text { Pensamento crítico, resolução de problemas e tomada de decisões } \\
\text { Aprender a aprender/metacognição (conhecimento sobre processos cognitivos) }\end{array}$ \\
\hline $\begin{array}{l}\text { Formas de Trabalhar } \\
\text { Trabalho }\end{array}$ & $\begin{array}{l}\text { Comunicação } \\
\text { Colaboração (trabalho em grupo) }\end{array}$ \\
\hline
\end{tabular}

Fonte: Binkley, M., Erstad, O., Hermna, J., Raizen, S., Ripley, M., Miller-Ricci, M., \& Rumble, M. (2012) ${ }^{56}$.

As pesquisas desenvolvidas por essas organizações, e os altos níveis de desemprego de jovens ao redor do mundo motivou a própria $\mathrm{UNESCO}^{57}$ a se dedicar ao mapeamento de competências, as quais também julga serem essenciais de serem trabalhadas já nos níveis fundamental e médio. Em 2010, publicou o documento Competências para a Vida e Trabalho, o qual contém orientações sobre como o tema deve ser trabalhado pelas organizações em suas formações. Além disso, eles têm procurado definir propostas curriculares para formação de professores, para prepará-los principalmente para atuarem com essas novas tecnologias

\footnotetext{
${ }^{55}$ ATCS: para mais informações visite o site http://atc21s.org/index.php/about/what-are-21st-century-skills/. Acesso em outubro/2011.

${ }^{56}$ Quadro elaborado com base nas informações contidas no texto sobre pesquisa realizada pelo referido grupo.

${ }^{57}$ UNESCO : vide áreas de Educação (http://www.unesco.org/new/en/education/themes/) e de Comunicação e Informação (http://www.unesco.org/new/en/communication-and-information/), do site da UNESCO. Acesso em outubro/2011.
} 
digitais na educação, de maneira que esses tenham condições de trabalhar habilidades e competências para a vida, com seus próprios alunos nos espaços educativos onde atuam.

Apesar da referida pesquisa ter tido o foco também no entendimento sobre as competências necessárias à formação de mão de obra qualificada, ao comparar as competências apresentadas no Quadro 7 com as competências do Quadro 8, identifiquei várias competências comuns a ambos os quadros, o que não me causou estranheza, pois muitas delas são importantes para a vida pessoal, social e profissional das pessoas.

A própria Secretaria Municipal de Educação de São Paulo, em seu documento sobre as Orientações Curriculares - Proposições de Expectativas de Aprendizagem, de Tecnologias de Informação e Comunicação, distribui as competências em quatro categorias: pessoais (aprender a ser); interpessoais (aprender a conviver); profissionais ou executivo-gerenciais (aprender a fazer); competências cognitivas (aprender a conhecer). Esse material apresenta orientações sobre como trabalhar as competências em projetos educacionais com mediação tecnológica (SÃO PAULO, 2010).

Pesquisadores e professores que já estão desenvolvendo suas aulas com base nas premissas educomunicativas, como as ligadas ao NCE/USP, e que já adotam os aparatos comunicacionais digitais em salas de aula nos seus diversos níveis de ensino, refletem que talvez um dos seus maiores questionamentos seja exatamente como planejar tais aulas a partir de dinâmicas que realmente desencadeiem processos cognitivos consistentes, voltados ao pensamento crítico e à construção de um conhecimento significativo para a vida desses educandos.

Frente a todas as colocações aqui apresentadas, listo algumas competências, que classifico como sendo educomunicativas - pelo fato de serem consideradas enquanto premissas das práticas com base no paradigma da Educomunicação - tendo sido utilizadas como indicadores em nesta pesquisa, quando busquei entender se os projetos estudados apresentavam em suas rubricas, critérios com descrição das mesmas, quais sejam:

(a) planejar o desenvolvimento do projeto com os demais membros do grupo;

(b) implementar colaborativamente as etapas planejadas; 
(c) tomar decisão de forma coletiva em tudo que diga respeito ao tema a ser estudado e/ou às etapas de desenvolvimento do projeto;

(d) operacionalizar e implementar o projeto em coerência com os postulados da Educomunicação, preservando o diálogo entre os colegas do grupo e promovendo a colaboração mútua na orientação dos colegas e na aprendizagem comum;

(e) manter a coerência entre as metas propostas e as soluções dadas aos problemas ligados ao desenvolvimento do projeto;

(h) comunicação por meio do uso de TIC.

Apresentadas todas as bases conceituais que estruturaram este estudo e destacados todos os respectivos indicadores que viabilizaram realização da pesquisa de campo, passo, agora, ao capítulo três, no qual apresento os detalhes desta última.

\subsection{Educomunicação e Práticas Pedagógico- Comunicacionais da Avaliação Formativa: reflexões sobre aproximações teóricas possíveis}

Uma das minhas hipóteses norteadoras é que as ações estratégicas do modelo de avaliação formativa adotada nos LIE, da DOT/SME-SP, são estruturadas com base nas premissas educomunicativas, as quais podem ser verificadas a partir de suas práticas pedagógicocomunicacionais.

Para verificar essa afirmação apresento no Quadro 9 um resumo de minhas reflexões sobre as possíveis aproximações conceituais, sendo que na coluna um há os temas e subtemas educomunicativos considerados para a análise de conteúdo da pesquisa empírica. E na coluna dois, apresento os comentários sobre as possíveis aproximações destes com os aspectos conceituais da avaliação dialógica e formativa sobre as quais discorremos neste Capítulo Dois.

Esse quadro originou-se de outro mais completo, o qual está disponibilizado no Anexo $\mathrm{H}$, com quatro colunas, sendo três delas dedicadas a cada uma das bases conceituais deste estudo e a quarta, para os comentários sobre as aproximações. 
Ainda sobre o Quadro 9, na coluna sobre os temas e subtemas educomunicativos, esses foram definidos exatamente a partir das características essenciais da Educomunicação apresentadas no capítulo 1. Ou seja, para o tema "Finalidade Principal", há 3 subtemas, quais sejam: empoderamento do aluno enquanto cidadão responsável; apoio à construção do conhecimento; acompanhamento do desenvolvimento das competências educomunicativas no contexto de ecossistemas comunicacionais. E na coluna com as considerações sobre as possíveis aproximações conceituais, a partir dos pontos de aproximação percebidos na tabela completa disponibilizada no Anexo $\mathrm{H}$, eu justifiquei como foram definidas as características.

Quadro 9 - Indicadores Educomunicativos

\begin{tabular}{|c|}
\hline $\begin{array}{l}\text { TEMAS E SUBTEMAS } \\
\text { EDUCOMUNICATIVOS } \\
\text { (SOARES, 1999; 2011) }\end{array}$ \\
\hline FINALIDADE PRINCIPAL \\
\hline $\begin{array}{l}\text { 1. Empoderamento do aluno enquanto } \\
\text { cidadão responsável }\end{array}$ \\
\hline 2. Apoio à construção do conhecimento \\
\hline $\begin{array}{l}\text { 3. Acompanhamento do desenvolvimento } \\
\text { das competências educomunicativas no } \\
\text { contexto de ecossistemas comunicacionais }\end{array}$ \\
\hline MOMENTO DE AVALIAÇÃO \\
\hline $\begin{array}{l}\text { 1. Acompanhamento ao longo do processo; } \\
\text { 2. Viabilização de intervenções e } \\
\text { orientações ao longo de todo o processo, e } \\
\text { não apenas no início ou final do mesmo. }\end{array}$ \\
\hline
\end{tabular}

DINÂMICA ENCERRAMENTO

1. Rodas de conversas, ao final do processo, para desenvolvimento de reflexões analíticas e reflexivas pelos alunos, de forma individual e/ou grupal.

\section{CONSIDERAÇÕES SOBRE AS POSSÍVEIS APROXIMAÇÕES} CONCEITUAIS

\section{FINALIDADE PRINCIPAL}

O paradigma da Educomunicação tem como sua finalidade o empoderamento, e consequentemente $\mathrm{o}$ apoio à construção do conhecimento, o que demanda um acompanhamento do desenvolvimento das práticas nos ecossistemas comunicacionais.

A avaliação dialógica destaca esses aspectos todos.

Já a avaliação formativa não fala em empoderamento, mas em autorregulação.

Contudo estamos considerando convergentes, pois a autorregulação implica que a criança e jovem compreenda e se aproprie de seu processo de aprendizagem, o que, a nosso ver, é convergente e complementar com a questão do empoderamento.

\section{MOMENTO DE AVALIAÇÃO}

Dada a finalidade principal ser o empoderamento, uma proposta de abordagem educomunicativa deve ser viável DURANTE o desenvolvimento das práticas, sendo que ambas as abordagens aqui analisadas apresentam essa característica.

\section{DINÂMICA ENCERRAMENTO}

Esta premissa educomunicativa também é atendida nas duas propostas de avaliação dialógica e formativa.

Vale destacar, que apesar da adoção de outra terminologia - avaliação entre pares ou autoavaliação individual - a avaliação formativa detalha mais objetivamente as ações que seriam desenvolvidas nessa roda de conversa.

\section{AÇÕES CONSIDERADAS}

PRATICAS PEDAGÓGICO-

\section{COMUNICACIONAIS}

1. Gestão Compartilhada da Comunicação (SOARES, 1999):

a. Ação comunicativa;

b. Apropriação e manejo das linguagens da comunicação; 
c. Uso dos recursos da informação para a produção cultural.

2. Participações de Protagonismo [Degraus de Participação: 5 a 10 (HART, 1992; COSTA,2006) ]:

a. Participação planejadora e operacional.

b. Participação decisória, planejadora e operacional.

c. Participação decisória, planejadora, operacional e avaliadora.

d. Participação colaborativa plena.

e. Participação plenamente autônoma.

f. Participação condutora.

3. Ações de Diálogo

a. Escuta mútua

b. Pensar juntos

c. Apontar outros pontos de vista

d. Compartilhar e refletir sobre ideias,

e. Fazer emergir ideias / buscar pluralidade de ideias

4. Novas relações entre professores e alunos (BACCEGA, 2011; CITELLI, 2011)

\section{COMPETÊNCIAS EDUCOMUNICATIVAS}

1. Diálogo (Pensar e construir conjuntamente)

2. Escuta mútua

3. Organização e expressão do pensamento (reflexão)

\section{Colaboração}

5. Compartilhamento (de experiências e de ideias)

6. Gestão da Compartilhada da Comunicação e Uso de TIC

7. Tomada Compartilhada de Decisão

8. Resolução Conjunta de Problemas

9. Avaliação (entre pares e autoavaliação) com as premissas educomunicativas, bem como suas demais dinâmicas.

O próprio fato de ser uma proposta derivada das ideias de Paulo Freire confirma que as suas premissas são convergentes com as da Educomunicação. E então esta proposta valida as premissas que definimos como sendo necessárias a uma proposta de avalição de abordagem educomunicativa.

Quanto às ações estratégicas da avaliação formativa, elas indicam também a convergência, e parecem se estruturar principalmente nas ações dialógicas e protagonistas, como estamos considerando como uma das nossas hipóteses norteadoras.

Contudo, por todas as ações estratégicas listadas e possibilidades de ocorrência de cada uma delas, entendemos que os comentários acerca da estrutura desta abordagem terem ou não fortes características dialógicas serão melhor estruturados a partir dos dados da pesquisa empírica.

\section{COMPETÊNCIAS CONSIDERADAS}

Para este tema e respectivos subtemas, os autores de ambas as propostas de avaliação indicam a possiblidade de trabalharmos inúmeras competências com a adoção dessas abordagens avaliativas, mas não mencionam competências específicas, como as que definimos aqui como sendo educomunicativas.

Na verdade, este tema foi definido principalmente para verificarmos se há competências educomunicativas sendo trabalhadas nas atividades dos projetos, quando analisamos seus quadros de rubricas. 


\section{OS PROJETOS DE INFORMÁTICA}

EDUCATIVA (DOT/SME-SP)

Como disse na Introdução desta tese, a pesquisa de campo foi realizada a partir de oito projetos ligados aos laboratórios de informática educativa de unidades educacionais da SMESP. Frente a isso, dedico este capítulo para a explicar mais detalhadamente o que é o Núcleo de Informática Educativa da SME-SP e quais foram os oito casos estudados.

De fato, o contexto das práticas dos laboratórios de informática educativa (LIE) é diversificado, principalmente no que se refere ao entendimento sobre como são definidas as orientações na DOT/SME-SP sobre suas práticas e como essas são realizadas de fato pelos 
POIE nos espaços dos ambientes escolares, passando pelas formações e acompanhamentos das Diretorias Regionais de Educação (DRE).

\subsection{Diretrizes dos Laboratórios de Informática Educativa, da SME-SP, e a Avaliação Formativa}

Exatamente para um melhor entendimento desse universo, início este tópico apresentando o organograma da SME-SP, para então explicar como se desenvolvem os fluxos comunicacionais com as orientações sobre as ações e projetos desenvolvidos nos LIE das unidades educacionais. Logo, do início desta pesquisa, até meados de 2015, a SME-SP apresentava o seguinte organograma:

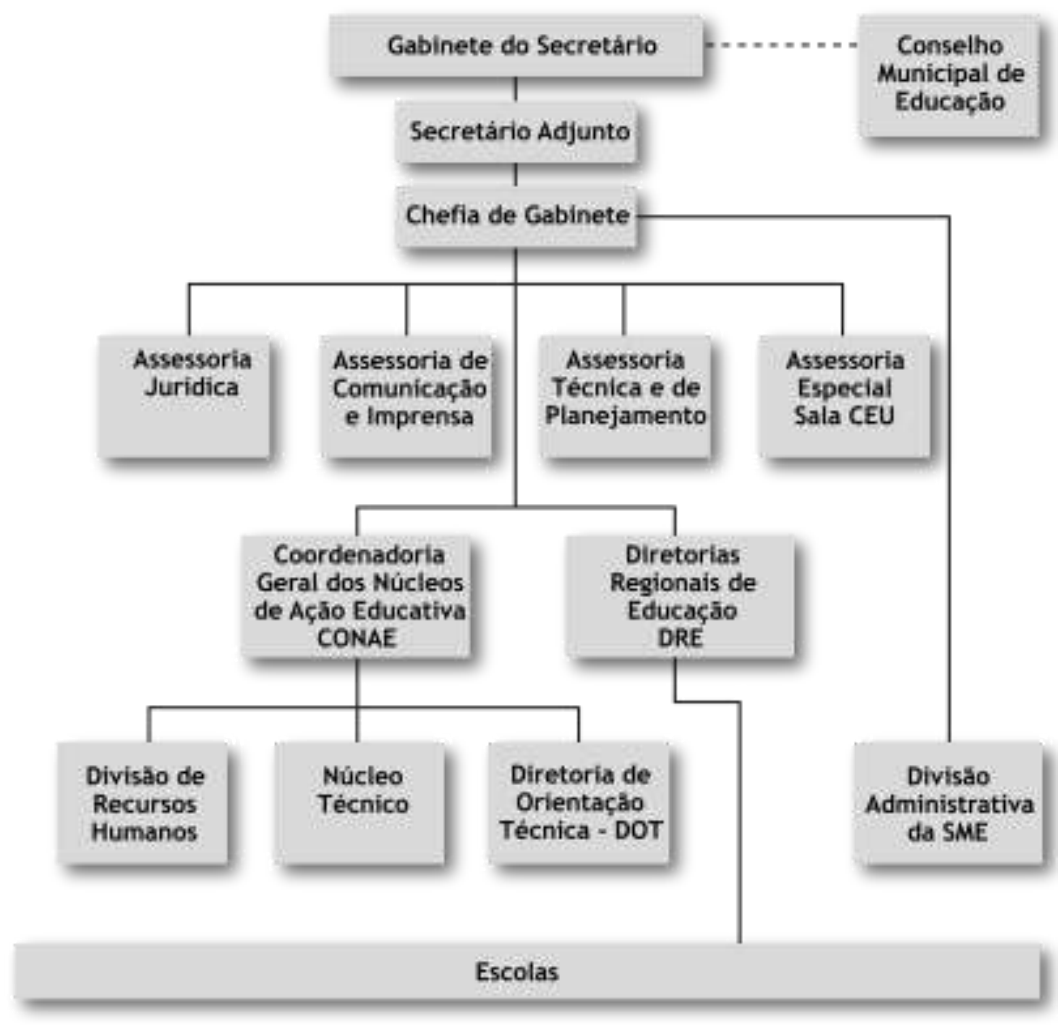

Figura 6 - Organograma Secretaria Municipal de Educação Fonte: Site SME-SP ${ }^{58}$

58 Fonte: Site 
O programa dos LIE, que em 2013 se transformou em Núcleo de Informática Educativa, está sob a responsabilidade da Diretoria de Orientação Técnica (DOT), a qual responde para a Coordenadoria Geral dos Núcleos de Ação Educativa (CONAE). O CONAE é formado por três unidades, a saber: Divisão de Recursos Humanos, Núcleo Técnico e Diretoria de Orientação Técnica. As atividades destas estão focadas na definição e implementação de todas as diretrizes, bem como viabilização delas, por meio da contratação e/ou gestão de recursos humanos e técnicos para os projetos, além da definição de abordagens a serem adotadas pelas treze Diretorias Regionais de Educação (DRE), distribuídas por toda a cidade de São Paulo: Butantã, Campo Limpo, Capela do Socorro, Freguesia/Brasilândia, Guaianases, Ipiranga, Itaquera, Jaçanã/Tremembé, Penha, Pirituba, Santo Amaro, São Mateus, São Miguel.

Especificamente sobre a DOT, esta se organiza da seguinte forma: Núcleo de Informática Educativa; Núcleo Nas Ondas do Rádio; Núcleo de Educação Etnicorracial; Equipe de Certificados; Divisão de Orientação Técnica de Educação Infantil; Divisão de Orientação Técnica de Ensino Fundamental e Médio; Divisão de Orientação Técnica de Educação de Jovens e Adultos; Equipe do Núcleo de Educação Especial; Sala e Espaço de Leitura.

Cada uma dessas treze DRE conta com uma equipe regional responsável pelas atividades dos LIE de suas respectivas unidades educacionais, equipe essa que oferece formação e atualização aos POIE sobre o uso de TIC, a partir da pedagogia de projetos e avaliação formativa, para que estejam aptos a desenvolverem os projetos dos LIE, considerando as orientações e diretrizes definidas pela coordenação geral da DOT.

Como mencionei no tópico sobre a justificativa desta pesquisa, na Introdução deste texto, as primeiras ações do que viria a se tornar o Núcleo de Informática Educativa datam de 1992 se iniciaram com a estruturação do projeto Gênese. Atualmente todas as escolas de Ensino Fundamental (aproximadamente 545 escolas) e de Ensino Médio (oito unidades) contam com seus LIE, cada um com vinte e um computadores, a maioria deles com conexão de internet por transmissão terrestre (cabo), com plataforma Windows e acesso a vários softwares, de diversas linguagens, para usos pedagógicos, incluindo alguns específicos para alunos portadores de deficiências.

Sob responsabilidade dos Professores Orientadores de Informática Educativa (POIE), esses espaços midiáticos são utilizados para oferecer uma aula semanal a cada uma de todas as 
turmas das referidas unidades escolares, mas os alunos podem fazer uso deles também em momentos fora do horário regular das suas aulas, para o desenvolvimento de pesquisas diversas. Além disso, ali são realizadas formações contínuas de professores e alunos, além do desenvolvimento de projetos focados no trabalho de competências específicas de comunicação, pesquisa e publicação na internet, autoria e protagonismo.

Apesar do termo ter sido adotado na Rede a partir de 1992, sobre o conjunto de normas que regem as práticas dos LIE, essas foram instituídas oficialmente com esse termo pelo Decreto 34.160/94, pela SME-SP. Durante as últimas décadas, as diretrizes sobre as dinâmicas desses laboratórios sofreram vários ajustes e atualizações, sendo que atualmente a organização dos LIE é regida principalmente pelas seguintes normas:

(a) Decreto 34.160/94: instituiu os LIE nas escolas municipais;

(b) Portaria SME nº 1.997/09: instituiu o Programa Aluno Monitor nas Unidades Educacionais da Rede Municipal de Ensino;

(c) Portaria SME no 5.792/09: instituiu o Programa Nas Ondas do Rádio nas Unidades Educacionais da Rede Municipal de Ensino, enquanto responsável para oferecer formações para o uso de diferentes linguagens nos projetos dos LIE;

(d) Diretrizes Curriculares Nacionais contidas nas diferentes Resoluções do Conselho Nacional de Educação, em especial, a Resolução CNE/CEB nº 04/10;

(e) Decreto $n^{\circ}$ 54.452/13: instituiu, na SME, o Programa de Reorganização Curricular e Administrativa, Ampliação e Fortalecimento da Rede Municipal de Ensino - Mais Educação São Paulo, regulamentado pela Portaria SME nº 5.930/13;

(f) Portaria SME-SP 5.930/13: definiu a responsabilidade dos LIE no programa Mais Educação São Paulo;

(g) Portaria SME-SP 900/14: apresentou a organização e diretrizes das práticas dos LIE, nas unidades educacionais da referida Rede Municipal de Ensino;

(h) Portaria SME no 7.464/15: criou o programa "São Paulo Integral" na cidade de São Paulo, e indica as práticas dos LIE para o mesmo; 
(i) Portaria SME-SP 7.656/15: atualizou e complementou a descrição da organização e atividades dos LIE.

Além dessas normas, houve algumas ações que contribuíram de alguma forma com esse processo de uso de TIC na educação, que adotaram diferentes propostas durante os últimos anos - da mais instrumental até modelos cada vez mais pedagógico-comunicacionais.

De 2002 a 2006, vigorou uma parceria da Fundação Telefônica com a SME-SP, para a realização de formações dos POIE para o uso de ferramentas da internet na escola. Dessa parceria foi criado o documento Caderno de Orientações Didáticas - Ler e Escrever Tecnologias na Educação, com dicas sobre o uso pedagógico de várias linguagens midiáticas em sala de aula. (SÃO PAULO, 2006)

Em 2008, foi realizada uma primeira avaliação dos projetos originados dessas formações, sendo que o foco foi a verificação das competências que já vinham sendo trabalhadas. Foi nesse mesmo ano que surgiu o programa Aluno Monitor ${ }^{59}$, voltado à formação de alunos que auxiliam os POIE na realização de projetos nos LIE, para o enriquecimento das práticas curriculares, incentivo à realização de atividades colaborativas e estímulo à comunicação entre as unidades da referida Rede.

O programa Aluno Monitor estrutura-se em encontros semanais dessas crianças e jovens com seu POIE responsável, no LIE da unidade educacional onde estudam, no contraturno do seu período de estudo. O objetivo é trabalhar diversas competências com os alunos, como capacidade de comunicação, tomada de decisões, solução de problemas, colaboração em equipe, protagonismo juvenil, responsabilidade social, dentre outras. Para tanto, esses alunos monitores desenvolvem projetos temáticos entre eles e o POIE, que trabalham planejamento e implementação de projetos, além de viabilizar e auxiliar no desenvolvimento de diversas atividades com as turmas de alunos atendidos pelo POIE, como orientação e auxílio destes últimos, durante o desenvolvimento das dinâmicas propostas para essas turmas, por esse docente. $\mathrm{O}$ aluno monitor assume o papel de facilitador na concretização dos processos pedagógico-comunicacionais dos LIE.

Quando da realização de nova avaliação dessas atividades, em 2010, houve a publicação, pela então equipe de Informática Educativa, de um novo documento (Orientações Curriculares -

\footnotetext{
${ }^{59}$ Regulamentado posteriormente pela Portaria SME no $1.997 / 09$, anteriormente mencionada neste texto.
} 
Tecnologias de Informação e Comunicação: proposições de expectativas de aprendizagem), o qual continha atualizações das orientações sobre o uso da TIC na Rede, tais como: aspectos básicos da formação do professor; premissas das chamadas competências do século XXI; modelo de avaliação do desenvolvimento de competências do século XXI; descrição dos programas da SME-SP que fazem uso das TIC no desenvolvimento de práticas educativas; contexto nacional e internacional sobre o uso das TIC. (SÃO PAULO, 2010)

Esses resultados auxiliaram na definição dos novos planos das práticas que passaram a ser adotadas pelos POIE. Além disso, nesse mesmo ano de 2010, e até com base nas orientações da portaria publicada em $2009^{60}$, começaram as primeiras dinâmicas integradas dos projetos dos LIE com alguns dos projetos do Nas Ondas do Rádio (NOR), que passou a ofertar formações sobre o uso de várias mídias e suas respectivas linguagens (ex.: fotografia, áudio, vídeo, histórias em quadrinhos, fanzine, jornal impresso, jornal mural, games na educação) para os POIE, em suas práticas.

Cabe destacar, porém, que as formações do NOR definidas pela portaria mencionada são também para os demais professores da Rede, pois o planejamento e execução de suas ações são independentes das atividades do Núcleo de Informática Educativa. Houve, contudo, uma maior aproximação entre os dois núcleos - Informática Educativa e Nas Ondas do Rádio pela convergência das práticas desenvolvidas por eles.

Em 2011, já havia sido identificada a necessidade de incentivar os POIE a realizarem registros de suas práticas e, apesar das práticas nos laboratórios não preverem um processo avaliativo específico e obrigatório, a equipe de informática educativa da DOT / SME-SP e os próprios gestores começaram a buscar opções de mecanismos de acompanhamento dessas. De fato, já havia a ideia de que esses mecanismos não deveriam ser de aprovação ou reprovação, mas principalmente de auxílio à construção e fortalecimento do conhecimento durante o desenvolvimento dos projetos, para trabalhar as competências do século XXI.

Paralelamente a essa busca, ganhava força a adoção da pedagogia de projetos com base em temáticas ligadas à unidade educacional e/ou seu entorno, o que significava um processo mais prolongado, desenvolvido em um número maior de aulas, e indicava a necessidade de espaços virtuais de aprendizagem para registro dessas atividades. Foi então que, em 2011, o Think

${ }^{60}$ Portaria SME no $5.792 / 09$. 
Quest $^{61}$, da Oracle Education Foundation, começou a ser utilizado por alguns desses POIE, para desenvolvimento de seus trabalhos nos LIE, o que resultou na indicação de uso dele, para a equipe de Informática Educativa estruturar e sistematizar uma proposta básica, a qual pudesse ser minimamente apresentada e disseminada pela referida Rede.

Nessas práticas prévias, foram pensadas as seguintes dinâmicas para a adoção do Think Quest: desenvolvimento de reflexões escritas durante as aulas de LIE; repositório de dados coletados pelos alunos, para desenvolvimento dos projetos; disponibilização dos produtos dos projetos, como fotos de criação de jardim suspenso, com uso de garrafa pet como vasinhos, ou vídeos dos espaços estudados, ou ainda publicação de livro de receitas, ao final de projeto sobre reflexão nutricional, a partir do lixo da escola; realização das autoavaliações dos alunos, com base em rubrica criada para o próprio projeto.

Todas essas buscas por opções de plataforma virtual de aprendizagem e de um modelo de avaliação formativa para os projetos resultaram em novas orientações das práticas dos LIE, com o objetivo de estimular os POIE a efetuarem registros e respectivas avaliações de suas práticas nos LIE. Em 2012 a equipe de Informática Educativa, na DOT / SME-SP, passou a dar formações aos gestores das treze DRE, orientando-os para que os projetos fossem registrados no ambiente virtual de aprendizagem ThinkQuest. Essa plataforma era simples de ser estruturada e configurada para uso em aulas presenciais e desenvolvimento de projetos, além do fato de que tinha uma fácil navegabilidade, o que resultou na sua indicação como opção para desenvolvimento e registro de atividades.

É nesse momento que se iniciam formações de gestores de DRE com foco na estruturação e no desenvolvimento de algumas ações estratégicas de avaliação formativa, com base nas premissas de Wiliam (2011), sendo que o foco principal foi o desenvolvimento da rubrica, para realização da autoavaliação, pelos POIE, e orientações sobre como realizar os registros de atividades dos LIE no ambiente virtual de aprendizagem Think Quest. Além disso, em 2012, houve a determinação, por parte da DOT / SME-SP, para que os projetos desenvolvidos nesses espaços dos LIE fossem sobre a temática Sustentabilidade.

${ }^{61}$ O ThinkQuest plataforma virtual de aprendizagem foi desenvolvida pela Oracle Education Foundation, para atividades educacionais presenciais do ensino fundamental, e tinha acesso gratuito, mas sua oferta foi descontinuada no ano de 2013, o que fez com que a equipe de Informática Educativa, da DOT/ SME-SP, passasse a indicar a plataforma Edmodo, como substituta do Think Quest. Para esta pesquisa empírica, alguns projetos analisados ainda são da época do Think Quest, e outros utilizaram outros recursos digitais para registro. 
A partir do exposto até aqui, pude constatar os desafios de implementação de novas orientações de prática junto à referida Rede, até pelo número de unidades educacionais envolvidas $^{62}$ e pelo número de POIE alocados nesses LIE (aproximadamente 900 Professores Orientadores de Informática Educativa), distribuídos pelas 13 DRE. Consequentemente, para que essas orientações sobre a adoção de ações estratégicas de avaliação formativa chegassem a esses docentes, a então equipe de Informática Educativa, da DOT / SME-SP, coordenada pela professora Jane Reolo da Silva ${ }^{63}$, nesse ano de 2012, iniciou suas formações com encontros presenciais mensais com os gestores das DRE, de maneira que pudesse desenvolver conjuntamente uma rubrica que contivesse os critérios com base nos quais os POIE deveriam se autoavaliar.

Foi um processo de construção conjunta muito rica entre esses gestores que, em um primeiro momento, foram divididos em pequenos grupos. $\mathrm{O}$ primeiro passo foi definir quais seriam os critérios que deveriam ser observados nesses processos de autoavaliação dos POIE, quanto a seus registros. Após a definição desses, com base nas competências do Século XXI, contidas no documento anteriormente publicado pela SME-SP sobre o tema ${ }^{64}$, os gestores foram divididos em pequenos grupos ou mesmo em pares de gestores, para que desenvolvessem os descritivos detalhados dos quatro critérios dessa rubrica. Feitas essas especificações, passaram à fase de reflexões conjuntas dos textos de cada um dos níveis, para que alinhassem as leituras de cada gestor em relação ao perfil dos POIE de suas Diretorias.

A rubrica completa e finalizada, com os descritivos de todos os critérios, a qual foi encaminhada pelos gestores das DRE aos seus POIE, consta como Rubrica 1, do Anexo B, aqui desta pesquisa. O relato desse processo me foi descrito pela professora e gestora Cristina Barroco Massei Fernandes ${ }^{65}$, que participou ativamente desse desenvolvimento, e pela então coordenadora da equipe de Informática Educativa, a professora especialista Jane Reolo.

\footnotetext{
${ }^{62}$ Como dito anteriormente, há aproximadamente 545 unidades educacionais de ensino fundamental.

${ }^{63}$ Mestranda em Educação (PUC-SP), especialista em Tecnologias Interativas Aplicadas à Educação (PUC-SP), graduada em Pedagogia, está diretora de escola da Rede Municipal de Educação de São Paulo, tendo sido coordenadora do Núcleo de Informática Educativa, da DOT/SME-SP, de 2012 a 2014.

${ }^{64}$ Mencionadas no tópico sobre competências, do Capítulo Dois.

${ }^{65}$ A professora Cristina Barroco Massei Fernandes, a qual passará a ser identificada neste texto simplesmente como professora Cristina Barroco, é graduada em Pedagogia pela USP, especialista em Tecnologias na Aprendizagem, pelo SENAC-SP, coordenadora pedagógica e formadora de professores e gestores da DRE Campo Limpo, em que responde pelas frentes de Informática Educativa / Tecnologias para Aprendizagem e Núcleo de Educomunicação.
} 
Ainda em 2012, na tentativa de atingir um número maior de POIE, a coordenadora Jane Reolo desenvolveu também a atividade Navegação Orientada, a qual consistia em escolher projetos dos LIE, bem estruturados e devidamente registrados no ThinkQuest, para serem visitados como exemplos de boas práticas. Tratava-se, como o nome diz, de uma visita orientada ao espaço do projeto - daí navegação orientada. O encontro se iniciava em um espaço do Facebook, onde os POIE se conectavam para conhecer o acesso ao projeto escolhido, bem como os destaques de boas práticas do mesmo, com detalhes sobre o que estariam analisando naquela visita. Na sequência, eles visitavam o link do projeto no ThinkQuest, e ainda tinham a oportunidade de conversar com o POIE responsável pelos projetos, para conhecer detalhes. Todo a comunicação era feita por escrito, ao vivo, a distância, no chat no Facebook, e tinha duração de uma hora. Foram realizados seis desses encontros em 2012.

Essas formações também focaram as orientações quanto ao uso e registro das práticas na plataforma indicada nesse ano de 2012, para que os POIE planejassem seus projetos, considerando os registros dessas práticas nesse ambiente, e se autoavaliassem com base na rubrica desenvolvida. Os gestores foram orientados, então, para passarem a rubrica desenvolvida para seus POIE, solicitando que escolhessem um projeto cujo registro tivesse sido feito junto ao ThinkQuest, para se autoavaliarem.

A disseminação da proposta de registro e respectiva autoavaliação dos POIE não chegou a se concretizar por toda a referida Rede, mas houve alguns casos exitosos. Alguns desses gestores, como a professora Cristina Barroco, da DRE Campo Limpo, e a professora especialista Regina Célia Fortuna Broti Gavassa ${ }^{66}$, da DRE São Mateus, relataram que fizeram ajustes nessa orientação dada pela equipe de Informática Educativa, da SME-SP, sendo que solicitaram para que os POIE não se limitassem às autoavaliações com a rubrica, mas também para utilizarem essa mesma ou desenvolveram outras, nos mesmos moldes, de maneira que seus alunos também vivenciassem esse processo de autoavaliação ao final dos projetos desenvolvidos nos LIE.

Especificamente sobre a proposta de avaliação formativa aqui em estudo, reforço que à equipe da Informática Educativa da DOT / SME-SP coube fazer orientações sobre a adoção da

\footnotetext{
${ }^{66}$ A professora Regina Gavassa é especialista em Informática Educativa, pela Universidade Federal de Lavras, e em Mídias na Educação, pela Universidade Federal de Pernambuco (UFPE/NCE-USP). Graduada em Estudos Sociais com habilitação em Geografia, pela Faculdade Capital, e em Pedagogia, pela Universidade Bandeirante de São Paulo. No período de 2012 a 2014 atuou como gestora da DRE São Mateus e, a partir de janeiro de 2015 até a data de depósito deste estudo, estava gestora do Núcleo de Informática Educativa, da DOT/SME-SP.
} 
mesma no desenvolvimento dos projetos de LIE, o que significa que houve uma apresentação dessa proposta metodológica sobre avaliação formativa. Contudo, nem os gestores das DRE, nem os POIE das unidades educacionais eram obrigados a adotá-la.

Esta pesquisa indicou que a execução dessa proposta encontrou vários desafios e obstáculos para sua disseminação, alguns dos quais serão mencionados em minhas análises, sendo que o próprio entendimento e disseminação dessas orientações, bem como a realização das respectivas formações sobre uma sistematização melhor estruturada ainda estava em desenvolvimento quando do depósito desta tese. Porém vale registrar que, mesmo não tendo sido adotada por um grande número de POIE em toda Rede, tive o cuidado de localizar e utilizar os dados de projetos que apresentassem pelo menos uma das ações estratégicas da proposta de avaliação formativa de Wiliam (2011), para não ter meus resultados comprometidos pela ausência das informações de que necessitávamos: ações de avaliação formativa que pudessem apresentar pontos de aproximação com as características do paradigma da Educomunicação.

\subsection{Dois Tipos de Amostra para um Universo Diversificado}

Antes de iniciar o desenvolvimento deste estudo, tive um contato inicial com as ações estratégicas de avaliação formativa desenvolvidas por algumas unidades educacionais da referida Rede, que sinalizou para a possibilidade de desenvolvimento desta minha pesquisa empírica. Contudo ao aprofundar meu conhecimento sobre as práticas desenvolvidas pelos POIE, nos vários LIE desses espaços educacionais, verifiquei a diversidade desse universo, o que fez com que a definição do tipo de pesquisa que realizaria se tornasse um dos meus grandes desafios.

Os objetivos deste meu estudo eram verificar se a avaliação formativa adotada pelos LIE, da DOT/SME-SP, se estrutura a partir das práticas pedagógico-comunicacionais e se há aspectos educomunicativos que norteiam as práticas dos LIE, da DOT/SME-SP, mas precisava considerar pelo menos três características desse universo dos LIE, da DOT/SME-SP: apesar da definição de adoção da pedagogia de projetos para o desenvolvimento das atividades nesse espaço, por parte da DOT / SME-SP, cada POIE tem certa autonomia quanto à abordagem 
metodológica adotada em seus LIE (cada projeto é um caso); não há obrigatoriedade oficial de uma avaliação de desempenho dos alunos que participam das atividades dos LIE (qualquer avaliação de desempenho que seja feita em virtude dessas atividades, não contam para efeito de média do aluno, ao final de um período de estudo), mas há a necessidade de apresentação de relatórios do que foi desenvolvido; não há um mapeamento detalhado de quantos projetos foram desenvolvidos com base na referida proposta e quais foram os resultados obtidos com eles, mas sabe-se que não foi (e segue não sendo) a maioria dos POIE que adotou tal $\operatorname{proposta}^{67}$.

Uma análise geral desse universo nos fez perceber que houve casos em que a adoção dessa proposta foi coordenada e acompanhada diretamente pelos gestores da DRE responsável, e houve casos em que os próprios POIE, uma vez que tiveram alguma orientação ou formação sobre ela, decidiram testar e adotar uma ou mais ações das estratégias propostas, principalmente quanto à criação e adoção de uma rubrica. E houve casos também em que os POIE sequer adotaram alguma das ações estratégicas de avaliação formativa aqui indicadas, mas desenvolvem grandes práticas a partir da pedagogia de projetos.

Frente a isso, a escolha dos projetos estudados foi feita com base nas indicações e comentários da gestora do Núcleo de Informática Educativa, no período de 2011 a 2014, Jane Reolo, e da professora Cristina Barroco, que me orientaram sobre quais os projetos e respectivas escolas que realmente haviam aplicado com certo sucesso ${ }^{68}$ algumas premissas da avaliação formativa a partir das ideias de Wiliam (2011). Por isso, decidi adotar dois grupos ou tipos de amostra,

\footnotetext{
${ }^{67}$ Lembramos que, segundo Wiliam (2011), o processo de uma proposta de avaliação formativa minimamente consistente e eficaz, do ponto de vista de resultados de aprendizagem, demanda tempo - pelo menos de dois a três anos, dependendo da instituição educacional sobre o qual estamos falando, podendo ser bem mais do que isso -, pois trata-se de uma mudança profunda da cultura de avaliação de desempenho, a qual propõe a transferência do controle desse processo, de um modelo centrado no professor e nos gestores da instituição, para um modelo onde o controle é compartilhado entre esse público e os alunos envolvidos diretamente no processo. Ao longo do desenvolvimento deste estudo, até observamos a necessidade de ajustes na implementação dessas ações estratégicas, mas esse tópico específico não foi foco desta pesquisa empírica. Consequentemente, em alguns momentos deste texto, até indicamos eventuais necessidades de ajuste, mas procuramos não emitir julgamento sobre essa proposta inicial, pois não foi o foco do nosso estudo.

${ }^{68}$ Trecho foi destacado pela autora, para nortear o critério de escolha adotado pelas professoras Jane Reolo da Silva e Cristina Barroco. Ou seja, como a Rede é grande e há uma certa dificuldade no registro dos projetos pelos POIE, e frente aos objetivos desta pesquisa, a professora Jane fez um mapeamento prévio sobre quais tinham sido os projetos que realmente tinham sido desenvolvidos com base em uma rubrica, pelo menos. Foi dela a indicação do Programa POIE 2012. E foi a professora Cristina quem indicou alguns dos projetos do POIE 2012, por ela coordenados, que mereceriam estudo mais detalhado sobre esses processos. Daí a classificação com certo sucesso.
} 
com a qual trabalhei: Grupo A, representado pelo Programa POIE 2012, que contou com a realização de 102 projetos, no total ${ }^{69}$; grupo $\mathrm{B}$, formado por quatro casos individuais.

Optei por estruturar esta pesquisa de campo a partir da proposta de estudo de caso instrumental, para que identificar os possíveis pontos de aproximação entre o paradigma da Educomunicação e abordagem de avaliação formativa, com um esclarecimento e/ou justificativa bem fundamentada dessa aproximação. Queria compreender como se daria essa eventual aproximação e porque poderia estabelecer essa aproximação, até para que pudesse afirmar - ou negar - que as práticas pedagógico-comunicacionais estruturam as ações estratégicas da avaliação formativa (STAKE, 2009).

Além disso, durante o desenvolvimento de minhas pesquisas conceituais e identificação de alguns dos possíveis indicadores dessas aproximações, decidi estudar mais do que um caso a partir dessa proposta instrumental, para que pudesse verificar essas ocorrências em mais de um projeto: “cada estudo de caso é instrumental para aprender sobre os efeitos das regras de classificação, mas deverá haver uma coordenação importante entre os estudos individuais. Poderemos chamar de estudos de caso colectivos." (STAKE, 2009, p. 19) ${ }^{70}$

Os casos escolhidos para serem estudados foram projetos desenvolvidos nos Laboratórios de Informática Educativa, de algumas unidades escolares da Rede Municipal de Ensino (Rede), de São Paulo. Sobre o Programa POIE 2012, do Grupo A, ele foi escolhido porque se desenvolveu a partir da implementação e avaliação de 102 projetos de LIE, da DRE Campo Limpo.

Um dos princípios de desenvolvimento de estudos de caso defendidos por Yin (2005), é o uso de várias fontes de evidências. Por isso, utilizamos as seguintes listadas aqui:

(a) Documentos oficiais publicados pela SME-SP, de orientação e regulamentação das práticas dos LIE;

(b) Registros nos ambientes virtuais de aprendizagem (AVA) - como ThinkQuest, Edmodo, Padlet, Popplet, Prezi, dentre outros: feitos pelos alunos e POIE participantes dos casos estudados - oito projetos, sendo quatro do Programa POIE 2012, do Grupo A, e quatro

\footnotetext{
${ }^{69}$ Para nossa pesquisa de campo, não verificamos todos os 102 projetos, mas verificamos os registros de práticas de pelo menos 20 deles, sendo que optamos por trabalhar mais detalhadamente com quatro.

${ }^{70}$ Grifo do autor. Tradução feita em Portugal, por Ana Maria Chaves, da Faculdade de Letras, Universidade de Lisboa.
} 
independentes de algum programa específico, do Grupo B, durante o desenvolvimento dos projetos (Ex.: repositórios de materiais e dados coletados pelos próprios alunos; repositório de descritivo e orientações do projeto; registro de trocas reflexivas dos e entre os alunos ${ }^{71}$; atividades de autoavaliação e/ou avaliação entre pares dos alunos);

(c) Criação do conteúdo de algumas das rubricas utilizadas nesses casos, bem como a verificação da forma como essas rubricas foram utilizadas (quando e como);

(d) Depoimentos dos POIE Douglas Tomé ${ }^{72}$, Gislaine Batista Munhoz ${ }^{73}$, José Rosemberg ${ }^{74}$, Margarete Gimenes Stalberg, Maria Helena Pereira ${ }^{75}$ e Nádia Melzer ${ }^{76}$, que coordenaram os projetos estudados;

(e) Depoimento da ex-coordenadora do Núcleo de Informática Educativa, Jane Reolo, e da gestora da DRE Campo Limpo, professora Cristina Barroco, sobre as orientações passadas aos POIE, acerca do uso da rubrica e aplicação da autoavaliação no desenvolvimento dos projetos de LIE, e dos POIE responsáveis por quatro dos projetos;

(f) Análises das respostas de alunos que participaram do Projeto A.3 (POIE Douglas Tomé), do Projeto B.1 (POIE José Rosemberg) e do Projeto B.4 (POIE Gislaine Batista Munhoz).

\subsection{Estudos de Caso dos Laboratórios de Informática Educativa da SME-SP}

$\mathrm{Na}$ Introdução desta pesquisa, quando apresenteis os aspectos de relevância e originalidade, indiquei que a escolha por estudar alguns dos projetos desenvolvidos pelos Laboratórios de Informática Educativa (LIE) da SME-SP se deu porque em minhas pesquisas iniciais sobre

\footnotetext{
${ }^{71}$ Esse uso será melhor explicado no Capítulo Quatro, sobre a apresentação dos dados coletados e suas respectivas análises.

${ }^{72}$ Professor da Rede-SP, graduado em Matemática (Unisa), pós-graduado em Tecnologias para Aprendizagem (SENAC-SP).

${ }^{73}$ Professora da Rede-SP, está gestora do Núcleo de Tecnologias de Aprendizagem, ex-POIE, é mestre em Educação (USP), com graduação em Geografia.

${ }^{74}$ Professor da Rede-SP, pós-graduado em Gestão Escolar, graduado em Pedagogia em Series Iniciais e Educação Infantil, ensino técnico em Magistério.

${ }^{75}$ Professora da Rede-SP, graduada em Botânica.

${ }^{76}$ Professora da Rede-SP.
} 
avaliação, identifiquei que a abordagem de avaliação formativa adotada nesses tinha suas bases em várias das premissas de Wiliam (2011).

À medida que evolui em minhas buscas conceituais e nas verificações pontuais das práticas dos projetos dos LIE, fui me convencendo de que esse parecia ser o contexto mais adequado à aplicação do nosso estudo. Escolhi, pois, estudar os seguintes projetos, divididos nos Grupos A e B.

\subsubsection{GRUPO A - PROGRAMA POIE 2012 / DRE Campo Limpo}

Este foi um programa composto por 102 projetos desenvolvidos nos LIE, de várias unidades educacionais, todas ligadas à Diretoria Regional de Educação (DRE) de Campo Limpo, São Paulo, cujo objetivo foi dar formação sobre o uso das ações estratégicas da avaliação formativa, com base principalmente nas ideias de Wiliam (2011), e acompanhar o processo de implementação dessas dinâmicas de avaliação em projetos, que esses POIE estavam desenvolvendo com seus respectivos alunos.

O POIE 2012 focava principalmente a disseminação da prática de registro dos projetos no AVA ThinkQuest, a implementação de processos de avaliação - entre pares e/ou autoavaliação - com rubricas formativas e atividades de trocas reflexivas com base nas rotinas de pensamento.

Antes de detalhar o que foi o programa, descrevo resumidamente qual é o contexto dessa diretoria regional. 


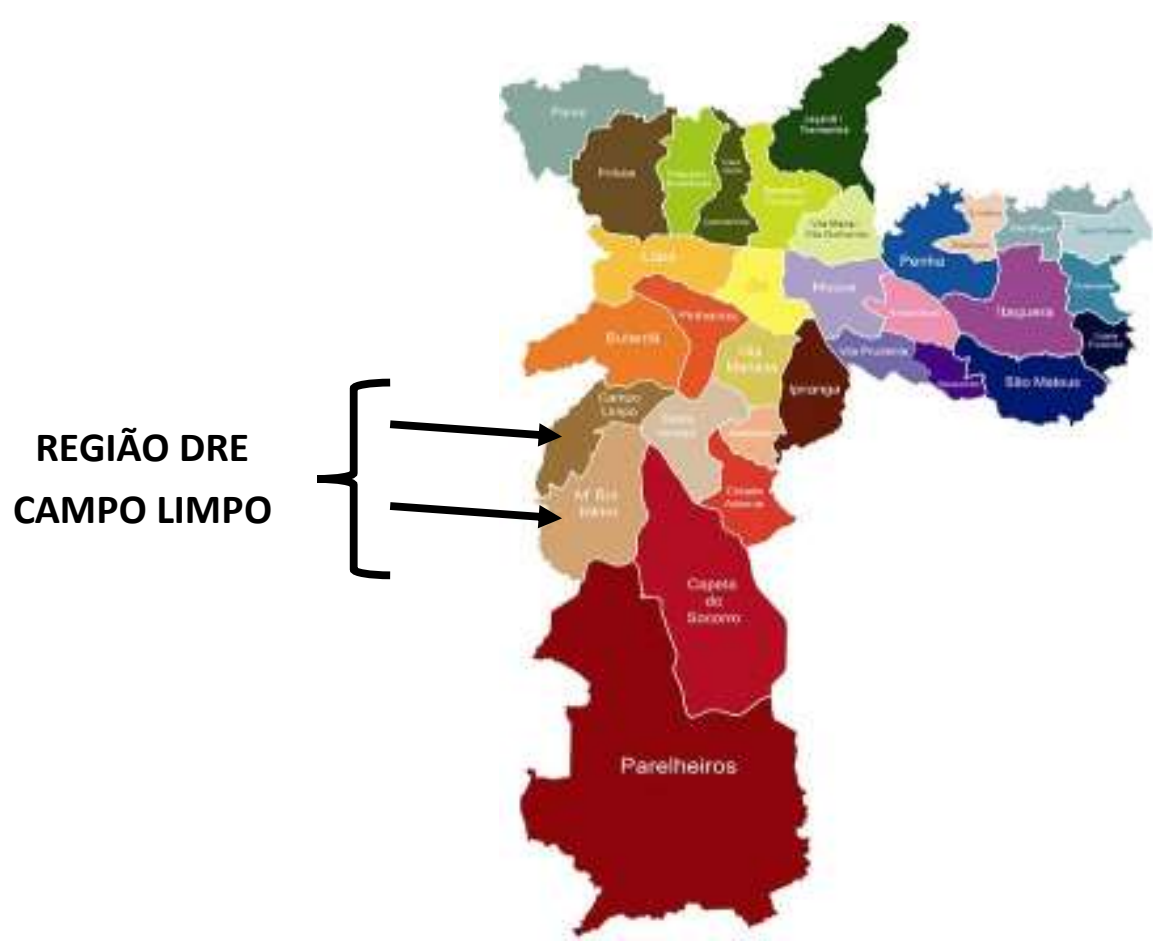

Figura 07: Mapa das Subprefeituras da Cidade de São Paulo/SP Fonte: Portal SME-SP ${ }^{77}$

A DRE Campo Limpo está localizada na zona sul da cidade de São Paulo, ligada às subprefeituras de Campo Limpo (Campo Limpo, Capão Redondo e Vila Andrade) e M`Boi Mirim (Jardim Ângela e Jardim São Luís), com uma área de aproximadamente cem quilômetros quadrados ${ }^{78}$. É uma comunidade formada por cerca de 6.900 professores e 112.651 alunos, distribuídos em 279 unidades educacionais. Na Figura 7, apresentamos o mapa das subprefeituras da cidade de São Paulo/SP, com a indicação das duas subprefeituras atendidas por essa DRE.

A razão de incluir este programa em minha pesquisa foi porque, a partir dele, pude verificar alguns dos processos comunicacionais adotados para a implementação da abordagem de

http://www.prefeitura.sp.gov.br/cidade/secretarias/subprefeituras/subprefeituras/mapa/index.php?p=14894 Úlimo acesso em 05/01/2016

${ }^{78}$ Dados publicados em 14/08/2015, no subsite da DRE- Campo Limpo, ligado ao portal da SME-SP. Link: http://portal.sme.prefeitura.sp.gov.br//Main/Noticia/Visualizar/PortalSMESP/DRE-Campo-Limpo-2. Último acesso: 05/01/2016. 
avaliação formativa para vários projetos de LIE. Mais do que isso, esse programa me permitiu conhecer o processo comunicacional adotado para a formação de atualização desses POIE, o que incluiu a exigência de registros específicos dos processos em um AVA (ThinkQuest), e a realização da própria autoavaliação desses POIE, embasada em uma ação conjunta de verificação reflexiva da gestão da DRE - Campo Limpo, com base na Rubrica 1 (ANEXO B $)^{79}$, desenvolvida durante a formação dos gestores, oferecida pela coordenação do Núcleo de Informática Educativa, da DOT / SME-SP.

Como descrito anteriormente, o processo de formação dos gestores das treze DRE da SMESP, que se desenvolveu durante diversos encontros mensais no Núcleo de Informática Educativa, na SME-SP, tinha o objetivo principal de preparar esses gestores para aplicarem algumas das ações estratégicas de avaliação formativa ao trabalho dos POIE. A orientação original que os gestores receberam da equipe de IE foi para que eles solicitassem a seus POIE que estes últimos escolhessem um projeto (coordenado e supervisionado por eles) em andamento ou já finalizado, para que avaliassem o próprio desempenho enquanto mediadores / facilitadores, considerando os critérios da rubrica ${ }^{80}$ elaborada colaborativamente por esse grupo de gestores, nos encontros da SME-SP, especialmente no que se refere aos registros do projeto desenvolvido, feitos no AVA ThinkQuest.

Contudo, os gestores da DRE Campo Limpo à época - a professora Cristina Barroco e o professor Mestre Ricardo de Souza -, decidiram que essa dinâmica não seria suficiente para que seus POIE compreendessem a aplicação desses processos e realmente passassem a adotar tais orientações. Logo, tomando por base essa solicitação original da equipe de IE, eles estruturaram o Programa POIE 2012, que consistiu não apenas na realização dessa autoavaliação, mas também de uma formação com inúmeras práticas de reflexão conjunta entre seus participantes, com momentos presenciais e a distância. E devido ao número total de POIE previsto para a referida formação, o POIE 2012 foi estruturado da seguinte forma:

\footnotetext{
${ }^{79}$ No Anexo B, apresentamos a versão final da rubrica - RUBRICA 1 - utilizada no programa POIE 2012, juntamente com outras rubricas, inclusive a primeira versão (RUBRICA 2) do que resultaria nessa RUBRICA 1, desse programa, bem como uma versão mais recente dela (RUBRICA 3), que foi desenvolvida agora em 2014, pela gestão da DRE e os POIE de suas unidades educacionais, para atualização da RUBRICA 1. Ainda nesse Anexo B, de exemplos de rubricas desenvolvidas pela DRE Campo Limpo, apresentamos mais três exemplos, sendo uma para projetos com uso de rádio (RUBRICA 4), uma para projetos de matemática (RUBRICA 5) e uma ainda para projetos na educação infantil (RUBRICA 6). Detalharemos melhor esses anexos quando analisarmos os dados obtidos.

${ }^{80}$ Rubrica 1, do ANEXO B desta pesquisa.
} 
Nome da Formação (parte central do Programa POIE 2012): WEB Currículo e sua compreensão nas práticas educacionais.

Carga horária: 64 horas de formação, distribuídas em 16 horas presenciais, na DRE Campo Limpo e 48 horas a distância.

Encontros presenciais: foram quatro encontros ao longo de todo o ano de 2012 (abril / junho / agosto / outubro), cada um com duração de 4 horas.

Número de Turmas: 5 Turmas para cada encontro

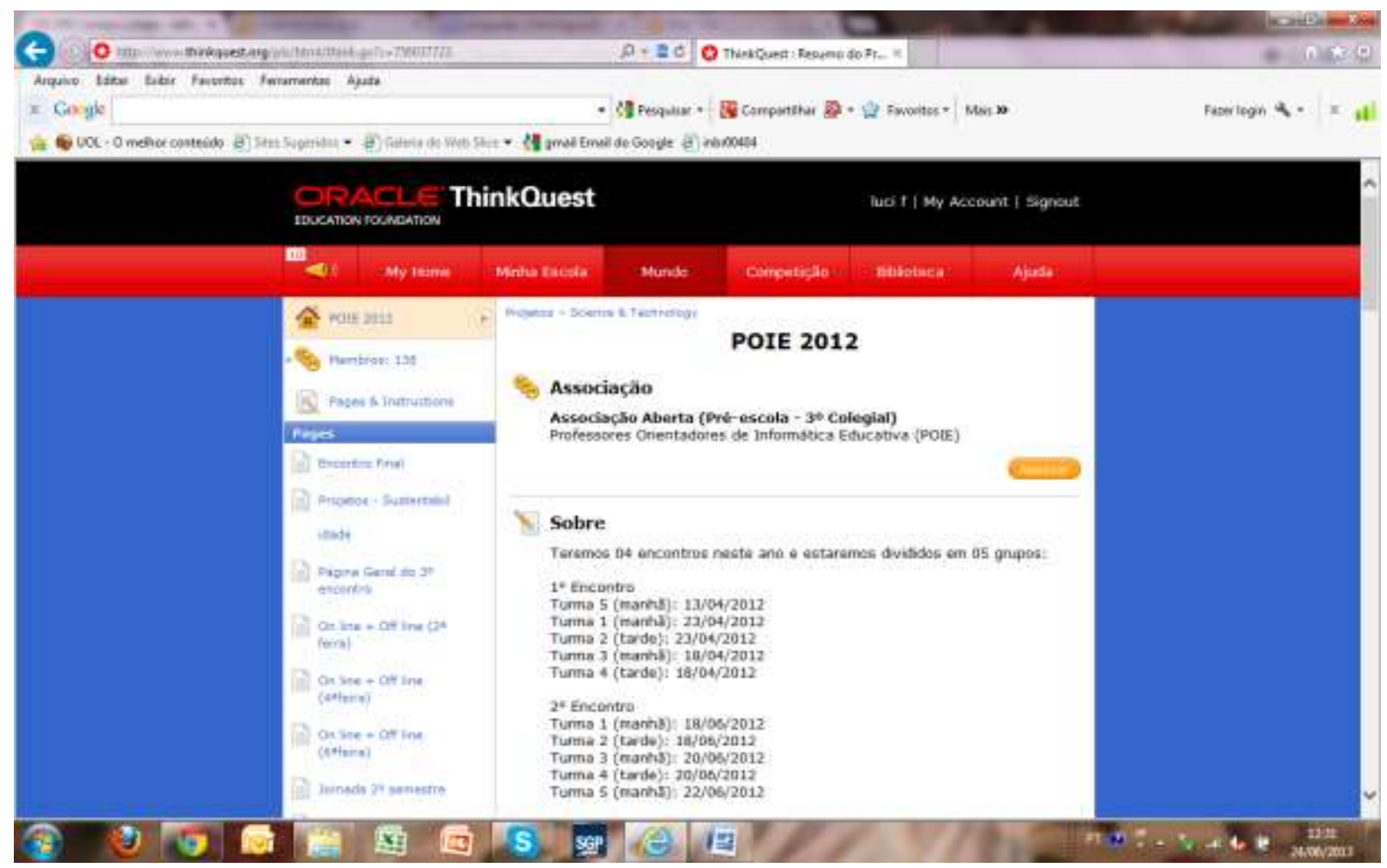

Figura 08 -Programa POIE 2012 - Tela do ThinkQuest

Fonte: Plataforma ThinkQuest, para NIE (DOT/SME-SP) ${ }^{81}$

Objetivos da Formação: disponibilizo aqui os objetivos publicados quando da publicação oficial de convocação dos POIE.

* Criar estrutura e organização dos espaços virtuais de formação, pesquisa, comunicação e publicação, em comunidade de prática, visando identificar, disseminar, aprofundar e consolidar boas práticas e casos de sucesso dos objetivos propostos nas OC-TIC;

* Promover, acompanhar e subsidiar em espaço virtual de aprendizagem as ações desenvolvidas pelos POIE para a inserção das linguagens midiáticas no currículo e na documentação pedagógica de registro em formação permanente presencial e a distância;

\footnotetext{
${ }^{81}$ Link desconhecido, pois plataforma não está mais disponível.
} 
* Utilizar os recursos tecnológicos como instrumento de protagonismo infantojuvenil, bem como a comunicação por meio das linguagens próprias das redes sociais e demais canais na internet;

* Refletir sobre as contribuições propiciadas pelo uso das tecnologias digitais de informação e comunicação na aprendizagem, no ensino e no desenvolvimento do currículo.

* Avaliar e refletir sobre as práticas educacionais por meio da avaliação formativa Rubrica e seus quatro níveis de evolução. (SÃO PAULO, 2012)

Metodologia: essa formação foi estruturada com base nas diretrizes curriculares da SME-SP, contidas nos documentos publicados pela equipe de IE, da DOT / SME-SP, de 2006 ${ }^{82}, 2010^{83}$ e pelas seguintes estratégicas de formação: "socialização, aprendizagem colaborativa na web, pesquisa, comunicação e publicação na internet, documentação pedagógica na perspectiva de prospecção". (SÃO PAULO, 2012)

Conteúdos trabalhados: a referida formação contou com a realização de várias atividades durante as quais foram trabalhados vários temas, para uma sistematização das práticas dos POIE nos LIE. Para tanto, foram abordados os seguintes tópicos, sempre a partir de dinâmicas colaborativas entre os POIE: planejamento, coordenação e acompanhamento de projetos com foco na construção coletiva e reflexiva do conhecimento, com mediação tecnológica, desenvolvidos em comunidades de aprendizagem colaborativa; desenvolvimento de competências específicas, como aprendizagem focada na investigação e solução de problemas; estruturação e gestão de projetos mediados por TIC, com objetivos educacionais; estruturação, implementação e fortalecimento de uma cultura de avaliação formativa, desenvolvida em comunidades virtuais de aprendizagem.

Critérios de Avaliação: uso da Rubrica 1 (ANEXO B) para avaliação dos processos desenvolvidos na formação, para familiarização com essa prática.

Certificação: $75 \%$ de participação nos encontros presenciais e nas atividades desenvolvidas a distância, no ambiente virtual do ThinkQuest.

As telas do ThinkQuest aqui apresentadas são do espaço criado para registro de várias das atividades reflexivas com esses POIE durante toda a formação - encontros presenciais e a distância, síncronos e assíncronos. $\mathrm{O}$ acesso a essas telas ${ }^{84}$ me permitiu acompanhar parte das

\footnotetext{
${ }^{82}$ Caderno de Orientações Didáticas - Ler e Escrever- Tecnologias na Educação

${ }^{83}$ Orientações Curriculares de TIC - proposições de expectativas de aprendizagem, tematização das práticas cotidianas

${ }^{84}$ Para coletarmos essas telas, quando fomos informados de que esse AVA não seria mais disponibilizados, escolhemos os projetos e fizemos prints de tela de todos, de maneira a termos os registros para este trabalho.
} 
ações implementadas, que teve um primeiro momento de orientação prática sobre o uso da plataforma ThinkQuest como ferramenta para registro das dinâmicas, com ênfase nos tipos de práticas reflexivas que poderiam ser planejadas, considerando a adoção de tal aparato tecnológico, com possibilidade de uso de múltiplas linguagens. Desse modo os POIE puderam refletir sobre especificidades das ações que propunham a seus alunos, desde a forma como estruturavam e registravam os detalhes do planejamento e implementação de projetos, até como formulavam e apresentavam perguntas reflexivas a seus alunos, sobre a temática central do projeto.

Outro aspecto tratado foi a avaliação entre pares, com o intuito de que os POIE fizessem um primeiro uso da rubrica a partir da avaliação dos registros de um projeto que não fosse o seu. Para essa atividade, foi solicitado que os POIE registrassem no fórum suas impressões sobre um determinado projeto, de um dos POIE participantes da formação, sempre com base nos níveis dos critérios da Rubrica 1 (ANEXO B).

Essas atividades realizadas no primeiro encontro, ocorrido na segunda quinzena de abril de 2012, permitiu que os POIE fizessem ajustes e aprimorassem os projetos que haviam escolhido para utilizar durante o programa POIE 2012. Nesse primeiro encontro, os gestores procuraram conhecer também quais os POIE que vinham adotando práticas ligadas aos Programas Aluno Monitor e Nas Ondas do Rádio, até para reforçarem como esses programas poderiam auxiliá-los ou mesmo como poderiam ser aprimorados.

Após a realização do primeiro encontro, que contou com as orientações sobre estruturação de projetos e registro de etapas do mesmo no AVA ThinkQuest, esses POIE tiveram um período de tempo para ajustarem seus projetos e respectivos registros, antes de solicitarem a um de seus pares que avaliasse o mesmo e antes de realizarem a primeira autoavaliação.

Quanto à autoavaliação do POIE, com base no projeto escolhido - novo ou em andamento no momento da realização do POIE 2012 - para ser avaliado, essa foi realizada em duas etapas. Isso porque os gestores da DRE Campo Limpo consideraram que os resultados de compreensão, internalização e adoção dessas ações estratégicas em suas atividades diárias seriam muito mais consistentes caso houvesse um processo reflexivo que permitisse os ajustes e a posterior avaliação e eventual validação dos mesmos em suas práticas. Então, as

Porém são muitas telas - cada projeto tem de 60 a 80 dessas telas e, por isso, não incluímos o total delas nos anexos. 
avaliações - autoavaliações dos próprios POIE (por escrito), avaliação de um de seus pares (na própria formação, oralmente) e avaliação dos gestores - foram desenvolvidas como segue:

Etapa 1: terminado o período concedido aos POIE, para realizarem os ajustes nos projetos, cada um deles enviou aos gestores da DRE sua própria autoavaliação.

Etapa 2: avaliação dos registros realizados no AVA ThinkQuest e/ou pelos relatos feitos pelos próprios POIE, agora pelos gestores da DRE Campo Limpo.

Após a realização dessas duas etapas, os gestores conversaram com cada POIE sobre os resultados obtidos para seus projetos, de maneira a refletirem sobre as razões dos mesmos e, principalmente, sobre as eventuais distorções entre as avaliações. O objetivo dessa dinâmica foi fazer com que os POIE conseguissem entender o uso formativo e propositivo da rubrica, de maneira que, ao final dessa atividade, compreendessem como poderiam aprimorar suas práticas de implementação e registro de projetos desenvolvidos junto aos LIE.

Ao final do POIE 2012, foi elaborado um relatório que destacou como a reflexão conjunta sobre as divergências entre as avaliações (POIE x gestores DRE Campo Limpo) foi essencial para que os POIE se dessem conta sobre como poderiam melhorar seus registros e práticas. $\mathrm{Na}$ análise dos dados coletados, apresento mais detalhes desse relatório cujo relatório completo consta do Anexo $\mathrm{C}^{85}$ deste estudo.

Alguns dos dados dos projetos do POIE 2012 utilizados no desenvolvimento da minha pesquisa empírica constam do quadro abaixo, mas os descritivos técnicos obtidos com base nos registros do AVA Think Quest, constam do Anexo E desta pesquisa. Realizei ainda entrevistas pessoais com os POIE responsáveis pelos mesmos e, mesmo tendo sido realizado em 2012, para efeito de conhecer as impressões dos alunos sobre as participações nos respectivos projetos, consegui que participantes do projeto A.3 respondessem às questões de um questionário de perguntas estruturadas.

\footnotetext{
85 Anexo C: no referido documento, nós retiramos os nomes dos POIE e de suas respectivas unidades educacionais de maneira a não expormos os professores que participaram do referido programa.
} 


\begin{tabular}{|c|c|c|c|}
\hline $\begin{array}{c}\text { UNIDADE } \\
\text { EDUCACIONAL }\end{array}$ & PROJETO & $\begin{array}{r}\text { POIE } \\
\text { Responsá }\end{array}$ & Dados \\
\hline $\begin{array}{l}\text { A.1 EMEF } \\
\text { Gianfrancesco } \\
\text { Guarnieri }\end{array}$ & $\begin{array}{l}\text { Sustentabilidade, o que é isso e } \\
\text { qual o meu papel? }\end{array}$ & Margarete & $\begin{array}{l}\text { Entrevista } \text { POIE + } \\
\text { Registros Think } \\
\text { Quest }\end{array}$ \\
\hline $\begin{array}{lrr}\text { A.2 EMEF } & \text { Jd. } \\
\text { Mitsutani } & - & \text { Paulo } \\
\text { Patarra } & & \end{array}$ & $\begin{array}{l}\text { EMEF Paulo Patarra Dando } \\
\text { Alguns Passos Rumo a um } \\
\text { Escola Sustentável }\end{array}$ & José Rosemberg & $\begin{array}{l}\text { Entrevista } \text { POIE + } \\
\text { Registros Think } \\
\text { Quest }\end{array}$ \\
\hline $\begin{array}{l}\text { A.3 EMEF Mauro } \\
\text { Faccio Gonçalves - } \\
\text { Zacharias }\end{array}$ & Sustentabilidade no Zaca - 5A & Douglas & $\begin{array}{lr}\text { Entrevista } & \text { POIE + } \\
\text { Registros } & \text { Think } \\
\text { Quest } & + \\
\text { Questionário } & 15 \\
\text { alunos } & \end{array}$ \\
\hline $\begin{array}{l}\text { A.4 EMEF Cyro } \\
\text { Albuquerque }\end{array}$ & Sustentabilidade & Nádia & $\begin{array}{l}\text { Entrevista POIE + } \\
\text { Registros Think } \\
\text { Quest }\end{array}$ \\
\hline
\end{tabular}

Para o Grupo A, observei que o tema trabalhado para todos os projetos foi Sustentabilidade, conforme orientação da SME-SP. Segundo a gestora Cristina Barroco, à medida que ela foi desenvolvendo o Programa POIE 2012, ela percebeu que em muitos casos, o projeto não evoluiu exatamente porque não era uma temática que tivesse relação com o contexto da unidade escolar. Em sua entrevista individual, ela comentou que o ideal é que o tema seja definido pelo POIE, junto com os alunos, acerca de aspectos ligados à escola e seu entorno:

Em 2012, a SME-SP veio com o projeto de sustentabilidade... era um tema fechado para todo mundo. E aí foi um ano que eu falei assim até: eu achei que fez água, sabe... quando para algumas pessoas esse tema casava com a realidade da escola e enfim, eles foram... e para algumas pessoas, não... eu senti que algumas pessoas que já estavam avançadas tentaram forçar a entrada desse projeto de sustentabilidade e não foi bacana ter um tema só para todo mundo...[...] tinham outras coisas lá na escola acontecendo, mas o projeto era sustentabilidade. Ou então forçar pelo menos uma turma para ter o que registrar no ambiente... tanto é que no final de 2012, nós fizemos a avaliação... para 2013, nós fechamos a proposta pedagógica, mas o tema tinha que estar coerente com o PPP da escola... tem que olhar para a sua realidade... tem que pensar o que está efervescendo na sua escola e precisa ser trabalhado por meio de um projeto. (FERNANDES, 2015, sem pag.)

Agora cumpre apresentar os descritivos resumidos desses projetos. 


\section{A.1. Sustentabilidade - o que é e qual o meu papel (Público-alvo: alunos de}

\section{2 a 14 anos; TIC: ThinkQuest)}

Projeto sobre sustentabilidade, para o qual a POIE focou em várias atividades voltadas à reflexão pelos alunos sobre o que significa, e sobre aspectos correlacionados como poluição e preservação do meio ambiente, desmatamento e reciclagem. Fizeram visitas a diferentes lugares, e o ambiente virtual foi utilizado para registro das dinâmicas e como suporte de reflexões, as quais foram realizadas oralmente.

Observei que a POIE publicou proposta reflexiva aos alunos no AVA e que as primeiras contribuições foram feitas nesse ambiente, para depois a POIE dar o feedback presencial, segundo seu depoimento na entrevista individual.

\section{A.2. EMEF Paulo Patarra dando alguns passos rumo a uma escola sustentável TIC: (Público-alvo: $5^{\circ}$ ano; TIC: ThinkQuest)}

Este projeto sobre sustentabilidade focou no entendimento sobre o tema, com reflexões teóricas com base em dados coletados na internet e posterior atividade para verificar maneiras sustentáveis de conscientizar os jovens e o entorno da escola sobre o cuidado com o planeta, a partir do destaque para pequenas ações do dia a dia que podem ser realizadas por todos. O produto final deste projeto foi a criação de histórias em quadrinhos com imagens de poluição da escola, para conscientização sobre importância de cuidar do meio ambiente.

\section{A.3. Sustentabilidade no Zaca (Público-alvo: $5^{\circ}$ ano; TIC: ThinkQuest)}

Para este projeto, o POIE responsável trabalhou aspectos de sustentabilidade, consumo consciente, reciclagem e tipos de lixo. Foram apresentadas diversas fotos da escola, para que alunos refletissem sobre como cuidar do meio ambiente, começando da escola. Ao final foi solicitado a todos uma redação de cerca de vinte páginas sobre a temática que estava sendo trabalhada.

Para este caso, a apresentação da rubrica ao aluno só foi feita ao final do projeto, sendo que os critérios da rubrica foram desenvolvidos pelo POIE, com a gestora da DRE Campo Limpo e outros POIE. 


\section{A.4. Movie Maker (Público-alvo: $7^{\circ}$ ano; TIC: ThinkQuest)}

Aqui a POIE responsável trabalhou aspectos de sustentabilidade, consumo consciente, reciclagem e tipos de lixo. Houve uma reflexão sobre como melhorar o bairro de entorno da escola com base nas premissas e problemas abordados nas aulas. Os alunos tiraram fotos para reflexão sobre quais as possibilidade de reciclar. O ponto alto do projeto foi quando eles criaram ítens de decoração a partir de materiais recicláveis. Fizeram um vídeo final sobre como trabalhar preservação do meio ambiente e mostraram nele os objetos criados.

\subsubsection{GRUPO B}

O Grupo B é composto por projetos que foram desenvolvidos pelos POIE, nos LIE, sem ligação com um programa específico de suas respectivas DRE, como ocorreu no Grupo A. No caso, todos eles receberam as orientações da coordenação do Núcleo de Informática Educativa ou dos próprios gestores de suas DRE, mas cada um deles teve maior autonomia para fazer os ajustes que julgou necessários, para a realização e suas práticas. Então, apresentamos um resumo dos mesmos, elaborado com base nos conteúdos aos quais tivemos acesso nas plataformas de aprendizagem utilizadas para registro e por meio de entrevistas pessoais, dos POIE responsáveis pelos mesmos.

Quadro 11: Projetos Grupo B

\begin{tabular}{|c|c|c|c|}
\hline $\begin{array}{c}\text { UNIDADE } \\
\text { EDUCACIONAL }\end{array}$ & PROJETO & $\begin{array}{c}\text { POIE } \\
\text { Responsável }\end{array}$ & Dados \\
\hline $\begin{array}{l}\text { B.1 EMEF Fagundes } \\
\text { Varella (2014) }\end{array}$ & $\begin{array}{l}\text { Estudando e intervindo no } \\
\text { mundo que nos cerca }\end{array}$ & José Rosemberg & $\begin{array}{l}\text { Entrevista POIE + } \\
\text { Registros Prezi + } \\
\text { Questionário } 15 \\
\text { alunos }\end{array}$ \\
\hline $\begin{array}{lrr}\text { B.2 EMEF } & \text { Jd. } \\
\text { Mitsutani } \quad- & \text { Paulo } \\
\text { Patarra (2014) } & \end{array}$ & Curiosos em Ação & José Rosemberg & $\begin{array}{l}\text { Entrevista POIE + } \\
\text { Registros Padlet }\end{array}$ \\
\hline $\begin{array}{l}\text { B.3 EMEF Des. } \\
\text { Achilles de Oliveira } \\
\text { Ribeira (2012) }\end{array}$ & Clube de Astronomia & Maria Helena Pereira & $\begin{array}{lr}\text { Entrevista POIE + } \\
\text { Registros Think } \\
\text { Quest }\end{array}$ \\
\hline 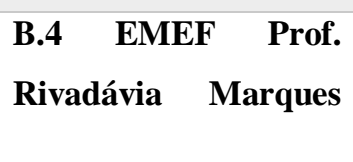 & Jogos do Riva & Gislaine Batista Munhoz & $\begin{array}{l}\text { Entrevista POIE + } \\
\text { Registros Site / } \\
\text { Facebook }\end{array}$ \\
\hline
\end{tabular}




\section{B.1. Estudando e Intervindo no Mundo que nos Cerca (Público Alvo: Alunos 7º Ano: 2014; TIC: Prezi / GoogleDocs)}

A nova estrutura curricular da SME-SP para o ensino fundamental está dividida em três ciclos, sendo que, para o Ciclo Autoral ou Terceiro Ciclo ${ }^{86}$, os alunos devem desenvolver um projeto que trabalhe um tema ligado à própria escola ou ainda no seu entorno, sendo que esse deve ser desenvolvido com o uso das TIC disponíveis nos LIE. De fato, esses trabalhos devem ser, em teoria coordenados pelo Professor Orientador da Sala de Leitura (POSL), ou de Inglês, ou de Educação Física ou de Artes, com o apoio do POIE, nos espaços do LIE.

Em função dessas orientações da SME-SP, em 2014, o POIE José Rosemberg decidiu trabalhar, com três turmas de $7^{\circ}$ ano, um projeto que fosse desenvolvido em parceria com um POSL da EMEF, sobre uma temática problemática escolhida pelos alunos envolvidos. Ele ocorreu durante cerca de três bimestres, mas em função de ocorrências como greve e feriados, dentre outras, o que teria sido um projeto desenvolvido durante 22 a 24 aulas, acabou sendo implementado ao longo de cerca de apenas 16 aulas de LIE. Foram três turmas, cada uma com uma média de trinta e três alunos, a maioria na faixa etária de 12 -14 anos.

O projeto iniciou na Sala de Leitura (SL), com a elaboração de uma lista de problemas da referida unidade educacional e do seu entorno, pelo POSL e os alunos de cada turma. O objetivo era a escolha de um dos temas para ser estudado pelos alunos e para posterior criação de propostas de soluções, sempre considerando a faixa etária desses participantes. Essa lista se originou não apenas da simples indicação deles, mas com base em uma reflexão conjunta que foi promovida por esse POSL durante sua elaboração. Um dos temas escolhidos para ser trabalhado pelos alunos foi exatamente a relação das enchentes com o lixo, até pela perda que as pessoas têm quando as enchentes ocorrem.

Após a escolha do tema trabalhado por cada uma das três turmas, votação essa coordenada agora pelo POIE José Rosemberg, os alunos foram distribuídos em grupos, para então definirem que aspecto da temática em estudo seria aprofundado. Em função da idade desses

\footnotetext{
${ }^{86}$ Para conhecer os detalhes da atual proposta curricular da SME-SP, dividida em três ciclos - Alfabetização, Interdisciplinar e Autoral -, o ideal é acessar a Portaria 5. 930/13, que contém as orientações sobre ela.
} 
alunos, coube a eles próprios, após a definição dos grupos, desenvolverem o planejamento e providenciarem a implementação e acompanhamento, sempre considerando a realização de pesquisas na internet, entrevistas com pessoas da comunidade escolar e do entorno, registro dos contextos ligados ao problema que estava sendo trabalhado (ex.: fotos, gravações em vídeo, desenhos, etc.), dentre outras ações. Ao referido POIE coube acompanhar e fazer intervenções pontuais para ajustes do desenvolvimento do projeto.

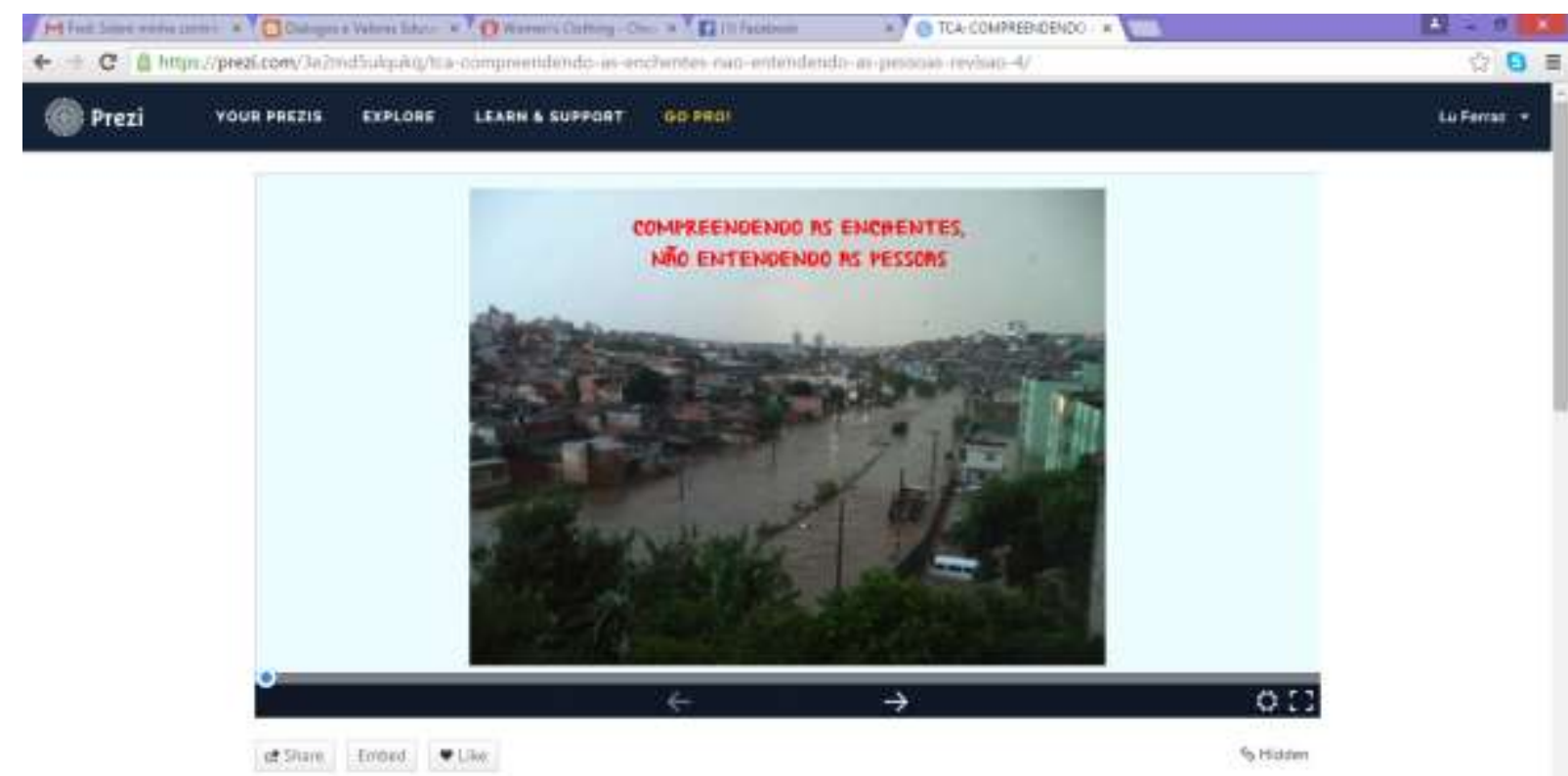

TCA: COMPREENDENDO AS ENCHENTES, NÃO ENTENDENDO

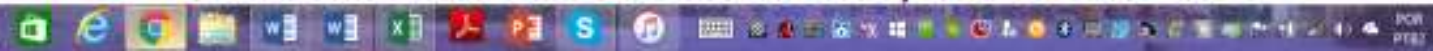

Figura 09: Projeto B.1 - Vídeo Final (disponibilizado no Prezi) Fonte: Plataforma Prezi ${ }^{87}$

O POIE responsável adotou o AVA Edmodo para registro das trocas reflexivas iniciais acerca do tema que seria trabalhado, mas os alunos também utilizaram vários recursos digitais para seu desenvolvimento como um todo e, ao final, produziram um vídeo com os problemas apurados sobre a temática escolhida para ser estudada. Esses trabalhos foram disponibilizados no Prezi $i^{88}$.

Apesar disso, dadas as características do projeto, para o desenvolvimento desta pesquisa, utilizei informações coletadas da seguinte forma: vídeos apresentados ao final da atividade; descritivos das dinâmicas do projeto, os quais foram coletados a partir de um questionário

\footnotetext{
${ }^{87}$ Link: https://prezi.com/3e2md5ulqukq/tca-compreendendo-as-enchentes-nao-entendendo-as-pessoas-revisao-4/ (Último acesso: 05-01-2016)

${ }^{88}$ Segue o link de um dos trabalhos finais, disponibilizado no Prezi: https://prezi.com/3e2md5ulqukq/tcacompreendendo-as-enchentes-nao-entendendo-as-pessoas-revisao-4/
} 
respondido por alguns dos alunos dessas turmas (16 jovens); respostas dadas na realização das autoavaliações, feitas com base em uma rubrica elaborada pelos alunos, ao final do projeto (disponibilizada no GoogleDocs); entrevista pessoal com o POIE José Rosemberg.

\section{B.2. Curiosos em Ação (Público alvo: 2ª Ano: 2014; TIC: Prezi / Padlet / Popplet / GoogleDocs)}

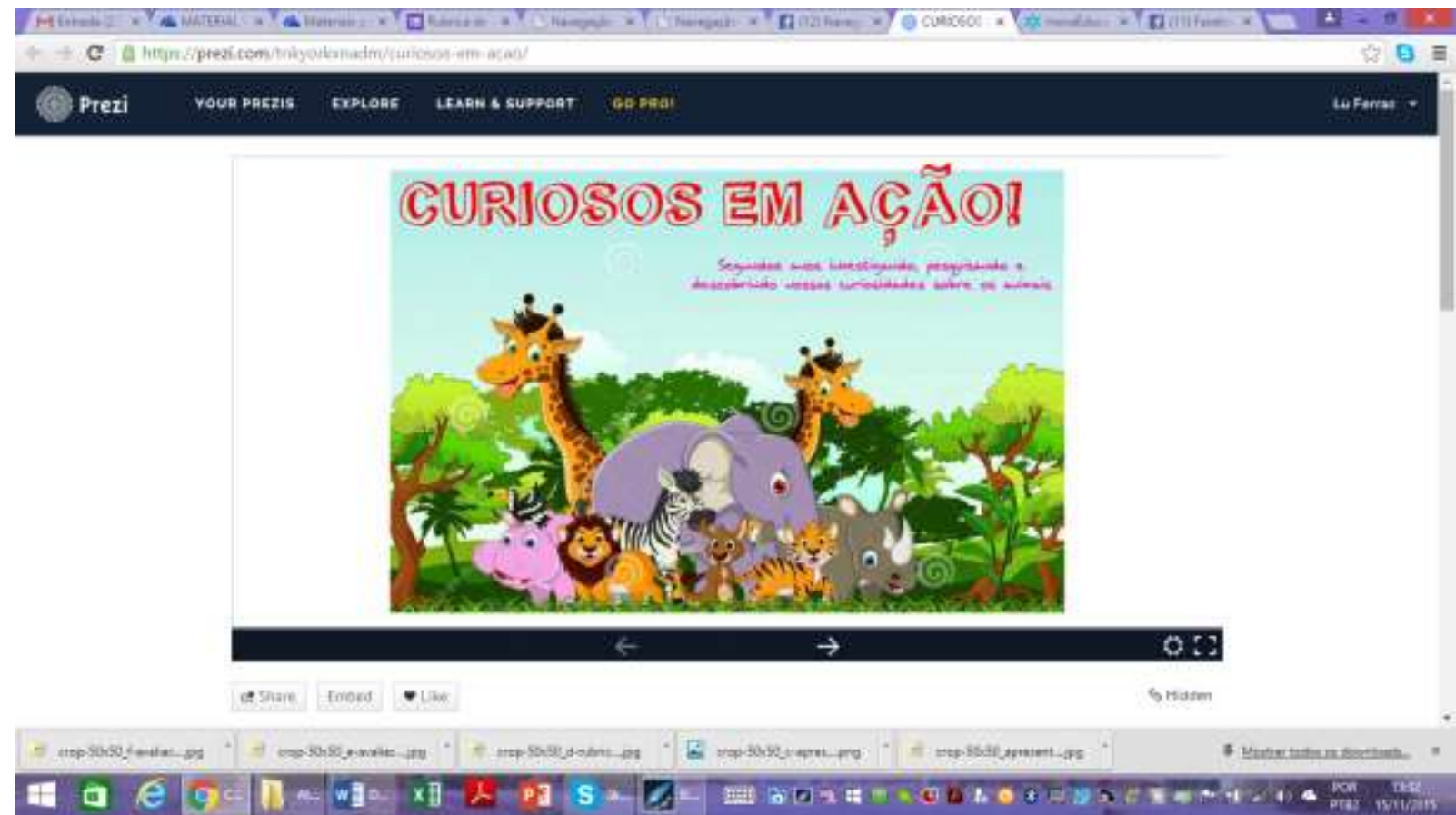

Figura 10: B.2 - Tela de Abertura Produto Final, no Prezi Fonte: Blog curiosos Em Ação ${ }^{89}$

Este projeto teve como principal objetivo o entendimento, pelos seus participantes do $2^{\circ}$ ano (crianças de 7 a 8 anos, em sua maioria), sobre como a internet é uma fonte quase que infinita de informações e que, por isso mesmo, é preciso atenção e cuidado no desenvolvimento de pesquisas. Tinha como foco trabalhar com essas crianças habilidades e competências mínimas de busca e seleção de informações, tomada de decisão e resolução de problemas (adequados à faixa etária) e a produção compartilhada de conhecimentos. Outros aspectos trabalhados foram leitura e escrita, considerando sua função social no contexto trabalhado pelo projeto, que focou no estudo de verbetes da sociedade.

\footnotetext{
${ }^{89}$ Site Curiosos em ação (http://afonso-schmidt-coord.blogspot.com.br/2015/03/blog-post.html). Último acesso: 05-01-2016.
} 


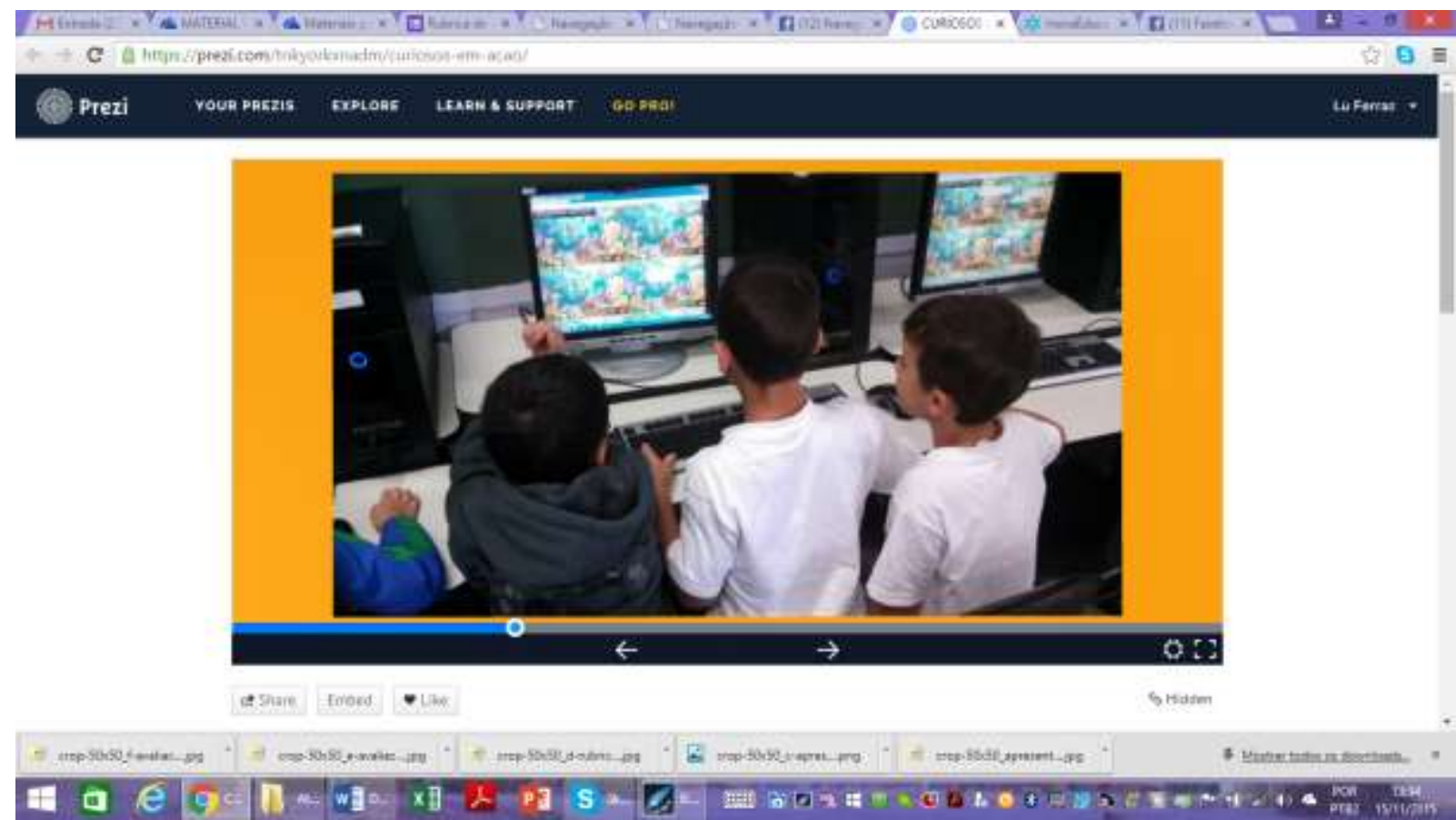

Figura 11: Projeto B.2 - Alunos desenvolvendo projetos no LIE Fonte: Blog curiosos Em Ação ${ }^{90}$

Inicialmente, houve a verificação dos conhecimentos que esses jovens participantes tinham sobre o tema em estudo, a qual foi feita a partir de uma roda de conversa para reflexão sobre o verbete curiosidade. Após esse primeiro momento, as turmas foram divididas em trios, agrupamentos esses que ficaram encarregados de escolher um animal qualquer, com destaque para um aspecto curioso / diferente do mesmo. Ou seja, deveriam buscar informações sobre o animal escolhido, sendo que o objetivo era destacar uma característica que fosse desconhecida e diferenciada para a maioria dos participantes. O registro desta etapa foi feito na ferramenta Padlet.

\footnotetext{
${ }^{90}$ Site Curiosos em ação (http://afonso-schmidt-coord.blogspot.com.br/2015/03/blog-post.html). Último acesso:
} 05-01-2016. 


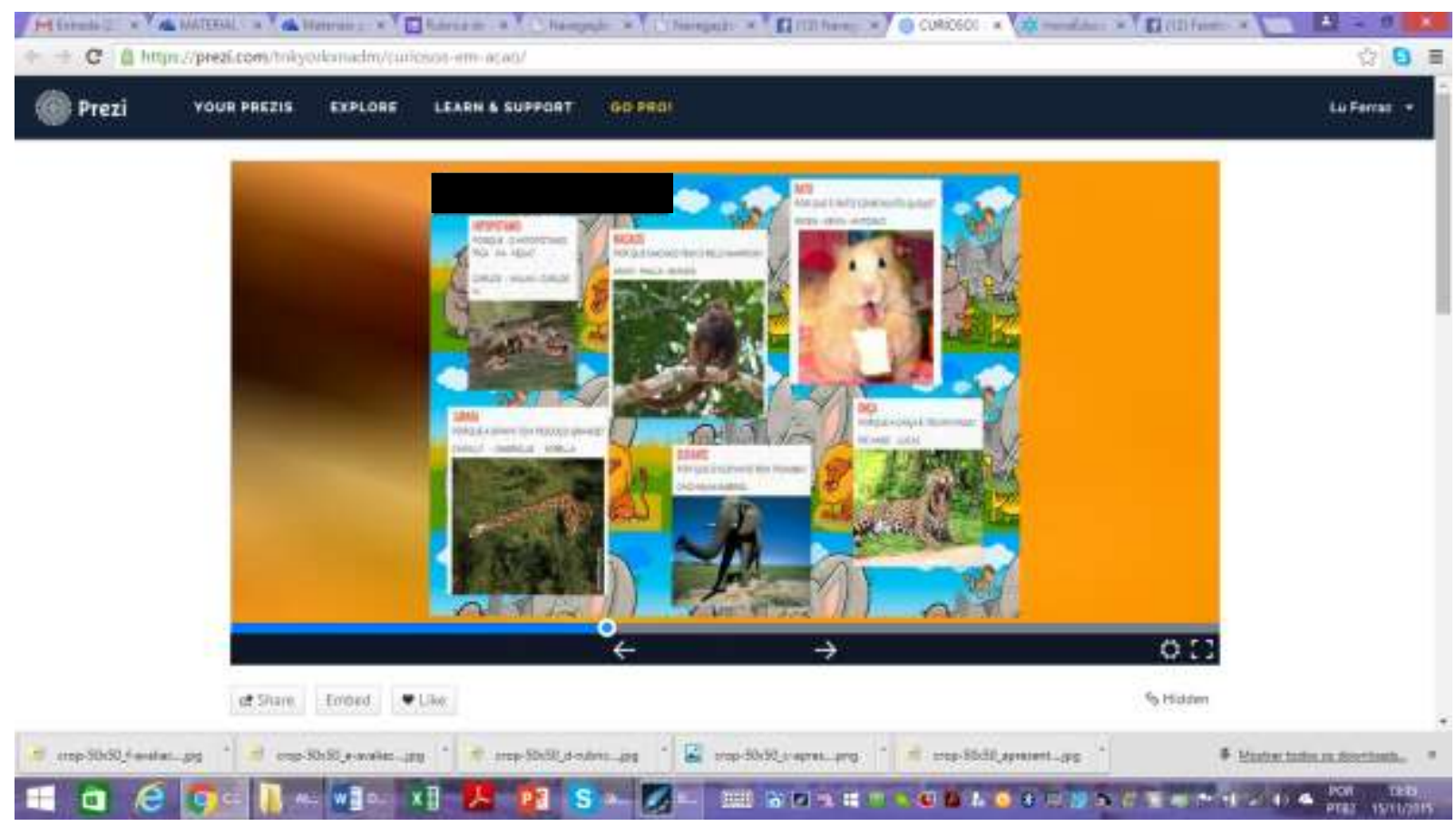

Figura 12: Projeto B.2 - Tela com slide do trabalho, no Padlet Fonte: Blog curiosos Em Ação ${ }^{91}$

O terceiro momento foi uma nova prática reflexiva, durante a qual esses alunos, ainda em pequenos grupos ou mesmo em agrupamentos maiores, deveriam refletir sobre como descobrir as curiosidades dos animais escolhidos pelos trios, agora sem utilização do computador. Nesse momento, eles foram percebendo, com base nas reflexões conjuntas mediadas pelo POIE responsável, o professor especialista José Rosemberg, como esses aparatos tecnológicos (computador, celular, tablet, e os aplicativos de busca, como Google, Yahoo e Bing) podem auxiliar nosso dia a dia, principalmente no que se refere à busca das informações diversas, mas sempre com critério e cuidado.

Para que reforçassem essa reflexão, eles buscaram inicialmente essas informações no Google, mas precisavam verificar se os textos obtidos como respostas atendiam a necessidade de esclarecer as curiosidades. Em caso afirmativo, essa descrição deveria ser passada para um arquivo em Word. E na aula seguinte, eles deveriam fazer a mesma busca, agora utilizando outras ferramentas, como o Bing e Yahoo, dentre outros. Quando da confirmação da curiosidade identificada, esses trios deveriam montar um slide em Power Point, apresentando a foto do animal, com a explicação sobre essa curiosidade.

\footnotetext{
${ }^{91}$ Site Curiosos em ação (http://afonso-schmidt-coord.blogspot.com.br/2015/03/blog-post.html). Último acesso: 05-01-2016.
} 
Ao final, todos os slides foram juntados em um arquivo de vídeo animado. Para música de fundo, o POIE responsável apresentou seis opções, para que eles fizessem uma votação sobre qual seria a escolhida. Ao final da edição desse vídeo, cada aluno recebeu um CD com a gravação do vídeo, para que levassem para suas famílias conhecerem o trabalho desenvolvido.

O registro detalhado das atividades desenvolvidas durante esse projeto foi feito no Prezi e Padlet, principalmente, sendo que, ao final, os alunos se autoavaliaram também com base em rubrica definida pelo POIE responsável. Para essa autoavaliação, a rubrica foi disponibilizada no GoogleDocs, e as imagens das telas estão disponíveis no ANEXO F ${ }^{92}$. Além disso, o POIE José Rosemberg utilizou o Popplet para publicação das etapas desenvolvidas durante o projeto.

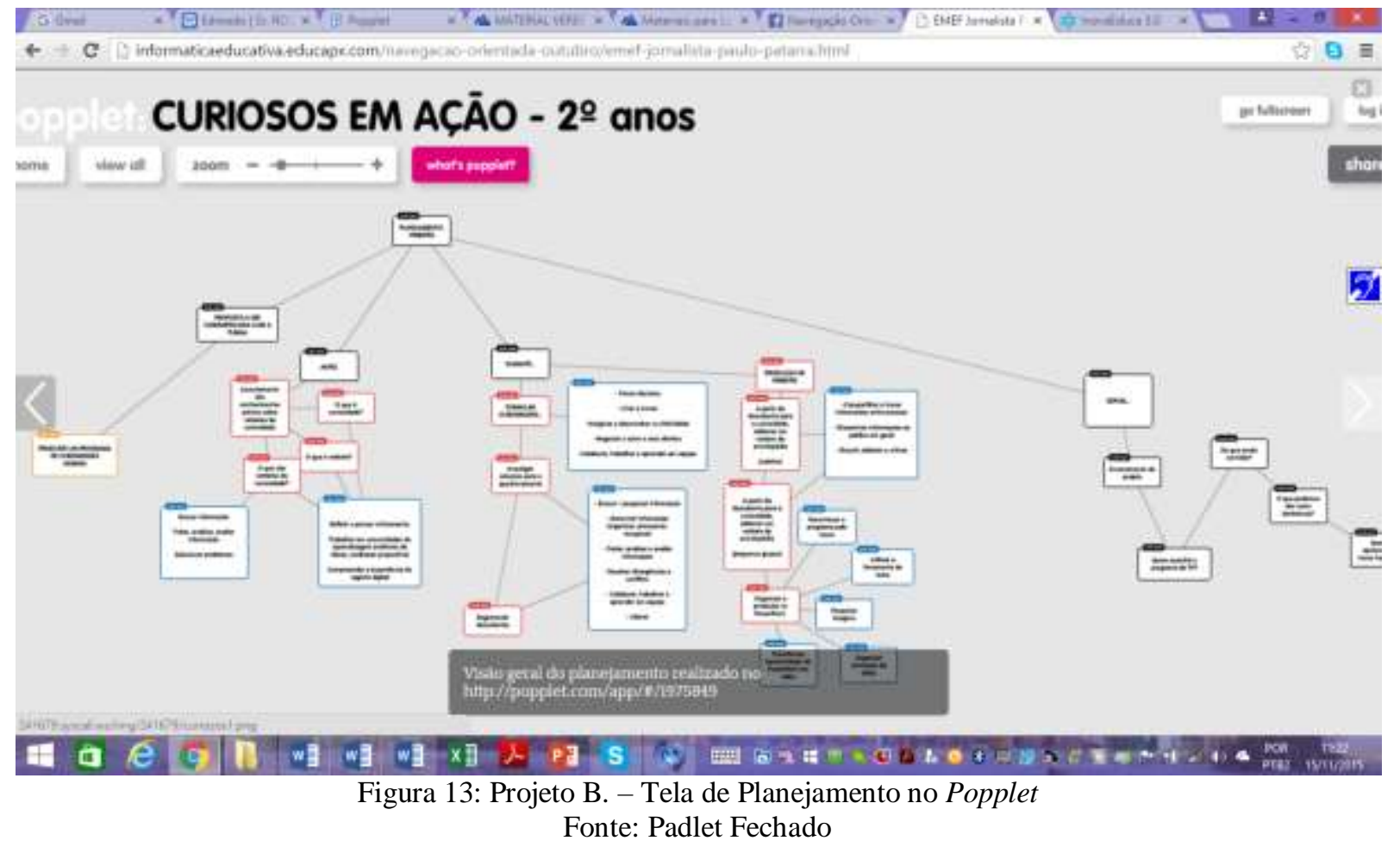

\section{B.3. Clube de Astronomia - (Público Alvo: Alunos 5' Ano: 2012; TIC:}

\section{ThinkQuest)}

O Clube de Astronomia foi um projeto coordenado pela POIE Maria Helena Pereira, do LIE e pela professora Nágila Polido, Professora Orientadora de Sala de Leitura (POSL), ambas da EMEF Des. Achilles de Oliveira Ribeiro, ligado à DRE São Mateus e foi implementado no

${ }^{92} \mathrm{O}$ ANEXO F contém as rubricas utilizadas em todos os oito projetos estudados. 
ano de 2012. Seu objetivo foi o estudo de Astronomia e ampliação do repertório cultural das crianças sobre o referido assunto, sendo que contou com a participação de uma turma mista (meninos e meninas) de vinte e quatro alunos do $5^{\circ}$ ano (antiga $4^{\mathrm{a}}$ serie), que tinham por volta de 9 a 10 anos, à época de sua realização. A adesão ao grupo foi por meio de inscrição livre, com base no interesse das crianças em conhecer a temática trabalhada. Sua realização deu-se durante o ano letivo de 2012.

Ele teve como objetivo incentivar o interesse dos seus participantes pela astronomia e ciências afins. Focava a produção de textos, a realização de dinâmicas reflexivas, a localização de constelações ou estrelas, a aprendizagem do uso do software Observatório Astronômico, as pesquisas diversas com uso de recursos da internet, a análise de cartas do céu e realização de rodas de leitura, sobre ficção científica e mitologia, dentre outros.

Esse projeto foi desenvolvido a partir do Programa Ampliar, que tem como objetivo principal a ampliação do período de permanência do aluno na escola, com participação em atividades educacionais focadas no desenvolvimento de competências diversas, considerando o uso de recursos e ambientes de aprendizagem disponíveis. Um dos programas que deveria ser trabalhado de forma integrada com esse Programa Ampliar era o Nas Ondas do Rádio, para auxiliar na disseminação e concretização de projetos educomunicativos nas unidades escolares de todos os níveis da respectiva Rede. Ou seja, os projetos desenvolvidos a partir do Ampliar visavam a promoção do:

[...] protagonismo infantojuvenil através das linguagens de comunicação associadas ao uso dos recursos das tecnologias da informação e da comunicação. Entre os benefícios dos projetos, destacamos a melhoria das competências leitora e escritora e a qualificação do convívio nas escolas em direção a um ambiente mais democrático, possibilitando, através da comunicação, entretenimento, aprendizado e espaço para expressão comunicativa e criativa. Para tanto, incentivamos iniciativas como: Rádio Escolar, Agência de Notícias, Jornal Mural, Jornal Impresso, Blog, Fanzine, Cinema \& Vídeo, Fotografia, HQ, entre outras. (SÃO PAULO, 2015) ${ }^{93}$

O estudo desse projeto foi incluído nesta pesquisa porque ele foi desenvolvido com base no planejamento e implementação de algumas das ações estratégicas de avaliação formativa orientadas pela equipe de Informática Educativa, da DOT / SME-SP e da gestão da DRE São Mateus, à época sob a responsabilidade da professora especialista Regina Gavassa, como dito anteriormente.

\footnotetext{
${ }^{93}$ Fonte: Portal Prefeitura Municipal de São Paulo, Página Projeto Ampliar (Link: http://portalsme.prefeitura.sp.gov.br/Projetos/educom/AnonimoSistema/MenuTexto.aspx?MenuID=50\&MenuID Aberto=49)
} 
Para este nosso estudo, analisei alguns dos aspectos do projeto disponibilizados na plataforma ThinkQuest utilizada para registro, bem como fizemos uma entrevista pessoal com a POIE responsável pelo desenvolvimento do projeto, a professora Maria Helena Pereira. Vale destacar que, além do registro no referido AVA, o trabalho contou com o uso de rubrica para autoavaliação dos seus participantes, ao final do mesmo.

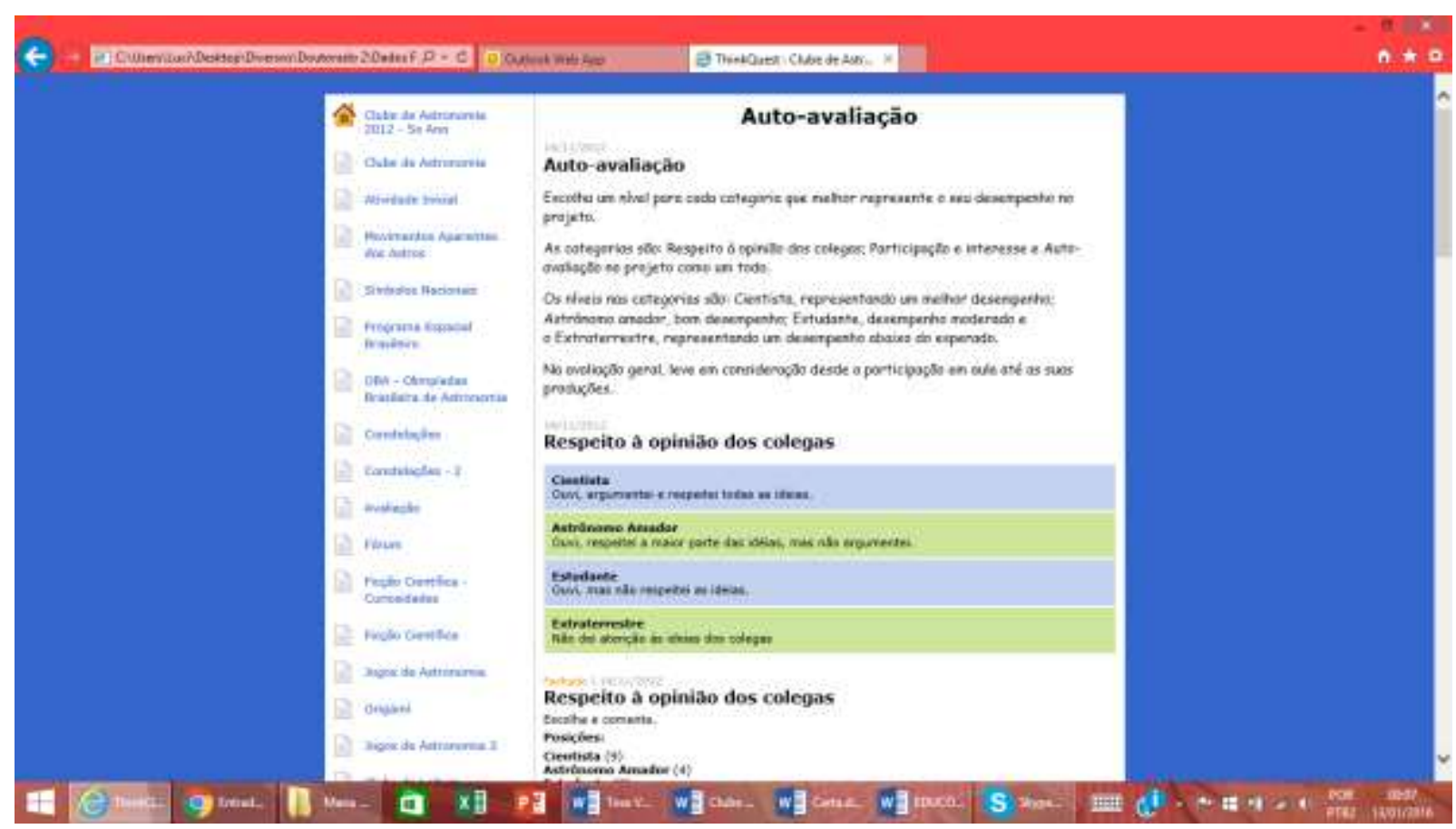

Figura 14: Projeto B.3 - Tela com critério de rubrica, para autoavaliação no ThinkQuest Fonte: Plataforma ThinkQuest, para NIE (DOT/SME-SP) ${ }^{94}$

\section{B.4. Jogos do Riva - Aluno Monitor (Site Jogos do Riva) ${ }^{95}$}

O projeto Jogos do Riva foi desenvolvido a partir do Programa de Aluno Monitor, pela então POIE Gislaine Batista Munhoz, da EMEF Prof. Rivadávia Marques Junior, unidade educacional ligada à DRE São Mateus, durante os anos de 2012 a 2014. Ele foi desenvolvido por crianças e jovens adolescentes durante os períodos em que atuavam como alunos monitores no LIE naquela escola.

Nasceu da demanda de professores do Ciclo de Alfabetização por jogos virtuais que auxiliassem no processo de seus alunos de primeiros anos. Nesse momento, ao invés de solicitar a seus alunos monitores para que buscassem opções prontas disponíveis na internet, a então POIE Gislaine propôs a seus alunos monitores que eles aprendessem como programar

\footnotetext{
${ }^{94}$ Link desconhecido, pois plataforma não está mais disponível.

${ }^{95}$ Link do site do projeto Jogos do Riva: http://jogosdoriva.webnode.com/
} 
jogos, de maneira que pudessem eles próprios trabalhar nesse desenvolvimento, considerando as solicitações dos referidos professores.

Eles foram testando alguns recursos que permitem esse tipo de atividade, sendo que chegaram a trabalhar com o software Hot Potatoes, mas optaram por focar no uso do Scratch e Power Point.

Com o passar do tempo, foram ganhando experiência e desenvolvendo jogos mais elaborados, sendo que, segundo esses alunos, do ponto de vista estético, os melhores jogos são os desenvolvidos no Power Point. A ideia de estruturação de um site para disponibilização dos jogos criados foi dos próprios alunos.

Além do site, o grupo de alunos montou duas páginas na plataforma Facebook: Jogos do Riva $^{96}$ (espaço para publicação sobre as últimas notícias do Projeto Jogos do Riva, como, por exemplo, lançamento de novos jogos, quem são os jovens envolvidos no projeto, participações do grupo em eventos, e desenvolvimento de novos projetos, dentre outras informações) e Escola de Aventureiros ${ }^{97}$ (espaço de reflexão sobre inovação do mundo de games e as atividades de gamificação).

E em que pese que alguns dos alunos já tenha passado para o Ensino Médio e saído do programa aluno monitor daquela unidade escolar, o grupo desses quatro alunos segue se encontrando mensalmente com sua antiga POIE Gislaine, para refletirem sobre o uso de jogos na educação, como faziam no projeto Jogos do Riva.

A decisão por incluir esse projeto em minha pesquisa apesar dele, a princípio, não seguir as orientações oficiais definidas da equipe de Informática Educativa, foi pelo fato de apresentar exemplos de algumas das ações estratégicas de avaliação formativa: desenvolvimento de rubrica, momentos de autoavaliação pelos alunos e avaliação entre pares, e registro das práticas em um ambiente virtual desenvolvido especificamente como repositório dos produtos desenvolvidos pelo grupo de alunos.

\footnotetext{
${ }^{96}$ Link: https://www.facebook.com/Jogos-do-Riva-411528135582829/info/?tab=page_info

${ }^{97}$ Link: https://www.facebook.com/Clube.Aventureiros/?fref=ts
} 


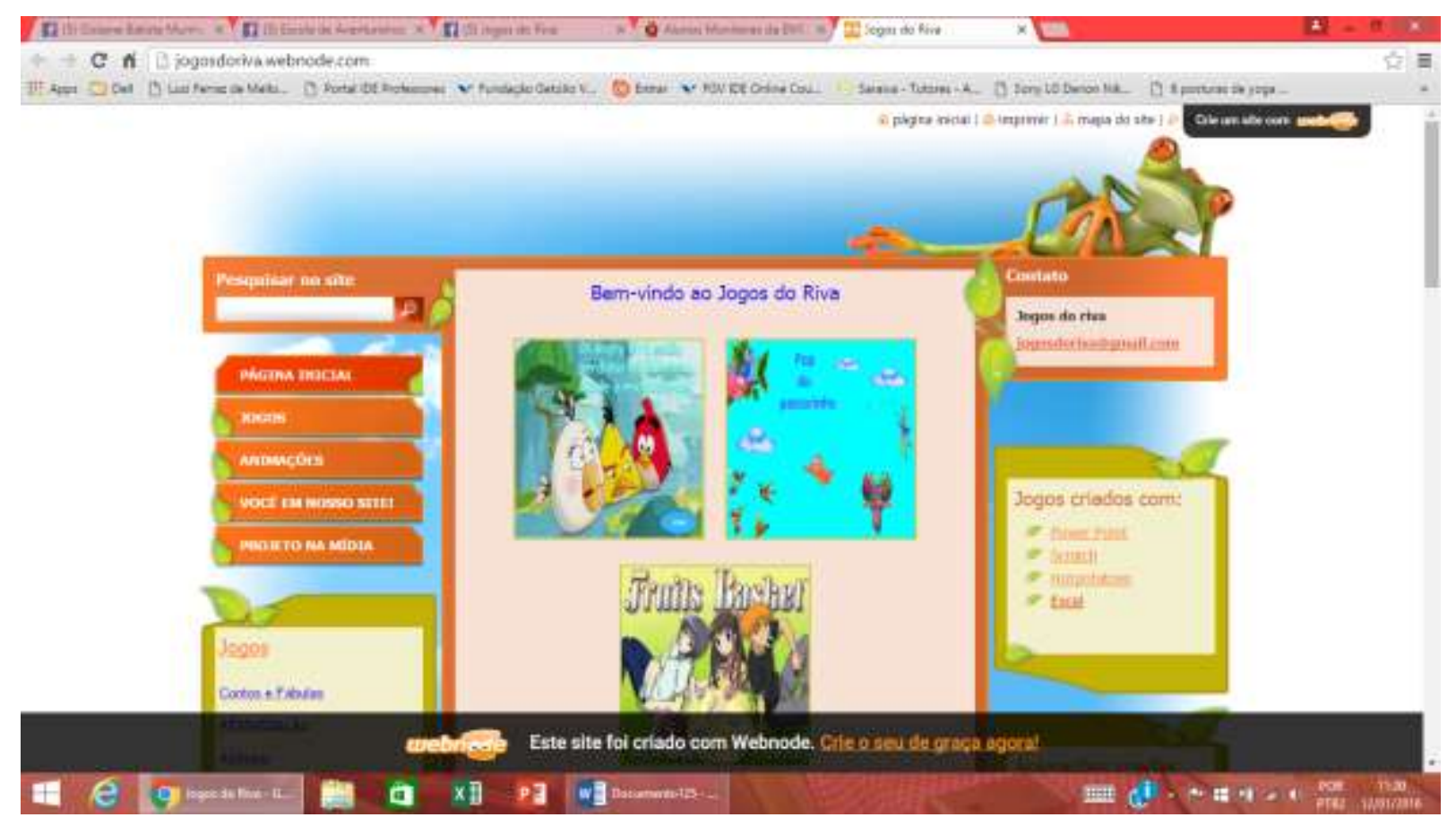

Figura 15 - Projeto B.4 - Tela de Abertura do site repositório dos Jogos do Riva Fonte: Site Institucional ${ }^{98}$

Uma característica diferenciada sobre esse projeto refere-se ao processo de adoção de uma rubrica. Isso porque em um determinado momento, após o desenvolvimento de inúmeros desses jogos, o grupo se deu conta, a partir das reflexões que vinham desenvolvendo sobre suas práticas, que precisavam definir critérios mais claros para as avaliações entre pares e autoavaliações. Frente a essa colocação, a POIE responsável, professora Gislaine, apresentou os princípios da avaliação formativa e da formulação de uma rubrica, sugerindo que eles estruturassem uma com os critérios que julgavam importantes de serem avaliados.

Daí resultou o quadro que estamos chamando aqui de Rubrica dos Jogos do Riva, o qual consta do ANEXO F, aqui deste estudo. Destaco que ela foi totalmente desenvolvida por esses alunos. Para verificação dos aspectos desta pesquisa, utilizei as informações coletadas durante entrevista pessoal com a POIE responsável, bem como as informações da rubrica.

Agora, vamos entender um pouco mais desse contexto, a partir das análises dos dados coletados!

\footnotetext{
${ }^{98}$ Link: https://www.facebook.com/Jogos-do-Riva-411528135582829/info/?tab=page_info (último acesso: 0501-2016)
} 


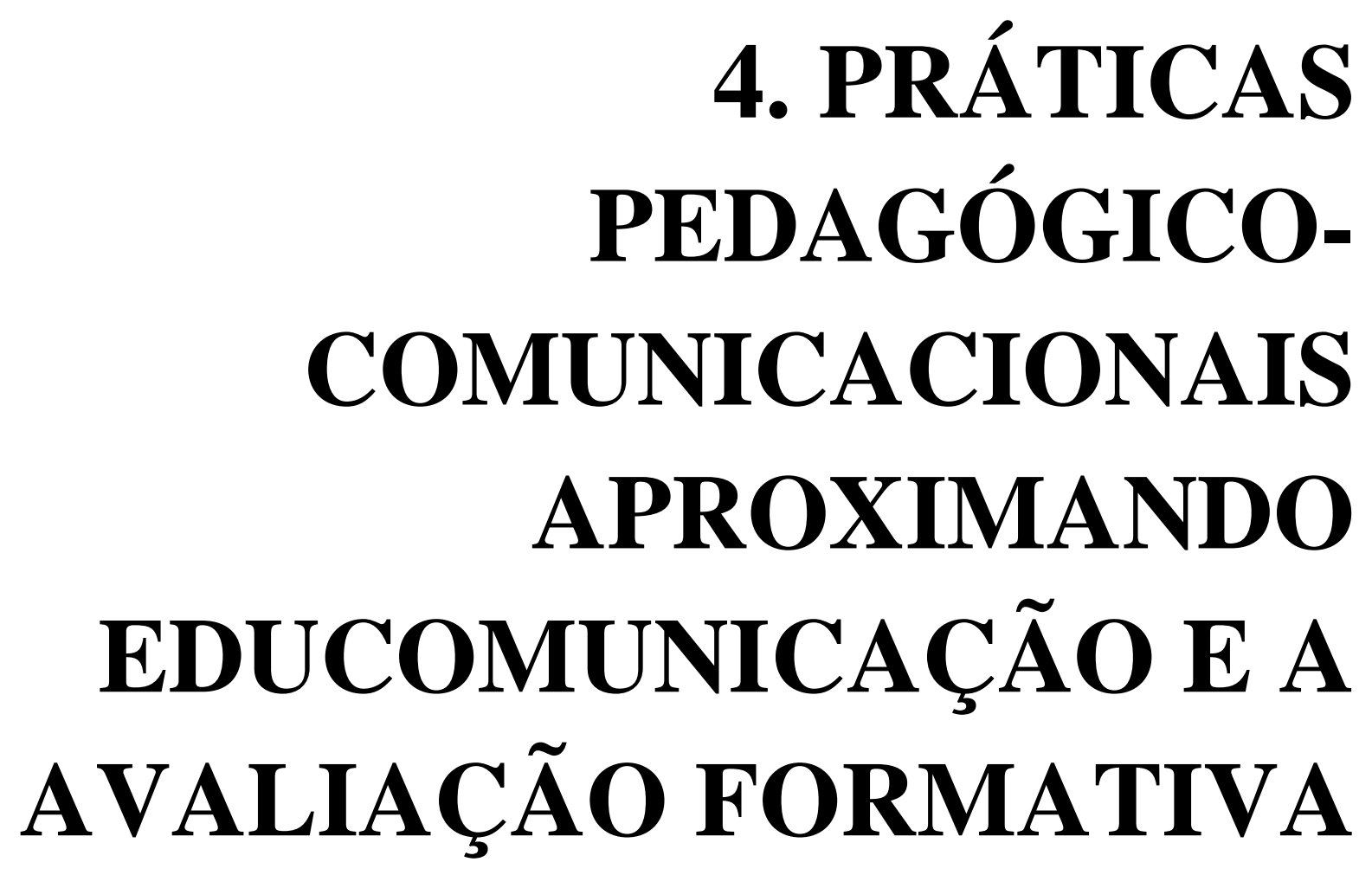

Para desenvolvermos as reflexões sobre as possíveis aproximações entre o paradigma da Educomunicação e as ações estratégicas da proposta de avaliação formativa adotada pelo Núcleo de Informática Educativa, da DOT/SME-SP, início este capítulo discorrendo sobre as normas que orientam as práticas desse Núcleo, para destacar aspectos desse contexto, os quais foram considerados quando da análise dos dados. Na sequência, apresento as análises dos dados coletados sobre os projetos estudados, dos Grupos A e B, com base nas categorias definidas com base nos indicadores conceituais deste estudo. 
O método principal adotado foi a Análise de Conteúdo principalmente para as entrevistas pessoais com os POIE, por meio da definição de uma categoria tema e seus respectivos subtemas, os quais estão listados no Quadro 13, utilizados para indicar os possíveis pontos de aproximação entre Educomunicação e a abordagem de avaliação formativa. (LAGO \& BENETTI, 2008; FRANCO, 2012)

Esses temas e subtemas foram definidos, por sua vez, com base no Anexo H, que contém o detalhamento do que seriam essas aproximações em termos conceituais.

Quadro 12 - Temas e Subtemas para Análise de Conteúdo

\begin{tabular}{|c|c|}
\hline TEMA & SUBTEMAS \\
\hline FINALIDADE PRINCIPAL & $\begin{array}{l}\text { 1. Empoderamento do aluno; } \\
\text { 2. Apoio à construção do conhecimento; } \\
\text { 3. Acompanhamento desenvolvimento de competências específicas / } \\
\text { educomunicativas. } \\
\text { 4. Leitura crítica dos meios. }\end{array}$ \\
\hline MOMENTO DE AVALIAÇÃO & 1. Durante o processo. \\
\hline DINÂMICA ENCERRAMENTO & $\begin{array}{l}\text { 1. Rodas de conversa, ao final do processo, para desenvolvimento de } \\
\text { reflexões analíticas e reflexivas pelos alunos, de forma individual e/ou } \\
\text { grupal. }\end{array}$ \\
\hline $\begin{array}{l}\text { PRÁTICAS } \\
\text { PEDAGÓGICO- } \\
\text { COMUNICACIONAIS }\end{array}$ & $\begin{array}{l}\text { 1. Gestão Compartilhada da Comunicação (SOARES, 1999): } \\
\text { a. Ação comunicativa; } \\
\text { b. Apropriação e manejo das linguagens da comunicação; } \\
\text { c. Uso dos recursos da informação para a produção cultural; } \\
\text { d. Leitura crítica dos meios. } \\
\text { 2. Participações de Protagonismo [Degraus de Participação: } 3 \text { a } 10 \text { (HART, } \\
\text { 1992; COSTA,2006)]: } \\
\text { a. Participação planejadora e operacional. } \\
\text { b. Participação decisória, planejadora e operacional. } \\
\text { c. Participação decisória, planejadora, operacional e avaliadora. } \\
\text { d. Participação colaborativa plena. } \\
\text { e. Participação plenamente autônoma. } \\
\text { f. Participação condutora. } \\
\text { 3. Ações de Diálogo } \\
\text { a. Escuta mútua; } \\
\text { b. Pensar juntos; } \\
\text { c. Apontar outros pontos de vista; } \\
\text { d. Compartilhar e refletir sobre ideias; } \\
\text { e. Fazer emergir ideias / buscar pluralidade de ideias. }\end{array}$ \\
\hline $\begin{array}{l}\text { COMPETÊNCIAS } \\
\text { EDUCOMUNICATIVAS } \\
\text { (OU CRITÉRIOS } \\
\text { EDUCOMUNICATIVOS DE } \\
\text { AVALIAÇÃO) }\end{array}$ & $\begin{array}{l}\text { 1. Saber dialogar (pensar conjuntamente); } \\
\text { 2. Saber escutar (garantindo ações conjuntas de escuta mútua); } \\
\text { 3. Saber organizar o pensamento (buscando formas colaborativas de } \\
\text { expressão); } \\
\text { 4. Saber colaborar em grupo ou em equipe para a execução dos projetos; } \\
\text { 5. Saber compartilhar (experiências e ideias); } \\
\text { 6. Saber implementar gestão compartilhada da comunicação; } \\
\text { 7. Usar colaborativamente das TIC, para registro de práticas dialógicas; } \\
\text { 8. Saber tomar decisão de forma compartilhada; } \\
\text { 9. Saber encontrar resolução de problemas de forma conjunta } \\
\text { 10. Ser capaz de promover avaliação entre pares, assim como a } \\
\text { autoavaliação. } \\
\text { 11. Leitura crítica dos meios. }\end{array}$ \\
\hline
\end{tabular}


Então, à medida que tratei de cada ação estratégica da avaliação formativa, realizei as análises com base nos temas e subtemas acima, para indicar as possíveis aproximações.

\subsection{Pressupostos educomunicativos nos Documentos Oficiais da SME-SP}

Dado que os dois objetivos desta pesquisa empírica eram verificar se a avaliação formativa adotada pelos LIE e as orientações de suas práticas se estruturavam a partir dos pressupostos educomunicativos, julguei importante verificar as normas que orientam essas práticas.

Especificamente sobre a identificação dessas premissas nos projetos dos LIE, apesar de ter apresentado vários documentos que, de alguma forma, normatizaram ou nortearam a estrutura do Núcleo de Informática Educativa, no Capítulo Três, há três deles que interessam mais diretamente para esta pesquisa.

O primeiro é a Portaria 5.930/13, que trata do Programa de Reorganização Curricular e Administrativa, Ampliação e Fortalecimento da Rede Municipal de Ensino de São Paulo "Mais Educação São Paulo". Isso porque ele define, entre inúmeros outros aspectos ligados às atividades dos LIE, as questões sobre metodologias curriculares e como as atividades dos LIE devem ser planejadas em parceira com os professores de Artes, Educação Física, Língua Inglesa e de Sala de Leitura. Isso principalmente para o caso do desenvolvimento dos Trabalhos Colaborativos Autorais (TCA), do Ciclo Autoral ( $3^{\circ}$ Ciclo). Como destaca o referido documento: "As aulas de Língua Inglesa, Educação Física, Arte, de Laboratório de Informática Educativa e de Sala de Leitura assumirão caráter integrador das diferentes áreas de conhecimento" (SÃO PAULO, 2013, Art. $6^{\circ}, \S 2^{\circ}$ ).

É exatamente essa portaria que define a pedagogia de projetos como a base para o desenvolvimento dos TCA, do $3^{\circ}$ Ciclo, que prevê: "Na elaboração do TCA, os educandos farão uso de metodologias de pesquisa, a partir de temáticas que subsidiem a construção do conhecimento e desenvolvimento de habilidades que possibilitem a compreensão da cidadania como participação social e política" (SÃO PAULO, 2013, Art. $10^{\circ}, \S 2^{\circ}$ ). Esse mesmo artigo destaca que são exatamente nos LIE e nas Salas de Leitura que essas atividades serão "programadas de modo integrador com as demais áreas, assegurando o planejamento, 
execução e avaliação dos TCAs" (SÃO PAULO, 2013, Art. 10², § $3^{\circ}$ ). Esses incisos já destacam aspectos convergentes com a Educomunicação, principalmente quanto ao desenvolvimento do empoderamento das crianças e jovens, para formação de cidadãos responsáveis, como destacado por Freinet (1985) e Freire (2002), dentre outros já mencionados nesta tese.

Em seu artigo $13^{\circ}$, esse dispositivo define que na unidade educacional a avaliação deverá ter um caráter formativo, o que nos sinaliza, pelo menos, para uma primeira orientação no sentido da adoção da avaliação formativa.

Especificamente sobre a identificação da adoção sistematizada e clara dos pressupostos da Educomunicação pelos projetos dos LIE, apesar de não estar mais em vigor, importante mencionar as orientações da Portaria da SME-SP 900/14 ${ }^{99}$, que vigorou até dezembro de 2015, durante a execução de três dos projetos do Grupo B:

Art. $2^{\circ}$ - O trabalho nos Laboratórios de Informática Educativa, por meio das práticas ali desenvolvidas, tem por objetivos:

I - promover a integração das áreas visando à concretização dos objetivos de cada um dos três Ciclos, a serem operacionalizados por meio dos Projetos PolíticoPedagógicos de cada Unidade Educacional.

II - possibilitar a criação de ambientes de aprendizagem inovadores, colaborativos, interativos e integradores;

III - potencializar o uso crítico e criativo dos diferentes recursos tecnológicos, como forma de expressão oral, escrita, registro, socialização e produção de textos em diferentes contextos e linguagens;

IV - favorecer o uso das Tecnologias da Informação e Comunicação - TICs, na integração com o currículo nos Ciclos de Alfabetização, Interdisciplinar e Autoral, e nas Etapas da Educação de Jovens e Adultos-EJA;

$\mathrm{V}$ - propiciar condições de acesso e uso das tecnologias voltadas para a pesquisa e produção do conhecimento para educandos e professores;

VI - potencializar o uso das Tecnologias da Informação e da Comunicação - TICs na atuação e formação docente, de educandos e demais segmentos da comunidade educativa;

VII - favorecer os avanços dos níveis de proficiência estabelecidos e nas metas de desenvolvimento da qualidade educacional, indicados nos sistemas de avaliação externa, em especial, no Sistema de Avaliação da Educação Básica (SAEB);

VIII - auxiliar, no âmbito de sua atuação, nas atividades de docência e de gestão pedagógica nos procedimentos de Avaliação da Aprendizagem, especialmente nas atividades de Recuperação Contínua e Paralela. (SÃO PAULO, 2014) ${ }^{100}$

\footnotetext{
${ }^{99}$ Regulamenta as práticas dos LIE.

${ }^{100}$ Portaria 5.930 de $12 / 2013$.
} 
A análise dos incisos desse artigo me permitiu identificar indicadores dos temas práticas pedagógico-comunicacionais e competências educomunicativas e seus respectivos subtemas, ainda que a palavra Educomunicação não tenha sido mencionada.

No final de 2015, a SME-SP publicou a Portaria 7.656/15 (SÃO PAULO, 2015), que substituiu a Portaria 900/14, da SME-SP (2014), passando a redefinir as operações dos LIE nas unidades educacionais da referida Rede. Identifiquei, no novo texto, algumas orientações igualmente convergentes com as premissas da Educomunicação:

Art. $2^{\circ}$ - O trabalho desenvolvido nos Laboratórios de Informática Educativa, terá como diretrizes para a sua ação pedagógica:

I - o currículo na perspectiva emancipatória e integradora, tendo a dialogicidade como norteador do trabalho pedagógico e o ambiente escolar como local de promoção do protagonismo do educando, com a ressignificação dos conteúdos, articulados à realidade social;

II - a Unidade Educacional como espaço de criação e recriação de cultura digital e dos conteúdos, tendo os educandos e docentes como produtores e consumidores conscientes desta cultura, a partir da mediação, compreensão e expressão das linguagens digitais;

III - as Tecnologias de Informação e Comunicação - TICs, como possibilidades de organização das iniciativas pedagógicas e da comunicação entre os educandos e educadores, e destes com o conhecimento;

IV - o registro das práticas pedagógicas como instrumento que acompanhe o educando na avaliação do seu processo de aprendizagem;

V - a valorização dos saberes e desenvolvimento das potencialidades dos educandos, tendo como pilares a compreensão, experimentação, colaboração e a capacidade de construir conhecimentos;

VI - a criação de ambientes estimuladores e colaborativos, com estratégias diversificadas no trabalho com projetos didáticos, podendo, inclusive, utilizar-se da robótica, gamificação cultura maker, raciocínio lógico espacial e pensamento crítico reflexivo no desenvolvimento de uma postura investigativa;

VII - a sistematização dos conteúdos produzidos coletivamente, a partir da decisão também coletiva de compartilhamento e do uso dos Recursos Educacionais Abertos. (SÃO PAULO, 2015) $)^{101}$

Os tópicos aqui listados indicam que muitas das características da Educomunicação, trabalhadas na SME-SP, entre 2001 e 2004, a partir do projeto Educom.rádio, atingindo, na ocasião, mais de 11 mil membros das comunidades educativas de 445 escolas da rede municipal, estão sendo revisitadas, a partir de 2015, nas orientações básicas para o desenvolvimento dos projetos a serem desenvolvidos durante as aulas nos LIE.

Não posso afirmar que existam relações de causa e efeito entre o Educom.Rádio e as novas normas. No entanto, acredito ter havido o amadurecimento de uma cultura portadora de pontos

101 Portaria 5.930 de $12 / 2013$. 
de vista pedagógicos inovadores, no presente, o qual se originou das diversas abordagens adotadas desde que Paulo Freire, enquanto Secretário Municipal de Educação, lançou as bases do hoje Núcleo de Tecnologias para Aprendizagem ${ }^{102}$ até o presente momento, incluindo a influência da formativa levada à base desta Rede pelo NCE/USP, nos anos iniciais do século XXI, e continuada, ao longo dos últimos 15 anos, com algumas das assessorias contratadas, como a equipe da Educarede / Telefonica (que apresentava propostas educomunicativas convergentes com a proposta do NCE - ECA/USP) e até mesmo algumas ações educomunicativas voltadas ao protagonismo infanto-juvenil adotadas no projeto Imprensa Jovem ligado ao Núcleo Nas Ondas do Rádio, entre outros.

Senão, vejamos, por exemplo, o inciso I, que explicita o diálogo e o protagonismo, como bases para o desenvolvimento dos projetos, enquanto que o inciso II sinaliza para a necessidade de que se trabalhe a autoria dos alunos com ações de caráter pedagógicocomunicacional, com ênfase nas trocas dialógicas reflexivas por meio de diversas linguagens, para a instalação de ecossistemas comunicativos. Ou mesmo o inciso III e seus subsequentes, que novamente estimulam práticas mediadas por TIC, que fomentam a criação de ecossistemas comunicativos (SOARES, 1999).

Logo, essas duas portarias que atualmente apresentam as bases das práticas dos LIE, já confirmam a existência de aspectos comuns entre a Educomunicação e as próprias práticas dos Laboratórios de Informática Educativa e sua proposta de avaliação formativa, especialmente porque, a princípio, esses projetos já devem ser planejados considerando perspectiva pedagógico-comunicacional, com base no diálogo reflexivo e no protagonismo.

Essa aproximação se torna mais clara quando no Artigo $3^{\circ}$, sobre as atribuições do POIE, é destacado o seu papel de coordenador dos projetos transdisciplinares previstos para serem desenvolvidos nos LIE, bem como de articulador e integrador com professores de outras temáticas, da mesma ou de outras unidades educacionais da Rede, o que nos remete à descrição do perfil do educomunicador, apresentada no Capítulo Um, desta tese.

102 A partir do final do final de 2015, o Núcleo de Informática Educativa passou a ser chamado de Núcleo de Tecnologias para Aprendizagem. Dado que os projetos aqui em estudo ocorreram quando ele ainda tinha a primeira denominação, optamos por mantê-la aqui neste estudo, para evitarmos possíveis confusões. Porém como neste momento estamos refletindo sobre a Portaria recentemente publicada, achamos por bem fazer este esclarecimento aqui. 
Vale resgatar os aspectos conceituais desse mesmo capítulo, sobre a necessidade de as práticas pedagógico-comunicacionais nos ambientes educacionais refletirem as novas relações da sociedade altamente midiática em que vivemos, com base nas ideias de Soares $(1999 ; 2011)$, Baccega (2011), Citelli (2011; 2004) e Martin-Barbero (2011; 2005), principalmente. Ou seja, esse inciso indica a necessidade de adoção de ações focadas não apenas no uso de ferramentas diversas de TIC, mas também na reflexão sobre o uso e consequências do mesmo, pelos alunos, dentre outras ações. Ouso aqui entender, então, que há, por parte da SME-SP, uma preocupação em que os alunos possam, efetivamente, vivenciar nesses espaços, práticas dialógicas, protagonistas e de gestão compartilhada da comunicação, refletindo sobre tais usos.

Especificamente sobre o tema dos processos de avaliação formativa, vale mencionar que o POIE é também responsável por: "construir instrumentos de registro que possibilitem diagnóstico, acompanhamento e avaliação dos processos de ensino e aprendizagem;" (SÃO PAULO, 2015, Art. $3^{\circ}$, Inciso III). Ou seja, apesar de não haver detalhamento sobre qual abordagem deva ser adotada, o POIE é instado a buscar opções de avaliação voltadas à formação e ao fortalecimento da construção de conhecimento nos espaços dos LIE.

Esses textos esclarecem sobre as obrigações desses POIE, de efetuarem algum tipo de registro que permita o acompanhamento e a avaliação dos processos, bem como mostram que, apesar desses POIE terem autonomia para definir uma série de ações para os espaços dos LIE, essas devem seguir premissas básicas definidas nessas Portarias, as quais já apresentam características da Educomunicação, apesar do termo não ser mencionado.

\subsection{Práticas Pedagógico-Comunicacionais nos Laboratórios de Informática Educativa}

Para o desenvolvimento deste tópico, verifiquei as informações sobre os oito projetos escolhidos para a realização desta pesquisa empírica, sendo que apresento aqui a estrutura resumida de cada um dos grupos A e B, no Quadro 14. A análise inicial desse quadro permite perceber que todos os casos analisados seguem uma estrutura básica de pedagogia de projetos, como indicado nas orientações normativas da SME-SP. Contudo, eles apresentam diferenças 
entre si, as quais aparecem quando foquei nos detalhes de suas execuções, assim como quando analisei o desenvolvimento das rubricas e da avaliação em si (autoavaliação e/ou em pares).

Quadro 13 - Descritivo Resumido dos Projetos Estudados, por Grupo

\begin{tabular}{|c|c|c|}
\hline DESCRITIVO & GRUPO A & GRUPO B \\
\hline $\begin{array}{l}\text { Abordagem } \\
\text { Metodológica }\end{array}$ & Pedagogia de Projetos & Pedagogia de Projetos \\
\hline $\begin{array}{l}\text { Etapas gerais } \\
\text { das atividades } \\
\text { desenvolvidas }\end{array}$ & $\begin{array}{l}\text { Definição de tema; } \\
\text { Orientação básica sobre as } \\
\text { diretrizes do projeto; } \\
\text { Definição das atividades de } \\
\text { desenvolvimento do projeto; } \\
\text { Definição das tecnologias de apoio; } \\
\text { Definição do produto tecnológico } \\
\text { final; } \\
\text { Rubrica de avaliação; } \\
\text { Forma de avaliação (autoavaliação } \\
\text { ou avaliação entre pares). }\end{array}$ & $\begin{array}{l}\text { Definição de tema; } \\
\text { Orientação básica sobre as } \\
\text { diretrizes do projeto; } \\
\text { Definição das atividades de } \\
\text { desenvolvimento do projeto; } \\
\text { Definição das tecnologias de apoio; } \\
\text { Definição do produto tecnológico } \\
\text { final; } \\
\text { Rubrica de avaliação; } \\
\text { Forma de avaliação (autoavaliação } \\
\text { ou avaliação entre pares). }\end{array}$ \\
\hline Tema & Sustentabilidade & $\begin{array}{l}\text { Violência; Drogas; Verbetes; } \\
\text { Alfabetização. }\end{array}$ \\
\hline $\begin{array}{l}\text { Rubrica com } \\
\text { indicadores de } \\
\text { avaliação }\end{array}$ & $\begin{array}{l}\text { Sim (desenvolvidas pelo professor } \\
\text { em algum momento do processo, } \\
\text { para serem aplicadas no final, com } \\
\text { os alunos) } \\
\text { Só foram apresentadas para os } \\
\text { alunos ao final do projeto }\end{array}$ & $\begin{array}{l}\text { Sim (desenvolvidas no início ou } \\
\text { durante, em parceria com os alunos, } \\
\text { para serem aplicados no final); } \\
\text { Foram desenvolvidas/apresentadas } \\
\text { no início ou no meio do projeto. }\end{array}$ \\
\hline $\begin{array}{l}\text { Registro do } \\
\text { Projeto }\end{array}$ & ThinkQuest; Google & $\begin{array}{l}\text { Edmodo }^{103} \text {, Popplet }^{104}, \text { Padlet }^{105} \text {, } \\
\text { GoogleDocs }{ }^{106}, \text { Site Repositório; } \\
\text { Programas de Astronomia; Word; } \\
\text { PowerPoint; Scratch }{ }^{107} ; \text { Hot } \\
\text { Potatoes. }^{108}\end{array}$ \\
\hline $\begin{array}{l}\text { Produto / peça } \\
\text { tecnológica final }\end{array}$ & $\begin{array}{l}\mathrm{HQ}^{109}, \text { Movie Maker } \\
\text { no Word }\end{array}$ & $\begin{array}{l}\text { Vídeo; CD; Jogos educativos; } \\
\text { Jogos de Tabuleiro e de Memória; }\end{array}$ \\
\hline Avaliação Final & Autoavaliação e avaliação entre & Autoavaliação e avaliação entre \\
\hline
\end{tabular}

${ }^{103}$ Edmodo: plataforma virtual de aprendizagem, muito semelhante ao Facebook, em termos de layout. Foi desenvolvida nos EUA, para ser utilizada como apoio a práticas de cursos presencial e a distância.

104 Popplet: aplicativo de apoio à aprendizagem, para a elaboração de mapas conceituais.

105 Padlet: aplicativo de apoio à aprendizagem, que permite a criação de murais virtuais.

${ }^{106}$ GoogleDocs: ferramenta do Google, para armazenamento de arquivos e elaboração e oferta de questionários e planilhas virtuais diversas.

107 Scratch: software de programação de jogos virtuais.

${ }^{108}$ Hot Potatoes: software de programação de jogos virtuais.

${ }^{109}$ HQ: programas digitais de criação de histórias em quadrinhos.

${ }^{110}$ Movie Maker: software para edição de vídeos. 
Meus estudos dos projetos dos Grupos A e B mostraram que a abordagem de avaliação formativa adotada, a princípio, apresenta ações desenhadas para prever esse acompanhamento e possibilidades de intervenção desde o início do processo até o seu final, sempre com o foco de auxiliar no fortalecimento da construção do conhecimento. Isso me permitiu verificar a perspectiva da existência de um ponto de aproximação entre a filosofia que preside os projetos e o conceito de Educomunicação.

$\mathrm{Na}$ verdade, falo de perspectivas de aproximação e não de identidade conceitual. Levei em conta que a prática, em si, dos projetos nem sempre considera a implementação das dinâmicas previstas quando do seu planejamento. O processo de execução não é, pois, linear ou muito claro, até mesmo pelo estilo pessoal dos próprios POIE, dentre outras razões.

Em alguns momentos, ocorreu o que Wiliam (2011) alerta no tocante ao fato de que a maioria dos professores dos dias atuais guarda fortemente internalizada a cultura de avaliação somativa, centrada no binômio "aprovação" ou "reprovação", nascida de uma cultura de controle. Portanto, não basta constatar simplesmente que a SME-SP tenha orientado sobre a sequência de atividades avaliativas a ser seguida. É preciso ir aos fatos, pois é a prática dos professores que vai mostrar quanto e como essas ações estão realmente ocorrendo. Há, na verdade, a necessidade de se pensar várias etapas de vivências reflexivas e práticas sobre o tema, de maneira a entender efetivamente quais são as referências internalizadas por parte desses POIE sobre o conceito de avaliação que adotam.

Colocadas estas primeiras observações, passo aos detalhes observados, agora considerando os temas e subtemas mencionados no Quadro PPP, definidos para a realização da análise de conteúdo, para poder verificar como esses casos se diferenciam entre si.

\subsubsection{Sobre as Rubricas: quando e como elaborar, e com qual finalidade}

Na busca por um melhor entendimento sobre rubricas enquanto critérios de avaliação, analisei os oito projetos já apresentados, considerando os temas de práticas pedagógicocomunicacionais e de competências educomunicativas, além do momento e do modo como foram aplicados - e seus respectivos subtemas. Apresento aqui o Quadro 14 com o resumo de 
quando e como foram elaboradas. Para uma consulta mais detalhada, as rubricas dos oito projetos encontram-se no Anexo F, com a indicação das referências das análises feitas, com base nesses indicadores.

Quadro 14: Elaboração das Rubricas - quando e como

\begin{tabular}{|c|c|c|c|}
\hline $\begin{array}{l}\text { TÍTULOS DOS } \\
\text { PROJETOS }\end{array}$ & $\begin{array}{l}\text { RESPONSÁVEIS } \\
\text { PELOS } \\
\text { PROJETOS }\end{array}$ & $\begin{array}{l}\text { QUANDO AS RUBRICAS } \\
\text { FORAM ELABORADAS }\end{array}$ & $\begin{array}{c}\text { COMO AS } \\
\text { RUBRICAS FORAM } \\
\text { ELABORADAS }\end{array}$ \\
\hline \multicolumn{4}{|c|}{ PROJETOS GRUPO A } \\
\hline A. Programa POIE 2012 & $\begin{array}{lr}\text { Gestores } & \text { DRE } \\
\text { Campo } & \text { Limpo: } \\
\text { Cristina e Ricardo }\end{array}$ & $\begin{array}{l}\text { Antes do programa, foi } \\
\text { apresentada logo no início }\end{array}$ & $\begin{array}{l}\text { Gestores das DRE e } \\
\text { coordenadoras do } \\
\text { Núcleo de Informática } \\
\text { Educativa (DOT/SME- } \\
\text { SP), sem participação } \\
\text { de POIE. }\end{array}$ \\
\hline $\begin{array}{l}\text { A.1 Sustentabilidade, o } \\
\text { que é isso e qual o meu } \\
\text { papel? }\end{array}$ & POIE Margarete & $\begin{array}{l}\text { Quase no final, um pouco antes } \\
\text { da realização da avaliação } \\
\text { (segundo a POIE, nasceu do } \\
\text { próprio projeto) }\end{array}$ & $\begin{array}{lr}\text { POIE, } & \text { sem } \\
\text { colaboração } & \text { ou } \\
\text { validação dos alunos. }\end{array}$ \\
\hline $\begin{array}{lll}\text { A.2 } & \text { EMEF Paulo } & \text { Patarra } \\
\text { Dando Alguns } & \text { Passos } \\
\text { Rumo a um } & \text { Escola } \\
\text { Sustentável } & & \end{array}$ & POIE Rosemberg & No início & $\begin{array}{lr}\text { Pelo POIE, } & \text { sem } \\
\text { colaboração } & \text { ou } \\
\text { validação dos alunos. }\end{array}$ \\
\hline $\begin{array}{l}\text { A.3 Sustentabilidade no } \\
\text { Zaca }-5 \mathrm{~A}\end{array}$ & POIE Douglas & $\begin{array}{l}\text { Elaborada no início, mas não } \\
\text { foi apresentada aos alunos. }\end{array}$ & $\begin{array}{lr}\text { POIE, gestora da } & \text { DRE } \\
\text { Campo Limpo, outros } \\
\text { POIE, apoiados } & \text { pelo } \\
\text { assessor } & \text { da } \\
\text { DOT/SME-SP, } & \text { sem } \\
\text { colaboração } & \text { ou } \\
\text { validação dos alunos. }\end{array}$ \\
\hline A.4 Sustentabilidade & POIE Nádia & $\begin{array}{l}\text { Quase no final, um pouco antes } \\
\text { da realização da avaliação } \\
\text { (segundo a POIE, nasceu do } \\
\text { próprio projeto) }\end{array}$ & $\begin{array}{lr}\text { Pelo POIE, } & \text { sem } \\
\text { colaboração } & \text { ou } \\
\text { validação dos alunos. }\end{array}$ \\
\hline \multicolumn{4}{|c|}{ PROJETOS GRUPO B } \\
\hline $\begin{array}{l}\text { B.1 Estudando e } \\
\text { Intervindo no Mundo que } \\
\text { nos Cerca }\end{array}$ & POIE Rosemberg & No início & $\begin{array}{lrr}\text { Pelo POIE, } & \text { em } \\
\text { conjunto com } & \text { os } \\
\text { alunos, no início } & \end{array}$ \\
\hline B.2 Curiosos em Ação & POIE Rosemberg & No início & $\begin{array}{l}\text { Pelo POIE, ajustado e } \\
\text { validado com os } \\
\text { alunos. }\end{array}$ \\
\hline B.3 Clube de Astronomia & POIE Maria Helena & No início & $\begin{array}{l}\text { Pelo POIE e POSL, } \\
\text { sem validação com } \\
\text { alunos }\end{array}$ \\
\hline B.4 Jogos do Riva & POIE Gislaine & No meio do projeto & $\begin{array}{l}\text { Por iniciativa e autoria } \\
\text { dos alunos }\end{array}$ \\
\hline
\end{tabular}


Sobre o momento em que foram elaboradas, percebi que, apesar das orientações do Núcleo de Informática Educativa e dos gestores das DRE terem sido para que esse instrumento fosse desenvolvido e apresentado aos alunos logo no início do processo, isso ocorreu apenas em alguns dos projetos do Grupo B, e em nenhum do Grupo A.

Verifiquei que houve projetos em que ele foi elaborado e simplesmente aplicado pelo POIE responsável e outros em que o docente contou com a contribuição parcial (para ajustes e/ou validação) ou total dos alunos envolvidos. As entrevistas revelaram algumas das razões pelas quais essas ações ocorreram dessa forma.

Quando da realização do Programa POIE 2012, tratava-se de algumas primeiras experiências com o uso de rubricas, sendo que vários desses professores optaram por verificar como se daria a dinâmica de aplicação desse instrumento, para entenderem inicialmente como seria a ação de autoavaliação ou avaliação entre pares. Já para os projetos realizados em 2014 (B.1; B.2; B.4), dois deles contavam com educadores com certa experiência tanto com o processo de criação de rubricas quanto com as mediações de processos voltados para o protagonismo das crianças e jovens e o diálogo.

O POIE Rosemberg, por exemplo, em seu projeto sobre sustentabilidade na EMEF Jardim Mitsutani - Paulo Patarra (A.4), aplicou a rubrica que tinha elaborado, mas apenas no final do processo. Já para os projetos B.1 e B.2, que coordenou em 2014, essas ações foram aprimoradas com a participação dos alunos. Seu relato apontou para a dificuldade dessa colaboração, pelo tempo que ela pode demandar, tanto para que os alunos compreendessem as rubricas, como para que eles contribuíssem na elaboração das mesmas.

A rubrica do projeto B.1, por exemplo, foi elaborada conjuntamente com os alunos, e levou cerca de cinco e seis aulas, até ser finalizada. Rosemberg iniciava as práticas e, em momentos da aula, destacava tópicos do processo, refletindo com os alunos sobre eventuais critérios que seriam levados em conta.

Sobre o fato de ter conseguido elaborar a rubrica de um projeto com alunos de 7 a 8 anos, ele informou que fez uso, com as crianças, de uma analogia entre as atividades necessárias para um processo de aprendizagem e o percurso de um ônibus, da casa deles até o shopping. 
Quadro 15: Projeto A.1; B.1; B.2 - Analise de conteúdo / Rosemberg - Rubrica

\begin{tabular}{|c|c|}
\hline FALA DO POIE ROSEMBERG & TEMA + SUBTEMA \\
\hline $\begin{array}{l}\text { Então... no caso dos los e } 2 \text { os, eu levei elas [rubricas] } \\
\text { semiprontas e eu apresentei uma primeira versão, } \\
\text { contando aquela velha estória que estou em } \\
\text { determinado lugar e quero chegar lá no shopping. E } \\
\text { para chegar no shopping, eu passo por alguns pontos } \\
\text { de ônibus. Então, cada parada da rubrica, daquele } \\
\text { texto, mostra parte do caminho que tenho que fazer } \\
\text { para o shopping... se estou mais perto do shopping ou } \\
\text { se estou mais distante do shopping... }\end{array}$ & $\begin{array}{l}\text { Momento de avaliação: durante o processo. } \\
\text { Finalidade principal: apoio à construção do } \\
\text { conhecimento. } \\
\text { Práticas Pedagógico-Comunicacionais: participação } \\
\text { de protagonismo; ações de diálogo (escuta mútua } \\
\text { pensar juntos, apontar outros pontos de vista) } \\
\text { Novas relações entre POIE e alunos. }\end{array}$ \\
\hline $\begin{array}{l}\text { Em tese foi isso... eu fui explicando para eles... e à } \\
\text { medida que eu identificava uma ou outra dificuldade } \\
\text { deles, de entendimento da rubrica, eu fazia uma ou } \\
\text { outra alteração... mas uma ou outra alteração que não } \\
\text { dizia respeito à linguagem em si, pois a linguagem a } \\
\text { gente foi dando um patamar acima... Então, fui } \\
\text { traduzindo mais ou menos o que eles falavam em } \\
\text { uma e outra linguagem, uma linguagem mais } \\
\text { apropriada para eles, mas numa linguagem um pouco } \\
\text { mais avançada para eles... até para não ficar só na } \\
\text { linguagem básica que eles têm... para darmos um } \\
\text { upgrade para eles... feito isso eles entenderam a } \\
\text { lógica de funcionamento da rubrica. E na hora das } \\
\text { avaliações por rubrica, eu e os monitores íamos } \\
\text { explicando cada etapa, de cada critério, para que eles } \\
\text { indicassem como eles estavam. Então por exemplo: } \\
\text { "olha, vocês tiveram que utilizar o programinha para } \\
\text { gravar a voz... então, vamos lá... no critério sobre o } \\
\text { programa de gravar a voz, você acha que você está } \\
\text { assim, assim, assim ou assim?" Então eles iam dando } \\
\text { as opções para as duplas e as duplas iam indicando o } \\
\text { nível onde se encaixavam num determinado critério... }\end{array}$ & $\begin{array}{l}\text { Momento de avaliação: durante o processo. } \\
\text { Finalidade principal: apoio à construção do } \\
\text { conhecimento. } \\
\text { Dinâmica de Encerramento: roda de conversa } \\
\text { (autoavaliação e avaliação entre pares). } \\
\text { Práticas Pedagógico-Comunicacionais: participação } \\
\text { de protagonismo; ações de diálogo (escuta mútua } \\
\text { pensar juntos, apontar outros pontos de vista). } \\
\text { Novas relações entre POIE e alunos. }\end{array}$ \\
\hline
\end{tabular}

A análise desses trechos de fala do Prof. Rosemberg me indicou que ele foi acompanhando, avaliando e intervindo durante o processo de desenvolvimento da aprendizagem e que as ações adotadas se destinavam a dar apoio à construção do conhecimento. Observei que ele adotou práticas que fomentavam vários tipos de participação com foco na vivência do protagonismo pelos alunos, com vários momentos de trocas reflexivas e de pensar juntos entre os alunos. Ou seja, houve a preocupação dele em fazer os alunos ouvirem uns aos outros e de apresentarem novos pontos de vista a partir de outros olhares. Enquanto dinâmica de encerramento, ele adotou a roda de conversa para realização da autoavaliação e avaliação 
entre pares. Finalmente observei como ele passou a estabelecer relações mais horizontalizadas com seus alunos.

A POIE Nádia, do projeto A.4, apontou para outra dificuldade nesse processo:

Quadro 16: Projeto A.4 - Analise de conteúdo / Nádia - autoavaliação dos alunos

\begin{tabular}{|l|l|}
\hline \multicolumn{1}{|c|}{ FALA DA POIE NADIA } & \multicolumn{1}{|c|}{ TEMA + SUBTEMA } \\
\hline $\begin{array}{l}\text { [...] Acho que a gente se considera muito detentor do } \\
\text { saber, onde quero chegar. Para mim era fácil avaliar }\end{array}$ & Novas relações entre POIE e alunos. \\
se eu tinha atingido os objetivos ou não. Eu estava & Práticas Pedagógico-Comunicacionais: ações de \\
visualizando. Então essa era a dificuldade da rubrica, \\
porque a rubrica é uma avaliação que acaba não \\
sendo feita por mim. É uma avaliação feita por eles. \\
$\begin{array}{l}\text { Deles mesmo.... Então, acho que é essa coisa, a gente } \\
\text { sair do conforto de vista). }\end{array}$ \\
\hline
\end{tabular}

Quando questionada sobre esse tema, disse que não havia recebido orientação para apresentar a rubrica para os alunos no início do projeto, e que aplicou a avaliação com esse quadro de critérios apenas no final, para seguir o modelo que vivenciou na formação da DRE Campo Limpo. E mais adiante, na entrevista, reconheceu sua própria dificuldade em aplicar a rubrica formativa com os alunos.

Ao analisar a falar desta POIE, pude perceber que não foi simples para ela esse processo de transformação das relações com seus alunos, de um modelo mais vertical para um mais horizontal. Porém ficou visível que não se tratava de uma resistência dela, mas do seu próprio processo de aprendizagem quanto a esse novo modelo de aula, mais dialógico, participativo, com momentos de se permitiu também ouvir os próprios alunos dialogando entre eles e com ela mesma.

Já a POIE Margarete, do projeto A.1, comentou sobre sua dúvida quanto à eficácia da rubrica, caso esta última seja desenvolvida antes das atividades dos projetos começarem. Alegou que desenvolver uma rubrica no início para projetos com base em protagonismo pode não contemplar todos os critérios necessários, ou pode contemplar indicadores desnecessários, pois muitas coisas novas podem surgir durante o processo. Disse preferir elaborar a rubrica durante o processo, a partir de verificações com os alunos, para então apresentá-la completa ao final, para os alunos fazerem suas autoavaliações. 
Por outro lado, ela comentou que a estrutura em si desse instrumento já ia surgindo à medida que as atividades dos alunos iam se desenvolvendo. É a isso que me refiro quando menciono que a aplicação também depende do estilo do professor que está coordenando e mediando o processo.

Quadro 17: Projeto A.1 - Analise de conteúdo / Margarete - indicadores e níveis da rubrica

\begin{tabular}{|l|l|}
\hline \multicolumn{1}{|c|}{ FALA DA POIE MARGARETE } & \multicolumn{1}{c|}{ TEMA + SUBTEMA } \\
\hline $\begin{array}{l}\text { Essa rubrica a gente desenvolveu não com eles, } \\
\text { sentando com eles... e fazendo..., mas observando o } \\
\text { andar do trabalho... as respostas que eles davam nas } \\
\text { perguntas... então, não foi desenvolvida uma rubrica } \\
\text { de avaliação do trabalho... não... acho que por causa } \\
\text { da dinâmica da aula, eu não consigo sentar comos. }\end{array}$ & diálogo (escuta mútua pensar juntos, apontar outros \\
alunos para eles fazerem uma rubrica, para que eles \\
pudessem realmente entender o que é uma rubrica...
\end{tabular}

Ainda sobre a POIE Margarete, observamos que ela também foi aos poucos desenvolvendo uma relação mais horizontal com seus alunos à medida que vivenciava as trocas dialógicas com participações com foco na vivência do protagonismo. Ela narra ainda outro aspecto importante que é a reflexão dela a partir da descoberta das várias competências passíveis de serem trabalhadas durante o processo de participação dialógica dos alunos com ênfase no protagonismo.

O POIE Douglas (A.3) optou por desenvolver a rubrica do projeto dele com a professora Cristina Barroco, e com o apoio do então assessor do Núcleo de Informática Educativa, o Prof. Dr. Cesar A. A. Nunes. Ele a classificou como uma rubrica muito simples, básica mesmo, pois queria verificar como os alunos reagiriam a esse novo instrumento e prática. $\mathrm{O}$ conjunto dos indicadores de avaliação foi apresentado a eles no início da atividade. 
Tabela 01: Projeto A.3 / POIE Douglas - Respostas questionário ${ }^{111}$

\begin{tabular}{|c|c|c|}
\hline OPÇÕES DE RESPOSTA & $\mathbf{N}^{\mathbf{0}}$ & $\%$ \\
\hline Não mudou nada, pois no final quem definiu mesmo os critérios foi o professor & 3 & $9.7 \%$ \\
\hline Foi legal, porque eu pude aprender como o professor avalia uma atividade nossa. & 6 & $19.4 \%$ \\
\hline $\begin{array}{l}\text { Foi legal porque eu pude perceber de que forma eu posso melhorar meu } \\
\text { desempenho. }\end{array}$ & 12 & $38.7 \%$ \\
\hline $\begin{array}{l}\text { Foi muito legal porque eu pude refletir com o professor e dar minha opinião sobre } \\
\text { como eu acho que um projeto deve ser desenvolvido. }\end{array}$ & 3 & $9.7 \%$ \\
\hline $\begin{array}{l}\text { Foi super legal, porque me dei conta de que dependendo da forma coo eu me dedico } \\
\text { no projeto, eu aprendo muito mais. }\end{array}$ & 7 & $22.5 \%$ \\
\hline
\end{tabular}

Tabela 02: Projeto A.3 / POIE Douglas - Respostas questionário

\begin{tabular}{|c|c|c|}
\hline OPÇÕES DE RESPOSTA & $\mathbf{N}^{\mathbf{0}}$ & $\%$ \\
\hline $\begin{array}{l}\text { não me ajudaram em nada, pois continuei agindo da mesma forma que agia sem } \\
\text { essa informação e continuei com pouco interesse na aula de informática educativa. }\end{array}$ & 1 & $4.2 \$$ \\
\hline $\begin{array}{l}\text { não me ajudaram em nada, pois continuei agindo da mesma forma que agia sem } \\
\text { essa informação, até porque sempre fui interessado e tive um boa participação na } \\
\text { aula. }\end{array}$ & 2 & $8.4 \%$ \\
\hline $\begin{array}{l}\text { me orientaram melhor sobre como deveria desenvolver a atividade (as etapas de } \\
\text { desenvolvimento da atividade ficaram mais claras). }\end{array}$ & 11 & $45.8 \%$ \\
\hline $\begin{array}{l}\text { me ajudaram a melhorar minha colaboração com meus colegas no projeto (eu não } \\
\text { sabia como poderia contribuir, mas os critérios me esclareceram como deveria } \\
\text { fazer isso). }\end{array}$ & 5 & $20.8 \%$ \\
\hline me ajudaram a pensar melhor sobre o conteúdo em estudo. & 4 & $16.8 \%$ \\
\hline não alteraram nada na forma como aprendo um conteúdo em sala. & 1 & $4.2 \%$ \\
\hline
\end{tabular}

Para esse questionário, eu apresentei propositadamente perguntas similares, em momentos diferentes, sobre o conhecimento da rubrica de avaliação, sendo que observei que conhecer esses indicadores auxiliou a maioria dos participantes quanto à forma de participar, inclusive em relação às práticas de colaboração com seus colegas e à aprendizagem sobre os temas tratados no projeto (sustentabilidade e uso de TIC).

As respostas dessa turma me lembraram das colocações de Hart (1992) e Costa (2006), sobre termos que deixar claro para as crianças e jovens o tipo de participação que esperamos deles,

${ }^{111}$ Esclarecemos que o referido questionário, cujas perguntas e respostas completas encontram-se disponíveis no ANEXO D, foi respondido por um total de 16 alunos. Porém para algumas das perguntas obtivemos mais respostas, pois pedimos que eles marcassem todos os tópicos que refletiam suas práticas (ou seja, poderiam marcar mais de uma das opções). 
para que consigamos atingir os objetivos de aprendizagem traçados para um projeto, quaisquer que sejam eles.

Sobre os casos do Grupo B, observei algo diferente do que foi constatado nos projetos do Grupo A. Como já comentei brevemente, no projeto B.1, desenvolvido com os alunos dos 7os anos, sob a facilitação do POIE Rosemberg, nos questionários de perguntas estruturadas, os alunos ${ }^{112}$ apontaram que ficaram sabendo dos critérios no início da prática e que gostaram disso, principalmente pelas seguintes razões:

Tabela 03: Projeto B.1 / POIE Rosemberg - Respostas questionário OPCCÕES DE RESPOSTA

Não mudou nada, pois no final quem definiu mesmo os critérios foi o professor

Foi legal, porque eu pude aprender como o professor avalia uma atividade nossa. Foi legal porque eu pude perceber de que forma eu posso melhorar meu desempenho.

\begin{tabular}{|l|l|l|l|l|l|l|}
\hline Foi muito legal porque eu pude refletir com o professor e dar minha opinião sobre & 4 & 17.4
\end{tabular} como eu acho que um projeto deve ser desenvolvido.

Foi super legal, porque eu me dei conta que dependendo da forma como eu me dedico no projeto, eu aprendo muito mais.

Tabela 04: Projeto B.1 / POIE Rosemberg - Respostas questionário

\begin{tabular}{|c|c|c|}
\hline OPÇÕES DE RESPOSTA & $\mathbf{N}^{\mathbf{0}}$ & $\%$ \\
\hline $\begin{array}{l}\text { não me ajudaram em nada, pois continuei agindo da mesma forma que agia sem } \\
\text { essa informação e continuei com pouco interesse na aula de informática educativa. }\end{array}$ & 3 & $12 \%$ \\
\hline $\begin{array}{l}\text { não me ajudaram em nada, pois continuei agindo da mesma forma que agia sem } \\
\text { essa informação, até porque sempre fui interessado e tive uma boa participação na } \\
\text { aula. }\end{array}$ & 2 & $8 \%$ \\
\hline $\begin{array}{l}\text { me orientaram melhor sobre como deveria desenvolver a atividade (as etapas de } \\
\text { desenvolvimento da atividade ficaram mais claras). }\end{array}$ & 9 & $36 \%$ \\
\hline $\begin{array}{l}\text { me ajudaram a melhorar minha colaboração com meus colegas no projeto (eu não } \\
\text { sabia como poderia contribuir, mas os critérios me esclareceram como deveria } \\
\text { fazer isso). }\end{array}$ & 6 & $24 \%$ \\
\hline me ajudaram a pensar melhor sobre o conteúdo em estudo. & 3 & $12 \%$ \\
\hline não alteraram nada na forma como aprendo um conteúdo em sala. & 2 & $8 \%$ \\
\hline
\end{tabular}

À medida que esse docente foi aplicando a rubrica, em vários outros projetos, percebeu a importância da forma como a comunicação tem que ser trabalhada para que a linguagem utilizada seja a adequada para o público com o qual quero dialogar, com o qual quero me comunicar. O próprio relato dos alunos aponta para a questão dos processos comunicacionais nesses espaços educacionais, e da necessidade de trocas reflexivas serem mais bem estruturadas. Ao conhecerem mais claramente o que era esperado deles, eles passaram a se

${ }^{112}$ Esclarecemos que o referido questionário, cujas perguntas e respostas completas encontram-se disponíveis no ANEXO D, foi respondido por um total de 17 alunos. Porém para algumas das perguntas obtivemos mais respostas, pois pedimos que eles marcassem todos os tópicos que refletiam suas práticas (ou seja, poderiam marcar mais de uma das opções). 
dedicar mais às etapas do projeto, inclusive sobre como podiam e deviam colaborar com os colegas.

Após a formação em 2012, o POIE Rosemberg desenvolveu vários projetos, procurando adotar o uso da rubrica na maioria deles, que lhe permitiu compreender melhor o seu uso e verificar quais a melhores opções de viabilização dessa utilização. Ele procura sempre apresentar a rubrica no início do processo para validação desse instrumento, independentemente do projeto e do público.

Para viabilizar esse contexto, Rosemberg elabora uma estrutura prévia, com base nas competências que pretende trabalhar com os alunos, para, então, apresentá-la para os alunos conhecerem, comentarem, ajustarem e validarem. Ao apresentar algo minimamente elaborado, o especialista conta que o processo se torna mais rápido e não menos enriquecedor, do ponto de vista de contribuições dos alunos e validação final.

Isso permitiu também que os próprios alunos entendessem mais claramente a função da rubrica. De fato, o POIE adotou essa prática para esse caso com os alunos dos $2^{\circ} \mathrm{s}$ anos, que foi bem enriquecedora para todos. E ao final, todos foram capazes de se autoavaliar, junto com seus pares, o que resultou em um processo reflexivo rico, sobre como realizar pesquisas na internet.

Para esse projeto, o POIE e seus alunos monitores chamavam os trios, e pediam para que se autoavaliassem. Como tinham desenvolvido o projeto conjuntamente, um aluno acabava corrigindo o outro, caso houvesse alguma avaliação que não refletia a realidade ocorrida durante as atividades. Isso gerou nova reflexão entre os próprios pares, para reconhecimento de suas limitações e superações. Aqui observei a importância da atividade de encerramento denominada roda de conversa que, por sua vez, se estrutura em práticas pedagógicocomunicacionais de tipos de protagonismo e diálogo. Pude observar uma proximidade cada vez maior, então, da Educomunicação com a proposta de avaliação formativa.

Já no projeto B.3, do Clube da Astronomia, realizado em 2012, a POIE Maria Helena relatou o que segue: 
Quadro 18: Projeto B.3 - Análise de Conteúdo / Maria Helena - Níveis de Rubrica

\begin{tabular}{|l|l|}
\hline \multicolumn{1}{|c|}{ FALA DA POIE MARIA HELENA } & \multicolumn{1}{|c|}{ TEMA + SUBTEMA } \\
\hline $\begin{array}{l}\text { As rubricas foram elaboradas pelos professores. Numa } \\
\text { continuidade do projeto, imaginávamos aperfeiçoá-las } \\
\text { com a ajuda dos alunos. Como o projeto não teve } \\
\text { continuidade, não tivemos essa oportunidade. }\end{array}$ & Novas relações entre POIE e alunos. \\
\hline $\begin{array}{l}\text { Acredito que o maior desafio em utilizar as rubricas, } \\
\text { seja na reflexão entre uma avaliação e outra. O aluno ter } \\
\text { que refletir onde ele deve melhorar, o que ele deixou de } \\
\text { fazer para não avançar um nível. Como esse tipo de } \\
\text { avaliação nunca haves entre POIE e alunos. } \\
\text { simplificamos a rubrica utilizadica feita com eles, nós } \\
\text { habituasse com esse tipo de reflexão. }\end{array}$ & reflexivo e compartilhado. \\
\hline
\end{tabular}

Ao analisar a fala da POIE Maria Helena, pude observar que a princípio não havia resistência ou dificuldade quanto à implementação de dinâmicas de trocas reflexivas dialógicas, com momentos de escuta e apresentação de ideias e soluções por parte dos alunos, o que resultava na vivência de novas relações entre a POIE e seus alunos. Dada a novidade da rubrica, ela optou por fazer a implementação da mesma com os alunos até para conhecer melhor o instrumento que passava a adotar. Pareceu um misto de cautela com curiosidade, mas a mesma se mostrou hábil e tranquila com a adoção de práticas com características educomunicativas.

Em seu depoimento, ela destaca exatamente a necessidade de etapas de adaptação com essa nova proposta de avaliação, explicando que optaram por fazer essa abordagem em um primeiro momento, para que os jovens se familiarizassem com o instrumento, sendo que estava prevista a solicitação de contribuições deles nas rubricas, para os próximos projetos.

Ao contrário do ocorrido nos demais casos, durante a entrevista sobre o Jogos do Riva, a POIE Gislaine reconheceu que fugiu totalmente às orientações da gestora da DRE São Mateus, a professora Regina Gavassa, e do Núcleo de Informática Educativa, da DOT/SME-SP, sendo que ela em si, não realizou a autoavaliação com base na rubrica dos gestores de DRE.

E foram os próprios alunos, durante o processo de trocas de ideias para a criação e desenvolvimento dos joguinhos para alfabetização, que sentiram falta de uma ferramenta que os auxiliasse no acompanhamento da participação e comprometimento deles, da construção do conhecimento do grupo, e sobre como poderiam melhorar, que os fez questionarem sobre uma possibilidade de avaliação que os amparasse nesse processo. 
Nesse momento, a POIE Gislaine sugeriu a elaboração e aplicação da rubrica, sendo que a ela coube orientar sobre como estruturar a rubrica. A definição dos critérios e descrição detalhada dos níveis dos mesmos foi feita pelos próprios alunos. E então eles faziam paradas estratégicas, momentos de trocas para fazerem as verificações a partir da mesma.

Daí considerar este caso como um dos principais exemplos sobre como a rubrica de fato norteia a construção do conhecimento e que, uma vez que a proposta é entendida por todos, os alunos conseguem desenvolvê-las e aplicá-las, sem tendências a se supervalorizarem ou subvalorizarem. Esse exemplo mostra o papel de apoio ao resgate do aluno com dificuldades, quando ele se perde no processo, para retomar o ritmo de construção do conhecimento. Mais do que isso, aponta fortes possibilidades de aproximação com a Educomunicação, sendo que aqui pude verificar todos os temas e subtemas apontados no Quadro 12.

Ou seja, a partir do descritivo da fala da POIE Gislaine eu pude identificar que o projeto teve como finalidade principal o empoderamento do aluno, o apoio à construção do conhecimento, o acompanhamento do desenvolvimento de competências específicas / educomunicativas, e a leitura crítica dos meios. O momento de avaliação ocorreu durante o processo e a dinâmica de encerramento de atividades era a roda de conversa. Dentre as práticas pedagógicocomunicacionais, observamos que houve uma gestão da comunicação mais elaborada, a partir de ações comunicativas específicas, apropriação e manejo das linguagens da comunicação uso dos recursos da informação para a produção cultural e leitura crítica dos meios. Além das ações de diálogo, pude confirmar ainda que a participação dos alunos variou entre plenamente autônoma e condutora. Finalmente, observei que praticamente todas as competências ditas educomunicativas foram trabalhadas em diferentes momentos, com maior ou menor foco. Porém foram trabalhadas. Exemplo:

De fato, ao serem questionadas sobre o que acharam de elaborar os critérios pelos quais seriam avaliadas, duas das alunas monitoras (total foi de quatro a cinco alunos, dependendo da época do projeto) da POIE Gislaine, que responderam ao questionário estruturado, declararam que foi muito bom, porque permitiu a participação delas nessa definição (ativamente participante) e elas se deram conta sobre como a aprendizagem delas está ligada à dedicação às atividades. Novamente, esse processo ajudou também para que compreendessem mais claramente como realizar as atividades do projeto.

Destaco ainda que a POIE Gislaine já adotava uma postura de facilitadora, fomentadora de práticas protagonistas e dialógicas em seu projeto, ao acompanhar as trocas reflexivas entre 
seus alunos monitores e intervir apenas como orientadora e estimuladora das trocas reflexivas, sem impor suas opiniões, com uma postura clara de educomunicadora. Ela mesma reconheceu durante a entrevista que esse processo foi se desenvolvendo durante suas práticas e seu entendimento sobre como deve ser uma prática de aprendizagem.

Sobre o desenvolvimento da rubrica, para ela, que já tinha experiência em práticas dialógicas e protagonistas, a adoção dessa ferramenta de avaliação não foi difícil, posto que já a havia utilizado quando desenvolvia projetos com WebQuest ${ }^{113}$, que utiliza as rubricas formativas.

Esses relatos confirmaram o que Soares (1999), Baccega (2011) e Citelli (2011) apontam, sobre a necessidade de as práticas nos espaços educativos passarem a refletir os novos ambientes comunicacionais da sociedade altamente tecnológica em que vivemos, sendo que os relatos apresentados confirmam que essas vivências são demandadas já da própria elaboração da rubrica. Trata-se de um processo que demanda muitas trocas entre os envolvidos, que resultem em reflexões até sobre referências internas dos mesmos, o que nos remete à criação do que Soares (1999) chama de ecossistemas comunicativos.

Aqui confirmei que a rubrica não se resume a um instrumento de avaliação formativa, e que a assimilação da sua proposta demanda a modificação das relações de controle e poder dentro desses espaços educativos. Mais do que isso, dados os pontos de aproximação que fui identificando, observei que a rubrica pode se caracterizar como um instrumento de acompanhamento e viabilização das próprias práticas pedagógico-comunicacionais de projetos com abordagem educomunicativa.

A própria estrutura da formação e autoavaliação do Programa POIE 2012 já aponta para essa preocupação em planejar e realizar processos de vivências reflexivas conjuntas, algo que converge com as próprias colocações de Soares (2011) e Citelli (2011), ao indicar a necessidade de mudanças nas formações dos professores desses espaços multimidiáticos, que viabilizem, inclusive, modificações nas próprias relações deles com seus alunos.

\footnotetext{
${ }^{113}$ WebQuest: conceito criado por Bernie Dodge, professor estadual da Califórnia (EUA), em 1995, é uma atividade investigativa em que as informações com as quais os alunos interagem provêm da internet. Fonte: http://www.fe.unb.br/catedraunescoead/areas/multimedia/objetos-de-aprendizagem/webquest/portal-educacionaldas-webquests
} 


\subsubsection{Autoavaliação, com base nos conteúdos das rubricas}

A rubrica consiste no detalhamento dos critérios utilizados para um processo de avaliação formativa, sendo que sua estrutura está dividida em quatro níveis de descritivos, que contêm ações das mais simples - nível confortável - até as mais reflexivas e dialógicas - nível avançado.

Anteriormente eu esclareci que o processo de desenvolvimento desse instrumento de avaliação já reflete o planejamento de práticas pedagógico-comunicacionais, uma vez que a sua elaboração implica na identificação de todas as ações necessárias ao desenvolvimento do indicador, competência ou critério ao qual se refere. Para a sua construção, faz-se necessário listar a dinâmicas passíveis de serem desenvolvidas em um projeto qualquer, para posterior distribuição das mesmas nos quatro níveis de forma cumulativa (ex.: o nível quatro apresenta todas as ações dos níveis anteriores e mais algumas). Quando esse instrumento é desenvolvido com outros professores ou mesmo com a participação dos próprios alunos, isso permite a reflexão sobre a importância de cada uma das atividades ali enumeradas, para a construção daquelas competências ou critérios que queremos trabalhar. Isso viabiliza a revisão das próprias relações interpessoais passíveis de ocorrerem durante o processo.

No Anexo B, encontrei um exemplo sobre a organicidade e dinamismo das mesmas. A rubrica 1 é o instrumento final das trocas reflexivas entre os gestores, finalizada em 2012, na formação do Núcleo de Informática Educativa. A primeira versão dela, também elaborada pelos POIE, é a $\mathrm{N}^{\circ}$ 2, que consta também desse Anexo B. E a Rubrica 3 é uma versão atualizada das duas anteriores, mas essa foi elaborada pela gestora da DRE Campo Limpo, professora Cristina Barroco, com seus POIE, em 2014, quando julgaram conjuntamente que já estavam prontos para dar um passo adiante nas práticas dos LIE.

Para ilustrar o procedimento de minha análise de conteúdo dessas rubricas, elaborei o Quadro 19, com base em um dos critérios retirado da Rubrica 1, Anexo B, do Programa POIE 2012, elaborada para a autoavaliação desse profissional. Essa versão considera os seguintes critérios: colaboração com tecnologia; atividade com tecnologia; promove a construção do conhecimento; avaliação formativa. No exemplo aqui destacado, a cada nível, observei uma maior diversificação das ações e das relações entre os participantes desses processos, inclusive do POIE com os alunos. 
Quadro 19: Análise de conteúdo de um dos critérios da rubrica do Programa POIE 2012

\begin{tabular}{|c|c|c|c|c|}
\hline Item & Confortável & Estável & Moderado & Avançado \\
\hline $\begin{array}{l}\begin{array}{l}\text { 3. Promove } \\
\text { construção } \\
\text { conhecimento }\end{array} \\
\\
\text { do } \\
\text { (PLANEJAMENTO } \\
\text { DE AÇÕES } \\
\text { PEDAGÓGICO } \\
\text { COMUNICACIONAIS } \\
\text { DE } \\
\text { PROTAGONISMO } \\
\text { DE PARTICIPAÇÃO } \\
\text { OPERACIONAL, } \\
\text { DIÁLOGO E } \\
\text { GESTÃO } \\
\text { COMPARTILHADA } \\
\text { DA COMUNICAÇÃO) }\end{array}$ & $\begin{array}{l}\text { Propõe atividades } \\
\text { de } \\
\text { individual ou em } \\
\text { grupo } \\
\text { ambiente virtual, } \\
\text { mas o aluno não } \\
\text { consegue sair do } \\
\text { nível da } 1^{\text {a }} \text { ideia. }\end{array}$ & $\begin{array}{l}\text { Propõe atividade } \\
\text { de pesquisa e de } \\
\text { compartilhamento } \\
\text { de ideias para } \\
\text { ampliação } \\
\text { repertório } \\
\text { relacionada à } 1^{\text {a }} \\
\text { ideia do aluno; } \\
\text { estimula o grupo a } \\
\text { comentar, debater, } \\
\text { avaliar, criticar } \\
\text { para a melhoria de } \\
\text { ideia, por meio de } \\
\text { chat, fórum, blog, } \\
\text { wiki e outros } \\
\text { recursos; }\end{array}$ & $\begin{array}{l}\text { Propõe a produção } \\
\text { coletiva } \\
\text { colaborativa } \\
\text { partindo antes das } \\
\text { ideias } \\
\text { posicionamentos } \\
\text { individuais dos } \\
\text { alunos; } \\
\text { compartilha as } \\
\text { produções; } \\
\text { estimula o grupo a } \\
\text { comentar, debater, } \\
\text { avaliar, criticar } \\
\text { para a melhoria } \\
\text { das produções. }\end{array}$ & $\begin{array}{l}\text { Propõe a produção } \\
\text { coletiva } \\
\text { colaborativa } \\
\text { partindo antes das } \\
\text { ideias } \\
\text { posicionamentos } \\
\text { individuais dos } \\
\text { alunos; incorpora } \\
\text { o uso das TIC para } \\
\text { otimizar o tempo } \\
\text { de cada aula e } \\
\text { atividade para que } \\
\text { o aluno possa } \\
\text { lançar mão de } \\
\text { recursos, } \\
\text { ferramentas, sites, } \\
\text { redes sociais para } \\
\text { resolver } \\
\text { problemas, expor } \\
\text { ideias, } \\
\text { contextualizar, } \\
\text { ampliar, criticar } \\
\text { ideias, buscar e } \\
\text { propor soluções de } \\
\text { problemas com } \\
\text { autonomia. }\end{array}$ \\
\hline
\end{tabular}

$\mathrm{Eu}$ verifiquei que até mesmo a escolha dos nomes dos níveis deve ser estratégica. Wiliam (2011) fala da importância de atribuirmos títulos que promovam algum tipo de estímulo ao aluno, para se dedicarem mais durante o processo de aprendizagem. E esse efeito pode ser percebido no relato da professora Cristina Barroco, quando ela comentou sobre as entrevistas pessoais que teve com seus POIE, para reflexão sobre suas respectivas autoavaliações.

Ela destacou o incômodo de alguns dos POIE de serem classificados como estando no nível confortável, pois eles temiam passar a impressão de estarem acomodados, o que não seria bom para um professor, cuja responsabilidade é a promoção da curiosidade de seus alunos, dentre outras. Em sua entrevista, a gestora comentou sobre a influência dos nomes dos níveis no desempenho dos participantes, também com o caso de uma turma de alunos de $2^{\circ}$ ano, que precisavam de uma rubrica simples, para que começassem a vivenciar esse processo reflexivo 
sobre a relação entre a dedicação às práticas das atividades de LIE e a aprendizagem deles. À época do projeto, havia um desenho animado japonês famoso entre as crianças, sobre ninjas Naruto -, sendo que as crianças adoravam brincar que eram ninjas, mestres e aprendizes.

Então, quando foi solicitada a auxiliar o POIE responsável pelo referido projeto, ela sugeriu que os nomes dos níveis fossem nomes dos papéis desse desenho (1. Estudante; 2. Ninja 3. Treinador de Ninja; 4. Mestre). E como o nível 4 era o mais alto, um dos aspectos contidos no descritivo desse nível era que ele deveria auxiliar seus colegas no esclarecimento de dúvidas sobre as atividades. Isso resultou que as crianças terminavam suas partes e saíam perguntando se alguém precisava de ajuda, pois queriam ser o grande mestre. Então passavam a vivenciar o papel de professor. No momento da autoavaliação, essa foi uma reflexão feita com as crianças sobre como se sentiram ensinando ao colega. Essa é a rubrica 5, do Anexo B.

Ainda sobre o uso da rubrica, o quadro da Figura 16, retirado do relatório final sobre as autoavaliações feitas pelos POIE ${ }^{114}$, que foram analisadas conjunta e reflexivamente com os gestores, em dois momentos da referida formação, nos aponta alguns dados importantes. $\mathrm{Na}$ primeira autoavaliação (setembro/2012), foram identificadas algumas distorções entre o que estava registrado no AVA e como o responsável havia se autoavaliado. Porém, após o processo reflexivo com os gestores responsáveis pelo referido programa, alguns deles fizeram ajustes em seus projetos e/ou nos níveis de sua segunda autoavaliação (novembro/2012). Os resultados finais indicaram uma redução de avaliação nos níveis moderado e avançado, para um aumento do nível estável e até do confortável.

Quadro 20: Programa POIE 2012 - Análise das Autoavaliações dos POIE e Gestores

\begin{tabular}{|c|c|c|c|c|c|c|c|c|c|c|c|c|c|c|c|c|c|}
\hline \multirow[b]{2}{*}{$\begin{array}{c}\text { Síntese } \\
\text { DRE } \\
\text { Campo } \\
\text { Limpo }\end{array}$} & \multirow[b]{2}{*}{$\begin{array}{c}\text { Ponto } \\
\text { de } \\
\text { Vista }\end{array}$} & \multicolumn{8}{|c|}{ AVALIAÇÃO SETEMBRO } & \multicolumn{8}{|c|}{ AVALIAÇÃO NOVEMBRO } \\
\hline & & \multicolumn{2}{|c|}{ 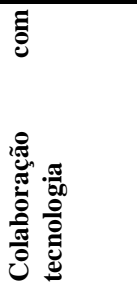 } & \multicolumn{2}{|c|}{ 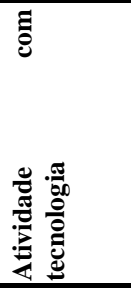 } & \multicolumn{2}{|c|}{ 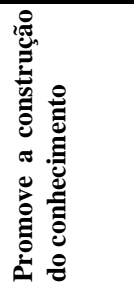 } & \multicolumn{2}{|c|}{ 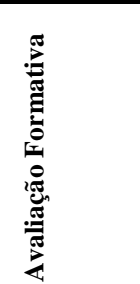 } & \multicolumn{2}{|c|}{ 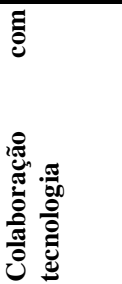 } & \multicolumn{2}{|c|}{ 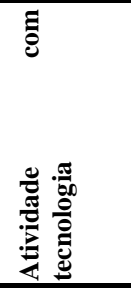 } & \multicolumn{2}{|c|}{ 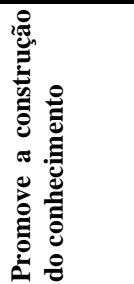 } & \multicolumn{2}{|l|}{ 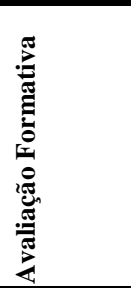 } \\
\hline \multirow{5}{*}{$\begin{array}{l}\text { Percentu } \\
\text { al de } \\
\text { indicaçãa } \\
\text { o dos } \\
\text { níveis da } \\
\text { rubrica } \\
\text { de } \\
\text { avaliaçã }\end{array}$} & \multirow{4}{*}{ POIE } & $\overline{\mathrm{C}}$ & $13 \%$ & $\overline{\mathrm{C}}$ & $5 \%$ & $\overline{\mathrm{C}}$ & $12 \%$ & $\overline{\mathbf{C}}$ & $16 \%$ & $\bar{C}$ & $16 \%$ & $\bar{C}$ & $14 \%$ & $\bar{C}$ & $23 \%$ & $\bar{C}$ & $25 \%$ \\
\hline & & $\mathbf{E}$ & $54 \%$ & $\mathbf{E}$ & $69 \%$ & $\mathbf{E}$ & $49 \%$ & E & $74 \%$ & $\mathbf{E}$ & $62 \%$ & $\mathbf{E}$ & $73 \%$ & $\mathbf{E}$ & $55 \%$ & $\mathbf{E}$ & $64 \%$ \\
\hline & & $\mathbf{M}$ & $30 \%$ & M & $21 \%$ & $\mathbf{M}$ & $29 \%$ & $N$ & $8 \%$ & $\mathbf{M}$ & $20 \%$ & M & $11 \%$ & $\mathbf{M}$ & $19 \%$ & $\mathbf{M}$ & $9 \%$ \\
\hline & & $\mathbf{A}$ & $3 \%$ & $\mathbf{A}$ & $5 \%$ & $\mathbf{A}$ & $10 \%$ & A & $2 \%$ & $\mathbf{A}$ & $2 \%$ & $\mathbf{A}$ & $2 \%$ & $\mathbf{A}$ & $3 \%$ & $\mathbf{A}$ & $2 \%$ \\
\hline & $\begin{array}{c}\text { TOTA } \\
\text { L }\end{array}$ & - & $\begin{array}{c}100 \\
\%\end{array}$ & - & $\begin{array}{c}100 \\
\%\end{array}$ & - & $\begin{array}{c}100 \\
\%\end{array}$ & - & $\begin{array}{c}100 \\
\%\end{array}$ & & $\begin{array}{c}100 \\
\%\end{array}$ & & $\begin{array}{c}100 \\
\%\end{array}$ & & $\begin{array}{c}100 \\
\%\end{array}$ & & $\begin{array}{c}100 \\
\%\end{array}$ \\
\hline
\end{tabular}

${ }^{114}$ Relatório final elaborada pela gestora Cristina Barroco, da DRE Campo Limpo. 


\begin{tabular}{|c|c|c|c|c|c|c|c|c|c|c|c|c|c|c|c|c|c|}
\hline o & & & & & & & & & & & & & & & & & \\
\hline \multirow{5}{*}{$\begin{array}{c}\text { Percentu } \\
\text { al de } \\
\text { indicaçã } \\
\text { o dos } \\
\text { níveis da } \\
\text { rubrica } \\
\text { de } \\
\text { avaliaçã } \\
\text { o }\end{array}$} & \multirow{4}{*}{ DRE } & C & $36 \%$ & C & $24 \%$ & C & $47 \%$ & C & $37 \%$ & C & $24 \%$ & C & $28 \%$ & C & $30 \%$ & C & $32 \%$ \\
\hline & & $\mathbf{E}$ & $57 \%$ & $\mathbf{E}$ & $75 \%$ & $\mathbf{E}$ & $51 \%$ & $\mathbf{E}$ & $62 \%$ & $\mathbf{E}$ & $61 \%$ & $\mathbf{E}$ & $70 \%$ & $\mathbf{E}$ & $63 \%$ & $\mathbf{E}$ & $66 \%$ \\
\hline & & M & $6 \%$ & M & $0 \%$ & M & $1 \%$ & M & $1 \%$ & M & $14 \%$ & M & $1 \%$ & M & $6 \%$ & M & $2 \%$ \\
\hline & & $\mathbf{A}$ & $1 \%$ & $\mathbf{A}$ & $1 \%$ & A & $1 \%$ & $\mathbf{A}$ & $0 \%$ & A & $1 \%$ & $\mathbf{A}$ & $1 \%$ & A & $1 \%$ & $\mathbf{A}$ & 0 \\
\hline & $\begin{array}{c}\text { TOTA } \\
\text { L }\end{array}$ & - & $\begin{array}{c}100 \\
\%\end{array}$ & - & $\begin{array}{c}100 \\
\%\end{array}$ & - & $\begin{array}{c}100 \\
\%\end{array}$ & - & $\begin{array}{c}100 \\
\%\end{array}$ & & $\begin{array}{c}100 \\
\%\end{array}$ & & $\begin{array}{c}100 \\
\%\end{array}$ & & $\begin{array}{c}100 \\
\%\end{array}$ & & $\begin{array}{c}100 \\
\%\end{array}$ \\
\hline
\end{tabular}

Fonte: Relatório Final DRE Campo Limpo (Anexo C)

Trata-se do que a Cristina Barroco comentou sobre o fato de que, ao refletirem com ela sobre as próprias práticas, alguns confirmaram que estavam fazendo exatamente o que haviam apontado em suas autoavaliações e, para esses casos, principalmente dos "confortáveis", por exemplo, ela já focava o rumo da reflexão para a conscientização dos mesmos sobre como poderiam fazer mais (os resultados de autoavaliação individual constam do Anexo C) e o que isso significava em termos concretos, com base no descritivo dos níveis subsequentes da rubrica. Aqui observei claramente a função de promover a reflexão sobre aquele critério, para mudar e melhorar a prática. A clareza e detalhamento promove a constatação que nem sempre o que pensamos que desenvolvemos foi o que ocorreu de fato.

A estrutura comunicacional do Programa POIE 2012 e seu processo de autoavaliação converge exatamente para a realização da roda de conversa, ao final do processo, para uma reflexão conjunta sobre todo o processo, de maneira a revisarmos e entendermos todo o conhecimento adquirido ou não durante um processo de aprendizagem, o que se caracteriza como mais um ponto de aproximação entre Educomunicação e a abordagem de avaliação formativa.

De fato, esses momentos me remeteram às práticas de rodas de conversa da avaliação dialógica, apresentadas no Capítulo Dois, e mesmo às atividades de pelo menos dois projetos do NCE (ECA/USP): Educom.Rádio, para a SME-SP, de 2001 a 2004; Educom.Jt, de 2006 a 2008, em parceria com o Jornal da Tarde, do Grupo O Estado de S. Paulo. Aliás que essas rodas de conversa são algumas das ações que transformam a atividade que poderia ser meramente instrumental, de uso de rádio ${ }^{115}$, para todo um processo de gestão da comunicação para trabalhar a leitura crítica dos meios com os alunos, por exemplo. Então, em que pese que não houvesse critérios claramente definidos e estruturados em rubricas, como dessa abordagem de avaliação formativa, a proposta de reflexão conjunta, ao final do projeto, sobre o processo de construção da aprendizagem, já existe nas premissas da Educomunicação. E 
ambas convergem também quanto ao momento de sua aplicação, pois ela permite o acompanhamento durante todo o processo de desenvolvimento dos projetos, até culminar com as autoavaliações finais.

Quanto aos que haviam se superavaliado ou subavaliado, houve um processo reflexivo de revisão das práticas realizadas nos LIE e registradas nas áreas dos respectivos projetos, no ThinkQuest, para que entendessem que não estavam realizando de fato, tudo o que imaginavam e/ou desejavam. E isso resultou em ajustes em algumas das práticas e respectivas autoavaliações.

Além disso, no Anexo F, apresentei as rubricas utilizadas por cada um dos oito projetos estudados, para ilustrar a riqueza que pode ser trabalhada com essa ferramenta de avaliação. Meu objetivo foi de analisar seus conteúdos, com base agora a partir dos temas práticas pedagógico-comunicacionais e de competências educomunicativas, para que pudesse identificar quais as práticas e competências previstas para serem trabalhadas nesses projetos, e se essas tinham aproximação com a Educomunicação, o que me indicaria a possibilidade de uso das mesmas para as dinâmicas de abordagem educomunicativa.

Constatei que cada uma delas apresenta, de certa forma, aspectos relacionados aos indicadores dos temas de práticas pedagógico-comunicacionais e de competências educomunicativas. As classificações foram apontadas diretamente nas matrizes de cada rubrica, no Anexo F, mas gostaria de comentar os critérios da rubrica do projeto B.4, do Jogos do Riva, a qual foi desenvolvida pelos alunos, por iniciativa deles.

Todos os seus critérios podem ser analisados com base nos temas das práticas pedagógicocomunicacionais e das competências educomunicativas, e seus subtemas, principalmente no que se refere aos tipos de participação protagonista e de relações com os demais membros do grupo. Essa seria um dos exemplos de que a rubrica pode ser uma ferramenta que auxilia a implementação de práticas pedagógico-comunicacionais nos espaços educacionais, e o desenvolvimento do que denominamos aqui de competências educomunicativas. Apresento aqui um quadro resumido, com três dos critérios da referida rubrica, e a indicação dos temas e subtemas com base nos quais desenvolvi minhas reflexões aqui apresentadas. 
Quadro 21: Projeto B.4 - Análise de Conteúdo/ Critérios

\begin{tabular}{|c|c|}
\hline Critérios & $\begin{array}{l}\text { Análise de Conteúdo: } \\
\text { Tema / Subtema }\end{array}$ \\
\hline Frequência e pontualidade & $\begin{array}{l}\text { Práticas Pedagógico-Comunicacionais - Indicador 4. Relações entre } \\
\text { participantes }\end{array}$ \\
\hline $\begin{array}{l}\text { Busca de conhecimento - } \\
\text { aprender a aprender }\end{array}$ & $\begin{array}{l}\text { Práticas Pedagógico-Comunicacionais - Indicador 3. Participações de } \\
\text { protagonismo (tipos) }\end{array}$ \\
\hline $\begin{array}{l}\text { Trabalho em parceria e } \\
\text { colaboração }\end{array}$ & $\begin{array}{l}\text { Práticas Pedagógico-Comunicacionais } \\
\text { Indicador 3. Diálogo (Compartilhar e refletir sobre ideias, Escuta mútua, } \\
\text { Pensar juntos; Apontar outros pontos de vista; Compartilhar e refletir } \\
\text { sobre ideias; Fazer emergir ideias / buscar pluralidade de ideias; } \\
\text { Indicador 4. Relações entre participantes. } \\
\text { Competências Educomunicativas: } \\
\text { Indicador 1. Colaboração em equipe; } \\
\text { Indicador 5. Compartilhamento (de experiências e de ideias) Colaboração } \\
\text { em equipe; } \\
\text { Indicador 7. Tomada Compartilhada de Decisão; } \\
\text { Indicador 8. Resolução Conjunta de Problemas; } \\
\text { Indicador 9. Avaliação (entre pares e autoavaliação). }\end{array}$ \\
\hline
\end{tabular}

\subsubsection{Novas Relações, Práticas Reflexivas e o Feedback: construindo um ecossistema comunicativo nos Laboratórios de Informática Educativa}

Dentre as dinâmicas desenvolvidas na formação dos POIE, identifiquei nos registros do ThinkQuest, realizados durante os encontros presenciais e reflexões conjuntas à distância, que houve toda uma preocupação por parte da gestão da DRE Campo Limpo, em preparar esse ambiente virtual, para o registro das trocas comunicacionais desenvolvidas durante esses encontros, o que propiciou um rico material reflexivo.

Quero destacar aqui três das dinâmicas ocorridas durante essa formação. A primeira delas refere-se ao compartilhamento de informações entre os POIE participantes, sobre o resumo de práticas dos projetos que cada um estava coordenando em seus respectivos LIE, e o estímulo para que os demais lessem e/ou pedissem mais informações sobre os mesmos, ou que apresentassem sugestões de melhoria das práticas articuladas nos projetos descritos.

Além disso, os POIE precisavam comentar os aspectos fortes e fracos, indicando o que modificariam para o desenvolvimento de um novo projeto sob a mesma temática. Com base nessas colocações, era permitido aos colegas POIE, que também apresentassem eventuais ideias de melhoria da proposta de estrutura de projeto. 
A própria entrevista com a Prof. Cristina (Anexo G) me fez identificar aspectos importantes como a preocupação para que a formação acerca da avaliação formativa permitisse que os POIE vivenciassem as práticas pedagógico-comunicacionais a partir de ações focadas na vivência da reflexão sobre o planejamento e implantação de processos de construção conjunta e colaborativa sempre procurando induzir os POIE a trabalharem mais as participações planejadora, operacional, avaliadora, colaborativa plena, a plenamente autônoma, com foco para o protagonismo. Houve em suas formações a preocupação também com a gestão compartilhada da comunicação a partir de práticas para a apropriação e manejo das linguagens da comunicação, uso dos recursos da informação para a produção cultural e a leitura crítica dos meios. Ela procurou trabalhar ações de diálogo, com momentos de compartilhamento e reflexão sobre diferentes ideias entre os POIE e incentivou para que adotassem esse tipo ação em suas próprias práticas.

Quanto às competências educomunicativas, observei que houve um foco em fazê-los trabalhar escuta, a organização de pensamento, a colaboração e o compartilhamento de experiências e ideias em grupo (POIE trocando experiências e habilidades com as ferramentas dos LIE), a tomada de decisões e a capacidade de promover a autoavaliação.

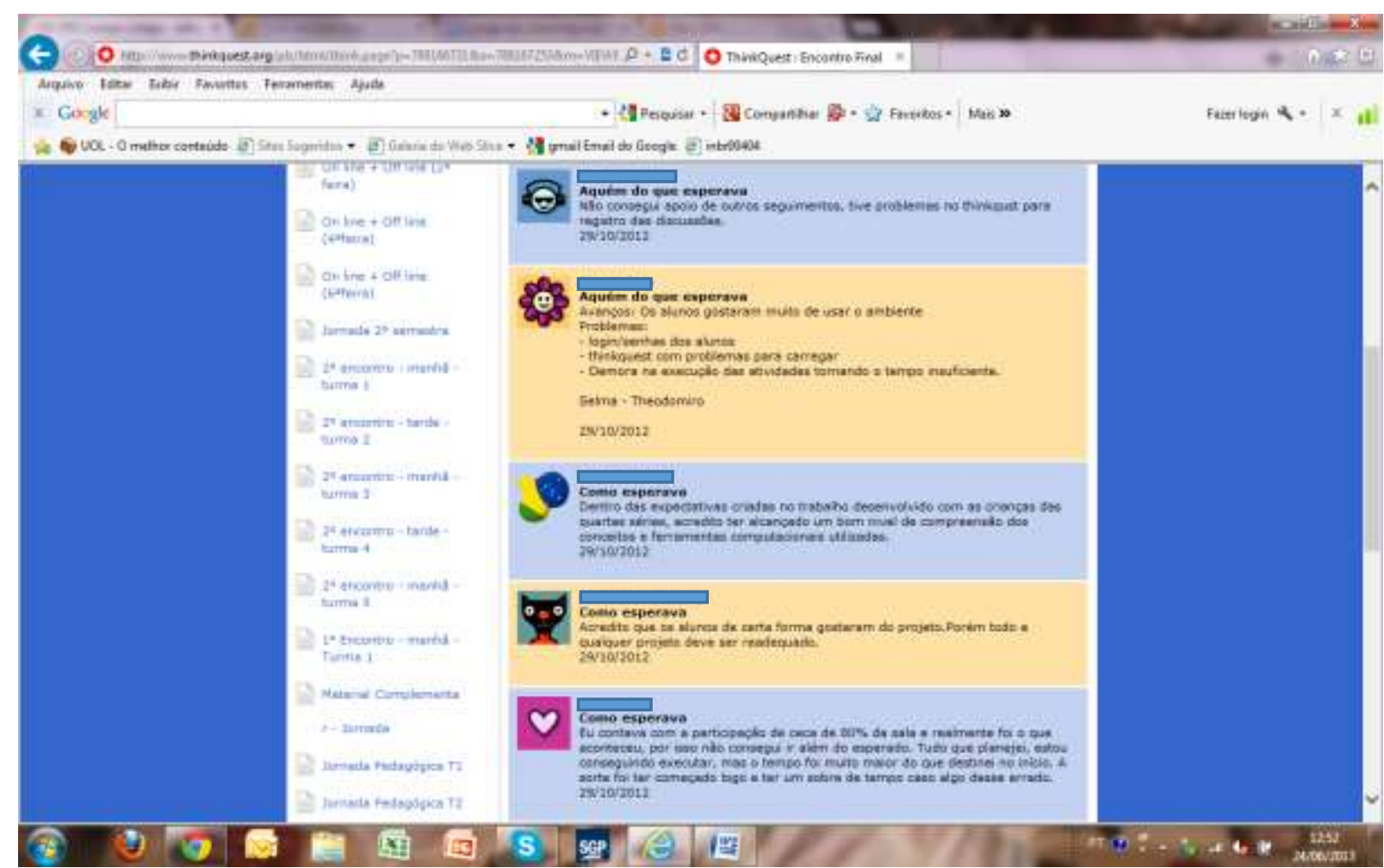

Figura 16 - Programa POIE 2012 - AVA ThinkQuest, trocas reflexivas entre POIE em encontro presencial 
Outra atividade foi para que os POIE indicassem suas dificuldades quanto ao uso de tecnologias específicas, de forma que outro POIE, que eventualmente conhecesse dicas sobre a ferramenta comunicacional indicada, pudesse esclarecer as dúvidas.

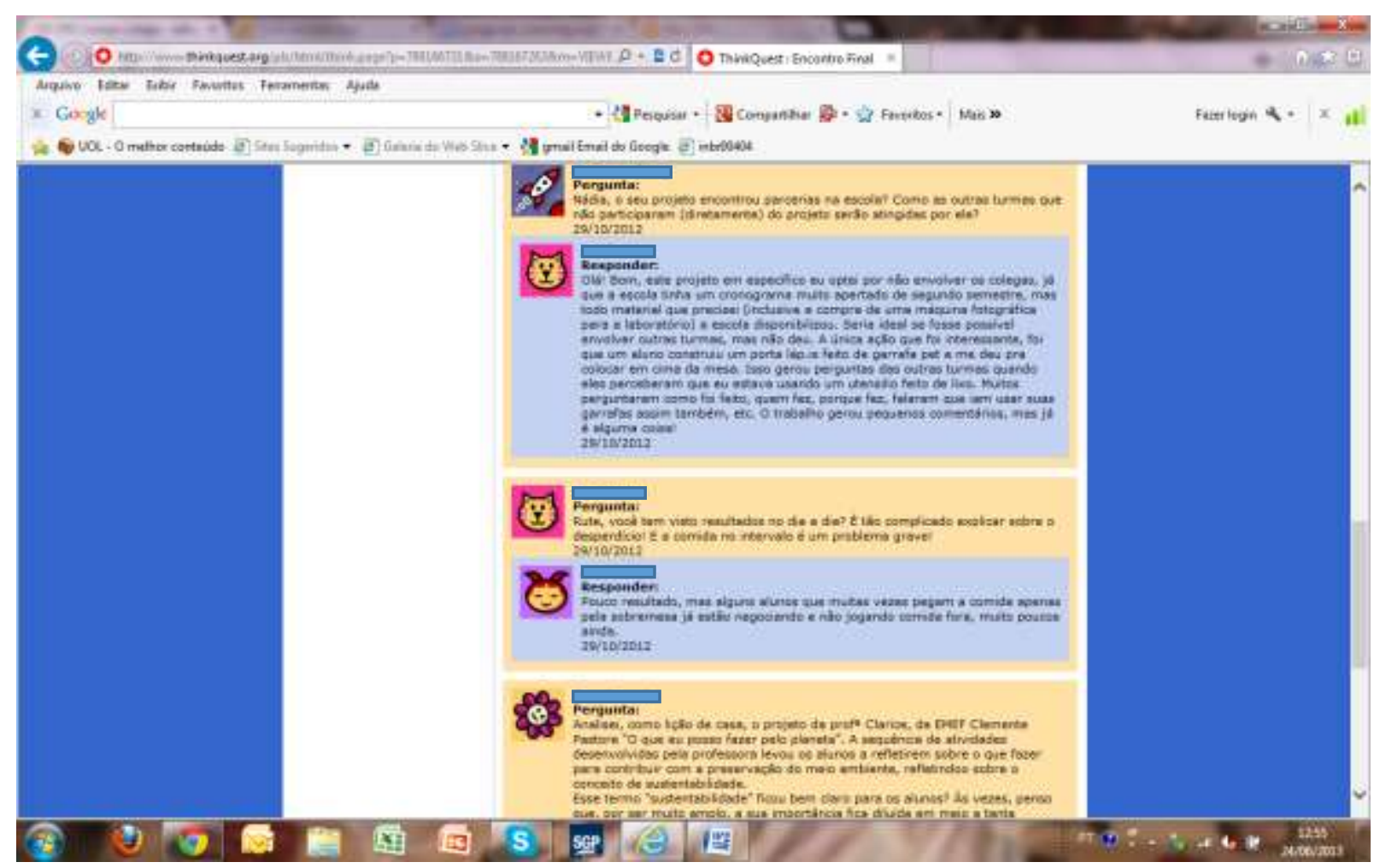

Figura 17 - Programa POIE 2012 - Trocas reflexivas entre POIE em encontro presencial Fonte: Plataforma ThinkQuest, para NIE (DOT/SME-SP) $)^{117}$

Ainda sobre a prática de uso da rubrica, ao final de cada encontro presencial, após todas as atividades, havia momentos de avaliação conjunta, aos quais chamaria até rodas de conversas virtuais presenciais, ao vivo ${ }^{118}$, com registros feitos também no ThinkQuest, sobre quão produtiva, ou não, havia sido a formação.

\footnotetext{
${ }^{116}$ Link desconhecido, pois plataforma não está mais disponível.

${ }^{117}$ Link desconhecido, pois plataforma não está mais disponível.

${ }^{118}$ Esse comentário foi feito para lembrarmos que os POIE se encontraram presencialmente, por quatro vezes, e que durante esses encontros, eles faziam seus comentários por escrito, no AVA ThinkQuest. Então esses registros estão sendo considerados como presenciais e virtuais, e não a distância.
} 


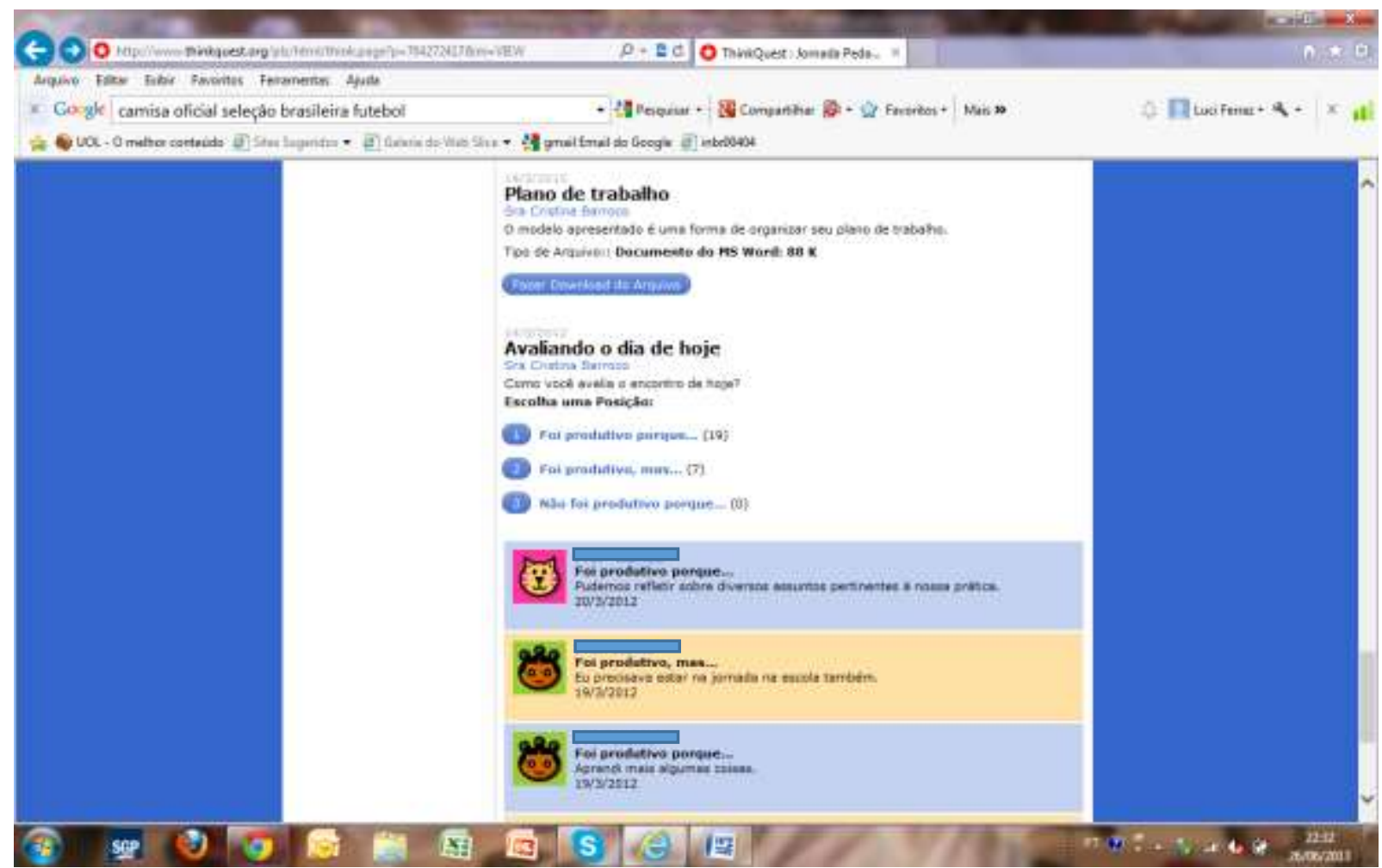

Figura 18 - Projeto POIE 2012 -autoavaliações nos encontros presenciais

Fonte: Plataforma ThinkQuest, para NIE (DOT/SME-SP) ${ }^{119}$

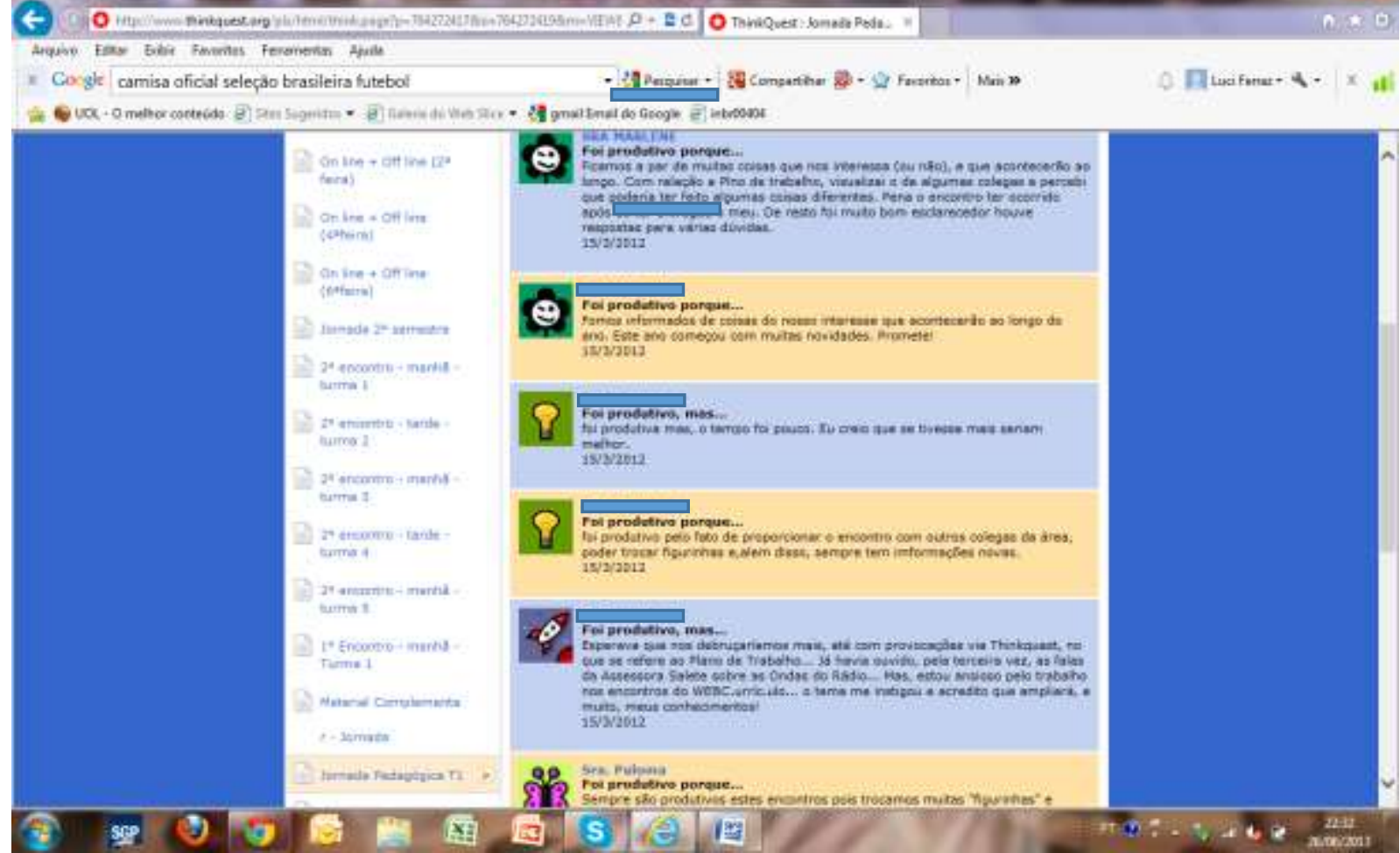

Figura 19 - Projeto POIE 2012 - autoavaliações nos encontros presenciais

${ }^{119}$ Link desconhecido, pois plataforma não está mais disponível. 
Quando verifiquei os conteúdos de tais comentários, com base nos subtemas das práticas pedagógico-comunicacionais, principalmente quanto à gestão compartilhada da comunicação, ao diálogo e às novas relações nos ambientes educacionais, por exemplo, pude observar a dificuldade que os próprios POIE tiveram inicialmente em avaliar as atividades do dia de forma mais objetiva, sendo que vários deles acabaram por se restringir a comentar que tinha sido produtivo ou não, porque fizeram, ou não, várias atividades importantes.

Aos poucos, contudo, eles passaram a ser mais específicos e a apontar aspectos positivos na formação e o que achavam que faltou, para futuros encontros. Isso aponta para a dificuldade de avaliar situações como essas, por temor de algum tipo de represália. Parece que a própria cultura de reprovação acaba fazendo com que as pessoas até temam esse tipo de procedimento.

O processo de formação constante dos POIE segue ano a ano, sendo que em 2014, a gestora Cristina Barroco promoveu uma revisão conjunta da Rubrica 1, do Anexo 2, com os POIE da DRE Campo Limpo, no sentido de atualizá-la, como comentamos no tópico anterior.

Esse tipo de atividade de reflexão conjunta por escrito, registrada no AVA ThinkQuest, foi verificado em todos os cinco projetos que adotaram essa plataforma de aprendizagem (quatro, do Grupo A, e um, do Grupo B), com trocas reflexivas mais aprofundadas ou mais simples.

Sobre o feedback dos POIE responsáveis, a essas postagens, em teoria eles deveriam aproveitar para resumir as postagens de todos os participantes e fazer comentários propositivos $\operatorname{logo}$ em seguida. Essa foi a orientação inicial do Núcleo de Informática Educativa, mas sua própria ex-coordenadora Jane Reolo concordou que em função do tempo de cada aula e do número de alunos participantes em cada turma, essa proposta ficou um tanto inviável em vários dos casos.

Na prática, os POIE adaptaram a orientação. Eles promoviam as reflexões, os alunos faziam as suas contribuições, o docente ainda estimulava um pouco mais a prática para então, encerrar as atividades. Na aula da semana seguinte, resgatava as reflexões e apresentava seus comentários, gerando mais algumas reflexões conjuntas. Esse foi o processo de feedback desenvolvido para os projetos do Grupo A.

${ }^{120}$ Link desconhecido, pois plataforma não está mais disponível. 
Pelas entrevistas realizadas com os quatro POIE, sobre essas práticas dialógicas no AVA, bem como sobre outros usos do mesmo, como repositório de materiais coletados para o desenvolvimento dos projetos, ficou claro que a análise dessas contribuições por si só não revela tudo que foi refletido e trabalhado, oralmente, ou mesmo por meio de outros canais de comunicação, utilizados durante o desenvolvimento do projeto.

Trata-se de um registro importante, mas que pode resultar em diferentes análises, caso não seja feita uma verificação do contexto completo com o POIE responsável. Por isso, apesar de termos tido acesso aos registros de aproximadamente 30 dos 102 projetos no AVA ThinkQuest, decidimos trabalhar apenas com os casos cujos POIE tiveram disponibilidade para nos relatar mais detalhes dos mesmos.

Apesar de não os termos considerado para este estudo, julgo importante destacar que houve outros casos de ricos registros, mas também houve casos em que o POIE mais estruturou a proposta no AVA, sem realmente aplicá-la. E o fato de não haver a postagem das respostas dos alunos não significa que o projeto não tenha ocorrido, pois isso pode ter acontecido oralmente apenas. Essas contribuições no AVA podem não ter sido realizadas por inúmeras variáveis, inclusive falta de infraestrutura de acesso à internet. Então, esses procedimentos são muito interessantes e contribuem para um histórico importante de práticas, mas, por si só, não refletem tudo o que ocorreu, sem que haja os comentários do POIE responsável.

Já no caso dos projetos do Grupo B, apenas o Curso de Astronomia utilizou também o AVA ThinkQuest para realização dos registros. Os demais fizeram uso de outras opções, pois à época do desenvolvimento dos mesmos, a disponibilização do ThinkQuest, pela Oracle Foundation, já havia sido descontinuada.

Alguns optaram pelo registro final do projeto no Prezi, ou pelo Power Point ou Popplet. Porém, na maioria dos casos, as trocas reflexivas desses projetos foram principalmente orais, ainda que tenham feito uso de tecnologias em todos eles, mas agora para o desenvolvimento de atividades específicas, como pesquisas compartilhadas sobre temas diversos no Google, entrevistas de membros da escola e da comunidade de entorno, levantamento de problemas ligados aos jovens, e até a montagem de um repositório de jogos educativos, desenvolvidos pelos alunos.

No caso desses três projetos (B.1; B.2; B.4), a entrevista com os POIE responsáveis também foi essencial, para o entendimento da dinâmica dos mesmos e identificação de todas as práticas dialógicas e reflexivas trabalhadas com os jovens do $7^{\circ}$ ano, no projeto sobre os 
problemas da escola, ou na dinâmica dos alunos de $2^{\circ}$ ano, para entenderem como fazer pesquisas conscientes na internet. Ou mesmo no caso dos Jogos do Riva, que resultou em duas páginas no Facebook e um site de repositório desses jogos.

No relato desses POIE, somado aos registros feitos por meio do uso de aparatos digitais diversos e plataformas específicas, identifiquei momentos de práticas pedagógicocomunicacionais, tanto para o desenvolvimento do projeto em si, como para a autoavaliação dos alunos, ao final desses projetos.

No relato do POIE Rosemberg, houve a preocupação com o acompanhamento e promoção de reflexão constante com os alunos, sendo que ele entende a importância dessa prática comunicacional com eles, e procura instiga-los ao máximo.

Quadro 22: Analise de conteúdo / Rosemberg - relações em sala de aula

\begin{tabular}{|c|c|}
\hline FALA DO POIE ROSEMBERG & TEMA + SUBTEMA \\
\hline $\begin{array}{l}\text { (Pergunta Luci: você teve muita dificuldade para fazer esse } \\
\text { processo, de sair desse modelo mais bancário, para um modelo } \\
\text { mais dialógico? Como foi ou está sendo esse processo para } \\
\text { você?) } \\
\text { Resposta Rosemberg: } \\
\text { Então... Acho que tranquilo nunca é... porque a gente já vem com } \\
\text { algumas coisas sedimentadas, querendo ou não... em alguns } \\
\text { momentos a gente avança, em outras recuamos um pouco... eu } \\
\text { sempre acho que estou o bam bam bam... aí eu ouço um pouco o } \\
\text { Cesar121 e acabo achando que tenho que voltar para o nível } 0 \text { de } \\
\text { novo... eu acho que é esse o processo... à medida que a gente } \\
\text { toma consciência do quanto estamos inacabados, mais a gente se } \\
\text { permite se abrir para o outro, procurando melhorar... então acho } \\
\text { que sair daquele modelo que só corrige certo e errado, e migrar } \\
\text { para esta nova proposta, que no meio da prova, você começa a } \\
\text { problematizar, perguntar... nem parece que é uma prova, } \\
\text { né?...fica mais dialogando em cima de algo, conversando sobre } \\
\text { uma reflexão, um pensamento, e dando qualidade para aquilo, ... } \\
\text { eu acho que não é um processo tranquilo... eu acho que é um } \\
\text { processo em que você dá } 3 \text { passos para a frente e } 1 \text { para trás... e } \\
\text { isso você tem que entender como normal, e que o seu foco é a } \\
\text { construção, é caminhar para a frente... em busca do horizonte... e } \\
\text { acho que inclusive, não é fácil porque você está num meio ... eu } \\
\text { não estou falando aqui de um meio acadêmico, das teorias, que } \\
\text { me dão subsídios... Mas um meio prático, do dia a dia, que isso } \\
\text { considera facilitar a vida do aluno, eles consideram você estar } \\
\text { dando respostas e eles não percebem que você não está dando } \\
\text { resposta, mas que está problematizando e fazendo eles pensarem }\end{array}$ & $\begin{array}{l}\text { (Práticas Pedagógico-Comunicacionais: } \\
\text { diálogo, relações, protagonismo; } \\
\text { Encerramento: Roda de conversa) }\end{array}$ \\
\hline
\end{tabular}

${ }^{121}$ Prof. Dr. Cesar Nunes, ex-assessor do Núcleo de Informática Educativa, da DOT/SME-SP. 
sobre o tema em estudo, permitindo que ele visualize o que ele já sabe e que construa a partir dali... e que visualize e perceba o que ele ainda precisa aprender e ir atrás...

Quadro 23: Analise de conteúdo / Rosemberg - relações em sala de aula

\section{FALA DO POIE ROSEMBERG}

Vejo que o meu jeito de trabalhar com as crianças, valorizando e incentivando a pensarem sobre problemas, para investigarem e resolvê-los, compartilhando com eles a ação pedagógica, isso os torna muito críticos motivados, com desejo de protagonizar ainda mais.

Uma das professoras que trabalha comigo há alguns anos sempre diz - não sei se em tom de brincadeira que não quer pegar nunca meus alunos, porque eles questionam muito... risos

Eu fico muito feliz com essa observação. Se eles questionam é porque eles estão pensando, estão se interessando e querem participar do fazer pedagógico... então se eles querem participar de alguma coisa, é porque interessa.

E quando eles querem participar, isso vai para as famílias também porque eles contam em casa... falam tudo... mas eu percebo que os professores com os quais eu trabalho respeitam meu trabalho, se encantam, mas poucos tentam fazê-lo ... a maioria não aposta nessa autonomia do aluno, e acreditam assim em coisas como o professor manda e o aluno faz... atividade sem nexo, descontextualizada... além disso, são poucos que trabalham com projetos... mas os poucos que se aventuram a trabalhar comigo ficam muito contentes em ver a mudança de atitude das crianças... e a aproximação das famílias... com o que ocorre na vida escolar do filho... então, mesmo assim em dia de semana, horário em que os pais trabalham, eles vão lá, participam das atividades... eles ficam encantados porque aquilo também é atividade deles... que os filhos levam todo dia... os filhos falam, tocam nesse assunto em casa... então, uma coisa curiosa é que os professores que não compram essa ideia, e recebem meus alunos no ano seguinte, se sentem pressionados... pois eles participam do encaminhamento do trabalho pedagógico, eles dão opinião, eles se fazem ouvir... eu já ouvi até queixas a respeito disso...

\section{TEMA + SUBTEMA}

Novas relações entre POIE e alunos

Práticas Pedagógico-Comunicacionais: ações de diálogo (escuta mútua pensar juntos, apontar outros pontos de vista) e tipos de protagonismo 
O cuidado com o tipo de feedback do POIE Rosemberg me remeteu às colocações de Wiliam (2011) sobre a importância de serem propositivos, com base também na rubrica em uso. Esse professor fala da diferença que é trabalhar a partir de novas relações com os alunos, compartilhando controle e poder dentro dos LIE, e promovendo trocas dialógicas com eles

Os alunos também nos auxiliaram quanto à validação do que os POIE nos relataram sobre suas práticas, referente aos casos A.3, do POIE Douglas, e B.1, do POIE Rosemberg. Os resultados da aplicação dos questionários constam do Anexo D respectivamente, mas quero comentar alguns aspectos aqui.

Observei em suas respostas que eles trabalham práticas pedagógico-comunicacionais em suas atividades, com aspectos de gestão da comunicação compartilhada, ao desenvolverem projetos conjuntos por meio do uso de diferentes mídias. Eles confirmaram também as práticas dialógicas e protagonistas, e relataram que aprendem a se relacionar melhor com seus colegas, por meio das negociações necessárias para a estruturação e realização das várias etapas do referido projeto.

Esses alunos revelaram que aprenderam muito sobre como trabalhar em grupo e até mesmo como apresentarem suas ideias e fazerem a negociações necessárias, para que todos consigam contribuir para o trabalho final. E avaliaram que a postura de mediador do professor, dando orientações, fazendo esclarecimentos e promovendo reflexões durante as dinâmicas os auxilia muito a compreenderem melhor a problemática em estudo.

Mesmo os relatos sobre todas as ações desenvolvidas para que conseguissem estruturar os produtos tecnológicos finais, como os próprios POIE chamam, me esclareceu exatamente sobre como o processo é extremamente participativo, com aspectos de colaboração, autonomia e condução por parte dos alunos envolvidos, o que nos permite dizer que eles apresentam também atividades de gestão compartilhada da comunicação e de desenvolvimento de competências do uso das TIC.

E isso mesmo quando o produto final inicialmente almejado acaba por não ser realizado, por fatores diversos, como tempo e falta de infraestrutura adequada, entre outros. Esse foi um dos temas das reflexões no Programa POIE 2012, como pude verificar nos registros aqui apresentados. 


\title{
4.3 Reflexões finais sobre as constatações feitas
}

\begin{abstract}
Aprender é descobrir aquilo que você já sabe. Fazer é demonstrar que você o sabe. Ensinar é lembrar aos outros que eles sabem tanto quanto você. Vocês são todos aprendizes, fazedores, professores. (Richard Bach, em Fernão Capelo Gaivota)
\end{abstract}

$\mathrm{Na}$ Introdução, relatei que o objetivo deste estudo foi o de verificar possíveis pontos de aproximação entre a abordagem de avaliação formativa adotada pelo Núcleo de Informática Educativa, da DOT/SME-SP e o campo da Educomunicação.

Como hipóteses norteadoras, considerei a efetiva existência de uma forte relação de sinergia filosófica e metodológica evolvendo, de um lado, as ações estratégicas da proposta de avaliação formativa de Wiliam (2011) e, de outro, os processos da natureza educomunicativa, sistematizados pelo Núcleo de Comunicação e Educação da USP (1999). Ou seja, imaginava que as dinâmicas estruturantes da referida proposta avaliativa seriam desenvolvidas necessariamente com base na criação de ecossistemas comunicativos de trocas intensas, estruturados por meio de práticas pedagógico-comunicacionais, garantindo, dessa forma, as interações entre todos os participantes do mesmo, focadas no trabalho de participação, visando o fortalecimento de suas práticas protagônicas.

Foi o que constatei, sendo que na sequência apresento as particularidades observadas, decorrentes da política que aproximou a prática avaliativa adotada pela Secretaria e os pressupostos da Educomunicação:

(a) Foco na formação da criança ou jovem adolescente enquanto cidadão responsável ${ }^{122}$, crítico e empoderado de seus direitos e deveres junto à sociedade. Verifiquei, efetivamente, que a própria dinâmica promovida pela avaliação formativa de Wiliam (2011) foca o processo de autorregulação, no qual o aluno conhece e se apropria das regras do processo de aprendizagem, para poder decidir sobre o que aprender, ou não, em cada curso. Pela análise dos dados empíricos da pesquisa, reafirmo que, inegavelmente, ao ter como objetivo a autorregulação, a proposta de Wiliam (2011), aplicada pela SME/SO, no Brasil, apresenta convergências conceituais com o paradigma do campo da Educomunicação.

${ }^{122}$ Termo utilizado por Célestin Freinet, o qual será explicado no capítulo um, sobre Educomunicação. 
(b) Adoção da pedagogia de projeto ${ }^{123}$ desenvolvida principalmente com práticas protagonistas de todos seus participantes, centrada no desenvolvimento e fortalecimento de competências comunicativas, incluindo a comunicação dialógica e a aprendizagem para a reflexão crítica sobre a realidade vivenciada. Aqui encontrei, igualmente, convergência entre os dois temas em estudo, sendo que os projetos analisados nos mostraram, em detalhes, a riqueza de possibilidades que emergem desta convivência conceitual.

(c) Evolução das competências comunicacionais no contexto de ecossistemas comunicacionais caracterizados por trocas intensas entre todos os participantes dos projetos educativos: este talvez tenha sido um dos aspectos que mais me motivou a propor o estudo desta aproximação, posto que é nesse acompanhamento que pude identificar e mapear as práticas pedagógicocomunicacionais, para a estruturação e fortalecimento de competências diversas, educomunicativas ou outras mais.

O estudo dos pontos de aproximação entre a Educomunicação e a proposta de avaliação formativa permitiu vislumbrar que o conceito se faz presente nesses projetos, em menor ou maior nível, dependendo da correlação analisada. Ao identificar isso, lembrei, a todo instante, da frase do Prof. Dr. Ismar de Oliveira Soares, em suas aulas de Gestão da Comunicação, para o curso de Licenciatura em Educomunicação (ECA/USP): temos que fazer a Educomunicação possível! Em outras palavras, as conquistas de uma prática dialógica e protagônica é fruto de uma evolução dos processos, pois implica em múltiplas ações confrontando-se com diferentes paradigmas de práticas educativas, convivendo no histórico biográfico de cada sujeito envolvido. A meta é que as práticas do paradigma da Educomunicação foquem permanentemente seus esforços no processo de transformação das relações no ecossistema comunicativo representado pela escola, envolvendo docentes e jovens, numa perspectiva cidadã, criativa e crítica.

Outro aspecto que merece ser destacado sobre a Educomunicação possível, a rubrica nos mostra que temos que cuidar para o fato de que a Educomunicação está no processo. Consequentemente, é nele que é preciso trabalhar, com base em parâmetros claros, definidos no descritivo das ações das etapas do projeto, e na rubrica derivada dessa definição de

${ }^{123}$ Abordagem pedagógica adotada em vários dos projetos trabalhados pelos membros do grupo do NCE ECA/USP, sob supervisão do Prof. Dr. Ismar de Oliveira Soares, cuja origem trataremos no Capítulo 1, a partir das ideias do especialista em educação John Dewey (DEWEY, 1956), que defendia que a experiência educativa em sala de aula deve promover a reflexão sobre ocorrências da vida real, a partir da realização de projetos temáticos ligados a problemas da escola e do entorno da mesma. 
dinâmicas, e não o contrário. Ou seja, não são as rubricas que norteiam os projetos, mas são os detalhes do projeto e os objetivos esperados deles que norteiam as rubricas.

Pude verificar que quando falo em participações dialógicas e reflexivas com características protagonistas, isso implica em várias trocas comunicacionais entre todos os participantes, e não apenas entre os alunos. E que muitas dessas práticas são passíveis de ocorrerem desde que haja uma relação mais igualitária e dialógica, do próprio professor responsável pelas mediações com os demais participantes. Hart (1992) e Costa (2006) apontam que o degrau de participação máxima de protagonismo é a condutora, quando os alunos decidem o que será feito e até dão orientações aos adultos mediadores.

Um exemplo que consideramos dessa prática foi o do Jogos do Riva, que apresenta os alunos conduzindo o processo, e a POIE orientando e apoiando as ações deles. Nesse caso, a rubrica nasceu dos alunos, durante o processo, novamente sob orientação da POIE, que foi analisando com eles os indicadores de avaliação. A análise dessa rubrica me indicou que eles acabaram por refletir competências educomunicativas, ligadas ao protagonismo. Ou seja, quando o professor internaliza esse processo de protagonismo e muda sua relação com os alunos e com os processos, as dinâmicas também vão se estruturando de outra forma.

De fato, ao verificar os indicadores de avaliação adotados em cada uma das rubricas, para os oito projetos, observei que, quanto mais detalhadas estavam as etapas no AVA ThinkQuest, mais detalhados estavam os critérios de suas rubricas, independente dela ter sido desenvolvida no início ou final. Ou seja, quanto melhor o docente responsável conhecia as competências que desejava trabalhar com o projeto, e as ações que permitiram a construção das mesmas, mais claros e detalhados foram os níveis desses indicadores.

Quando o docente responsável percebe todas as ações passíveis de serem desenvolvidas, ele passa a ter clareza, inclusive, sobre os momentos em que sua mediação será mais demandada, e como poderá executar isso. Isso destaca a organicidade da rubrica, que pode ser escrita e reescrita, ou ajustada a qualquer momento, reforçando para a importância do POIE conhecer detalhadamente quais as ações - pedagógicas e comunicacionais - de cada etapa do projeto, sempre com base nos objetivos de aprendizagem que deseja que seus alunos trabalhem, considerando os perfis deles. Aqui obtive mais um ponto de aproximação com a Educomunicação, a partir dos temas das práticas pedagógico-comunicacionais e indicadores educomunicativos, e seus respectivos subtemas. 
(d) Oferta de intervenções e orientações ao longo de todo o processo comunicacional de um projeto educativo, e não apenas no início ou final do mesmo. Constatei que quando o diálogo entre o educador e educados se dá ao longo de todo o processo da ação avaliativa, a realização de devolutivas propositivas ganha intensidade, efetivando e ampliando o grau educomunicativo do processo.

Uma das lembranças que tenho do trabalho avaliativo implementado no projeto Educom.Jt, é outra fala do Prof. Ismar, motivando o fortalecimento da construção conjunta do conhecimento por parte de todos os envolvidos na avaliação, evitando centrar a preocupação do orientador apenas no ato de aprovar ou reprovar o trabalho de seus discípulos. Novamente, vi que a proposta de Wiliam converge com essa premissa, e apresenta opções de viabilização de acompanhamento e intervenção, durante todo o processo. Para tanto, ele fala, nesse ponto, da devolutiva propositiva, algo que pude observar na prática dos POIE, tanto nos projetos que utilizaram o AVA ThinkQuest, quanto nos três outros.

(e) Rodas de conversas, ao final do processo, para desenvolvimento de reflexões analíticas pelos alunos de forma individual e/ou grupal. Encontramos, igualmente, convergência de ideias para este tópico, sendo que as avaliações, quer fossem autoavaliações nos grupos pequenos, ou mesmo avaliações entre pares, mostram-se extremamente ricas, com pontos similares às rodas de conversa de final de prática, do programa Educom.Jt, em termos de procedimentos.

Os resultados analisados aqui neste capítulo me mostraram não apenas o quanto as ações estratégicas da referida proposta têm pontos importantes de aproximação com a Educomunicação, mas que dependem fortemente dos processos comunicacionais para seu sucesso.

Os resultados obtidos reforçaram minha ideia da necessidade de passar a pensar em práticas pedagógico-comunicacionais para a estruturação de ecossistemas comunicativos de trocas dialógicas intensas, estruturado com base nessas ações comunicacionais para o atingimento dos objetivos de aprendizagem.

Outro aspecto que merece destaque é o próprio processo de elaboração desse instrumento de avaliação, que converge com a proposta educomunicativa, ao poder ser elaborada conjuntamente. E novamente houve um aprendizado aqui, sobre a dificuldade de estabelecer 
esses ambientes de negociação, e a necessidade de definir etapas para evoluir nessa caminhada ao empoderamento.

E resgatar esse objetivo principal da Educomunicação, que é o empoderamento do indivíduo enquanto cidadão responsável, passa pelo seu direito a ter voz, inclusive sobre seu processo de avaliação. É preciso desgarrar de referências muitas vezes instauradas em nós desde pequenos, sobre a abordagem de avaliação a partir do controle e poder, pela aprovação ou reprovação, para identificarmos os pontos que merecem atenção nesse percurso de diálogo e protagonismo, para o empoderamento.

Aqui, há um último aspecto a ser considerado: um dos receios que eu tinha no início da pesquisa era o de que, ao final, acabasse por identificar que o dispositivo que aponta para a necessidade de se definir rubricas como indicativos do processo de avaliação pudesse limitar e restringir os processos de aprendizagem. Porém, o que observei foi que esta prática, quando desenvolvida solidariamente, se reinventa permanentemente, atualizando e recriando o processo avaliativo, desde que as pessoas envolvidas nessa prática estejam preparadas para isso e assumam a decisão de assim proceder. 


\section{ÚLTIMAS}

\section{CONSIDERAÇÕES}

Como mencionei no início da tese, ao decidir pelo tema desta pesquisa, meu objetivo principal foi o de identificar uma abordagem de avaliação, que auxiliasse a implementação de práticas definidas com base no paradigma da Educomunicação, viabilizando o acompanhamento do processo.

À medida que defini os temas e subtemas educomunicativos, com base nos quais desenvolvi parte das análises dos conteúdos coletados, pude visualizar suas organicidade e fluidez, como ela adquire aspectos diferentes, dependendo do perfil do responsável que está regendo o processo, mas não são menos importantes.

"Educomunicação possível" e "nenhum a menos" - este segundo termo, no sentido de que os alunos devem aprender, e não serem simplesmente aprovados ou reprovados - foram as expressões que mais me perseguiram, e, de certa forma, me guiaram durante esta pesquisa.

A necessidade de definir indicadores educomunicativos para, a partir deles, buscar os pontos comuns com essas estratégias da proposta de avaliação adotada pelos LIE, da DOT/SME-SP, me permitiu identificar as diferenças de entendimento que as características educomunicativas 
podem ter, dependendo do contexto em que estão sendo consideradas, ou mesmo do entendimento que, as pessoas envolvidas no projeto, têm desses termos.

A análise das rubricas me fez compreender, por exemplo, as dificuldades que muitas vezes temos, de apresentar e diferenciar a proposta do paradigma da Educomunicação, de outras propostas que fazem uso das tecnologias, mas que são de caráter mais instrumental. $\mathrm{O}$ desenvolvimento deste estudo me permitiu trabalhar na definição do que é o diálogo educomunicativo para o empoderamento, e de quais são as suas características essenciais, características essas que me auxiliam a desenhar com mais detalhes planos comunicacionais, que possam ser integrados, os quais consolidem a execução das práticas pedagógicas.

Quando analisei as normatizações do Núcleo de Informática Educativa, ao longo das suas mais de duas décadas, observei as modificações de orientações que o mesmo sofreu, algumas em função da evolução das tecnologias, outras em decorrência dos estudos sobre os usos das mesmas nos espaços educacionais, sem contar as modificações com origem nas visões pedagógicas particulares dos gestores da área. Assim, o Núcleo que nasceu, em 1992, com a Prefeita Luiza Erundina, se, na época, esboçava características dialógicas e reflexivas inerentes ao pensamento do então Secretário Municipal de Educação, Paulo Freire, acabou, com o passar dos anos, por assumir perspectiva mais instrumental.

No entanto, a postura instrumentalista acabou sendo revista na última década e meia, em consequência de um trabalho persistente das gestões do próprio NIE. Sobre as razões das mudanças, a presente tese veio agregar a cultura que se estabeleceu na base da Secretaria quando a Educomunicação foi oferecida como referencial para professores e alunos de 455 escolas do munício no início do século XXI. O fato ficou comprovado pela prática de avaliação formativa adotada na segunda década do século.

Constatei, pois, que as orientações normativas atuais indicam uma opção totalmente convergente com a Educomunicação. Ao adotar uma proposta de avaliação formativa que defende a adoção de processos dialógicos e reflexivos, orientados por feedbacks propositivos por parte do professor responsável, voltada à promoção da autonomia do aluno e, consequentemente, para a formação de um cidadão responsável, como defendido por Dewey (1976a), Freinet (1985) e Freire (2002), a Secretaria de Educação reforça nossa conclusão de que uma aproximação entre o paradigma da Educomunicação e a referida proposta de avaliação formativa pode converter-se em política pública. Foi o que ocorreu em São Paulo. 


\section{REFERÊNCIAS}

ALKIN, Marvin C.; CHRISTIE, Christina A. An Evaluation Theory Tree. In ALKIN, Marvin C. (org.). Evaluation Roots - Tracing Theorists' Views and Influences. Thousand Oaks/CA/USA: Sage, 2004.

BACCEGA, Maria Aparecida. Comunicação/Educação e a construção de uma nova variável histórica. In: In CITELLI, Adilson; COSTA, Maria Cristina C. (Org.). Educomunicação Construindo uma nova área de conhecimento. São Paulo: Paulinas, 2011, p. 31 - 42. (Coleção Educomunicação)

- A História no campo da Comunicação/Educação. Revista Comunicação \& Educação, no 10,1997 , p. 07 a 14.

BECHARA, Minidicionário de Língua Portuguesa - atualizado pelo novo acordo Ortográfico. Rio de Janeiro: Nova Fronteira, 2009 (ajustar/indicar o número da pág. da referência, na p. 26 da tese)

BELLANCA, James; BRANDT, Ron (Org.). $21^{\text {st }}$ Century Skills - Rethinking how students learn. Bloomington: Solution Tree Press, 2010.

BINKLEY, M., Erstad, ET. AL (2012) Defining Twenty-First Century Skills. In Griffin, P., Care, E., \& McGaw, B. Assessment and Teaching of 21st Century Skills, Dordrecht, Springer, 2012, pos. (buscar posição e-book)

BOHM, David. O Pensamento como um Sistema. São Paulo: Madras, 2007.

BOHM, David. Diálogo: comunicação e redes de convivência. São Paulo: Palas Athena, 2005.

BOURDIEU, Pierre. O Campo Científico. In: ORTIZ, Renato. Pierre Bourdieu - Coleção Grandes Cientistas Sociais. São Paulo: Ática, 1983, p. 122 - 155. 
BUENO, Francisco da Silveira. Grande Dicionário Etimológico-Prosódico da Língua Portuguesa. Santos/SP: Brasília Limitada, 1974, v. I - IX.

CASTELLS, Manuel. Poder da Comunicação. Lisboa: Fundação Calouste Gulbenkian, 2013.

CASTELLS, Manuel. A Sociedade em Rede - A era da informação: economia, sociedade e cultura - Vol. I. São Paulo: Paz e Terra, 1999.

CIPRIANO, Luckesi. Avaliação da Aprendizagem - componente do ato pedagógico. São Paulo: Cortez, 2011.

CITELLI, Adilson. Comunicação e Educação: implicações contemporâneas. In CITELLI, Adilson; COSTA, Maria Cristina C. (Org.). Educomunicação - Construindo uma nova área de conhecimento. São Paulo: Paulinas, 2011, p. 59 - 76. (Coleção Educomunicação)

CITELLI, Adilson. Palavras, meios de comunicação e educação. São Paulo: Cortez, 2006.

SENAC, 2004.

Comunicação e Educação - A Linguagem em Movimento. São Paulo:

COSTA, Antônio Carlos Gomes. Protagonismo Juvenil - adolescência, educação e participação democrática. São Paulo: FTD/Fundação Odebrecht, 2006.

COSTA, Maria Cristina C. (Org.) Gestão da Comunicação: Terceiro Setor, Organizações não Governamentais, Responsabilidade Social e Novas Formas de Cidadania. São Paulo: Atlas, 2006.

DEWEY, John. Experiência e Educação. Tradução Anísio Teixeira. São Paulo: Nacional, 1976a. Atualidades Pedagógicas.

DEWEY, John. Democracia e educação. Tradução Godofredo Rangel e Anísio Teixeira. São Paulo: Nacional, 1976b. Atualidades Pedagógicas. Vol. 2.

EBOLI, Marisa. Educação Corporativa. São Paulo: Ed. Gente, 2004

FERNANDES, Cristina B. M. Entrevista sobre Programa POIE 2012. Outubro/2015. Gravação em MP3, cujas partes da transcrição encontram-se no Anexo F. Entrevista concedida a Luci Ferraz de Mello.

FITZSIMONS Annette; et al. Empowerment and Participation in Youth Work. Reino Unido: Learning Matters, 2011.

FONSECA, Sergio C. Paulo Freire e Anísio Teixeira - Convergências e Divergências (1959 - 1969). Jundiaí: Paco Editorial, 2011.

FRAGOSO, Suely; RECUERO, Raquel; AMARAL, Adriana. Métodos de pesquisa para internet. Porto Alegre: Editora Sulina, 2012.

FRANCO, Maria Laura P. B. Análise de conteúdo. Brasília: Liber Livro, 2009. 
FREINET, Célestin. Pedagogia do Bom Senso. São Paulo: Martins Fontes, 1985.

FREIRE, Paulo. Educação como prática da liberdade. Rio de Janeiro: Paz e Terra, 2009.

FREIRE, Paulo. Extensão ou Comunicação? Rio de Janeiro: Paz e Terra, 2002.

FREIRE, Paulo. Pedagogia do Oprimido. Rio de Janeiro: Paz e Terra, 2005.

FREIRE, Paulo. Pedagogia da autonomia: saberes necessários à política educativa. São Paulo: Paz e Terra, 1996. (Coleção Leitura)

GIBBS, Graham. Análise de Dados Qualitativos. Porto Alegre: Artmed, 2009. (Coleção Pesquisa Qualitativa)

HADJI, Charles. Ajudar os alunos a fazer a autorregulação da sua aprendizagem: por que? Como? Pinhais: Editora Melo, 2011. . Avaliação desmistificada. Porto Alegre: Artmed, 2001. . Avaliação, regras do jogo - das intenções aos instrumentos. Porto/Portugal: Porto Editora, 1994.

HART, Roger A. Children's participation: The Theory and Practice of Involving Young Citizens in Community Development and Environmental Care. Londres/New York: UNICEF / Earthscan, 2008. (e-book)

HART, Roger A. Children's Experience of Place. New York: Irvintgton / Halsted - Division of John Wiley \& Sons, 1979.

HART, Roger A. Children's participation: from tokenism to citizenship. Florença: UNICEF, 1992.

HATTIE, John. Visible learning for teachers: maximizing impact on learning. New York: Routledge, 2012.

HOFFMANN, Jussara. Avaliação, mito \& desafio - uma perspectiva construtivista. Porto Alegre: Mediação, 2012. . O jogo do contrário em avaliação. Porto Alegre: Mediação, 2011.

HUERGO, Jorge. Una guia de comunicación/educación, por las diagonales de la cultura y la política". In: APARICI, Roberto (coord.). Educomunicacíon: más allá del 2.0. Barcelona: ed. Gedisa, 2010.

. "Comunicación/Educación: itinerários transversales". In: VALDERRAMA, Carlos Eduardo. Comunicación-educación: coordenadas, abordajes y travesías. Bogotá: Universidad Central, 2000, p. 3-25.

ISAACS, William. Dialogue and the art of thinking together: a pioneering approach to communicating in business and in life. New York, Doubleday, 1999. 
JOHNSON, Steve. Digital Tools for Teaching - 30 e-tools for collaborating, creating, and publishing across the curriculum. Gainesville/Florida/EUA: Maupin House, 2011.

KOZINETS, Robert V. Netnography: doing ethnographic research online. Los Angeles: Sage, 2011.

LAGO, Claudia; BENETTI, Marcio (Org.). Metodologia de Pesquisa em Jornalismo. São Paulo: Vozes, 2007.

LOPES, Maria Immacolata Vassallo de. Pesquisa em Comunicação. São Paulo: Loyola, 2005.

estatuto disciplinar, in Revista USP, 48, dez. 2000 - Fev. 2001, 2000.

LUCKESI, Cipriano Carlos. Avaliação da aprendizagem escolar - estudos e proposições. São Paulo: Cortez, 2011a.

São Paulo: Cortez, 2011b. . Avaliação da aprendizagem: componente do ato pedagógico.

MARIOTTI, Humberto. Diálogo: um método de reflexão conjunta e observação compartilhada da experiência. Último acesso em: outubro/2015. Disponível em: (http://www.teoriadacomplexidade.com.br/textos/dialogo/Dialogo-Metodo-de-Reflexao.pdf)

MARTIN-BARBERO, Jesus. Desafios culturais: da comunicação à Educomunicação. In CITELLI, Adilson; COSTA, Maria Cristina C. (Org.). Educomunicação - Construindo uma nova área de conhecimento. São Paulo: Paulinas, 2011, pag. 121 a 134.

Cultura y Nuevas Mediaciones Tecnológicas. In América Latina: otras visiones de la cultura, CAB, Bogotá, 2005 (Apostila do curso "Novas Sensibilidades - urbanias e cidadanias", Texto 4).

. La educación desde la comunicación. In Enciclopedia Lationamericana de Sociocultura y Comunicación. Buenos Aires: Grupo Ed. Norma, 2002.

. De la comunicación a la filosofia y vice-versa: nuevos mapas, nuevos retos. In: CANCLINI, Nestor Garcia, et al. Mapas Nocturnos: Diálogos com la obra de Jesús Martin-Barbero. Editoras Maria Cristina Laverde y Rossana Reguillo, Santafé de Bogotá: Siglo del Hombre Editores, Universidad Central, Departamento de Investigadores, 1998, p. 201 a 222.

MELLO, Luci Ferraz; SOARES, Ismar de Oliveira. Educomunicação e Tutoria em EAD: Gestão da Comunicação para a Educação, para o Diálogo e Pensamento Crítico na EAD. In Revista FGV Online, ed. 9, setembro/2015, p. 50 - 85.

MELZER, Nádia. Entrevista sobre as práticas de avaliação formativa nos laboratórios de Informática Educativa, da DOT/SME-SP. Outubro/2015. Gravação em MP3, cujas partes da transcrição encontram-se no Anexo F. Entrevista concedida a Luci Ferraz de Mello. 
MIZUKAMI, Maria da Graça Nicoletti. Ensino: as abordagens do processo. São Paulo: E.P.U. - Editora Pedagógica e Universitária Ltda., 1986.

MUNHOZ, Gislaine B. Entrevista sobre as práticas de avaliação formativa nos laboratórios de Informática Educativa, da DOT/SME-SP. Outubro/2015. Gravação em MP3, cujas partes da transcrição encontram-se no Anexo F. Entrevista concedida a Luci Ferraz de Mello.

NUNES, Cesar A. A. Rotinas de Pensamento. Publicado em: não informado. Disponível em: http://portalsme.prefeitura.sp.gov.br/Projetos/ie/Documentos/concepcaoteorica/Rotinas\%20de \%20pensamento.pdf

NUNES, Cesar A. A. Reflexões sobre o Uso de Tecnologia na Rede Municipal de Educação de São Paulo. Publicado em 27/07/2011. Disponível em: http://portalsme.prefeitura.sp.gov.br/Projetos/ie/Documentos/concepcaoteorica/Rotinas\% 20de\%20pensamento.pdf

- Vídeo: Usando rubricas para promover o pensamento e a aprendizagem. Evento Jornada Pedagógica, SME-SP. Acessado em: Set/2014. Disponível em: https://www.youtube.com/watch?v=sx8-bPVKhjY

PENTEADO, Heloisa D. Pedagogia da Comunicação: sujeitos comunicantes. In PENTEADO, Heloisa D (Org.). Pedagogia da Comunicação - teorias e práticas. São Paulo: Cortez, 2001, pág. 13 a 22.

PERRENOUD, Philippe. Avaliação - Da Excelência à Regulação das Aprendizagens: Entre Duas lógicas. Porto Alegre: Artmed, 2007.

. Dez novas competências para ensinar. Porto Alegre: Artmed, 2000.

PERRENOUD, Philippe; et al (Org.). As Competências para Ensinar no século XXI: a formação dos professores e o desafio da avaliação. Porto alegre: Artmed, 2002.

PIAGET, Jean. Biologia e conhecimento: ensaio sobre as relações entre as regulações orgânicas e os processos cognoscitivos. Petrópolis/RJ: Vozes, 2000.

1982.

. O nascimento da inteligência da criança. Rio de Janeiro: Zahar Editores,

PINHEIRO, Rose Mara. A Educomunicação nos centros de pesquisa do país - Um mapeamento sobre a produção acadêmica com ênfase à contribuição da ECA/USP na construção do campo. São Paulo: USP, 2013. 222f. Tese (Doutorado em Ciências da Comunicação) - Programa de Pós-Graduação em Comunicação, Escola de Comunicações e Artes, Universidade de São Paulo, São Paulo, 2013.

PORTO, Tania M. E. Educação para a mídia/pedagogia da comunicação: caminhos e desafios. In PENTEADO, Heloisa D (Org.). Pedagogia da Comunicação - teorias e práticas. São Paulo: Cortez, 2001, pág. 23 a 50.

REOLO, Jane. O Programa Aluno Monitor, da SME-SP. Anais do VI Encontro Brasileiro de Educomunicação. São Paulo, out. 2014. 
ROMÃO, José Eustáquio. Avaliação Dialógica: desafios e perspectivas. São Paulo: Cortez, 2011.

ROSEMBERG, José. Entrevista sobre as práticas de avaliação formativa nos laboratórios de Informática Educativa, da DOT/SME-SP. Outubro/2015. Gravação em MP3, cujas partes da transcrição encontram-se no Anexo F. Entrevista concedida a Luci Ferraz de Mello.

SANTOS, Roberto Vatan dos. Abordagens do Processo de Ensino e Aprendizagem. Revista Integração, Jan./Fev. /Mar. 2005, Ano XI, nr. 40, 2005, p. 19 a 31.

SÃO PAULO. SME. Portaria $\mathrm{n}^{\mathrm{o}}$ 7.656, de 17 de dezembro de 2015. Dispõe sobre a organização dos laboratórios de informática educativa nas unidades educacionais da rede municipal de ensino. Diário Oficial, São Paulo, SP, 18 dez. 2015, p. 14. Disponível em: http://www.sinpeem.com.br/lermais_materias.php?cd_materias=9337\#.VoBR6fkrLIU. Acesso em: dez.2015.

SÃO PAULO. SME. Portaria n ${ }^{\circ}$ 7.464, de 03 de dezembro de 2015. Institui o Programa "São Paulo Integral", nas Escolas Municipais de São Paulo. Disponível em: http://www.sinesp.org.br/index.php?option=com_content\&view=article\&id=13824:portariano-7464-de-03-de-dezembro-de-2015-institui-o-programa-sao-paulo-integral-nas-escolasmunicipais\&catid=48: saiu-no-doc\&Itemid=221. Último acesso em jan/2016.

Portaria $\mathrm{n}^{\circ}$ 900, de 24 de janeiro de 2014. Dispõe sobre a organização dos Laboratórios e Informática Educativa nas Unidades Educacionais da Rede Municipal de Ensino, e dá outras providências. Diário Oficial, São Paulo, SP, 25 jan. 2014a, p. 13. Disponível em: <www.docidadesp.imprensaoficial.com.br/NavegaEdicao.aspx?ClipID=3N530QAMDNRM8e 8S31MKR30H7QO\&PalavraChave=portaria\%20900>. Acesso em: set. 2014.

Informática Educativa - Concepção e Estrutura. 2014b. Disponível em: <portalsme.prefeitura.sp.gov.br/Projetos/ie/anonimosistema/detalhe.aspx?List=Lists/home\&Id entificador=Destaque1\&KeyField=Cursos $>$. Acesso em: set. 2014.

. Programa Nas Ondas do Radio - Metodologia. 2014 c. Disponível em <portalsme.prefeitura.sp.gov.br/Projetos/ondas/AnonimoSistema/MenuTexto.aspx?MenuID=2 2\&MenuIDAberto=1>. Acesso: set. 2014.

Portaria $\mathrm{n}^{\circ} 5.930$, de 14 de outubro de 2013. Dispõe sobre a integração do Ensino Fundamental com duração de 8 (oito) anos ao Ensino Fundamental com duração de 9 (nove) anos. Diário Oficial, São Paulo, SP, 25 out. 2013, p. 13. Disponível em: <http://www.docidadesp.imprensaoficial.com.br/NavegaEdicao.aspx?ClipID=5C9AM32SHL 8MJe45UMIQSUJ141T\&PalavraChave $=$ mais $\% 20$ educa $\%$ E7\%E3o\%20s\%E3o\%20paulo $>$. Acesso em: set. 2014.

Gabinete do Secretário. Portaria no 8.346, de 14 de outubro de 1993. Constitui grupo executivo de informática educativa com atribuições específicas. Diário Oficial, São Paulo, SP, 17 dez. 1993, p. 14. 
.Orientações curriculares: proposições de expectativas de aprendizagem Tecnologias de Informação e Comunicação. São Paulo: SME; DOT, 2010. 126 p. Disponível em:

<portalsme.prefeitura.sp.gov.br/Projetos/BibliPed/Documentos/publicacoes/Informatica\%20ed ucativa/Orienta\%C3\%A7\%C3\%B5es\%20curriculares_tic.pdf>. Acesso em: set. 2014.

. Informática Educativa - Concepção e Estrutura. 2014b. Disponível em: <portalsme.prefeitura.sp.gov.br/Projetos/ie/anonimosistema/detalhe.aspx?List=Lists/home\&Id entificador=Destaque1\&KeyField=Cursos $>$. Acesso em: set. 2014.

.Diagnóstico de Avaliação Formativa - Acesso pelo Portal da SME-SP.

2014d. Disponível em: <portalsme.prefeitura.sp.gov.br/Documentos/BibliPed/EnsFundMedio/CicloI/OrientaCurricula res_ExpectativasAprendizagem_EnsFnd_cicloI.pdf>. Acesso: set. 2014.

.Comunicado 566, de 30/03/2012. Convocação para formação Web Currículo e sua compreensão nas práticas educacionais. Cidade. Publicado no Diário Oficial do Estado de São Paulo, pág. 48, de 31/03/2012. Disponível em http://www.jusbrasil.com.br/diarios/35798102/dosp-cidade-31-03-2012-pg-48

Portaria 5792/09, de Dezembro de 2009. Define normas complementares e procedimentos para a implementação do "Programa Nas Ondas do Rádio", nas Escolas Municipais de São Paulo. Disponível em: http://www3.prefeitura.sp.gov.br/cadlem/secretarias/negocios_juridicos/cadlem/integra.asp?alt $=15122009 \mathrm{P} \% 20057922009 \mathrm{SME} \% 20 \% 20 \% 20 \% 20 \% 20 \% 20 \% 20 \% 20 \% 20 \&$ secr $=29 \& \mathrm{depto}=$ 0\&descr tipo=PORTARIA. Último acesso: Jan/2016.

Orientações curriculares - Tecnologias de Informação e Comunicação Proposições de Expectativas de Aprendizagem para o Ensino Fundamental - Ciclo I Primeiro ao Quinto Ano. Ano 2007.

SÃO PAULO, SME; EDUCAREDE, Fundação Telefonica. Caderno de orientações didáticas: ler e escrever tecnologias na educação. 2006. Disponível em: <portalsme.prefeitura.sp.gov.br/documentos/BibliPed/Infoeduc/caderno_impresso.pdf>.

Acesso em: set. 2014.

SÃO PAULO, SME. Projeto Gênese - A Informática Chega ao Aluno da Escola Pública Municipal. 1992.

SCARDAMALIA, Marlene; et al. New Assessments and Environments for Knowledge Building. In GRIFFIN, Patrick; et al (org.). Assessment and Teaching of 21st Century Skills. Victoria/Austrália: Springer, 2012, pos. 6373 a 8396. (e-book)

SIERRA, Francisco. El legado de Gramsci. In SIERRA, Francisco. Introducción a la teoria de la comunicación educativa, Sevilla Editorial, MAD, 2000, p. 145-173.

SILVA, Jane R. Entrevista sobre as práticas de avaliação formativa nos laboratórios de Informática Educativa, da DOT/SME-SP. Outubro/2015. Gravação em MP3, cujas partes da transcrição encontram-se no Anexo F. Entrevista concedida a Luci Ferraz de Mello. 
SOARES, Ismar de Oliveira. Educomunicação: o conceito, o profissional, a aplicação contribuições para a reforma do ensino médio. São Paulo: Paulinas, 2011.

. Planejamento de Projetos de Gestão Comunicativa. In: COSTA, Maria Cristina Castilho (Org.). Gestão da Comunicação - Projetos de Intervenção. $1^{\text {a }}$ Ed. São Paulo: Paulinas, 2009.

. A Tutoria em EaD, na Perspectiva da Educomunicação, disponível em http://www.cca.eca.usp.br/node/74. Acesso em: 04/04/2009.

A mediação tecnológica nos espaços educativos: uma perspectiva educomunicativa. In: Comunicação \& Educação. p. 31-40. Ano. XII, n. 1. jan/abr, 2007.

- "EAD como prática educomunicativa: emoção e racionalidade operativa”. In: SILVA, Marco. Educação Online, Edições Loyola, São Paulo, 2003, p.89-103.

. Gestão da Comunicação e educação: caminhos da Educomunicação. In: Revista Comunicação \& Educação. São Paulo: ECA/USP/ Salesiana, n. 23, p. 16-25, jan./abr., 2002.

Educação a distância como prática educomunicativa: emoção e envolvimento na formação continuada de professores da rede pública. Revista USP, no. 55, São Paulo, Editora USP. 2002b.

Comunicação/Educação, a emergência de um novo campo e o perfil de seus profissionais, in Contato, Brasília, Ano I, N.I, jan./mar., 1999, pg. 19-74.

Cidade Nova, 1996. - Sociedade da Informação ou da Comunicação? São Paulo: Tecnologia da Informação e novos atores sociais. Revista Comunicação e Educação, no. 4, São Paulo, Moderna/ECA-USP, 1995.

Gestão da Comunicação no Espaço Educativo: possibilidades e limites de um novo campo profissional. Apostila.

STAKE, Robert E. A Arte da Investigação em Estudos de Caso. Thousand Oaks/CA: Sage Publications, 1995. Verificar (Stake pág. 121)

STALBERG, Margarete G. Entrevista sobre as práticas de avaliação formativa nos laboratórios de Informática Educativa, da DOT/SME-SP. Outubro/2015. Gravação em MP3, cujas partes da transcrição encontram-se no Anexo F. Entrevista concedida a Luci Ferraz de Mello.

TEIXEIRA, Anísio; ROCHA E SILVA, Maurício. Diálogo sobre a lógica do conhecimento. Rio de Janeiro: UFRJ, 2007.

TEIXEIRA, Maria Cecília Sanchez. Discursos pedagógico, mito e ideologia: o imaginário de Paulo Freire e Anísio Teixeira. Rio de Janeiro: Quartet, 2000. 
TILESTON, Donna Walker. What every parents should know about schools, standards, and high stakes tests. Thousand Oaks/ CA \& Londres/Inglaterra: Corwin \& Sage, 2006.

TORRES, C.; MORROW, Raymond. Reading Freire and Habermas - Critical Pedagogy and Transformative Social Change. N. York: Teachers College, 2002.

TOME, Douglas. Entrevista sobre as práticas de avaliação formativa nos laboratórios de Informática Educativa, da DOT/SME-SP. Outubro/2015. Gravação em MP3, cujas partes da transcrição encontram-se no Anexo F. Entrevista concedida a Luci Ferraz de Mello.

UNESCO Padrões de competências em TIC para Professores - Diretrizes de Implementação (Versão 1). Paris: UNESCO, 2009. Acesso em 01/2013. Disponível: http://unesdoc.unesco.org/images/0015/001562/156209por.pdf

VALDERRAMA H., Carlos Eduardo. Ciudadanía y Comunicación - Saberes, opiniones y haceres escolares. Bogotá: Siglo del Hombre Editores y Universidad Central, Instituto de Estudios Sociales Contemporáneos, 2007

VYGOTSKY, Lev S. Pensamento e da Linguagem. São Paulo: Martins Fontes, 2005.

WILIAM, Dylan. Embedded formative assessment. Bloomington: Solution Tree Press, 2011.

WILIAM, Dylan; LEAHY, Siobhán. Embedding Formative Assessment - Practical Techniques for K-12 Classrooms. West Palm Beach/FL/EUA: Learning Sciences International, 2015.

WILSON, Carolyn; et al (Org). Alfabetização midiática e informacional. Brasília: UNESCO/UFTM, 2013.

WOLTON, Dominique. É preciso salvar a comunicação. São Paulo: Paulus, 2006. Informar não é comunicar. Porto Alegre: Sulina, 2011.

YANKELOVICH, Daniel. The magic of dialogue: transforming conflict into cooperation. New York: Touchstone, 2001.

YIN, Robert K. Estudo de Caso - Planejamento e Métodos. Porto alegre: Bookman, 2005.

ZAALOUK, Malak. The Pedagogy of Empowerment - Community Schools as a Social Movement in Egypt. Cairo/New York: American University of Cairo, 2004.

ZABALA, Antoni; ARNAU, Laia. Como aprender e ensinar competências. Porto Alegre: Artmed, 2010. 


\section{ANEXOS}

\section{Anexo A - Exemplo de Aula Educom.Jt}

Aula sobre Debate Político na Escola, publicada na coluna Pais e Mestres, do Jornal da Tarde, do Grupo O Estado de S. Paulo, como parte das publicações do Projeto Educom.Jt, coordenado pelo Núcleo de Comunicação e Educação, ECA/USP, e o referido periódico.

\section{Anexo B - Rubricas DRE Campo Limpo}

Conjunto de rubricas desenvolvidas e/ou adotadas em projetos e programas da DRE Campo Limpo, incluindo a rubrica do Programa POIE 2012, e seus exemplos de derivações.

\section{Anexo C - Relatório DRE Campo Limpo}

Relatório Final da DRE Campo Limpo, sobre os resultados obtidos no Programa POIE 2012, desenvolvido pelos gestores Cristina Barroco e Ricardo, sem ao nome dos POIE participantes.

\section{Anexo D - Questionários e Respostas do Alunos}

Questionários e respectivas respostas, de alunos dos projetos A.3, B.1 e B.4.

\section{Anexo E - Descritivos Técnicos dos Projetos Estudados}


Descritivo da estrutura de cada um dos projetos estudados.

\section{Anexo F - Rubricas dos Projetos}

Rubricas de todos os projetos estudados nesta pesquisa empírica.

\section{Anexo G - Entrevistas}

Partes das Entrevistas Realizadas com os POIE e Gestores

\section{Anexo H - Categorias Temáticas e Respectivos Subtemas: Aproximações Conceituais}

\section{Possíveis}

\section{Anexo I - Autorizações}

I.1 - Autorização Secretaria Municipal de Educação de São Paulo

I.2 - Autorização EMEF Prof. Rivadávia Marques Junior

I.3 - Autorização EMEF Des. Achilles de Oliveira Ribeiro

I.4 - Autorização Cristina Barroco Massei Fernandes

I.5 - Autorização Margarete Giveres Stalberg

I.6 - Autorização José Rosemberg

I.7 - Autorização Douglas Ferreira Tomé

I.8 - Autorização Nádia Melzer Bariviera

I.9 - Autorização José Rosemberg (Projetos B.1 e B.2)

I.10 - Autorização Maria Helena (Projeto B.3)

I.11 - Autorização Nágila Polido (Projeto B.3)

I.12 - Autorização Gislaine Batista Munhoz (Projeto B.4)

I.13 - Autorização Jane Reolo Silva (Gestora Núcleo de Informática Educativa 2012 a 2014) 


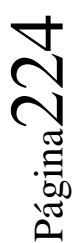




\section{Anexo A - Sugestão de Aula Projeto Educom.Jt}

Coluna Pais \& Mestres, Jornal da Tarde, Grupo O Estado de S. Paulo, 26/09/2006.

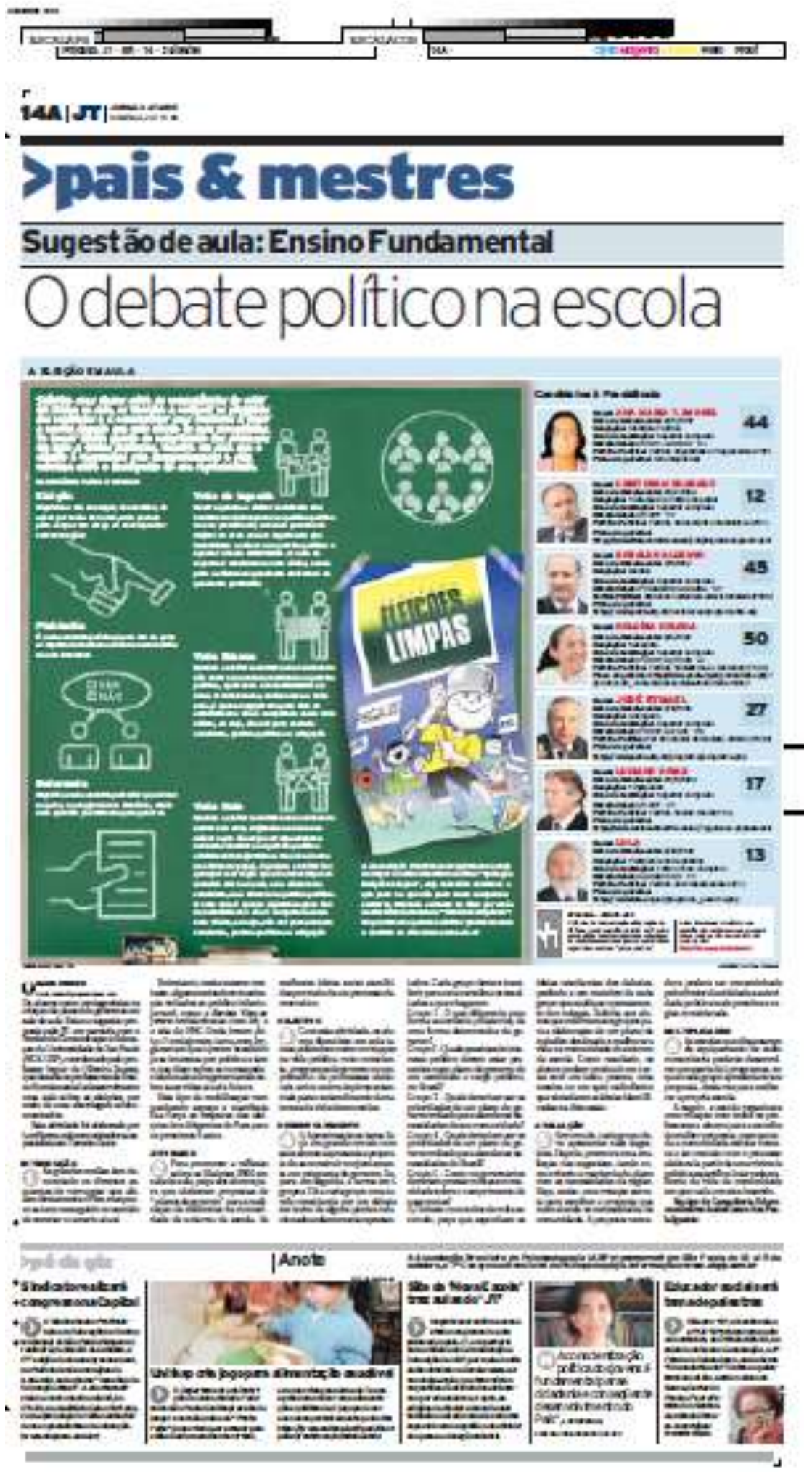




\section{Anexo B - Rubrica DRE Campo Limpo}

\section{Anexo B.1: Rubrica AUTOAVALIAÇÃ̃ POIE}

Elaborada pelo Grupo Colaborativo de Gestores de DRE, durante a formação em avaliação formativa dos gestores de DRE, na DOT-e / SME-SP (2011): Versão Final (adotada no Programa POIE 2012)

\begin{tabular}{|c|c|c|c|c|}
\hline ITEM & Confortável & Estável & Moderado & Avançado \\
\hline $\begin{array}{l}\text { 1. Colaboração com } \\
\text { tecnologia }\end{array}$ & $\begin{array}{l}\text { Nunca utiliza tecnologia para o } \\
\text { aluno expor ideia, conhecer as } \\
\text { ideias dos colegas e discuti-las; } \\
\text { Ou acha que simplesmente } \\
\text { publicar Blog, Páginas e Sites } \\
\text { próprios ou da U.E., usar o } \\
\text { Twitter, Facebook, MSN, } \\
\text { ORKUT e outros já é } \\
\text { colaboração. }\end{array}$ & $\begin{array}{l}\text { Utiliza ambientes virtuais para } \\
\text { o aluno expor ideias, conhecer } \\
\text { as ideias dos outros e comentar. }\end{array}$ & $\begin{array}{l}\text { Utiliza ambientes virtuais para } \\
\text { o aluno expor ideias, conhecer, } \\
\text { comentar e contra-argumentar } \\
\text { as ideias dos outros; utiliza } \\
\text { recursos e ferramentas para que } \\
\text { o aluno amplie repertório sobre } \\
\text { sua } 1^{\mathrm{a}} \text { ideia e as dos colegas. }\end{array}$ & $\begin{array}{l}\text { Utiliza ambientes virtuais para } \\
\text { o aluno expor suas ideias } \\
\text { individualmente, propõe que } \\
\text { conheça e comente a ideia do } \\
\text { outro, promove a participação } \\
\text { de todos; debate; problematiza, } \\
\text { sintetiza para que os alunos } \\
\text { possam chegar a conclusões e } \\
\text { posicionamentos e a atividade } \\
\text { não seja esvaziada de sentido. }\end{array}$ \\
\hline $\begin{array}{l}\text { 2. Atividade } \\
\text { tecnologia }\end{array}$ & $\begin{array}{l}\text { A tecnologia é usada de } \\
\text { maneira forçada, mesmo } \\
\text { quando não seria necessária; } \\
\text { Ou faz atividades só para } \\
\text { apropriação do software e } \\
\text { replicar as atividades } \\
\text { desenvolvidas em sala de aula; } \\
\text { ou usa tecnologia por modismo, } \\
\text { para dizer que faz e que está } \\
\text { sempre em consonância com os } \\
\text { avanços tecnológicos; ou a }\end{array}$ & $\begin{array}{l}\text { Utiliza as TIC para o aluno } \\
\text { pesquisar para ampliar ideias } \\
\text { próprias e/ou do grupo; } \\
\text { comunicar-se por meio de } \\
\text { diferentes } \\
\text { midiáticas, em dinguagens } \\
\text { ambientes virtuais interativos e } \\
\text { colaborativos; publicar e } \\
\text { socializar produções finais de } \\
\text { atividades e projetos; estimular } \\
\text { a autoria e o protagonismo dos }\end{array}$ & $\begin{array}{l}\text { Propõe atividades de cunho } \\
\text { individual e/ou coletivo de } \\
\text { modo que o aluno possa decidir } \\
\text { qual a(s) tecnologia(s) mais } \\
\text { adequada para a elaboração do } \\
\text { seu produto; estimula o } \\
\text { compartilhamento das } \\
\text { produções entre os alunos para } \\
\text { a melhoria de ideias e/ou } \\
\text { solução de problemas } \\
\text { apresentados nas etapas de }\end{array}$ & $\begin{array}{l}\text { Propõe a convergência de } \\
\text { diferentes mídias e ambientes } \\
\text { virtuais para a produção, } \\
\text { comunicação e publicação de } \\
\text { propostas que evidenciem a } \\
\text { autoria e o protagonismo do } \\
\text { aluno; } \\
\text { compropore } \\
\text { produções entre os alunos de } \\
\text { outras escolas e comunidades } \\
\text { para intercâmbios e processos }\end{array}$ \\
\hline
\end{tabular}




\begin{tabular}{|c|c|c|c|c|}
\hline & $\begin{array}{l}\text { pesquisa está centrada somente } \\
\text { nos temas propostos pelos } \\
\text { professores das diferentes áreas } \\
\text { do conhecimento ou conduzida } \\
\text { de modo aleatório. }\end{array}$ & alunos. & $\begin{array}{l}\text { elaboração do produto; propõe } \\
\text { o uso diferentes mídias para } \\
\text { registro do processo de } \\
\text { elaboração do produto. }\end{array}$ & de melhoria de ideias; \\
\hline ITEM & Confortável & Estável & Moderado & Avançado \\
\hline $\begin{array}{lr}\text { 3. Promove } & \text { a } \\
\text { construção } & \text { do } \\
\text { conhecimento } & \end{array}$ & $\begin{array}{l}\text { Propõe atividades de produção } \\
\text { individual ou em grupo em } \\
\text { ambiente virtual, mas o aluno } \\
\text { não consegue sair do nível da } 1^{\text {a }} \\
\text { ideia }\end{array}$ & $\begin{array}{l}\text { Propõe atividade de pesquisa e } \\
\text { de compartilhamento de ideias } \\
\text { para ampliação de repertório } \\
\text { relacionada à } 1^{\text {a }} \text { ideia do aluno; } \\
\text { estimula o grupo a comentar, } \\
\text { debater, avaliar, criticar para a } \\
\text { melhoria de ideia, por meio de } \\
\text { chat, fórum, blog, wiki e outros } \\
\text { recursos; }\end{array}$ & $\begin{array}{l}\text { Propõe a produção coletiva } \\
\text { colaborativa partindo antes das } \\
\text { ideias e posicionamentos } \\
\text { individuais dos } \\
\text { compartilha as produções; } \\
\text { estimula o grupo a comentar, } \\
\text { debater, avaliar, criticar para a } \\
\text { melhoria das produções. }\end{array}$ & $\begin{array}{l}\text { Propõe a produção coletiva } \\
\text { colaborativa partindo antes das } \\
\text { ideias e posicionamentos } \\
\text { individuais dos alunos; } \\
\text { Incorpora o uso das TIC para } \\
\text { otimizar o tempo de cada aula e } \\
\text { atividade para que o aluno } \\
\text { possa lançar mão de recursos, } \\
\text { ferramentas, sites, redes sociais } \\
\text { para resolver problemas, expor } \\
\text { ideias, contextualizar, ampliar, } \\
\text { criticar ideias, buscar e propor } \\
\text { soluções de problemas com } \\
\text { autonomia. }\end{array}$ \\
\hline 4. Avaliação formativa & $\begin{array}{l}\text { Não faz nenhum tipo de } \\
\text { avaliação; Ou avalia o produto } \\
\text { final atribuindo um conceito: } \\
\text { NS, S ou P; }\end{array}$ & $\begin{array}{l}\text { Acompanha o processo de } \\
\text { desenvolvimento da proposta do } \\
\text { aluno presencial e a distância; } \\
\text { oferece devolutiva; orienta e } \\
\text { estimula a ampliação da } \\
\text { produção; o aluno faz sua } \\
\text { autoavaliação }\end{array}$ & $\begin{array}{l}\text { Cria rubricas de avaliação do } \\
\text { processo de desenvolvimento } \\
\text { dos alunos; apresenta as } \\
\text { rubricas para os alunos e } \\
\text { oferece } \\
\text { sistematicamente para o aluno } \\
\text { tendo como referência as } \\
\text { rubricas elaboradas; discute e }\end{array}$ & $\begin{array}{l}\text { Oferece devolutivas } \\
\text { sistematicamente para o aluno } \\
\text { tendo como referência as } \\
\text { rubricas elaboradas; discute e } \\
\text { orienta os alunos sobre processo } \\
\text { de avaliação formativa por meio } \\
\text { de rubricas; Propõe e elabora } \\
\text { junto com os alunos a avaliação }\end{array}$ \\
\hline
\end{tabular}




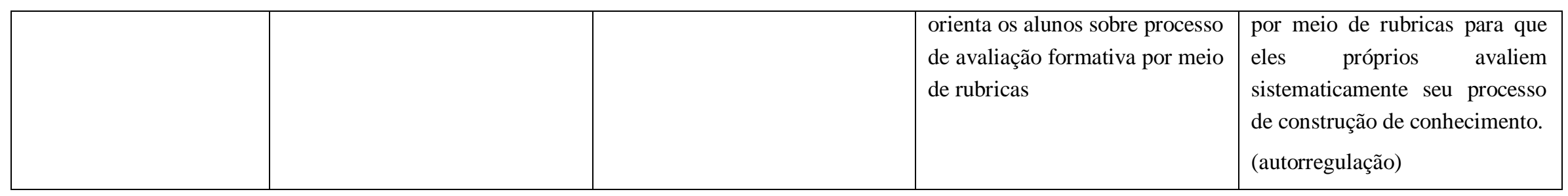

\section{Anexo B.2: Rubrica AUTOAVALIAÇÃO POIE - versão inicial / teste}

Elaborada pelo Grupo Colaborativo de Gestores de DRE, durante a formação em avaliação formativa dos gestores de DRE, na DOT-e / SME-SP (2011): $1^{\text {a }}$ versão

\begin{tabular}{|c|c|c|c|c|}
\hline ITEM & BÁSICO & INTERMEDIÁRIO & AVANÇADO & ESPECIALISTA \\
\hline $\begin{array}{l}\text { O trabalho promove a } \\
\text { construção do } \\
\text { conhecimento }\end{array}$ & $\begin{array}{l}\text { Não organiza as atividades em } \\
\text { forma de projeto. OU a } \\
\text { proposta de trabalho envolve } \\
\text { conhecimentos que a turma já } \\
\text { construiu. }\end{array}$ & $\begin{array}{l}\text { Não realiza as atividades como } \\
\text { um projeto, mas indica uma } \\
\text { sequência didática na } \\
\text { organização das atividades. OU } \\
\text { a proposta de trabalho envolve } \\
\text { conhecimentos que o aluno já } \\
\text { construiu, mas pode ser } \\
\text { desafiadora para uma parte da } \\
\text { turma. }\end{array}$ & $\begin{array}{l}\text { Organiza o trabalho como um } \\
\text { projeto, mas as fases podem } \\
\text { ficar mais claras; OU, a } \\
\text { proposta de trabalho promove a } \\
\text { construção do conhecimento, } \\
\text { mas não prevê a expansão } \\
\text { desse novo conhecimento } \\
\text { adquirido. }\end{array}$ & $\begin{array}{l}\text { Organiza as atividades como } \\
\text { um projeto, apresentando } \\
\text { claramente as propostas e o } \\
\text { objetivo final; OU, a proposta } \\
\text { de trabalho promove a } \\
\text { construção do conhecimento, } \\
\text { levando os alunos a ampliar seu } \\
\text { repertório, expandir as ideias do } \\
\text { grupo e publicar suas } \\
\text { considerações. }\end{array}$ \\
\hline
\end{tabular}




\section{Anexo B.3: Rubrica AUTOAVAliAÇÃo POIE - Versão Revisada / Atualizada DRE Campo Limpo, em}

\section{4}

Elaborada pelos gestores da DRE Campo Limpo, em parceria com POIE de suas unidades educacionais, com base na Rubrica 1, de 2012, aqui apresentada: Versão Revisada 2014.

\begin{tabular}{|c|c|c|c|c|}
\hline & Sentado & Em pé & Andando & Correndo \\
\hline $\begin{array}{l}\text { 1. Colaboração com } \\
\text { tecnologia }\end{array}$ & $\begin{array}{l}\text { Utiliza tecnologia de maneira } \\
\text { limitada, para o aluno expor } \\
\text { ideia, conhecer as ideias dos } \\
\text { colegas e discuti-las; Acha que } \\
\text { publicar Blog, Páginas e Sites } \\
\text { próprios ou da U.E., usar o } \\
\text { Twitter, Facebook, Edmodo, } \\
\text { Instagram, WhatsApp, e outros } \\
\text { já é colaboração. }\end{array}$ & $\begin{array}{l}\text { Utiliza diferentes ambientes } \\
\text { virtuais para o aluno expor } \\
\text { ideias, conhecer as ideias dos } \\
\text { outros e comentar. }\end{array}$ & $\begin{array}{l}\text { Utiliza diferentes ambientes } \\
\text { virtuais para o aluno expor } \\
\text { ideias, conhecer, comentar e } \\
\text { contra-argumentar as ideias dos } \\
\text { outros; utiliza recursos e } \\
\text { ferramentas para que o aluno } \\
\text { amplie o repertório sobre sua } 1^{\text {a }} \\
\text { ideia e as dos colegas. }\end{array}$ & $\begin{array}{l}\text { Utiliza ambientes virtuais para o } \\
\text { aluno expor suas ideias } \\
\text { individualmente, propõe que } \\
\text { conheça e comente a ideia do } \\
\text { outro, promove a participação de } \\
\text { todos, a interação e o debate; } \\
\text { problematiza, sintetiza para que } \\
\text { os alunos possam chegar a } \\
\text { conclusões e posicionamentos } \\
\text { que sirvam de sustentação para } \\
\text { sua atuação na sociedade. }\end{array}$ \\
\hline $\begin{array}{l}\text { 2. Atividade com } \\
\text { tecnologia }\end{array}$ & $\begin{array}{l}\text { O professor isoladamente } \\
\text { propõe os temas a serem } \\
\text { desenvolvidos pelos alunos. } \\
\text { Para isso, ensina apenas como } \\
\text { manusear o software; Uso da } \\
\text { tecnologia não como ferramenta } \\
\text { para uma aprendizagem, mas } \\
\text { sim como objetivo em si } \\
\text { mesma; Não há nenhum tipo de } \\
\text { diálogo do laboratório de } \\
\text { informática com as outras áreas }\end{array}$ & $\begin{array}{l}\text { Utiliza as TIC para o aluno } \\
\text { pesquisar para ampliar ideias } \\
\text { próprias e/ou do grupo; há } \\
\text { pouca produção } \\
\text { conhecimentos relevantes, mas } \\
\text { possibilita o uso das diferentes } \\
\text { linguagens midiáticas, em } \\
\text { ambientes virtuais interativos e } \\
\text { colaborativos (Edmodo, } \\
\text { Instagram, Padlet, Skype); } \\
\text { publica e socializa produções }\end{array}$ & $\begin{array}{l}\text { Propõe atividades de cunho } \\
\text { individual e/ou coletivo de } \\
\text { modo que o aluno possa decidir } \\
\text { qual a tecnologia mais adequada } \\
\text { para a elaboração do seu } \\
\text { produto; estimula } \\
\text { compartilhamento } \\
\text { produções entre os alunos para } \\
\text { a melhoria de ideias e/ou } \\
\text { solução de problemas } \\
\text { apresentados nas etapas de }\end{array}$ & $\begin{array}{l}\text { Propõe a convergência de } \\
\text { diferentes mídias e ambientes } \\
\text { virtuais para a produção, } \\
\text { comunicação e publicação de } \\
\text { propostas que evidenciem a } \\
\text { autoria e o protagonismo do } \\
\text { aluno; propõe } \\
\text { compartilhamento das produções } \\
\text { entre os alunos dos diferentes } \\
\text { ciclos, de outras escolas e } \\
\text { comunidades para intercâmbios e }\end{array}$ \\
\hline
\end{tabular}




\begin{tabular}{|c|c|c|c|c|}
\hline & $\begin{array}{l}\text { do conhecimento. O uso de } \\
\text { atividades com tecnologias não } \\
\text { considera os interesses e } \\
\text { conhecimentos prévios dos } \\
\text { estudantes. }\end{array}$ & $\begin{array}{l}\text { finais de atividades e projetos; } \\
\text { estimula a autoria e o } \\
\text { protagonismo dos alunos. } \\
\text { Utiliza a pasta "compartilhada" } \\
\text { como local para armazenar as } \\
\text { pesquisas e para trocas de } \\
\text { informações. }\end{array}$ & $\begin{array}{l}\text { elaboração do produto; propõe } \\
\text { o uso de diferentes mídias para } \\
\text { registro do processo de } \\
\text { elaboração do produto. }\end{array}$ & $\begin{array}{l}\text { processos de melhoria de ideias. } \\
\text { O aluno pode decidir qual a } \\
\text { tecnologia mais adequada para a } \\
\text { elaboração do seu produto. }\end{array}$ \\
\hline ITEM & Confortável & Estável & Moderado & Avançado \\
\hline $\begin{array}{lr}\text { 3. Promove } & \text { a } \\
\text { construção } & \text { do } \\
\text { conhecimento } & \end{array}$ & $\begin{array}{l}\text { Direciona atividades de } \\
\text { produção individual ou em } \\
\text { grupo em ambiente virtual, mas } \\
\text { o aluno não apresenta avanços a } \\
\text { partir da ideia inicial. }\end{array}$ & $\begin{array}{l}\text { Propõe atividade de pesquisa e } \\
\text { de compartilhamento de ideias } \\
\text { para ampliação de repertório } \\
\text { relacionada à } 1^{\text {a }} \text { ideia do aluno; } \\
\text { estimula o grupo a comentar, } \\
\text { debater, avaliar, criticar para a } \\
\text { melhoria de ideia, por meio de } \\
\text { blog, wiki e outros recurso. }\end{array}$ & $\begin{array}{l}\text { Propõe a produção coletiva } \\
\text { colaborativa partindo antes das } \\
\text { ideias e posicionamentos } \\
\text { individuais dos alunos; } \\
\text { compartilha as produções; } \\
\text { estimula o grupo a comentar, } \\
\text { debater, avaliar, criticar para a } \\
\text { melhoria das produções. }\end{array}$ & $\begin{array}{l}\text { Propõe a produção coletiva } \\
\text { colaborativa partindo antes das } \\
\text { ideias e posicionamentos } \\
\text { individuais dos alunos; Incorpora } \\
\text { o uso das TIC para otimizar o } \\
\text { tempo de cada aula e atividade } \\
\text { para que o aluno possa lançar } \\
\text { mão de recursos, ferramentas, } \\
\text { sites, redes sociais para resolver } \\
\text { problemas, expor ideias, } \\
\text { contextualizar, ampliar, criticar } \\
\text { ideias, buscar e propor soluções } \\
\text { de problemas com autonomia. }\end{array}$ \\
\hline 4. Avaliação formativa & $\begin{array}{l}\text { Não faz nenhum tipo de } \\
\text { avaliação; OU avalia o produto } \\
\text { final atribuindo um conceito no } \\
\text { ciclo de alfabetização e uma } \\
\text { nota nos ciclos interdisciplinar e } \\
\text { autoral. }\end{array}$ & $\begin{array}{l}\text { Acompanha o processo de } \\
\text { desenvolvimento da proposta do } \\
\text { aluno presencial e a distância; } \\
\text { oferece devolutiva; orienta e } \\
\text { estimula a ampliação da } \\
\text { produção; Estimula o aluno } \\
\text { com relação à importância de } \\
\text { realizar a autoavaliação. }\end{array}$ & $\begin{array}{l}\text { Cria rubricas de avaliação do } \\
\text { processo de desenvolvimento } \\
\text { dos alunos; apresenta-as para os } \\
\text { alunos e oferece devolutivas } \\
\text { sistematicamente, tendo como } \\
\text { referência as rubricas } \\
\text { elaboradas; discute e orienta os } \\
\text { alunos sobre processo de } \\
\text { avaliação formativa por meio de }\end{array}$ & $\begin{array}{l}\text { Oferece } \\
\text { sistematicamente para o aluno } \\
\text { tendo como referência as rubricas } \\
\text { elaboradas; discute e orienta os } \\
\text { alunos sobre processo de } \\
\text { avaliação formativa por meio } \\
\text { delas; Propõe e elabora junto com } \\
\text { os alunos a avaliação por meio de } \\
\text { rubricas para que eles próprios } \\
\text { avaliem sistematicamente seu }\end{array}$ \\
\hline
\end{tabular}




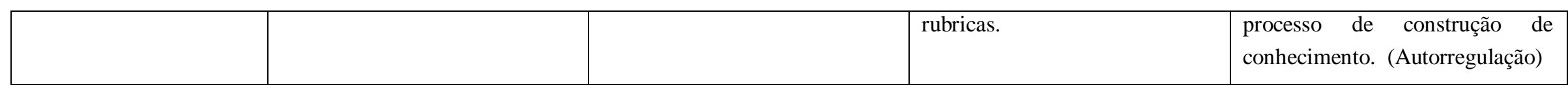

\section{Anexo B.4: Rubrica Projetos de Rádio, dos Laboratórios de Informática Educativa, desenvolvida pela}

\section{DRE Campo Limpo}

Exemplo do que poderia ser uma rubrica para ser aplicada aos projetos de rádio, desenvolvidos nos LIE, das unidades educacionais da DRE Campo Limpo (desenvolvida entre 2012 e 2014).

\begin{tabular}{|c|c|c|c|c|}
\hline & ATARI & PS1 & PS2 & XBOX \\
\hline $\begin{array}{l}\text { PROTAGONISMO } \\
\text { DOS ALUNOS }\end{array}$ & $\begin{array}{l}\text { Faz o que o professor orienta } \\
\text { na rádio. }\end{array}$ & $\begin{array}{l}\text { Faz o que o professor orienta e } \\
\text { tem ideias para melhorar a } \\
\text { rádio. }\end{array}$ & $\begin{array}{l}\text { Faz o que o professor orienta, } \\
\text { tem ideias para melhorar a rádio } \\
\text { e apresenta as ideias para } \\
\text { professor e parceiros. }\end{array}$ & $\begin{array}{l}\text { Faz o que o professor orienta, tem } \\
\text { ideias para melhorar a rádio, } \\
\text { apresenta as ideias para o } \\
\text { professor e parceiros e se } \\
\text { mobiliza para que a rádio dê } \\
\text { certo. }\end{array}$ \\
\hline COLABORAÇÃ̃O & $\begin{array}{l}\text { Realiza atividades propostas } \\
\text { de modo individualizado. }\end{array}$ & $\begin{array}{l}\text { Atua de modo pouco } \\
\text { colaborativo na elaboração do } \\
\text { produto final. Não consegue } \\
\text { mobilizar quem não está se } \\
\text { envolvendo. }\end{array}$ & $\begin{array}{l}\text { Atua de modo colaborativo, } \\
\text { com a tecnologia ou sem ela, na } \\
\text { elaboração do produto final, } \\
\text { dando ideias, problematizando, } \\
\text { sintetizando, levando o grupo a } \\
\text { conclusões e posicionamentos. } \\
\text { Ainda não consegue mobilizar } \\
\text { quem não está se envolvendo. }\end{array}$ & $\begin{array}{l}\text { Atua de modo colaborativo, com } \\
\text { a tecnologia ou sem ela, na } \\
\text { elaboração do produto final, } \\
\text { dando ideias, problematizando, } \\
\text { sintetizando, levando o grupo a } \\
\text { conclusões e posicionamentos. } \\
\text { Consegue mobilizar quem não } \\
\text { estava se envolvendo e incorpora } \\
\text { a capacidade de motivar o grupo. }\end{array}$ \\
\hline CULTURA DE PAZ & $\begin{array}{llr}\text { Trabalha de } & & \text { forma } \\
\text { individualizada, } & & \text { sem } \\
\text { compromisso } & \text { com } & \text { a } \\
\text { disseminação da } & \text { cultura } & \text { de }\end{array}$ & $\begin{array}{l}\text { Trabalha de forma } \\
\text { individualizada, mas já } \\
\text { demonstra preocupação com a } \\
\text { disseminação da cultura de paz } \\
\text { na escola. }\end{array}$ & $\begin{array}{l}\text { Trabalha de forma coletiva } \\
\text { organizando ações } \\
\text { disseminem a cultura de paz na } \\
\text { escola. }\end{array}$ & $\begin{array}{l}\text { Trabalha de forma coletiva } \\
\text { organizando ações que } \\
\text { disseminem a cultura de paz na } \\
\text { escola, buscando incluir os alunos } \\
\text { que não se envolvem. }\end{array}$ \\
\hline
\end{tabular}




\begin{tabular}{|c|c|c|c|c|c|}
\hline & & paz na escola. & & & \\
\hline $\begin{array}{l}\text { COMPETÊNCIA } \\
\text { LEITORA } \\
\text { ESCRITORA }\end{array}$ & $\mathbf{E}$ & $\begin{array}{l}\text { Pesquisa/ produz os textos } \\
\text { para os programas de rádio. }\end{array}$ & $\begin{array}{l}\text { Pesquisa/ produz os textos para } \\
\text { os programas de rádio e faz a } \\
\text { gravação. }\end{array}$ & $\begin{array}{l}\text { Pesquisa/ produz os textos para } \\
\text { os programas de rádio, faz a } \\
\text { gravação e cuida para que o } \\
\text { texto seja adequado ao ambiente } \\
\text { escolar. }\end{array}$ & $\begin{array}{l}\text { Pesquisa/ produz os textos para os } \\
\text { programas de rádio, faz a } \\
\text { gravação, cuida para que o texto } \\
\text { seja adequado ao ambiente } \\
\text { escolar e contribua com o } \\
\text { crescimento cultural dos ouvintes. }\end{array}$ \\
\hline
\end{tabular}

\section{Anexo B.5: Rubrica Projetos de Matemática, dos Laboratórios de Informática Educativa, desenvolvida}

\section{pela DRE Campo Limpo}

Exemplo do que poderia ser uma rubrica para ser aplicada a projetos de conteúdo de matemática, desenvolvidos nos LIE, das unidades educacionais da DRE Campo Limpo (desenvolvida entre 2012 e 2014).

\begin{tabular}{|c|c|c|c|c|}
\hline & Estudante 1 & Ninja 2 & Treinador de Ninja 3 & Mestre 4 \\
\hline Aprendizagem & $\begin{array}{l}\text { Só consigo resolver problemas } \\
\text { com a ajuda de um colega ou } \\
\text { da professora. }\end{array}$ & $\begin{array}{l}\text { Já consigo resolver alguns } \\
\text { problemas sozinho e outros só } \\
\text { com a ajuda de um colega ou } \\
\text { da professora. }\end{array}$ & $\begin{array}{l}\text { Já consigo resolver problemas } \\
\text { sem ajuda. }\end{array}$ & $\begin{array}{l}\text { Já consigo resolver os vários tipos } \\
\text { de problemas apresentados pela } \\
\text { professora sem ajuda. }\end{array}$ \\
\hline Colaboração & $\begin{array}{l}\text { Realizei as atividades sozinho, } \\
\text { mas fiquei com algumas } \\
\text { dúvidas. }\end{array}$ & $\begin{array}{l}\text { Participei das atividades, com } \\
\text { ajuda dos colegas. }\end{array}$ & $\begin{array}{l}\text { Participei das atividades e } \\
\text { ajudei os colegas. }\end{array}$ & $\begin{array}{l}\text { Participei das atividades, pedi } \\
\text { ajuda quando tinha dúvidas e } \\
\text { também ajudei os colegas. }\end{array}$ \\
\hline
\end{tabular}




\section{Anexo B.6: Rubrica Projetos de Promoção de Pensamento e Aprendizagem Conjunta e Reflexiva, para}

\section{sugestão para aplicação na Educação Infantil, desenvolvida pela DRE Campo Limpo (entre 2012 e 2014)}

Meta de SME/Informática Educativa: 100\% das escolas de Educação Infantil - EMEI tenham, no mínimo, um professor mediador de mídias no universo infantil.

Objetivo: Incorporar as linguagens midiáticas nas próprias rotinas da Educação Infantil, em propostas de atividades que já estão sendo desenvolvidas pelos professores cotidianamente.

\begin{tabular}{|c|c|c|c|c|}
\hline CRITÉRIOS & Confortável & Estável & Moderado & Avançado \\
\hline 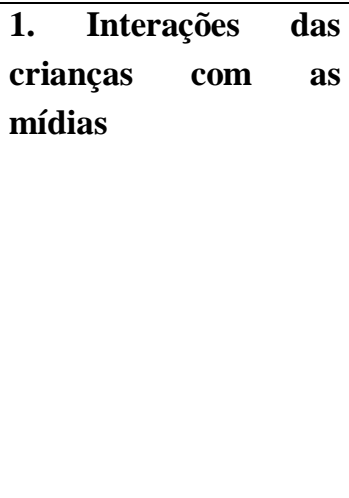 & $\begin{array}{l}\text { As propostas de atividades com } \\
\text { as mídias são usadas como pano } \\
\text { de fundo. Ex.: ver um vídeo, } \\
\text { escutar uma música, apresentar } \\
\text { um Power Point. }\end{array}$ & $\begin{array}{l}\text { As mídias são utilizadas para } \\
\text { interação das crianças no teatro, } \\
\text { dança, karaokê, videokê, campo } \\
\text { dirigido... }\end{array}$ & $\begin{array}{l}\text { As mídias são utilizadas para a } \\
\text { criança expor ideias, conhecer as } \\
\text { ideias dos outros e comentar. } \\
\text { OU as mídias são utilizadas } \\
\text { como narrativa oral e escrita dos } \\
\text { repertórios oferecidos } \\
\text { reelaborados e criativos. As } \\
\text { mídias são utilizadas sob o ponto } \\
\text { de vista do olhar da criança. }\end{array}$ & $\begin{array}{l}\text { Ambientes virtuais são utilizados } \\
\text { para o aluno expor suas ideias } \\
\text { individualmente, conhecer e } \\
\text { comentar a ideia do outro. OU A } \\
\text { atividade promove a participação } \\
\text { de todos; o debate, a } \\
\text { problematização. OU as mídias } \\
\text { são utilizadas para promover } \\
\text { interação e colaboração com } \\
\text { diferentes e múltiplas linguagens. }\end{array}$ \\
\hline $\begin{array}{l}\text { 2. Atividade com } \\
\text { tecnologia }\end{array}$ & $\begin{array}{l}\text { As mídias são utilizadas como } \\
\text { recursos de apoio em diferentes } \\
\text { linguagens. }\end{array}$ & $\begin{array}{l}\text { As mídias são utilizadas para } \\
\text { exploração de diferentes e } \\
\text { múltiplas linguagens. }\end{array}$ & $\begin{array}{l}\text { As mídias são utilizadas para } \\
\text { exploração e o registro da } \\
\text { atividade em } \quad \text { diferentes e } \\
\text { múltiplas linguagens. }\end{array}$ & $\begin{array}{l}\text { As mídias são utilizadas para } \\
\text { exploração e o registro da } \\
\text { atividade em } \\
\text { múltiplas } \\
\text { evidenciando a autoria entes e } \\
\text { protagonismo do aluno: criar } \\
\text { narrativas em grupo; construir } \\
\text { sons colaborativamente, interagir } \\
\text { com diferentes espaços e } \\
\text { programas (softwares) no }\end{array}$ \\
\hline
\end{tabular}




\begin{tabular}{|c|c|c|c|c|}
\hline & & & & computador). \\
\hline CRITÉRIO & Confortável & Estável & Moderado & Avançado \\
\hline $\begin{array}{lr}\begin{array}{l}\text { 3. Promove } \\
\text { construção }\end{array} & \text { a } \\
\text { conhecimento } & \end{array}$ & $\begin{array}{l}\text { As crianças se apropriam das } \\
\text { músicas e vídeos como ouvintes. } \\
\text { OU as práticas com artes } \\
\text { gráficas estão associadas a } \\
\text { histórias, temas e datas } \\
\text { comemorativas. }\end{array}$ & $\begin{array}{l}\text { As crianças exploram, associam } \\
\text { sons e imagens por meio das } \\
\text { linguagens midiáticas. OU } \\
\text { interagem com as mídias por } \\
\text { meio de narrativas, canto, } \\
\text { interpretações. OU as práticas } \\
\text { com artes gráficas são parte do } \\
\text { processo de construção de uma } \\
\text { história, peça teatral. }\end{array}$ & $\begin{array}{l}\text { A atividade propõe a produção } \\
\text { colaborativa, construção de } \\
\text { ideias e posicionamentos } \\
\text { individuais dos alunos dirigida } \\
\text { pelo professor. OU estimula o } \\
\text { grupo a comentar, debater, } \\
\text { avaliar, criticar, escolher } \\
\text { produções para compor uma } \\
\text { atividade. }\end{array}$ & $\begin{array}{l}\text { A atividade propõe a produção } \\
\text { colaborativa partindo do } \\
\text { protagonismo das crianças e } \\
\text { mediada pelo professor. OU A } \\
\text { produção evidencia } \\
\text { autonomia da criança no uso de } \\
\text { múltiplas linguagens e escolha de } \\
\text { mídias diferenciadas e /ou } \\
\text { convergentes. }\end{array}$ \\
\hline
\end{tabular}




\begin{tabular}{|c|c|c|c|c|}
\hline $\begin{array}{ll}4 . & \text { Avaliação } \\
\text { formativa } & \end{array}$ & $\begin{array}{l}\text { A atividade não prevê avaliação; } \\
\text { OU as avaliações são realizadas } \\
\text { apenas no final do ano. }\end{array}$ & $\begin{array}{l}\text { No desenvolvimento da proposta } \\
\text { do aluno fica evidente o } \\
\text { acompanhamento do professor } \\
\text { por meio de registros } \\
\text { videográficos ou imagéticos. OU } \\
\text { a proposta prevê, diagnósticos, } \\
\text { avaliações contínuas } \\
\text { devolutivas/orientações para o } \\
\text { aluno. }\end{array}$ & $\begin{array}{l}\text { A proposta prevê a auto } \\
\text { avaliação das crianças. OU a } \\
\text { proposta prevê devolutivas } \\
\text { sistemáticas para o aluno. OU os } \\
\text { registros videográficos, sonoros, } \\
\text { imagéticos... também são } \\
\text { representados por meio do } \\
\text { protagonismo infantil. }\end{array}$ & $\begin{array}{l}\text { A proposta prevê rubricas de } \\
\text { avaliação do professor no } \\
\text { processo de desenvolvimento dos } \\
\text { alunos. OU os registros } \\
\text { promovem a prospecção e as } \\
\text { intervenções mediadas pelo } \\
\text { professor. OU a criança tem a } \\
\text { autonomia da escolha, da criação } \\
\text { e recriação, da autoavaliação e } \\
\text { avaliação do grupo em suas } \\
\text { produções. }\end{array}$ \\
\hline
\end{tabular}




\section{Anexo B.7: Rubrica adotada em alguns projetos do Programa POIE 2012}

Texto de motivação à autoavaliação, no ThinkQuest: Meninos e meninas, vejam qual a sua classificação no desenvolvimento das atividades do projeto sustentabilidade: como classifica sua participação? Como você classifica sua participação no projeto Sustentabilidade? Para tanto observe a tabela abaixo:

\begin{tabular}{|c|c|c|c|c|}
\hline CRITÉRIOS & FUSCA & UNO MILLE & ECOSPORT & CAMARO AMARELO \\
\hline $\begin{array}{l}\text { Com projeto } \\
\text { sustentabilidade }\end{array}$ & $\begin{array}{l}\text { Não mudei de atitude diante dos } \\
\text { problemas encontrados no bairro, } \\
\text { pois não participei das } \\
\text { atividades. }\end{array}$ & $\begin{array}{l}\text { Aprendi algumas coisas, mas } \\
\text { não vejo como mudar algo no } \\
\text { meu dia-a-dia }\end{array}$ & $\begin{array}{l}\text { A partir das atividades que } \\
\text { participei, vou incorporar } \\
\text { algumas atitudes em prol da } \\
\text { sustentabilidade. }\end{array}$ & $\begin{array}{l}\text { Diante das atividades, não só } \\
\text { incorporei algumas mudanças de } \\
\text { atitudes como também tenho } \\
\text { condições de dar o testemunho de } \\
\text { como essa mudança é benéfica no } \\
\text { meu cotidiano }\end{array}$ \\
\hline $\begin{array}{l}\text { Os recursos } \\
\text { tecnológicos usados na } \\
\text { sala de informática }\end{array}$ & $\begin{array}{l}\text { Não desenvolvi nenhuma das } \\
\text { atividades propostas. }\end{array}$ & $\begin{array}{l}\text { Participei de algumas atividades, } \\
\text { mas não conclui nenhuma delas. }\end{array}$ & $\begin{array}{l}\text { Desenvolvi e conclui pelo menos } \\
\text { uma das atividades usando os } \\
\text { recursos, mas não tenho } \\
\text { segurança em usar os recursos } \\
\text { propostos na sala de informática } \\
\text { em outras atividades. }\end{array}$ & $\begin{array}{l}\text { Desenvolvi todas as atividades } \\
\text { propostas e tenho condições de } \\
\text { usar o Photoshop, GIMP, o Pivot, } \\
\text { Movie Maker em outros } \\
\text { trabalhos. }\end{array}$ \\
\hline
\end{tabular}




\section{Anexo C - Relatório Final das Autoavaliações dos POIE / DRE Campo Limpo}

Relatório Final da DRE Campo Limpo, sobre os resultados obtidos no Programa POIE 2012, desenvolvido pelos gestores Cristina Barroco e

Ricardo de Souza, sem ao nome dos POIE participantes.

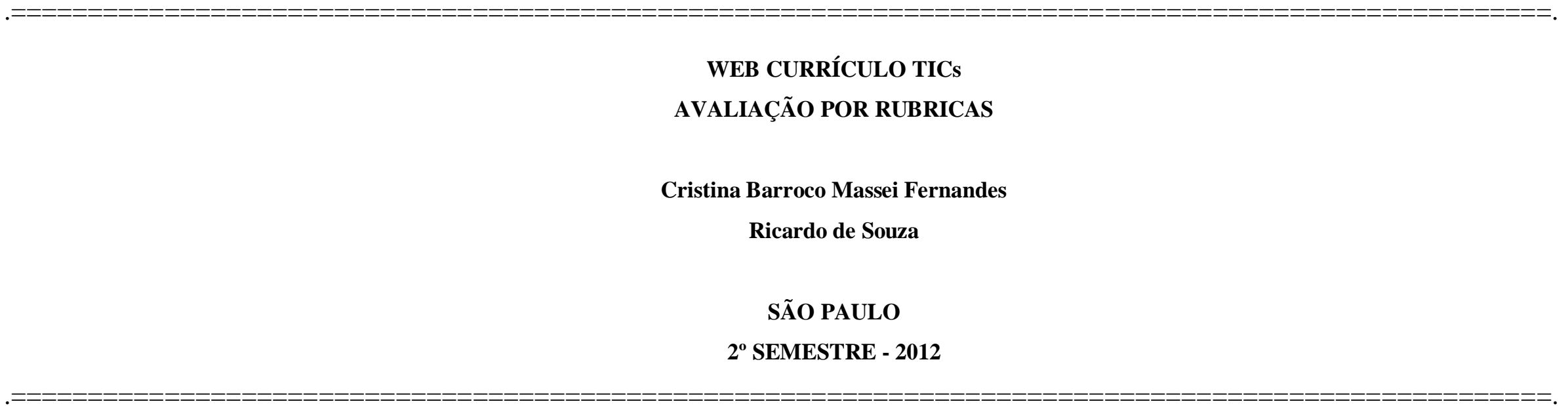

1. INTRODUÇÃO

De acordo com as orientações da equipe de Informática Educativa de SME e sua assessoria, o presente documento esboça o início de um processo de Avaliação Formativa do trabalho dos POIEs (Professores Orientadores de Informática Educativa) da DRE Campo Limpo.

Realizamos este processo de avaliação em duas etapas:

Etapa I: Durante a formação WEB Currículo realizada em 21 e 22/09/2012 solicitamos aos POIEs que realizassem a análise de um projeto desenvolvido no Laboratório de Informática seguindo a Rubrica de Avaliação criada pela equipe de Informática Educativa com a colaboração de todos os formadores das DREs. Esta análise ocorreu em duplas com o intuito de aproximar duas visões, a primeira sendo a do idealizador do projeto e a segunda de um par que observa de fora. Acreditamos que estas duas visões ajudem aos POIEs a afinarem o olhar ao proceder com a avaliação. 
Etapa II: Após a avaliação realizada pelos POIEs enunciada na Etapa I, nós, formadores da DRE, fazendo uso da Rubrica de Avaliação, realizamos uma análise dos projetos apresentados por estes profissionais disponibilizados no ambiente virtual de aprendizagem ThinkQuest (por meio de link ou através de relato). Vale ressaltar que alguns POIEs não disponibilizaram suas propostas, nestes casos não houve como avaliá-los.

A autoavaliação realizada pelos POIEs serve de indicador para o planejamento do próximo Encontro que ocorrerá nos dias 25 e 26/11/2012.

\section{ORGANIZAÇÃO DOS DADOS}

Com o propósito de registrar este processo avaliativo os dados são apresentados em tabelas organizadas por meio das legendas a seguir. A Legenda I indica os rótulos de avaliação. A Legenda II indica o nível de discrepância/concordância entre os pontos de vista dos POIEs e da DRE.

A Tabela 01 combina as informações contidas nas legendas I e II tomando por base dois pontos de observação: a visão do POIE (construída com um par durante o encontro) e a visão da DRE (olhar dos formadores da DRE Campo Limpo).

\section{LEGENDA I - NÍVEIS DE AVALIAÇÃO}

C - ConfortávelE - EstávelM - ModeradoA - Avançado

\section{LEGENDA II - NÍVEL DE DISCREPÂNCIA NA AVALIAÇÃo}

Letra (Nível de Avaliação Indicado) em Negrito: Os pontos de vista do POIE e da DRE são equivalentes.

Letra (Nível de Avaliação Indicado) Sublinhada: O ponto de vista do POIE diverge parcialmente do ponto de vista da DRE.

Letra (Nível de Avaliação Indicado) Sublinhada e em Itálico: O ponto de vista do POIE diverge totalmente do ponto de vista da DRE.

\section{LEGENDA III - IMPOSSIBILIDADE DE AVALIAR}

O POIE não disponibilizou os projetos para avaliação ou a síntese enviada não permitiu a nossa avaliação. 
3. LEVANTAMENTO DOS DADOS

TABELA 01 - PLANILHA DE AVALIAÇÃO DOS TRABALHOS DOS POIES

\begin{tabular}{|c|c|c|c|c|c|c|c|c|c|}
\hline \multirow[b]{2}{*}{ POIE } & \multirow[b]{2}{*}{$\begin{array}{c}\text { Ponto } \\
\text { De } \\
\text { Vista }\end{array}$} & \multicolumn{4}{|c|}{ AVALIAÇÃO SETEMBRO } & \multicolumn{4}{|c|}{ AVALIAÇÃO NOVEMBRO } \\
\hline & & 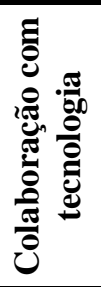 & 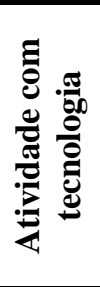 & 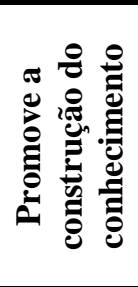 & 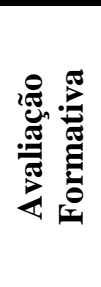 & 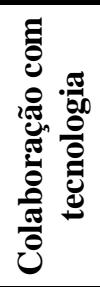 & 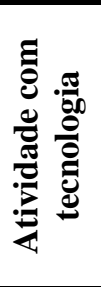 & 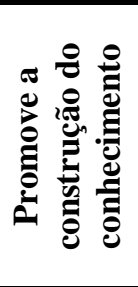 & 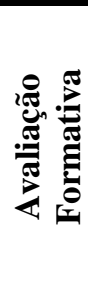 \\
\hline \multirow[t]{2}{*}{ (01) } & POIE & $\underline{\mathbf{E}}$ & $\mathbf{E}$ & $\underline{M}$ & $\mathbf{E}$ & $\underline{\mathbf{E}}$ & $\underline{\mathbf{E}}$ & $\mathbf{E}$ & $\mathbf{E}$ \\
\hline & DRE & $\mathbf{C}$ & $\mathbf{E}$ & $\mathbf{C}$ & $\mathbf{E}$ & $\mathbf{C}$ & $\mathbf{C}$ & $\mathbf{E}$ & $\mathbf{E}$ \\
\hline \multirow[t]{2}{*}{$(02)$} & POIE & $\underline{\mathbf{M}}$ & $\underline{A}$ & $\underline{A}$ & $\underline{M}$ & $\underline{\mathbf{C}}$ & $\mathbf{E}$ & $\underline{\mathbf{C}}$ & $\mathbf{C}$ \\
\hline & DRE & $\mathbf{E}$ & $\mathbf{C}$ & $\mathbf{C}$ & $\mathbf{C}$ & $\mathbf{E}$ & $\mathbf{E}$ & $\mathbf{E}$ & $\mathbf{C}$ \\
\hline \multirow[t]{2}{*}{ (03) } & POIE & - & $\square$ & - & घ & $\mathbf{\square}$ & - & $\mathbf{\square}$ & $\square$ \\
\hline & DRE & - & a & - & $\mathbf{\square}$ & - & - & $\mathbf{\square}$ & 口 \\
\hline \multirow[t]{2}{*}{ (04) } & POIE & $\underline{\mathbf{E}}$ & $\underline{\mathbf{M}}$ & $\underline{\mathbf{M}}$ & $\mathbf{E}$ & $\underline{\mathrm{C}}$ & $\mathbf{E}$ & $\mathbf{E}$ & $\mathbf{E}$ \\
\hline & DRE & $\mathbf{C}$ & $\mathbf{E}$ & $\mathbf{E}$ & $\mathbf{E}$ & $\mathbf{E}$ & $\mathbf{E}$ & $\mathbf{E}$ & $\mathbf{E}$ \\
\hline \multirow[t]{2}{*}{$(05)$} & POIE & $\mathbf{C}$ & $\mathbf{C}$ & $\mathbf{C}$ & $\mathbf{C}$ & $\mathbf{E}$ & $\mathbf{E}$ & $\mathbf{E}$ & $\mathbf{E}$ \\
\hline & DRE & $\mathbf{C}$ & $\mathbf{C}$ & $\mathbf{C}$ & $\mathbf{C}$ & $\mathbf{E}$ & $\mathbf{E}$ & $\mathbf{E}$ & $\mathbf{E}$ \\
\hline (06) & POIE & घ & - & - & घ & - & - & a & - \\
\hline
\end{tabular}




\begin{tabular}{|c|c|c|c|c|c|c|c|c|c|}
\hline & DRE & - & - & - & - & - & - & - & - \\
\hline \multirow[t]{2}{*}{ (07) } & POIE & M & $\mathbf{E}$ & M & $\mathbf{E}$ & - & - & - & - \\
\hline & DRE & - & - & - & - & - & - & - & - \\
\hline \multirow[t]{2}{*}{ (08) } & POIE & - & - & - & - & - & - & - & - \\
\hline & DRE & - & - & - & - & - & - & - & - \\
\hline \multirow[t]{2}{*}{ (09) } & POIE & C & $\mathbf{E}$ & C & $\mathbf{E}$ & $\mathbf{M}$ & $\mathbf{E}$ & $\mathbf{E}$ & $\mathbf{E}$ \\
\hline & DRE & C & $\mathbf{E}$ & C & $\mathbf{E}$ & $\mathbf{M}$ & $\mathbf{E}$ & $\mathbf{E}$ & $\mathbf{E}$ \\
\hline \multirow[t]{2}{*}{ (10) } & POIE & $\underline{\mathbf{M}}$ & $\underline{\mathbf{E}}$ & $\underline{\mathbf{M}}$ & $\mathbf{E}$ & C & C & $\mathbf{E}$ & $\mathbf{E}$ \\
\hline & DRE & $\mathbf{E}$ & C & $\mathbf{E}$ & $\mathbf{E}$ & C & C & $\mathbf{E}$ & $\mathbf{E}$ \\
\hline \multirow[t]{2}{*}{ (11) } & POIE & - & - & - & - & $\underline{\mathbf{E}}$ & $\mathbf{E}$ & $\underline{\mathbf{E}}$ & $\underline{\mathbf{E}}$ \\
\hline & DRE & - & - & - & - & C & $\mathbf{E}$ & C & C \\
\hline \multirow[t]{2}{*}{ (12) } & POIE & M & $\underline{\mathbf{M}}$ & $\mathbf{E}$ & $\mathbf{E}$ & - & - & - & - \\
\hline & DRE & M & $\mathbf{E}$ & $\mathbf{E}$ & $\mathbf{E}$ & $\mathbf{M}$ & $\mathbf{E}$ & $\mathbf{E}$ & $\mathbf{E}$ \\
\hline \multirow[t]{2}{*}{ (13) } & POIE & $\underline{\mathbf{E}}$ & $\mathbf{E}$ & $\underline{\mathbf{E}}$ & $\mathbf{E}$ & $\mathbf{M}$ & $\mathbf{E}$ & $\mathbf{M}$ & $\mathbf{E}$ \\
\hline & DRE & $\mathbf{M}$ & $\mathbf{E}$ & M & $\mathbf{E}$ & $\mathbf{M}$ & $\mathbf{E}$ & M & $\mathbf{E}$ \\
\hline
\end{tabular}




\begin{tabular}{|c|c|c|c|c|c|c|c|c|c|}
\hline \multirow[t]{2}{*}{ (14) } & POIE & $\underline{\mathbf{M}}$ & $\mathbf{E}$ & $\underline{\mathbf{M}}$ & $\mathbf{E}$ & $\mathbf{E}$ & $\mathbf{E}$ & $\mathbf{E}$ & $\mathbf{E}$ \\
\hline & DRE & $\mathbf{E}$ & $\mathbf{E}$ & $\mathbf{E}$ & $\mathbf{E}$ & $\mathbf{E}$ & $\mathbf{E}$ & $\mathbf{E}$ & $\mathbf{E}$ \\
\hline \multirow[t]{2}{*}{ (15) } & POIE & I & I & I & . & . & I & I & . \\
\hline & DRE & - & $\square$ & $\square$ & - & - & - & - & - \\
\hline \multirow[t]{2}{*}{ (16) } & POIE & $\underline{\mathbf{M}}$ & $\mathbf{E}$ & $\underline{\mathbf{M}}$ & $\mathbf{E}$ & $\mathbf{E}$ & $\mathbf{E}$ & $\underline{\mathbf{M}}$ & $\mathbf{E}$ \\
\hline & DRE & $\mathbf{E}$ & $\mathbf{E}$ & $\bar{E}$ & $\mathbf{E}$ & $\mathbf{E}$ & $\mathbf{E}$ & $\mathbf{E}$ & $\mathbf{E}$ \\
\hline \multirow[t]{2}{*}{ (17) } & POIE & $\underline{\mathbf{E}}$ & $\mathbf{E}$ & $\underline{M}$ & $\underline{\underline{M}}$ & च & $\square$ & . & च \\
\hline & DRE & C & $\mathbf{E}$ & C & $\mathbf{E}$ & C & $\mathbf{E}$ & C & $\mathbf{E}$ \\
\hline \multirow[t]{2}{*}{ (18) } & POIE & M & $\mathbf{E}$ & $\mathbf{E}$ & $\mathbf{E}$ & $\underline{\mathbf{M}}$ & $\mathbf{E}$ & $\mathbf{E}$ & $\mathbf{E}$ \\
\hline & DRE & $\mathbf{M}$ & $\mathbf{E}$ & $\mathbf{E}$ & $\mathbf{E}$ & $\mathbf{E}$ & $\mathbf{E}$ & $\mathbf{E}$ & $\mathbf{E}$ \\
\hline \multirow[t]{2}{*}{ (19) } & POIE & I & - & - & - & $\underline{\mathbf{M}}$ & $\underline{\mathbf{M}}$ & $\underline{\mathbf{A}}$ & $\underline{\underline{M}}$ \\
\hline & DRE & - & - & - & - & $\mathbf{E}$ & $\mathbf{E}$ & $\mathbf{M}$ & $\mathbf{E}$ \\
\hline \multirow[t]{2}{*}{ (20) } & POIE & $\underline{\mathbf{E}}$ & $\underline{\mathbf{E}}$ & $\underline{\mathbf{M}}$ & $\mathbf{E}$ & च & $\square$ & - & च \\
\hline & DRE & C & C & $\mathbf{E}$ & $\mathbf{E}$ & C & C & $\mathbf{E}$ & $\bar{E}$ \\
\hline \multirow[t]{2}{*}{ (21) } & POIE & $\bar{C}$ & $\mathbf{E}$ & $\underline{\boldsymbol{A}}$ & $\mathbf{E}$ & $\underline{M}$ & $\underline{\mathbf{E}}$ & C & $\mathbf{E}$ \\
\hline & DRE & C & $\mathbf{E}$ & $\mathbf{E}$ & $\mathbf{E}$ & C & $\mathrm{C}$ & C & $\mathbf{E}$ \\
\hline \multirow[t]{2}{*}{ (22) } & POIE & $\underline{\mathbf{E}}$ & $\mathbf{E}$ & $\underline{\mathbf{E}}$ & $\mathbf{E}$ & $\mathbf{E}$ & $\mathbf{E}$ & $\mathbf{E}$ & $\mathbf{E}$ \\
\hline & DRE & $\mathbf{C}$ & $\mathbf{E}$ & $\mathbf{C}$ & $\mathbf{E}$ & $\mathbf{E}$ & $\mathbf{E}$ & $\mathbf{E}$ & $\mathbf{E}$ \\
\hline \multirow[t]{2}{*}{ (23) } & POIE & $\underline{\mathbf{E}}$ & $\underline{\mathbf{E}}$ & $\underline{\mathbf{E}}$ & C & $\underline{\mathbf{E}}$ & C & C & $\mathbf{E}$ \\
\hline & DRE & C & C & C & C & C & C & C & $\mathbf{E}$ \\
\hline
\end{tabular}




\begin{tabular}{|c|c|c|c|c|c|c|c|c|c|}
\hline \multirow[t]{2}{*}{ (24) } & POIE & - & - & - & - & - & - & - & - \\
\hline & DRE & - & - & - & - & - & - & - & - \\
\hline \multirow[t]{2}{*}{ (25) } & POIE & $\mathbf{E}$ & $\underline{A}$ & $\underline{\mathbf{M}}$ & C & - & - & - & - \\
\hline & DRE & $\mathbf{E}$ & $\mathbf{E}$ & $\mathbf{E}$ & C & $\mathbf{E}$ & $\mathbf{E}$ & $\mathbf{E}$ & C \\
\hline \multirow[t]{2}{*}{ (26) } & POIE & - & - & - & - & - & - & - & - \\
\hline & DRE & - & - & - & - & - & - & - & - \\
\hline \multirow[t]{2}{*}{ (27) } & POIE & घ & - & - & - & - & - & - & - \\
\hline & DRE & - & - & $\square$ & - & - & - & " & - \\
\hline \multirow[t]{2}{*}{ (28) } & POIE & $\underline{\mathbf{E}}$ & $\mathbf{E}$ & $\underline{\mathbf{E}}$ & $\mathbf{E}$ & $\mathbf{E}$ & $\mathbf{E}$ & $\mathbf{E}$ & $\mathbf{E}$ \\
\hline & DRE & C & $\mathbf{E}$ & C & $\bar{E}$ & $\mathbf{E}$ & $\mathbf{E}$ & $\mathbf{E}$ & $\bar{E}$ \\
\hline \multirow[t]{2}{*}{ (29) } & POIE & $\mathbf{E}$ & $\mathbf{E}$ & $\mathbf{E}$ & $\mathbf{E}$ & $\mathbf{E}$ & $\mathbf{E}$ & $\mathbf{E}$ & $\mathbf{E}$ \\
\hline & DRE & $\mathbf{E}$ & $\mathbf{E}$ & $\mathbf{E}$ & $\mathbf{E}$ & $\mathbf{E}$ & $\mathbf{E}$ & $\mathbf{E}$ & $\mathbf{E}$ \\
\hline
\end{tabular}




\begin{tabular}{|c|c|c|c|c|c|c|c|c|c|}
\hline \multirow[t]{2}{*}{ (30) } & POIE & $\mathbf{E}$ & $\mathbf{E}$ & C & $\mathbf{E}$ & $\mathbf{E}$ & $\mathbf{E}$ & C & C \\
\hline & DRE & $\mathbf{E}$ & $\mathbf{E}$ & $\mathbf{C}$ & $\bar{E}$ & $\mathbf{E}$ & $\mathbf{E}$ & $\mathbf{C}$ & C \\
\hline \multirow[t]{2}{*}{ (31) } & POIE & C & $\mathbf{E}$ & $\underline{A}$ & $\mathbf{E}$ & $\underline{M}$ & $\underline{\mathbf{E}}$ & C & $\mathbf{E}$ \\
\hline & DRE & C & $\mathbf{E}$ & $\mathbf{E}$ & $\mathbf{E}$ & $\mathbf{C}$ & C & $\mathbf{C}$ & $\mathbf{E}$ \\
\hline \multirow[t]{2}{*}{ (32) } & POIE & $\underline{\mathbf{C}}$ & $\mathbf{E}$ & $\underline{A}$ & $\mathbf{E}$ & - & $\square$ & - & - \\
\hline & DRE & $\mathbf{E}$ & $\mathbf{E}$ & $\mathbf{E}$ & $\mathbf{E}$ & $\mathbf{E}$ & $\mathbf{E}$ & $\mathbf{E}$ & $\mathbf{E}$ \\
\hline \multirow[t]{2}{*}{ (33) } & POIE & - & - & - & - & - & - & - & - \\
\hline & DRE & $\mathbf{E}$ & $\mathbf{E}$ & $\mathbf{E}$ & $\mathbf{E}$ & $\mathbf{E}$ & $\mathbf{E}$ & $\mathbf{E}$ & $\mathbf{E}$ \\
\hline \multirow[t]{2}{*}{ (34) } & POIE & - & - & " & - & - & - & - & - \\
\hline & DRE & - & " & - & - & - & - & - & - \\
\hline \multirow[t]{2}{*}{ (35) } & POIE & . & I. & . & . & M & $\mathbf{E}$ & $\mathbf{E}$ & $\underline{\mathbf{M}}$ \\
\hline & DRE & - & . & - & - & M & $\mathbf{E}$ & $\mathbf{E}$ & $\mathbf{E}$ \\
\hline \multirow[t]{2}{*}{ (36) } & POIE & $\mathbf{E}$ & $\mathbf{E}$ & $\underline{\mathbf{M}}$ & $\mathbf{E}$ & $\mathbf{M}$ & $\mathbf{E}$ & $\mathbf{E}$ & $\mathbf{M}$ \\
\hline & DRE & $\mathbf{E}$ & $\mathbf{E}$ & $\mathbf{E}$ & $\mathbf{E}$ & M & $\mathbf{E}$ & $\mathbf{E}$ & $\overline{\mathbf{M}}$ \\
\hline \multirow[t]{2}{*}{ (37) } & POIE & $\underline{\mathbf{E}}$ & $\mathbf{E}$ & $\underline{\mathbf{M}}$ & $\mathbf{E}$ & $\mathbf{E}$ & $\underline{M}$ & $\mathbf{M}$ & $\mathbf{E}$ \\
\hline & DRE & C & $\mathbf{E}$ & $\mathbf{E}$ & $\mathbf{E}$ & $\mathbf{E}$ & C & $\mathbf{E}$ & $\mathbf{E}$ \\
\hline \multirow[t]{2}{*}{ (38) } & $\begin{array}{l}\text { POIE } \\
\end{array}$ & $\mathbf{E}$ & $\underline{\mathbf{M}}$ & $\mathbf{E}$ & $\underline{\mathbf{M}}$ & $\mathbf{E}$ & $\mathbf{E}$ & $\mathbf{E}$ & $\mathbf{E}$ \\
\hline & DRE & $\mathbf{E}$ & $\mathbf{E}$ & $\mathbf{E}$ & $\mathbf{E}$ & $\mathbf{E}$ & $\mathbf{E}$ & $\mathbf{E}$ & $\mathbf{E}$ \\
\hline \multirow[t]{2}{*}{ (39) } & POIE & . & " & - & . & - & - & - & - \\
\hline & DRE & - & . & - & - & - & - & - & - \\
\hline
\end{tabular}




\begin{tabular}{|c|c|c|c|c|c|c|c|c|c|}
\hline \multirow[t]{2}{*}{ (40) } & POIE & $\underline{\mathbf{M}}$ & $\mathbf{E}$ & $\mathbf{E}$ & $\mathbf{E}$ & M & $\mathbf{E}$ & $\mathbf{E}$ & $\mathbf{E}$ \\
\hline & DRE & $\mathbf{E}$ & $\mathbf{E}$ & $\mathbf{E}$ & $\mathbf{E}$ & $\mathbf{M}$ & $\mathbf{E}$ & $\mathbf{E}$ & $\mathbf{E}$ \\
\hline \multirow[t]{2}{*}{ (41) } & POIE & $\underline{\boldsymbol{A}}$ & $\underline{\mathbf{M}}$ & $\underline{A}$ & $\mathbf{E}$ & $\mathbf{E}$ & $\mathbf{E}$ & $\underline{\mathbf{M}}$ & $\mathbf{E}$ \\
\hline & DRE & $\mathbf{E}$ & $\mathbf{E}$ & $\mathbf{E}$ & $\mathbf{E}$ & $\mathbf{E}$ & $\mathbf{E}$ & $\mathbf{E}$ & $\mathbf{E}$ \\
\hline \multirow[t]{2}{*}{ (42) } & POIE & $\underline{M}$ & $\underline{M}$ & $\underline{A}$ & $\underline{M}$ & C & $\underline{\mathbf{C}}$ & C & $\underline{\mathbf{C}}$ \\
\hline & DRE & C & C & C & C & C & $\mathbf{E}$ & C & $\mathbf{E}$ \\
\hline \multirow[t]{2}{*}{ (43) } & POIE & - & - & - & - & - & - & - & - \\
\hline & DRE & - & - & - & - & - & - & - & - \\
\hline \multirow[t]{2}{*}{ (44) } & POIE & - & - & - & - & - & - & - & - \\
\hline & DRE & - & " & $\square$ & - & - & - & - & - \\
\hline \multirow[t]{2}{*}{ (45) } & POIE & $\mathbf{E}$ & $\mathbf{E}$ & $\underline{\mathbf{E}}$ & C & - & - & - & - \\
\hline & DRE & $\mathbf{E}$ & $\mathbf{E}$ & C & C & $\mathbf{E}$ & $\mathbf{E}$ & $\mathbf{C}$ & C \\
\hline
\end{tabular}




\begin{tabular}{|c|c|c|c|c|c|c|c|c|c|}
\hline \multirow[t]{2}{*}{ (46) } & POIE & - & Ш & 匹 & - & ฮ & 匹 & - & I \\
\hline & DRE & $\square$ & n & " & $\square$ & a & n & a & $\pi$ \\
\hline \multirow[t]{2}{*}{ (47) } & POIE & $\underline{M}$ & $\underline{A}$ & $\underline{A}$ & $\underline{M}$ & ש & . & - & - \\
\hline & DRE & C & $\mathbf{E}$ & $\mathbf{C}$ & C & C & $\mathbf{E}$ & C & $\mathbf{C}$ \\
\hline \multirow[t]{2}{*}{$(48)$} & POIE & - & I & I & - & - & - & - & - \\
\hline & DRE & $\square$ & " & I & $\square$ & 匹 & I & घ & $\square$ \\
\hline \multirow[t]{2}{*}{ (49) } & POIE & $\mathbf{E}$ & $\mathbf{E}$ & $\mathbf{E}$ & $\mathbf{E}$ & $\mathbf{E}$ & $\mathbf{E}$ & $\mathbf{E}$ & $\mathbf{E}$ \\
\hline & DRE & $\mathbf{E}$ & $\mathbf{E}$ & $\mathbf{E}$ & $\mathbf{E}$ & $\mathbf{E}$ & $\mathbf{E}$ & $\mathbf{E}$ & $\mathbf{E}$ \\
\hline \multirow[t]{2}{*}{ (50) } & POIE & - & - & - & - & - & - & - & - \\
\hline & DRE & - & - & - & - & • & 匹 & - & - \\
\hline \multirow[t]{2}{*}{ (51) } & POIE & C & C & C & C & C & $\mathbf{C}$ & C & C \\
\hline & DRE & C & C & C & C & C & C & C & C \\
\hline \multirow[t]{2}{*}{ (52) } & POIE & $\underline{\mathbf{M}}$ & $\underline{\mathbf{E}}$ & $\mathbf{E}$ & $\mathbf{E}$ & $\underline{M}$ & $\mathbf{E}$ & $\mathbf{E}$ & $\mathbf{E}$ \\
\hline & DRE & $\mathbf{E}$ & $\mathbf{C}$ & $\mathbf{E}$ & $\mathbf{E}$ & $\mathbf{E}$ & $\mathbf{E}$ & $\mathbf{E}$ & $\mathbf{E}$ \\
\hline \multirow[t]{2}{*}{ (53) } & POIE & $\underline{\mathbf{M}}$ & $\mathbf{E}$ & $\mathbf{E}$ & $\mathbf{E}$ & - & - & - & - \\
\hline & DRE & $\mathbf{E}$ & $\mathbf{E}$ & $\mathbf{E}$ & $\mathbf{E}$ & $\mathbf{E}$ & $\mathbf{E}$ & $\mathbf{E}$ & $\mathbf{E}$ \\
\hline \multirow[t]{2}{*}{ (54) } & POIE & $\pi$ & $\square$ & घ & 匹 & घ & घ & a & $\square$ \\
\hline & DRE & - & $\pi$ & $\pi$ & - & ש & I & - & $\pi$ \\
\hline \multirow[t]{2}{*}{ (55) } & POIE & $\underline{\mathbf{M}}$ & $\mathbf{E}$ & $\underline{M}$ & $\mathbf{E}$ & $\mathbf{E}$ & $\mathbf{E}$ & $\underline{\mathbf{C}}$ & $\mathbf{E}$ \\
\hline & DRE & $\mathbf{E}$ & $\mathbf{E}$ & C & $\mathbf{E}$ & $\mathbf{E}$ & $\mathbf{E}$ & $\mathbf{E}$ & $\mathbf{E}$ \\
\hline
\end{tabular}




\begin{tabular}{|c|c|c|c|c|c|c|c|c|c|}
\hline \multirow[t]{2}{*}{ (56) } & POIE & $\mathbf{E}$ & $\mathbf{E}$ & $\mathbf{E}$ & C & $\mathbf{M}$ & $\underline{\mathbf{M}}$ & $\mathbf{M}$ & $\mathbf{E}$ \\
\hline & DRE & $\mathbf{E}$ & $\mathbf{E}$ & $\mathbf{E}$ & C & $\mathbf{M}$ & $\mathbf{E}$ & $\mathbf{M}$ & $\mathbf{E}$ \\
\hline \multirow[t]{2}{*}{ (57) } & POIE & n & - & - & - & $\underline{\mathrm{C}}$ & C & $\mathbf{E}$ & $\mathbf{E}$ \\
\hline & DRE & $\pi$ & . & - & - & $\mathbf{E}$ & $\mathbf{C}$ & $\mathbf{E}$ & $\overline{\mathbf{E}}$ \\
\hline \multirow[t]{2}{*}{ (58) } & POIE & $\mathbf{E}$ & $\underline{\mathbf{M}}$ & $\underline{\mathbf{E}}$ & C & $\underline{\mathbf{E}}$ & C & $\underline{M}$ & $\underline{A}$ \\
\hline & DRE & $\mathbf{E}$ & $\mathbf{E}$ & C & C & C & $\mathbf{C}$ & C & $\bar{C}$ \\
\hline \multirow[t]{2}{*}{ (59) } & POIE & $\underline{\mathbf{E}}$ & $\underline{\mathbf{E}}$ & $\underline{\mathbf{E}}$ & $\underline{\mathbf{E}}$ & $\mathbf{E}$ & $\mathbf{E}$ & $\mathbf{E}$ & $\mathbf{E}$ \\
\hline & DRE & $\bar{C}$ & $\mathbf{C}$ & $\mathbf{C}$ & C & $\mathbf{E}$ & $\mathbf{M}$ & $\mathbf{E}$ & $\overline{\mathbf{E}}$ \\
\hline \multirow[t]{2}{*}{$(60)$} & POIE & I & . & I & I & I & I & I & - \\
\hline & DRE & - & - & - & - & - & - & - & $\pi$ \\
\hline \multirow[t]{2}{*}{ (61) } & POIE & $\underline{\mathbf{E}}$ & $\mathbf{E}$ & $\underline{\mathbf{E}}$ & $\mathbf{E}$ & $\bar{E}$ & $\mathbf{E}$ & $\mathbf{E}$ & $\mathbf{E}$ \\
\hline & DRE & C & $\mathbf{E}$ & $\mathbf{C}$ & $\mathbf{E}$ & $\mathbf{E}$ & $\mathbf{E}$ & $\mathbf{E}$ & $\mathbf{E}$ \\
\hline
\end{tabular}




\begin{tabular}{|c|c|c|c|c|c|c|c|c|c|}
\hline \multirow[t]{2}{*}{$(62)$} & POIE & $\underline{\mathbf{M}}$ & $\underline{M}$ & $\underline{M}$ & $\underline{M}$ & C & C & $\underline{\mathbf{M}}$ & $\underline{\mathrm{C}}$ \\
\hline & DRE & $\mathbf{E}$ & C & C & $\mathbf{C}$ & $\mathbf{C}$ & C & $\mathbf{E}$ & $\mathbf{E}$ \\
\hline \multirow[t]{2}{*}{ (63) } & POIE & $\mathbf{E}$ & $\mathbf{E}$ & $\underline{\mathbf{M}}$ & $\mathbf{E}$ & $\mathbf{E}$ & $\underline{\mathbf{E}}$ & $\underline{\mathbf{E}}$ & C \\
\hline & DRE & $\mathbf{E}$ & $\mathbf{E}$ & $\mathbf{E}$ & $\mathbf{E}$ & $\mathbf{E}$ & C & C & C \\
\hline \multirow[t]{2}{*}{$(64)$} & POIE & $\underline{\mathbf{M}}$ & $\mathbf{E}$ & $\mathbf{E}$ & $\mathbf{E}$ & $\mathbf{E}$ & $\mathbf{E}$ & $\underline{\mathbf{M}}$ & $\underline{\mathbf{M}}$ \\
\hline & DRE & $\mathbf{E}$ & $\mathbf{E}$ & $\mathbf{E}$ & $\mathbf{E}$ & $\mathbf{E}$ & $\mathbf{E}$ & $\mathbf{E}$ & $\mathbf{E}$ \\
\hline \multirow[t]{2}{*}{ (65) } & POIE & $\mathbf{E}$ & $\mathbf{E}$ & $\underline{\mathbf{E}}$ & $\mathbf{E}$ & - & - & - & - \\
\hline & DRE & $\mathbf{E}$ & $\mathbf{E}$ & C & $\mathbf{E}$ & $\mathbf{E}$ & $\mathbf{E}$ & C & $\mathbf{E}$ \\
\hline \multirow[t]{2}{*}{ (66) } & POIE & $\mathbf{E}$ & $\mathbf{E}$ & C & $\mathbf{E}$ & $\underline{\mathbf{E}}$ & $\mathbf{E}$ & $\underline{\mathrm{C}}$ & $\mathbf{E}$ \\
\hline & DRE & $\pi$ & $\pi$ & $\pi$ & $\pi$ & $\mathbf{M}$ & $\mathbf{E}$ & $\mathbf{E}$ & $\mathbf{E}$ \\
\hline \multirow[t]{2}{*}{ (67) } & POIE & $\underline{\mathbf{E}}$ & $\underline{M}$ & $\underline{M}$ & $\underline{\mathbf{E}}$ & $\underline{\mathbf{M}}$ & $\underline{\mathbf{E}}$ & $\underline{\mathbf{E}}$ & $\underline{\mathbf{E}}$ \\
\hline & DRE & C & C & C & C & $\mathbf{E}$ & C & C & C \\
\hline \multirow[t]{2}{*}{ (68) } & POIE & $\mathbf{E}$ & $\underline{\mathbf{E}}$ & $\underline{\mathbf{E}}$ & $\mathbf{E}$ & $\mathbf{E}$ & $\mathbf{E}$ & $\underline{\mathbf{M}}$ & C \\
\hline & DRE & $\mathbf{E}$ & C & C & $\mathbf{E}$ & $\mathbf{E}$ & $\mathbf{E}$ & $\mathbf{E}$ & C \\
\hline \multirow[t]{2}{*}{ (69) } & POIE & $\underline{\mathbf{M}}$ & $\mathbf{E}$ & $\mathbf{E}$ & C & $\underline{\mathbf{E}}$ & $\underline{\mathrm{C}}$ & $\mathbf{E}$ & C \\
\hline & DRE & $\mathbf{E}$ & $\mathbf{E}$ & $\mathbf{E}$ & C & $\mathbf{M}$ & $\mathbf{E}$ & $\mathbf{E}$ & C \\
\hline \multirow[t]{2}{*}{ (70) } & POIE & - & - & $\square$ & I & - & . & Ш & ฮ \\
\hline & DRE & - & $\pi$ & I & $\pi$ & ש & I & I & $\pi$ \\
\hline \multirow[t]{2}{*}{ (71) } & POIE & $\underline{\mathbf{E}}$ & $\mathbf{E}$ & $\mathbf{E}$ & $\mathbf{E}$ & $\mathbf{E}$ & $\mathbf{E}$ & $\mathbf{E}$ & $\mathbf{E}$ \\
\hline & DRE & C & $\mathbf{E}$ & $\mathbf{E}$ & $\mathbf{E}$ & $\mathbf{E}$ & $\mathbf{E}$ & $\mathbf{E}$ & $\mathbf{E}$ \\
\hline
\end{tabular}




\begin{tabular}{|c|c|c|c|c|c|c|c|c|c|}
\hline \multirow[t]{2}{*}{ (72) } & POIE & $\underline{\mathbf{E}}$ & $\underline{\mathbf{E}}$ & $\underline{\mathbf{E}}$ & $\underline{\mathbf{E}}$ & $\underline{\mathbf{E}}$ & $\underline{M}$ & C & C \\
\hline & DRE & C & C & C & C & C & C & C & C \\
\hline \multirow[t]{2}{*}{ (73) } & POIE & $\underline{\mathbf{M}}$ & $\underline{\text { M }}$ & $\underline{\mathbf{M}}$ & $\underline{\mathbf{E}}$ & A & $\mathbf{A}$ & A & $\mathbf{M}$ \\
\hline & DRE & A & A & A & M & A & $\mathbf{A}$ & A & $\mathbf{M}$ \\
\hline \multirow[t]{2}{*}{ (74) } & POIE & $\mathbf{E}$ & C & C & $\mathbf{E}$ & $\mathbf{E}$ & $\underline{\mathbf{E}}$ & $\mathbf{E}$ & C \\
\hline & DRE & $\mathbf{E}$ & C & C & $\mathbf{E}$ & $\mathbf{E}$ & C & $\mathbf{E}$ & $\mathbf{C}$ \\
\hline \multirow[t]{2}{*}{ (75) } & POIE & $\underline{A}$ & $\underline{\mathbf{M}}$ & $\underline{A}$ & $\underline{A}$ & $\mathbf{E}$ & $\mathbf{E}$ & $\mathbf{M}$ & $\mathbf{E}$ \\
\hline & DRE & $\mathbf{E}$ & $\mathbf{E}$ & $\mathbf{E}$ & $\mathbf{E}$ & $\mathbf{E}$ & $\mathbf{E}$ & $\mathbf{M}$ & $\mathbf{E}$ \\
\hline \multirow[t]{2}{*}{ (76) } & POIE & $\underline{\mathbf{E}}$ & $\mathbf{E}$ & $\underline{\mathbf{E}}$ & $\mathbf{E}$ & $\underline{\mathrm{C}}$ & $\mathbf{E}$ & C & $\mathbf{C}$ \\
\hline & DRE & C & $\mathbf{E}$ & C & $\mathbf{E}$ & $\mathbf{E}$ & $\mathbf{E}$ & $\mathbf{C}$ & $\mathbf{C}$ \\
\hline \multirow[t]{2}{*}{ (77) } & POIE & $\mathbf{E}$ & $\mathbf{E}$ & $\underline{M}$ & $\underline{\mathbf{E}}$ & $\underline{\mathbf{E}}$ & $\mathbf{E}$ & $\underline{\mathbf{C}}$ & $\mathbf{C}$ \\
\hline & DRE & $\mathbf{E}$ & $\mathbf{E}$ & C & C & $\mathbf{M}$ & $\mathbf{E}$ & $\mathbf{E}$ & C \\
\hline
\end{tabular}




\begin{tabular}{|c|c|c|c|c|c|c|c|c|c|}
\hline \multirow[t]{2}{*}{$(78)$} & POIE & $\mathbf{E}$ & $\mathbf{E}$ & $\underline{M}$ & $\underline{\mathbf{E}}$ & $\underline{\mathbf{E}}$ & $\mathbf{E}$ & $\underline{\mathrm{C}}$ & C \\
\hline & DRE & $\mathbf{E}$ & $\mathbf{E}$ & $\mathbf{C}$ & C & $\mathbf{M}$ & $\mathbf{E}$ & $\mathbf{E}$ & $\bar{C}$ \\
\hline \multirow[t]{2}{*}{ (79) } & POIE & $\underline{\mathbf{M}}$ & $\mathbf{E}$ & $\underline{\mathbf{E}}$ & $\mathbf{E}$ & $\mathbf{E}$ & $\mathbf{E}$ & $\underline{\mathbf{E}}$ & $\mathbf{E}$ \\
\hline & DRE & $\mathbf{E}$ & $\mathbf{E}$ & $\mathbf{C}$ & $\mathbf{E}$ & $\mathbf{E}$ & $\mathbf{E}$ & C & $\mathbf{E}$ \\
\hline \multirow[t]{2}{*}{ (80) } & POIE & $\mathbf{E}$ & $\underline{\mathbf{M}}$ & $\mathbf{E}$ & $\mathbf{E}$ & $\underline{\mathbf{E}}$ & $\underline{\mathbf{E}}$ & $\underline{\mathbf{E}}$ & $\underline{\mathbf{E}}$ \\
\hline & DRE & $\mathbf{E}$ & $\mathbf{E}$ & $\mathbf{E}$ & $\mathbf{E}$ & C & $\mathbf{C}$ & $\mathbf{C}$ & $\mathbf{C}$ \\
\hline \multirow[t]{2}{*}{ (81) } & POIE & C & $\mathbf{E}$ & $\underline{\mathbf{E}}$ & $\underline{A}$ & $\underline{\mathbf{E}}$ & $\underline{\mathbf{E}}$ & $\underline{M}$ & $\mathbf{E}$ \\
\hline & DRE & C & $\mathbf{E}$ & C & $\mathbf{E}$ & C & $\mathbf{C}$ & C & $\mathbf{E}$ \\
\hline \multirow[t]{2}{*}{ (82) } & POIE & - & - & - & - & - & - & - & - \\
\hline & DRE & $\pi$ & $\pi$ & $\pi$ & - & - & 匹 & - & - \\
\hline \multirow[t]{2}{*}{ (83) } & POIE & - & - & - & - & - & - & - & - \\
\hline & DRE & $\mathbf{E}$ & $\mathbf{E}$ & C & C & $\mathbf{E}$ & $\mathbf{E}$ & C & C \\
\hline \multirow[t]{2}{*}{ (84) } & POIE & $\mathbf{E}$ & $\mathbf{E}$ & C & $\mathbf{E}$ & C & C & C & C \\
\hline & DRE & $\mathbf{E}$ & $\mathbf{E}$ & $\mathbf{C}$ & $\mathbf{E}$ & $\mathbf{C}$ & $\mathbf{C}$ & $\mathbf{C}$ & $\mathbf{C}$ \\
\hline \multirow[t]{2}{*}{ (85) } & POIE & - & - & - & - & - & - & I & - \\
\hline & DRE & ח & ח & 匹 & 匹 & $\square$ & 匹 & 匹 & I \\
\hline \multirow[t]{2}{*}{ (86) } & POIE & $\mathbf{E}$ & $\mathbf{E}$ & $\underline{\mathrm{C}}$ & $\mathbf{E}$ & घ & घ & घ & $\square$ \\
\hline & DRE & $\mathbf{E}$ & $\mathbf{E}$ & $\mathbf{E}$ & $\mathbf{E}$ & $\mathbf{E}$ & $\mathbf{E}$ & $\mathbf{E}$ & $\mathbf{E}$ \\
\hline \multirow[t]{2}{*}{ (87) } & POIE & $\mathbf{E}$ & $\mathbf{E}$ & $\mathbf{E}$ & C & $\mathbf{E}$ & $\mathbf{E}$ & $\mathbf{E}$ & $\mathbf{E}$ \\
\hline & DRE & $\mathbf{E}$ & $\mathbf{E}$ & $\mathbf{E}$ & C & $\mathbf{E}$ & $\mathbf{E}$ & $\mathbf{E}$ & $\mathbf{E}$ \\
\hline
\end{tabular}




\begin{tabular}{|c|c|c|c|c|c|c|c|c|c|}
\hline \multirow[t]{2}{*}{ (88) } & POIE & $\underline{\mathbf{E}}$ & $\mathbf{E}$ & $\underline{\mathbf{M}}$ & $\mathbf{E}$ & $\mathbf{E}$ & M & $\mathbf{M}$ & $\mathbf{E}$ \\
\hline & DRE & C & $\mathbf{E}$ & $\mathbf{E}$ & $\mathbf{E}$ & $\mathbf{E}$ & $\mathbf{E}$ & $\mathbf{E}$ & $\mathbf{E}$ \\
\hline \multirow[t]{2}{*}{ (89) } & POIE & $\mathbf{E}$ & $\underline{\mathbf{M}}$ & $\underline{\mathbf{M}}$ & $\mathbf{E}$ & $\mathbf{E}$ & $\mathbf{E}$ & $\mathbf{E}$ & $\mathbf{E}$ \\
\hline & DRE & $\mathbf{E}$ & $\mathbf{E}$ & $\mathbf{E}$ & $\mathbf{E}$ & $\mathbf{E}$ & $\mathbf{E}$ & $\mathbf{E}$ & $\mathbf{E}$ \\
\hline \multirow[t]{2}{*}{ (90) } & POIE & C & C & C & C & $\mathbf{E}$ & $\mathbf{E}$ & $\mathbf{E}$ & $\mathbf{E}$ \\
\hline & DRE & C & C & C & C & $\mathbf{E}$ & $\mathbf{E}$ & $\mathbf{E}$ & $\mathbf{E}$ \\
\hline \multirow[t]{2}{*}{ (91) } & POIE & M & $\mathbf{E}$ & $\mathbf{E}$ & $\mathbf{E}$ & M & $\mathbf{E}$ & A & $\mathbf{E}$ \\
\hline & DRE & M & $\mathbf{E}$ & $\mathbf{E}$ & $\mathbf{E}$ & - & - & " & - \\
\hline \multirow[t]{2}{*}{ (92) } & POIE & $\mathbf{E}$ & $\mathbf{E}$ & $\mathbf{E}$ & $\mathbf{E}$ & - & - & - & - \\
\hline & DRE & - & - & - & - & - & - & - & - \\
\hline \multirow[t]{2}{*}{ (93) } & POIE & $\underline{\mathbf{M}}$ & $\underline{\mathbf{E}}$ & $\underline{\mathbf{E}}$ & $\underline{\mathbf{E}}$ & " & - & - & - \\
\hline & DRE & $\mathbf{E}$ & C & C & C & $\mathbf{E}$ & C & C & C \\
\hline \multirow[t]{2}{*}{ (94) } & $\begin{array}{l}\text { POIE } \\
\end{array}$ & $\underline{\mathbf{M}}$ & $\underline{\mathbf{E}}$ & $\underline{\mathbf{E}}$ & $\underline{\mathbf{E}}$ & घ & घ & घ & घ \\
\hline & DRE & $\mathbf{E}$ & $\mathrm{C}$ & C & C & $\mathbf{E}$ & C & C & C \\
\hline \multirow[t]{2}{*}{ (95) } & $\begin{array}{l}\text { POIE } \\
\end{array}$ & $\mathbf{E}$ & $\underline{\mathbf{M}}$ & $\mathbf{E}$ & $\mathbf{E}$ & I & I & प & 匹 \\
\hline & DRE & $\mathbf{E}$ & $\mathbf{E}$ & $\mathbf{E}$ & $\mathbf{E}$ & $\mathbf{E}$ & $\mathbf{E}$ & $\mathbf{E}$ & $\mathbf{E}$ \\
\hline \multirow[t]{2}{*}{ (96) } & $\begin{array}{l}\text { POIE } \\
\end{array}$ & $\mathbf{E}$ & $\mathbf{E}$ & $\mathbf{E}$ & C & $\mathbf{E}$ & $\mathbf{E}$ & $\mathbf{E}$ & C \\
\hline & $\begin{array}{l}\text { DRE } \\
\end{array}$ & $\mathbf{E}$ & $\mathbf{E}$ & $\mathbf{E}$ & C & $\mathbf{E}$ & $\mathbf{E}$ & $\mathbf{E}$ & C \\
\hline \multirow[t]{2}{*}{ (97) } & POIE & $\mathbf{E}$ & $\underline{\mathbf{M}}$ & $\underline{\mathbf{E}}$ & $\mathbf{E}$ & $\mathbf{E}$ & $\mathbf{E}$ & $\mathbf{E}$ & $\mathbf{E}$ \\
\hline & DRE & $\mathbf{E}$ & $\mathbf{E}$ & C & $\mathbf{E}$ & $\mathbf{E}$ & $\mathbf{E}$ & $\mathbf{E}$ & $\mathbf{E}$ \\
\hline
\end{tabular}




\begin{tabular}{|c|c|c|c|c|c|c|c|c|c|}
\hline \multirow[t]{2}{*}{ (98) } & POIE & C & $\mathbf{E}$ & $\mathbf{E}$ & C & $\mathbf{E}$ & $\underline{\mathbf{M}}$ & $\mathbf{E}$ & $\mathbf{E}$ \\
\hline & DRE & C & $\mathbf{E}$ & $\mathbf{E}$ & $\mathrm{C}$ & $\mathbf{E}$ & $\mathbf{E}$ & $\mathbf{E}$ & $\mathbf{E}$ \\
\hline \multirow[t]{2}{*}{ (99) } & POIE & $\mathbf{E}$ & $\underline{\mathbf{M}}$ & $\underline{\mathbf{M}}$ & $\mathbf{E}$ & $\underline{\mathrm{C}}$ & $\underline{\mathrm{C}}$ & $\underline{\mathrm{C}}$ & $\underline{\mathrm{C}}$ \\
\hline & DRE & $\mathbf{E}$ & $\mathbf{E}$ & $\mathbf{E}$ & $\mathbf{E}$ & $\mathbf{E}$ & $\mathbf{E}$ & $\mathbf{E}$ & $\mathbf{E}$ \\
\hline \multirow[t]{2}{*}{ (100) } & POIE & $\underline{\mathbf{E}}$ & $\underline{\mathbf{E}}$ & $\underline{\mathbf{E}}$ & $\underline{\mathbf{E}}$ & - & - & - & - \\
\hline & DRE & C & C & C & C & C & C & C & C \\
\hline \multirow[t]{2}{*}{ (101) } & POIE & $\underline{M}$ & $\underline{A}$ & $\underline{M}$ & $\underline{\mathbf{E}}$ & $\mathbf{E}$ & $\mathbf{M}$ & $\mathbf{E}$ & $\bar{M}$ \\
\hline & DRE & C & C & C & C & - & I & $\square$ & $\square$ \\
\hline \multirow[t]{2}{*}{ (102) } & POIE & $\underline{M}$ & $\underline{M}$ & $\underline{\mathbf{E}}$ & $\underline{\mathbf{E}}$ & - & - & $\square$ & - \\
\hline & DRE & C & C & C & C & C & C & C & C \\
\hline
\end{tabular}




\section{SÍNTESE DOS DADOS}

TABELA 02 - Análise das indicações dos níveis de avaliação (em percentual)

\begin{tabular}{|c|c|c|c|c|c|c|c|c|c|c|c|c|c|c|c|c|c|}
\hline \multirow[b]{2}{*}{$\begin{array}{c}\text { Síntese } \\
\text { DRE Campo Limpo }\end{array}$} & \multirow[b]{2}{*}{$\begin{array}{l}\text { Ponto } \\
\text { De } \\
\text { Vista }\end{array}$} & \multicolumn{8}{|c|}{ AVALIAÇÃO SETEMBRO } & \multicolumn{8}{|c|}{ AVALIAÇÃO NOVEMBRO } \\
\hline & & \multicolumn{2}{|c|}{ 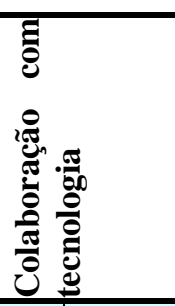 } & \multicolumn{2}{|c|}{ 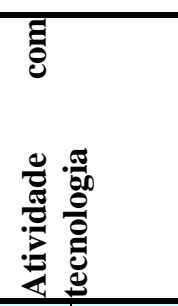 } & \multicolumn{2}{|c|}{ 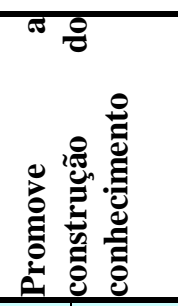 } & \multicolumn{2}{|c|}{ 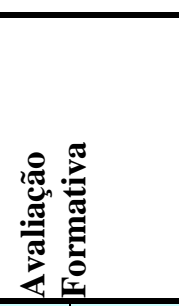 } & \multicolumn{2}{|c|}{ 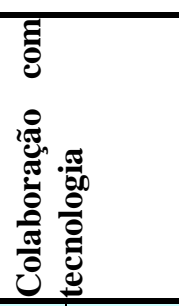 } & \multicolumn{2}{|c|}{ 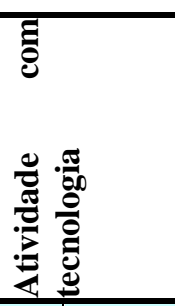 } & \multicolumn{2}{|c|}{ 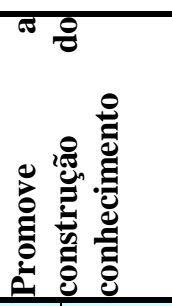 } & \multicolumn{2}{|c|}{ 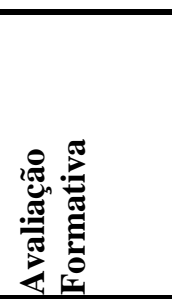 } \\
\hline \multirow{5}{*}{$\begin{array}{c}\text { Percentual de indicação } \\
\text { dos níveis da rubrica de } \\
\text { avaliação }\end{array}$} & \multirow{4}{*}{ POIE } & $\bar{C}$ & $13 \%$ & $\mathbf{C}$ & $5 \%$ & $\mathbf{C}$ & $12 \%$ & $\mathbf{C}$ & $16 \%$ & $\mathbf{C}$ & $16 \%$ & $\mathbf{C}$ & $14 \%$ & $\mathbf{C}$ & $23 \%$ & $\mathbf{C}$ & $25 \%$ \\
\hline & & $\mathbf{E}$ & $54 \%$ & $\mathbf{E}$ & $69 \%$ & $\mathbf{E}$ & $49 \%$ & $\mathbf{E}$ & $74 \%$ & $\mathbf{E}$ & $62 \%$ & $\mathbf{E}$ & $73 \%$ & $\mathbf{E}$ & $55 \%$ & $\mathbf{E}$ & $64 \%$ \\
\hline & & $\vec{M}$ & $30 \%$ & $\mathbf{M}$ & $21 \%$ & $\mathbf{M}$ & $29 \%$ & $\mathbf{M}$ & $8 \%$ & $\mathbf{M}$ & $20 \%$ & $\mathbf{M}$ & $11 \%$ & $\mathbf{M}$ & $19 \%$ & $\mathbf{M}$ & $9 \%$ \\
\hline & & $\mathbf{A}$ & $3 \%$ & $\mathbf{A}$ & $5 \%$ & $\mathbf{A}$ & $10 \%$ & $\mathbf{A}$ & $2 \%$ & $\mathbf{A}$ & $2 \%$ & $\mathbf{A}$ & $2 \%$ & $\mathbf{A}$ & $3 \%$ & $\mathbf{A}$ & $2 \%$ \\
\hline & TOTAL & - & $100 \%$ & - & $100 \%$ & - & $100 \%$ & - & $100 \%$ & & $100 \%$ & & $100 \%$ & & $100 \%$ & & $100 \%$ \\
\hline \multirow{5}{*}{$\begin{array}{c}\text { Percentual de indicação } \\
\text { dos níveis da rubrica de } \\
\text { avaliação }\end{array}$} & \multirow{4}{*}{ DRE } & $\bar{C}$ & $36 \%$ & $\mathrm{C}$ & $24 \%$ & $\mathrm{C}$ & $47 \%$ & $\mathrm{C}$ & $37 \%$ & $\mathrm{C}$ & $24 \%$ & $\mathrm{C}$ & $28 \%$ & $\mathbf{C}$ & $30 \%$ & $\mathrm{C}$ & $32 \%$ \\
\hline & & $\mathbf{E}$ & $57 \%$ & $\mathbf{E}$ & $75 \%$ & $\mathbf{E}$ & $51 \%$ & $\mathbf{E}$ & $62 \%$ & $\mathbf{E}$ & $61 \%$ & $\mathbf{E}$ & $70 \%$ & $\mathbf{E}$ & $63 \%$ & $\mathbf{E}$ & $66 \%$ \\
\hline & & $\mathbf{M}$ & $6 \%$ & $\mathbf{M}$ & $0 \%$ & $\mathbf{M}$ & $1 \%$ & $\mathbf{M}$ & $1 \%$ & $\mathbf{M}$ & $14 \%$ & $\mathbf{M}$ & $1 \%$ & $\mathbf{M}$ & $6 \%$ & $\mathbf{M}$ & $2 \%$ \\
\hline & & $\mathbf{A}$ & $1 \%$ & $\mathbf{A}$ & $1 \%$ & $\mathbf{A}$ & $1 \%$ & $\mathbf{A}$ & $0 \%$ & $\mathbf{A}$ & $1 \%$ & $\mathbf{A}$ & $1 \%$ & $\mathbf{A}$ & $1 \%$ & $\mathbf{A}$ & 0 \\
\hline & TOTAL & - & $100 \%$ & - & $100 \%$ & - & $100 \%$ & - & $100 \%$ & & $100 \%$ & & $100 \%$ & & $100 \%$ & & $100 \%$ \\
\hline
\end{tabular}


TABELA 03 - Análise das indicações dos níveis de avaliação (números absolutos)

\begin{tabular}{|c|c|c|c|c|c|c|c|c|c|c|c|c|c|c|c|c|c|}
\hline \multirow{6}{*}{$\begin{array}{c}\text { Síntese } \\
\text { DRE Campo Limpo } \\
\begin{array}{c}\text { Percentual de indicação } \\
\text { dos níveis da rubrica de } \\
\text { avaliação }\end{array}\end{array}$} & \multirow{6}{*}{$\begin{array}{c}\text { Ponto } \\
\text { De } \\
\text { Vista } \\
\\
\\
\text { POIE }\end{array}$} & \multicolumn{8}{|c|}{ AVALIAÇÃO SETEMBRO } & \multicolumn{8}{|c|}{ AVALIAÇÃO NOVEMBRO } \\
\hline & & \multicolumn{2}{|c|}{ 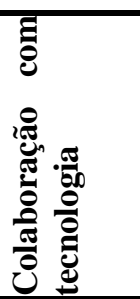 } & \multicolumn{2}{|c|}{ 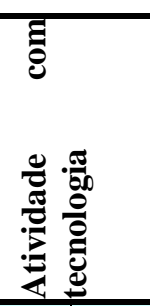 } & \multicolumn{2}{|c|}{ 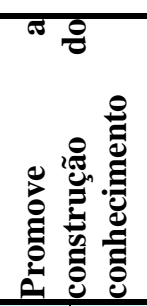 } & \multicolumn{2}{|c|}{ 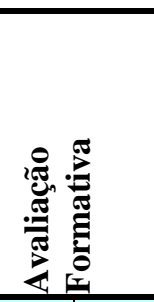 } & \multicolumn{2}{|c|}{ 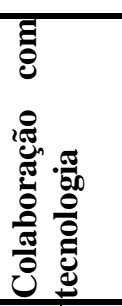 } & \multicolumn{2}{|c|}{ 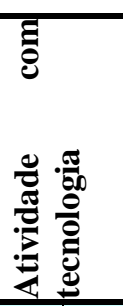 } & \multicolumn{2}{|c|}{ 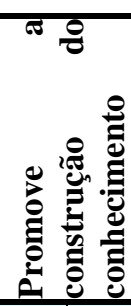 } & \multicolumn{2}{|c|}{ 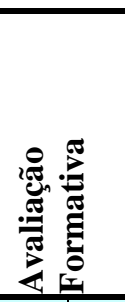 } \\
\hline & & $\mathbf{C}$ & 10 & $\mathbf{C}$ & 4 & $\mathbf{C}$ & 9 & $\bar{C}$ & 12 & $\mathbf{C}$ & 10 & $\bar{C}$ & 9 & $\mathbf{C}$ & 15 & $\bar{C}$ & 16 \\
\hline & & $\mathbf{E}$ & 42 & $\mathbf{E}$ & 53 & $\mathbf{E}$ & 38 & $\mathbf{E}$ & 57 & $\mathbf{E}$ & 40 & $\mathbf{E}$ & 47 & $\mathbf{E}$ & 35 & $\mathbf{E}$ & 41 \\
\hline & & $\mathbf{M}$ & 23 & $\mathbf{M}$ & 16 & $\mathbf{M}$ & 22 & $\mathbf{M}$ & 6 & $\mathbf{M}$ & 13 & $\mathbf{M}$ & 7 & $\mathbf{M}$ & 12 & $\mathbf{M}$ & 6 \\
\hline & & $\mathbf{A}$ & 2 & $\mathbf{A}$ & 4 & $\mathbf{A}$ & 8 & $\mathbf{A}$ & 2 & $\mathbf{A}$ & 1 & $\mathbf{A}$ & 1 & $\mathbf{A}$ & 2 & $\mathbf{A}$ & 1 \\
\hline & TOTAL & - & 77 & - & 77 & - & 77 & - & 77 & & 64 & & 64 & & 64 & & 64 \\
\hline \multirow{5}{*}{$\begin{array}{c}\text { Percentual de indicação } \\
\text { dos níveis da rubrica de } \\
\text { avaliação }\end{array}$} & \multirow{4}{*}{ DRE } & $\mathrm{C}$ & 25 & $\mathrm{C}$ & 17 & $\mathrm{C}$ & 33 & $\mathrm{C}$ & 26 & $\mathrm{C}$ & 19 & $\mathrm{C}$ & 22 & $\mathrm{C}$ & 24 & $\mathrm{C}$ & 25 \\
\hline & & $\mathbf{E}$ & 41 & $\mathbf{E}$ & 53 & $\mathbf{E}$ & 36 & $\mathbf{E}$ & 44 & $\mathbf{E}$ & 48 & $\mathbf{E}$ & 55 & $\mathbf{E}$ & 50 & $\mathbf{E}$ & 52 \\
\hline & & $\mathbf{M}$ & 4 & $\mathbf{M}$ & 0 & $\mathbf{M}$ & 1 & $\mathbf{M}$ & 1 & $\mathbf{M}$ & 11 & $\mathbf{M}$ & 1 & $\mathbf{M}$ & 4 & $\mathbf{M}$ & 2 \\
\hline & & $\mathbf{A}$ & 1 & $\mathbf{A}$ & 1 & $\mathbf{A}$ & 1 & $\mathbf{A}$ & 0 & $\mathbf{A}$ & 1 & $\mathbf{A}$ & 1 & $\mathbf{A}$ & 1 & $\mathbf{A}$ & 0 \\
\hline & TOTAL & - & 71 & - & 71 & - & 71 & - & 71 & & 79 & & 79 & & 79 & & 79 \\
\hline
\end{tabular}


TABELA 04 - Percentual de discrepância/concordância na avaliação

\begin{tabular}{|c|c|c|c|c|c|c|c|c|c|}
\hline \multirow{2}{*}{\multicolumn{2}{|c|}{$\begin{array}{c}\text { Síntese } \\
\text { DRE Campo Limpo }\end{array}$}} & \multicolumn{4}{|c|}{ AVALIAÇÃO SETEMBRO } & \multicolumn{4}{|c|}{ AVALIAÇÃO NOVEMBRO } \\
\hline & & 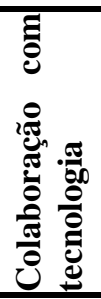 & 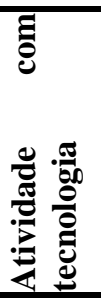 & 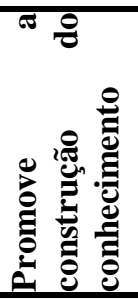 & 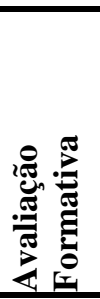 & 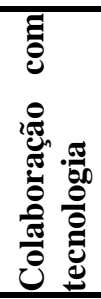 & 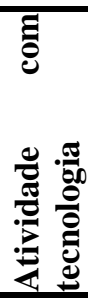 & $\begin{array}{l}\text { "ᄋ } \\
\\
\end{array}$ & 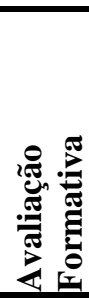 \\
\hline \multicolumn{2}{|c|}{$\begin{array}{l}\text { Percentual de concordância entre os } \\
\text { pontos de vista da DRE e dos POIEs }\end{array}$} & $\mathbf{5 0 \%}$ & $87 \%$ & $36 \%$ & $76 \%$ & - & - & - & - \\
\hline \multirow{2}{*}{$\begin{array}{l}\text { Percentual de discrepância } \\
\text { entre os pontos de vista dos } \\
\text { POIEs e da DRE }\end{array}$} & $\begin{array}{l}\text { Discrep. } \\
\text { Parcial }\end{array}$ & $\underline{41 \%}$ & $\underline{\mathbf{3 \%}}$ & $\underline{\mathbf{4 3 \%}}$ & $\underline{17 \%}$ & - & - & - & - \\
\hline & $\begin{array}{l}\text { Discrep. } \\
\text { Total }\end{array}$ & $\underline{9 \%}$ & $\underline{10 \%}$ & $\underline{21 \%}$ & $\underline{7 \%}$ & - & - & - & - \\
\hline
\end{tabular}

\section{CONSIDERAÇÕES PARCIAIS (APÓS O ENCONTRO DE FORMAÇÃO DO MÊS DE SETEMBRO)}

Nossa meta é que nenhum projeto desenvolvido nos Laboratórios de Informática Educativa da DRE Campo Limpo esteja no nível confortável, além disso, pretendemos que os projetos que se encontram nos outros níveis, consigam avançar pelo menos um nível. Os dados nos indicam onde está o nosso maior foco de intervenção.

Como o processo de Avaliação por Rubrica envolve reflexão acerca das práticas desenvolvidas, as discrepâncias aparecem (em maior ou menor intensidade), pois a mesma remete a um juízo de valor. Percebemos que em linhas gerais de acordo com a Tabela 04, os POIEs se aproximaram razoavelmente da avaliação realizada pelos formadores. Ou seja, o nível de consciência acerca de suas práticas encontra-se satisfatório. 
Em relação aos itens da rubrica, percebemos que devemos investir mais em "Atividade com Tecnologia" e principalmente em "Promoção do conhecimento", pois foram os itens com maior discrepância entre o que a DRE espera e o que os POIEs apontaram.

O trabalho, portanto, deve focar a melhoria das práticas pedagógicas, no sentido de avançar nos níveis da rubrica em questão em todos os itens.

\section{CONSIDERAÇÕES FINAIS}

Na formação do mês de novembro retomamos nossas metas com os POIEs:

- 100\% das escolas tivessem pelo menos 1 turma cadastrada e desenvolvendo atividades no ThinkQuest;

- nenhum projeto desenvolvido nos Laboratórios de Informática Educativa da DRE Campo Limpo esteja no nível confortável;

- os projetos que se encontram nos outros níveis, consigam avançar pelo menos um nível.

Depois de analisar as postagens e relatórios disponíveis, podemos afirmar:

- Chegamos ao mês de novembro com 28 escolas (de um total de 74 escolas) que ainda não possuem alunos cadastrados. No entanto, a soma de professores cadastrados nessas escolas é 159

Há 4 escolas desse total de 28 que não possuíam POIEs no ano de 2011.

Temos apenas 1 escola sem professores ou alunos com conta ativa, ressaltando que essa escola ficou sem POIE o ano todo.

Segundo o relatório fornecido pela Oracle, encerramos o ano com 305 projetos em desenvolvimento e 10133 usuários ativos.

- Ainda temos projetos avaliados no nível Confortável, segundo a rubrica proposta na formação, no entanto já podemos afirmar que tratar-se apenas de total de projetos avaliados.

- Houve avanço em pelos menos 1 nível em \% dos trabalhos avaliados. 
Durante o mês de outubro fizemos a divulgação de alguns projetos indicados pelos POIEs apontando também qual era a nossa avaliação e solicitando que o grupo contribuísse para que houvesse avanço dos níveis.

A devolutiva dada aos POIEs no mês de novembro foi um complemento a esse trabalho que estava sendo feito a distância e causou um movimento no grupo. Os POIEs que ainda não haviam recebido os seus dados estavam curiosos por saber como havíamos avaliado. Deixamos claro que se tratava de uma avaliação dos registros e que a discrepância entre a avaliação feita por eles e a nossa podia apontar que a prática precisava ser aprimorada ou que o registro não estava representando tudo que havia sido realizado. 


\section{Anexo D - Questionários e Respostas dos alunos (Projetos}

\section{A.3; B.1; B.4)}

\section{Anexo D.1: respostas dos alunos do projeto A.3, sob responsabilidade do POIE Douglas (Sustentabilidade no Zaca)}

1.Alunos Respondentes:

Oculto por razões de preservação dos menores

2.Sexo

\begin{tabular}{|c|c|c|}
\hline SEXO & $\mathbf{N}^{\mathbf{0}}$ RESPOSTAS & PERCENTUAL \\
\hline Feminino & 9 & $52.9 \%$ \\
\hline Masculino & 8 & $47.1 \%$ \\
\hline 3.Idade (Atual / em 2015) & & \\
\hline IDADE & $\mathbf{N}^{\mathbf{0}}$ RESPOSTAS & PERCENTUAL \\
\hline $\mathbf{1 1}$ anos ou menos & 0 & $0 \%$ \\
\hline $\mathbf{1 2}$ anos & 0 & $0 \%$ \\
\hline $\mathbf{1 3}$ anos & 1 & $5.9 \%$ \\
\hline $\mathbf{1 4}$ anos & 12 & $70.6 \%$ \\
\hline $\mathbf{1 5}$ anos ou mais & 4 & $23.5 \%$ \\
\hline
\end{tabular}

4.Número de alunos no seu grupo: Grupos de 5 a 6 alunos

5.Em que momento você foi orientada(o) sobre o quadro com os níveis dos critérios de avaliação do projeto:

\begin{tabular}{|c|c|c|}
\hline OPÇÕES DE RESPOSTA & $\mathbf{N}^{\mathbf{0}}$ & $\%$ \\
\hline No início do projeto, antes de iniciarem as atividades ligadas ao projeto. & 13 & $76.5 \%$ \\
\hline $\begin{array}{l}\text { No meio do projeto, quando os alunos já haviam começado a fazer algumas das } \\
\text { atividades. }\end{array}$ & 4 & $23.5 \%$ \\
\hline No final da realização do projeto. & 0 & $0 \%$ \\
\hline $\begin{array}{l}\text { Os critérios de avaliação não foram informados em momento algum, e os alunos só } \\
\text { receberam alguns comentários do professor de informática educativa, no final da } \\
\text { atividade, sem nenhuma justificativa. }\end{array}$ & 0 & $0 \%$ \\
\hline
\end{tabular}

6.Sobre os critérios de avaliação e seus níveis: 


\begin{tabular}{|c|c|c|}
\hline OPÇÕES DE RESPOSTA & $\mathbf{N}^{\mathbf{o}}$ & $\%$ \\
\hline $\begin{array}{l}\text { O quadro com esses critérios de avaliação e seus níveis foi apresentado pronto para } \\
\text { a turma, pelo professor de informática educativa, apenas para os alunos } \\
\text { conhecerem como seriam avaliados no final do projeto. }\end{array}$ & 2 & $70.6 \%$ \\
\hline $\begin{array}{l}\text { O quadro com esses critérios de avaliação e seus níveis foi apresentado pronto para } \\
\text { a turma, pelo professor de informática educativa, para que os alunos lessem os } \\
\text { critérios e comentassem se concordavam com ele, sendo que houve algumas poucas } \\
\text { alterações no quadro inicial que foi mostrado aos alunos, por causa dos } \\
\text { comentários dos alunos da turma. }\end{array}$ & 3 & $17.6 \%$ \\
\hline $\begin{array}{l}\text { Os critérios e as descrições / explicações sobre os seus níveis de avaliação foram } \\
\text { definidos pelos alunos em parceria com o professor da sala de informática } \\
\text { educativa. }\end{array}$ & 2 & $11.8 \%$ \\
\hline $\begin{array}{l}\text { Os critérios e as descrições / explicações dos seus níveis de avaliação foram } \\
\text { definidos pelos alunos, e o professor da sala de informática educativa só concordou } \\
\text { e acatou. }\end{array}$ & 0 & $0 \%$ \\
\hline $\begin{array}{l}\text { Como respondi na questão anterior, o professor não apresentou claramente esses } \\
\text { critérios para os alunos. }\end{array}$ & 0 & $0 \%$ \\
\hline
\end{tabular}

7.Sobre a participação dos alunos na elaboração da rubrica de avaliação (critérios e seus níveis de avaliação) de atividade, assinale todas as opções que ocorreram durante o desenvolvimento do projeto:

\begin{tabular}{|c|c|c|}
\hline OPÇÕES DE RESPOSTA & $\mathbf{N}^{\mathbf{o}}$ & $\%$ \\
\hline Não mudou nada, pois no final quem definiu mesmo os critérios foi o professor & 3 & $9.7 \%$ \\
\hline Foi legal, porque eu pude aprender como o professor avalia uma atividade nossa. & 6 & $19.4 \%$ \\
\hline $\begin{array}{l}\text { Foi legal porque eu pude perceber de que forma eu posso melhorar meu } \\
\text { desempenho. }\end{array}$ & 12 & $38.7 \%$ \\
\hline $\begin{array}{l}\text { Foi muito legal porque eu pude refletir com o professor e dar minha opinião sobre } \\
\text { como eu acho que um projeto deve ser desenvolvido. }\end{array}$ & 3 & $9.7 \%$ \\
\hline $\begin{array}{l}\text { Foi super legal, porque eu me dei conta que dependendo da forma como eu me } \\
\text { dedico no projeto, eu aprendo muito mais. }\end{array}$ & 7 & $22.5 \%$ \\
\hline
\end{tabular}

8.Quanto às etapas do desenvolvimento do projeto em si, já na Sala de Informática Educativa:

\begin{tabular}{|c|c|c|}
\hline OPÇÕES DE RESPOSTA & $\mathbf{N}^{\mathbf{o}}$ & $\%$ \\
\hline $\begin{array}{l}\text { O professor apresentou os objetivos do trabalho, definiu o produto final desse } \\
\text { projeto (um vídeo), detalhou todo o planejamento de atividades que deveriam ser } \\
\text { desenvolvidas, dividiu os alunos em grupos (definindo que aluno iria para qual } \\
\text { grupo), e distribuiu as tarefas por aluno em cada grupo. }\end{array}$ & 7 & $41.2 \%$ \\
\hline $\begin{array}{l}\text { O professor apresentou os objetivos do trabalho, definiu o produto final desse } \\
\text { projeto (um vídeo), detalhou todo o planejamento de atividades que deveriam ser } \\
\text { desenvolvidas, dividiu os alunos em grupos (definindo que aluno iria para qual } \\
\text { grupo), e deixou que cada grupo distribuísse as tarefas entre eles. }\end{array}$ & 8 & $47.1 \%$ \\
\hline $\begin{array}{l}\text { O professor apresentou os objetivos do trabalho, definiu o produto final desse } \\
\text { projeto (um vídeo), detalhou todo o planejamento de atividades que deveriam ser }\end{array}$ & 1 & $5.9 \%$ \\
\hline
\end{tabular}


desenvolvidas, solicitou que os alunos se organizassem em grupos de 5 a 6 alunos (os alunos definiram os componentes de seus grupos), e deixou que cada grupo distribuísse entre eles as tarefas que foram apontadas para serem desenvolvidas.

O professor apresentou os objetivos gerais do trabalho, definiu o produto final 1 $5.9 \%$ desse projeto (um vídeo), apresentou o planejamento geral das atividades que deveriam ser desenvolvidas, solicitou que os alunos se organizassem em grupos de 5 a 6 alunos (os alunos definiram os componentes de seus grupos), e deixou que cada grupo definisse como as atividades seriam executadas, onde as informações seriam coletadas e que distribuísse as tarefas entre eles.

9.Ainda sobre o desenvolvimento do projeto sobre o estudo do problema escolhido pela turma, assinale as atividades que constaram de todo o projeto (clicar em todos os tópicos que refletem as atividades desenvolvidas pelo seu grupo):

\begin{tabular}{|c|c|c|}
\hline OPÇÕES DE RESPOSTA & $\mathbf{N}^{\mathbf{o}}$ & $\%$ \\
\hline $\begin{array}{l}\text { O grupo definiu o que gostariam de estudar mais detalhadamente sobre o problema } \\
\text { principal que seria pesquisado. }\end{array}$ & 7 & $41.2 \%$ \\
\hline $\begin{array}{l}\text { O grupo distribuiu as tarefas entre os alunos e depois simplesmente juntou as } \\
\text { partes que cada um desenvolveu individualmente, para fazer o vídeo final. }\end{array}$ & 8 & $47.1 \%$ \\
\hline $\begin{array}{l}\text { O grupo distribuiu as tarefas entre os alunos, e depois todos se juntaram, para que } \\
\text { todos analisassem tudo o que havia sido coletado, e para definirem conjuntamente } \\
\text { sobre o que constaria do vídeo final. }\end{array}$ & 3 & $17.6 \%$ \\
\hline $\begin{array}{l}\text { O grupo acabou fazendo mais atividades do que as indicadas pelo professor, pois } \\
\text { queriam saber mais sobre o tema em estudo. }\end{array}$ & 1 & $5.9 \%$ \\
\hline $\begin{array}{l}\text { O grupo realizou pesquisas na internet, apenas durante as aulas de Informática } \\
\text { Educativa. }\end{array}$ & 6 & $35.3 \%$ \\
\hline $\begin{array}{l}\text { O grupo realizou pesquisas na internet, durante as aulas de Informática Educativa, } \\
\text { bem como em suas casas ou lan-houses da comunidade. }\end{array}$ & 7 & $41.2 \%$ \\
\hline $\begin{array}{l}\text { O grupo entrevistou outros alunos da escola, registrando essas conversas com } \\
\text { gravador de voz. }\end{array}$ & 3 & $17.6 \%$ \\
\hline $\begin{array}{l}\text { O grupo entrevistou outros alunos da escola, registrando essas conversas com áudio } \\
\text { e vídeo. }\end{array}$ & 2 & $11.8 \%$ \\
\hline O grupo entrevistou outros alunos da escola, registrando essas conversas com fotos. & 0 & $0 \%$ \\
\hline $\begin{array}{l}\text { O grupo entrevistou outros funcionários da escola, registrando essas conversas com } \\
\text { gravador de voz. }\end{array}$ & 1 & $9 \%$ \\
\hline $\begin{array}{l}\text { O grupo entrevistou outros funcionários da escola, registrando essas conversas com } \\
\text { áudio e vídeo. }\end{array}$ & 1 & $5.9 \%$ \\
\hline $\begin{array}{l}\text { O grupo entrevistou outros funcionários da escola, registrando essas conversas com } \\
\text { fotos. }\end{array}$ & 0 & $0 \%$ \\
\hline $\begin{array}{l}\text { O grupo entrevistou outras pessoas da comunidade de entorno, registrando essas } \\
\text { conversas com gravador de voz. }\end{array}$ & 0 & $0 \%$ \\
\hline $\begin{array}{l}\text { O grupo entrevistou outras pessoas da comunidade de entorno, registrando essas } \\
\text { conversas com áudio e vídeo. }\end{array}$ & 2 & $11.8 \%$ \\
\hline O grupo entrevistou outras pessoas da comunidade de entorno, registrando ess & 0 & $0 \%$ \\
\hline
\end{tabular}


conversas com fotos.

O grupo armazenou as informações coletadas durante todas as atividades em alguma ferramenta de registro ou arquivo (Ex.: EdModo, Facebook, Pasta de arquivos no computador da sala de Informática Educativa, pen drive). Caso tenha utilizado, conte-nos qual foi no campo "outros", por favor.

10.Quanto ao relacionamento entre os alunos do seu grupo (caso haja comentários adicionais que queira fazer sobre o projeto, escreva no campo "outros"), clique nos quadradinhos dizem algo que você tenha vivenciado durante a realização do projeto:

\begin{tabular}{|c|c|c|}
\hline OPÇÕES DE RESPOSTA & $\mathbf{N}^{\mathbf{0}}$ & $\%$ \\
\hline $\begin{array}{l}\text { Havia um ou dois alunos que definiam as atividades e que passavam as orientações } \\
\text { para os demais alunos. }\end{array}$ & 3 & $17.6 \%$ \\
\hline $\begin{array}{l}\text { Havia um ou dois alunos que definiam e que faziam as atividades, sendo que os } \\
\text { demais alunos do grupo acabavam fazendo o que esses mandavam. }\end{array}$ & 4 & $23.5 \%$ \\
\hline $\begin{array}{l}\text { Apenas } 2 \text { ou } 3 \text { dos alunos do grupo fizeram a maioria das atividades, e os demais só } \\
\text { acompanharam e concordaram, porque simplesmente não estavam interessados. }\end{array}$ & 1 & $5.9 \%$ \\
\hline $\begin{array}{l}\text { Todos os integrantes do grupo contribuíram para o projeto, sendo que a divisão das } \\
\text { tarefas era negociada entre todos do grupo. }\end{array}$ & 7 & $41.2 \%$ \\
\hline $\begin{array}{l}\text { Descobri que opiniões diferentes nem sempre são opostas, pois elas podem ser } \\
\text { complementares. }\end{array}$ & 5 & $29.4 \%$ \\
\hline $\begin{array}{l}\text { Em alguns momentos nós discordávamos sobre o que deveria ser feito, mas o } \\
\text { professor intervinha e ajudava a acalmar as discussões. }\end{array}$ & 3 & $17.6 \%$ \\
\hline $\begin{array}{l}\text { Houve alguns desentendimentos, mas acabamos chegando a alguns acordos e } \\
\text { conseguimos fazer um bom trabalho. }\end{array}$ & 4 & $23.5 \%$ \\
\hline Descobri que trabalhar em grupo não é fácil e que não gosto de fazer isso. & 0 & $0 \%$ \\
\hline $\begin{array}{l}\text { Descobri que trabalhar em grupo não é fácil, mas é bem legal porque aprendo } \\
\text { mais. }\end{array}$ & 6 & $35.3 \%$ \\
\hline $\begin{array}{l}\text { Descobri que minhas ideias também são importantes para o grupo e que também } \\
\text { posso contribuir, por pouco que pareça. }\end{array}$ & 3 & $17.6 \%$ \\
\hline Fiquei feliz por ter feito o projeto em grupo e gostaria de dar continuidade. & 2 & $11.8 \%$ \\
\hline Descobri que também posso me divertir enquanto aprendo coisa novas. & 2 & $11.8 \%$ \\
\hline $\begin{array}{l}\text { Descobri que pesquisar com meus colegas me ajuda a pensar melhor sobre os } \\
\text { problemas. }\end{array}$ & 1 & $5.9 \%$ \\
\hline Eu gostaria de ter colaborado mais, mas sou tímido(a). & 2 & $1.8 \%$ \\
\hline $\begin{array}{l}\text { Pensei que não fosse colaborar muito, porque sou tímido(a), mas acabei ajudando } \\
\text { com as tecnologias de gravações (adoro mexer com isso). }\end{array}$ & & $5.9 \%$ \\
\hline $\begin{array}{l}\text { Achei que não fosse falar muito, mas acabei dando algumas boas ideias (eu curti } \\
\text { isso). }\end{array}$ & & $0 \%$ \\
\hline Outros & & $0 \%$ \\
\hline
\end{tabular}


11.Quanto ao acompanhamento do professor da Sala de Informática Educativa:

\begin{tabular}{|c|c|c|}
\hline OPÇÕES DE RESPOSTA & $\mathbf{N}^{\mathbf{o}}$ & $\%$ \\
\hline $\begin{array}{l}\text { O professor só apresentou as orientações iniciais e depois esperou a finalização da } \\
\text { tarefa. }\end{array}$ & 2 & $11.8 \%$ \\
\hline $\begin{array}{l}\text { O professor só apresentou as orientações iniciais e depois ele simplesmente } \\
\text { fiscalizou se estávamos fazendo as atividades e esperou a finalização da tarefa. }\end{array}$ & 6 & $35.3 \%$ \\
\hline $\begin{array}{l}\text { O professor apresentou as orientações e depois acompanhou o desenvolvimento das } \\
\text { atividades, mas só se manifestou para chamar a atenção dos grupos que não } \\
\text { estavam fazendo o que precisava ser feito. }\end{array}$ & 5 & $29.4 \%$ \\
\hline $\begin{array}{l}\text { O professor apresentou as orientações e depois acompanhou o desenvolvimento das } \\
\text { atividades, sendo que fez comentários e intervenções durante todo o processo, junto } \\
\text { a todos os grupos, para ajudar na organização das ideias e das atividades, sempre } \\
\text { que sua ajuda foi solicitada ou sempre que identificava que o grupo precisava de } \\
\text { ajuda. Ele apresentava as soluções de imediato. }\end{array}$ & 3 & $17.6 \%$ \\
\hline $\begin{array}{l}\text { O professor apresentou as orientações e depois acompanhou o desenvolvimento das } \\
\text { atividades, sendo que fez comentários e intervenções durante todo o processo, junto } \\
\text { a todos os grupos, para ajudar na organização das ideias e das atividades, sempre } \\
\text { que sua ajuda foi solicitada ou sempre que identificava que o grupo precisava de } \\
\text { ajuda. Ele refletia com o grupo qual a melhoria maneira de prosseguir. }\end{array}$ & 1 & $5.9 \%$ \\
\hline
\end{tabular}

12. Caso tenha tido conhecimento dos critérios de avaliação das atividades desde o início do projeto, considerando exatamente esse conhecimento mais claro sobre o que era esperado de você nas atividades do processo, assinale a(s) opção(ões) que explica(m) melhor como esses critérios a(o) ajudaram no projeto:

\begin{tabular}{|c|c|c|}
\hline OPÇÕES DE RESPOSTA & $\mathbf{N}^{\mathbf{0}}$ & $\%$ \\
\hline $\begin{array}{l}\text { não me ajudaram em nada, pois continuei agindo da mesma forma que agia sem } \\
\text { essa informação e continuei com pouco interesse na aula de informática educativa. }\end{array}$ & 1 & $4.2 \%$ \\
\hline $\begin{array}{l}\text { não me ajudaram em nada, pois continuei agindo da mesma forma que agia sem } \\
\text { essa informação, até porque sempre fui interessado e tive um boa participação na } \\
\text { aula. }\end{array}$ & 2 & $8.4 \%$ \\
\hline $\begin{array}{l}\text { me orientaram melhor sobre como deveria desenvolver a atividade (as etapas de } \\
\text { desenvolvimento da atividade ficaram mais claras). }\end{array}$ & 11 & $45.8 \%$ \\
\hline $\begin{array}{l}\text { me ajudaram a melhorar minha colaboração com meus colegas no projeto (eu não } \\
\text { sabia como poderia contribuir, mas os critérios me esclareceram como deveria } \\
\text { fazer isso) }\end{array}$ & 5 & $20.8 \%$ \\
\hline me ajudaram a pensar melhor sobre o conteúdo em estudo. & 4 & $16.8 \%$ \\
\hline não alteraram nada na forma como aprendo um conteúdo em sala. & 1 & $4.2 \%$ \\
\hline
\end{tabular}

13.Sobre a sua participação e contribuições com o seu grupo: 
Raramente ofereceu ideias úteis ao grupo e, em alguns momentos, até se recusou a participar.

Algumas vezes ofereceu ideias úteis ao grupo e teve uma participação satisfatória, quando sua ajuda foi solicitada.

Normalmente oferecia ideias úteis ao grupo e apresentou contribuições 8 importantes, quando se esforçou em ajudar.

\begin{tabular}{|l|l|l|l|l|}
\hline Rotineiramente oferecia ideias úteis ao grupo e se caracterizou como um líder nato, & 1 & $5.9 \%$
\end{tabular} que contribuiu com muita dedicação.

14.Quando realizou a sua autoavaliação individual, você:

\section{OPÇÕES DE RESPOSTA}

\section{$\mathbf{N}^{\circ}$}

3

Foi indiferente conhecer os critérios no início, pois não acha as aulas de informática educativa importantes, já que nem tem nota.

Você gostou de conhecer critérios de avaliação diferentes, logo no início do projeto, mas isso não afetou seu desempenho em grupo, durante o desenvolvimento do projeto, pois não acha as aulas de informática educativa importantes, já que nem tem nota.

Você gostou de conhecer os critérios de avaliação no início, mas isso não afetou seu desempenho em grupo, durante o desenvolvimento do projeto, pois já era dedicado aos projetos da aula de informática educativa.

Você gostou de conhecer os critérios de avaliação no início, pois isso ajudou você a se envolver e se dedicar da forma correta ao projeto, o que enriqueceu o seu processo de aprendizagem sobre o tema tratado.

15.Quando realizou a avaliação dos seus colegas de grupo, você:

\begin{tabular}{|c|c|c|}
\hline OPÇÕES DE RESPOSTA & $\mathbf{N}^{\mathbf{0}}$ & $\%$ \\
\hline $\begin{array}{l}\text { Não achei que teve ganho porque os alunos acordam o que falarão uns dos outros e } \\
\text { fica tudo na mesma. }\end{array}$ & 1 & $5.9 \%$ \\
\hline Achei muito ruim porque não gosto de dedurar meus colegas. & 2 & $11.8 \%$ \\
\hline $\begin{array}{l}\text { Foi legal porque isso ajudou a fazer com que todos os alunos participassem mais, já } \\
\text { que sabiam que seriam avaliados por todos. }\end{array}$ & 10 & $58.8 \%$ \\
\hline $\begin{array}{l}\text { Foi legal porque nos ajudou a termos um outro olhar sobre a nossa participação, } \\
\text { indicando onde e como podemos melhorar na próxima. }\end{array}$ & 2 & $11.8 \%$ \\
\hline $\begin{array}{l}\text { Foi muito legal porque isso me ajudou a perceber como minha participação é } \\
\text { importante para o sucesso da equipe e que minha colaboração ativa faz diferença. }\end{array}$ & 2 & $11.8 \%$ \\
\hline
\end{tabular}

16.0 que você mais gostou desse processo todo? Marque todas as respostas que tiverem a ver com o que você achou:

\begin{tabular}{|l|c|c|}
\multicolumn{1}{|c|}{ OPÇÕES DE RESPOSTA } & No $^{\mathbf{0}}$ & $\%$ \\
\hline $\begin{array}{l}\text { Não vi diferença desse projeto para outros, que não tinham essa tal de rubrica e } \\
\text { critérios de autoavaliação. }\end{array}$ & 5 & $29.4 \%$ \\
\hline
\end{tabular}


Gostei de saber antes como seria avaliado, para eu saber como deveria desenvolver o projeto.

Gostei de poder refletir com meus colegas sobre os critérios pelos quais seríamos avaliados.

Gostei de poder emitir a minha opinião em vários momentos e ver que posso fazer diferença no desenvolvimento das diretrizes / orientações do projeto.

Eu me senti parte da organização da atividade, o que fez com que eu me dedicasse mais.

Pude refletir sobre diversos temas que me interessam, mais livremente, e pude falar o que pensava, sem ser mal interpretado.

Eu pouco participei falando o que pensava, mas todas as reflexões feitas pelos meus colegas me ajudaram a perceber problemas da escola e da comunidade de entorno aos quais eu também estou exposto.

Não gostei desse modelo de atividade: muita gente falando acaba ficando muito confuso. Prefiro ouvir só o professor.

Não gosto de ter que falar o que penso e não estou interessado no que os outros 0 $0 \%$ alunos pensam. Estou na escola para ouvir só o que o professor diz.

17.Marque abaixo os eventuais recursos midiáticos utilizados durante a realização do projeto (pode ser mais de 1):

\begin{tabular}{|c|c|c|}
\hline OPÇÕES DE RESPOSTA & $\mathbf{N}^{\mathbf{o}}$ & $\%$ \\
\hline GoogleDocs (votações) & 3 & $17.6 \%$ \\
\hline GoogleDocs (armazenamento / compartilhamento de arquivos, como vídeos) & 6 & $35.3 \%$ \\
\hline EdModo (trocas reflexivas entre os alunos) & 6 & $35.3 \%$ \\
\hline Edmodo (repositório dos vídeos desenvolvidos) & 3 & $17.6 \%$ \\
\hline Youtube (repositório dos vídeos desenvolvidos) & 5 & $29.4 \%$ \\
\hline Prezi (apresentação final do projeto, com link do vídeo) & 0 & $0 \%$ \\
\hline Power Point (apresentação final do projeto, com link do vídeo) & 7 & $41.2 \%$ \\
\hline Google (pesquisa sobre o tema problema) & 8 & $47.1 \%$ \\
\hline Facebook (pesquisa sobre o tema problema) & 2 & $11.8 \%$ \\
\hline Facebook (grupo fechado / secreto, para discussões do grupo) & 2 & $11.8 \%$ \\
\hline Facebook (sala de aula virtual da turma) & 0 & $0 \%$ \\
\hline Outros & 0 & $0 \%$ \\
\hline
\end{tabular}

Indique uma ou duas atividades de todo o projeto, de que você mais gostou. E explique o porquê: Respostas: teve o projeto da casa que eu me interessei; não sei; ThinkQuest; nada; o que é sustentabilidade; Edmodo, pois tem várias atividades legais; gostei; eu gostei de tudo mais o que eu fiquei mais tive vontade de aprender mesmo foi da nicotina porque, sei lá, é importante; Edmodo; sobre a natureza, pois hoje em dia está em "escassez" tudo o que a natureza nos dá porque o homem sempre coloca a "mão" onde está quieto, sendo, colocam indústrias (shoppings, lojas, casas, prédios, etc.) onde era a casa dos animais

Se fosse perguntado a você o que mudaria nesse projeto, para melhorar, o que você sugeriria? 
Respostas: mudaria a forma de ser executado, já que quando começamos a fazer fomos agilizados, etc.; mais orientação da parte do professor que alguma forma anime os estudantes; nada; nada; nada

Se você pudesse mandar uma mensagem ao professor Douglas, que coordenou esse projeto com a sua turma, qual seria ela? (caso não tenha nada a dizer, escreva NADA no espaço, para finalizar!)

Respostas: Parabéns, pois hoje em dia as pessoas estão pobres de conhecimento naturais, pois cada dia estão consumistas e egoístas, só pensando em comprar, desperdiçar, em seu bem-estar, seu ego, entre outras coisas. Parabéns é o que tenho a dizer, pois seu trabalho nos fez refletir e ir à procura de informações, entre outras coisas; Nada; Nada; Não sei. 


\section{Anexo D - Questionários e Respostas dos alunos (Projetos}

\section{A.3; B.1; B.4)}

\section{Anexo D.2: respostas dos alunos do projeto B.1, sob responsabilidade do POIE Rosemberg}

1.Alunos Respondentes:

Oculto por razões de preservação dos menores

2.Sexo

\begin{tabular}{|l|c|c|}
\hline \multicolumn{1}{|c|}{ SEXO } & $\mathbf{N}^{\mathbf{0}}$ RESPOSTAS & PERCENTUAL \\
\hline Feminino & 7 & $43.8 \%$ \\
\hline Masculino & 9 & $56.3 \%$ \\
\hline
\end{tabular}

3.Idade

\begin{tabular}{|l|c|c|}
\hline \multicolumn{1}{|c|}{ IDADE } & $\mathbf{N}^{\mathbf{0}}$ RESPOSTAS & PERCENTUAL \\
\hline $\mathbf{1 1}$ anos ou menos & 0 & $0 \%$ \\
\hline $\mathbf{1 2}$ anos & 0 & $0 \%$ \\
\hline $\mathbf{1 4}$ anos & 12 & $75 \%$ \\
\hline $\mathbf{1 5}$ anos ou mais & 3 & $18.8 \%$ \\
\hline
\end{tabular}

4. Número de alunos no seu grupo: 5 a 6 alunos

5. Tema problema estudado pelo seu grupo: Drogas na Comunidade

6. Sobre as trocas nas atividades reflexivas mediadas pela professora da Sala de Leitura:

A dinâmica consistiu na apresentação de uma lista pronta de problemas que teriam na escola e/ou na comunidade de entorno, elaborada pela própria professora, sendo que os alunos só tiveram que confirmar ou negar a existência de tais problemas.

A dinâmica consistiu na apresentação de fotos de várias áreas da escola e/ou da comunidade de entorno, com problemas diversos, para os alunos confirmarem se esses temas deveriam constar ou não dessa lista de problemas.

A dinâmica consistiu em pedir que os alunos apontassem rapidamente alguns temas que consideravam problemáticos na escola e/ou na comunidade de entorno, para montagem de uma lista básica dos mesmos, sem reflexão conjunta inicial sobre tais temas com os alunos.

A dinâmica consistiu em pedir que os alunos listassem eventuais problemas da

\begin{tabular}{|c|c|}
\hline $\mathbf{N}^{\mathbf{0}}$ & $\%$ \\
\hline 4 & $25 \%$ \\
\hline 6 & $37.4 \%$ \\
\hline 3 & $18.8 \%$ \\
\hline & \\
\hline 3 & $18.8 \%$ \\
\hline
\end{tabular}
escola e/ou da comunidade de entorno, com reflexão conjunta inicial sobre tais temas com os alunos, para elaboração da lista com possíveis temas a serem trabalhados nos projetos. 
7. Quanto às trocas reflexivas já na aula da Informática Educativa, que resultaram na definição do tema problemático que foi estudado em mais detalhes por cada grupo da turma:

\begin{tabular}{|c|c|c|}
\hline OPÇ̃̃ES DE RESPOSTA & $\mathbf{N}^{\mathbf{0}}$ & $\%$ \\
\hline $\begin{array}{l}\text { Foi o professor da Sala de Informática Educativa quem escolheu o tema } \\
\text { problemático a ser trabalhado no projeto, sem considerar a lista desenvolvida } \\
\text { na aula da Sala de Leitura. }\end{array}$ & 1 & $6.3 \%$ \\
\hline $\begin{array}{l}\text { Foi o professor da Sala de Informática Educativa quem escolheu o tema } \\
\text { problemático, a partir da lista desenvolvida na aula da Sala de Leitura. }\end{array}$ & 5 & $31.3 \%$ \\
\hline $\begin{array}{l}\text { O professor da Sala de Informática Educativa revisou com os alunos os } \\
\text { tópicos da lista de problemas elaborada na aula da Sala de Leitura, para que } \\
\text { esses confirmassem para ele que todos os tópicos realmente refletiam } \\
\text { problemas da escola e/ou da comunidade de entorno, para então ele próprio } \\
\text { escolher o tema que seria estudado por cada turma. }\end{array}$ & 5 & $31.3 \%$ \\
\hline $\begin{array}{l}\text { O professor da Sala de Informática Educativa revisou com os alunos os } \\
\text { tópicos da lista de problemas elaborada na aula da Sala de Leitura, para que } \\
\text { esses confirmassem para ele que todos os tópicos realmente refletiam } \\
\text { problemas da escola e/ou da comunidade de entorno, para então ele } \\
\text { coordenar uma votação entre os alunos de cada turma, para que os alunos } \\
\text { escolhessem o tema problemático sobre o qual queriam estudar. }\end{array}$ & 5 & $31.3 \%$ \\
\hline
\end{tabular}

8. Em que momento você foi orientada(o) sobre o quadro com os níveis dos critérios de avaliação do projeto:

\begin{tabular}{|c|c|c|}
\hline OPÇÕES DE RESPOSTA & $\mathbf{N}^{\mathbf{o}}$ & $\%$ \\
\hline No início do projeto, antes de iniciarem as atividades ligadas ao projeto. & 5 & $31.2 \%$ \\
\hline $\begin{array}{l}\text { No meio do projeto, quando os alunos já haviam começado a fazer algumas das } \\
\text { atividades. }\end{array}$ & 6 & $37.5 \%$ \\
\hline No final da realização do projeto. & 4 & $25 \%$ \\
\hline $\begin{array}{l}\text { Os critérios de avaliação não foram informados em momento algum, e os alunos só } \\
\text { receberam alguns comentários do professor de informática educativa, no final da } \\
\text { atividade, sem nenhuma justificativa. }\end{array}$ & 1 & $6.3 \%$ \\
\hline
\end{tabular}

9. Sobre os critérios de avaliação e seus níveis:

\begin{tabular}{|c|c|c|}
\hline OPÇÕES DE RESPOSTA & $\mathbf{N}^{\circ}$ & $\%$ \\
\hline $\begin{array}{l}\text { O quadro com esses critérios de avaliação e seus níveis foi apresentado pronto para } \\
\text { a turma, pelo professor de informática educativa, apenas para os alunos } \\
\text { conhecerem como seriam avaliados no final do projeto. }\end{array}$ & 1 & $6.3 \%$ \\
\hline $\begin{array}{l}\text { O quadro com esses critérios de avaliação e seus níveis foi apresentado pronto para } \\
\text { a turma, pelo professor de informática educativa, para que os alunos lessem os } \\
\text { critérios e comentassem se concordavam com ele, sendo que houve algumas poucas } \\
\text { alterações no quadro inicial que foi mostrado aos alunos, por causa dos } \\
\text { comentários dos alunos da turma. }\end{array}$ & 11 & $68.8 \%$ \\
\hline $\begin{array}{l}\text { Os critérios e as descrições / explicações sobre os seus níveis de avaliação foram } \\
\text { definidos pelos alunos em parceria com o professor da sala de informática } \\
\text { educativa. }\end{array}$ & 2 & $12.5 \%$ \\
\hline $\begin{array}{l}\text { Os critérios e as descrições / explicações dos seus níveis de avaliação foram } \\
\text { definidos pelos alunos, e o professor da sala de informática educativa só concordou } \\
\text { e acatou. }\end{array}$ & 1 & $6.3 \%$ \\
\hline $\begin{array}{l}\text { Como respondi na questão anterior, o professor não apresentou claramente esses } \\
\text { critérios para os alunos. }\end{array}$ & 1 & $6.3 \%$ \\
\hline
\end{tabular}


10. Sobre a participação dos alunos na elaboração da rubrica de avaliação (critérios e seus níveis de avaliação) de atividade, assinale todas as opções que ocorreram durante o desenvolvimento do projeto:

\begin{tabular}{|c|c|c|}
\hline OPÇÕES DE RESPOSTA & $\mathbf{N}^{\mathbf{o}}$ & $\%$ \\
\hline Não mudou nada, pois no final quem definiu mesmo os critérios foi o professor & 4 & $17.4 \%$ \\
\hline Foi legal, porque eu pude aprender como o professor avalia uma atividade nossa. & 9 & $39.2 \%$ \\
\hline $\begin{array}{l}\text { Foi legal porque eu pude perceber de que forma eu posso melhorar meu } \\
\text { desempenho. }\end{array}$ & 3 & $13 \%$ \\
\hline $\begin{array}{l}\text { Foi muito legal porque eu pude refletir com o professor e dar minha opinião sobre } \\
\text { como eu acho que um projeto deve ser desenvolvido. }\end{array}$ & 4 & $17.4 \%$ \\
\hline $\begin{array}{l}\text { Foi super legal, porque eu me dei conta que dependendo da forma como eu me } \\
\text { dedico no projeto, eu aprendo muito mais. }\end{array}$ & 3 & $13 \%$ \\
\hline
\end{tabular}

11. Quanto às etapas do desenvolvimento do projeto em si, já na Sala de Informática Educativa:

\begin{tabular}{|c|c|c|}
\hline OPÇÕES DE RESPOSTA & $\mathbf{N}^{\mathbf{0}}$ & $\%$ \\
\hline $\begin{array}{l}\text { O professor apresentou os objetivos do trabalho, definiu o produto final desse } \\
\text { projeto (um vídeo), detalhou todo o planejamento de atividades que deveriam ser } \\
\text { desenvolvidas, dividiu os alunos em grupos (definindo que aluno iria para qual } \\
\text { grupo), e distribuiu as tarefas por aluno em cada grupo. }\end{array}$ & 0 & $0 \%$ \\
\hline $\begin{array}{l}\text { O professor apresentou os objetivos do trabalho, definiu o produto final desse } \\
\text { projeto (um vídeo), detalhou todo o planejamento de atividades que deveriam ser } \\
\text { desenvolvidas, dividiu os alunos em grupos (definindo que aluno iria para qual } \\
\text { grupo), e deixou que cada grupo distribuísse as tarefas entre eles. }\end{array}$ & 6 & $37.5 \%$ \\
\hline $\begin{array}{l}\text { O professor apresentou os objetivos do trabalho, definiu o produto final desse } \\
\text { projeto (um vídeo), detalhou todo o planejamento de atividades que deveriam ser } \\
\text { desenvolvidas, solicitou que os alunos se organizassem em grupos de } 5 \text { a } 6 \text { alunos } \\
\text { (os alunos definiram os componentes de seus grupos), e deixou que cada grupo } \\
\text { distribuísse entre eles as tarefas que foram apontadas para serem desenvolvidas. }\end{array}$ & 7 & $43.75 \%$ \\
\hline $\begin{array}{l}\text { O professor apresentou os objetivos gerais do trabalho, definiu o produto final } \\
\text { desse projeto (um vídeo), apresentou o planejamento geral das atividades que } \\
\text { deveriam ser desenvolvidas, solicitou que os alunos se organizassem em grupos de } 5 \\
\text { a } 6 \text { alunos (os alunos definiram os componentes de seus grupos), e deixou que cada } \\
\text { grupo definisse como as atividades seriam executadas, onde as informações seriam } \\
\text { coletadas e que distribuísse as tarefas entre eles. }\end{array}$ & 3 & $18.75 \%$ \\
\hline
\end{tabular}


12. Ainda sobre o desenvolvimento do projeto sobre o estudo do problema escolhido pela turma, assinale as atividades que constaram de todo o projeto (clicar em todos os tópicos que refletem as atividades desenvolvidas pelo seu grupo):

\begin{tabular}{|c|c|c|}
\hline OPÇŌES DE RESPOSTA & $\mathbf{N}^{\mathbf{0}}$ & $\%$ \\
\hline $\begin{array}{l}\text { O grupo definiu o que gostariam de estudar mais detalhadamente sobre o } \\
\text { problema principal que seria pesquisado. }\end{array}$ & 2 & $4.2 \%$ \\
\hline $\begin{array}{l}\text { O grupo distribuiu as tarefas entre os alunos e depois simplesmente juntou as } \\
\text { partes que cada um desenvolveu individualmente, para fazer o vídeo final. }\end{array}$ & 1 & $2.1 \%$ \\
\hline $\begin{array}{l}\text { O grupo distribuiu as tarefas entre os alunos, e depois todos se juntaram, para que } \\
\text { todos analisassem tudo o que havia sido coletado, e para definirem conjuntamente } \\
\text { sobre o que constaria do vídeo final. }\end{array}$ & 8 & $16.7 \%$ \\
\hline $\begin{array}{l}\text { O grupo acabou fazendo mais atividades do que as indicadas pelo professor, pois } \\
\text { queriam saber mais sobre o tema em estudo. }\end{array}$ & 2 & $4.1 \%$ \\
\hline $\begin{array}{l}\text { O grupo realizou pesquisas na internet, apenas durante as aulas de Informática } \\
\text { Educativa. }\end{array}$ & 5 & $10.4 \%$ \\
\hline $\begin{array}{l}\text { O grupo realizou pesquisas na internet, durante as aulas de Informática Educativa, } \\
\text { bem como em suas casas ou lan-houses da comunidade. }\end{array}$ & 4 & $8.3 \%$ \\
\hline $\begin{array}{l}\text { O grupo entrevistou outros alunos da escola, registrando essas conversas com } \\
\text { gravador de voz. }\end{array}$ & 1 & $2.1 \%$ \\
\hline $\begin{array}{l}\text { O grupo entrevistou outros alunos da escola, registrando essas conversas com áudio } \\
\text { e vídeo. }\end{array}$ & 1 & $2.1 \%$ \\
\hline O grupo entrevistou outros alunos da escola, registrando essas conversas com fotos. & 3 & 6.25 \\
\hline $\begin{array}{l}\text { O grupo entrevistou outros funcionários da escola, registrando essas conversas com } \\
\text { gravador de voz. }\end{array}$ & 1 & $2.1 \%$ \\
\hline $\begin{array}{l}\text { O grupo entrevistou outros funcionários da escola, registrando essas conversas com } \\
\text { áudio e vídeo. }\end{array}$ & 1 & $2.1 \%$ \\
\hline $\begin{array}{l}\text { O grupo entrevistou outros funcionários da escola, registrando essas conversas com } \\
\text { fotos. }\end{array}$ & 0 & $0 \%$ \\
\hline $\begin{array}{l}\text { O grupo entrevistou outras pessoas da comunidade de entorno, registrando essas } \\
\text { conversas com gravador de voz. }\end{array}$ & 1 & $2.1 \%$ \\
\hline $\begin{array}{l}\text { O grupo entrevistou outras pessoas da comunidade de entorno, registrando essas } \\
\text { conversas com áudio e vídeo. }\end{array}$ & 3 & 6.25 \\
\hline $\begin{array}{l}\text { O grupo entrevistou outras pessoas da comunidade de entorno, registrando essas } \\
\text { conversas com fotos. }\end{array}$ & 1 & $2.1 \%$ \\
\hline $\begin{array}{l}\text { O grupo armazenou as informações coletadas durante todas as atividades em } \\
\text { alguma ferramenta de registro ou arquivo (Ex.: EdModo, Facebook, Pasta de } \\
\text { arquivos no computador da sala de Informática Educativa, pen drive). Caso tenha } \\
\text { utilizado, conte-nos qual foi no campo "outros", por favor. }\end{array}$ & 2 & $4.1 \%$ \\
\hline $\begin{array}{l}\text { Outros (O grupo definiu o que gostariam de estudar mais detalhadamente sobre o } \\
\text { problema principal que seria pesquisado) }\end{array}$ & 12 & $25 \%$ \\
\hline
\end{tabular}

13. Quanto ao relacionamento entre os alunos do seu grupo (caso haja comentários adicionais que queira fazer sobre o projeto, escreva no campo "outros"), clique nos quadradinhos dizem algo que você tenha vivenciado durante a realização do projeto:

\begin{tabular}{|c|c|c|}
\hline OPÇÕES DE RESPOSTA & $\mathbf{N}^{\mathbf{o}}$ & $\%$ \\
\hline $\begin{array}{l}\text { Havia um ou dois alunos que definiam as atividades e que passavam as orientações } \\
\text { para os demais alunos. }\end{array}$ & 4 & $13.3 \%$ \\
\hline $\begin{array}{l}\text { Havia um ou dois alunos que definiam e que faziam as atividades, sendo que os } \\
\text { demais alunos do grupo acabavam fazendo o que esses mandavam. }\end{array}$ & 2 & $6.7 \%$ \\
\hline $\begin{array}{l}\text { Apenas } 2 \text { ou } 3 \text { dos alunos do grupo fizeram a maioria das atividades, e os demais só } \\
\text { acompanharam e concordaram, porque simplesmente não estavam interessados. }\end{array}$ & 3 & $10 \%$ \\
\hline $\begin{array}{l}\text { Todos os integrantes do grupo contribuíram para o projeto, sendo que a divisão } \\
\text { das tarefas era negociada entre todos do grupo. }\end{array}$ & 3 & $10 \%$ \\
\hline $\begin{array}{l}\text { Descobri que opiniões diferentes nem sempre são opostas, pois elas podem ser } \\
\text { complementares. }\end{array}$ & 0 & $0 \%$ \\
\hline $\begin{array}{l}\text { Em alguns momentos nós discordávamos sobre o que deveria ser feito, mas o } \\
\text { professor intervinha e ajudava a acalmar as discussões. }\end{array}$ & 6 & $20 \%$ \\
\hline
\end{tabular}


Houve alguns desentendimentos, mas acabamos chegando a alguns acordos e conseguimos fazer um bom trabalho.

Descobri que trabalhar em grupo não é fácil e que não gosto de fazer isso.

\begin{tabular}{|c|c|}
\hline 3 & $10 \%$ \\
\hline 0 & $0 \%$ \\
\hline 1 & $3.3 \%$ \\
\hline 1 & $3.3 \%$ \\
\hline
\end{tabular}

mais.

\begin{tabular}{|l|l|l|l|}
\hline Descobri que minhas ideias também são importantes para o grupo e que também & 1 & $3.3 \%$
\end{tabular} posso contribuir, por pouco que pareça.

Fiquei feliz por ter feito o projeto em grupo e gostaria de dar continuidade.

Descobri que também posso me divertir enquanto aprendo coisa novas. problemas.

Eu gostaria de ter colaborado mais, mas sou tímido(a).

Pensei que não fosse colaborar muito, porque sou tímido(a), mas acabei ajudando com as tecnologias de gravações (adoro mexer com isso).

Achei que não fosse falar muito, mas acabei dando algumas boas ideias (eu curti isso).

Outros

14. Quanto ao acompanhamento do professor da Sala de Informática Educativa:

\begin{tabular}{|c|c|c|}
\hline OPÇÕES DE RESPOSTA & $\mathbf{N}^{\mathbf{0}}$ & $\%$ \\
\hline $\begin{array}{l}\text { O professor só apresentou as orientações iniciais e depois esperou a finalização da } \\
\text { tarefa. }\end{array}$ & 2 & $12.5 \%$ \\
\hline $\begin{array}{l}\text { O professor só apresentou as orientações iniciais e depois ele simplesmente } \\
\text { fiscalizou se estávamos fazendo as atividades e esperou a finalização da tarefa. }\end{array}$ & 1 & $6.25 \%$ \\
\hline $\begin{array}{l}\text { O professor apresentou as orientações e depois acompanhou o desenvolvimento das } \\
\text { atividades, mas só se manifestou para chamar a atenção dos grupos que não } \\
\text { estavam fazendo o que precisava ser feito. }\end{array}$ & 2 & $12.5 \%$ \\
\hline $\begin{array}{l}\text { O professor apresentou as orientações e depois acompanhou o desenvolvimento das } \\
\text { atividades, sendo que fez comentários e intervenções durante todo o processo, junto } \\
\text { a todos os grupos, para ajudar na organização das ideias e das atividades, sempre } \\
\text { que sua ajuda foi solicitada ou sempre que identificava que o grupo precisava de } \\
\text { ajuda. Ele apresentava as soluções de imediato. }\end{array}$ & 8 & $50 \%$ \\
\hline $\begin{array}{l}\text { O professor apresentou as orientações e depois acompanhou o desenvolvimento das } \\
\text { atividades, sendo que fez comentários e intervenções durante todo o processo, junto } \\
\text { a todos os grupos, para ajudar na organização das ideias e das atividades, sempre } \\
\text { que sua ajuda foi solicitada ou sempre que identificava que o grupo precisava de } \\
\text { ajuda. Ele refletia com o grupo qual a melhoria maneira de prosseguir. }\end{array}$ & 3 & $18.75 \%$ \\
\hline
\end{tabular}

15. Caso tenha tido conhecimento dos critérios de avaliação das atividades desde o início do projeto, considerando exatamente esse conhecimento mais claro sobre o que era esperado de você nas atividades do processo, assinale a(s) opção(ões) que explica(m) melhor como esses critérios a(o) ajudaram no projeto:

\begin{tabular}{|c|c|c|}
\hline OPÇÕES DE RESPOSTA & $\mathbf{N}^{\mathbf{0}}$ & $\%$ \\
\hline $\begin{array}{l}\text { não me ajudaram em nada, pois continuei agindo da mesma forma que agia sem } \\
\text { essa informação e continuei com pouco interesse na aula de informática educativa. }\end{array}$ & 3 & $12 \%$ \\
\hline $\begin{array}{l}\text { não me ajudaram em nada, pois continuei agindo da mesma forma que agia sem } \\
\text { essa informação, até porque sempre fui interessado e tive uma boa participação na } \\
\text { aula. }\end{array}$ & 2 & $8 \%$ \\
\hline $\begin{array}{l}\text { me orientaram melhor sobre como deveria desenvolver a atividade (as etapas de } \\
\text { desenvolvimento da atividade ficaram mais claras). }\end{array}$ & 9 & $36 \%$ \\
\hline $\begin{array}{l}\text { me ajudaram a melhorar minha colaboração com meus colegas no projeto (eu não } \\
\text { sabia como poderia contribuir, mas os critérios me esclareceram como deveria } \\
\text { fazer isso). }\end{array}$ & 6 & $24 \%$ \\
\hline me ajudaram a pensar melhor sobre o conteúdo em estudo. & 3 & $12 \%$ \\
\hline não alteraram nada na forma como aprendo um conteúdo em sala. & 2 & $8 \%$ \\
\hline
\end{tabular}


16. Sobre a sua participação e contribuições com o seu grupo:

\begin{tabular}{|c|c|c|}
\hline OPÇÕES DE RESPOSTA & $\mathbf{N}^{\mathbf{o}}$ & $\%$ \\
\hline $\begin{array}{l}\text { Raramente ofereceu ideias úteis ao grupo e, em alguns momentos, até se recusou a } \\
\text { participar. }\end{array}$ & 1 & $6.25 \%$ \\
\hline $\begin{array}{l}\text { Algumas vezes ofereceu ideias úteis ao grupo e teve uma participação satisfatória, } \\
\text { quando sua ajuda foi solicitada. }\end{array}$ & 7 & $43.75 \%$ \\
\hline $\begin{array}{l}\text { Normalmente oferecia ideias úteis ao grupo e apresentou contribuições } \\
\text { importantes, quando se esforçou em ajudar. }\end{array}$ & 5 & $31.25 \%$ \\
\hline $\begin{array}{l}\text { Rotineiramente oferecia ideias úteis ao grupo e se caracterizou como um líder nato, } \\
\text { que contribuiu com muita dedicação. }\end{array}$ & 3 & $18.75 \%$ \\
\hline
\end{tabular}

17. Quando realizou a sua autoavaliação individual, você:

\section{OPÇÕES DE RESPOSTA}

Foi indiferente conhecer os critérios no início, pois não acha as aulas de informática educativa importantes, já que nem tem nota.

Você gostou de conhecer critérios de avaliação diferentes, logo no início do projeto, mas isso não afetou seu desempenho em grupo, durante o desenvolvimento do projeto, pois não acha as aulas de informática educativa importantes, já que nem tem nota.

Você gostou de conhecer os critérios de avaliação no início, mas isso não afetou seu desempenho em grupo, durante o desenvolvimento do projeto, pois já era dedicado aos projetos da aula de informática educativa.

Você gostou de conhecer os critérios de avaliação no início, pois isso ajudou você a se envolver e se dedicar da forma correta ao projeto, o que enriqueceu o seu processo de aprendizagem sobre o tema tratado.

18. Quando realizou a avaliação dos seus colegas de grupo, você:

\begin{tabular}{|c|c|c|}
\hline OPÇÕES DE RESPOSTA & $\mathbf{N}^{\mathbf{0}}$ & $\%$ \\
\hline $\begin{array}{l}\text { Não achei que teve ganho porque os alunos acordam o que falarão uns dos outros e } \\
\text { fica tudo na mesma. }\end{array}$ & 2 & $12.5 \%$ \\
\hline Achei muito ruim porque não gosto de dedurar meus colegas. & 2 & $12.5 \%$ \\
\hline $\begin{array}{l}\text { Foi legal porque isso ajudou a fazer com que todos os alunos participassem mais, já } \\
\text { que sabiam que seriam avaliados por todos. }\end{array}$ & 5 & $31.25 \%$ \\
\hline $\begin{array}{l}\text { Foi legal porque nos ajudou a termos um outro olhar sobre a nossa participação, } \\
\text { indicando onde e como podemos melhorar na próxima. }\end{array}$ & 5 & $31.25 \%$ \\
\hline $\begin{array}{l}\text { Foi muito legal porque isso me ajudou a perceber como minha participação é } \\
\text { importante para o sucesso da equipe e que minha colaboração ativa faz diferença. }\end{array}$ & 2 & $12.5 \%$ \\
\hline
\end{tabular}

19. O que você mais gostou desse processo todo? Marque todas as respostas que tiverem a ver com o que você achou:

\begin{tabular}{|c|c|c|}
\hline OPÇÕES DE RESPOSTA & $\mathbf{N}^{\mathbf{0}}$ & $\%$ \\
\hline $\begin{array}{l}\text { Não vi diferença desse projeto para outros, que não tinham essa tal de rubrica e } \\
\text { critérios de autoavaliação. }\end{array}$ & 0 & $0 \%$ \\
\hline $\begin{array}{l}\text { Gostei de saber antes como seria avaliado, para eu saber como deveria desenvolver } \\
\text { o projeto. }\end{array}$ & 1 & $5.6 \%$ \\
\hline $\begin{array}{l}\text { Gostei de poder refletir com meus colegas sobre os critérios pelos quais seríamos } \\
\text { avaliados. }\end{array}$ & 4 & $22.3 \%$ \\
\hline $\begin{array}{l}\text { Gostei de poder emitir a minha opinião em vários momentos e ver que posso fazer } \\
\text { diferença no desenvolvimento das diretrizes / orientações do projeto. }\end{array}$ & 5 & $27.8 \%$ \\
\hline
\end{tabular}


Eu me senti parte da organização da atividade, o que fez com que eu me dedicasse mais.

Pude refletir sobre diversos temas que me interessam, mais livremente, e pude falar o que pensava, sem ser mal interpretado.

Eu pouco participei falando o que pensava, mas todas as reflexões feitas pelos meus colegas me ajudaram a perceber problemas da escola e da comunidade de entorno aos quais eu também estou exposto.

Não gostei desse modelo de atividade: muita gente falando acaba ficando muito confuso. Prefiro ouvir só o professor.

Não gosto de ter que falar o que penso e não estou interessado no que os outros alunos pensam. Estou na escola para ouvir só o que o professor diz.

20. Marque abaixo os eventuais recursos midiáticos utilizados durante a realização do projeto (pode ser mais de 1):

\begin{tabular}{|l|l|l|}
\hline \multicolumn{1}{|c|}{ OPÇÕES DE RESPOSTA } & $\mathbf{N}^{\mathbf{0}}$ & \multicolumn{1}{c|}{$\%$} \\
\hline GoogleDocs (votações) & 2 & $8 \%$ \\
\hline GoogleDocs (armazenamento / compartilhamento de arquivos, como vídeos) & 6 & $24 \%$ \\
\hline EdModo (trocas reflexivas entre os alunos) & 1 & $4 \%$ \\
\hline Edmodo (repositório dos vídeos desenvolvidos) & 2 & $8 \%$ \\
\hline Youtube (repositório dos vídeos desenvolvidos) & 5 & $20 \%$ \\
\hline Prezi (apresentação final do projeto, com link do vídeo) & 2 & $8 \%$ \\
\hline Power Point (apresentação final do projeto, com link do vídeo) & 2 & $8 \%$ \\
\hline Google (pesquisa sobre o tema problema) & 2 & $8 \%$ \\
\hline Facebook (pesquisa sobre o tema problema) & 0 & $0 \%$ \\
\hline Facebook (grupo fechado / secreto, para discussões do grupo) & 2 & $8 \%$ \\
\hline Facebook (sala de aula virtual da turma) & 1 & $4 \%$ \\
\hline Outros & 0 & $0 \%$ \\
\hline
\end{tabular}

Indique uma ou duas atividades de todo o projeto, de que você mais gostou. E explique o porquê: Respostas: Youtube, porque eu gosto; a segunda parte; gostei de tudo; o vídeo; vídeo foi legal; tudo; nenhuma

Se fosse perguntado a você o que mudaria nesse projeto, para melhorar, o que você sugeriria? Respostas: nada; colocaria mais coisas; não sei

Se você pudesse mandar uma mensagem ao professor José Rosemberg, que coordenou esse projeto com a sua turma, qual seria ela? (caso não tenha nada a dizer, escreva NADA no espaço, para finalizar!) Respostas: que a atividade foi muito legal e aprendi muito; parabéns 


\section{Anexo D - Questionários e Respostas dos alunos (Projetos}

\section{A.3; B.1; B.4)}

\section{Anexo D.3: respostas dos alunos do projeto B.4, sob responsabilidade do POIE Gislaine (Jogos do Riva)}

7.Alunos Respondentes:

Oculto por razões de preservação dos menores

8.Sexo

\begin{tabular}{|c|c|c|}
\hline \multicolumn{1}{|c|}{ SEXO } & $\mathbf{N}^{\mathbf{0}}$ RESPOSTAS & PERCENTUAL \\
\hline Feminino & 2 & $100 \%$ \\
\hline Masculino & 0 & $0 \%$ \\
\hline 9.Idade & & \\
\hline \multicolumn{1}{|c|}{ IDADE } & $\mathbf{N}^{\mathbf{0}}$ RESPOSTAS & PERCENTUAL \\
\hline $\mathbf{1 1}$ anos ou menos & 0 & $0 \%$ \\
\hline $\mathbf{1 2}$ anos & 0 & $0 \%$ \\
\hline $\mathbf{1 3}$ anos & 0 & $0 \%$ \\
\hline $\mathbf{1 4}$ anos & 1 & $50 \%$ \\
\hline $\mathbf{1 5}$ anos ou mais & 1 & $50 \%$ \\
\hline
\end{tabular}

10.Em que momento você foi orientada(o) sobre o quadro com os níveis dos critérios de avaliação do projeto:

\begin{tabular}{|c|c|c|}
\hline OPÇÕES DE RESPOSTA & $\mathbf{N}^{\mathbf{0}}$ & $\%$ \\
\hline No início do projeto, antes de iniciarem as atividades ligadas ao projeto. & 1 & $50 \%$ \\
\hline $\begin{array}{l}\text { No meio do projeto, quando os alunos já haviam começado a fazer algumas das } \\
\text { atividades. }\end{array}$ & 1 & $50 \%$ \\
\hline No final da realização do projeto. & 0 & $0 \%$ \\
\hline $\begin{array}{l}\text { Os critérios de avaliação não foram informados em momento algum, e os alunos só } \\
\text { receberam alguns comentários do professor de informática educativa, no final da } \\
\text { atividade, sem nenhuma justificativa. }\end{array}$ & 0 & $0 \%$ \\
\hline
\end{tabular}

11.Sobre esses combinados, para avaliação e seus níveis:

\begin{tabular}{|c|c|c|}
\hline OPÇÕES DE RESPOSTA & $\mathbf{N}^{\mathbf{0}}$ & $\%$ \\
\hline $\begin{array}{l}\text { O quadro com esses combinados de avaliação e seus níveis foi apresentado pronto } \\
\text { para a turma, pelo professor de informática educativa, apenas para os alunos } \\
\text { conhecerem como seriam avaliados no final do projeto. }\end{array}$ & 0 & $0 \%$ \\
\hline
\end{tabular}


O quadro com esses combinados de avaliação e seus níveis foi apresentado pronto para a turma, pelo professor de informática educativa, para que os alunos lessem os critérios e comentassem se concordavam com ele, sendo que houve algumas poucas alterações no quadro inicial que foi mostrado aos alunos, por causa dos comentários dos alunos da turma.

Os tópicos dos combinados e as descrições / explicações sobre os seus níveis de avaliação foram definidos pelos alunos em parceria com o professor da sala de informática educativa.

Os tópicos dos combinados e as descrições / explicações dos seus níveis de avaliação foram definidos pelos alunos, e o professor da sala de informática educativa só concordou e acatou.

Como respondi na questão anterior, o professor não apresentou claramente esses critérios para os alunos.

12.Sobre a participação dos alunos na elaboração dos combinados de avaliação (critérios e seus níveis de avaliação) de atividade, assinale todas as opções que ocorreram durante o desenvolvimento do projeto:

\begin{tabular}{|c|c|c|}
\hline OPÇÕES DE RESPOSTA & $\mathbf{N}^{\mathbf{o}}$ & $\%$ \\
\hline Não mudou nada, pois no final quem definiu mesmo os critérios foi o professor & 0 & $0 \%$ \\
\hline Foi legal, porque eu pude aprender como o professor avalia uma atividade nossa. & 0 & $0 \%$ \\
\hline $\begin{array}{l}\text { Foi legal porque eu pude perceber de que forma eu posso melhorar meu } \\
\text { desempenho. }\end{array}$ & 0 & $0 \%$ \\
\hline $\begin{array}{l}\text { Foi muito legal porque eu pude refletir com o professor e dar minha opinião sobre } \\
\text { como eu acho que um projeto deve ser desenvolvido. }\end{array}$ & 1 & $50 \%$ \\
\hline $\begin{array}{l}\text { Foi super legal, porque eu me dei conta que dependendo da forma como eu me } \\
\text { dedico no projeto, eu aprendo muito mais. }\end{array}$ & 1 & $50 \%$ \\
\hline
\end{tabular}

13.Quanto às etapas do desenvolvimento do projeto em si, já na Sala de Informática Educativa:

\begin{tabular}{|c|c|c|}
\hline OPÇÕES DE RESPOSTA & $\mathbf{N}^{\mathbf{o}}$ & $\%$ \\
\hline $\begin{array}{l}\text { O professor apresentou os objetivos do trabalho, definiu o produto final desse } \\
\text { projeto (um vídeo), detalhou todo o planejamento de atividades que deveriam ser } \\
\text { desenvolvidas, dividiu os alunos em grupos (definindo que aluno iria para qual } \\
\text { grupo), e distribuiu as tarefas por aluno em cada grupo. }\end{array}$ & 0 & $0 \%$ \\
\hline $\begin{array}{l}\text { O professor apresentou os objetivos do trabalho, definiu o produto final desse } \\
\text { projeto (um vídeo), detalhou todo o planejamento de atividades que deveriam ser } \\
\text { desenvolvidas, dividiu os alunos em grupos (definindo que aluno iria para qual } \\
\text { grupo), e deixou que cada grupo distribuísse as tarefas entre eles. }\end{array}$ & 0 & $0 \%$ \\
\hline $\begin{array}{l}\text { O professor apresentou os objetivos do trabalho, definiu o produto final desse } \\
\text { projeto (um vídeo), detalhou todo o planejamento de atividades que deveriam ser } \\
\text { desenvolvidas, solicitou que os alunos se organizassem em grupos de } 5 \text { a } 6 \text { alunos } \\
\text { (os alunos definiram os componentes de seus grupos), e deixou que cada grupo } \\
\text { distribuísse entre eles as tarefas que foram apontadas para serem desenvolvidas. }\end{array}$ & 1 & $50 \%$ \\
\hline O professor apresentou os objetivos gerais do trabalho, definiu o produto final & 1 & $50 \%$ \\
\hline
\end{tabular}


desse projeto (um vídeo), apresentou o planejamento geral das atividades que deveriam ser desenvolvidas, solicitou que os alunos se organizassem em grupos de 5 a 6 alunos (os alunos definiram os componentes de seus grupos), e deixou que cada grupo definisse como as atividades seriam executadas, onde as informações seriam coletadas e que distribuísse as tarefas entre eles.

14.Ainda sobre o desenvolvimento do projeto sobre o estudo do problema escolhido pela turma, assinale as atividades que constaram de todo o projeto (clicar em todos os tópicos que refletem as atividades desenvolvidas pelo seu grupo):

\begin{tabular}{|c|c|c|}
\hline OPÇÕES DE RESPOSTA & $\mathbf{N}^{\mathbf{0}}$ & $\%$ \\
\hline $\begin{array}{l}\text { O grupo definiu o que gostariam de estudar mais detalhadamente sobre o } \\
\text { problema principal que seria pesquisado. }\end{array}$ & 1 & $10 \%$ \\
\hline $\begin{array}{l}\text { O grupo distribuiu as tarefas entre os alunos e depois simplesmente juntou } \\
\text { as partes que cada um desenvolveu individualmente, para fazer o vídeo final. }\end{array}$ & 1 & $10 \%$ \\
\hline $\begin{array}{l}\text { O grupo distribuiu as tarefas entre os alunos, e depois todos se juntaram, } \\
\text { para que todos analisassem tudo o que havia sido coletado, e para definirem } \\
\text { conjuntamente sobre o que constaria do vídeo final. }\end{array}$ & 2 & $20 \%$ \\
\hline $\begin{array}{l}\text { O grupo acabou fazendo mais atividades do que as indicadas pelo professor, pois } \\
\text { queriam saber mais sobre o tema em estudo. }\end{array}$ & 1 & $10 \%$ \\
\hline $\begin{array}{l}\text { O grupo realizou pesquisas na internet, apenas durante as aulas de Informática } \\
\text { Educativa. }\end{array}$ & 0 & $0 \%$ \\
\hline $\begin{array}{l}\text { O grupo realizou pesquisas na internet, durante as aulas de Informática Educativa, } \\
\text { bem como em suas casas ou lan-houses da comunidade. }\end{array}$ & 1 & $10 \%$ \\
\hline $\begin{array}{l}\text { O grupo entrevistou outros alunos da escola, registrando essas conversas com } \\
\text { gravador de voz. }\end{array}$ & 0 & $0 \%$ \\
\hline $\begin{array}{l}\text { O grupo entrevistou outros alunos da escola, registrando essas conversas com áudio } \\
\text { e vídeo. }\end{array}$ & 0 & $0 \%$ \\
\hline O grupo entrevistou outros alunos da escola, registrando essas conversas com fotos. & 0 & $0 \%$ \\
\hline $\begin{array}{l}\text { O grupo entrevistou outros funcionários da escola, registrando essas conversas com } \\
\text { gravador de voz. }\end{array}$ & 0 & $0 \%$ \\
\hline $\begin{array}{l}\text { O grupo entrevistou outros funcionários da escola, registrando essas conversas com } \\
\text { áudio e vídeo. }\end{array}$ & 0 & $0 \%$ \\
\hline $\begin{array}{l}\text { O grupo entrevistou outros funcionários da escola, registrando essas conversas com } \\
\text { fotos. }\end{array}$ & 0 & $0 \%$ \\
\hline $\begin{array}{l}\text { O grupo entrevistou outras pessoas da comunidade de entorno, registrando essas } \\
\text { conversas com gravador de voz. }\end{array}$ & 0 & $0 \%$ \\
\hline $\begin{array}{l}\text { O grupo entrevistou outras pessoas da comunidade de entorno, registrando essas } \\
\text { conversas com áudio e vídeo. }\end{array}$ & 0 & $0 \%$ \\
\hline $\begin{array}{l}\text { O grupo entrevistou outras pessoas da comunidade de entorno, registrando essas } \\
\text { conversas com fotos. }\end{array}$ & 0 & $0 \%$ \\
\hline $\begin{array}{l}\text { O grupo armazenou as informações coletadas durante todas as atividades em } \\
\text { alguma ferramenta de registro ou arquivo (Ex.: EdModo, Facebook, Pasta de } \\
\text { arquivos no computador da sala de Informática Educativa, pen drive). Caso tenha }\end{array}$ & 2 & $20 \%$ \\
\hline
\end{tabular}


utilizado, conte-nos qual foi no campo "outros", por favor.

Outros

15.Quanto ao relacionamento entre os alunos do seu grupo (caso haja comentários adicionais que queira fazer sobre o projeto, escreva no campo "outros"), clique nos quadradinhos dizem algo que você tenha vivenciado durante a realização do projeto:

\begin{tabular}{|c|c|c|}
\hline OPÇÕES DE RESPOSTA & $\mathbf{N}^{\mathbf{0}}$ & $\%$ \\
\hline $\begin{array}{l}\text { Havia um ou dois alunos que definiam as atividades e que passavam as orientações } \\
\text { para os demais alunos. }\end{array}$ & 1 & $6.5 \%$ \\
\hline $\begin{array}{l}\text { Havia um ou dois alunos que definiam e que faziam as atividades, sendo que os } \\
\text { demais alunos do grupo acabavam fazendo o que esses mandavam. }\end{array}$ & 0 & $0 \%$ \\
\hline $\begin{array}{l}\text { Apenas } 2 \text { ou } 3 \text { dos alunos do grupo fizeram a maioria das atividades, e os demais só } \\
\text { acompanharam e concordaram, porque simplesmente não estavam interessados. }\end{array}$ & 2 & $12 \%$ \\
\hline $\begin{array}{l}\text { Todos os integrantes do grupo contribuíram para o projeto, sendo que a divisão das } \\
\text { tarefas era negociada entre todos do grupo. }\end{array}$ & 1 & $6.5 \%$ \\
\hline $\begin{array}{l}\text { Descobri que opiniões diferentes nem sempre são opostas, pois elas podem ser } \\
\text { complementares. }\end{array}$ & 1 & $6.5 \%$ \\
\hline $\begin{array}{l}\text { Em alguns momentos nós discordávamos sobre o que deveria ser feito, mas o } \\
\text { professor intervinha e ajudava a acalmar as discussões. }\end{array}$ & 2 & $12 \%$ \\
\hline $\begin{array}{l}\text { Houve alguns desentendimentos, mas acabamos chegando a alguns acordos e } \\
\text { conseguimos fazer um bom trabalho. }\end{array}$ & 2 & $12 \%$ \\
\hline Descobri que trabalhar em grupo não é fácil e que não gosto de fazer isso. & 0 & $0 \%$ \\
\hline $\begin{array}{l}\text { Descobri que trabalhar em grupo não é fácil, mas é bem legal porque aprendo } \\
\text { mais. }\end{array}$ & 1 & $6.5 \%$ \\
\hline $\begin{array}{l}\text { Descobri que minhas ideias também são importantes para o grupo e que também } \\
\text { posso contribuir, por pouco que pareça. }\end{array}$ & 1 & $6.5 \%$ \\
\hline Fiquei feliz por ter feito o projeto em grupo e gostaria de dar continuidade. & 1 & $6.5 \%$ \\
\hline Descobri que também posso me divertir enquanto aprendo coisa novas. & 1 & $6.5 \%$ \\
\hline $\begin{array}{l}\text { Descobri que pesquisar com meus colegas me ajuda a pensar melhor sobre os } \\
\text { problemas. }\end{array}$ & 1 & $6.5 \%$ \\
\hline Eu gostaria de ter colaborado mais, mas sou tímido(a). & 0 & $0 \%$ \\
\hline $\begin{array}{l}\text { Pensei que não fosse colaborar muito, porque sou tímido(a), mas acabei ajudando } \\
\text { com as tecnologias de gravações (adoro mexer com isso). }\end{array}$ & 0 & $0 \%$ \\
\hline $\begin{array}{l}\text { Achei que não fosse falar muito, mas acabei dando algumas boas ideias (eu curti } \\
\text { isso). }\end{array}$ & 1 & $6.5 \%$ \\
\hline Outros & 1 & $6.5 \%$ \\
\hline
\end{tabular}


16.Quanto ao acompanhamento do professor da Sala de Informática Educativa:

\begin{tabular}{|c|c|c|}
\hline OPÇÕES DE RESPOSTA & $\mathbf{N}^{\mathbf{o}}$ & $\%$ \\
\hline $\begin{array}{l}\text { O professor só apresentou as orientações iniciais e depois esperou a finalização da } \\
\text { tarefa. }\end{array}$ & 0 & $0 \%$ \\
\hline $\begin{array}{l}\text { O professor só apresentou as orientações iniciais e depois ele simplesmente } \\
\text { fiscalizou se estávamos fazendo as atividades e esperou a finalização da tarefa. }\end{array}$ & 0 & $0 \%$ \\
\hline $\begin{array}{l}\text { O professor apresentou as orientações e depois acompanhou o desenvolvimento das } \\
\text { atividades, mas só se manifestou para chamar a atenção dos grupos que não } \\
\text { estavam fazendo o que precisava ser feito. }\end{array}$ & 1 & $50 \%$ \\
\hline $\begin{array}{l}\text { O professor apresentou as orientações e depois acompanhou o desenvolvimento das } \\
\text { atividades, sendo que fez comentários e intervenções durante todo o processo, junto } \\
\text { a todos os grupos, para ajudar na organização das ideias e das atividades, sempre } \\
\text { que sua ajuda foi solicitada ou sempre que identificava que o grupo precisava de } \\
\text { ajuda. Ele apresentava as soluções de imediato. }\end{array}$ & 0 & $0 \%$ \\
\hline $\begin{array}{l}\text { O professor apresentou as orientações e depois acompanhou o desenvolvimento das } \\
\text { atividades, sendo que fez comentários e intervenções durante todo o processo, junto } \\
\text { a todos os grupos, para ajudar na organização das ideias e das atividades, sempre } \\
\text { que sua ajuda foi solicitada ou sempre que identificava que o grupo precisava de } \\
\text { ajuda. Ele refletia com o grupo qual a melhoria maneira de prosseguir. }\end{array}$ & 1 & $50 \%$ \\
\hline
\end{tabular}

17. Caso tenha tido conhecimento dos combinados (critérios) de avaliação das atividades desde o início do projeto, considerando exatamente esse conhecimento mais claro sobre o que era esperado de você nas atividades do processo, assinale a(s) opção(ões) que explica(m) melhor como esses critérios a(o) ajudaram no projeto:

\begin{tabular}{|c|c|c|}
\hline OPÇÕES DE RESPOSTA & $\mathbf{N}^{\mathbf{o}}$ & $\%$ \\
\hline $\begin{array}{l}\text { não me ajudaram em nada, pois continuei agindo da mesma forma que agia sem } \\
\text { essa informação e continuei com pouco interesse na aula de informática educativa. }\end{array}$ & 0 & $0 \%$ \\
\hline $\begin{array}{l}\text { não me ajudaram em nada, pois continuei agindo da mesma forma que agia sem } \\
\text { essa informação, até porque sempre fui interessado e tive uma boa participação na } \\
\text { aula. }\end{array}$ & 0 & $0 \%$ \\
\hline $\begin{array}{l}\text { me orientaram melhor sobre como deveria desenvolver a atividade (as etapas de } \\
\text { desenvolvimento da atividade ficaram mais claras). }\end{array}$ & 1 & $50 \%$ \\
\hline $\begin{array}{l}\text { me ajudaram a melhorar minha colaboração com meus colegas no projeto (eu não } \\
\text { sabia como poderia contribuir, mas os critérios me esclareceram como deveria } \\
\text { fazer isso). }\end{array}$ & 0 & $0 \%$ \\
\hline me ajudaram a pensar melhor sobre o conteúdo em estudo. & 0 & $0 \%$ \\
\hline não alteraram nada na forma como aprendo um conteúdo em sala. & 1 & $50 \%$ \\
\hline
\end{tabular}


18.Sobre a sua participação e contribuições com o seu grupo:

\begin{tabular}{|l|c|c|}
\hline \multicolumn{1}{|c|}{ OPÇÕES DE RESPOSTA } & No & $\%$ \\
\hline $\begin{array}{l}\text { Raramente ofereceu ideias úteis ao grupo e, em alguns momentos, até se recusou a } \\
\text { participar. }\end{array}$ & 0 & $0 \%$ \\
\hline $\begin{array}{l}\text { Algumas vezes ofereceu ideias úteis ao grupo e teve uma participação satisfatória, } \\
\text { quando sua ajuda foi solicitada. }\end{array}$ & 0 & $0 \%$ \\
\hline $\begin{array}{l}\text { Normalmente oferecia ideias úteis ao grupo e apresentou contribuições } \\
\text { importantes, quando se esforçou em ajudar. }\end{array}$ & 1 & $50 \%$ \\
\hline $\begin{array}{l}\text { Rotineiramente oferecia ideias úteis ao grupo e se caracterizou como um líder nato, } \\
\text { que contribuiu com muita dedicação. }\end{array}$ & 1 & $50 \%$ \\
\hline
\end{tabular}

19.Quando realizou a sua autoavaliação individual, você:

\begin{tabular}{|c|c|c|}
\hline OPÇÕES DE RESPOSTA & $\mathbf{N}^{\mathbf{o}}$ & $\%$ \\
\hline $\begin{array}{l}\text { Foi indiferente conhecer os critérios no início, pois não acha as aulas de informática } \\
\text { educativa importantes, já que nem tem nota. }\end{array}$ & 0 & $0 \%$ \\
\hline $\begin{array}{l}\text { Você gostou de conhecer critérios de avaliação diferentes, logo no início do projeto, } \\
\text { mas isso não afetou seu desempenho em grupo, durante o desenvolvimento do } \\
\text { projeto, pois não acha as aulas de informática educativa importantes, já que nem } \\
\text { tem nota. }\end{array}$ & 0 & $0 \%$ \\
\hline $\begin{array}{l}\text { Você gostou de conhecer os critérios de avaliação no início, mas isso não afetou seu } \\
\text { desempenho em grupo, durante o desenvolvimento do projeto, pois já era dedicado } \\
\text { aos projetos da aula de informática educativa. }\end{array}$ & 2 & $100 \%$ \\
\hline $\begin{array}{l}\text { Você gostou de conhecer os critérios de avaliação no início, pois isso ajudou você a } \\
\text { se envolver e se dedicar da forma correta ao projeto, o que enriqueceu o seu } \\
\text { processo de aprendizagem sobre o tema tratado. }\end{array}$ & 0 & $0 \%$ \\
\hline
\end{tabular}

20.Quando realizou a avaliação dos seus colegas de grupo, você:

\begin{tabular}{|l|l|l|}
\hline \multicolumn{1}{|c|}{ OPÇÕES DE RESPOSTA } & \multicolumn{1}{|c|}{$\mathbf{N}^{\mathbf{0}}$} & $\%$ \\
\hline $\begin{array}{l}\text { Não achei que teve ganho porque os alunos acordam o que falarão uns dos outros e } \\
\text { fica tudo na mesma. }\end{array}$ & 0 & $0 \%$ \\
\hline $\begin{array}{l}\text { Achei muito ruim porque não gosto de dedurar meus colegas. } \\
\text { Foi legal porque isso ajudou a fazer com que todos os alunos participassem mais, já } \\
\text { que sabiam que seriam avaliados por todos. }\end{array}$ & 0 & $0 \%$ \\
\hline Foi legal porque nos ajudou a termos um outro olhar sobre a nossa participação, & 1 & $50 \%$ \\
\hline
\end{tabular}


indicando onde e como podemos melhorar na próxima.

Foi muito legal porque isso me ajudou a perceber como minha participação é 1

importante para o sucesso da equipe e que minha colaboração ativa faz diferença.

21.0 que você mais gostou desse processo todo? Marque todas as respostas que tiverem a ver com o que você achou:

\begin{tabular}{|c|c|c|}
\hline OPÇÕES DE RESPOSTA & $\mathbf{N}^{\mathbf{0}}$ & $\%$ \\
\hline $\begin{array}{l}\text { Não vi diferença desse projeto para outros, que não tinham essa tal de rubrica e } \\
\text { critérios de autoavaliação. }\end{array}$ & 0 & $0 \%$ \\
\hline $\begin{array}{l}\text { Gostei de saber antes como seria avaliado, para eu saber como deveria desenvolver } \\
\text { o projeto. }\end{array}$ & 0 & $0 \%$ \\
\hline $\begin{array}{l}\text { Gostei de poder refletir com meus colegas sobre os critérios pelos quais seríamos } \\
\text { avaliados. }\end{array}$ & 1 & $16.7 \%$ \\
\hline $\begin{array}{l}\text { Gostei de poder emitir a minha opinião em vários momentos e ver que posso fazer } \\
\text { diferença no desenvolvimento das diretrizes / orientações do projeto. }\end{array}$ & 1 & $16.7 \%$ \\
\hline $\begin{array}{l}\text { Eu me senti parte da organização da atividade, o que fez com que eu me dedicasse } \\
\text { mais. }\end{array}$ & 2 & $33.3 \%$ \\
\hline $\begin{array}{l}\text { Pude refletir sobre diversos temas que me interessam, mais livremente, e pude falar } \\
\text { o que pensava, sem ser mal interpretado. }\end{array}$ & 2 & $33.3 \%$ \\
\hline $\begin{array}{l}\text { Eu pouco participei falando o que pensava, mas todas as reflexões feitas pelos meus } \\
\text { colegas me ajudaram a perceber problemas da escola e da comunidade de entorno } \\
\text { aos quais eu também estou exposto. }\end{array}$ & 0 & $0 \%$ \\
\hline $\begin{array}{l}\text { Não gostei desse modelo de atividade: muita gente falando acaba ficando muito } \\
\text { confuso. Prefiro ouvir só o professor. }\end{array}$ & 0 & $0 \%$ \\
\hline $\begin{array}{l}\text { Não gosto de ter que falar o que penso e não estou interessado no que os outros } \\
\text { alunos pensam. Estou na escola para ouvir só o que o professor diz. }\end{array}$ & 0 & $0 \%$ \\
\hline
\end{tabular}

22.Marque abaixo os eventuais recursos midiáticos utilizados durante a realização do projeto (pode ser mais de 1):

\begin{tabular}{|c|c|c|c|}
\hline & OPÇÕES DE RESPOSTA & \multicolumn{2}{|l|}{$\mathbf{N}^{\mathbf{0}}$} \\
\hline & GoogleDocs (votações) & 0 & $0 \%$ \\
\hline vídeos) & GoogleDocs (armazenamento / compartilhamento de arquivos, como & 1 & $11.11 \%$ \\
\hline & EdModo (trocas reflexivas entre os alunos) & 0 & $0 \%$ \\
\hline & Edmodo (repositório dos vídeos desenvolvidos) & 0 & $0 \%$ \\
\hline & Youtube (repositório dos vídeos desenvolvidos) & 1 & $11.11 \%$ \\
\hline & Prezi (apresentação final do projeto, com link do vídeo) & 0 & $0 \%$ \\
\hline & Power Point (apresentação final do projeto, com link do vídeo) & 1 & $11.11 \%$ \\
\hline & Google (pesquisa sobre o tema problema) & 2 & $22.22 \%$ \\
\hline & Facebook (pesquisa sobre o tema problema) & 0 & $0 \%$ \\
\hline & Facebook (grupo fechado / secreto, para discussões do grupo) & 2 & $22.22 \%$ \\
\hline
\end{tabular}




\begin{tabular}{|l|c|c|}
\hline Facebook (sala de aula virtual da turma) & 0 & $0 \%$ \\
\hline Outros & 2 & $22.23 \%$ \\
\hline
\end{tabular}

\section{Indique uma ou duas atividades de todo o projeto, de que você mais gostou. E explique o porquê:}

Respostas: Criar jogos no PowerPoint, pois foi uma experiência nova na minha vida e adorei realiza-la! Primeiro os cosplays, porque conseguimos colocar uma coisa que alguns de nós gostamos dentro do projeto. Depois a montagem de cenários, porque algo além da tecnologia, e ninguém aprecia esperar um trabalho manual dentro de um projeto que tem como principal proposta o uso da tecnologia.

\section{Se fosse perguntado a você o que mudaria nesse projeto, para melhorar, o que você sugeriria?}

Respostas: sugeriria para passarmos menos tempo planejando e mais tempo fazendo coisas que pensamos. Quando planejamos perdemos o foco principal, mas quando realizamos as primeiras ideias que vêm na cabeça, é mais fácil lembrar da essência do projeto.

Que todos os alunos se empenhassem mais! Pois infelizmente, ainda tem alguns no projeto que não tem disciplina nenhuma.

\section{Se você pudesse mandar uma mensagem à professora Gislaine, que coordenou esse projeto com a} sua turma, qual seria ela? (caso não tenha nada a dizer, escreva NADA no espaço, para finalizar!)

\section{Respostas:}

Aluna 1: Pro, muito obrigada por chamar a gente para participar desse projeto, e por continuar com ele, mesmo que a maioria de nós nem estamos mais no Rivadávia. Desculpa se nós te deixamos louca e comemos todo o seu sorvete. Mesmo que um dia seus aluninhos se tornem universitários superocupados, pode chamar a gente que a gente dá um jeito de aparecer. Me lembrarei dos seus métodos nada convencionais quando eu tiver minha sala de aula. É isso! Até mais!

Aluna 2: Muito obrigada por proporcionar tantas oportunidades boas para mim e para meus colegas! Você não imagina o quanto isso é importante para a gente. E o que mais me chama a atenção em você, é que você acredita na gente. Outros professores não se importam com nossas opiniões, mas você nos ouve e aceita nossas propostas. 


\section{Anexo E - Descritivos Técnicos dos Projetos Estudados}

Os dados contidos nas fichas técnicas abaixo sãos dos projetos do Grupo A e Grupo B, analisados para esta pesquisa empírica (dados retirados dos registros no AVA ThinkQuest e das entrevistas com os POIE responsáveis).

\begin{tabular}{|c|c|}
\hline Grupo & GRUPO A \\
\hline Classificação & Programa "Guarda-chuva" \\
\hline Nome do Projeto & POIE 2012 \\
\hline Unidade & DRE Campo Limpo \\
\hline Responsável & Cristina Fernandes Barroco \\
\hline Duração & 4 encontros anuais \\
\hline Resumo Geral & $\begin{array}{l}\text { Formação dos POIE, das diversas unidades escolares } \\
\text { ligadas às DRE - Campo Limpo, sobre pedagogia de } \\
\text { projetos (base no protagonismo e interações dialógicas e } \\
\text { reflexivas), com foco nas práticas de registro dos projetos } \\
\text { no AVA ThinkQuest e na implementação de ações } \\
\text { estratégicas de avaliação formativa, a partir das premissas } \\
\text { de Wiliam (2011) - criação e uso de rubricas formativas, } \\
\text { feedback propositivo e autoavaliações /avaliação entre } \\
\text { pares. Foram apresentadas as premissas da referida pratica } \\
\text { aos POIE, que por sua vez, escolheram um projeto para } \\
\text { aplicarem a mesma, algo que fizeram durante o ano de } \\
\text { 2012, inclusive com avaliação com base em rubricas. }\end{array}$ \\
\hline \multicolumn{2}{|l|}{ Estrutura / Ações } \\
\hline $\begin{array}{l}\text { Produto / Peça } \\
\text { Tecnológica Final }\end{array}$ & $\begin{array}{l}\text { Estrutura de Pedagogia de Projetos de IE, integrado com } \\
\text { abordagem de Avaliação Formativa. }\end{array}$ \\
\hline $\begin{array}{l}\mathbf{N}^{\mathbf{0}} \text { de alunos } \\
\text { Participantes }\end{array}$ & $\begin{array}{l}102 \text { POIE, cada um com um projeto. Observação: para } \\
\text { efeito desta pesquisa de campo, analisamos apenas } 12 \text { dos } \\
\text { projetos desenvolvidos e avaliados durante o } \\
\text { desenvolvimento deste programa. }\end{array}$ \\
\hline Registro? Onde? & AVA ThinkQuest \\
\hline Rubrica? & $\begin{array}{l}\text { Rubrica POIE SME, aplicada para autoavaliação do POIE, } \\
\text { sobre sua gestão do projeto }\end{array}$ \\
\hline Rubrica Início? & Sim \\
\hline Rubrica Final? & Sim \\
\hline Autoavaliação Oral? & Sim \\
\hline $\begin{array}{l}\text { Autoavaliação } \\
\text { Registrada? Onde? }\end{array}$ & $\begin{array}{l}\text { Sim, no AVA, com detalhamentos sobre o projeto, no } \\
\left.\text { Encontro Final ( } 4^{\circ} \text { encontro presencial }\right)\end{array}$ \\
\hline $\begin{array}{l}\text { Feedback avaliação? } \\
\text { Como? }\end{array}$ & $\begin{array}{l}\text { Sim, por escrito. Gestores nos forneceu um relatório final } \\
\text { sobre as autoavaliações apresentadas pelos POIE. }\end{array}$ \\
\hline $\begin{array}{l}\text { Narrativa reflexiva } \\
\text { entre alunos / } \\
\text { participantes? }\end{array}$ & Sim, muitas \\
\hline Rubrica (Conteúdos) & Vide Anexo F. \\
\hline $\begin{array}{l}\text { Narrativa } \\
\text { Autoavaliação }\end{array}$ & $\begin{array}{l}\text { Não houve postagem no AVA, mas foi feita devolutiva por } \\
\text { escrito, com reflexões propositivas por parte dos gestores. }\end{array}$ \\
\hline
\end{tabular}




\begin{tabular}{|l|l|}
\hline Narrativa feedback & $\begin{array}{l}\text { Feito oralmente e por escrito, com reflexões claras sobre } \\
\text { quão adequada estava ou não a autoavaliação feita. Isso foi } \\
\text { feito em 2 momentos, até para que, no 2o momento, os } \\
\text { gestores pudessem verificar se houve dedicação e efeito da } \\
\text { formação e do feedback dado anteriormente. }\end{array}$ \\
\hline $\begin{array}{l}\text { Considerações } \\
\text { complementares } \\
\text { necessário) }\end{array} \quad$ (se & $\begin{array}{l}\text { Professora Cristina Barroco, uma das responsáveis pelo } \\
\text { Programa 2012, da DRE Campo Limpo, concedeu uma } \\
\text { entrevista com perguntas semiestruturadas, cujo quadro de } \\
\text { Análise de Conteúdo consta do ANEXO G }\end{array}$ \\
\hline
\end{tabular}




\begin{tabular}{|c|c|}
\hline Grupo & GRUPO A \\
\hline Classificação & Projeto A.1 \\
\hline Nome do Projeto & Sustentabilidade - o que é e qual o meu papel? \\
\hline Unidade & EMEF Gianfrancesco Guarnieri \\
\hline Responsável & Margarete Gimenes Stalberg \\
\hline Duração & 16 a 20 aulas \\
\hline Resumo Geral & $\begin{array}{l}\text { Quando pensamos em sustentabilidade, nos vem à } \\
\text { memória as palavras: poluição, desmatamento, reciclagem } \\
\text { e preservação do meio ambiente. Este projeto visa ampliar } \\
\text { nossos conhecimentos sobre o tema Sustentabilidade, } \\
\text { englobando os conceitos sociais e econômicos. Evitar o } \\
\text { desperdício de água, economizar energia elétrica, e reciclar } \\
\text { materiais são algumas das ações que todos nós podemos } \\
\text { fazer, porém, para que o mundo seja sustentável, } \\
\text { precisamos não só pensar nos problemas ambientais, mas } \\
\text { nas desigualdades sociais e no consumo consciente. A } \\
\text { educação é veículo multiplicador de saberes e, através de } \\
\text { diferentes áreas de conhecimento, pode planejar ações para } \\
\text { a construção de uma escola e um planeta sustentáveis. }\end{array}$ \\
\hline Estrutura / Ações & $\begin{array}{l}\text { 1. Sustentabilidade (interpretação de foto sobre meio } \\
\text { ambiente); 2. Sustentabilidade Reciclagem (interpretação } \\
\text { de desenho sobre reciclagem). } \\
\text { Questão essencial: o que sabemos sobre sustentabilidade e } \\
\text { quais as ações que podemos tomar para ajudar ao planeta a } \\
\text { ser um lugar sustentável, focando o meio ambiente, as } \\
\text { desigualdades sociais e econômicas. } \\
\text { Acesso a especialista sobre o tema: receberam na escola o } \\
\text { diretor de uma ONG que recicla entulho na cidade de } \\
\text { Osasco, Vídeos foram presentados sobre o assunto e } \\
\text { depois foram feitas entrevista com os convidados. }\end{array}$ \\
\hline $\begin{array}{l}\text { Produto / Peça } \\
\text { Tecnológica Final }\end{array}$ & $\begin{array}{l}\text { Registro no ThinkQuest, vídeos no Movie Maker, } \\
\text { apresentação para a comunidade escolar e pais. }\end{array}$ \\
\hline $\begin{array}{l}\mathbf{N}^{\mathbf{0}} \text { de alunos / } \\
\text { Participantes }\end{array}$ & 220 alunos (7o A, B, C, D, E; 8a A, B, C, D) \\
\hline Registro? Onde? & AVA ThinkQuest \\
\hline Rubrica? & Sim \\
\hline Rubrica Início? & Não \\
\hline Rubrica Final? & Sim \\
\hline Autoavaliação Oral? & $\begin{array}{l}\text { Comentários complementares de autoavaliação também } \\
\text { foram feitos oralmente }\end{array}$ \\
\hline $\begin{array}{l}\text { Autoavaliação } \\
\text { Registrada? Onde? }\end{array}$ & $\begin{array}{l}\text { Autoavaliação, indicando o nível em que se encontrava, } \\
\text { com justificativa simples sobre o nível indicado. }\end{array}$ \\
\hline $\begin{array}{l}\text { Feedback avaliação? } \\
\text { Como? }\end{array}$ & $\begin{array}{l}\text { POIE apresentou feedback oral com alunos, à medida que } \\
\text { registravam suas autoavaliações no AVA. }\end{array}$ \\
\hline $\begin{array}{l}\text { Narrativa reflexiva } \\
\text { entre alunos / } \\
\text { participantes? }\end{array}$ & $\begin{array}{l}\text { Houve proposta de reflexões a cada passo da atividade, } \\
\text { mas a rubrica só foi apresentada aos alunos no momento da } \\
\text { autoavaliação, ao final do projeto. Houve reflexão inicial e } \\
\text { solicitação de melhoria de ideias sobre o significado de }\end{array}$ \\
\hline
\end{tabular}




\begin{tabular}{|c|c|}
\hline & $\begin{array}{l}\text { sustentabilidade, houve visitas a espaços para observação, } \\
\text { registro com foto e reflexão, houve reflexão sobre palestra } \\
\text { de especialista em reciclagem e coleta seletiva, reflexão } \\
\text { sobre conscientização e compromisso com o meio } \\
\text { ambiente. Foi feita reflexão conjunta também sobre quais } \\
\text { os materiais que podem ser reciclados }\end{array}$ \\
\hline Rubrica (Conteúdos) & $\begin{array}{l}\text { Autoavaliação sobre participação no projeto (2 turmas): } \\
\text { Ótimo (Participei do projeto fazendo todas as atividades, } \\
\text { interagi com o meu colega compartilhando ideias e } \\
\text { sugestões para a construção de um mundo melhor); Bom } \\
\text { (Participei do projeto fazendo todas as atividades); Poderia } \\
\text { ter me esforçado mais (Deixei de fazer algumas } \\
\text { atividades); Participei pouco (Não consegui me envolver } \\
\text { no Projeto por falta de interesse) /// Rubrica simples, após } \\
\text { atividade reflexiva sobre Sustentabilidade(para } 2 \text { turmas): } \\
\text { 1. Aprendi coisas novas (34); 2. Já sabia, mas foi legal } \\
\text { (19); 3. Não acrescentou nada para mim (3); 4. Legal, vou } \\
\text { pesquisar mais (1); 5. Fiquei mais consciente (30) }\end{array}$ \\
\hline $\begin{array}{l}\text { Narrativa } \\
\text { Autoavaliação }\end{array}$ & $\begin{array}{l}\text { Autoavaliação sobre participação no projeto ( } 2 \text { turmas): } \\
\text { ótimo (9); Bom (62); Poderia ter me esforçado mais (6); } \\
\text { Participei pouco (3) }\end{array}$ \\
\hline Narrativa feedback & Feita oralmente, com base nas rubricas \\
\hline $\begin{array}{l}\text { Considerações } \\
\text { complementares } \quad \text { (se } \\
\text { necessário) }\end{array}$ & $\begin{array}{l}\text { O ambiente foi utilizado muito mais para registro das } \\
\text { atividades, do que como suporte das reflexões. Mostrou } \\
\text { fotos das visitas feitas para conscientização, reflexões } \\
\text { feitas oralmente em sala de informática educativa. } \\
\text { Professora Margarete Gimenes Stalberg, POIE responsável } \\
\text { por este projeto, concedeu uma entrevista, com perguntas } \\
\text { semiestruturadas, sobre este e mais alguns projetos por ele } \\
\text { coordenados junto ao LIE da referida unidade, cujo quadro } \\
\text { de Análise de Conteúdo consta do Anexo G. }\end{array}$ \\
\hline
\end{tabular}




\begin{tabular}{|c|c|}
\hline Grupo & GRUPO A \\
\hline Classificação & Projeto A.2 \\
\hline Nome do Projeto & $\begin{array}{l}\text { EMEF Paulo Patarra dando alguns passos rumo a uma } \\
\text { escola sustentável }\end{array}$ \\
\hline Unidade & EMEF Jardim Mitsumi I - Paulo Patarra \\
\hline Responsável & José Rosemberg \\
\hline Duração & 18 a 20 aulas. \\
\hline Resumo Geral & $\begin{array}{l}\text { Foi estudado o que é sustentabilidade e Meio Ambiente. } \\
\text { Depois deles entenderem o que é, organizaram maneiras } \\
\text { sustentáveis para divulgar a preocupação que se deve ter } \\
\text { com o cuidado do nosso planeta, por meio das mais } \\
\text { pequenas ações. Ou seja, divulgaram o que cada um } \\
\text { poderia fazer, por meio de ações simples, para cuidar do } \\
\text { meio ambiente local. Questão essencial é: o que podemos } \\
\text { fazer para diminuir a poluição ambiental? Produto final } \\
\text { pretendido: criação de comerciais educativos para passar } \\
\text { na rádio escolar e banners / folders que serão } \\
\text { compartilhados via e-mail. Produto final realizado: HQ, no } \\
\text { PowerPoint, com imagens da poluição na escola. }\end{array}$ \\
\hline Estrutura / Ações & $\begin{array}{l}\text { 1. Sustentabilidade: o que é isso?; 2. Sustentabilidade: } \\
\text { compreendendo melhor; } 3 \text {. Sustentabilidade: Nossa Escola } \\
\text { (alunos mapeiam aspectos do ambiente da escola, a partir } \\
\text { de fotos de vários espaços da escola; quem causa a } \\
\text { poluição na escola); Livro de Visitas. Observação: eles } \\
\text { refletiram sobre como ter atitudes sustentáveis, uso } \\
\text { consciente da eletricidade, sacolas, como se desfazer de } \\
\text { óleo de cozinha, como e o quê reciclar do lixo de casa. } \\
\text { Apresentação de um especialista: cartunista Jean Pires. }\end{array}$ \\
\hline $\begin{array}{l}\text { Produto / Peça } \\
\text { Tecnológica Final }\end{array}$ & $\begin{array}{l}\text { Criação de HQs, em Shareware e PowerPoint, com } \\
\text { imagens da poluição na escola. Exposição dos trabalhos na } \\
\text { escola. }\end{array}$ \\
\hline $\begin{array}{l}\mathbf{N}^{\mathbf{0}} \text { de alunos / } \\
\text { Participantes }\end{array}$ & 67 alunos $\left(7^{\circ}\right.$ ano $)$ \\
\hline Registro? Onde? & AVA ThinkQuest \\
\hline Rubrica? & Rubrica desenvolvida para a atividade \\
\hline Rubrica Início? & Não \\
\hline Rubrica Final? & Sim (como foi feito na formação do Programa POIE 2012) \\
\hline Autoavaliação Oral? & Não \\
\hline $\begin{array}{l}\text { Autoavaliação } \\
\text { Registrada? Onde? }\end{array}$ & Sim \\
\hline $\begin{array}{l}\text { Feedback avaliação? } \\
\text { Como? }\end{array}$ & Sim, oral \\
\hline $\begin{array}{l}\text { Narrativa reflexiva } \\
\text { entre alunos / } \\
\text { participantes? }\end{array}$ & $\begin{array}{l}\text { 1.2: } 18 \text { respostas simples (nunca ouvi falar); } 1.4 \text { (o que } \\
\text { você acha que é sustentabilidade): } 18 \text { descrições simples; } \\
2.2 \text { (o que mais chamou sua atenção no filme): } 12 \\
\text { respostas; } 2.4 \text { (melhoria de ideias, com base nas respostas } \\
\text { dos colegas): } 10 \text { respostas; } 2.5 \text { (como ter atitudes } \\
\text { responsáveis): } 9 \text { respostas }\end{array}$ \\
\hline
\end{tabular}




\begin{tabular}{|c|c|}
\hline Rubrica (Conteúdos) & $\begin{array}{l}\text { 1. Papel no chão (não realizei as atividades e nem pensei } \\
\text { no tema Sustentabilidade, Meio Ambiente e na minha } \\
\text { escola); } 2 \text {. Papel em qualquer cesto (Realizei as atividades } \\
\text { propostas, tenho alguma ideia do que é sustentabilidade, } \\
\text { mas isso não tem nada a ver comigo); 3. Papel no cesto } \\
\text { azul (Realizei as atividades propostas, reforcei meus } \\
\text { conhecimentos sobre sustentabilidade, quero tornar minha } \\
\text { escola numa escola sustentável, mas ainda não sei como); } \\
\text { 4. Papel reciclado, papel novo (Realizei as atividades } \\
\text { propostas, reforcei meus conhecimentos sobre } \\
\text { sustentabilidade, quero tornar minha escola numa escola } \\
\text { sustentável e, após pesquisas e estudo, já estou } \\
\text { organizando meios de mobilizar comunidade escolar). }\end{array}$ \\
\hline $\begin{array}{l}\text { Narrativa } \\
\text { Autoavaliação }\end{array}$ & $\begin{array}{l}\text { 2.6 Avaliação: 1 Papel no Chão; 0 Qualquer cesto; } 10 \\
\text { Cesto Azul; } 1 \text { Reciclado, Papel Novo }\end{array}$ \\
\hline Narrativa feedback & Feita oralmente, com base na rubrica. \\
\hline $\begin{array}{l}\text { Considerações } \\
\text { complementares } \\
\text { necessário) }\end{array}$ & $\begin{array}{l}\text { Grande envolvimento dos alunos no desenvolvimento das } \\
\text { atividades. Eles não conseguiram fazer o produto final } \\
\text { desejado, em função de problemas de infraestrutura } \\
\text { (acesso ao TQ e problemas de software de finalização dos } \\
\text { HQ). Professor José Rosemberg, POIE responsável por } \\
\text { este projeto, concedeu uma entrevista, com perguntas } \\
\text { semiestruturadas, sobre este e mais alguns projetos por ele } \\
\text { coordenados junto ao LIE da referida unidade, cujo quadro } \\
\text { de Análise de Conteúdo consta do ANEXO }\end{array}$ \\
\hline
\end{tabular}




\begin{tabular}{|c|c|}
\hline Grupo & GRUPO A \\
\hline Classificação & Projeto A.3 \\
\hline Nome do Projeto & Sustentabilidade no Zaca $-5^{\mathrm{a}}$ \\
\hline Unidade & EMMEF Mauro Faccio Gonçalves - Zacaria \\
\hline Responsável & Douglas Tomé \\
\hline Duração & 12 a 16 encontros com os alunos \\
\hline Resumo Geral & $\begin{array}{l}\text { Estudo do tema: Sustentabilidade, aprendendo um pouco } \\
\text { mais, fazendo a diferença para um mundo e um futuro } \\
\text { melhor. Muitos defendem o tema por estar na moda. } \\
\text { Outros acreditam que é possível. E você? Vamos fazer } \\
\text { parte deste desafio? }\end{array}$ \\
\hline Estrutura / Ações & $\begin{array}{l}\text { 1. Primeiro contato; 2. Aprendendo um pouco mais; } \\
\text { Espaço para professores: o que poderia melhorar }\end{array}$ \\
\hline $\begin{array}{l}\text { Produto I Peça } \\
\text { Tecnológica Final }\end{array}$ & $\begin{array}{l}\text { Fotos de pontos da escola, para refletirem sobre como } \\
\text { cuidar do meio ambiente, a partir da escola. Texto } \\
\text { individual de cerca de } 20 \text { linhas, com reflexões sobre } \\
\text { Sustentabilidade (Word). }\end{array}$ \\
\hline $\begin{array}{lll}\mathbf{N}^{\mathbf{o}} & \text { de alunos } \\
\text { Participantes }\end{array}$ & Cerca de 60 alunos \\
\hline Registro? Onde? & AVA ThinkQuest \\
\hline Rubrica? & Rubrica desenvolvida para o projeto \\
\hline Rubrica Início? & Sim, validada com alunos \\
\hline Rubrica Final? & Sim \\
\hline Autoavaliação Oral? & Sim \\
\hline $\begin{array}{l}\text { Autoavaliação } \\
\text { Registrada? Onde? }\end{array}$ & Não \\
\hline $\begin{array}{l}\text { Feedback avaliação? } \\
\text { Como? }\end{array}$ & Sim \\
\hline $\begin{array}{l}\text { Narrativa reflexiva } \\
\text { entre alunos } \\
\text { participantes? }\end{array}$ & $\begin{array}{l}1.2 \text { (o que significa sustentabilidade): } \text { mais de } 60 \\
\text { comentários; } 1.3 \text { (melhoria de ideias): mais de } 60 \\
\text { comentários, sobre como ficou mais fácil a definição; } 1.6 \\
\text { (comentários sobre conteúdo do vídeo): } 63 \text { comentários; } \\
1.7 \text { (ideia para uma escola melhor: } 50 \text { respostas; } 1.8 \text { (quero } \\
\text { um bairro melhor): } 46 \text { respostas; } 1.9 \text { (uma cidade melhor): } \\
60 \text { respostas; } 2.2 \text { (atitude na minha casa - } 4 \text { opções); } 2.3 \\
\text { (imagens e casa: o que posso fazer para mudar): } 33 \\
\text { comentários; Pesquisa final: cerca de } 20 \text { sugestões de sites }\end{array}$ \\
\hline Rubrica (Conteúdos) & $\begin{array}{l}\text { Parte Desenvolvimento Reflexivo }- \text { Rubrica sobre } \\
\text { consumo: Reutilizamos o que é possível; Consumimos } \\
\text { com consciência; Separamos os materiais; Jogamos tudo } \\
\text { no lixo. } \\
\text { Parte Final: Azul (aprendi muito); Amarelo (aprendi } \\
\text { "coisas" novas); Vermelho (aprendi só um pouco); Preto } \\
\text { (não aprendi nada). }\end{array}$ \\
\hline $\begin{array}{l}\text { Narrativa } \\
\text { Autoavaliação }\end{array}$ & Não foi registrado no AVA, foi feito apenas oralmente. \\
\hline Narrativa feedback & Feita oralmente, com base na rubrica da atividade. \\
\hline Considerações & POIE tinha grande familiaridade com a plataforma de \\
\hline
\end{tabular}




\begin{tabular}{|ll|l|}
\hline $\begin{array}{l}\text { complementares } \\
\text { necessário) }\end{array}$ & (se & $\begin{array}{l}\text { aprendizagem adotada. Apresentação da rubrica para os } \\
\text { alunos só foi feita no momento da avaliação. Os dois } \\
\text { critérios da rubrica foram desenvolvidos pelo POIE, em } \\
\text { parceria com gestores da DRE Campo Limpo e outro } \\
\text { POIE, sob orientação do assessor da DOT/SME-SP, Prof. } \\
\text { Cesar Nunes. Foi uma rubrica bem simples mesmo, } \\
\text { aplicada oralmente, em momentos de atividades reflexivas } \\
\text { específicas. }\end{array}$ \\
\hline
\end{tabular}




\begin{tabular}{|c|c|}
\hline Grupo & GRUPO A \\
\hline Classificação & Projeto A.4 \\
\hline Nome do Projeto & 7a Serie B (2012) - Movie Maker \\
\hline Unidade & EMEF Cyro Albuquerque \\
\hline Responsável & Nádia Melzer \\
\hline Duração & 16 a 20 aulas \\
\hline Resumo Geral & $\begin{array}{l}\text { Identificação e conscientização sobre atitudes sustentáveis } \\
\text { dentro da escola. Os alunos deverão refletir sobre o meio } \\
\text { ambiente e como ele aparece na escola. A seguir deverão } \\
\text { planejar o percurso e definir as metas para uma aula } \\
\text { sustentável e deverão desenvolver e postar um trabalho no } \\
\text { Movie Maker. }\end{array}$ \\
\hline Estrutura / Ações & $\begin{array}{l}\text { Explorando o ambiente; Planejando nossas ações } \\
\text { sustentáveis; Trabalho Power Point; Criando o vídeo no } \\
\text { Movie Maker; Trabalho Movie Maker; Fechando conceitos }\end{array}$ \\
\hline $\begin{array}{l}\text { Produto I Peça } \\
\text { Tecnológica Final }\end{array}$ & $\begin{array}{l}\text { Um vídeo - movie maker com fotos - sobre como trabalhar } \\
\text { a preservação do meio ambiente. Montagem de um objeto } \\
\text { de decoração ou de uso, com material reciclável, para } \\
\text { registro com Movie Maker, via Power Point. }\end{array}$ \\
\hline $\begin{array}{l}\mathbf{N}^{\mathbf{0}} \text { de alunos } / \\
\text { Participantes }\end{array}$ & 38 alunos $\left(7^{\mathrm{a}}\right.$ série $\left.\mathrm{B}-2012\right)$ \\
\hline Registro? Onde? & AVA ThinkQuest \\
\hline Rubrica? & Sim \\
\hline Rubrica Início? & Não \\
\hline Rubrica Final? & Sim \\
\hline Autoavaliação Oral? & Sim \\
\hline $\begin{array}{l}\text { Autoavaliação } \\
\text { Registrada? Onde? }\end{array}$ & Reflexão oral, com POIE \\
\hline $\begin{array}{l}\text { Feedback avaliação? } \\
\text { Como? }\end{array}$ & $\begin{array}{l}\text { Vídeos de conscientização: } 14 \text {; Dica de reciclagem: 4; } \\
\text { Avaliando compreensão: } 6 \text { a } 7 \text { registros apenas }\end{array}$ \\
\hline $\begin{array}{l}\text { Narrativa reflexiva } \\
\text { entre alunos / } \\
\text { participantes? }\end{array}$ & $\begin{array}{l}\text { Houve uma reflexão sobre como melhorar o bairro de } \\
\text { entorno da escola, com base nas premissas e problemas } \\
\text { abordados nas aulas; alunos tiram fotos para reflexão sobre } \\
\text { quais as possibilidades de reciclar; alunos apresentam um } \\
\text { vídeo e fazem uma mostra sobre item reciclável que } \\
\text { propuseram; Power Point com o que refletiram; reflexão } \\
\text { final sobre as propostas recicláveis que fizeram. Após a } \\
\text { postagem das ideias, houve reflexão de melhoria de ideias, } \\
\text { para que alunos lessem as ideias dos colegas, analisassem e } \\
\text { revissem as colocações deles. Em outra etapa, houve a } \\
\text { elaboração de lista dos materiais que precisariam para } \\
\text { montar os itens recicláveis. Avaliação sobre como foi o } \\
\text { processo de criação do item feito de material reciclado. }\end{array}$ \\
\hline Rubrica (Conteúdos) & $\begin{array}{l}100 \% \text { Sustentável (eu me envolvi no projeto, ajudei meus } \\
\text { colegas a conseguir cumprir todas as etapas com } \\
\text { facilidade. Pretendo colocar em pratica minhas ações } \\
\text { sustentáveis e as dos colegas também); Pensando em }\end{array}$ \\
\hline
\end{tabular}




\begin{tabular}{|l|l|}
\hline & $\begin{array}{l}\text { Sustentabilidade (Consegui terminar as etapas mas tive } \\
\text { algumas dificuldades. Poderia ter ajuda de os outros e } \\
\text { conversado mais a respeito do tema, porém fiz um bom } \\
\text { trabalho. Já reciclo muitas coisas e não costumo misturar } \\
\text { lixos); Reciclável (Não consegui terminar todas as etapas e } \\
\text { tive muitas dificuldades. Poderia ter conversado mais e } \\
\text { tirado minhas dúvidas com o professor(a) e/ou colegas. } \\
\text { Preciso aproveitar mais, mateias e jogar menos coisas no } \\
\text { lixo orgânico); Não Reciclável (Não consegui terminar as } \\
\text { atividades, pois não me interessei pelo projeto. Fiz } \\
\text { algumas partes, mas minha participação foi insuficiente. } \\
\text { Preciso melhorar ainda e não vou desistir. Não costumo } \\
\text { separar lixo, mas tenho consciência que minhas ações vão } \\
\text { prejudicar o planeta). }\end{array}$ \\
\hline $\begin{array}{l}\text { Narrativa } \\
\text { Autoavaliação }\end{array}$ & $\begin{array}{l}\text { Não foi registrado no AVA, foi feito apenas oralmente } \\
\text { Narrativa feedback } \\
\begin{array}{l}\text { Considerações } \\
\text { complementares } \\
\text { necessário) }\end{array} \\
\text { (se }\end{array} \quad \begin{array}{l}\text { Feita oralmente, com base nas rubricas } \\
\text { Grande envolvimento dos alunos no desenvolvimento das } \\
\text { atividades. Professora Nádia Melzer, POIE responsável por } \\
\text { semiestruturadas, sobre este e mais alguns projetos por ele } \\
\text { coordenados junto ao LIE da referida unidade, cujo quadro } \\
\text { de Análise de Conteúdo consta do Anexo G. }\end{array}$ \\
\hline
\end{tabular}




\begin{tabular}{|c|c|}
\hline Grupo & GRUPO B \\
\hline Classificação & Projeto B.1 \\
\hline Nome do Projeto & Estudando e Intervindo no Mundo que nos Cerca \\
\hline Unidade & EMEF Fagundes Varella \\
\hline Responsável & José Rosemberg \\
\hline Duração & 16 a 20 aulas \\
\hline Resumo Geral & $\begin{array}{l}\text { Atividade desenvolvida com professora de Sala de Leitura } \\
\text { (POSL), com base nas diretrizes do TCA, do Ciclo Autoral } \\
\left(3^{\circ} \text { Ciclo), para realizar levantamento dos problemas da }\right. \\
\text { escola e dos seus entornos, para posterior apresentação de } \\
\text { ideias de solução para os mesmos }\end{array}$ \\
\hline Estrutura / Ações & $\begin{array}{l}\text { 1. Identificação conjunta de lista de problemas da escola e } \\
\text { do entorno (com POSL); 2. Definição de um problema a } \\
\text { ser tratado, por turma (POIE); 3. Distribuição dos alunos } \\
\text { em grupos de } 5 \text { a } 6 ; 4 \text {. Apresentação da rubrica de } \\
\text { avaliação e reflexão conjunta sobre o problema escolhido } \\
\text { para ser estudado; } 5 \text {. Pesquisas e levantamento de dados } \\
\text { sobre a pesquisa; } 6 \text {. Elaboração de vídeos, disponibilizados } \\
\text { no Prezi, sobre o problema estudado; } 7 \text {. Reflexão final } \\
\text { conjunta. }\end{array}$ \\
\hline $\begin{array}{l}\text { Produto / Peça } \\
\text { Tecnológica Final }\end{array}$ & Vídeo disponibilizado no Prezi \\
\hline $\begin{array}{l}\mathbf{N}^{\mathbf{a}} \text { de alunos / } \\
\text { Participantes }\end{array}$ & $\begin{array}{l}\text { Aproximadamente } 105 \text { alunos de } 7^{\circ} \text { Ano ( } 3 \text { turmas de mais } \\
\text { ou menos } 33 \text { alunos) }\end{array}$ \\
\hline Registro? Onde? & EdModo; Prezi; GoogleDocs \\
\hline Rubrica? & Sim \\
\hline Rubrica Início? & $\begin{array}{l}\text { Sim, apresentada, ajustada e validada com alunos no início } \\
\text { da disciplina }\end{array}$ \\
\hline Rubrica Final? & Sim \\
\hline Autoavaliação Oral? & Sim \\
\hline $\begin{array}{l}\text { Autoavaliação } \\
\text { Registrada? Onde? }\end{array}$ & $\begin{array}{l}\text { Registrada no GoogleDocs, com reflexão oral com os } \\
\text { alunos }\end{array}$ \\
\hline $\begin{array}{l}\text { Feedback avaliação? } \\
\text { Como? }\end{array}$ & $\begin{array}{l}\text { Vídeos com o mapeamento do problema estudado - } \\
\text { violência e drogas - na escola e no entorno dela }\end{array}$ \\
\hline
\end{tabular}




\begin{tabular}{|l|l|}
\hline $\begin{array}{l}\text { Narrativa reflexiva } \\
\text { entre alunos } \\
\text { participantes? }\end{array}$ & $\begin{array}{l}\text { Houve uma reflexão sobre como melhorar o bairro de } \\
\text { entorno da escola, com base nas premissas e problemas } \\
\text { abordados nas aulas; alunos tiram fotos e fizeram } \\
\text { entrevistas com pessoa ligadas ao entorno e a aspectos do } \\
\text { problema em estudo; elaboração de um vídeo com e } \\
\text { disponibilização no Prezi. A ideia era prosseguir com as } \\
\text { reflexões, para que alunos apresentassem soluções para os } \\
\text { referidos problemas, mas isso não foi possível, por conta } \\
\text { do tempo disponível para execução do projeto (em função } \\
\text { de greves e outras atividades, que fizeram reduzir o } \\
\text { número de aulas disponível para realização de todas as } \\
\text { etapas da atividade). }\end{array}$ \\
\hline $\begin{array}{l}\text { Rubrica (Conteúdos) } \\
\text { Aurrativa }\end{array}$ & $\begin{array}{l}\text { Registrada no GoogleDocs, que gerou um relatório com } \\
\text { essas respostas. }\end{array}$ \\
\hline Narrativa feedback & Feita oralmente, com base nas rubricas \\
\hline $\begin{array}{l}\text { Considerações } \\
\text { complementares } \\
\text { necessário) }\end{array}$ & $\begin{array}{l}\text { Grande envolvimento dos alunos na elaboração e execução } \\
\text { do projeto. Alunos responderam ao questionário de } \\
\text { perguntas estruturadas. }\end{array}$ \\
\hline
\end{tabular}




\begin{tabular}{|c|c|}
\hline Grupo & GRUPO B \\
\hline Classificação & Projeto B.2 \\
\hline Nome do Projeto & Curiosos em Ação - 2º Ano (2014) \\
\hline Unidade & EMEF Jd. Mitsutani - Paulo Patarra \\
\hline Responsável & José Rosemberg \\
\hline Duração & 16 a 20 aulas \\
\hline Resumo Geral & $\begin{array}{l}\text { Atividade voltada para as crianças vivenciarem as práticas } \\
\text { de pesquisa na internet, a partir de um tema adequado à } \\
\text { idade das crianças. Para tanto, utilizaram sites de busca, } \\
\text { como Google. }\end{array}$ \\
\hline Estrutura / Ações & $\begin{array}{l}\text { Definição de duplas ou trios; Apresentação do tema que } \\
\text { seria tratado e roda de conversa, para verificação do } \\
\text { conhecimento dos alunos sobre o tema em estudo; escolha } \\
\text { de um animal, para verificar seu(s) aspecto(s) } \\
\text { diferenciado(s); Registro dessa atividade no Padlet; busca } \\
\text { de informações sem recursos da internet e com recursos da } \\
\text { internet; montagem de slide no Power Point, com } \\
\text { curiosidade do animal escolhido; Edição dos slides em um } \\
\text { único vídeo; gravação de DVD, com o vídeo final }\end{array}$ \\
\hline $\begin{array}{l}\text { Produto / Peça } \\
\text { Tecnológica Final }\end{array}$ & $\begin{array}{l}\text { Vídeo com trabalho unificado, contendo todos os slides de } \\
\text { cada trio, que foi salvo em um DVD (cada aluno recebeu } \\
\text { uma cópia para levar e compartilhar com a família) }\end{array}$ \\
\hline $\begin{array}{l}\mathbf{N}^{\mathbf{a}} \text { de alunos / } \\
\text { Participantes }\end{array}$ & $\begin{array}{l}\text { Aproximadamente } 105 \text { alunos de } 7^{\circ} \text { Ano ( } 3 \text { turmas de mais } \\
\text { ou menos } 33 \text { alunos) }\end{array}$ \\
\hline Registro? Onde? & $\begin{array}{l}\text { Prezi; Padlet; Popplet; GoogleDocs; Sites de busca na } \\
\text { internet; Power Point; DVD com vídeo final }\end{array}$ \\
\hline Rubrica? & Sim \\
\hline Rubrica Início? & $\begin{array}{l}\text { Sim, desenvolvida em conjunto com os alunos no início da } \\
\text { disciplina, durante seis aulas (nessas aulas, houve } \\
\text { atividades do projeto, intercaladas com reflexão para } \\
\text { definição dos critérios da rubrica de avaliação) }\end{array}$ \\
\hline Rubrica Final? & Sim \\
\hline Autoavaliação Oral? & Sim \\
\hline $\begin{array}{l}\text { Autoavaliação } \\
\text { Registrada? Onde? }\end{array}$ & $\begin{array}{l}\text { Registrada no GoogleDocs, com reflexão oral com os } \\
\text { alunos }\end{array}$ \\
\hline
\end{tabular}




\begin{tabular}{|c|c|}
\hline $\begin{array}{l}\text { Feedback avaliação? } \\
\text { Como? }\end{array}$ & $\begin{array}{l}\text { Sim, feito oralmente, durante análise dos resultados } \\
\text { obtidos com o questionário das rubricas no GoogleDocs. }\end{array}$ \\
\hline $\begin{array}{l}\text { Narrativa reflexiva } \\
\text { entre alunos / } \\
\text { participantes? }\end{array}$ & - \\
\hline Rubrica (Conteúdos) & Vide ANEXO F. \\
\hline $\begin{array}{l}\text { Narrativa } \\
\text { Autoavaliação }\end{array}$ & $\begin{array}{l}\text { Registrada no GoogleDocs, que gerou um relatório com } \\
\text { essas respostas. }\end{array}$ \\
\hline Narrativa feedback & Feita oralmente, com base nas rubricas \\
\hline $\begin{array}{l}\text { Considerações } \\
\text { complementares } \quad \text { (se } \\
\text { necessário) }\end{array}$ & $\begin{array}{l}\text { Grande envolvimento dos alunos na elaboração e execução } \\
\text { do projeto. Alunos responderam o questionário de } \\
\text { perguntas estruturadas. }\end{array}$ \\
\hline
\end{tabular}




\begin{tabular}{|c|c|}
\hline Grupo & GRUPO B \\
\hline Classificação & Projeto B.3 \\
\hline Nome do Projeto & Clube de Astronomia \\
\hline Unidade & EMEF Des. Achilles de Oliveira Ribeira \\
\hline Responsável & $\begin{array}{l}\text { Maria Helena Pereira [Profs. Claudio Francisco, Maria } \\
\text { Helena Pereira (POIE), Nágila Euclides da Silva Polido } \\
\text { (POSL) e Rosana L. A. de Oliveira }\end{array}$ \\
\hline Duração & 8 meses $\left(1^{\circ}\right.$ e $2^{\circ}$ Semestre de 2012$)$ \\
\hline Resumo Geral & $\begin{array}{l}\text { Ele teve como objetivo incentivar o interesse dos seus } \\
\text { participantes pela astronomia e ciências afins. Focava a } \\
\text { produção de textos, desenvolvimento de dinâmicas } \\
\text { reflexivas, localização de constelações ou estrelas, } \\
\text { aprendizagem do uso do software Observatório } \\
\text { Astronômico, desenvolvimento de pesquisas diversas com } \\
\text { uso de recursos da internet, análise de cartas do céu e } \\
\text { realização de rodas de leitura, sobre ficção científica e } \\
\text { mitologia, dentre outros. }\end{array}$ \\
\hline Estrutura / Ações & $\begin{array}{l}\text { Clube de Astronomia; Atividade Inicial; Movimentos } \\
\text { Aparentes dos Astros; Símbolos Nacionais; Programa } \\
\text { Espacial Brasileiro; OBA - Olimpíadas Brasileiras de } \\
\text { Astronomia; Constelações; Discussões no Fórum Virtual } \\
\text { (aulas presenciais); Jogos de Astronomia; Autoavaliação. }\end{array}$ \\
\hline $\begin{array}{l}\text { Produto / Peça } \\
\text { Tecnológica Final }\end{array}$ & Produção de textos no Word \\
\hline $\begin{array}{l}\mathbf{N}^{\mathbf{0}} \text { de alunos / } \\
\text { Participantes }\end{array}$ & Alunos de $5^{\circ}$ Ano \\
\hline Registro? Onde? & AVA ThinkQuest \\
\hline Rubrica? & Sim \\
\hline Rubrica Início? & Sim, mas apresentada de maneira informativa \\
\hline Rubrica Final? & Sim \\
\hline Autoavaliação Oral? & Sim \\
\hline $\begin{array}{l}\text { Autoavaliação } \\
\text { Registrada? Onde? }\end{array}$ & $\begin{array}{l}\text { Sim, no GoogleDocs. Link do questionário com as rubricas } \\
\text { foi disponibilizado no AVA ThinkQuest, para que todos } \\
\text { pudessem ter acesso às perguntas do questionário }\end{array}$ \\
\hline $\begin{array}{l}\text { Feedback avaliação? } \\
\text { Como? }\end{array}$ & $\begin{array}{l}\text { Feedback oral, para promover reflexão sobre respostas } \\
\text { apresentadas, com os alunos }\end{array}$ \\
\hline
\end{tabular}




\begin{tabular}{|c|c|}
\hline $\begin{array}{l}\text { Narrativa reflexiva } \\
\text { entre alunos / } \\
\text { participantes? }\end{array}$ & $\begin{array}{l}\text { Focava a produção de textos no Word, desenvolvimento de } \\
\text { dinâmicas reflexivas, localização de constelações ou } \\
\text { estrelas, aprendizagem do uso do software Observatório } \\
\text { Astronômico, desenvolvimento de pesquisas diversas com } \\
\text { uso de recursos da internet, análise de cartas do céu e } \\
\text { realização de rodas de leitura, sobre ficção científica e } \\
\text { mitologia, dentre outros. }\end{array}$ \\
\hline Rubrica (Conteúdos) & $\begin{array}{l}\text { Rubrica ThinkQuest } \\
\text { Vide quadro no ANEXO F. } \\
\text { Rubrica GoogleDocs: } \\
\text { Escolha uma posição que melhor representa você no } \\
\text { trabalho proposto neste projeto e deixe sua sugestão ou } \\
\text { crítica. } \\
\text { Nível } 1 \text { - Figurante: Compreendi muito pouco a proposta, } \\
\text { explorei o ambiente e as atividades, não contribui com } \\
\text { novas ideias. Não consegui finalizar todas as atividades. } \\
\text { Nível } 2 \text { - Participação Especial: Compreendi parte da } \\
\text { proposta, explorei o ambiente e as atividades contribuindo } \\
\text { com algumas ideias. Finalizei as atividades com alguma } \\
\text { dificuldade. } \\
\text { Nível } 3 \text { - Coadjuvante: Compreendi boa parte da proposta, } \\
\text { explorei o ambiente e as atividades, contribuindo com } \\
\text { ideias e questionei alguns posicionamentos. Estou disposto } \\
\text { a ampliar minha compreensão sobre o tema. Finalizei as } \\
\text { atividades. } \\
\text { Nível } 4 \text { - Protagonista: Compreendi a proposta, explorei o } \\
\text { ambiente e as atividades, contribuindo com ideias e } \\
\text { provocando o debate e a reflexão com o grupo. Estou } \\
\text { motivado a pesquisar sobre o tema para ampliar minha } \\
\text { compreensão e compartilhar com os colegas. Finalizei } \\
\text { todas as atividades com facilidade. }\end{array}$ \\
\hline $\begin{array}{l}\text { Narrativa } \\
\text { Autoavaliação }\end{array}$ & $\begin{array}{l}\text { Vide comentários de entrevista semiestruturada a POIE } \\
\text { Maria Helena, no ANEXO G }\end{array}$ \\
\hline Narrativa feedback & $\begin{array}{l}\text { Vide comentários de entrevista semiestruturada a POIE } \\
\text { Maria Helena, no ANEXO G }\end{array}$ \\
\hline $\begin{array}{l}\text { Considerações } \\
\text { complementares } \\
\text { necessário) }\end{array}$ & Nada a complementar. \\
\hline
\end{tabular}




\begin{tabular}{|c|c|}
\hline Grupo & GRUPO B \\
\hline Classificação & Projeto B.4 \\
\hline Nome do Projeto & Jogos do Riva / Programa Aluno Monitor \\
\hline Unidade & EMEF Prof. Rivadávia Marques Junior \\
\hline Responsável & Gislaine Batista Munhoz \\
\hline Duração & $2012-2014$ \\
\hline Resumo Geral & $\begin{array}{l}\text { Projeto ligado ao Programa Aluno Monitor, que visava a } \\
\text { programação e produção de jogos para servirem de apoio à } \\
\text { alfabetização dos alunos do } 1^{\circ} \text { ano da referida unidade } \\
\text { educacional }\end{array}$ \\
\hline Estrutura / Ações & $\begin{array}{l}\text { Reunião com os professores de } 1^{\circ} \text { ano, para entenderem as } \\
\text { necessidades de alfabetização; reflexões conjuntas sobre } \\
\text { possíveis jogos e plataformas de configurações; } \\
\text { desenvolvimento dos jogos, individualmente ou em } \\
\text { parceria; apresentação aos demais membros do grupo, para } \\
\text { avaliação e ajustes; apresentação para os professores de } 1^{\circ} \\
\text { ano; divulgação para os alunos e comunidade; pesquisas e } \\
\text { testes constantes sobre novos aplicativos e configurações } \\
\text { para jogos, na internet. }\end{array}$ \\
\hline $\begin{array}{l}\text { Produto I Peça } \\
\text { Tecnológica Final }\end{array}$ & $\begin{array}{l}\text { Joguinhos eletrônicos de apoio à alfabetização de alunos } \\
\text { de } 1^{\circ} \text {; disponibilização no servidor SME-SP; site } \\
\text { repositório dos jogos; } \\
\text { Duas páginas no Facebook; Scratch; PowerPoint (para } \\
\text { programação de joguinhos); Hot Potato }\end{array}$ \\
\hline $\begin{array}{l}\mathbf{N}^{\mathbf{0}} \text { de alunos / } \\
\text { Participantes }\end{array}$ & Alunos de $5^{\circ}$ Ano \\
\hline Registro? Onde? & 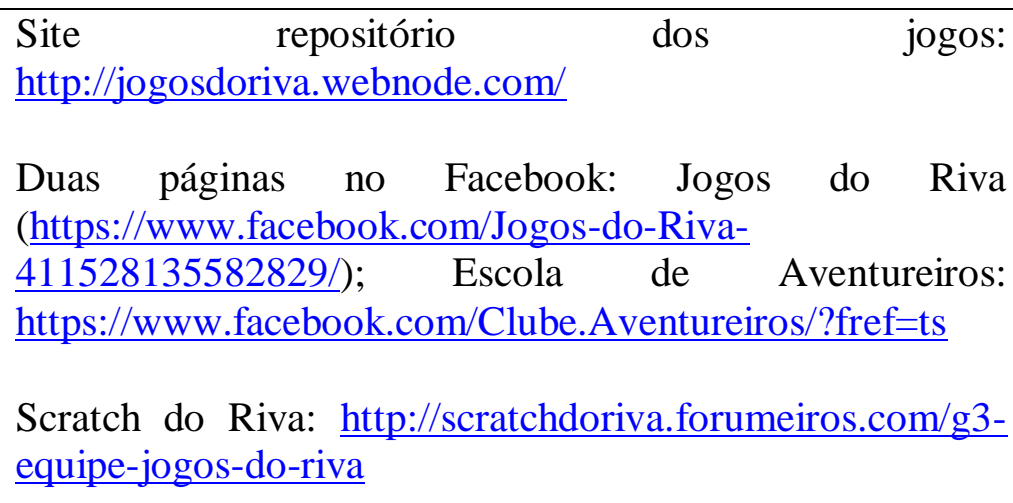 \\
\hline Rubrica? & Sim \\
\hline Rubrica Início? & Não, desenvolvida no meio do projeto, por iniciativa dos \\
\hline
\end{tabular}




\begin{tabular}{|l|l|}
\hline \multicolumn{1}{|c|}{} & próprios alunos \\
\hline Rubrica Final? & Sim \\
\hline Autoavaliação Oral? & Sim \\
\hline $\begin{array}{l}\text { Autoavaliação } \\
\text { Registrada? Onde? }\end{array}$ & Não, mas foi feita oralmente. \\
\hline $\begin{array}{l}\text { Feedback avaliação? } \\
\text { Como? }\end{array}$ & $\begin{array}{l}\text { Feedback oral, para promover reflexão sobre respostas } \\
\text { apresentadas, com os alunos. }\end{array}$ \\
\hline $\begin{array}{l}\text { Narrativa reflexiva } \\
\text { entre alunos } \\
\text { participantes? }\end{array}$ & - \\
\hline $\begin{array}{l}\text { Rubrica (Conteúdos) } \\
\text { Narrativa } \\
\text { Autoavaliação }\end{array}$ & $\begin{array}{l}\text { Vide quadro no ANEXO F. } \\
\text { Gislaine, no ANEXO G }\end{array}$ \\
\hline $\begin{array}{l}\text { Narrativa feedback } \\
\text { Vide comentários de entrevista semiestruturada a POIE } \\
\text { Gislaine, no ANEXO G } \\
\text { Complementarios de entrevista semiestruturada a POIE } \\
\text { necessário) }\end{array}$ & $\begin{array}{l}\text { Conforme relato da POIE Gislaine, os alunos pedem aos } \\
\text { visitantes do site repositório, para que avaliem os jogos, de } \\
\text { maneira que possam atualiza-los e melhora-los. }\end{array}$ \\
\hline
\end{tabular}




\section{Anexo F - Rubricas dos Projetos}

Anexo F.1: Rubrica Projeto A.1 - Projeto: Sustentabilidade - O que é e qual o meu papel

Unidade: EMEF GIANFRANCESCO GUARNIERI

POIE: MARGARETE

\begin{tabular}{|c|c|c|c|c|c|c|}
\hline CRITERIO & Nível 1 & Nível 2 & Nível 3 & Nível 4 & Nível 5 & $\begin{array}{l}\text { Análise de Conteúdo: } \\
\text { Categoria / Indicador }\end{array}$ \\
\hline $\begin{array}{l}\text { Opinião sobre a } \\
\text { atividade }\end{array}$ & Aprendi coisas novas & $\begin{array}{l}\text { Já sabia, mas foi } \\
\text { legal }\end{array}$ & $\begin{array}{l}\text { Não acrescentou } \\
\text { nada para mim }\end{array}$ & $\begin{array}{l}\text { Ouvi, argumentei e } \\
\text { respeitei todas as } \\
\text { ideias. }\end{array}$ & $\mid \begin{array}{ll}\text { Fiquei mais } \\
\text { consciente. }\end{array}$ & $\begin{array}{l}\text { Práticas Pedagógico- } \\
\text { Comunicacionais: } \\
\text { Indicador 2: Tipos de } \\
\text { Participação - detalha como } \\
\text { construir e fortalecer ações } \\
\text { protagonistas, rr como } \\
\text { indicado por Hart (1992) e } \\
\text { Costa (2006) } \\
\text { Indicador 4 Relações entre } \\
\text { participantes } \\
\text { Competências } \\
\text { Educomunicativas: todas } \\
\text { as nove. }\end{array}$ \\
\hline $\begin{array}{l}\text { Participação no } \\
\text { projeto }\end{array}$ & Ótimo & Bom & $\begin{array}{l}\text { Poderia ter me } \\
\text { esforçado mais }\end{array}$ & Participei pouco & Não há & $\begin{array}{l}\text { Práticas Pedagógico- } \\
\text { Comunicacionais: } \\
\text { Indicador 2: Tipos de } \\
\text { Participação-detalha como } \\
\text { construir e fortalecer ações } \\
\text { protagonistas, como } \\
\text { indicado por Hart (1992) e } \\
\text { Costa (2006) } \\
\text { Indicador 4 / Relações entre } \\
\text { participantes }\end{array}$ \\
\hline
\end{tabular}




\begin{tabular}{|c|c|c|c|c|c|c|}
\hline $\begin{array}{l}\text { Grau de } \\
\text { compromisso } \\
\text { com } \\
\text { sustentabilidade } \\
\text { no futuro }\end{array}$ & 0\% - Tô nem aí & $50 \%$ - Beleza & $75 \%$ legal, tô dentro & $\begin{array}{l}100 \% \text { - Muito legal, } \\
\text { tô dentro }\end{array}$ & Não se aplica & $\begin{array}{l}\text { Não se aplicam, a } \\
\text { princípio. }\end{array}$ \\
\hline $\begin{array}{l}\text { Promovendo } \\
\text { reflexão para } \\
\text { conscientização } \\
\text { sobre o tema em } \\
\text { estudo }\end{array}$ & $\begin{array}{l}\text { Não me importo sobre o } \\
\text { assunto. }\end{array}$ & $\begin{array}{l}\text { Ao ver meu bairro } \\
\text { com lixo nas } \\
\text { calçadas, ruas e } \\
\text { córregos, me sinto } \\
\text { desconfortável. }\end{array}$ & $\begin{array}{l}\text { Ao ver meu bairro } \\
\text { com lixo nas } \\
\text { calçadas, ruas e } \\
\text { córregos me sinto } \\
\text { desconfortável } \\
\text { colaboro } \\
\text { jogando lixo nas vias } \\
\text { públicas. }\end{array}$ & $\begin{array}{l}\text { Ao ver meu bairro } \\
\text { com lixo nas } \\
\text { calçadas, ruas e } \\
\text { córregos me sinto } \\
\text { desconfortável } \mathrm{e} \\
\text { colaboro rano } \\
\text { jogando lixo nas } \\
\text { vias públicas, e } \\
\text { converso com } \\
\text { familiares sobre o } \\
\text { assunto. }\end{array}$ & & $\begin{array}{l}\text { Práticas Pedagógico- } \\
\text { Comunicacionais: } \\
\text { Indicador 2: Tipos de } \\
\text { Participação-detalha como } \\
\text { construir e fortalecer ações } \\
\text { protagonistas, r como } \\
\text { indicado por Hart (1992) e } \\
\text { Costa (2006) } \\
\text { Indicador 4 / Relações entre } \\
\text { participantes }\end{array}$ \\
\hline
\end{tabular}




\section{Anexo F.2: Rubrica Projeto A.2 - Projeto: Patarra dando alguns passos rumo à sustentabilidade}

Unidade: EMEF JD. Mitsutani - Paulo Patarra

POIE: José Rosemberg

\begin{tabular}{|c|c|c|c|c|c|}
\hline CRITERIO & PAPEL NO CHÃO & $\begin{array}{l}\text { PAPEL EM } \\
\text { QUALQUER } \\
\text { CESTO }\end{array}$ & $\begin{array}{c}\text { PAPEL NO CESTO } \\
\text { AZUL }\end{array}$ & $\begin{array}{c}\text { PAPEL } \\
\text { RECICLADO, } \\
\text { PAPEL NOVO }\end{array}$ & $\begin{array}{l}\text { Análise de Conteúdo: } \\
\text { Categoria / Indicador }\end{array}$ \\
\hline $\begin{array}{l}\text { Participação } \\
\text { nas atividades }\end{array}$ & $\begin{array}{lr}\text { Não realizei } & \text { as } \\
\text { atividades e nem } \\
\text { pensei no tema } \\
\text { Sustentabilidade, Meio } \\
\text { Ambiente e na } \\
\text { escola. }\end{array}$ & $\begin{array}{l}\text { Realizei as atividades } \\
\text { propostas, tenho } \\
\text { alguma ideia do que é } \\
\text { sustentabilidade, mas } \\
\text { isso não tem nada a } \\
\text { ver comigo. }\end{array}$ & $\begin{array}{l}\text { Realizei as atividades } \\
\text { propostas, reforcei } \\
\text { meus conhecimentos } \\
\text { sobre } \\
\text { sustentabilidade, } \\
\text { quero tornar minha } \\
\text { escola numa escola } \\
\text { sustentável, mas } \\
\text { ainda não sei como. }\end{array}$ & $\begin{array}{l}\text { Papel reciclado, papel } \\
\text { novo (Realizei as as } \\
\text { atividades propostas, } \\
\text { reforcei r meus } \\
\text { conhecimentos sobre } \\
\text { sustentabilidade, quero } \\
\text { tornar minha escola } \\
\text { numa } \\
\text { sustentável e, apóa } \\
\text { pesquisas e estudo, já } \\
\text { estou organizando } \\
\text { meios de mobilizar } \\
\text { comunidade escolar. }\end{array}$ & $\begin{array}{l}\text { Práticas Pedagógico- } \\
\text { Comunicacionais: } \\
\text { Indicador 2: Tipos de } \\
\text { Participação - detalha como } \\
\text { construir e fortalecer ações } \\
\text { protagonistas, como indicado } \\
\text { por Hart (1992) e Costa (2006) } \\
\text { Indicador 4 / Relações entre } \\
\text { participantes } \\
\text { Competências } \\
\text { Educomunicativas: todas as } \\
\text { nove. }\end{array}$ \\
\hline
\end{tabular}




\section{Anexo F.3: Rubrica Projeto A.3 - Projeto: Sustentabilidade no Zaca}

Unidade: EMEF MAURO FACCIO GONÇALVES - ZACHARIAS

POIE: DOUGLAS

\begin{tabular}{|c|c|c|c|c|c|}
\hline CRITERIO & PRETO & VERMELHO & AMARELO & AZUL & $\begin{array}{l}\text { Análise de Conteúdo: } \\
\text { Categoria / Indicador }\end{array}$ \\
\hline $\begin{array}{l}\text { Percepção de } \\
\text { aprendizagem do } \\
\text { aluno }\end{array}$ & Não aprendi nada. & Aprendi pouco. & Aprendi "coisas" novas. & Aprendi muito. & $\begin{array}{l}\text { Práticas } \\
\text { Comunicacionais: } \\
\text { Indicador 2: }\end{array}$ \\
\hline $\begin{array}{l}\text { Consumo } \\
\text { consciente } \\
\text { gestão do lixo } \\
\text { seletivo }\end{array}$ & Jogamos tudo no lixo & Separamos materiais & $\begin{array}{l}\text { Consumimos } \\
\text { consciência. }\end{array}$ & $\begin{array}{l}\text { Reutilizamos o que é } \\
\text { possível. }\end{array}$ & $\begin{array}{l}\text { Ligado ao conteúdo em si, e neste } \\
\text { momento não se aplica, a } \\
\text { princípio. } \\
\text { FINALIDADE PRINCIPAL } \\
\text { Empoderamento do aluno enquanto } \\
\text { cidadão responsável }\end{array}$ \\
\hline
\end{tabular}




\section{Anexo F.4: Rubrica Projeto A.4 - Projeto: Sustentabilidade}

\section{Unidade: EMEF CYRO ALBUQUERQUE}

POIE: NADIA

\begin{tabular}{|c|c|c|c|c|c|}
\hline CRITERIO & NÃO RECICLÁVEL & RECICLÁVEL & $\begin{array}{c}\text { PENSANDO EM } \\
\text { SUSTENTABILIDADE }\end{array}$ & 100\% SUSTENTÁVEL & $\begin{array}{l}\text { Análise de Conteúdo: } \\
\text { Categoria / Indicador }\end{array}$ \\
\hline $\begin{array}{l}\text { Participação no } \\
\text { projeto como um } \\
\text { todo }\end{array}$ & $\begin{array}{l}\text { Não consegui terminar as } \\
\text { atividades, pois não me } \\
\text { interessei pelo projeto. } \\
\text { Fiz algumas partes, mas } \\
\text { minha participação foi } \\
\text { insuficiente. Preciso } \\
\text { melhorar ainda e não vou } \\
\text { desistir. Não costumo } \\
\text { separar lixo, mas tenho } \\
\text { consciência que minhas } \\
\text { ações vão prejudicar o } \\
\text { planeta. }\end{array}$ & $\begin{array}{l}\text { Não consegui terminar } \\
\text { todas as etapas e tive } \\
\text { muitas dificuldades. } \\
\text { Poderia ter conversado } \\
\text { mais e tirado minhas } \\
\text { dúvidas com } \quad \text { o } \\
\text { professor(a) rou } \\
\text { colegas. } \\
\text { aproveitar mais, mateias } \\
\text { e jogar menos coisas no } \\
\text { lixo orgânico }\end{array}$ & $\begin{array}{l}\text { Consegui terminar as } \\
\text { etapas mas tive algumas } \\
\text { dificuldades. Poderia ter } \\
\text { ajuda de os outros e } \\
\text { conversado mais a } \\
\text { respeito do tema, porém } \\
\text { fiz um bom trabalho. Já } \\
\text { reciclo muitas coisas e } \\
\text { não costumo misturar } \\
\text { lixos }\end{array}$ & $\begin{array}{l}\text { Eu me envolvi no } \\
\text { projeto, ajudei meus } \\
\text { colegas a conseguir } \\
\text { cumprir todas as etapas } \\
\text { com facilidade. Pretendo } \\
\text { colocar em pratica } \\
\text { minhas ações } \\
\text { sustentáveis e as dos } \\
\text { colegas também }\end{array}$ & 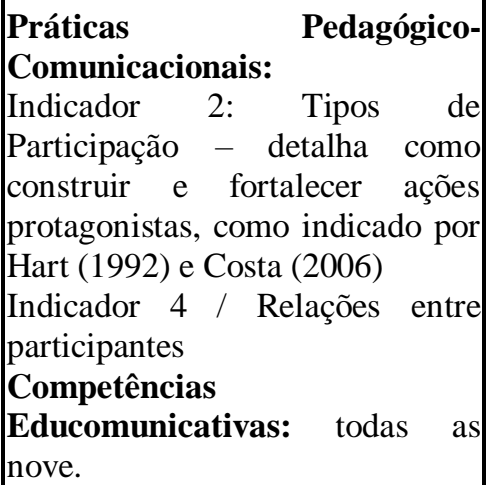 \\
\hline
\end{tabular}




\section{Anexo F.5: Rubrica Projeto B.1 - Projeto: Sustentabilidade no Zaca}

Unidade: EMEF JD. Mitsutani - Paulo Patarra

POIE: José Rosemberg

\begin{tabular}{|c|c|c|c|c|c|}
\hline CRITERIO & FOLHA & GAFANHOTO & PÁSSARO & GAVIÃO & $\begin{array}{l}\text { Análise de Conteúdo: } \\
\text { Categoria / Indicador }\end{array}$ \\
\hline Pesquisa & $\begin{array}{l}\text { Não feito nenhuma } \\
\text { pesquisa sobre o tema do } \\
\text { meu projeto. }\end{array}$ & $\begin{array}{l}\text { Tenho } \quad \text { pesquisado } \\
\text { quando o professor } \\
\text { manda, mas não } \\
\text { capricho na pesquisa: } \\
\text { pego o primeiro site, } \\
\text { recorto e colo. }\end{array}$ & $\begin{array}{l}\text { Tenho pesquisado } \\
\text { quando professor } \\
\text { manda. Consulto mais } \\
\text { de um site e antes de } \\
\text { escrever, procuro ler e } \\
\text { entender. Só que acabo } \\
\text { copiando o mesmo } \\
\text { texto. }\end{array}$ & 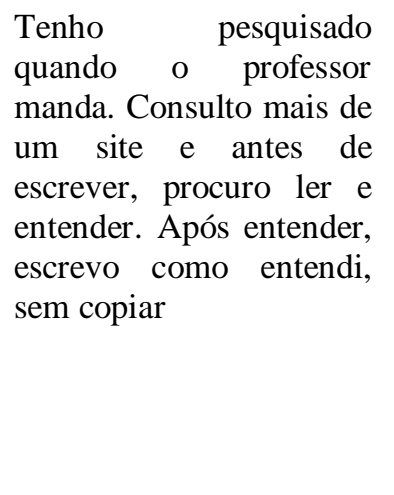 & 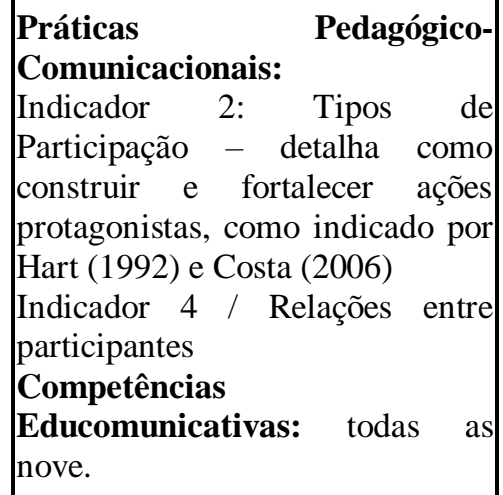 \\
\hline Participação & $\begin{array}{l}\text { Não participo dos } \\
\text { trabalhos, apenas disfarço } \\
\text { o período de aula de } \\
\text { informática. }\end{array}$ & $\begin{array}{l}\text { Participo das pesquisas, } \\
\text { sem muito interesse. }\end{array}$ & $\begin{array}{l}\text { Participo das pesquisas, } \\
\text { com meus colegas, mas } \\
\text { não dou ideia das } \\
\text { respostas. Nessa hora, só } \\
\text { olho. }\end{array}$ & $\begin{array}{l}\text { Participo das pesquisas, } \\
\text { ajudo meu colega a } \\
\text { compreender os textos, } \\
\text { dou ideias sobre as } \\
\text { respostas a produzir }\end{array}$ & 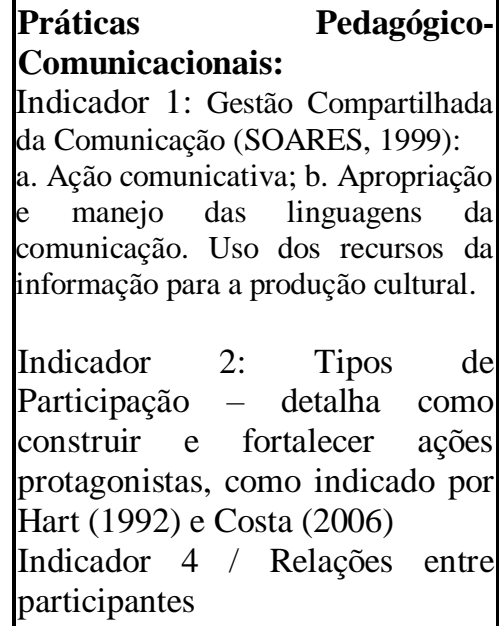 \\
\hline
\end{tabular}




\begin{tabular}{|c|c|c|c|c|c|c|}
\hline & & & & & & $\begin{array}{l}\text { Indicador } 3 \text { - Ações de Diálogo } \\
\text { a. Escuta mútua; b. Pensar juntos; c. } \\
\text { Apontar outros pontos de vista: d. } \\
\text { Compartilhar e refletir sobre ideias, e. } \\
\text { Fazer emergir ideias / buscar } \\
\text { pluralidade de ideias } \\
\text { Competências } \\
\text { Educomunicativas: todas as } \\
\text { nove. }\end{array}$ \\
\hline Colaboração & & $\begin{array}{l}\text { Não fiz grupo ou não } \\
\text { ajudo meu grupo a } \\
\text { realizar a atividade. }\end{array}$ & $\begin{array}{l}\text { Ajudo meu grupo, } \\
\text { lembrando o que o } \\
\text { professor falou, mas não } \\
\text { dou minha opinião ou } \\
\text { não ouço a opinião dos } \\
\text { meus colegas para } \\
\text { escrever as respostas }\end{array}$ & $\begin{array}{lr}\text { Ajudo o meu } & \text { grupo, } \\
\text { lembrando } & \text { as } \\
\text { orientações } & \text { do } \\
\text { professor, } & \text { dando } \\
\text { opiniões } & \text { sobre a } \\
\text { pesquisa e ouvindo os } \\
\text { meus colegas antes de } \\
\text { responder por escrito. }\end{array}$ & $\begin{array}{l}\text { Ajudo meu grupo, dou } \\
\text { opiniões sobre a } \\
\text { pesquisa, ouço a opinião } \\
\text { dos meus colegas para } \\
\text { responder e colaboro } \\
\text { com outros grupos que } \\
\text { necessitem. }\end{array}$ & 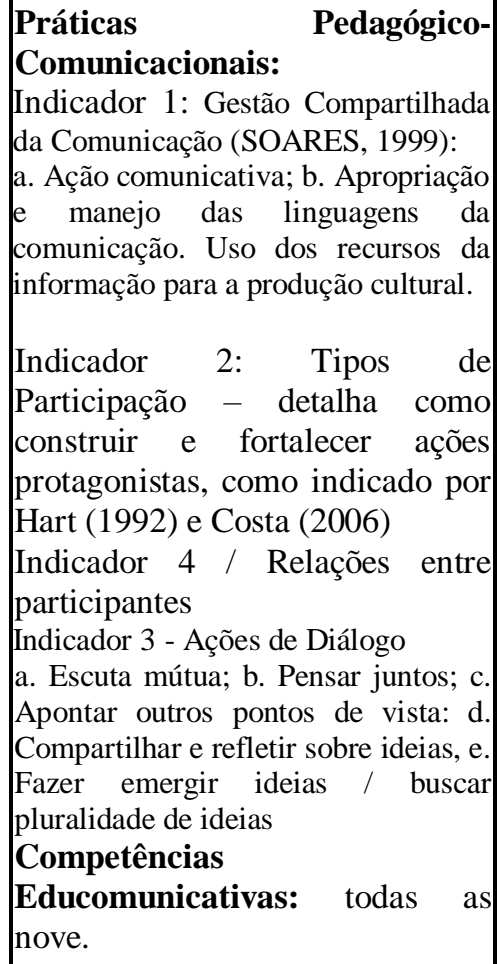 \\
\hline $\begin{array}{l}\text { Avaliando } \\
\text { POIE }\end{array}$ & & $\begin{array}{l}\text { Não propõe atividades, } \\
\text { não ajuda, não ensina e é } \\
\text { grosseiro. }\end{array}$ & $\begin{array}{l}\text { Propõe atividades, } \\
\text { ensina os alunos, mas } \\
\text { não ajuda e é grosseiro. }\end{array}$ & $\begin{array}{l}\text { Propõe atividades, } \\
\text { ensina os alunos, ajuda } \\
\text { quando precisam, mas } \\
\text { não tem jeito para } \\
\text { conversar. }\end{array}$ & $\begin{array}{l}\text { Propõe atividades, ensina } \\
\text { os alunos, ajuda quando } \\
\text { precisam e quando há } \\
\text { conflito, resolve com } \\
\text { educação. }\end{array}$ & \\
\hline
\end{tabular}




\section{Anexo F.6: Rubrica Projeto B.2 - Projeto: Curiosos em Ação}

Unidade: EMEF JD. Mitsutani - Paulo Patarra

POIE: José Rosemberg

\begin{tabular}{|c|c|c|c|c|c|}
\hline CRITERIO & BICHO-PREGUIÇA & TARTARUGA & GATO & GUEPARDO & $\begin{array}{l}\text { Análise de Conteúdo: } \\
\text { Categoria / Indicador }\end{array}$ \\
\hline $\begin{array}{l}\text { Gênero textual } \\
\text { estudado }\end{array}$ & $\begin{array}{l}\text { Não sei o que são } \\
\text { verbetes de curiosidade }\end{array}$ & $\begin{array}{l}\text { Sei o que é verbete de } \\
\text { curiosidade, mas não } \\
\text { consigo escrever um. }\end{array}$ & $\begin{array}{l}\text { Sei que são verbetes de } \\
\text { curiosidade e consigo } \\
\text { escrever um se tiver } \\
\text { ajuda. }\end{array}$ & $\begin{array}{l}\text { Sei o que são verbetes de } \\
\text { curiosidade, consigo } \\
\text { escrever sem ajuda, } \\
\text { posso ajudar alguém que } \\
\text { não saiba como faz. }\end{array}$ & 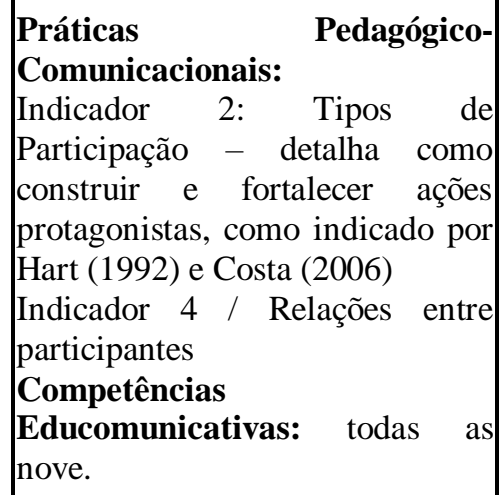 \\
\hline A Pesquisa & $\begin{array}{l}\text { Não sei como se pesquisa } \\
\text { no computador. }\end{array}$ & $\begin{array}{l}\text { Sei entrar no Google, } \\
\text { mas não sei o que fazer } \\
\text { com o monte de sites } \\
\text { que aparecem. }\end{array}$ & $\begin{array}{l}\text { Sei entrar no Google, } \\
\text { consigo fazer pesquisa, } \\
\text { e assim que acho a } \\
\text { resposta já escrevo, sem } \\
\text { conferir outros sites se } \\
\text { está correta. }\end{array}$ & $\begin{array}{l}\text { Sei entrar no Google, } \\
\text { consigo escrever minha } \\
\text { pesquisa, escolho sites à } \\
\text { procura da resposta e } \\
\text { verifico se está correta } \\
\text { antes de registrar. }\end{array}$ & \\
\hline Participação & $\begin{array}{l}\text { Não faço nada para } \\
\text { ajudar. }\end{array}$ & $\begin{array}{l}\text { Tento ajudar o meu } \\
\text { colega mas brigamos e o } \\
\text { trabalho não anda. }\end{array}$ & $\begin{array}{l}\text { Tento ajudar o meu } \\
\text { colega ou ele tenta me } \\
\text { ajudar, mas acabamos } \\
\text { brigando por não } \\
\text { concordar em algumas } \\
\text { coisas e chamamos o } \\
\text { professor para resolver. }\end{array}$ & $\begin{array}{l}\text { Tento ajudar meu colega } \\
\text { ou ele tenta me ajudar, } \\
\text { combinamos a divisão de } \\
\text { tarefas, ouvimos as } \\
\text { opiniões um do outro e } \\
\text { quando tem a chance de } \\
\text { brigar, conversamos para } \\
\text { resolver. }\end{array}$ & 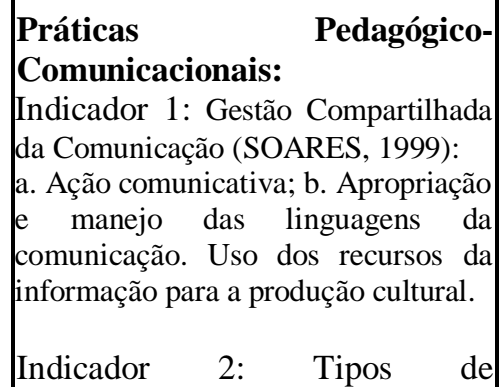 \\
\hline
\end{tabular}




\begin{tabular}{|c|c|c|c|c|c|}
\hline & & & & & $\begin{array}{l}\text { Participação }- \text { detalha como } \\
\text { construir e fortalecer ações } \\
\text { protagonistas, como indicado por } \\
\text { Hart (1992) e Costa (2006) } \\
\text { Indicador 4 / Relações entre } \\
\text { participantes } \\
\text { Indicador 3 - Ações de Diálogo } \\
\text { a. Escuta mútua; b. Pensar juntos; c. } \\
\text { Apontar outros pontos de vista: d. } \\
\text { Compartilhar e refletir sobre ideias, e. } \\
\text { Fazer emergir ideias / buscar } \\
\text { pluralidade de ideias } \\
\text { Competências } \\
\text { Educomunicativas: todas as } \\
\text { nove. }\end{array}$ \\
\hline O PowerPoint & $\begin{array}{l}\text { Não sei usar e nem sei } \\
\text { onde ele fica para eu } \\
\text { abri-lo. }\end{array}$ & $\begin{array}{l}\text { Sei onde fica o } \\
\text { PowerPoint, conheço o } \\
\text { ícone, mas preciso de } \\
\text { ajuda para escrever, usar } \\
\text { formas e colocar } \\
\text { animação. }\end{array}$ & $\begin{array}{l}\text { Sei onde fica o } \\
\text { PowerPoint, conheço } \\
\text { seu ícone, sei escrever } \\
\text { nele, sei usar formas, } \\
\text { mas preciso de ajuda } \\
\text { para colocar animação. }\end{array}$ & $\begin{array}{l}\text { Sei onde fica o } \\
\text { PowerPoint, conheço seu } \\
\text { ícone, sei escrever nele, } \\
\text { sei usar formas, consigo } \\
\text { colocar animação e posso } \\
\text { ajudar quem tiver } \\
\text { dificuldade. }\end{array}$ & $\begin{array}{l}\text { Práticas Pedagógico- } \\
\text { Comunicacionais: } \\
\text { Indicador 1: Gestão Compartilhada } \\
\text { da Comunicação (SOARES, 1999): } \\
\text { a. Ação comunicativa; b. Apropriação } \\
\text { e manejo das linguagens da } \\
\text { comunicação. Uso dos recursos da da } \\
\text { informação para a produção cultural. }\end{array}$ \\
\hline
\end{tabular}




\section{Anexo F.7: Rubrica Projeto B.3 - Projeto: Clube da Astronomia (Aluno Monitor - Trabalho}

\section{comprometido, parceria de sucesso)}

Unidade: EMEF Des. Achilles de Oliveira Ribeira (DRE São Mateus)

POIE: Maria Helena Pereira

\begin{tabular}{|c|c|c|c|c|c|}
\hline CRITERIO & EXTRATERRESTRE & ESTUDANTE & $\begin{array}{l}\text { ASTRÔNOMO } \\
\text { AMADOR }\end{array}$ & CIENTISTA & $\begin{array}{l}\text { Análise de Conteúdo: } \\
\text { Categoria / Indicador }\end{array}$ \\
\hline $\begin{array}{l}\text { Respeito quanto } \\
\text { à opinião dos } \\
\text { colegas }\end{array}$ & $\begin{array}{l}\text { Não dei atenção às ideias } \\
\text { dos colegas }\end{array}$ & $\begin{array}{l}\text { Ouvi, mas não respeitei } \\
\text { as ideias. }\end{array}$ & $\begin{array}{l}\text { Ouvi, respeitei a maior } \\
\text { parte das ideias, mas não } \\
\text { argumentei. }\end{array}$ & $\begin{array}{l}\text { Ouvi, argumentei e } \\
\text { respeitei todas as ideias. }\end{array}$ & $\begin{array}{l}\text { Práticas } \\
\text { Comunicacionais: }\end{array}$ \\
\hline $\begin{array}{l}\text { Participação } \\
\text { interesse }\end{array}$ & $\begin{array}{l}\text { Não participou, nem teve } \\
\text { interesse pelo projeto. }\end{array}$ & $\begin{array}{lll}\text { Participei } & \text { de } & \text { algumas } \\
\text { atividades } & \text { com } & \text { pouco } \\
\text { interesse. } & & \end{array}$ & $\begin{array}{l}\text { Participei de todas as } \\
\text { atividades. }\end{array}$ & $\begin{array}{l}\text { Participei de todas as } \\
\text { atividades com dedicação } \\
\text { e interesse. }\end{array}$ & 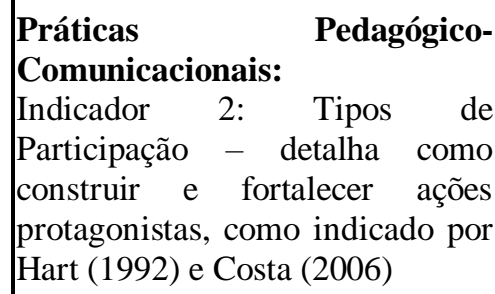 \\
\hline
\end{tabular}




\begin{tabular}{|c|c|c|c|c|c|}
\hline $\begin{array}{l}\text { Autoavaliação no } \\
\text { projeto }\end{array}$ & $\begin{array}{l}\text { Compreendi muito pouco } \\
\text { a proposta, explorei o } \\
\text { ambiente e as atividades, } \\
\text { não contribui com novas } \\
\text { ideias. Não consegui } \\
\text { finalizar todas as } \\
\text { atividades. Estive sempre } \\
\text { no "mundo da Lua"! }\end{array}$ & $\begin{array}{l}\text { Compreendi parte da } \\
\text { proposta, explorei o } \\
\text { ambiente e as atividades } \\
\text { contribuindorr com } \\
\text { algumas ideias. Finalizei } \\
\text { as atividades com } \\
\text { alguma dificuldade. }\end{array}$ & $\begin{array}{l}\text { Compreendi boa parte } \\
\text { da proposta, explorei o } \\
\text { ambiente e as } \\
\text { atividades, contribuindo } \\
\text { com ideias e questionei } \\
\text { alguns posicionamentos. } \\
\text { Estou disposto a ampliar } \\
\text { minha compreensão } \\
\text { sobre o tema. Finalizei } \\
\text { as atividades. }\end{array}$ & $\begin{array}{l}\text { Compreendi a proposta, } \\
\text { explorei o ambiente e as } \\
\text { atividades, contribuindo } \\
\text { com ideias e provocando } \\
\text { o debate e a reflexão com } \\
\text { o grupo. Estou motivado } \\
\text { a pesquisar sobre o tema } \\
\text { para ampliar minha } \\
\text { compreensão ra } \\
\text { compartilhar com os } \\
\text { colegas. Finalizei todas } \\
\text { as atividades com } \\
\text { facilidade. }\end{array}$ & \begin{tabular}{llrr} 
Práticas & \multicolumn{2}{r}{ Pedagógico- } \\
Comunicacionais & & \\
Indicador & 1 & - & Gestão \\
compartilhada & da & comunicação, \\
com mediação tecnológica & \\
Indicador & 2 : & Tipos & de \\
Participação & - & detalha & como \\
construir e & fortalecer & ações \\
protagonistas, como indicado por \\
Hart (1992) e Costa (2006) \\
Indicador 4 / Relações entre \\
participante & & \\
Competências & & \\
Educomunicativas: & todas & as \\
nove. & &
\end{tabular} \\
\hline \multicolumn{6}{|c|}{$\begin{array}{l}\text { RUBRICA DISPONIBILIZADA NO GOOGLE DOCS } \\
\text { (MAS RESULTADOS NÃO FORAM DISPONIBILIZADOS NO THINKQUEST, } \\
\text { COMO OS REALIZADOS DIRETAMENTE NO REFERIDO AVA) }\end{array}$} \\
\hline CRITERIO & FIGURANTE & $\begin{array}{l}\text { PARTICIPAÇÃO } \\
\text { ESPECIAL }\end{array}$ & COADJUVANTE & PROTAGONISTA & $\begin{array}{l}\text { Análise de Conteúdo: } \\
\text { Categoria / Indicador }\end{array}$ \\
\hline $\begin{array}{ll}\text { Tipo } & \text { de } \\
\text { Participação } & \text { no } \\
\text { Projeto } & \end{array}$ & $\begin{array}{l}\text { Compreendi muito pouco } \\
\text { a proposta, explorei o } \\
\text { ambiente e as atividades, } \\
\text { não contribui com novas } \\
\text { ideias. Não consegui } \\
\text { finalizar todas as } \\
\text { atividades. }\end{array}$ & $\begin{array}{l}\text { Compreendi parte da } \\
\text { proposta, explorei o } \\
\text { ambiente e as atividades } \\
\text { contribuindor com } \\
\text { algumas ideias. Finalizei } \\
\text { as atividades com } \\
\text { alguma dificuldade. }\end{array}$ & $\begin{array}{l}\text { Compreendi boa parte } \\
\text { da proposta, explorei o } \\
\text { ambiente e as } \\
\text { atividades, contribuindo } \\
\text { com ideias e questionei } \\
\text { alguns posicionamentos. } \\
\text { Estou disposto a ampliar } \\
\text { minha compreensão } \\
\text { sobre o tema. Finalizei } \\
\text { as atividades. }\end{array}$ & $\begin{array}{l}\text { Compreendi a proposta, } \\
\text { explorei o ambiente e as } \\
\text { atividades, contribuindo } \\
\text { com ideias e provocando } \\
\text { o debate e a reflexão com } \\
\text { o grupo. Estou motivado } \\
\text { a pesquisar sobre o tema } \\
\text { para ampliar minha } \\
\text { compreensão or os } \\
\text { compartilhar com os } \\
\text { colegas. Finalizei todas } \\
\text { as atividades com } \\
\text { facilidade. }\end{array}$ & \begin{tabular}{llrr} 
Práticas & \multicolumn{2}{l}{ Pedagógico- } \\
Comunicacionais - & \\
Indicador & 1 & - & Gestão \\
compartilhada & da & comunicação, \\
com mediação tecnológica & \\
Indicador & 2 : & Tipos & de \\
Participação & - & detalha & como \\
construir e & fortalecer & ações \\
protagonistas, como indicado por \\
Hart (1992) e Costa (2006) \\
Indicador 4 / Relações entre \\
participantes & & \\
Competências & & \\
Educomunicativas: & todas & as \\
nove. &
\end{tabular} \\
\hline
\end{tabular}




\section{Anexo F.8: Rubrica Projeto B.4 - Projeto: Jogos do Riva}

Unidade: EMEF Rivadávia Marques Junior (DRE São Mateus)

POIE: Gislaine Batista Munhoz

\begin{tabular}{|c|c|c|c|c|c|}
\hline CRITERIOS & RAICHU & PIKACHU & PICHU & $\begin{array}{c}\text { NÃO É UM } \\
\text { POKEMON AINDA }\end{array}$ & $\begin{array}{l}\text { Análise de Conteúdo: } \\
\text { Categoria / Indicador }\end{array}$ \\
\hline $\begin{array}{l}\text { Frequência e } \\
\text { pontualidade }\end{array}$ & $\begin{array}{l}\text { Sempre chega na hora } \\
\text { e está sempre } \\
\text { presente }\end{array}$ & $\begin{array}{l}\text { Sempre está presente, } \\
\text { mas nunca chega na } \\
\text { hora }\end{array}$ & $\begin{array}{l}\text { Quase não vem e } \\
\text { quando vem nunca } \\
\text { chega na hora }\end{array}$ & $\begin{array}{l}\text { Se pontualidade e sem } \\
\text { compromisso }\end{array}$ & $\begin{array}{l}\text { Práticas Pedagógico-Comunicacionais } \\
\text { Indicador 4 / Relações entre } \\
\text { participantes }\end{array}$ \\
\hline $\begin{array}{lr}\text { Busca de } \\
\text { conhecimento } & - \\
\text { aprender a aprender }\end{array}$ & $\begin{array}{l}\text { Sempre esta desposto } \\
\text { a aprender }\end{array}$ & $\begin{array}{l}\text { Esta desposto a } \\
\text { aprender e quando } \\
\text { não consegue abaixa } \\
\text { a cabeça }\end{array}$ & $\begin{array}{l}\text { Busca o conhecimento, } \\
\text { mas não aprende }\end{array}$ & $\begin{array}{l}\text { Não busca } 0 \\
\text { conhecimento e não } \\
\text { tem vontade de } \\
\text { aprender e abaixa a } \\
\text { cabeça }\end{array}$ & $\begin{array}{l}\text { Práticas Pedagógico-Comunicacionais } \\
\text { 3. Participações de protagonismo (tipos) }\end{array}$ \\
\hline $\begin{array}{l}\text { Trabalho em parceria, } \\
\text { e colaboração }\end{array}$ & $\begin{array}{l}\text { Conversa com seus } \\
\text { parceiros e auxilia } \\
\text { quando ele precisa de } \\
\text { ajuda }\end{array}$ & $\begin{array}{l}\text { Trabalha, mas nem } \\
\text { sempre gosta de } \\
\text { trabalhar em parceria }\end{array}$ & $\begin{array}{l}\text { Não conversa e quando } \\
\text { conversa atrapalha }\end{array}$ & $\begin{array}{l}\text { Não conversa com } \\
\text { ninguém e quando é } \\
\text { para fazer as coisas, } \\
\text { faz errado }\end{array}$ & $\begin{array}{l}\text { - Práticas Pedagógico-Comunicacionais } \\
\text { 1. Diálogo (Compartilhar e refletir sobre } \\
\text { ideias, Escuta mútua, pensar juntos; } \\
\text { Apontar outros pontos de vista; } \\
\text { Compartilhar e refletir sobre ideias; } \\
\text { Fazer emergir ideias / buscar pluralidade } \\
\text { de ideias; } \\
\text { 4. Relações entre participantes. } \\
\text { - Competências Educomunicativas: } \\
\text { 1. Colaboração em equipe; } \\
\text { 5. Compartilhamento (de experiências e } \\
\text { de ideias) Colaboração em equipe; } \\
\text { 7. Tomada Compartilhada de Decisão; } \\
\text { 8. Resolução Conjunta de Problemas; } \\
\text { 9. Avaliação (entre pares } \\
\text { autoavaliação). }\end{array}$ \\
\hline
\end{tabular}




\begin{tabular}{|c|c|c|c|c|c|}
\hline $\begin{array}{l}\text { Motivação, empenho, } \\
\text { inciativa } \\
\text { solidariedade }\end{array}$ & $\begin{array}{l}\text { Tem motivação se } \\
\text { empenha nas } \\
\text { atividades sempre } \\
\text { toma inciativa e é } \\
\text { solitário }\end{array}$ & $\begin{array}{l}\text { Tem empenho e } \\
\text { motivação mais não } \\
\text { tem iniciativa com os } \\
\text { colegas }\end{array}$ & $\begin{array}{l}\text { Nunca está motivado e } \\
\text { não tem empenho nas } \\
\text { atividades mais sempre } \\
\text { toma a iniciativa com } \\
\text { os colegas }\end{array}$ & $\begin{array}{l}\text { Nunca está motivado } \\
\text { e não tem empenho } \\
\text { nas atividades e não } \\
\text { tem iniciativa com os } \\
\text { colegas }\end{array}$ & $\begin{array}{l}\text { Práticas Pedagógico-Comunicacionais } \\
\text { Indicador 4 / Relações entre } \\
\text { participantes }\end{array}$ \\
\hline $\begin{array}{l}\text { Aluno monitor como } \\
\text { modelo }\end{array}$ & $\begin{array}{l}\text { Um aluno no qual os } \\
\text { alunos mais novos se } \\
\text { refletem }\end{array}$ & $\begin{array}{l}\text { O aluno é bom mais } \\
\text { nem sempre é bom } \\
\text { para os novos }\end{array}$ & $\begin{array}{l}\text { É um aluno bom, mas } \\
\text { quando entra novos } \\
\text { quer se amostrar }\end{array}$ & $\begin{array}{l}\text { Um aluno que } \\
\text { ninguém se espelha } \\
\text { nele }\end{array}$ & $\begin{array}{l}\text { Práticas Pedagógico-Comunicacionais } \\
- \\
\text { Indicador } 1 \text { - Gestão compartilhada da } \\
\text { comunicação, com mediação tecnológica } \\
\text { Indicador 2: Tipos de Participação } \\
\text { detalha como construir e fortalecer ações } \\
\text { protagonistas, como indicado por Hart } \\
\text { (1992) e Costa (2006) } \\
\text { Indicador } 4 \text { / Relações entre participante }\end{array}$ \\
\hline $\begin{array}{l}\text { Auxílio com os alunos } \\
\text { durante as aulas }\end{array}$ & $\begin{array}{l}\text { Tem uma conexão } \\
\text { muito boa com os } \\
\text { alunos }\end{array}$ & $\begin{array}{l}\text { É um bom monitor } \\
\text { mas devem em } \\
\text { quando da mancada }\end{array}$ & $\begin{array}{l}\text { Não tem conexão com } \\
\text { os alunos e ensina } \\
\text { errado }\end{array}$ & $\begin{array}{l}\text { Não ajuda os alunos e } \\
\text { fica em jogo }\end{array}$ & $\begin{array}{l}\text { Práticas Pedagógico-Comunicacionais } \\
- \\
\text { Indicador } 1 \text { - Gestão compartilhada da } \\
\text { comunicação, com mediação tecnológica } \\
\text { Indicador } 4 \text { / Relações entre participante }\end{array}$ \\
\hline $\begin{array}{l}\text { Satisfação em ser } \\
\text { aluno monitor }\end{array}$ & $\begin{array}{l}\text { É muito bom ajudar } \\
\text { quem tem dificuldade }\end{array}$ & $\begin{array}{l}\text { É bom aprender a } \\
\text { fazer jogos }\end{array}$ & $\begin{array}{l}\text { As vezes tem que fazer } \\
\text { jogos difíceis }\end{array}$ & $\begin{array}{l}\text { É ruim acordar cedo } \\
\text { por isso não gosto de } \\
\text { acordar cedo }\end{array}$ & \\
\hline $\begin{array}{l}\text { Criatividade } \\
\text { Inovação na criação } \\
\text { de games }\end{array}$ & $\begin{array}{l}\text { Sempre está em busca } \\
\text { de criatividade tanto } \\
\text { na elaboração e nos } \\
\text { personagens }\end{array}$ & $\begin{array}{l}\text { Buscar criatividade } \\
\text { nos personagens e as } \\
\text { vezes r busca } \\
\text { criatividade nos jogos }\end{array}$ & $\begin{array}{lr}\text { Sempre } & \text { tem } \\
\text { criatividade nos jogos, } \\
\text { mas não nos } \\
\text { personagens }\end{array}$ & $\begin{array}{l}\text { Sempre faz a mesma } \\
\text { coisa e não tem } \\
\text { criatividade nos jogos }\end{array}$ & \\
\hline
\end{tabular}




\section{Anexo G - Quadros de Trechos da Entrevistas dos POIE}

\section{Anexo G.1: Entrevista Cristina Barroco Massei Fernandes (coordenadora DRE Campo Limpo)}

\begin{tabular}{|c|c|c|}
\hline PERGUNTAS & $\begin{array}{c}\text { ENTREVISTA } \\
\text { CRISTINA } \\
\end{array}$ & INDICADORES \\
\hline & $\begin{array}{l}\text { Bem, deixe eu organizar a minha cabeça porque } 2012 \text {... então... eu fiquei } \\
\text { pensando nessa linha do tempo... A gente conheceu o Cesar e começou a } \\
\text { trabalhar no ThinkQuest em } 2009 \text {, mas isso foi só a DRE Campo Limpo, porque } \\
\text { o Douglas conheceu o Cesar, eu conversei com ele e tal... e ele veio aqui na DRE } \\
\text { e a gente começou com o ThinkQuest aqui na DRE Campo Limpo em } 2009 . \text { E } \\
\text { em } 2010 \text {, eu montei a formação para os professores no ambiente independente de } \\
\text { SME... ai o Cesar veio, conversou com a Lia... então, chegou em SME depois } \\
\text { disso... de } 2010 \text { para } 2011 \ldots \text { estou pensando nessa linha do tempo... primeiro a } \\
\text { gente se entendeu no ambiente, organizamos a formação, por conta desse registro } \\
\text { da formação de professores...e ai não tinha em } 2010 \text { uma obrigatoriedade que ele } \\
\text { fizesse com alunos no ambiente... ele estava se apropriando, ele era o aluno, o } \\
\text { POIE estava aluno no ambiente... é claro que alguns já iniciavam... o Douglas, } \\
\text { por exemplo, já usava o ThinkQuest antes de eu começar... }\end{array}$ & $\begin{array}{l}\text { Neste relato, podemos identificar todos os aspectos da } \\
\text { Educomunicação, e aqui podemos entender como uma } \\
\text { formação para os POIE pode ser pensada e como uma nova } \\
\text { orientação é passada a eles. }\end{array}$ \\
\hline $\begin{array}{l}\text { No ThinkQuest, o acesso } \\
\text { era tranquilo... não tinha } \\
\text { problema como o } \\
\text { Edmodo? Ou tinha? }\end{array}$ & $\begin{array}{l}\text { Era melhor... a conexão funcionava melhor... e eu penso que os alunos se } \\
\text { encontravam melhor naquele ambiente... o Douglas brinca que eu, ele o } \\
\text { Rosemberg, que nós somos a viúvas do ThinkQuest.... A gente fica comparando... } \\
\text { por mais que cada um tenha um jeito, a gente se encontrava melhor ali... e em } \\
2011 \text {, bombou a rubrica, foi o que você falou... os gestores das DREs escreveram } \\
\text { rubrica e levaram para suas formações... na minha turma tem gente que está como } \\
\text { POIE há muito tempo... então nós fomos nos apropriando da rubrica e é claro... } \\
\text { hoje temos } 120 \text { POIEs na DRE Campo Limpo... então tem gente que tem } 17 \text { anos, } \\
\text { tem gente no caminho que chegou hoje... hoje eu tive uma POIE recém } \\
\text { designada, que veio fazer uma formação comigo... então é claro que a } \\
\text { apropriação não foi igual para todos... mas em } 2011 \text { ela chegou assim... a ideia da } \\
\text { rubrica chegou com força... eu fiquei pensando também enquanto você falava, do } \\
\text { quanto essa comunicação fez diferença entre eles... algumas pessoas entenderam } \\
\text { a ideia da rubrica como uma parada de reflexão, de um lugar, um caminho que } \\
\text { estou e como posso avançar porque tem sempre um nível que descreve o que se } \\
\text { espera... mas eu não posso dizer que todos entenderam a rubrica... algumas } \\
\text { pessoas se classificam... por mais que digamos que é uma parada para reflexão... } \\
\text { eu não estou dizendo que você professor é nível básico... você está confortável... } \\
\text { estou dizendo que esta proposta permite isto ou aquilo... algumas pessoas }\end{array}$ & \\
\hline
\end{tabular}




\begin{tabular}{|c|c|c|}
\hline & $\begin{array}{l}\text { entenderam e outras não. Então, em } 2011 \text {, eu tinha o Ricardo que trabalhava } \\
\text { comigo porque duas pessoas sempre pensam melhor uma pauta... e aí nós fizemos } \\
\text { assim: uma formação onde o POIE colocava ao projeto dele e ele se avaliava... e } \\
\text { depois eu olhava para esse registro e fazíamos a nossa avaliação com a mesma } \\
\text { rubrica... e fizemos um trabalho grande... fizemos um documento que mostrava } \\
\text { que níveis o POIE tinha se colocado a partir de } 4 \text { critérios e em que nível nós } \\
\text { tínhamos colocado aquele projeto dele... }\end{array}$ & \\
\hline $\begin{array}{lr}\text { E era um projeto que ele } \\
\text { tinha ou } \\
\text { desenvolvendo } \\
\text { escola? }\end{array}$ & 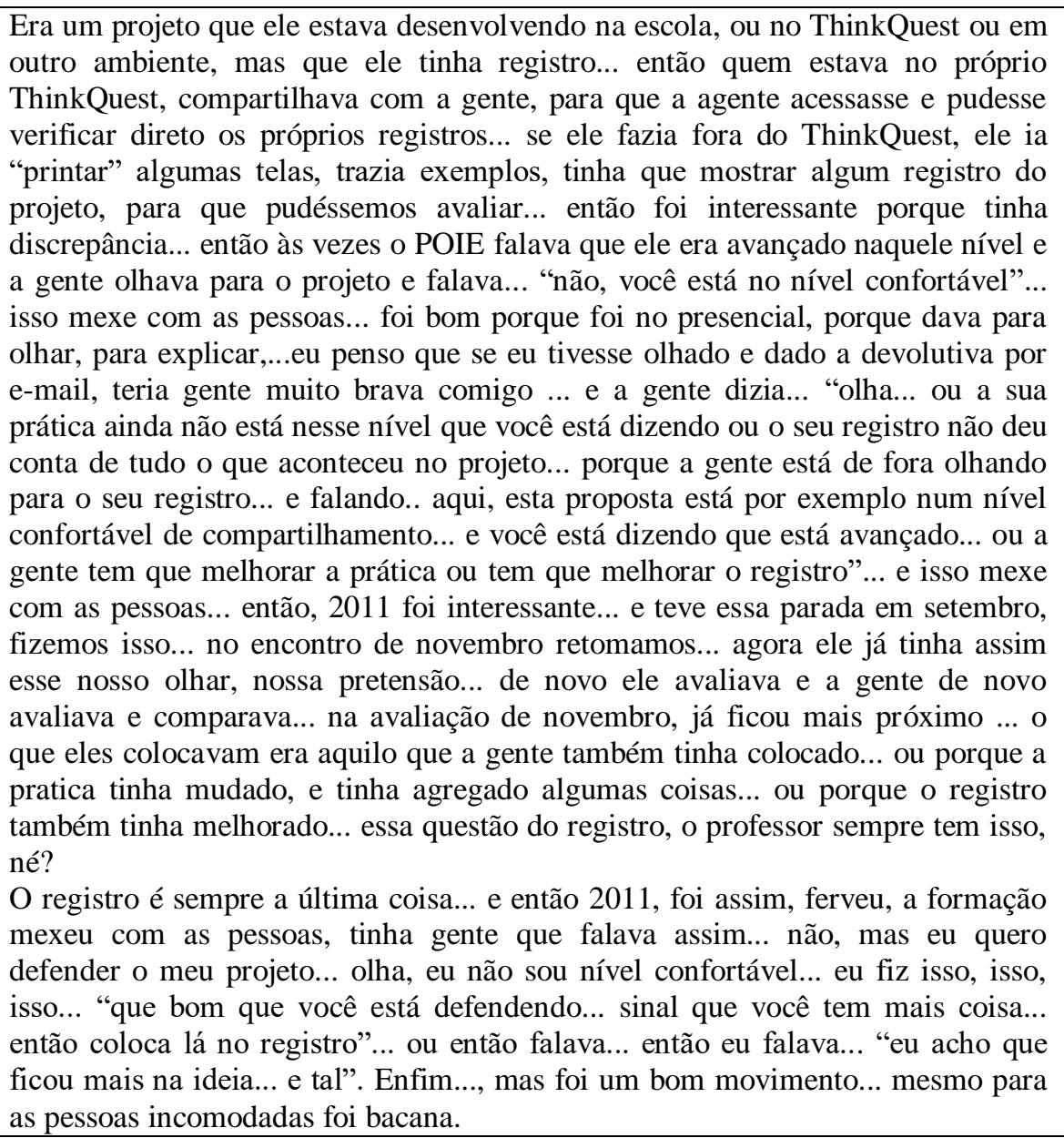 & $\begin{array}{l}\text { 1. Gestão Compartilhada da Comunicação (SOARES, 1999): } \\
\text { a. Ação comunicativa; } \\
\text { b. Apropriação e manejo das linguagens da comunicação; } \\
\text { c. Uso dos recursos da informação para a produção cultural. } \\
\text { 2. Participações de Protagonismo [Degraus de Participação: } 5 \text { a } 10 \\
\text { (HART, 1992; COSTA,2006) ]: } \\
\text { a. Participação planejadora e operacional. } \\
\text { b. Participação decisória, planejadora e operacional. } \\
\text { c. Participacão decisória, planejadora, operacional e avaliadora. } \\
\text { d. Participação colaborativa plena. } \\
\text { e. Participação plenamente autônoma. } \\
\text { f. Participação condutora. } \\
\text { 3. Ações de Diálogo } \\
\text { a. Escuta mútua } \\
\text { b. Pensar juntos } \\
\text { c. Apontar outros pontos de vista } \\
\text { d. Compartilhar e refletir sobre ideias, } \\
\text { e. Fazer emergir ideias / buscar pluralidade de ideias }\end{array}$ \\
\hline
\end{tabular}




\begin{tabular}{|c|c|c|}
\hline & $\begin{array}{l}\text { Em 2012, a SME-SP veio com o projeto de sustentabilidade... então, era um tema } \\
\text { fechado para todo mundo. E aí foi um ano que eu falei assim até... eu acho que } \\
\text { fez água, sabe... quando para algumas pessoas esse tema casava com a realidade } \\
\text { da escola, eles foram... e para algumas pessoas, não. Eu senti que algumas } \\
\text { pessoas que já estavam avançadas tentaram forçar a entrada desse projeto de } \\
\text { sustentabilidade e não foi bacana ter um tema só para todo mundo. }\end{array}$ & \\
\hline $\begin{array}{l}\text { Você acha que frustrou } \\
\text { muita gente? }\end{array}$ & $\begin{array}{l}\text { Eu acho porque... assim... tinham outras coisas lá na escola acontecendo, mas o } \\
\text { projeto era sustentabilidade. }\end{array}$ & \\
\hline $\begin{array}{l}\text { Eles tiveram que abrir } \\
\text { mão? }\end{array}$ & $\begin{array}{l}\text { Sim ... ou então forçar pelo menos uma turma para ter o que registrar no } \\
\text { ambiente... tanto é que no final de } 2012 \text {, nós fizemos a avaliação e acertamos que } \\
\text { para } 2013 \text {, nós fecharíamos a proposta pedagógica, mas o tema teria que estar } \\
\text { coerente com o PPP da escola... tem que olhar para a sua realidade... tem que } \\
\text { pensar o que está efervescendo na sua escola e precisa ser trabalhado por meio de } \\
\text { um projeto... e aí essa...a DRE Campo Limpo... eu estou aqui desde } 2005 . . \text { eu } \\
\text { falo que tem gente que não me aguenta mais... } 10 \text { anos de formação comigo. }\end{array}$ & A importância do registro \\
\hline $\begin{array}{l}\text { Eu não acho, não... } \\
\text { porque você tem um } \\
\text { aspecto do que eu vejo, } \\
\text { que você inova e } \\
\text { atualiza... isso é um } \\
\text { ganho grande... }\end{array}$ & $\begin{array}{l}\text { Eu acho que o que me ajuda também nessa questão de estar há } 10 \text { anos neste } \\
\text { posto é o vínculo porque para algumas pessoas eu sei o que posso dizer "precisa } \\
\text { melhorar"... para outras, eu preciso falar... "então, e se a gente fizer diferente...” a } \\
\text { gente acaba criando vinculo... eu consigo falar abertamente com algumas pessoas } \\
\text { sobre o que está pegando, o que precisa ser melhorado... ela está me ajudando, a } \\
\text { gente tem essa coisa de parceria... estar há muito tempo ajuda em alguns } \\
\text { aspectos... eu não posso parar de estudar de jeito nenhum porque tem que ter } \\
\text { repertório para essa turma... eu tenho um pessoal muito avançado... o Rosemberg } \\
\text { infelizmente não é mais POIE... mas o Douglas é um super parceiro... tem alguns } \\
\text { que foram para a coordenação, tem muito POIE que passou no concurso de } \\
\text { coordenaria pedagógica... então, tem muito parceiro do outro lado, do ponto de } \\
\text { vista da coordenação... desde } 2005 \text {, eu tenho essa liberdade.. a DRE Campo } \\
\text { Limpo é muito boa de trabalhar porque me dá essa liberdade de criar, vem uma } \\
\text { proposta de SME, mas eu monto as minhas pautas... e a gente sabe que em alguns } \\
\text { lugares tem uma intervenção muito forte... mesmo mudando a gestão eu posso } \\
\text { montar a pauta, tem uma orientação de SME, mas... então, lá em } 2012 \text { a pauta era } \\
\text { da WebCurrículo que era a formação linha de SME, mas eu que adaptava para a } \\
\text { minha realidade... então a agente combinou de ter um parte de discussão de } \\
\text { concepção mesmo, dentro do papel da informática educativa e da avaliação } \\
\text { formativa, e uma parte a gente tentava vivenciar... uma aula... então ... fazia uma }\end{array}$ & $\begin{array}{l}\text { A importância de estar sempre buscando melhorar e } \\
\text { atualizar. } \\
\text { E o estímulo à reflexão a partir da rubrica. }\end{array}$ \\
\hline
\end{tabular}




\begin{tabular}{|c|c|c|}
\hline & $\begin{array}{l}\text { proposta como se eles fossem meus alunos e a gente avaliava por uma rubrica, } \\
\text { como se eles fossem meus alunos... fizemos isso num encontro onde a gente } \\
\text { estava ensinando a linguagem Prezi mas não era solto... então era assim, vamos } \\
\text { registrar dentro do Prezi o que a gente pesquisou e discutia ali no portal e tinha } \\
\text { uma avaliação... então, eles avaliavam o recurso da aula, se é um bom recurso, se } \\
\text { eu já me apropriei dele, se eu consigo usar para mim, se eu consigo usar para } \\
\text { mim e dentro de um projeto com diferentes perspectivas para o aluno...e } \\
\text { possíveis... então ... inclusive a gente fez em } 2012 \text { a avaliação das nossas próprias } \\
\text { pautas com a mesma rubrica... Eu colocava isso para eles... eu não preciso estar } \\
\text { no avançado porque eu tenho uma pauta de } 4 \text { horas... uma pauta de } 4 \text { horas é } \\
\text { diferente de ter um projeto com várias aulas seguidas..., mas eu olho para a } \\
\text { rubrica e vejo, não quero estar no nível confortável... na minha pauta... será que } \\
\text { estou permitindo que as pessoas exponham as ideias, conheçam as ideias dos } \\
\text { outros? Argumentem e contraargumentem? A gente procurava... sabe essa } \\
\text { questão de dar repertorio mesmo, de modelagem... acho que no bom sentido a } \\
\text { palavra é modelagem... porque eles repetem muitas coisas que a gente faz na } \\
\text { formação. }\end{array}$ & \\
\hline $\begin{array}{l}\text { Tem coisas que você tem } \\
\text { que dar o exemplo. } \\
\text { Então, é mais ou menos } \\
\text { ou que você está me } \\
\text { falando... você pratica na } \\
\text { formação com eles, até } \\
\text { para eles apreenderem a } \\
\text { prática e poderem } \\
\text { replicar depois nas } \\
\text { escolas deles? }\end{array}$ & $\begin{array}{l}\text { Eu fico pensando assim: quando eles olham para a rubrica, todo mundo quer estar } \\
\text { no avançado. Eles se sentem envergonhados de não estarem lá no nível mais alto } \\
\text { da rubrica. Uma rubrica não é para isso: ela é para reflexão. O que é que eu estou } \\
\text { propondo? Eu cobro do meu aluno que ele seja crítico e mais uma série de coisas, } \\
\text { mas a minha proposta permite isso? Então, a rubrica tem a função de olhar } \\
\text { mesmo esses aspectos e sua viabilidade... } \\
\text { O que você está propondo? O projeto que você está propondo ao aluno permite } \\
\text { que ele chegue no nível avançado? Porque ele se ele não chegar e você também } \\
\text { não fez por onde, não permitiu, não proporcionou. Enfim, não é o seu problema, } \\
\text { mas você para para pensar na próxima vez, na próxima proposta. Eu tenho que } \\
\text { cobrar dentro daquilo que eu permito. Então, a gente se usava como próprio } \\
\text { modelo mesmo: “olha, eu olhei para minha pauta, em que momento eu pedi para } \\
\text { que vocês expusessem a primeira ideia, em que momento do encontro, eu pedi } \\
\text { para que vocês compartilhassem, que um melhorasse a ideia do outro, eu fiz a } \\
\text { síntese dessa discussão toda? Então eu queria que eles olhassem mesmo para isso, } \\
\text { para que fosse repertório mesmo e para que eles tivessem esse bom exemplo para } \\
\text { seguir lá na escola. } \\
\text { E aí isso foi assim, ao longo do ano, tinha sempre um momento em que nós } \\
\text { discutíamos a teoria do projeto. Então, assim, o que é uma boa pergunta? Como é } \\
\text { que você elabora uma boa pergunta? O que disparou esse projeto? "Fui eu que } \\
\text { tive uma ideia... ah, vou falar de sustentabilidade"... Ou... "eu olhei para o }\end{array}$ & $\begin{array}{l}\text { 1. Gestão Compartilhada da Comunicação (SOARES, 1999): } \\
\text { a. Ação comunicativa; } \\
\text { b. Apropriação e manejo das linguagens da comunicação; } \\
\text { c. Uso dos recursos da informação para a produção cultural. } \\
\text { 2. Participações de Protagonismo [Degraus de Participação: } 5 \text { a } 10 \\
\text { (HART, 1992; COSTA,2006) ]: } \\
\text { a. Participação planejadora e operacional. } \\
\text { b. Participação decisória, planejadora e operacional. } \\
\text { c. Participação decisória, planejadora, operacional e avaliadora. } \\
\text { d. Participação colaborativa plena. } \\
\text { e. Participação plenamente autônoma. } \\
\text { f. Participação condutora. } \\
\text { 3. Ações de Diálogo } \\
\text { a. Escuta mútua } \\
\text { b. Pensar juntos } \\
\text { c. Apontar outros pontos de vista } \\
\text { d. Compartilhar e refletir sobre ideias, } \\
\text { e. Fazer emergir ideias / buscar pluralidade de ideias }\end{array}$ \\
\hline
\end{tabular}




\begin{tabular}{|c|c|c|}
\hline & $\begin{array}{l}\text { entorno... Eu analisei, vi qual era a questão essencial... e discuti com o aluno qual } \\
\text { seria o produto final? Seria um produto só ou eles tinham possibilidades? Então } \\
\text { isso a gente ia discutindo ao longo do ano e depois trabalhávamos com alguma } \\
\text { outra ferramenta que pudesse ampliar. Senão todo mundo fazia Power Point. } \\
\text { Sabe assim a febre do Power Point? } \\
\text { Então, tem algumas pessoas que falam: "Não, não é para trabalhar ferramenta na } \\
\text { formação com POIE. Temos que trabalhar concepção e teoria." } \\
\text { Eu acho que as duas coisas podem caminhar juntas porque eles também têm que } \\
\text { ampliar o conhecimento. Senão todo mundo faz Power Point. } \\
\text { Então, na hora que eu expliquei o Prezi, não era o Prezi solto. É uma linguagem } \\
\text { diferente que atende a um tipo de produto final. Aí nós entramos com animação. } \\
\text { É, alguns produtos podem ser em linguagem de animação. Então eu trabalhava } \\
\text { linguagens também. }\end{array}$ & \\
\hline $\begin{array}{l}\text { Pelo que você está } \\
\text { falando, isso é } \\
\text { importante. Como é que } \\
\text { você vai apresentar e } \\
\text { trabalhar com os alunos? } \\
\text { É o que chamamos de } \\
\text { gestão da comunicação. } \\
\text { Se você tem objetivos de } \\
\text { aprendizagem que você } \\
\text { quer atingir, você tem } \\
\text { que trabalhar essa } \\
\text { comunicação para } \\
\text { conseguir que o pessoal } \\
\text { se comunique a ponto de } \\
\text { chegar até esse objetivo. } \\
\text { Pegando esse gancho, } \\
\text { como é que você vê essa } \\
\text { questão } \\
\text { comunicação? Você } \\
\text { acha que isso é algo que } \\
\text { faz sentido para você? }\end{array}$ & $\begin{array}{l}\text { Luci, quando você estava falando, a princípio, eu fiquei pensando também nessa } \\
\text { questão sobre como a gente comunica aquilo que pensa que quer, e qual a } \\
\text { proposta. E fiquei me perguntando como essa proposta chega na escola. Então, } \\
\text { nesses anos de formação eu dava formação de matemática. Âs vezes alguns } \\
\text { POIEs chegavam e falavam: "olha, eu fiz isso porque a Cris falou na formação". } \\
\text { E eu falava: "Meu deus do céu! A pessoa entendeu e....". Assim, uma coisa } \\
\text { avessa do que eu tinha falado. E chegava na escola e falava que fui eu que falei } \\
\text { na formação. Então temos que pensar bem como fazer para que a comunicação } \\
\text { fique muito clara, para que a pessoa entenda porque tem a mediação e tem o que } \\
\text { o outro entende. Então eu acho muito importante a questão da comunicação } \\
\text { porque... eu vou dar o exemplo da rubrica... para algumas pessoas, eu penso que } \\
\text { ficou claro... que é uma parada para reflexão, que não era no final do projeto, mas } \\
\text { que ela precisava ser apresentada no começo. Ao longo do tempo tem que prever } \\
\text { essas paradas para reflexão. No final, onde eles iam lá para perceber se houve } \\
\text { avanço, e algumas pessoas falavam assim: "Ahn... eu vou classificar... o menino } \\
\text { é...." Veja que não é nem o projeto, é o menino. O menino é confortável, é } \\
\text { avançado, o outro é expert. Então, assim, como é que o outro entendeu? Como foi } \\
\text { feita a comunicação, como eu comuniquei na formação e quais concepções que } \\
\text { ele tem também? }\end{array}$ & $\begin{array}{l}\text { 2. Participações de Protagonismo [Degraus de Participação: } 5 \text { a } 10 \\
\text { (HART, 1992; COSTA,2006) ]: } \\
\text { a. Participação planejadora e operacional. } \\
\text { b. Participação decisória, planejadora e operacional. } \\
\text { c. Participação decisória, planejadora, operacional e avaliadora. } \\
\text { d. Participação colaborativa plena. } \\
\text { e. Participação plenamente autônoma. } \\
\text { f. Participação condutora. } \\
\text { 3. Ações de Diálogo } \\
\text { a. Escuta mútua } \\
\text { b. Pensar juntos } \\
\text { c. Apontar outros pontos de vista } \\
\text { d. Compartilhar e refletir sobre ideias, } \\
\text { e. Fazer emergir ideias / buscar pluralidade de ideias }\end{array}$ \\
\hline
\end{tabular}




\begin{tabular}{|c|c|c|}
\hline $\begin{array}{l}\text { Totalmente porque o que } \\
\text { entendemos é a leitura } \\
\text { que temos do mundo. }\end{array}$ & $\begin{array}{l}\text { Ele é gigante mesmo. Eu vou mandar para você amanhã. Eu vou ver se eu tenho } \\
\text { salvo aqui em casa. Senão amanhã eu te mando lá da DRE, que é essa retomada } \\
\text { que nós fizemos. Demos um tratamento na informação desses momentos em que } \\
\text { o POIE se avaliou e que depois nós fizemos a avaliação e cutucamos mesmo para } \\
\text { que eles mexessem nesses projetos. Queríamos que eles olhassem. Então eu tenho } \\
\text { isso tudo registrado, eu vou mandar para você. }\end{array}$ & \\
\hline $\begin{array}{l}\text { Qual foi a rubrica com a } \\
\text { qual você começou a } \\
\text { conversar com eles e } \\
\text { qual foi o resultado final } \\
\text { dessa rubrica deles? }\end{array}$ & $\begin{array}{l}\text { A rubrica com a qual nós começamos foi a que veio da SME. Nós gestores } \\
\text { construímos lá com a mediação do Cesar. } \\
\text { E quando fizemos o POIE 2012, o Cesar não estava presente. Aí já era apenas eu } \\
\text { junto com os POIE... aí chegou um tempo... eu estou pensando aqui se foi } 2013 . . \\
\text { A gente olhou para a rubrica e falamos: "temos já uma certa autonomia para } \\
\text { mexer nela. Então não precisamos mais seguir a mesma que o restante das DRE } \\
\text { estão utilizando". Aí mexemos um pouco nela. E neste ano de } 2015 \text { já mexemos } \\
\text { de novo. Então a gente vai olhando para ela e dizendo assim: "Isso aqui é mais } \\
\text { importante e isso aqui já não tem peso pois já ultrapassamos". Trouxemos alguns } \\
\text { exemplos, o Rosemberg fez bastante rubricas com as turmas dele. Então eu } \\
\text { acabei construindo uma rubrica junto com ele. Uma rubrica de rádio para as } \\
\text { equipes da imprensa jovem, do rádio. Foi interessante porque nós fizemos com o } \\
\text { nome de videogames, os rótulos. Só podia ser adulto para fazer o que fizemos } \\
\text { porque o nível mais básico era Atari. Aí a gente disse: "mas a gente sabe o que é } \\
\text { Atari? " Pusemos Atari, ps1, ps2 e Xbox. Quando fomos trabalhar com os alunos, } \\
\text { eles disseram, não é Xbox, a gente quer PS4. Então nós temos que ter o olhar do } \\
\text { aluno porque a gente olha de um outro lugar que não é o mesmo do aluno. }\end{array}$ & \\
\hline $\begin{array}{l}\text { Eles têm as referências } \\
\text { deles e tem que validar } \\
\text { com eles. Daí a } \\
\text { importância do processo } \\
\text { de validação. }\end{array}$ & $\begin{array}{l}\text { Eu acompanhei um projeto de matemática por } 2 \text { anos com o professor Vinicius de } \\
\text { Macedo. O foco era sua cara porque eram as interações na aula de matemática, } \\
\text { como os alunos se comunicavam nas aulas de matemática. Foi bacana e eu fiz } \\
\text { uma rubrica junto com os alunos. }\end{array}$ & $\begin{array}{l}\text { Como estimular a participação a partir da rubrica, como } \\
\text { trazê-la mais para o contexto da criança? }\end{array}$ \\
\hline $\begin{array}{l}\text { Esse de matemática que } \\
\text { vê falou... a a } \\
\text { comunicação na aula de }\end{array}$ & $\begin{array}{l}\text { Esse de matemática não tinha POIE. Era com aluno de } 5^{\circ} \text { ano...não, era } 4^{\circ} \text { ano... a } \\
\text { nossa investigação era como ele se comunicava na aula de matemática... quem } \\
\text { aplicava esse projeto era o Vinício de Macedo... E trazíamos propostas. Ele }\end{array}$ & $\begin{array}{l}\text { Construindo conjuntamente. Propiciando experiências de } \\
\text { construir conjuntamente } \\
\text { 1. Gestão Compartilhada da Comunicação (SOARES, 1999): }\end{array}$ \\
\hline
\end{tabular}




\begin{tabular}{|c|c|}
\hline $\begin{array}{l}\text { matemática... esse me } \\
\text { interessou bastante. }\end{array}$ & $\begin{array}{l}\text { estava sempre trabalhando em duplas ou no grande grupo... a ideia era que eles } \\
\text { fizessem a atividade e contassem para as pessoas como é que eles pensaram... as } \\
\text { vezes contavam ali na dupla, um para o outro, o que tinha pensado e negociavam } \\
\text { e discutiam até chegar num ponto. Ou então, no final eles apresentavam para a } \\
\text { sala. Então todo mundo resolvia o mesmo problema, mas por caminhos } \\
\text { diferentes. Eles tinham que contar que caminhos eles tinham percorrido e nós } \\
\text { tínhamos uma rubrica de avaliação para essas crianças. A ideia da rubrica não foi } \\
\text { para o projeto inteiro, foi só para o Campo Limpo porque como eu já trabalhava } \\
\text { isso com POIE acabei trazendo essa pratica. Eu escrevi junto com as crianças. Na } \\
\text { verdade, praticamente fui eu que escrevi porque eles não tinham tanto repertório. } \\
\text { Falavam pouco, mas nos rótulos, eles queriam dar palpite, claro. E era a época } \\
\text { que tinha um desenho que chamava Naruto, que era a febre do momento. Eles } \\
\text { falavam assim, tudo em japonês. Eu falava: "Ahn, mas eu não sei escrever em } \\
\text { japonês... vocês vão ter que me ajudar". E eles falavam: "então a gente vai } \\
\text { traduzir para você". E eles que me ensinaram. Os níveis da rubrica eram: } \\
\text { estudante ou ajudante, aprendiz de ninja, ninja e mestre. Ninguém queria ser } \\
\text { estudante. Todo mundo queria ser ninja ou mestre. Eles falavam assim: o mestre } \\
\text { é aquele que faz a atividade, tira dúvida e vê se o colega tem dúvida. Ele ajuda". } \\
\text { Então eles terminavam a lição e falavam assim: "olá, você quer que eu te ajude? } \\
\text { Eu preciso ajudar para ser mestre". Todo mundo queria ser mestre... então todo } \\
\text { mundo queria poder ajudar, pois era o nível mais alto da rubrica, que era o que } \\
\text { eles tinham dado o nome. Todos queriam ser mestres e o nível mestre não podia } \\
\text { deixar o colega sem ajuda. Então eles saíam procurando quem eles poderiam } \\
\text { aiudar para poderem assumir o nível mestre. É bem bacana essa questão. }\end{array}$ \\
\hline & $\begin{array}{l}\text { Sobre colocar aluno e professor junto, a gestora do CEU Paraisópolis me chamou } \\
\text { porque eles têm alguns problemas de invasão da piscina. Ela queria fazer um } \\
\text { vídeo e trabalhar com as EMEFs do entorno a respeito do uso da piscina. Ela me } \\
\text { chamou para perguntar o que eu achava. Eu falei: "Olha, eu acho que não vai dar } \\
\text { em nada se vocês adultos fizerem o vídeo e forem para as outras escolas e } \\
\text { passarem tipo isso está certo e isso está errado. Por que vocês não convidam a } \\
\text { Imprensa Jovem ali do entorno para produzir o material, para que eles } \\
\text { entrevistem as pessoas, conversem, e editem o vídeo e usem nas escolas deles??" } \\
\text { Ela falou: "Nossa, não tinha pensado nisso". Então, porque é uma coisa da }\end{array}$ \\
\hline
\end{tabular}

a. Ação comunicativa;

b. Apropriação e manejo das linguagens da comunicação;

c. Uso dos recursos da informação para a produção cultural.

2. Participações de Protagonismo [Degraus de Participação: 5 a 10 (HART, 1992; COSTA, 2006) ]:

a. Participação planejadora e operacional.

b. Participação decisória, planejadora e operacional.

c. Participação decisória, planejadora, operacional e avaliadora.

d. Participação colaborativa plena.

e. Participação plenamente autônoma.

f. Participação condutora.

3. Ações de Diálogo

a. Escuta mútua

b. Pensar juntos

c. Apontar outros pontos de vista

d. Compartilhar e refletir sobre ideias,

e. Fazer emergir ideias / buscar pluralidade de ideias

Refletindo sobre os problemas do entorno. E propondo soluções educomunicativas.

Ela falou: "Nossa, não tinha pensado nisso". Então, porque é uma coisa da 


\begin{tabular}{|c|c|}
\hline & Educomunicação. \\
\hline Protagonismo & $\begin{array}{l}\text { Você sabe que eu tenho um POIE que é novo e este caso é recente. No ano } \\
\text { passado, tivemos um evento no dia do estudante na DRE. O pessoal foi na DRE, } \\
\text { foram conversar com um pessoal que mexe com hip hop, essas coisas. Um desses } \\
\text { meninos pegou o microfone para fazer uma pergunta e assim muito articulado. } \\
\text { Um menino excelente. Eu fiquei apaixonada pelo jeito que ele fez a pergunta para } \\
\text { todas as pessoas. Depois liguei para o POIE e disse: "nossa, você tem um aluno } \\
\text { que é muito bom, tal". Ele falou: "Olha, Cris, sabe, sem condição nenhuma, } \\
\text { abandonado, a escola já tinha desistido dele e aí eu peguei esse menino para a } \\
\text { Imprensa e levei. Era uma das primeiras vezes que ele saía com a gente. Foi nesse } \\
\text { evento da DRE". Eu fui conversando com ele e falei: "Vamos fazer uma coisa } \\
\text { louca? A câmara Municipal está me pedindo uma dupla de mestres de cerimônia, } \\
\text { para fazer a apresentação do prêmio Paulo Freire. Será lá na Câmara. Vamos } \\
\text { levar esse menino?" Ele falou: "Você acha? " "Eu acho"... e daí na hora, ele } \\
\text { falou assim, "eu topo". } \\
\text { Ainda a direção da escola falou: "nossa, vocês são loucos. Você tem certeza de } \\
\text { que vão levar esse garoto? " Eu falei "Gente, ele fala muito bem, ele é } \\
\text { articulado". Aí a direção também resolveu abraçar a ideia e alugaram inclusive } \\
\text { roupa para ele. Conversaram, ele foi e fez a apresentação super direitinho. E foi } \\
\text { assim: levaram um casal, ele encantou as pessoas. O meu diretor regional adora a } \\
\text { ideia de Imprensa Jovem, de mestre de cerimônia. Sempre que tem evento ele } \\
\text { pede para ter criança junto com ele. De vez em quando ele passa por mim e fala: } \\
\text { "cadê o Iuri??" Porque ele ficou famoso e era um menino que a escola já tinha } \\
\text { desistido dele, a amília já tinha desistido, mas o menino está lá. Ele gravou um } \\
\text { vídeo falando da experiência dele como mestre de cerimônia e do projeto do } \\
\text { Wiliam lá na escola. }\end{array}$ \\
\hline
\end{tabular}




\section{Anexo G.2: Entrevista POIE Douglas Tomé}

\begin{tabular}{|c|c|}
\hline $\begin{array}{l}\text { ENTREVISTA } \\
\text { DOUGLAS }\end{array}$ & INDICADORES \\
\hline $\begin{array}{l}\text { Quase que o segundo semestre inteiro, propomos o tema sustentabilidade, era algo que uma professora já } \\
\text { vinha desenvolvendo com os alunos, mas sem ligação com a informática } \\
\text { Aí eu falei assim poxa vida, vamos desenvolver, vamos aproveitar e desenvolver o projeto com essa turma } \\
\text { Na realidade, eu tento quando eu monto um projeto eu tento aplicar com várias turmas e anos diferentes. } \\
\text { Alguns com mais aprofundamentos e outros com um pouco menos. }\end{array}$ & Tema escolhido \\
\hline $\begin{array}{l}\text { Mas esse projeto especificamente foi trabalhado com os } 5^{\circ} \text { anos, com os alunos do } 5^{\circ} \text { da turma da manhã e } \\
\text { outra do período da tarde. } \\
\text { Algo em torno de } 80 \text { alunos amis ou menos }\end{array}$ & Perfil dos alunos \\
\hline $\begin{array}{l}\text { A proposta era discutir realmente o tema sustentabilidade, como olhar diferente, não para um espaço grande, } \\
\text { mas para um espaço menor, muitas vezes dentro da nossa sala de aula, dentro do quadrado aonde eu estou } \\
\text { sentado. } \\
\text { Não pensar em sustentabilidade em mudar o muno, mas pensa-la no meu quadradinho para tentar melhorar } \\
\text { esse ambiente e aí sim crescendo e mudando essa consciência de uma pessoa que se preocupa com a } \\
\text { sustentabilidade }\end{array}$ & $\begin{array}{l}\text { O Tema } \\
\text { Percebemos que há a preocupação do professor em trazer } \\
\text { o tema para algo que tenha a ver com o contexto dos } \\
\text { alunos, de forma que eles se engajem no projeto. }\end{array}$ \\
\hline $\begin{array}{l}\text { Essa turma que a gente trabalhou pensando quando você fala no perfil, eram os alunos do } 5^{\circ} \text { ano, alunos com } \\
12 \text { anos de idade na maioria, de um bairro pobre da zona sul de SP, onde vemos que faltam muitas coisas. } \\
\text { Infraestrutura muito precária no bairro e tivemos essa preocupação de tentar mudar o pedacinho, como falei }\end{array}$ & Perfil dos alunos \\
\hline $\begin{array}{l}\text { Vamos mudar o ambiente em que eu vivo, um pequeno ambiente, para depois nos preocuparmos com cidade, } \\
\text { se preocupar com pais, se preocupar como planeta terra... a preocupação basicamente era essa pequenininha }\end{array}$ & $\begin{array}{l}\text { O Tema } \\
\text { Percebemos que há a preocupação do professor em trazer } \\
\text { o tema para algo que tenha a ver com o contexto dos } \\
\text { alunos, de forma que eles se engajem no projeto. }\end{array}$ \\
\hline $\begin{array}{l}\text { O perfil dos alunos tinha essa cara, essa cara de alunos da escola da prefeitura, com } 12 \text { anos de idade... } \\
\text { quando você me pergunta se foi só o aluno monitor, foi desenvolvido com a turma inteira... }\end{array}$ & $\begin{array}{l}\text { O Tema } \\
\text { Percebemos que há a preocupação do professor em trazer } \\
\text { o tema para algo que tenha a ver com o contexto dos } \\
\text { alunos, de forma que eles se engajem no projeto. }\end{array}$ \\
\hline $\begin{array}{l}\text { O projeto eu penso numa turma, de um determinado ano, mas acabo aplicando nos anos seguintes também } \\
\text { então eu quando faço um projeto é para todos participarem. }\end{array}$ & $\begin{array}{l}\text { O Tema } \\
\text { Percebemos que há a preocupação do professor em trazer } \\
\text { o tema para algo que tenha a ver com o contexto dos }\end{array}$ \\
\hline
\end{tabular}




\begin{tabular}{|c|c|}
\hline & alunos, de forma que eles se engajem no projeto. \\
\hline $\begin{array}{l}\text { Esse da sustentabilidade foi isso... colocamos para os alunos o problema... e foi convidado que todos } \\
\text { participassem } \\
\text { É logico alguns se empenham mais no desenvolvimento do projeto e outros as vezes tem mais dificuldade de } \\
\text { se colocar. }\end{array}$ & $\begin{array}{l}\text { Indicador 1 - Gestão compartilhada da comunicação, com } \\
\text { mediação tecnológica } \\
\text { Indicador 2: Tipos de Participação - detalha como } \\
\text { construir e fortalecer ações protagonistas, como indicado } \\
\text { por Hart (1992) e Costa (2006) } \\
\text { Indicador 4 / Relações entre participante }\end{array}$ \\
\hline $\begin{array}{l}\text { O gostoso do TQ era que quando acontecia a publicação e a gente lançava as perguntas, o aluno ainda não } \\
\text { estava influenciado pela resposta do colega... então ele colocava a opinião dele... então em vários momentos... } \\
\text { a gente vê a primeira contribuição que o aluno deu... quando colocamos o primeiro contato e eu coloco aquela } \\
\text { imagem de suste e ainda questiono o que significa sustentabilidade para ele, ele vai apresentar uma resposta } \\
\text { sem ter a influência externa e a rede ou a influência da resposta do colega... ele vai colocar o que ele acha que } \\
\text { significa sustentabilidade... vemos várias respostas interessantes... quando coloquei essa pergunta... em vários } \\
\text { momentos você vê que a preocupação dos alunos que se colocam falando de sustentabilidade, e cuidar da } \\
\text { natureza, é viver num mundo melhor, é viver sem modifica a natureza e aí as colocações meio que vão } \\
\text { seguindo nesse passo... }\end{array}$ & $\begin{array}{l}\text { Plataforma permitia que as trocas reflexivas no presencial } \\
\text { fossem registradas em sua maioria. Esses registros nos } \\
\text { mostram parte da riqueza dessas trocas. } \\
\text { 1. Gestão Compartilhada da Comunicação: a. Ação } \\
\text { comunicativa; b. Apropriação e manejo das linguagens da } \\
\text { comunicação; c. Uso dos recursos da informação para a } \\
\text { produção cultural. } \\
\text { 2. Participações de Protagonismo: a. Participação planejadora e } \\
\text { operacional; b. Participação decisória, planejadora e operacional; } \\
\text { c. Participação decisória, planejadora, operacional e avaliadora; } \\
\text { d. Participação colaborativa plena; e. Participação plenamente } \\
\text { autônoma; f. Participação condutora. } \\
\text { 3. Ações de Diálogo: a. Escuta mútua; b. Pensar juntos; c. } \\
\text { Apontar outros pontos de vista; d. Compartilhar e refletir } \\
\text { sobre ideias; e. Fazer emergir ideias / buscar pluralidade } \\
\text { de ideias } \\
\text { 4. Relações entre as pessoas nos ambientes do LIE, para } \\
\text { criação de um novo ecossistema comunicativo. }\end{array}$ \\
\hline $\begin{array}{l}\text { Mas mesmo assim tiveram alunos que acabaram deixando para responder depois e quando eles pegam e } \\
\text { deixam para responder depois, eles pesquisam o tema e colocam uma resposta mais didática, para aquilo que } \\
\text { eu estava questionando no inicio } \\
\text { Ai você viu que depois que a gente questionou o que era sustentabilidade...eu perguntei para que os alunos } \\
\text { retomassem a resposta que o colega tinha dado... essa é uma pratica que tenho, de tentar fazer o aluno sempre } \\
\text { ler as contribuições dos colegas, promover uma melhoria de ideias...a partir da ideia que eu tinha e da } \\
\text { contribuição que o colega deu, eu peço para que ele leia e tente as vezes reformular a sua respostas } \\
\text { melhorando a sua resposta ou eu peço para que ele destaque } 1 \text { [a como eu fiz na atividade do projeto, } \\
\text { perguntando se era muito importante ou se era importante, mas justificar. }\end{array}$ & $\begin{array}{l}\text { 1. Gestão Compartilhada da Comunicação: a. Ação } \\
\text { comunicativa; b. Apropriação e manejo das linguagens da } \\
\text { comunicação; c. Uso dos recursos da informação para a } \\
\text { produção cultural. } \\
\text { 2. Participações de Protagonismo: a. Participação planejadora e } \\
\text { operacional; b. Participação decisória, planejadora e operacional; } \\
\text { c. Participação decisória, planejadora, operacional e avaliadora; } \\
\text { d. Participação colaborativa plena; e. Participação plenamente } \\
\text { autônoma; f. Participação condutora. } \\
\text { 3. Ações de Diálogo: a. Escuta mútua; b. Pensar juntos; c. }\end{array}$ \\
\hline
\end{tabular}




\begin{tabular}{|c|c|}
\hline & $\begin{array}{l}\text { Apontar outros pontos de vista; d. Compartilhar e refletir sobre } \\
\text { ideias; e. Fazer emergir ideias / buscar pluralidade de ideias } \\
\text { 4. Relações entre as pessoas nos ambientes do LIE, para criação } \\
\text { de um novo ecossistema comunicativo. }\end{array}$ \\
\hline $\begin{array}{l}\text { Eu gostava muito dessa ferramenta do TQ que você escolhia marcar as opções, mas quando você escolhia } \\
\text { uma das opções, mas ela só registrava se você justificasse sua resposta...e isso é interessante o aluno tentava } \\
\text { se colocar da melhor maneira possível fazer uma avaliação desse primeiro momento de um jeito legal... } \\
\text { depois desses momentos a gente começa a mostrar para eles, apresentamos o projeto, apresentamos vídeo que } \\
\text { falava sobre sustentabilidade, criamos uma interação com os alunos de qual vídeo ele teve preferência... mas } \\
\text { aquela velha história... ele clica e justifica... o porquê... na turma que discute essa primeira parte, se você } \\
\text { olhar, a gente teve algo em torno de umas } 60 \text { contribuições nesse primeiro momento... são } 60 \text { contribuição de } \\
\text { alunos de uma mesma turma, vemos que eles acabam participando quando colocamos um tema e eles se } \\
\text { envolvem com esse tema. }\end{array}$ & $\begin{array}{l}\text { 1. Gestão Compartilhada da Comunicação: a. Ação } \\
\text { comunicativa; b. Apropriação e manejo das linguagens da } \\
\text { comunicação; c. Uso dos recursos da informação para a } \\
\text { produção cultural. } \\
\text { 4. Relações entre as pessoas nos ambientes do LIE, para criação } \\
\text { de um novo ecossistema comunicativo. }\end{array}$ \\
\hline $\begin{array}{l}\text { E eles gostaram porque eles acabaram por se envolver bastante com isso... assim a nossa intenção é logico } \\
\text { que seria mudar o mundo, mas como não é possível, a gente queira que pelo menos tivesse pelo uma } \\
\text { intervenção dentro ou nos arredores da escola... o projeto acabou não finalizando porque esse momento não } \\
\text { aconteceu... nós tivemos momento de pensar no que poderia ser feito para melhorar a escola... tinha até um } \\
\text { questionamento: por que eu quero uma escola melhor? O que precisa ser melhorado dentro da escola ... então } \\
\text { teve isso, mas depois acabamos não dando continuidade a essa parte }\end{array}$ & $\begin{array}{l}\text { A importância de o tema ser trabalhado em um contexto } \\
\text { que tenha correlação com os alunos e em um processo que } \\
\text { os envolva também, de forma ativa e com gestão } \\
\text { compartilhada. } \\
\text { 1. Gestão Compartilhada da Comunicação: a. Ação } \\
\text { comunicativa; b. Apropriação e manejo das linguagens da } \\
\text { comunicação; c. Uso dos recursos da informação para a } \\
\text { produção cultural. } \\
\text { 4. Relações entre as pessoas nos ambientes do LIE, para criação } \\
\text { de um novo ecossistema comunicativo. }\end{array}$ \\
\hline $\begin{array}{l}\text { Quando questionamos o melhor da escola, também questionamos o que precisaria melhorar no bairro... então } \\
\text { são coisas que vínhamos ... assim plantando uma semente dentro de cada um...s e a gente não conseguiu ter } \\
\text { um trabalho finalizado de um produto final, com certeza nós tivemos sementes plantadas na cabeça de cada } \\
\text { um...esse semente esperamos que tenha sustido efeito, numa preocupação maior com o futuro... tanto que no } \\
2^{\circ} \text { momento, a gente lança o desafio do trabalho deles, do pensar sustentabilidade fora da escola, o que ele } \\
\text { poderia fazer na casa dele para melhorar, foi feito pesquisa, publicamos imagens, no final foi solicitado até } \\
\text { que escrevessem um pequeno texto...que não foi um produto final... a gente tinha intenção que fosse algo } \\
\text { mais, mas que falasse sobre sustentabilidade...então a gente acredita que parte do objetivo do projeto foi } \\
\text { atingido... }\end{array}$ & $\begin{array}{l}\text { A importância de o tema ser trabalhado em um contexto } \\
\text { que tenha correlação com os alunos e em um processo que } \\
\text { os envolva também, de forma ativa e com gestão } \\
\text { compartilhada. } \\
\text { 1. Gestão Compartilhada da Comunicação: a. Ação } \\
\text { comunicativa; b. Apropriação e manejo das linguagens da } \\
\text { comunicação; c. Uso dos recursos da informação para a } \\
\text { produção cultural. } \\
\text { 4. Relações entre as pessoas nos ambientes do LIE, para criação } \\
\text { de um novo ecossistema comunicativo. }\end{array}$ \\
\hline $\begin{array}{l}\text { É que professor tem expectativa grande, grandes sonhos, vejo que parte daquilo que foi proposto no início, a } \\
\text { gente conseguiu atingir... }\end{array}$ & \\
\hline
\end{tabular}


Para falar rubrica, hoje para mim ainda é muito difícil

Em 2012 era mais difícil ainda... eu ainda estava e estou aprendendo a trabalhar com rubricas... quando pensamos no projeto, a rubrica foi bem simples...e foi conversado um pouco na formação de POIE, onde a Cristina veio falando disso para todos... eu conhecia um pouco antes porque em 2008 quando comecei a trabalhar com o TQ... logo em seguida teve um curso de formação com o Cesar... na formação que antecedeu um encontro de formação presencial... foi a primeira vez que ouvi falar sobre rubricas. E quando fizemos essa formação na DRE campo limpo, com a presença do Cesar, apresentando o TQ, a Cris começou a ter contato com a rubrica... foi quando depois de um tempo o Cesar foi para a prefeitura como assessor e rubrica começou a pegar em toda rede municipal
A dificuldade do processo reflexivo da rubrica Seu entendimento demanda tempo, pois são relações e reflexões.

1. Gestão Compartilhada da Comunicação: a. Ação comunicativa; b. Apropriação e manejo das linguagens da comunicação; c. Uso dos recursos da informação para a produção cultural

2. Participações de Protagonismo: a. Participação planejadora e operacional; b. Participação decisória, planejadora e operacional; c. Participação decisória, planejadora, operacional e avaliadora d. Participação colaborativa plena; e. Participação plenamente autônoma; f. Participação condutora.

3. Ações de Diálogo: a. Escuta mútua; b. Pensar juntos; c. Apontar outros pontos de vista; d. Compartilhar e refletir sobre ideias; e. Fazer emergir ideias / buscar pluralidade de ideias

4. Relações entre as pessoas nos ambientes do LIE, para criação de um novo ecossistema comunicativo.

Mas o Cesar e a Cris já comentavam com o pessoal da DRE Campo limpo... então a rubrica desse projeto, foi criada e meio que em conjunto, com a participação do pessoal da DRE, com outro POIE da escola e comigo... era uma coisa bem simples... criamos uma rubrica pensando em avaliar o processo, mas utilizando só em um momento... uma coisa bem simples...

E até meio engraçado falarmos que é uma rubrica...foi no final da primeira parte do trabalho onde o aluno deveria avaliar o que ele tinha aprendido até o momento. E aí definimos isso e m 4 cores azul amarelo vermelho e preto... o azul falava que ele tinha aprendido muito sobre o tema e o preto, ele não tinha aprendido nada... s duas do meio falavam de etapas intermediarias, mas os alunos só ficaram sabendo da rubrica, na hora de utilizá-las... não foi um processo de construção com eles

Hoje a gente vê que é possível e viável que essa construção da rubrica seja feita de forma compartilhada com os professores envolvidos e com os alunos e que seja utilizada durante todo o processo

A grande dificuldade ainda de trabalhar com rubricas é tentar adequar cada nível ao projeto que você está fazendo... eu tenho tentado montar algumas rubricas que independente do projeto que está sendo desenvolvido, ela sirva, mas não é uma tarefa fácil...e assim, como alei, já tem um certo tempo que trabalho com as rubricas, não do jeito que eu gostaria, gostaria que fosse mais dentro do meu trabalho no dia a dia, mas é algo que eu venho tentando construir... acho que o grande desafio é esse... colocar essa rubrica dentro do meu dia a dia de verdade, que os alunos no início possam construir junto comigo e utilizar durante todo o
Como é o processo reflexivo da rubrica? Ele envolve todos. Daí a necessidade de muar as relações. E podemos usar as rubricas para estimular essa reflexão para a mudança.

1. Gestão Compartilhada da Comunicação: a. Ação comunicativa; b. Apropriação e manejo das linguagens da 
processo da atividade desenvolvida... já pensando no registro do trabalho desenvolvido, do AVA, o registro aconteceu dentro do TQ... a gente tinha na época já utilizava bastante o ambiente... toda a orientação, as contribuições, as colocações dos alunos, as minhas retomadas, de forma de registro ou na própria aula, abríamos as publicações dos alunos e fazer os comentários, ele ficou focado todo dentro do TQ... então o aluno podia retomar que ele deu e ver as respostas do colega, podia melhorar a resposta que o colega deu... isso era um processo de avaliação que nós fazíamos dentro do ambiente TQ... era um ambiente gostoso... a molecada gostava de trabalhar... eu especialmente fiquei muito triste quando fui informado que a plataforma sairia do ar... e quando ela saiu do ar nos tivemos uma preocupação grande... e agora o TQ saiu, onde vamos registrar... e depois de um certo estudo, tivemos uma reunião na DRE CL e nesse reunião foi apresentado o EdModo... ele não tem a mesma facilidade que tinha o TQ, em organizar e publicar, mas foi o ambiente que acabei utilizando para substitui-lo

Hoje eu consigo apresentar a s atividades para os alunos também dentro desse ambiente... então toda a organização acontece dentro do EdModo... o aluno quando chega para meu aluno, ele sabe que para saber o que precisa fazer de novo ou em que etapa do processo ele está, ele acessa o EdModo ou seja, não preciso falar o que é necessário... ele acessa...c ada turma, sala de aula virtual, eu tenho a sala de aula virtual, desde $3^{\circ}$ ano $\mathrm{A}$, dos pequenininhos, até os alunos dos 9 os anos... do $4^{\circ}, 5^{\circ}, 6^{\circ}, 7^{\circ}, 8^{\circ}$ e $9^{\circ}$ anos... a gente utiliza esse ambiente para deixar registrada as atividades... muitas vezes um projeto é desenvolvido com todas as turmas... e as vezes o projeto são determinados.

Então o AVA escolhido hoje, que me ajuda nas minhas aulas é o EdModo... só que dentro do EdModo a gente acaba os alunos a acessar outros ambientes... um deles, por exemplo é o Khan Academy,... que é um ambiente que fala de matemática e onde eu consigo acompanhar o desenvolvimento de cada um, as relações que foram feitas, estamos conseguindo algumas parcerias com a professora de matemática da escola, tanto eu quanto o outro POIE, já falamos até com a Cris para oferecermos uma formação sobre o Khan Academy, para todos os professores

E um ambiente que eu também curto bastante nas minhas aulas do ensino médio, na escola particular eu utilizo Khan semanalmente... tenho aula semanal que vamos ao laboratório de informática e cada um segue comunicação; c. Uso dos recursos da informação para a produção cultural.

2. Participações de Protagonismo: a. Participação planejadora operacional; b. Participação decisória, planejadora e operacional; c. Participação decisória, planejadora, operacional e avaliadora d. Participação colaborativa plena; e. Participação plenamente autônoma; f. Participação condutora.

3. Ações de Diálogo: a. Escuta mútua; b. Pensar juntos; c. Apontar outros pontos de vista; d. Compartilhar e refletir sobre ideias; e. Fazer emergir ideias / buscar pluralidade de ideias

4. Relações entre as pessoas nos ambientes do LIE, para criação de um novo ecossistema comunicativo.

1. Gestão Compartilhada da Comunicação: a. Ação comunicativa; b. Apropriação e manejo das linguagens da comunicação; c. Uso dos recursos da informação para a produção cultural.

2. Participações de Protagonismo: a. Participação planejadora operacional; b. Participação decisória, planejadora e operacional c. Participação decisória, planejadora, operacional e avaliadora d. Participação colaborativa plena; e. Participação plenamente autônoma; f. Participação condutora.

3. Ações de Diálogo: a. Escuta mútua; b. Pensar juntos; c. Apontar outros pontos de vista; d. Compartilhar e refletir sobre ideias; e. Fazer emergir ideias / buscar pluralidade de ideias

4. Relações entre as pessoas nos ambientes do LIE, para criação de um novo ecossistema comunicativo.

1. Gestão Compartilhada da Comunicação: a. Ação comunicativa; b. Apropriação e manejo das linguagens da comunicação; c. Uso dos recursos da informação para a produção cultural. 
seu roteiro de atividade... dentro desse roteiro eu procuro colocar um momento que seja relacionado com as aulas que tivemos na sala, mas eles acabam seguindo caminhos diferentes e abre discussão... as vezes os alunos estão muito mais envolvidos quando estão utilizando esse ambiente do que quando estão na própria aula... acabam perguntando mais... é legal porque eu tiro o foco do professor,... o foco é a máquina... vai, faz a atividade, assiste a videoaula, e depois ele quando precisa muito, que não está conseguindo andar, ele me chama... eu deixo de ser o centro e passo a ser um mediador ou orientador do processo de aprendizagem de matemática... mas isso é na escola particular ... na prefeitura também faço mas como é uma aula semanal e a aula não está focada na matemática, eles acabam por explorar e aprender a utilizar o ambiente.

Nas formações de POIE, qualquer que seja, sempre tem uma rubrica envolvida. Na realidade, nós da DRE Campo Limpo, nós utilizamos uma rubrica que é meio que padrão para todas as atividades que são feitas desenvolvidas, mas ela é retomada a cada formação nossa.

Temos formações bimestrais e as formações bimestrais nos utilizamos a rubrica como base para realizar a autoavaliação... por exemplo, a nossa última formação a Cris propôs a criação de alguns jogos e cada um utilizou um ambiente diferente para montar jogos... teve grupo que utilizou o hot potatoes, o meu grupo por exemplo utilizou o power point fazendo hiperlinks para criar jogos para crianças e ai no final da história autoavaliação foi através de rubrica... ela vem sendo incorporada por nos professores... às vezes com mais intensidade, às vezes com menos intensidade... mas a gente procura estar sempre ligado à rubrica... os POIE sabem o que é uma rubrica...não sei se utilizam... eu tento utilizar um pouco, mas não sei sobre as práticas dos meus colegas... até agora estamos fazendo um curso oferecido pela prefeitura e uma das etapas desse curso é a criação de uma rubrica de avaliação

Então quer dizer é algo que já temos contato, mas é algo novo... ainda temos bastante coisa para aprendermos sobre avaliação por rubrica

E toda vez que tenho possibilidade de formação que esteja dando procuro também inserir uma rubrica para que as pessoas tenham contato... vejo que a maioria dos professores não sabem o que é isso, eles têm uma ideia totalmente diferente... quando falamos em rubrica, eles imaginam um visto de assinatura... que é outro significado da palavra rubrica...

Então a gente conta um pouco o que é mostra exemplos, mas também ainda não consegui fazer com que o professor montasse uma rubrica... já tentei fazer conversar na escola da prefeitura de sentarmos juntos e montar mas esse espaço ainda não conquistei... mas também não desisti... é outro desafio que foi citado ali comunicação; c. Uso dos recursos da informação para a produção cultural.

2. Participações de Protagonismo: a. Participação operacional; b Participação planejadora e operacional; c. Participação decisória planejadora e operacional; d. Participação decisória, planejadora, operacional e avaliadora; e. Participação colaborativa plena; $f$ Participação plenamente autônoma; g. Participação condutora.

3. Ações de Diálogo: a. Escuta mútua; b. Pensar juntos; c. Apontar outros pontos de vista; d. Compartilhar e refletir sobre ideias; e. Fazer emergir ideias / buscar pluralidade de ideias

4. Relações entre as pessoas nos ambientes do LIE, para criação de um novo ecossistema comunicativo.

Os professores refletindo e revendo sempre as práticas e as relações.

1. Gestão Compartilhada da Comunicação: a. Ação comunicativa; b. Apropriação e manejo das linguagens da comunicação; c. Uso dos recursos da informação para a produção cultural.

2. Participações de Protagonismo: a. Participação operacional; b Participação planejadora e operacional; c. Participação decisória planejadora e operacional; d. Participação decisória, planejadora, operacional e avaliadora; e. Participação colaborativa plena; $f$. Participação plenamente autônoma; g. Participação condutora.

3. Ações de Diálogo: a. Escuta mútua; b. Pensar juntos; c. Apontar outros pontos de vista; d. Compartilhar e refletir sobre ideias; e. Fazer emergir ideias / buscar pluralidade de ideias

4. Relações entre as pessoas nos ambientes do LIE, para criação de um novo ecossistema comunicativo. 
acima... é um outro desafio que eu tenho vontade de tentar desenvolver... quando você fala em maior ganho, eu acho que o maior ganho é você poder ser sincero na sua avaliação você conseguir observar o nível que está e procurar melhorar, porque ele te mostra qual o caminho a seguir para você mudar o seu nível... eu acho que isso é interessante e mesmo que assim a pessoa não se avalie exatamente no nível que está, internamente ele sabe qual os eu nível e ele sabe o que precisa ser feito para melhorar... uma coisa também que fazemos nas formações de POIE é que não serve só para avaliar a gente, não

A gente avalia o trabalho do grupo, nessa formação de jogos... avaliamos o nosso trabalho, mas avaliamos o trabalho de cada um que apresentou lá o seu jogo, seu projeto trabalho desenvolvido... isso é sempre que acontece em todas as formações tem momentos da avaliação nossa, individual, do nosso próprio trabalho, e tem momento de avaliarmos o trabalho do colega

É logico que alguns, às vezes, vão mais pela amizade... sou amigo de fulano e não quero falar ... e acabam dando uma autoavaliação não muito apurada... isso ocorre, demonstra falta de maturidade, mas já avançamos muito

Eu vejo que o pessoal está pegando firme na hora de usar a rubrica para avaliar o seu trabalho e dos colegas. 


\section{Anexo G.3: Entrevista POIE Gislaine Munhoz}

\begin{tabular}{|c|c|c|}
\hline PERGUNTAS & $\begin{array}{c}\text { ENTREVISTA } \\
\text { GISLAINE }\end{array}$ & OBSERVAÇÃO \\
\hline $\begin{array}{l}\text { (01) qual foi a duração } \\
\text { do projeto (aulas e } \\
\text { meses)? } \\
\text { Luci: quando você fala } 4 \\
\text { a } 6 \text { aula semanais por } \\
\text { semestre? Por semana? }\end{array}$ & $\begin{array}{l}\text { Começou em } 2012 \text { mais ou menos com 4aulas semanais... } 4 \text { a } 6 \text { aulas } \\
\text { semanais... e foi até } 2014 \ldots \text { fim de } 2014 \ldots \text { e agora ele acontece de forma bem } \\
\text { esporádica } \\
\text { Por semana mesmo... que eram os momentos em que eu tinha os alunos } \\
\text { monitores... que trabalhavam comigo } \\
\text { Gislaine: isso... ele entrava no processo... o mais velho passava para o mais } \\
\text { novo. }\end{array}$ & Dados do projeto / atividades desenvolvidas no LIE. \\
\hline $\begin{array}{l}\text { Então quem fazia esse } \\
\text { processo de passagem de } \\
\text { bastão não era você } \\
\text { enquanto POIE? Sempre } \\
\text { o aluno mais velho que } \\
\text { ensinava o outro aluno? } \\
\text { Sempre foi assim? }\end{array}$ & $\begin{array}{l}\text { Não ... não era eu... sempre o aluno mais velho... sempre foi assim... um aluno } \\
\text { mais avançado que passava para o outro... o que eu mediava era o processo de } \\
\text { conversar... então organizava os momentos de sentar, conversar e definir o que ia } \\
\text { ser feito, para que eles pudessem falar o que iria ser feito, o que não iria ser } \\
\text { feito... chegava com algumas diretrizes e abria espaço para eles conversarem... } \\
\text { foi daí que surgiu o projeto, na verdade... }\end{array}$ & $\begin{array}{l}\text { Aqui já temos um aspecto diferenciado, no que se refere até à } \\
\text { passagem de orientação para os novos alunos monitores, que estão } \\
\text { chegando: era de responsabilidade dos próprios alunos. Então ali já } \\
\text { inicia a apropriação do processo de aprendizagem. Identificamos todos } \\
\text { os indicadores destacados. } \\
\text { 1. Gestão Compartilhada da Comunicação: a. Ação comunicativa; b. } \\
\text { Apropriação e manejo das linguagens da comunicação; c. Uso dos } \\
\text { recursos da informação para a produção cultural. } \\
\text { 2. Participaçães de Protagonismo: a. Participação planejadora e } \\
\text { operacional; b. Participação decisória, planejadora e operacional; c. } \\
\text { Participação decisória, planejadora, operacional e avaliadora; d. } \\
\text { Participação colaborativa plena; e. Participação plenamente autônoma; } \\
\text { f. Participação condutora. } \\
\text { 3. Ações de Diálogo: a. Escuta mútua; b. Pensar juntos; c. Apontar } \\
\text { outros pontos de vista; d. Compartilhar e refletir sobre ideias; e. Fazer } \\
\text { emergir ideias / buscar pluralidade de ideias } \\
\text { 4. Relações entre as pessoas nos ambientes do LIE, para criação de um } \\
\text { novo ecossistema comunicativo. }\end{array}$ \\
\hline $\begin{array}{l}\text { Me conta um pouquinho } \\
\text { desse processo, quem } \\
\text { deu ideia, quem iniciou, }\end{array}$ & $\begin{array}{l}\text { na verdade esse processo começou em } 2011 \text {, dos alunos virem para a monitoria } \\
\text { para ficar no Facebook ... eles queriam muito ficar no Facebook porque no } \\
\text { Facebook tinham os joguinhos... era por isso que eles gostavam de ficar no }\end{array}$ & $\begin{array}{l}\text { Vemos que o projeto nasce de uma situação que não parecia ideal, mas } \\
\text { a POIE soube administrar, no sentido de trazer os jovens para a } \\
\text { reflexão, de forma propositiva e instigadora. Ela propôs uma atividade } \\
\text { desafiadora, mas antes procurou entender a razão deles gostarem tanto }\end{array}$ \\
\hline
\end{tabular}




\begin{tabular}{|c|c|}
\hline como iniciou... & $\begin{array}{l}\text { programa aluno monitor... isso começou a me incomodar porque começou aquela } \\
\text { relação de cobrança... normalmente eles iam para a monitoria muito empenhados } \\
\text { em ajudar os colegas... ou para fazer os projetos aqui da secretaria... e ai nesse } \\
\text { ano, alunos que eu considerava bons, começaram a ficar no Facebook.. E aí eu } \\
\text { pensei... bom, ficar brigando com eles - até porque tinham alguns joguinhos que } \\
\text { pareciam bem interessantes... e o projeto da escola em paralelo já era de estar } \\
\text { ensinando jogos na sala de aula... então seria incoerente da minha parte proibir o } \\
\text { jogo..., mas estava me incomodando eles fazerem isso sem um contexto de } \\
\text { aprendizagem... então deixe-me contar um pouco o que foi... } \\
\text { Então eu chamei esses alunos, perguntei o que esses jogos tinham de bom, o que } \\
\text { eles aprendiam com esses jogos...tudo... eles não tinham muita clareza mas } \\
\text { tentaram apontar algumas coisas, né! E paralelamente a isso algumas professoras } \\
\text { do } 1^{\circ} \text { ano, que já tinham incorporado essa questão de usar os joguinhos na sala } \\
\text { de aula... jogo didáticos... jogos educativos... elas começavam a pedir jogos que } \\
\text { tivessem o perfil da sala... jogos que tivessem o perfil que elas estivessem } \\
\text { trabalhando... na época era assim... lista de frutas, lista de animais... }\end{array}$ \\
\hline $\begin{array}{l}\text { (02) qual o perfil dos } \\
\text { alunos } \\
\text { participantes? } \\
\text { Luci: então, ele pegava o } \\
\text { projeto andando... e aí } \\
\text { ele entrava no processo }\end{array}$ & $\begin{array}{l}\text { Dos alunos que faziam os jogos eram alunos de } 8^{\text {a }} 16 \text { anos... que ficavam no } \\
\text { contra-turno da escola e perfil de aprendizagem... e perfil de aprendizagem era } \\
\text { variado... tinha alunos assim, bem dedicados... muitas vezes, que não eram muito } \\
\text { valorizados... na sala, por serem dedicados... e alunos medianos }\end{array}$ \\
\hline $\begin{array}{l}\text { (03) só aluno monitor ou } \\
\text { demais alunos, das } \\
\text { turmas que você } \\
\text { atendia? }\end{array}$ & $\begin{array}{l}\text { Não... aí os alunos monitores construíam os jogos, que eram esses que eu estou } \\
\text { dizendo que eram mais direcionados... e esses jogos eram usados com as crianças } \\
\text { do primeiro ano... }\end{array}$ \\
\hline $\begin{array}{l}\text { Então aí você já começa } \\
\text { um contexto mais } \\
\text { interdisciplinar }\end{array}$ & $\begin{array}{l}\text { ai conversei com essas professoras... só que a gente não tinha esse... porque era } \\
\text { assim ... muitos professores, eles tem a ideia de que tem tudo na internet... e eu } \\
\text { falei da dificuldade de não ter jogos específicos dessa forma, mas que tinham } \\
\text { alguns programinhas com os quais nós poderíamos construir... não jogos mas } \\
\text { talvez atividades online... e aí surgiu o "start" de perguntar para esses alunos se } \\
\text { eles não queriam construir esses jogos já que eu não teria tempo... e ai eu } \\
\text { conversei com as professoras e perguntei... se a gente montar algumas atividades } \\
\text { com os alunos, alguns joguinhos com os alunos, vocês usariam na aula? Aí elas } \\
\text { foram superabertas e aí eu perguntei para eles se eles não fariam isso... } \\
\text { E apresentei uma ferramenta que chama Hot Potato... e eles construíram porque }\end{array}$ \\
\hline
\end{tabular}

de jogo e buscou o lado positivo desse contexto. Passível de utilizar todos os indicadores aqui listados:

1. Gestão Compartilhada da Comunicação: a. Ação comunicativa; b. Apropriação e manejo das linguagens da comunicação; c. Uso dos recursos da informação para a produção cultural.

2. Participações de Protagonismo: a. Participação planejadora e operacional; b. Participação decisória, planejadora e operacional; c. Participação decisória, planejadora, operacional e avaliadora; d. Participação colaborativa plena; e. Participação plenamente autônoma; f. Participação condutora.

3. Ações de Diálogo: a. Escuta mútua; b. Pensar juntos; c. Apontar outros pontos de vista; d. Compartilhar e refletir sobre ideias; e. Fazer emergir ideias / buscar pluralidade de ideias

4. Relações entre as pessoas nos ambientes do LIE, para criação de um novo ecossistema comunicativo.

Perfil do aluno

\section{Perfil do aluno}

POIE procura envolver os alunos em todas as tomadas de decisão e reflexão, inclusive na verificação sobre a necessidade dos professores do ciclo de alfabetização.

1. Gestão Compartilhada da Comunicação: a. Ação comunicativa; b. Apropriação e manejo das linguagens da comunicação; c. Uso dos recursos da informação para a produção cultural.

2. Participações de Protagonismo: a. Participação planejadora e operacional; b. Participação decisória, planejadora e operacional; c. Participação decisória, planejadora, operacional e avaliadora; d. 


\begin{tabular}{|c|c|c|}
\hline & $\begin{array}{l}\text { ela é muito intuitiva, não é muito difícil... e aí eles montaram ... e apresentei uma } \\
\text { outra, chamada J Click... e aí a maneira que a gente apresenta é sempre da } \\
\text { maneira que a gente faz... então eu quis apresentar alguns tutoriais, alguma coisa } \\
\text { nessa linha e eles não gostaram de aprender por tutorial... e pediram para ir } \\
\text { fuçando... "posso mexer, professora? "... Eu respondia "pode"... e aí eles } \\
\text { começaram a desenvolver algumas coisas... e eu entrava apenas em alguns } \\
\text { momentos... eu me pautando pelos tutoriais e eles fuçando nas ferramentas... eu } \\
\text { tentei vídeo, tentei escrito, tentei de tudo... não adiantou... tanto que o } J \text {-Click, } \\
\text { eles não se interessaram, eles acharam que era ... então essa ferramenta eles não } \\
\text { aprovaram... aí fizemos os joguinhos... e quando eles propuseram os joguinhos } \\
\text { para as crianças e viram as crianças jogarem, aí eles ... }\end{array}$ & $\begin{array}{l}\text { Participação colaborativa plena; e. Participação plenamente autônoma; } \\
\text { f. Participação condutora. } \\
\text { 3. Ações de Diálogo: a. Escuta mútua; b. Pensar juntos; c. Apontar } \\
\text { outros pontos de vista; d. Compartilhar e refletir sobre ideias; e. Fazer } \\
\text { emergir ideias / buscar pluralidade de ideias } \\
\text { 4. Relações entre as pessoas nos ambientes do LIE, para criação de um } \\
\text { novo ecossistema comunicativo. }\end{array}$ \\
\hline $\begin{array}{l}\text { Então o professor de } \\
\text { matemática trabalhando } \\
\text { a partir do universo das } \\
\text { frutas... }\end{array}$ & $\begin{array}{l}\text { isso... e aí eles falavam: "Nossa, isso é legal"... e as professoras deram aquele } \\
\text { incentivo... "olha, esse joguinho é legal"... e isso assim... não era só um jogo ... } \\
\text { era aquela atividade com vários joguinhos... era um percurso que a gente } \\
\text { montava com vários joguinhos, dentre esses um feito pelos alunos... e foi muito } \\
\text { interessante porque isso motivou muito... o Hot Potatoes tem um limite... ele faz } \\
\text { até } 5 \text { atividades... assim que eles descobriram todas as atividades, eles já não } \\
\text { acharam mais graça, não acharam tão interessante... e na escola, a gente já tinha } \\
\text { uma cultura de criar animações no Power point... então a gente isso com os } \\
\text { alunos do } 2^{\circ} \text { ano... para eles aprenderem sequência de estória, enredo, o que vem } \\
\text { antes, o que vem depois, o que é personagem,... e eu achei que se dava para } \\
\text { fazer animação, era possível fazer game também... procurei também... a gente } \\
\text { busca essa questão dos tutoriais... achei um jogo de futebol feito no Power } \\
\text { point... uma simulação de um jogo de futebol, né! Apresentei para os alunos... } \\
\text { eles não quiseram fazer os tutoriais, mas eles entenderam a lógica e a partir daí } \\
\text { eles começaram a fazer jogos, muitos jogos de labirinto... utilizando hyperlinks... }\end{array}$ & $\begin{array}{l}\text { 1. Gestão Compartilhada da Comunicação: a. Ação comunicativa; b. } \\
\text { Apropriação e manejo das linguagens da comunicação; c. Uso dos } \\
\text { recursos da informação para a produção cultural. } \\
\text { 2. Participações de Protagonismo: a. Participação planejadora e } \\
\text { operacional; b. Participação decisória, planejadora e operacional; c. } \\
\text { Participação decisória, planejadora, operacional e avaliadora; d. } \\
\text { Participação colaborativa plena; e. Participação plenamente autônoma; } \\
\text { f. Participação condutora. } \\
\text { 3. Ações de Diálogo: a. Escuta mútua; b. Pensar juntos; c. Apontar } \\
\text { outros pontos de vista; d. Compartilhar e refletir sobre ideias; e. Fazer } \\
\text { emergir ideias / buscar pluralidade de ideias } \\
\text { 4. Relações entre as pessoas nos ambientes do LIE, para criação de um } \\
\text { novo ecossistema comunicativo. }\end{array}$ \\
\hline $\begin{array}{l}\text { Você tem todos esses } \\
\text { jogos? }\end{array}$ & $\begin{array}{l}\text { Tenho todos esses jogos... e aí o de labirinto foi o que mais, foi o que eles } \\
\text { gostaram mais... e aí eles começaram com uma estória de fazer um labirinto que } \\
\text { fosse intransponível... e aí eu falava... "olha um labirinto que seja intransponível, } \\
\text { não é atrativo... pode não atrair"..., mas não adiantava... eles insistiam em fazer } \\
\text { labirinto intransponível, principalmente para mim, que não conseguia ... } \\
\text { E aí tudo bem... querem fazer intransponível, vamos passar para eles... aí eles } \\
\text { viram que quando eles não passavam de tela, aí eles descobriram também que } \\
\text { tinha um jeito de driblar a tela... que era só dar um enter... aí eles ficaram muito } \\
\text { bravos e descobriram um jeito de fechar essa tela, para ela não ser transposta... } \\
\text { por isso que é assim, né... não podia usar só esses jogos na aula... porque acabava } \\
\text { sendo uma experimentação também... então usava outros também... e aí eles }\end{array}$ & $\begin{array}{l}\text { Exemplo de gestão da comunicação e criação de ecossistemas } \\
\text { comunicativos de trocas intensas e reflexivas. }\end{array}$ \\
\hline
\end{tabular}




\begin{tabular}{|c|c|c|}
\hline & $\begin{array}{l}\text { descobriram como fazia isso... e aí eles perceberam que o labirinto... isso eu acho } \\
\text { que foi uma das grandes sacadas deles... eles perceberam que o jogo não era para } \\
\text { eles... que o jogo era para um outro... que o jogo tinha que atender as } \\
\text { necessidades de uma outra pessoa ... e isso foi muito interessante... e aí no fim de } \\
2012 \ldots \text { eu não vou lembrar direito... } 2012 \text { ou } 2013 \ldots \text { acho que foi } 2012 \ldots \text { eu } \\
\text { apresentei para uma das alunas o Scratch... uma das alunas do projeto que eu vi } \\
\text { que ela era bem avançada, Karina, ela se encontrou com o Scratch... mas não } \\
\text { com a linguagem de programação, porque naquele momento, eu não via o } \\
\text { Scratch como uma linguagem de programação, mas como uma ferramenta para } \\
\text { fazer jogo... vi, sabia que eram códigos que estavam ali... mas ele servia para } \\
\text { mim, como uma ferramenta para fazer jogo... e uma das alunas entrou nos sites, } \\
\text { se cadastrou e começou a conversar com gente do mundo inteiro... trocar } \\
\text { informações... e começou a melhorar os jogos... e aí ela ficou muito encantada } \\
\text { com isso... aí ela volta das férias super encantada... e aí ela fala para mim... } \\
\text { "professora, a gente tem que colocar o nosso material num site"... aí eu falei: } \\
\text { "num site???"... Nessa época, eu acho que ela tinha } 12 \text { anos... }\end{array}$ & \\
\hline E tudo isso em inglês? & $\begin{array}{l}\text { : é... eles usam muito o Google Tradutor... todos eles... assim, o inglês não é um } \\
\text { impeditivo para eles para fazerem o que quer que seja... e aí ela conversou .... } \\
\text { tudo... e aí eu fiquei um pouco receosa... e falei que se eles montassem ... porque } \\
\text { era fim de semestre... uma coisa assim... ou de bimestre ... ou foi um pouco } \\
\text { antes... eu acho que eu apresentei o Scratch, ela gostou e foi para as férias... por } \\
\text { isso que ela voltou com mais novidades... era fim de ano e eles .... porque a gente } \\
\text { tem que fazer, tem que fazer... então eu disse... então façam, depois eu olho... } \\
\text { aquela coisa do professor: eu valido... e aí ... a gente vê se colocarmos no ar... ela } \\
\text { fez um site super bonitinho... com um outro menino que era um jovem tech na } \\
\text { época, que ajudou,... eu fui dando algumas sugestões... mas depois a gente } \\
\text { apresentou o layout para a equipe... como eu falei, a gente sempre tinha essa } \\
\text { reunião de pauta, para trocarmos ideias... eles gostaram, e apresentei... aí as } \\
\text { professoras acharam aquilo o máximo porque aí os alunos podiam acessar... deu } \\
\text { autonomia para os outros.. Que não era eu quem propunha os jogos... eles que } \\
\text { definiam... e aí nessa época eu já tinha um percurso de jogos, então a gente } \\
\text { deixou algumas aulas que seriam livres, mas não eram livres... para eles } \\
\text { explorarem o site ... e isso foi muito legal, porque eles escolheram o jogo que } \\
\text { eles queriam, e os alunos começaram a perceber que jogo que era mais atrativo, } \\
\text { mais legal, menos legal, ... e isso foi muito interessante, porque eles sempre } \\
\text { acompanhavam... }\end{array}$ & $\begin{array}{l}\text { 1. Gestão Compartilhada da Comunicação: a. Ação comunicativa; b. } \\
\text { Apropriação e manejo das linguagens da comunicação; c. Uso dos } \\
\text { recursos da informação para a produção cultural. } \\
\text { 4. Relações entre as pessoas nos ambientes do LIE, para criação de um } \\
\text { novo ecossistema comunicativo. }\end{array}$ \\
\hline Então eles criaram um & Isso... alunos, pais, famílias, escola... e para a gente ter um lugar organizado, & 4. Relações entre as pessoas nos ambientes do LIE, para criação de um \\
\hline
\end{tabular}




\begin{tabular}{|c|c|}
\hline $\begin{array}{l}\text { site, para disponibilizar } \\
\text { os jogos deles para os } \\
\text { alunos dos 1os anos } \\
\text { terem acesso a todos os } \\
\text { jogos deles... }\end{array}$ & $\begin{array}{l}\text { porque até então, quem organizava o que seria exposto era eu... aí eu perdi a } \\
\text { autonomia. }\end{array}$ \\
\hline $\begin{array}{l}\text { Aí as professoras } \\
\text { acessavam com as } \\
\text { classes de aluninhos } \\
\text { delas... para poder jogar } \\
\text { conforme o contexto, } \\
\text { elas localizavam ali... }\end{array}$ & $\begin{array}{l}\text { Ou então assim... porque o que acontecia... como não eram apenas jogos das } \\
\text { crianças, sempre tinha um percurso que eu numerava de } 1 \text { a } 2 . \text { os joguinhos que } \\
\text { seriam colocados... era um uso tradicional dos joguinhos... mas assim... é legal } \\
\text { entender que era a maneira que elas também compreendiam o jogo... eu não } \\
\text { podia chegar com algo muuuuito inovador porque elas ainda estavam vendo } \\
\text { aquilo como uma ferramenta didática... então era mais ou menos, era um } \\
\text { percurso ... e aí isso combinou com o final do ano... que aí as crianças do } 1^{\circ} \text { e do } \\
\text { 2o anos já tinham autonomia, de buscar, de entrar no hyperlink... e aí a gente } \\
\text { deixou isso livre... para eles acessarem os jogos que eles tinham gostado... e isso } \\
\text { foi muito interessante... e tinha alguns jogos que... o que acontecia também... } \\
\text { Eles não gostam de arrumar o jogo... isso é muito chato de fazer... Então, no ano } \\
\text { seguinte, eu tive a ideia de fazer uma curadoria interna... Então, eu apresentava } \\
\text { o jogo para eles, terminou? Terminou... então acabamos com aquela coisa de } \\
\text { termina, não termina... aquela relação muito de entregar uma atividade... } \\
\text { mostrava o jogo, fiz um questionário no Google Docs... e os alunos que iam } \\
\text { jogar, eles foram convidados a dar opinião sobre o jogo, o que tinha gostado, o } \\
\text { que não tinha gostado... e eu achei que aluno não gosta de responder } \\
\text { questionário... e assim... eles começaram a responder ... no começo eu acabei até } \\
\text { nem pensando muito no tempo... então eu fiz muitas questões... e aí não dava } \\
\text { tempo, eles queriam voltar, para terminar de responder o questionário...porque } \\
\text { eles sabiam que aqueles questionário ia ajudar a melhorar um jogo que ele } \\
\text { gostou ou que ele não gostou...e só depois de todo esse processo de verificação e } \\
\text { ajuste, que o jogo ia para o site... o jogo só subia para o site depois de passar por } \\
\text { essa curadoria... foi um processo legal também... }\end{array}$ \\
\hline $\begin{array}{lrrr}\text { Mas é o que } & \text { você } \\
\text { pretende } & \text { fazer } & \text { no } \\
\text { doutorado? } & & \\
\end{array}$ & $\begin{array}{l}\text { Essa coisa do aluno ser protagonista de todo o processo mesmo, inclusive das } \\
\text { ações do próprio projeto... da continuidade... porque a partir do momento que o } \\
\text { site entra no ar, eu perco completamente oooo.... não é perder, vamos dizer } \\
\text { assim... não era mais eu quem estava estipulando as próximas etapas... tanto que } \\
\text { agora eu acho que alguns alunos saíram do projeto, e eles já acham que não tem } \\
\text { mais que chamar Jogos do Riva, que tem que ser outro nome porque eles já } \\
\text { saíram, já não estão mais na escola... e tem alguns jogos que eu não consegui } \\
\text { subir para o site... eles foram feitos em } 2014 \text {, que são com gifs, que eles } \\
\text { descobriram como extrair de filmes e desenhos... e descobriram como colocar o }\end{array}$ \\
\hline
\end{tabular}

novo ecossistema comunicativo.

1. Gestão Compartilhada da Comunicação: a. Ação comunicativa; b. Apropriação e manejo das linguagens da comunicação; c. Uso dos recursos da informação para a produção cultural.

4. Relações entre as pessoas nos ambientes do LIE, para criação de um novo ecossistema comunicativo.

Fala muito do percurso de construção do conhecimento dos alunos.

Talvez esta seja uma das falas que melhor descreve como a mudança nas relações viabiliza o protagonismo, e como os alunos se apropriam.

1. Gestão Compartilhada da Comunicação: a. Ação comunicativa; b. Apropriação e manejo das linguagens da comunicação; c. Uso dos recursos da informação para a produção cultural.

2. Participações de Protagonismo: a. Participação planejadora e operacional; b. Participação decisória, planejadora e operacional; c. Participação decisória, planejadora, operacional e avaliadora; d. 


\begin{tabular}{|c|c|c|}
\hline & gif e subir por áudio e para dar a ideia de cinema mesmo... & $\begin{array}{l}\text { Participação colaborativa plena; e. Participação plenamente autônoma; } \\
\text { f. Participação condutora. } \\
\text { 3. Ações de Diálogo: a. Escuta mútua; b. Pensar juntos; c. Apontar } \\
\text { outros pontos de vista; d. Compartilhar e refletir sobre ideias; e. Fazer } \\
\text { emergir ideias / buscar pluralidade de ideias } \\
\text { 4. Relações entre as pessoas nos ambientes do LIE, para criação de um } \\
\text { novo ecossistema comunicativo. }\end{array}$ \\
\hline $\begin{array}{l}\text { Hoje eles estão com que } \\
\text { idade? }\end{array}$ & $\begin{array}{l}15 \text { - } 16 \text { anos... e os que estão ainda no projeto, que fiaram na escola, estão com } \\
12 \text { - } 13 \text {-14 anos... e hoje em dia, a professora que está no meu lugar, ela tenta } \\
\text { fazer isso, principalmente com os Scratch... que aí tem controle de voz e } \\
\text { programação... mas eu percebo que a linguagem de programação no caso do } \\
\text { projeto, ela só tem sentido se ela serve para fazer um jogo... se ela não servir para } \\
\text { fazer um jogo, ela não tem sentido... então eles preferem fazer no Power point } \\
\text { porque visualmente o jogo fica mais bonito ... e eles tem mais possibilidades de } \\
\text { descobertas... porque eles tem que simular... então eles colocam lá... botão } \\
\text { iniciar... como que eu faço a ideia de que está carregando... Então descobrir } \\
\text { como fazer isso com as ferramentas do Power point para eles é mais interessante } \\
\text { do que no Scratch... que eu posso fazer o remix de outro jogo, descobrir a } \\
\text { resposta... no Power point, eles sentem mais desafiados... por incrível que pareça, } \\
\text { né... } \\
\text { E visualmente fica realmente muito melhor, né... }\end{array}$ & $\begin{array}{l}\text { Como a postura do professor interfere nesses processos. E } \\
\text { como os tipos de tecnologias influenciam na motivação e } \\
\text { engajamento da turma. } \\
\text { 1. Gestão Compartilhada da Comunicação: a. Ação comunicativa; b. } \\
\text { Apropriação e manejo das linguagens da comunicação; c. Uso dos } \\
\text { recursos da informação para a produção cultural. } \\
\text { 4. Relações entre as pessoas nos ambientes do LIE, para criação de um } \\
\text { novo ecossistema comunicativo. }\end{array}$ \\
\hline $\begin{array}{l}\text { Divulgam para a } \\
\text { comunidade, planejam e } \\
\text { executam as tarefas... } \\
\text { compartilham... como é } \\
\text { que esse processo do } \\
\text { desenvolvimento? Todo } \\
\text { mundo faz tudo? }\end{array}$ & $\begin{array}{l}\text { : Não... esse é um grande problema do projeto... porque o que aconteceu... eles } \\
\text { começaram a ter uma certa visibilidade... porque nós começamos a leva-los em } \\
\text { eventos , em alguns lugares, e sempre que entra um aluno novo... por exemplo... } \\
\text { eles são convidados para vir aqui na secretaria... todos do projeto são } \\
\text { convidados... Independentemente do nível que ele está... se ele é iniciante, se ele } \\
\text { já mais avançado... ele vem de qualquer jeito... e às vezes esse que vem... ele } \\
\text { acaba tendo uma ideia de que é fácil... de que é legal... passear com a escola... e à } \\
\text { vezes ele nãos e empenha tanto quanto os outros, né... aí tem o grupo que gosta } \\
\text { mais do } S c r a t c h . . . \text { consegue achar soluções no Scratch... e tem um grupo que } \\
\text { consegue achar mais soluções no Power point... também em isso... e } \\
\text { normalmente, quem trabalha com Scratch, trabalha com os dois... quem trabalha } \\
\text { com Power point não gosta muito do } S c r a t c h . . . \text { não gosta mesmo... }\end{array}$ & $\begin{array}{l}\text { Os resultados desse tipo de projeto. } \\
\text { 1. Gestão Compartilhada da Comunicação: a. Ação comunicativa; b. } \\
\text { Apropriação e manejo das linguagens da comunicação; c. Uso dos } \\
\text { recursos da informação para a produção cultural. } \\
\text { 2. Participações de Protagonismo: a. Participação planejadora e } \\
\text { operacional; b. Participação decisória, planejadora e operacional; c. } \\
\text { Participação decisória, planejadora, operacional e avaliadora; d. } \\
\text { Participação colaborativa plena; e. Participação plenamente autônoma; } \\
\text { f. Participação condutora. } \\
\text { 3. Ações de Diálogo: a. Escuta mútua; b. Pensar juntos; c. Apontar } \\
\text { outros pontos de vista; d. Compartilhar e refletir sobre ideias; e. Fazer } \\
\text { emergir ideias / buscar pluralidade de ideias } \\
\text { 4. Relações entre as pessoas nos ambientes do LIE, para criação de um } \\
\text { novo ecossistema comunicativo. }\end{array}$ \\
\hline
\end{tabular}




\begin{tabular}{|c|c|c|}
\hline $\begin{array}{l}\text { Então, no momento que } \\
\text { foi para o site, até } \\
\text { quando } \\
\text { continuaram, enquanto } \\
\text { alunos monitores, } \\
\text { fazendo projeto? Em que } \\
\text { momento esse projeto } \\
\text { deixou de ser um projeto } \\
\text { de atividade de aluno } \\
\text { monitor, da informática } \\
\text { educativa, para ter o voo } \\
\text { solo... }\end{array}$ & $\begin{array}{l}\text { acho que foi quando nós não tínhamos mais a obrigação de fazer jogo de } \\
\text { alfabetização... e sim de entretenimento... e aí ele passa a ser um projeto que ele } \\
\text { não é um ... quer dizer... nós ainda usávamos esses jogos com as crianças, mas } \\
\text { num outro patamar, quer dizer assim... por exemplo eu faço um jogo sobre o } \\
\text { desenho A Hora da Aventura... para o professor, isso ainda não é um conteúdo } \\
\text { didático... então, ele permite que eu use na aula aquele jogo porque tem relações } \\
\text { espaciais... porque ele trabalha o desenvolvimento de algumas habilidades } \\
\text { importantes... mas o professor da sala de aula formal não consegue fazer esse } \\
\text { link...e aí ele se torna um projeto solo porque a gente não tem o compromisso de } \\
\text { fazer jogo de alfabetização, como fazíamos no início, por demanda dos } \\
\text { professores dos los anos.... Quer dizer, não temos um conteúdo pré- } \\
\text { determinado... Assim, que era fazer com letrinhas, palavras... }\end{array}$ & $\begin{array}{l}\text { Os resultados desse tipo de projeto. } \\
\text { 1. Gestão Compartilhada da Comunicação: a. Ação comunicativa; b. } \\
\text { Apropriação e manejo das linguagens da comunicação; c. Uso dos } \\
\text { recursos da informação para a produção cultural. } \\
\text { 2. Participações de Protagonismo: a. Participação planejadora e } \\
\text { operacional; b. Participação decisória, planejadora e operacional; c. } \\
\text { Participação decisória, planejadora, operacional e avaliadora; d. } \\
\text { Participação colaborativa plena; e. Participação plenamente autônoma; } \\
\text { f. Participação condutora. } \\
\text { 3. Ações de Diálogo: a. Escuta mútua; b. Pensar juntos; c. Apontar } \\
\text { outros pontos de vista; d. Compartilhar e refletir sobre ideias; e. Fazer } \\
\text { emergir ideias / buscar pluralidade de ideias } \\
\text { 4. Relações entre as pessoas nos ambientes do LIE, para criação de um } \\
\text { novo ecossistema comunicativo. }\end{array}$ \\
\hline $\begin{array}{l}\text { Que foi a encomenda de } \\
\text { um professor... }\end{array}$ & $\begin{array}{l}\text { Aí a lógica passa a ser outra... não era um professor que determinava o } \\
\text { conteúdo, mas o grupo mesmo que determinava que conteúdo que seria colocado } \\
\text { no jogo... que é aí que eu descobri que tem um universo riquíssimo de filmes, } \\
\text { desenho, animação, de personagens... de personagens que tem enredo super } \\
\text { intricado }\end{array}$ & \\
\hline $\begin{array}{l}\text { Então eu quero saber } 2 \\
\text { coisas: primeiro, como é } \\
\text { esse processo de } \\
\text { planejar o jogo? O } \\
\text { processo de planejar } \\
\text { esse jogo... deles } \\
\text { planejarem o jogo... } \\
\text { você senta com eles, eles } \\
\text { sentam sozinhos... e te } \\
\text { entregam os jogos } \\
\text { prontos... }\end{array}$ & $\begin{array}{l}\text { então... no começo eu meio que pautava... vamos fazer jogo sobre isso... mas } \\
\text { depois eu percebi que isso, principalmente com o "A Cidade que a Gente quer", } \\
\text { eu matei assim o projeto... essa parte... eu comecei falando... agora nós vamos } \\
\text { fazer sobre a cidade que a gente quer, levei vídeo, bonitinho, falei do Rilki, } \\
\text { acabou... acabou... acabou... foi assim... foi uma abordagem péssima... e eles } \\
\text { falam isso inclusive para mim... professora a gente não gosta do Scratch por } \\
\text { causa disso... eles falam dessa forma para mim ... foi uma abordagem muito } \\
\text { ruim... } \\
\text { Eu tentei impor um tema... impor um logica e uma ferramenta... Eu impus } 3 \\
\text { coisas... a logica, a ferramenta e o tema... mesmo assim... mas nessa } \\
\text { perspectiva.... sabe do diálogo que a gente não escuta.... Eu sentei e falei... gente, } \\
\text { agora... que nós somos os jogos do Riva... nós vamos fazer... né... acho que a }\end{array}$ & $\begin{array}{l}\text { Como o tema influencia também na motivação. Tem que ter } \\
\text { aderência ao dia a dia deles, eles precisam estar envolvidos, } \\
\text { para realmente se engajarem. } \\
\begin{array}{l}\text { Novamente como a mudança da postura e das relações } \\
\text { influencia nesses processos. }\end{array}\end{array}$ \\
\hline
\end{tabular}




\begin{tabular}{|c|c|c|}
\hline & $\begin{array}{l}\text { forma como eu fiz foi nível zero de protagonismo... porque era o que eu queria } \\
\text { que eles fizessem... aí eu sentei, eles fizeram... eles tentaram.... mas não tinha } \\
\text { inspiração de fazer nada com aquilo... não viram significado, é péssimo, falaram: } \\
\text { falar do meu bairro??? O meu bairro é feio... e é muito mais legal eu falar da } \\
\text { hora da Aventura... e aí foi péssimo... tanto que eu nem consegui entregar as } \\
\text { atividades do projeto... Eu consegui fazer com os alunos de } 9^{\circ} \text { ano ainda... só... } \\
\text { uma animação, básica... uma animaçãozinha... que eles não conheciam a } \\
\text { ferramenta e aí eles acharam interessante... foi o que eu consegui fazer no Cidade } \\
\text { que a Gente quer... }\end{array}$ & \\
\hline Porque você quis impor? & $\begin{array}{l}\text { Impor um tema... impor um logica e uma ferramenta.... Eu impus } 3 \text { coisas... a } \\
\text { logica, a ferramenta e o tema... mesmo assim. Mas nessa perspectiva.... sabe do } \\
\text { diálogo que a gente não escuta.... Eu sentei e falei... gente, agora... que nós } \\
\text { somos os jogos do Riva... nós vamos fazer... né... acho que a forma como eu fiz } \\
\text { foi nível zero de protagonismo... porque era o que eu queria que eles fizessem... } \\
\text { aí eu sentei, eles fizeram... eles tentaram.... mas não tinha inspiração de fazer } \\
\text { nada com aquilo... não viram significado, é péssimo, falaram: falar do meu } \\
\text { bairro??? O meu bairro é feio... e é muito mais legal eu falar da hora da } \\
\text { Aventura... e aí foi péssimo... tanto que eu nem consegui entregar as atividades } \\
\text { do projeto... Eu consegui fazer com os alunos de } 9^{\circ} \text { ano ainda... só... uma } \\
\text { animação, básica... uma animaçãozinha... que eles não conheciam a ferramenta e } \\
\text { aí eles acharam interessante... foi o que eu consegui fazer no Cidade que a Gente } \\
\text { quer... }\end{array}$ & \\
\hline $\begin{array}{l}\text { E aí eles levam o tema... } \\
\text { e aí como é que eles } \\
\text { desenvolvem? }\end{array}$ & $\begin{array}{l}\text { Aí assim... você falou do percurso... o percurso meio que a gente tem que dar... } \\
\text { eles não têm muito essa autonomia de ah, eu começo por aqui e faço isso... } \\
\text { aqueles que já fazem o jogo, sim, eles têm autonomia..., mas eu percebo que eles } \\
\text { vão muito pelo desafio que eles querem fazer... então por exemplo, eles pegam } \\
\text { um Power point porque eles querem fazer um labirinto... como que esse labirinto } \\
\text { entra na estória que eles estão contando? Às vezes eles até trazem a estória, uma } \\
\text { riqueza que tem essa estória e o conflito dessa estória... mas eles ainda não } \\
\text { conseguem transformar isso em jogo... mas eles trazem o conflito... ahnn... } \\
\text { porque tem esse personagem X,, que briga com o personagem Y... ou que se dá } \\
\text { bem... ou a Jujuba vai buscar, vai até o castelo... ai eles tentam transmitir de } \\
\text { forma muito simples, superficial, isso num jogo... e aí eles caem no labirinto } \\
\text { porque o labirinto dá uma ideia de percurso... mas eles trazem, mas ainda não } \\
\text { conseguem transformar isso num jogo completo... precisaria ter um jogo mais } \\
\text { completo... mas eles trazem aquela dinâmica... do pular, do ir atrás, que é o que a } \\
\text { maior parte dos jogos trazem... uma coisa interessante é que eles também } \\
\text { tentaram trabalhar com Minecraft... depois que eles vieram do sul... ai meio que } \\
\text { se proliferou o uso disso.. No } S B \text { Games... aí eles quiseram trabalhar, a gente não }\end{array}$ & $\begin{array}{l}\text { Os resultados desse tipo de projeto. } \\
\text { 1. Gestão Compartilhada da Comunicação: a. Ação comunicativa; b. } \\
\text { Apropriação e manejo das linguagens da comunicação; c. Uso dos } \\
\text { recursos da informação para a produção cultural. } \\
\text { 2. Participações de Protagonismo: a. Participação operacional; b. } \\
\text { Participação planejadora e operacional; c. Participação decisória, } \\
\text { planejadora e operacional; d. Participação decisória, planejadora, } \\
\text { operacional e avaliadora; e. Participação colaborativa plena; f. } \\
\text { Participação plenamente autônoma; g. Participação condutora. } \\
\text { 3. Ações de Diálogo: a. Escuta mútua; b. Pensar juntos; c. Apontar } \\
\text { outros pontos de vista; d. Compartilhar e refletir sobre ideias; e. Fazer } \\
\text { emergir ideias / buscar pluralidade de ideias } \\
\text { 4. Relações entre as pessoas nos ambientes do LIE, para criação de um } \\
\text { novo ecossistema comunicativo. }\end{array}$ \\
\hline
\end{tabular}




\begin{tabular}{|c|c|c|}
\hline & $\begin{array}{l}\text { tinha na escola, mas eles conseguiram acho que } 1 \text { a } 2 \text { maquinas... aí eles foram } \\
\text { estudar mesmo para aprender no Minecraft ... aí um dos alunos me disse... } \\
\text { professora, o Minecraft tem dois modos... o modo construtor... E o modo } \\
\text { sobrevivente... eu: Ahn, é? O aluno: é.... no modo sobrevivente, a agente não } \\
\text { aprende nada... a gente só sai matando... já no construtor, sim... no construtor é } \\
\text { como no Power point... a gente constrói, elabora, pensa,... eu achei muito legal... } \\
\text { aí perguntei para outro aluno... por que que eles gostavam tanto de jogos } \\
\text { violentos? E aí ele trouxe uma resposta super elaborada que era exatamente } \\
\text { aquilo que eu queria ouvir, né... que ele achou que eu queria ouvir... "não, } \\
\text { professora, porque é bom a gente jogar jogos violentos porque a gente pensa } \\
\text { como o assassino pode pensar... e hoje em dia, como está tudo tão violento, é } \\
\text { importante a gente saber como o assassino pensa"... }\end{array}$ & \\
\hline $\begin{array}{l}\text { Então, eles trabalhavam } \\
\text { juntos no planejamento } \\
\text { inicial, mas depois } \\
\text { durante o processo eles } \\
\text { falam entre eles... }\end{array}$ & $\begin{array}{l}\text { isso... conversavam muito... assim, na verdade, a ideia era sempre } \\
\text { individual... a elaboração às vezes ela era conjunta, mas normalmente o jogo } \\
\text { tinha uma característica bem pessoal mesmo..., mas eles trocavam sempre o } \\
\text { tempo todo. }\end{array}$ & $\begin{array}{l}\text { 3. Ações de Diálogo: a. Escuta mútua; b. Pensar juntos; c. Apontar } \\
\text { outros pontos de vista; d. Compartilhar e refletir sobre ideias; e. Fazer } \\
\text { emergir ideias / buscar pluralidade de ideias } \\
\text { 4. Relações entre as pessoas nos ambientes do LIE, para criação de um } \\
\text { novo ecossistema comunicativo. }\end{array}$ \\
\hline $\begin{array}{l}\text { Então eles avaliavam os } \\
\text { jogos uns dos outros o } \\
\text { tempo todo? }\end{array}$ & $\begin{array}{l}\text { Isso... é... mais ou menos... é aí que eu queria chegar, porque, por exemplo... } \\
\text { essa é a importância do feedback..., mas eles queriam um feedback imediato } \\
\text { meu... e eu não dava conta de dar esse feedback de imediato... e aí ficava aquele } \\
\text { feedback de professor... arruma o erro de português... arruma... entendeu? E não } \\
\text { era o feedback talvez que eles gostariam... se o jogo estava atrativo, se o jogo } \\
\text { estava legal, e foi aí que eu tive a ideia de pedir aos alunos para que eles } \\
\text { passassem a dar o feedback... }\end{array}$ & $\begin{array}{l}\text { 3. Ações de Diálogo: a. Escuta mútua; b. Pensar juntos; c. Apontar } \\
\text { outros pontos de vista; d. Compartilhar e refletir sobre ideias; e. Fazer } \\
\text { emergir ideias / buscar pluralidade de ideias } \\
\text { 4. Relações entre as pessoas nos ambientes do LIE, para criação de um } \\
\text { novo ecossistema comunicativo. }\end{array}$ \\
\hline $\begin{array}{l}\text { A rubrica em } r \text { si... } \\
\text { quando que você } \\
\text { começou a usar? Se você } \\
\text { usou? }\end{array}$ & $\begin{array}{l}\text { : então... eu usei a rubrica meio ... eu vi sentido de fazer a rubrica... acho que ela } \\
\text { serviria até para fazer esse feedback, essa devolutiva mais elaborada aos } \\
\text { alunos..., mas ela entra meio que para ... precisava fazer uma rubrica... era uma } \\
\text { professora que precisava fazer uma rubrica... até para entender tudo e eu sento } \\
\text { com eles e digo... vocês não acham legal a gente ter uns parâmetros da atuação } \\
\text { do monitor nesse projeto? Aí sentei com eles... a gente conversou bastante... } \\
\text { perguntei... uma parte que foi muito legal... essa parte dos critérios, eu meio que } \\
\text { baseei em algumas que já tinham colocado... e me baseei um pouco na rubrica do } \\
\text { aluno monitor que já existia na época... e os critérios foi a parte mais legal de } \\
\text { discutir... que foi dizer quem era esse personagem... e aí eles ... essa coisa de } \\
\text { Pokémon... que passa por vários estágios de evolução... níveis... Que foi onde } \\
\text { eles conseguiram entender o que era a rubrica... e é um termo que eles utilizam }\end{array}$ & $\begin{array}{l}\text { 2. Participações de Protagonismo: a. Participação planejadora e } \\
\text { operacional; b. Participação decisória, planejadora e operacional; c. } \\
\text { Participação decisória, planejadora, operacional e avaliadora; d. } \\
\text { Participação colaborativa plena; e. Participação plenamente autônoma; } \\
\text { f. Participação condutora. } \\
\text { 3. Ações de Diálogo: a. Escuta mútua; b. Pensar juntos; c. Apontar } \\
\text { outros pontos de vista; d. Compartilhar e refletir sobre ideias; e. Fazer } \\
\text { emergir ideias / buscar pluralidade de ideias } \\
\text { 4. Relações entre as pessoas nos ambientes do LIE, para criação de um } \\
\text { novo ecossistema comunicativo. }\end{array}$ \\
\hline
\end{tabular}




\begin{tabular}{|c|c|c|}
\hline & $\begin{array}{l}\text { até hoje... "ahn... sou Pokémon avançado... "... então, eles brincam com isso... os } \\
\text { termos, eles se apropriaram bem... e aí, a parte da escrita a gente foi construindo } \\
\text { meio que paulatinamente... e aí fizemos um documento, se não me engano no } \\
\text { servidor e eles iam escrevendo no próprio Power point juntos... para melhorar o } \\
\text { que era e o que não era... para contribuir... e aí foi feito dessa forma }\end{array}$ & \\
\hline Como ela era aplicada? & $\begin{array}{l}\text { Então. Em alguns momentos ela era aplicada... às vezes nessa reunião de pauta, a } \\
\text { gente retomava essa rubrica, mas ficava muito nessa coisa... "ahn. Eu estou nesse } \\
\text { nível... ahn eu não estou nesse nível." Aí ficou nessa coisa bem instrumental... } \\
\text { ahn eu estou nesse nível... eu acho que eles se apropriaram mais dos nomes do } \\
\text { que dos critérios propriamente... e acho que a rubrica ficou muito extensa, com } \\
\text { muitos critérios... então assim, ficou... diluiu... sabe, assim ... então nesse } \\
\text { momento eu sou Pikachu, nesse momento sou Raichu... então foi assim que eles } \\
\text { se apropriaram..., mas não dela como um todo... dos itens... isso não. }\end{array}$ & $\begin{array}{l}\text { 2. Participações de Protagonismo: a. Participação planejadora e } \\
\text { operacional; b. Participação decisória, planejadora e operacional; c. } \\
\text { Participação decisória, planejadora, operacional e avaliadora; d. } \\
\text { Participação colaborativa plena; e. Participação plenamente autônoma; } \\
\text { f. Participação condutora. } \\
\text { 3. Ações de Diálogo: a. Escuta mútua; b. Pensar juntos; c. Apontar } \\
\text { outros pontos de vista; d. Compartilhar e refletir sobre ideias; e. Fazer } \\
\text { emergir ideias / buscar pluralidade de ideias } \\
\text { 4. Relações entre as pessoas nos ambientes do LIE, para criação de um } \\
\text { novo ecossistema comunicativo. }\end{array}$ \\
\hline $\begin{array}{l}\text { Mas pelo menos ele } \\
\text { fazia a autoavaliação e } \\
\text { normalmente a } \\
\text { autoavaliação que eles } \\
\text { faziam era apropriada, } \\
\text { coerente? }\end{array}$ & $\begin{array}{l}\text { É mas se eu pedisse para eles usarem o papel, eles iam falar que... bem, eles } \\
\text { tentavam puxar a sardinha para o lado deles, para um nível mais evoluído, para } \\
\text { melhor, para avançar um pouco mais do que tinham feito mesmo..., mas eu não } \\
\text { avancei muito nessa atividade com a rubrica, de forma mais sistemática, não... o } \\
\text { processo de construção foi mais rico do que o uso em si que eu fiz depois... o } \\
\text { processo de elaborar... }\end{array}$ & Buscando um novo equilíbrio nas relações \\
\hline
\end{tabular}




\section{Anexo G.4: Entrevista POIE José Rosemberg}

\begin{tabular}{|c|c|c|}
\hline PERGUNTAS & $\begin{array}{ll}\text { ENTREVISTA } \\
\text { ROSEMBERG }\end{array}$ & INDICADORES \\
\hline $\begin{array}{l}\text { Eu quero saber de fato, o que } \\
\text { você implantou... então, se } \\
\text { você puder me contar } \\
\text { primeiro, o que foi o projeto... } \\
\text { depois, dentro do que é o } \\
\text { projeto, do que é a proposta } \\
\text { original da SME, o que você } \\
\text { fez que foi orientado para } \\
\text { você? E o que você não fez, } \\
\text { por que você adaptou? }\end{array}$ & $\begin{array}{l}\text { Durante os projetos nós fomos colocando esse viés das avaliações por rubricas... } \\
\text { então foram vários projetos diferentes para cada ano do ciclo de alfabetização e } \\
\text { em cada projeto tinha uma rubrica específica... acho que foi isso inclusive que foi } \\
\text { mostrado na navegação orientada... a Jane pediu as rubricas e aí socializou esse } \\
\text { uso das rubricas, né... }\end{array}$ & Contextualizando \\
\hline $\begin{array}{l}\text { Então me conta o que é um } \\
\text { projeto de alfabetização }\end{array}$ & $\begin{array}{l}\text { é um projeto, que como eu estava ligado ao laboratório de informática educativa, } \\
\text { que usa as tecnologias e meios de comunicação para que esses alunos escrevam e } \\
\text { leiam melhor mas numa situação real de comunicação... façam o texto na } \\
\text { situação comunicativa... então naquele ano, os } 2 \text { os anos estavam trabalhando } \\
\text { com verbetes e curiosidades... então nós estudamos verbetes e curiosidades, eles } \\
\text { elaboraram alguns verbetes e curiosidades ... foi feito todo um processo de } \\
\text { levantamento de curiosidades acerca de animais... e todo esse processo ia sendo } \\
\text { avaliado com base nessas rubricas.. Isso no } 20 \text { ano... no } 10 \text { ano era mais voltado } \\
\text { para as cantigas... então sempre assim... com um gênero textual como centro... e } \\
\text { ali o trabalho de pesquisa, de ampliaçãa de conhecimento deles e uma } \\
\text { finalização com uma situação comunicativa... um CD para compartilhar, um } \\
\text { vídeo para postar no Youtube... algo nesse sentido... }\end{array}$ & $\begin{array}{l}\text { Curiosos em ação... o processo, pelos olhos do POIE... } \\
\text { trabalhando os processos comunicacionais, os ajustes } \\
\text { dos símbolos, para o universo das crianças } \\
\text { 1. Gestão Compartilhada da Comunicação: a. Ação } \\
\text { comunicativa; b. Apropriação e manejo das linguagens } \\
\text { da comunicação; c. Uso dos recursos da informação } \\
\text { para a produção cultural. } \\
\text { 2. Participações de Protagonismo: a. Participação planejadora } \\
\text { e operacional; b. Participação decisória, planejadora e } \\
\text { operacional; c. Participação decisória, planejadora, } \\
\text { operacional e avaliadora; d. Participação colaborativa plena; } \\
\text { e. Participação plenamente autônoma; f. Participação } \\
\text { condutora. } \\
\text { 3. Ações de Diálogo: a. Escuta mútua; b. Pensar juntos; } \\
\text { c. Apontar outros pontos de vista; d. Compartilhar e } \\
\text { refletir sobre ideias; e. Fazer emergir ideias / buscar } \\
\text { pluralidade de ideias } \\
\text { 4. Relações entre as pessoas nos ambientes do LIE, } \\
\text { para criação de um novo ecossistema comunicativo. }\end{array}$ \\
\hline $\begin{array}{l}\text { O que foi que eles } \\
\text { trabalharam mesmo no } 10\end{array}$ & : foi com parlendas... & Tema \\
\hline
\end{tabular}




\begin{tabular}{|c|c|c|}
\hline ano? & & \\
\hline Quantas turmas foram? & Nas 2 escolas, 3 numa escola e 4 na outra... 7 turmas ao todo... todas de 10 ano... & Perfil \\
\hline $\begin{array}{l}\text { : e verbete e curiosidades do } \\
20 \text { ano, quantas turmas } \\
\text { foram? }\end{array}$ & 8 turmas nas 2 escolas & Perfil \\
\hline Quantos alunos em média? & $\begin{array}{l}\text { Os } 1 \text { os anos tinham em média } 25 \text { a } 30 \text { alunos... já os } 20 \text { anos, em média } 32 \text {-33 } \\
\text { alunos... }\end{array}$ & Perfil \\
\hline $\begin{array}{l}\text { Como era a execução? Era a } \\
\text { mesma estrutura de ações para } \\
\text { ambos os projetos ou você } \\
\text { tinha um processo, } \\
\text { procedimentos diferentes para } \\
\text { cada projeto? Conte um pouco } \\
\text { por projeto, como foi o passo } \\
\text { a passo de cada um deles... } \\
\text { vamos começar pelo 1o ano. }\end{array}$ & $\begin{array}{l}\text { ema ambas tem uma estrutura geral... nas duas tem um caminhar... 1o } \\
\text { problematizar e mobilizar para o projeto (seduzi-los para que comprem a } \\
\text { execução do projeto)... seduzi-lo para o tema... 2o passo: apuração do que eles já } \\
\text { conhecem da temática que será estudada e trabalhada... 3o passo: pesquisar, } \\
\text { buscar conhecer mais sobre isso, até para ver se o que eles sabem tem realmente } \\
\text { a ver com aquilo sobre o que vamos tratar... ampliar o repertorio deles e depois, } \\
\text { passamos à parte da finalização do projeto... então, o que nós vamos fazer para } \\
\text { apresentar em cima disso... e o que nós vamos precisar de tecnologia e de língua } \\
\text { para dar conta disso... no lo ano... eles já estudavam parlendas na sala de aula... } \\
\text { mas algumas turmas, nem tinham tanto... havia diferenças de conhecimento } \\
\text { sobre o tema entre as turmas do mesmo ano... então muitos cantavam cantigas e } \\
\text { iam para outro tema que não eram as parlendas... por isso, nós fizemos um } \\
\text { levantamento do que eles sabiam sobre parlendas, depois nós começamos a } \\
\text { pesquisar no Youtube e no Google algumas parlendas... e como é 1o ano... está } \\
\text { começando a questão de alfabetização... quem ajudava nesse processo eram os } \\
\text { alunos monitores... era como se eu tivesse um aluno monitor tutorando } 2 \\
\text { duplas... ficava ali ajudando as duplas a pesquisar, mostrando como deveriam } \\
\text { fazer isso, lendo... }\end{array}$ & $\begin{array}{l}\text { 1. Gestão Compartilhada da Comunicação: a. Ação } \\
\text { comunicativa; b. Apropriação e manejo das linguagens } \\
\text { da comunicação; c. Uso dos recursos da informação } \\
\text { para a produção cultural. } \\
\text { 2. Participações de Protagonismo: a. Participação planejadora } \\
\text { e operacional; b. Participação decisória, planejadora e } \\
\text { operacional; c. Participação decisória, planejadora, } \\
\text { operacional e avaliadora; d. Participação colaborativa plena; } \\
\text { e. Participação plenamente autônoma; f. Participação } \\
\text { condutora. } \\
\text { 3. Ações de Diálogo: a. Escuta mútua; b. Pensar juntos; } \\
\text { c. Apontar outros pontos de vista; d. Compartilhar e } \\
\text { refletir sobre ideias; e. Fazer emergir ideias / buscar } \\
\text { pluralidade de ideias } \\
\text { 4. Relações entre as pessoas nos ambientes do LIE, } \\
\text { para criação de um novo ecossistema comunicativo. }\end{array}$ \\
\hline $\begin{array}{l}\text { Então os alunos trabalhavam } \\
\text { em duplas? }\end{array}$ & $\begin{array}{l}\text { : isso trabalhavam em duplas... feito essa parte de ampliar o repertorio... e à } \\
\text { medida que eles iam lendo... aí tinham as parlendas que eles conheciam... e as } \\
\text { parlendas que eles não conheciam e que foram aprendendo, foram pedindo para a } \\
\text { professora contar... eu mesmo cantando e arranjando algum vídeo e tudo mais... } \\
\text { ai fomos para a parte da finalização que era construir um CD... montar o CD... } \\
\text { então na montagem do CD, nós vamos para o conhecimento especifico da } \\
\text { informática, que era mexer no Audacity... então brincamos, mexemos no } \\
\text { Audacity, até eles se organizarem como que iriam apresentar...então em ambas } \\
\text { as escolas, eles se organizaram de modo a montar um jogral, por exemplo... cada } \\
\text { um cantando uma parte da parlenda para a gente gravar... outras duplas, não... as } \\
\text { duplas cantavam juntos... outros se agruparam... então eram duplas e juntaram } 6\end{array}$ & $\begin{array}{l}\text { 1. Gestão Compartilhada da Comunicação: a. Ação } \\
\text { comunicativa; b. Apropriação e manejo das linguagens } \\
\text { da comunicação; c. Uso dos recursos da informação } \\
\text { para a produção cultural. } \\
\text { 2. Participaçães de Protagonismo: a. Participação planejadora } \\
\text { e operacional; b. Participação decisória, planejadora e } \\
\text { operacional; c. Participação decisória, planejadora, } \\
\text { operacional e avaliadora; d. Participação colaborativa plena; } \\
\text { e. Participação plenamente autônoma; f. Participação } \\
\text { condutora. }\end{array}$ \\
\hline
\end{tabular}




\begin{tabular}{|c|c|c|}
\hline & $\begin{array}{l}\text { alunos para dividir melhor o texto escolhido... então cada um deu um } \\
\text { encaminhamento para esse produto final do CD... e no final com CD pronto, nós } \\
\text { apresentamos o CD na reunião de pais e eles levaram para casa... }\end{array}$ & $\begin{array}{l}\text { 3. Ações de Diálogo: a. Escuta mútua; b. Pensar juntos; } \\
\text { c. Apontar outros pontos de vista; d. Compartilhar e } \\
\text { refletir sobre ideias; e. Fazer emergir ideias / buscar } \\
\text { pluralidade de ideias } \\
\text { 4. Relações entre as pessoas nos ambientes do LIE, } \\
\text { para criação de um novo ecossistema comunicativo. }\end{array}$ \\
\hline $\begin{array}{l}\text { Qual o papel dos registros na } \\
\text { plataforma, par a que você } \\
\text { utilizou a plataforma }\end{array}$ & $\begin{array}{l}\text { então... antigamente, eu usava o TQ... ele tinha um aspecto mais infantil...mais } \\
\text { adequado para as crianças... eu achava ele melhor... com essas crianças, eu não } \\
\text { usei muito o EdModo... por problemas de conexão na escola... a conexão era } \\
\text { muito ruim... ficava rodando e parava de carregar... demorava para carregar o } \\
\text { EdModo e acabava bloqueando... então muita coisa a gente fez ou coletivo, na } \\
\text { questão de levantamento de hipóteses... e nessa validação de hipóteses... e na } \\
\text { questão das rubricas, nós fizemos na época a votação nas rubricas... então, eu } \\
\text { apresentei as rubricas... aí fomos entendendo juntos o que era cada passo, } \\
\text { dividindo esses passos, o que representava cada nível da rubrica, e aí eles iam } \\
\text { vendo e os monitores que avaliavam... eles vinham, se posicionavam, ou seja, } \\
\text { eles apresentavam em que nível eles estavam da rubrica e o monitor ia anotando } \\
\text { para mim... então embora fosse uma parte de tecnologia, eu fiz sem tecnologia } \\
\text { por conta da internet... ou da falta de internet... }\end{array}$ & $\begin{array}{l}\text { 1. Gestão Compartilhada da Comunicação: a. Ação } \\
\text { comunicativa; b. Apropriação e manejo das linguagens } \\
\text { da comunicação; c. Uso dos recursos da informação } \\
\text { para a produção cultural. }\end{array}$ \\
\hline $\begin{array}{l}\text { Você diz que trabalhou em } \\
\text { coletivo as hipóteses e depois } \\
\text { classificou... detalhe um } \\
\text { pouco o que foi trabalhar } \\
\text { essas rubricas... como você } \\
\text { fez para detalhar os critérios } \\
\text { da rubrica da atividade para } \\
\text { eles, como foi a explicação } \\
\text { para eles entenderem? Foi } \\
\text { mais expositiva, mais } \\
\text { participativa, você levou as } \\
\text { rubricas prontas ou semi- } \\
\text { prontas e eles finalizaram? } \\
\text { Como foi esse processo? }\end{array}$ & $\begin{array}{l}\text { Então no caso dos } 1 \text { os e } 2 \text { os, eu levei elas semi prontas e eu apresentei duma } \\
\text { primeira versão contando aquela velha estória que estou em determinado lugar e } \\
\text { quero chegar lá no shopping... e para chegar no shopping eu passo por alguns } \\
\text { pontos de ônibus... e aí cada pare da rubrica, daquele texto, mostra que parte do } \\
\text { caminho para o shopping eu estou... se estou mais perto do shopping ou se estou } \\
\text { mais distante do shopping... }\end{array}$ & Iniciando com as rubricas semi prontas. \\
\hline Eu gostei da analogia & $\begin{array}{l}\text { em tese foi isso... eu fui explicando para eles... e à medida que eu identificava } \\
\text { uma ou outra dificuldade deles de entendimento da rubrica, aí eu fazia uma ou }\end{array}$ & $\begin{array}{l}\text { 1. Gestão Compartilhada da Comunicação: a. Ação } \\
\text { comunicativa; b. Apropriação e manejo das linguagens }\end{array}$ \\
\hline
\end{tabular}




\begin{tabular}{|c|c|c|}
\hline & $\begin{array}{l}\text { outra alteração... mas uma ou outra alteração que não dizia respeito à linguagem } \\
\text { em si, pois a linguagem a gente foi dando um patamar acima... então fomos } \\
\text { traduzindo mais ou menos o que eles falavam em uma outra linguagem, uma } \\
\text { linguagem mais apropriada para eles, mas numa linguagem um pouco mais } \\
\text { avançada para eles... até para não ficar só na linguagem básica que eles tem... } \\
\text { para darmos um upgrade para eles... feito isso eles entenderam a lógica de } \\
\text { funcionamento da rubrica e na hora das avaliações por rubrica, eu e os monitores } \\
\text { íamos explicando cada etapa de cada critério para eles indicarem como eles } \\
\text { estavam... então por exemplo, olha, vocês tiveram que utilizar o programinha } \\
\text { para gravar a voz... então vamos lá... no critério sobre o programa de gravar a } \\
\text { voz, você acha que você está assim, assim, assim ou assim? Então eles iam } \\
\text { dando as opções para as duplas e as duplas iam indicando o nível onde se } \\
\text { encaixavam num determinado critério... }\end{array}$ & $\begin{array}{l}\text { da comunicação; c. Uso dos recursos da informação } \\
\text { para a produção cultural. } \\
\text { 2. Participações de Protagonismo: a. Participação planejadora } \\
\text { e operacional; b. Participação decisória, planejadora e } \\
\text { operacional; c. Participação decisória, planejadora, } \\
\text { operacional e avaliadora; d. Participação colaborativa plena; } \\
\text { e. Participação plenamente autônoma; f. Participação } \\
\text { condutora. } \\
\text { 3. Ações de Diálogo: a. Escuta mútua; b. Pensar juntos; } \\
\text { c. Apontar outros pontos de vista; d. Compartilhar e } \\
\text { refletir sobre ideias; e. Fazer emergir ideias / buscar } \\
\text { pluralidade de ideias } \\
\text { 4. Relações entre as pessoas nos ambientes do LIE, } \\
\text { para criação de um novo ecossistema comunicativo. }\end{array}$ \\
\hline $\begin{array}{l}\text { Quero retomar um pouco esse } \\
\text { aspecto de negociações das } \\
\text { rubricas porque essas trocas } \\
\text { me interessam observar } \\
\text { melhor... o processo } \\
\text { comunicacional... como foi } \\
\text { isso? As crianças foram se } \\
\text { manifestando, elas gostaram? } \\
\text { Como foi a sua intervenção } \\
\text { para que } \\
\text { manifestassem elas se } \\
\text { apresentassem sugestões? } \\
\text { Como foi faze-las } \\
\text { participarem e intervirem? }\end{array}$ & $\begin{array}{l}\text { então assim, a primeira coisa que eu contrastei ao conversar com eles sobre } \\
\text { rubrica foi como se dava a avaliação em sala de aula... então, e muitos deles } \\
\text { foram falando... então a professora dava certo ou errado... acertava, errava, tinha } \\
\text { nota, tinha } P \text {, tinha } S \text {, tinha NS... e aí eu fui colocando para eles na questão da } \\
\text { informática... que nós faríamos de um outro jeito uma vez que na informática } \\
\text { nem tinha uma nota, um critério obrigatório de avaliação ... então nesse outro } \\
\text { jeito, eles ficaram meio assim... olhando, meio na expectativa... ao conversar } \\
\text { com eles sobre essa questão das rubricas... dos pontos de ônibus... e explicando } \\
\text { assim que cada etapa eu dava um nome diferente... depois eu vou resgatar as } \\
\text { rubricas para ver esses nomes, esses títulos de níveis... um nome mais lúdico, } \\
\text { então eles começaram a gostar... então numa primeira etapa... eles ficavam muito } \\
\text { assim na questão do nome... eu lembro, por exemplo... que o dos verbetes de } \\
\text { animais, eram nomes de animais... e os verbetes tinham a ver com a velocidade... } \\
\text { então ia desde animais lentos até animais rápidos... e ai eles ficavam muito na } \\
\text { questão do animal... que animal eles queriam ser... e aos poucos eles foram } \\
\text { entendendo que o foco não era o animal... que o foco era o estágio que eles } \\
\text { estavam... }\end{array}$ & $\begin{array}{l}\text { 1. Gestão Compartilhada da Comunicação: a. Ação } \\
\text { comunicativa; b. Apropriação e manejo das linguagens } \\
\text { da comunicação; c. Uso dos recursos da informação } \\
\text { para a produção cultural. } \\
\text { 2. Participações de Protagonismo: a. Participação planejadora } \\
\text { e operacional; b. Participação decisória, planejadora e } \\
\text { operacional; c. Participação decisória, planejadora, } \\
\text { operacional e avaliadora; d. Participação colaborativa plena; } \\
\text { e. Participação plenamente autônoma; f. Participação } \\
\text { condutora. } \\
\text { 3. Ações de Diálogo: a. Escuta mútua; b. Pensar juntos; } \\
\text { c. Apontar outros pontos de vista; d. Compartilhar e } \\
\text { refletir sobre ideias; e. Fazer emergir ideias / buscar } \\
\text { pluralidade de ideias } \\
\text { 4. Relações entre as pessoas nos ambientes do LIE, } \\
\text { para criação de um novo ecossistema comunicativo. }\end{array}$ \\
\hline : isso durante a execução? & $\begin{array}{l}\text { : isso... isso foi durante a execução do projeto... e depois na finalização... então... } \\
\text { foi muita conversa, eles foram sinalizando, colocando algumas pistas que vão } \\
\text { elucidando para os outros... foi mais nesse sentido... }\end{array}$ & \\
\hline Essas $\quad$ pistas & Essas pistas seriam até assim... às vezes, uma palavra que eu explico de um & \\
\hline
\end{tabular}




\begin{tabular}{|c|c|c|}
\hline $\begin{array}{l}\text { negociações para as rubricas } \\
\text { ainda ou já a atividade em si? }\end{array}$ & $\begin{array}{l}\text { jeito... e o outro aluno que entendeu fala de um outro jeito a mesma coisa, de } \\
\text { forma que os pares entendam melhor aquilo que eu estou colocando... }\end{array}$ & \\
\hline $\begin{array}{l}\text { Então as próprias... qual é a } \\
\text { idade dos alunos? Eles estão } \\
\text { no } 1^{\circ} \text { e } 2^{\circ} \text { ano... então }\end{array}$ & : 6-7 anos para os 1os. E 7-8 anos para os 2os. & Perfil \\
\hline $\begin{array}{l}\text { Então você está falando de } \\
\text { crianças mesmo... }\end{array}$ & Isso mesmo... são os pequenos... & \\
\hline $\begin{array}{l}\text { Então ... com isso, você } \\
\text { colocava as coisas e as } \\
\text { crianças iam traduzindo para } \\
\text { os colegas? }\end{array}$ & $\begin{array}{l}\text { : isso... o fulano não entendeu direito o que era... ainda estava pensando no } \\
\text { animal... o colega... "não, não é para falar o animal que você gosta... se você for } \\
\text { animal rápido, quer dizer que você está bom"... "ah então eu quero ser animal } \\
\text { rápido"... "não, mas você não pode porque você ainda não sabe fazer isso e } \\
\text { isso..." então... ao contrário do que alguns imaginam, as crianças tinham sim } \\
\text { entendimento... }\end{array}$ & $\begin{array}{l}\text { A reflexão na autoavaliação, com seus pares: a riqueza } \\
\text { do processo, quando o professor faz a gestão da } \\
\text { comunicação. } \\
\text { 1. Gestão Compartilhada da Comunicação: a. Ação } \\
\text { comunicativa; b. Apropriação e manejo das linguagens } \\
\text { da comunicação; c. Uso dos recursos da informação } \\
\text { para a produção cultural. } \\
\text { 2. Participaçães de Protagonismo: a. Participação planejadora } \\
\text { e operacional; b. Participação decisória, planejadora e } \\
\text { operacional; c. Participação decisória, planejadora, } \\
\text { operacional e avaliadora; d. Participação colaborativa plena; } \\
\text { e. Participação plenamente autônoma; f. Participação } \\
\text { condutora. } \\
\text { 3. Ações de Diálogo: a. Escuta mútua; b. Pensar juntos; } \\
\text { c. Apontar outros pontos de vista; d. Compartilhar e } \\
\text { refletir sobre ideias; e. Fazer emergir ideias / buscar }\end{array}$ \\
\hline
\end{tabular}




\begin{tabular}{|c|c|c|}
\hline & & $\begin{array}{l}\text { pluralidade de ideias } \\
\text { 4. Relações entre as pessoas nos ambientes do LIE, } \\
\text { para criação de um novo ecossistema comunicativo. }\end{array}$ \\
\hline $\begin{array}{lccr}\text { Isso no } & \text { processo } & \text { de } \\
\text { autoavaliação } & \text { então... } & \text { então } \\
\text { eles }\end{array}$ & $\begin{array}{l}\text { : isso no processo de autoavaliação... para compreender as rubricas, para } \\
\text { poderem se autoavaliar... }\end{array}$ & \\
\hline $\begin{array}{l}\text { Mas aí tinha então tanto a } \\
\text { autoavaliação como a } \\
\text { avaliação entre pares, porque } \\
\text { o par ajudava ele a entender e } \\
\text { aí ele se colocar, se identificar } \\
\text { no nível? É isso? }\end{array}$ & $\begin{array}{l}\text { : exato... e o interessante... o foco era a autoavaliação mesmo... a avaliação entre } \\
\text { pares aparecia, na verdade, de maneira informal... quando o aluno se colocava, se } \\
\text { classificava num nível no qual ele ainda não estava... e como ele estava fazendo } \\
\text { isso na frente do colega de dupla dele, esse colega acabava interferindo e } \\
\text { falando, porque ele sabe, foi ele quem desenvolveu a atividade com ele... "essa } \\
\text { parte eu que precisei te ajudar... então como você diz que fez sozinho? Não fez } \\
\text { não"... }\end{array}$ & \\
\hline $\begin{array}{l}\text { Então eles eram censores } \\
\text { deles próprios? }\end{array}$ & : isso... & \\
\hline $\begin{array}{l}\text { Uma experiência bem } \\
\text { interessante... essa negociação } \\
\text { das rubricas quanto tempo, } \\
\text { levou para vocês definirem as } \\
\text { rubricas? }\end{array}$ & $\begin{array}{l}\text { Olha... pensando que o projeto teve uns } 4 \text { a } 5 \text { meses... nós levamos de } 1,5 \text { a } 2 \\
\text { meses para desenvolve-las... na verdade foi de } 5 \text { a } 6 \text { semanas... uma aula por } \\
\text { semana, aulas de } 45 \text { minutos cada... }\end{array}$ & \\
\hline $\begin{array}{l}\text { Então levou de } 5 \text { a 6aulas para } \\
\text { essa definição final, para } \\
\text { validarem e iniciarem a } \\
\text { atividade? }\end{array}$ & $\begin{array}{l}\text { na verdade, o projeto já estava caminhando em paralelo, nós fomos definindo e } \\
\text { ajustando as rubricas ao longo do início do processo que já havia iniciado... foi } \\
\text { meio que tudo ao mesmo tempo... o projeto está caminhando... em alguns } \\
\text { momentos a gente parava aquela aula do projeto para falar de rubrica... deixava } \\
\text { de trabalhar no projeto para trabalhar um pouco mais a rubrica... então quando a } \\
\text { rubrica ficou pronta, as coisas, os níveis já estavam assimilados por eles... e aí } \\
\text { também é óbvio, né: contei com o apoio dos alunos mais velhos para poder } \\
\text { ajudar nessa questão de voltar a leitura para entender novamente a rubrica... para } \\
\text { as crianças irem se avaliando... }\end{array}$ & Quando e como ajustar as rubricas \\
\hline $\begin{array}{l}\text { Então... você disse que teve } \\
\text { de } 4 \text { a } 5 \text { meses até chegar no } \\
\text { produto final, que foi o } \mathrm{CD} \text {, } \\
\text { que foi distribuído aos pais... } \\
\text { quando você fala que } \\
\text { contextualizou um pouco... } \\
\text { até para saber o que e quanto } \\
\text { os alunos conheciam dos dois }\end{array}$ & $\begin{array}{l}\text { eu não cheguei a usar as rotinas de pensamento... para contextualizar esse } \\
\text { conteúdo, esses temas... primeiro, eu usava muito o levantamento de } \\
\text { conhecimento prévio deles sobre o tema... usava muito a questão que eu sabia } \\
\text { que esses temas, de alguma forma já estava sendo trabalhado em todas as } \\
\text { turmas... eu sabia que eles tinham pelo menos um conhecimento mínimo, sabia } \\
\text { que não vinham totalmente "vazios"... eles já traziam alguma coisa para } \\
\text { compor... e aí o trabalho foi mais de ampliação desse repertório... }\end{array}$ & \\
\hline
\end{tabular}




\begin{tabular}{|c|c|c|}
\hline $\begin{array}{l}\text { temas trabalhados, para o } 1^{\circ} \text { e } \\
2^{\circ} \text { ano, e até para você } \\
\text { trabalhar no sentido de } \\
\text { alinhar, para eles ficarem na } \\
\text { mesma página, vamos dizer } \\
\text { assim, como foi esse trabalho } \\
\text { de alinhamento? Você gerava } \\
\text { reflexão como? Você chegou } \\
\text { a usar as rotinas de } \\
\text { pensamento que o Cesar fazia } \\
\text { ou não? }\end{array}$ & & \\
\hline $\begin{array}{l}\text { Quem te ajudou nesse } \\
\text { processo: foi a professora de } \\
\text { português ou o que? Você fez } \\
\text { sozinho? }\end{array}$ & $\begin{array}{l}\text { Ahnn... essa parte eu fiz sozinho... quem me ajudou mesmo nessa parte de } \\
\text { ampliação de repertório deles foram os próprios alunos monitores nas pesquisas } \\
\text { que eles fizeram junto com as crianças... }\end{array}$ & \\
\hline $\begin{array}{l}\text { Foi você quem teve a ideia de } \\
\text { trabalhar esses temas? }\end{array}$ & Sim, porque eu já sabia que fazia parte do currículo deles & \\
\hline $\begin{array}{l}\text { Mas então não foi algo que os } \\
\text { professores tenham pedido } \\
\text { para você trabalhar, } \\
\text { especificamente? }\end{array}$ & Não & \\
\hline $\begin{array}{l}\text { Existe essa conversa com os } \\
\text { professores das disciplinas? }\end{array}$ & $\begin{array}{l}\text { Depende... teve m } 2013, \ldots \text { pérai... em } 2010 \text { uma das professoras veio com essa } \\
\text { conversa e a gente trabalhou junto, né... as vezes era só ele, as vezes era só eu, e } \\
\text { as vezes era compartilhado na informática... e aí a gente organizou e fez junto... } \\
\text { inclusive era o mesmo tema... que foi o tema parlendas, do } 1^{\circ} \text { ano... outras vezes, } \\
\text { não... então depende muito do regente da sala... }\end{array}$ & \\
\hline $\begin{array}{l}\text { Quero esmiuçar um pouco } \\
\text { mais essa parte... como é que } \\
\text { vocês fazem as colocações } \\
\text { para a crianças... como é que } \\
\text { você começa a trabalhar um } \\
\text { tema, como você começa uma } \\
\text { atividade de projeto? Como é } \\
\text { que você faz a garotada } \\
\text { participar, a querer se } \\
\text { interessar? }\end{array}$ & $\begin{array}{l}\text { :com a turma do } 1^{\circ} \text { ano que o produto final que eu tinha em mete era ao final } \\
\text { gravar um } \mathrm{CD} \text {, o que foi que eu falei para eles.... Falei o seguinte... "nós vamos } \\
\text { estudar parlendas... vocês já ouviram falar sobre parlendas? “ Aí eles começam a } \\
\text { contar desde o que são as lendas... os que tiveram menos contato... até alguém } \\
\text { começar a cantar um ou outra música... e aí quando eu vejo que alguém consegue } \\
\text { conhecer a música... ou então eu vou induzindo para isso... o que eu faço... eu } \\
\text { chamo um grupo e falo: então vamos cantar essa música... do sorvete coloré.... } \\
\text { Agora vamos cantar essa música aqui, que era uma música para pular corda.... E } \\
\text { ia contextualizando e esmiuçando com eles... para que eu canto essas músicas? } \\
\text { Eu canto essa música para alguém ouvir e ficar emocionado, porque essa música } \\
\text { é muito bonita? Para que eu canto isso? E aí eles começam a dar sugestões... uma }\end{array}$ & $\begin{array}{l}\text { 1. Gestão Compartilhada da Comunicação: a. Ação } \\
\text { comunicativa; b. Apropriação e manejo das linguagens } \\
\text { da comunicação; c. Uso dos recursos da informação } \\
\text { para a produção cultural. } \\
\text { 2. Participações de Protagonismo: a. Participação planejadora } \\
\text { e operacional; b. Participação decisória, planejadora e } \\
\text { operacional; c. Participação decisória, planejadora, } \\
\text { operacional e avaliadora; d. Participação colaborativa plena; } \\
\text { e. Participação plenamente autônoma; f. Participação } \\
\text { condutora. }\end{array}$ \\
\hline
\end{tabular}




\begin{tabular}{|c|c|c|}
\hline & $\begin{array}{l}\text { fala daqui o outro fala dali... e acaba saindo de alguém que a música é para } \\
\text { brincar... então é uma música para eu começar uma brincadeira, para eu pular } \\
\text { corda, música para eu fazer roda e ficar batendo na mão... e aí eu lanço uma } \\
\text { ideia, que é a seguinte... "e se a gente fizesse um CD, igual aqueles de cantor } \\
\text { famoso, que toca no rádio, vão tocar no rádio de vocês, vocês vão ficar todos } \\
\text { famosos e fizessem um CD com essas músicas, com essas parlendas? " Aí eles já } \\
\text { se animam porque vai fazer um CD, vai ficar famoso, vai tocar no rádio... "mas } \\
\text { para fazer isso, nós temos que ver.... será que a gente já tem } 10 \text { músicas? } 20 \\
\text { músicas? Será que temos música suficiente para montar um CD? " e aí eles se } \\
\text { deparam que não tem tudo isso de música, de parlenda para começar... porque às } \\
\text { vezes eles começam a cantar uma cantiga e logo vão dizendo... "ahn... então, } \\
\text { esse não é"... "não é esse tipo de música que vai no nosso CD”... então quando } \\
\text { eles percebem eu eles precisam conhecer, saber mais músicas desse tipo, aí a } \\
\text { dinâmica já vai meio que no automático... eles vão procurar saber mais } \\
\text { músicas... eles começam a procurar mais músicas... e fica esse convite... é a } \\
\text { necessidade de nós conhecermos mais músicas para poder colocar no nosso CD }\end{array}$ & $\begin{array}{l}\text { 3. Ações de Diálogo: a. Escuta mútua; b. Pensar juntos; } \\
\text { c. Apontar outros pontos de vista; d. Compartilhar e } \\
\text { refletir sobre ideias; e. Fazer emergir ideias / buscar } \\
\text { pluralidade de ideias } \\
\text { 4. Relações entre as pessoas nos ambientes do LIE, } \\
\text { para criação de um novo ecossistema comunicativo. }\end{array}$ \\
\hline $\begin{array}{l}\text { : quando eles começavam } \\
\text { com esse processo de falar, } \\
\text { “olha essa música aqui”... } \\
\text { quem é que falava se estava } \\
\text { certa ou errada... era você ou } \\
\text { eram os próprios colegas? }\end{array}$ & $\begin{array}{l}\text { não, aí era eu que falava porque uma das coisas que eu observo é que mesmo os } \\
\text { professores lá de primeiro ano, eles tem dificuldade de compreender a diferença } \\
\text { entre parlenda e cantiga... então... vários deles classificam tudo da mesma } \\
\text { forma... e no currículo deles, pelo menos até então da prefeitura, trabalha-se o } \\
\text { gênero parlendas no primeiro ano, e cantigas no segundo ano... então, assim, eu } \\
\text { ficava muito preocupado em já de uma maneira mais lúdica e didática, que eles } \\
\text { já compreendessem, que não ficasse nada assim profético, de eu ficar falando e } \\
\text { eles ouvindo... mas principalmente que eles entendessem a diferença entre os } \\
\text { dois... então quando vinha uma cantiga, eu colocava um grupinho e falava... } \\
\text { "então vamos brincar dessa cantiga, vem cá que eu vou ensinar como brinca"... } \\
\text { então geralmente cantiga você tem... mãos dadas, vai dando a volta, sempre a } \\
\text { roda em movimento, um abaixa... então é uma coisa mais estática... sempre ali } \\
\text { no conjunto da roda... já na parlenda, temos mais opções de disposição dos } \\
\text { participantes... até quando faz a roda, temos um batendo na mão do outro... } \\
\text { pulando, descendo, nã nã nã... quando é para pular corda, está pulando corda... } \\
\text { quando é cantiga para começar uma brincadeira, já é outra estória... aí eles } \\
\text { começaram a perceber a diferença da parlenda para a cantiga... então, depois } \\
\text { dessa dramatização que a gente pergunta... "Então, é a mesma coisa?"... "ahn, } \\
\text { então, não é”... então a que nós vamos cantar este ano é esta daqui... e como } \\
\text { tinha um currículo da informática, já que eu dava aula do primeiro até o nono } \\
\text { ano... então eu deixava para o segundo ano, um trabalho similar a esse com } \\
\text { relação a cantigas... }\end{array}$ & $\begin{array}{l}\text { 1. Gestão Compartilhada da Comunicação: a. Ação } \\
\text { comunicativa; b. Apropriação e manejo das linguagens } \\
\text { da comunicação; c. Uso dos recursos da informação } \\
\text { para a produção cultural. } \\
\text { 2. Participações de Protagonismo: a. Participação planejadora } \\
\text { e operacional; b. Participação decisória, planejadora e } \\
\text { operacional; c. Participação decisória, planejadora, } \\
\text { operacional e avaliadora; d. Participação colaborativa plena; } \\
\text { e. Participação plenamente autônoma; f. Participação } \\
\text { condutora. } \\
\text { 3. Ações de Diálogo: a. Escuta mútua; b. Pensar juntos; } \\
\text { c. Apontar outros pontos de vista; d. Compartilhar e } \\
\text { refletir sobre ideias; e. Fazer emergir ideias / buscar } \\
\text { pluralidade de ideias } \\
\text { 4. Relaçães entre as pessoas nos ambientes do LIE, } \\
\text { para criação de um novo ecossistema comunicativo. }\end{array}$ \\
\hline
\end{tabular}




\begin{tabular}{|c|c|c|}
\hline $\begin{array}{l}\text { Então, primeiro você brincava } \\
\text { com as crianças e ia } \\
\text { dramatizando para poder } \\
\text { chamar a atenção... então você } \\
\text { ia fazendo uma aproximação } \\
\text { da teoria com a prática, e } \\
\text { mostrando para eles o que era } \\
\text { o que? }\end{array}$ & $\begin{array}{l}\text { : isso porque você só ficar lá cantando e vai para o } \mathrm{CD} \text {, não é para isso que serve } \\
\text { a parlenda, né... a parlenda não serve só para ir par ao CD ficar ouvindo... Ela } \\
\text { serve para brincar... }\end{array}$ & \\
\hline $\begin{array}{l}\text { E aí você ia estimulando isso } \\
\text { para eles, ia fazendo até eles } \\
\text { começarem a ter essa } \\
\text { consciência para aí então } \\
\text { poder fixar melhor o tema }\end{array}$ & $\begin{array}{l}\text { : isso... e quando a gente começava a brincar com parlendas e quando eles } \\
\text { entendiam o que era uma parlenda, eles começavam a trazer outras, que fazem } \\
\text { parte do universo deles, que outras vezes eles até brincavam em casa ou na } \\
\text { escola e nem sabiam o que era... }\end{array}$ & \\
\hline $\begin{array}{l}\text { Então, eles começavam a } \\
\text { brincar e você ia fazendo as } \\
\text { intervenções para eles } \\
\text { perceberem o que era o quê... } \\
\text { e tudo mais... e depois eles } \\
\text { passaram a ser mais proativos, } \\
\text { no sentido de trazer exemplos } \\
\text { ou você que estimulou } \\
\text { também? }\end{array}$ & $\begin{array}{l}\text { foram as duas opções... aquele que queria, trazia um exemplo e aí eu elogiava } \\
\text { ele, colocava, olha que legal que ele trouxe mais um exemplo, ... se alguém tiver } \\
\text { mais, pode trazer também... eu orientava alguns para olhar no caderno de apoio, } \\
\text { que era o que eles usavam na sala de aula com o professor, porque lá tinha mais } \\
\text { exemplos... e também a pesquisa na internet... e aí parlenda é muito difícil de } \\
\text { você encontrar cantada, por exemplo, no Youtube... então, muitos alunos } \\
\text { monitores achavam as parlendas mesmo por escrito, com imagens... então era } \\
\text { nas imagens... ai o aluno monitor começava a pesquisar... às vezes, nem o aluno } \\
\text { monitor conhecia a parlenda... então ai gente cantava como seria aquilo... como } \\
\text { que brincava... começava a criar sentidos para e com eles... e aí a ideia era a } \\
\text { seguinte... o aluno do primeiro ano, por exemplo, ele não estava ali propriamente } \\
\text { "pesquisando"... mas ele estava vivenciando aquilo, o monitor desenvolvia a } \\
\text { pesquisa conversando com ele, mostrando como que a gente faz para pesquisar, } \\
\text { como que ele buscava e via as coisas, selecionava minimamente na internet... } \\
\text { isso vai dando subsídios para ele, para quando chegar no segundo ano, quando eu } \\
\text { fizer um trabalho similar com cantigas, ele já terá alguns elementos melhor } \\
\text { constituídos que servirão de referência para ele... }\end{array}$ & $\begin{array}{l}\text { 1. Gestão Compartilhada da Comunicação: a. Ação } \\
\text { comunicativa; b. Apropriação e manejo das linguagens } \\
\text { da comunicação; c. Uso dos recursos da informação } \\
\text { para a produção cultural. } \\
\text { 2. Participações de Protagonismo: a. Participação planejadora } \\
\text { e operacional; b. Participação decisória, planejadora e } \\
\text { operacional; c. Participação decisória, planejadora, } \\
\text { operacional e avaliadora; d. Participação colaborativa plena; } \\
\text { e. Participação plenamente autônoma; f. Participação } \\
\text { condutora. } \\
\text { 3. Ações de Diálogo: a. Escuta mútua; b. Pensar juntos; } \\
\text { c. Apontar outros pontos de vista; d. Compartilhar e } \\
\text { refletir sobre ideias; e. Fazer emergir ideias / buscar } \\
\text { pluralidade de ideias } \\
\text { 4. Relações entre as pessoas nos ambientes do LIE, } \\
\text { para criação de um novo ecossistema comunicativo. }\end{array}$ \\
\hline $\begin{array}{l}\text { A rubrica, vocês iam } \\
\text { lembrando delas durante o } \\
\text { processo, ou vocês só } \\
\text { recuperaram a rubrica no final } \\
\text { da atividade? }\end{array}$ & $\begin{array}{l}\text { então, uma vez constituída a rubrica... porque assim, o projeto ... na verdade eu } \\
\text { sempre digo que eu nunca consigo fazer aquilo que o Cesar dizia de fazer a } \\
\text { rubrica antes... acaba começando o trabalho para depois ir montando a rubrica... } \\
\text { então, assim, uma vez montada a rubrica, em alguns momentos a gente parava, } \\
\text { nem que fosse para nesse momento, que poderia ser um momento intermediário, } \\
\text { para não ficar toda hora registrando... mas fazíamos uma pausa pelo menos para } \\
\text { lermos e destacar "o ponto de ônibus que a gente precisa chegar"... e olha o que }\end{array}$ & \\
\hline
\end{tabular}




\begin{tabular}{|c|c|c|}
\hline & $\begin{array}{l}\text { vocês estão fazendo... vocês acham que estão perto desse ponto? Vocês estão } \\
\text { longe desse ponto? }\end{array}$ & \\
\hline $\begin{array}{l}\text { e quem fazia esses breves } \\
\text { verificações e intervenções: } \\
\text { era você ou era o aluno } \\
\text { monitor junto com eles, ou } \\
\text { eram os dois? }\end{array}$ & $\begin{array}{l}\text { Essa intervenção geral de ficar lembrando onde eles tinham que chegar era eu... } \\
\text { aqui era mais uma reflexão... e quando era o apontamento, quando era mesmo a } \\
\text { autoavaliação, aí o aluno monitor ajudava... }\end{array}$ & \\
\hline $\begin{array}{l}\text { Aí ele ia ouvindo cada um? } \\
\text { Os alunos monitores te } \\
\text { ajudavam nesse sentido, de } \\
\text { uns ouvirem alguns grupos e } \\
\text { outros ouviam outros grupos? }\end{array}$ & $\begin{array}{l}\text { Isso nós dividíamos o grupo e íamos ouvindo as autoavaliações, de dupla em } \\
\text { dupla... }\end{array}$ & \\
\hline $\begin{array}{r}\text { Você falou... quantos alunos } \\
\text { monitores te ajudaram? }\end{array}$ & No ano passado eu tinha uns 5 a 6 alunos monitores... & \\
\hline $\begin{array}{l}\text { Nas } 2 \text { escolas, para os } 2 \text { anos, } \\
\text { eram os mesmos alunos } \\
\text { monitores? }\end{array}$ & Não ... eram alunos da própria escola... & \\
\hline $\begin{array}{l}\text { O que eu quis dizer é.... o } \\
\text { aluno monitor atendia com } \\
\text { vocês todas as turmas? Ou ele } \\
\text { mudava conforme a série com } \\
\text { quem você } \\
\text { trabalhando? }\end{array}$ & Ahn... entendi... eles atendiam todos as series comigo... & \\
\hline $\begin{array}{l}\text { Então quantos em cada } \\
\text { escola? }\end{array}$ & $\begin{array}{l}\text { Foram } 6 \text { alunos em uma escola e } 6 \text { alunos em outra escola... } \\
\text { Eu atendia por bloco... então atendia primeiro ano de manhã e tarde... esses dias } \\
\text { que eu tinha muitas crianças pequenas, eram os dias que eu mobilizava mais } \\
\text { alunos monitores para estarem comigo, me dando apoio em atividade com eles... } \\
\text { porque eu sabia que precisaria desse apoio... }\end{array}$ & \\
\hline $\begin{array}{l}\text { Você falou que não fez o } \\
\text { registro, né?... E quando você } \\
\text { fez na navegação orientada, } \\
\text { porque eu não participei dessa } \\
\text { navegação... depois eu vou } \\
\text { recuperar essa navegação... }\end{array}$ & $\begin{array}{l}\text { Então, no EdModo, com o } 1^{\circ} \text { e } 2^{\circ} \text { ano eu não fiz registro... eu tinha feito no TQ } \\
\text { antes... no EdModo eu não fiz... então trabalho ficou bem fora da proposta do } \\
\text { Cesar... até porque foi um ano bem complicado por causa da falta de acesso à } \\
\text { internet... isso no ano passado... por conta do plano A, B e C.... eu fiquei } \\
\text { aplicando o plano E direto... porque sempre tinha algum problema com relação à } \\
\text { internet... }\end{array}$ & Os problemas de infraestrutura \\
\hline
\end{tabular}


Outros projetos, com a Cris... explicando... como você fazia os feedbacks? Eram essas intervenções suas? Os alunos monitores também davam feedback? Ou você ia explicando e lembrava da questão da rubrica

Então era o aluno monitor e os dois... ou você e os dois.. ou vocês 4 ?

\begin{tabular}{l} 
\\
\hline $\begin{array}{l}\text { O atendimento demorado que } \\
\text { você fala, era de quanto } \\
\text { tempo, em média? }\end{array}$ \\
\hline $\begin{array}{l}\text { : e sempre aquela coisa de } \\
\text { um... quando você fala } \\
\text { dialógico... de um ouvindo o } \\
\text { outro, dando resposta, } \\
\text { questionando e você percebia } \\
\text { que mesmo nessa idade que } \\
\text { eles refletiam minimamente } \\
\text { sobre isso... }\end{array}$ \\
\hline
\end{tabular}

isso... isso durante o processo... e ai quando tinha aquele momento de avaliação com base na rubrica, em determinados momentos, que aí era para sentar e eu registrar mesmo, não era apenas uma reflexão para resgate... o que acontecia... eles vinham, eu já tinha me organizado com os monitores... deixávamos todos fazendo uma atividade autônoma, diferente, que não tinha relação com esse projeto maior... e íamos chamando as duplas... e nesse momento, nós retomávamos com eles a rubrica, onde que cada um estava... então um falava... ah eu estou aqui... e nós respondíamos... ah, tá... você acha que está aqui... então vamos lá, vamos fazer o check lista... você fez isso, fez isso, fez aquilo, você já consegue fazer esta parte? ... Ahn, isso eu não consegui... Ahn... então eu acho que não sou esse ... sou um pouco menos... um pouco mais para trás... ou não... Ahn eu consigo fazer isso sozinho... então às vezes ele até se colocava como menos e era para mais... então eles diziam assim... era muito no dialógico, de 2 em $2 \ldots$

Na verdade, éramos todos juntos... como eram 6 monitores mais eu... então numa rodada a gente atendia 14 crianças... 7 duplas... que iam vindo de 2 em 2, para serem atendidos por cada um da nossa equipe... só que eram atendimentos demorados por isso... porque a gente verificava com eles se tinham feito tudo o que o nível no qual se encaixaram dizia... tínhamos que ler com eles, conversar com eles... para verificar mesmo em que parte estavam, até onde tinham conseguido chegar..

olha, eu acho que mais ou menos uns 15 minutos por grupo, conversando com eles..

: isso... isso eles conseguiam pensar bem... é o que eu falo... às vezes eles até se julgavam menos do que eles estavam ... e daí conversando... você consegue fazer isso? Já, eu consigo... consegue fazer aquilo... faço também... você sabe qual o desenho que eu encontro para gravar? Sei... Ahn... então você acha que você ainda está aqui, se você já sabe tudo isso?
1. Gestão Compartilhada da Comunicação: a. Ação comunicativa; b. Apropriação e manejo das linguagens da comunicação; c. Uso dos recursos da informação para a produção cultural.

2. Participações de Protagonismo: a. Participação planejadora e operacional; b. Participação decisória, planejadora e operacional; c. Participação decisória, planejadora, operacional e avaliadora; d. Participação colaborativa plena; e. Participação plenamente autônoma; f. Participação condutora.

3. Ações de Diálogo: a. Escuta mútua; b. Pensar juntos; c. Apontar outros pontos de vista; d. Compartilhar e refletir sobre ideias; e. Fazer emergir ideias / buscar pluralidade de ideias

4. Relações entre as pessoas nos ambientes do LIE para criação de um novo ecossistema comunicativo. 


\begin{tabular}{|c|c|c|}
\hline $\begin{array}{l}\text { relação a autoavaliação, você } \\
\text { acha que isso ajuda nesse } \\
\text { processo de organizar essa } \\
\text { gestão da comunicação? }\end{array}$ & $\begin{array}{l}\text { processo ... então eu acho que você tendo esses registros de processo... e ai tem a } \\
\text { avaliação por rubrica como uma delas, você m mais elementos para voltar e } \\
\text { observar como aquilo como foi que evoluiu, você tem clareza, se está no } \\
\text { caminho certo, se poderia mexer de outro jeito... então quando o aluno me } \\
\text { responde que está num nível, eu já anotei e guardei... eu guardei para que em } \\
\text { outro momento eu resgate e me lembre de onde ele estava no início ... eu posso } \\
\text { ver isso e lembrar com cuidado... olhar e refletir... será que estou sendo claro... } \\
\text { ou será que estou sendo claro só para mim? }\end{array}$ & \\
\hline $\begin{array}{l}\text { Então o próprio uso da rubrica } \\
\text { começou a fazer você ficar } \\
\text { mais atento ao seu processo } \\
\text { comunicacional com os } \\
\text { alunos? }\end{array}$ & $\begin{array}{l}\text { : isso... porque até então a gente dava uma atividade qualquer, com alguma } \\
\text { avaliação, mas eu não encarava muito com muita dialogicidade... era tarefa... } \\
\text { faziam, eu recolhia... analisava... sem conversa alguma com os alunos... estava } \\
\text { ali no papel... era só o que eu analisava... e à medida que fui adotando e fazendo } \\
\text { a rubrica... fui conversando com os alunos sobre isso... aí você começa a criar } \\
\text { esse habito de conversar com os alunos... de ouvir os alunos... então ás vezes até } \\
\text { assim... numa avaliação de matemática, eles vão lá e fazem... resolvam uma } \\
\text { situação problema e me tragam a resposta que vou olhar que está errado... } \\
\text { naquele momento da prova mesmo, eu peço... Ahn encosta aqui do meu lado... } \\
\text { me conta o que você fez aqui... ah, eu fiz isso isso isso... fui por aqui... então eu } \\
\text { começo a entender o pensamento dele, do raciocínio dele... coisa que até um } \\
\text { tempo atrás eu não dava valor... porque eu julgava apenas o que estava escrito } \\
\text { ali, como certo ou errado... e as vezes a resposta parece muito absurda, muito } \\
\text { errada, mas se eu paro para olhar, se eu peço para contar o que ele pensou, que } \\
\text { ele foi tentando escrever ali, vai me dando mais clareza... e é aí que eu faço a } \\
\text { intervenção... Ahn.. Você pensou isso, mas é isso aqui que você pensou? Por que } \\
\text { você foi por esse caminho? Escreve aí, me explica... pode escrever mesmo, } \\
\text { explicando... conta para mim o que você pensou porque aqui não está claro... } \\
\text { então eu começo a apurar isso... aí eu começo a perceber que boa parte do } \\
\text { raciocínio estava correta mas se não conversasse estaria tudo errado... }\end{array}$ & $\begin{array}{l}\text { 1. Gestão Compartilhada da Comunicação: a. Ação } \\
\text { comunicativa; b. Apropriação e manejo das linguagens } \\
\text { da comunicação; c. Uso dos recursos da informação } \\
\text { para a produção cultural. } \\
\text { 2. Participações de Protagonismo: a. Participação planejadora } \\
\text { e operacional; b. Participação decisória, planejadora e } \\
\text { operacional; c. Participação decisória, planejadora, } \\
\text { operacional e avaliadora; d. Participação colaborativa plena; } \\
\text { e. Participação plenamente automo; f. Participação } \\
\text { condutora. } \\
\text { 3. Ações de Diálogo: a. Escuta mútua; b. Pensar juntos; } \\
\text { c. Apontar outros pontos de vista; d. Compartilhar e } \\
\text { refletir sobre ideias; e. Fazer emergir ideias / buscar } \\
\text { pluralidade de ideias } \\
\text { 4. Relações entre as pessoas nos ambientes do LIE, } \\
\text { para criação de um novo ecossistema comunicativo. }\end{array}$ \\
\hline $\begin{array}{l}\text { Ou seja, você tem que ter uma } \\
\text { boa comunicação para ser } \\
\text { professor? Aquilo que PF } \\
\text { falava que educar é } \\
\text { comunicar... }\end{array}$ & $\begin{array}{l}\text { É isso... e eu acho que cada vez mais força muito esse enfoque nas falas da } \\
\text { avaliação formativa....na formação continuada eles reforçam sempre: nós temos } \\
\text { que dar ouvidos e voz aos alunos... temos que dar mais ouvidos aos alunos... } \\
\text { temos que falar menos e temos que ouvir mais o que eles têm par anos dizer em } \\
\text { sala de aula }\end{array}$ & \\
\hline $\begin{array}{l}\text { Você teve muita dificuldade } \\
\text { para fazer esse processo, de }\end{array}$ & $\begin{array}{l}\text { então, acho que tranquilo nunca é... porque a gente já vem com algumas coisas } \\
\text { sedimentadas, querendo ou não... em alguns momentos a gente avança, em }\end{array}$ & $\begin{array}{l}\text { Fazer a reflexão contínua é papel do educomunicador! } \\
\text { 1. Gestão Compartilhada da Comunicação: a. Ação }\end{array}$ \\
\hline
\end{tabular}


sair desse modelo mais bancário, para um modelo mais dialógico? Como foi ou está sendo esse processo para você

Você acha, então que com a avaliação somativa, ele não consegue ter essa dimensão com a avaliação formativa quando ele tem mais comunicação, em que o próprio processo comunicativo estimula mais o processo reflexivo, pensamento crítico? outras recuamos um pouco... eu sempre acho que estou o bam bam bam... aí eu ouço um pouco o Cesar e acabo achando que tenho que voltar para o nível 0 de novo... eu acho que é esse o processo... na medida que a gente toma consciência do quanto estamos inacabados, mais a gente se permite se abrir para o outro, procurando melhorar... então acho que sair daquele modelo que só corrige certo e errado e migrar para esta nova proposta que no meio da prova, você começa a problematizar, perguntar... nem parece que é uma prova, né?...fica mais dialogando em cima de algo, conversando sobre uma reflexão, um pensamento, e dando qualidade para aquilo, ... eu acho que não é um processo tranquilo... eu acho que é um processo em que você dá 3 passos para a frente e 1 para trás... e isso você tem que entender como normal, e que o seu foco é a construção, é caminhar para a frente... em busca do horizonte... e acho que inclusive, não é fácil porque você está num meio ... eu não estou falando aqui de um meio acadêmico, das teorias, que me dão subsídios... Mas um meio pratico, do dia a dia, que isso considera facilitar a vida do aluno, eles consideram você estar dando respostas e eles não percebem que você não está dando resposta, mas que está problematizando e fazendo eles pensarem sobre o tema em estudo, permitindo que ele visualize o que ele já sabe e que construa a partir dali... e que visualize e perceba o que ele ainda precisa aprender e ir atrás...

eu acho que sim porque na somativa, o que me interessa são apenas alguns pontos... eu sou 10, parece que eu sei tudo... e de repente eu simplesmente decorei tudo... ou é algo que eu gosto e me identifiquei... eu somei 1 e parece que eu não sei nada... mas de repente eu não estava bem, estava nervoso ou aquele ponto realmente não ficou muito claro para mim... e muitas vezes nessa avaliação somativa, muito embora pega, volta retoma, muitas vezes você só quer ir para frente no conteúdo e o aluno que se vire para aprender... você quer o 1 , vai para o $2 \ldots$ e num processo com essa abordagem fica muito visível o que eu preciso melhorar... porque vai... eu tirei $7 \ldots$ mas o que eu precisava para tirar 10 ? Era só acertar essas 3 perguntas... será que avaliar conhecimento se resume a acertar ou errar questões cujas repostas podem ser decoradas? Por que eu precisava de mais conhecimento ali? Qual a diferença de um 8 para um 9? Que as vezes é a diferença do $\mathrm{S}$ para o $\mathrm{P}$... então quando vamos para essa abordagem mais formativa... e isso é o que estou tentando melhorar na questão das rubricas... que é me antecipar desde o início sobre o que eu faço... eu deixo claro ali na mesa ... e aí vai da maturidade da turma... estamos falando de um $1^{\circ}$ ano mas às vezes ele é bem coerente e maduro para algumas conversas, leva a sério a aprendizagem... mesmo na formação das rubricas e no entendimento delas... então quando eu deixo claro desde o início qual o caminho, o que eu pretendo comunicativa; b. Apropriação e manejo das linguagens da comunicação; c. Uso dos recursos da informação para a produção cultural.

2. Participações de Protagonismo: a. Participação planejadora eperacional; b Participação decisória, planejadora e operacional; c. Participação decisória, planejadora operacional e avaliadora; d. Participação colaborativa plena e. Participação plenamente autônoma; f. Participação condutora.

3. Ações de Diálogo: a. Escuta mútua; b. Pensar juntos c. Apontar outros pontos de vista; d. Compartilhar e refletir sobre ideias; e. Fazer emergir ideias / buscar pluralidade de ideias

4. Relações entre as pessoas nos ambientes do LIE para criação de um novo ecossistema comunicativo.

1. Gestão Compartilhada da Comunicação: a. Ação comunicativa; b. Apropriação e manejo das linguagens da comunicação; c. Uso dos recursos da informação para a produção cultural.

2. Participações de Protagonismo: a. Participação planejadora e operacional; b. Participação decisória, planejadora e operacional; c. Participação decisória, planejadora, operacional e avaliadora; d. Participação colaborativa plena; e. Participação plenamente autônoma; f. Participação condutora.

3. Ações de Diálogo: a. Escuta mútua; b. Pensar juntos; c. Apontar outros pontos de vista; d. Compartilhar e refletir sobre ideias; e. Fazer emergir ideias / buscar pluralidade de ideias

4. Relações entre as pessoas nos ambientes do LIE para criação de um novo ecossistema comunicativo. 


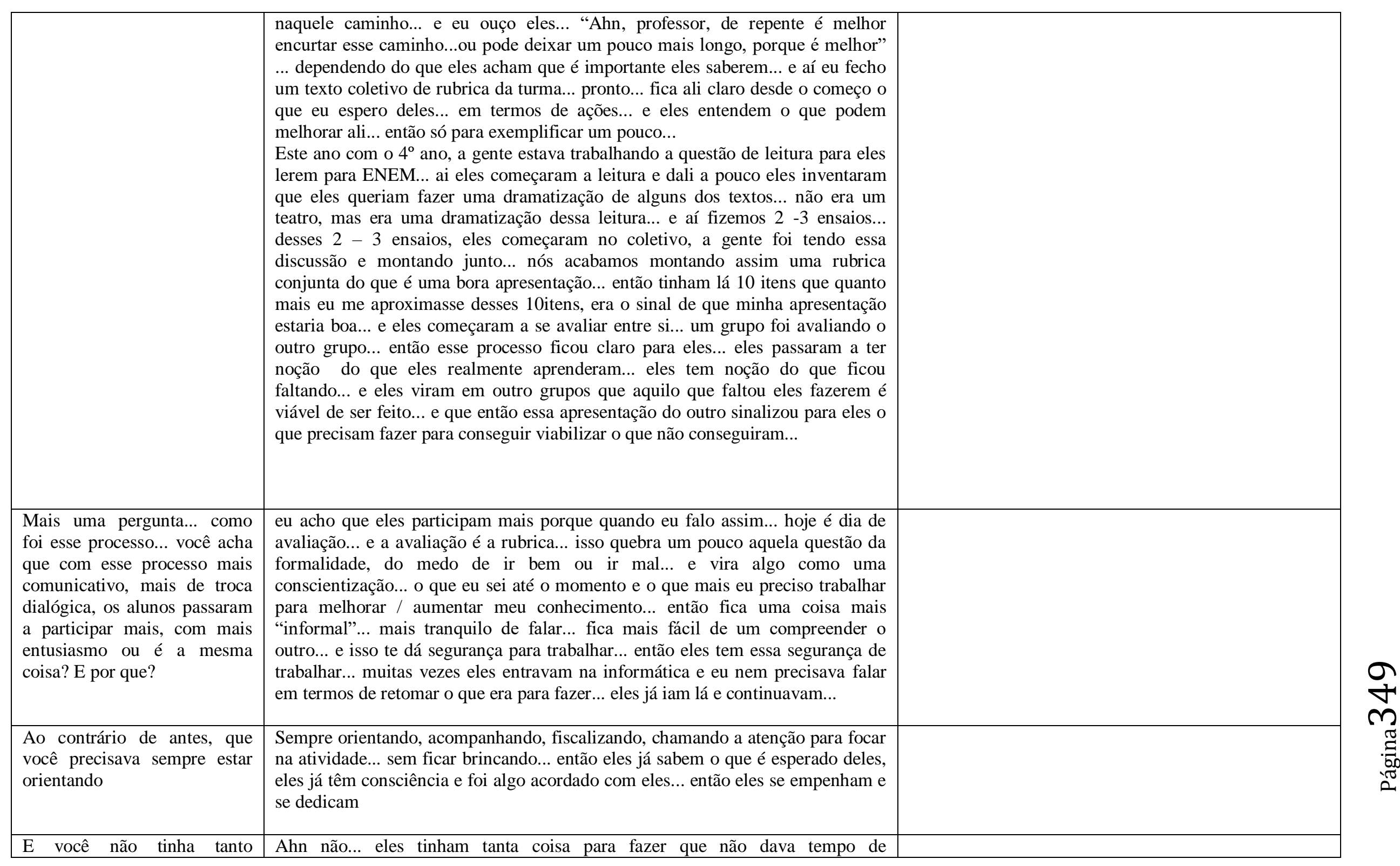




\begin{tabular}{|c|c|c|}
\hline $\begin{array}{l}\text { problema inclusive com } \\
\text { disciplina porque eles estavam } \\
\text { mais focados com a realização } \\
\text { da tarefa. }\end{array}$ & indisciplina... & \\
\hline \multicolumn{3}{|l|}{ Coisa que não acontecia antes } \\
\hline $\begin{array}{l}\text { Quando eles começam a } \\
\text { responder e à medida que eles } \\
\text { vão participando, como você } \\
\text { dá o feedback? Como são as } \\
\text { suas intervenções? }\end{array}$ & $\begin{array}{l}\text { Na medida que eles vão respondendo... sempre a maior problematização que eu } \\
\text { vou traçando com eles é assim... muitas vezes, eles colocam uma resposta que é } \\
\text { muito curta que falta informação... então eu não só convido eles a lerem de novo, } \\
\text { como eu leio para eles... porque é aquela coisa... às vezes eles leem e acham que } \\
\text { está tudo muito claro... então eu falo ali no tom da resposta que eles } \\
\text { apresentaram... e a partir daí eu começo a fazer perguntas... quando eu pergunto } \\
\text { se deu para entender, eles respondem... Ahn deu... então me explica aqui onde } \\
\text { que está tal coisa... que eu não consegui entender... você falou mas aqui na sua } \\
\text { explicação eu não entendi... então explique para mim... tem outra pessoa que vai } \\
\text { assistir isso e ela também em que entender... então eles começam a criar } \\
\text { feedbacks na questão da organização pessoal no fim dessa comunicação, de te } \\
\text { mais cuidado nessa escrita, na forma como apresentam suas justificativas e } \\
\text { explicações... eles se preocupam muito com a questão ortográfica mas não se } \\
\text { preocupam com a questão de deixar claro para o outro o que está sendo escrito } \\
\text { ali... }\end{array}$ & $\begin{array}{l}\text { 1. Gestão Compartilhada da Comunicação: a. Ação } \\
\text { comunicativa; b. Apropriação e manejo das linguagens } \\
\text { da comunicação; c. Uso dos recursos da informação } \\
\text { para a produção cultural. } \\
\text { 2. Participaçães de Protagonismo: a. Participação planejadora } \\
\text { e operacional; b. Participação decisória, planejadora e } \\
\text { operacional; c. Participação decisória, planejadora, } \\
\text { operacional e avaliadora; d. Participação colaborativa plena; } \\
\text { e. Participação plenamente autônoma; f. Participação } \\
\text { condutora. } \\
\text { 3. Ações de Diálogo: a. Escuta mútua; b. Pensar juntos; } \\
\text { c. Apontar outros pontos de vista; d. Compartilhar e } \\
\text { refletir sobre ideias; e. Fazer emergir ideias / buscar } \\
\text { pluralidade de ideias } \\
\text { 4. Relações entre as pessoas nos ambientes do LIE, } \\
\text { para criação de um novo ecossistema comunicativo. }\end{array}$ \\
\hline $\begin{array}{l}\text { Aí eles começam a rever o } \\
\text { próprio processo de } \\
\text { pensamento deles... }\end{array}$ & $\begin{array}{l}\text { E como é um trabalho em grupo, sempre tem aquele lá... são um trabalho em } \\
\text { grupo, mas está usando um computador, está usando } 2 \text { computadores... então é } \\
\text { assim, quem está do lado, está olhando o que está acontecendo, está vendo o que } \\
\text { o outro está escrevendo para dar esse parâmetro mínimo de entendimento... se } \\
\text { está dando para entender ou não... }\end{array}$ & \\
\hline $\begin{array}{l}\text { Esses grupos têm brigas entre } \\
\text { eles? }\end{array}$ & $\begin{array}{l}\text { Ahn... tem mais na questão de execução das tarefas... os maiores dão mais } \\
\text { trabalho que os menores nessa questão... são um que não está fazendo e precisa } \\
\text { de ajuda... outro que está fazendo sozinho e não está deixando eu participar... os } \\
\text { problemas são mais nessa linha a questão dos conflitos entre eles. }\end{array}$ & \\
\hline
\end{tabular}




\begin{tabular}{|c|c|c|}
\hline & $\begin{array}{l}\text { De ideias, eles se ouvem bem uns aos outros... até porque muitas vezes eles têm } \\
\text { um pensamento mais comum entre eles... }\end{array}$ & \\
\hline $\begin{array}{l}\text { E eles fizeram algum registro } \\
\text { disso? Onde foi? }\end{array}$ & $\begin{array}{l}\text { As pesquisas eles fizeram no Word... em termos de rascunho... e depois } \\
\text { montaram os vídeos... a parte do tema que escolheram, eu fiz no Google drive... } \\
\text { e a avaliação por rubricas, também eles fizeram no Google drive... }\end{array}$ & \\
\hline Você não gosta dele? & $\begin{array}{l}\text { eu falo para o Cesar que quem usou o TQ tem dificuldade de usar o EdModo... } \\
\text { tenho muita dificuldade de usar... eu não sei se é uma especificidade das minhas } \\
\text { escolas... ele carrega na internet... então eu estou trabalhando com todo mundo } \\
\text { no EdModo... ai todo mundo entrou... daí a pouco tem } 10 \text { computadores que } \\
\text { perderam a conexão... ai dos } 10 \text { que ainda tinham conexão } 5 \text { param de } \\
\text { funcionar... então começa a aparecer muito ruído na aula... esse problema acaba } \\
\text { virando foco e o trabalho não vai para a frente... para as crianças de fund. } 1 \text { e } \\
\text { fund. 2, precisa de um ambiente mais lúdico que chame a atenção... que seja } \\
\text { agradável... por isso eu digo que sou viúva do ThinkQuest porque ele dava uma } \\
\text { organização melhor e mais lúdica para esses alunos... ele não deixa a tela cheia... } \\
\text { não dá aquele impacto cheio de coisa para ler... dá para ir colocando ilustração, } \\
\text { em meio a uma pergunta... tem lugar para responder... dá para deixar tudo } \\
\text { organizado e de fácil localização... fica fácil dos alunos consultarem e } \\
\text { localizarem... são bastante intuitivo... então eu nem estou dizendo que eles } \\
\text { tenham dificuldade com o EdModo... eu estou dizendo que eu tenho... }\end{array}$ & \\
\hline $\begin{array}{l}\text { Como é que foi } \\
\text { autoavaliação deles? }\end{array}$ & $\begin{array}{l}\text { Foi um processo bem interessantes porque o primeiro a ser, ... ao considerarem } \\
\text { os níveis, eles já começaram a querer se jogar para o alto... eu nem estou } \\
\text { participando, ajudando, contribuindo tanto, mas quero ser o bam bam bam da } \\
\text { rubrica... eu me coloco já no nível } 4 \ldots \text { Mas quando eu tenho a dimensão que os } \\
\text { outros vão te avaliar, foi aí que eles começaram a ficar com a pulga atrás da } \\
\text { orelha... ou seja, não adianta eu falar que eu sou melhor de todos, se quando eu } \\
\text { for ler o nível de avaliação eles começarem a dizer que eu não fiz nada do que eu } \\
\text { disse que fiz... e as outras } 5 \text { pessoas do grupo me avaliarem no nível la abaixo... } \\
\text { porque na verdade você não ajudou... e aí o que eu faço... quem está com a } \\
\text { razão? Você fez tudo tudo tudo... ou o seu grupo que está te avaliando direito... } \\
\text { daí eles começaram a pensar nessa perspectiva... e aí nisso como não é uma coisa } \\
\text { assim que vá implicar em repetência... que tem punição... eles fazem com mais } \\
\text { tranquilidade e se conscientizam sobre o que precisam realmente melhorar... } \\
\text { assim a aprendizagem toma o primeiro lugar... e aí vira mesmo ferramenta de } \\
\text { aprendizagem... }\end{array}$ & $\begin{array}{l}\text { 1. Gestão Compartilhada da Comunicação: a. Ação } \\
\text { comunicativa; b. Apropriação e manejo das linguagens } \\
\text { da comunicação; c. Uso dos recursos da informação } \\
\text { para a produção cultural. } \\
\text { 2. Participações de Protagonismo: a. Participação planejadora } \\
\text { e operacional; b. Participação decisória, planejadora e } \\
\text { operacional; c. Participação decisória, planejadora, } \\
\text { operacional e avaliadora; d. Participação colaborativa plena; } \\
\text { e. Participação plenamente autônoma; f. Participação } \\
\text { condutora. } \\
\text { 3. Ações de Diálogo: a. Escuta mútua; b. Pensar juntos; } \\
\text { c. Apontar outros pontos de vista; d. Compartilhar e } \\
\text { refletir sobre ideias; e. Fazer emergir ideias / buscar } \\
\text { pluralidade de ideias }\end{array}$ \\
\hline
\end{tabular}




\begin{tabular}{|c|c|c|}
\hline & & $\begin{array}{l}\text { 4. Relações entre as pessoas nos ambientes do LIE, } \\
\text { para criação de um novo ecossistema comunicativo. }\end{array}$ \\
\hline $\begin{array}{l}\text { Então ela acaba sendo } \\
\text { formativa mesmo? }\end{array}$ & Isso & \\
\hline $\begin{array}{l}\text { E de novo o processo } \\
\text { comunicacional } \\
\text { interativo? }\end{array}$ & $\begin{array}{l}\text { Sim eles têm acesso a isso, como os outros avaliaram ele... então o que ele } \\
\text { precisa melhor para sair desse nível mais baixo e ir para um mais alto }\end{array}$ & \\
\hline $\begin{array}{l}\text { O registro de vídeo foi para o } \\
\text { Grive. }\end{array}$ & : esses do 7o eu tenho todos... & \\
\hline Esses da 7a serie & : eram 3 turmas, cada uma com 35 alunos & \\
\hline \multirow[t]{2}{*}{ E os grupos eram de quantos } & Grupos tinham em média uns 6 alunos por grupo & \\
\hline & $\begin{array}{l}\text { Os de } 1 \text { o e } 2 \text { o são do Patarra... do } 7^{\circ} \text { são do Fagundes... estão no } 8^{\circ} \ldots \text { eu não } \\
\text { tenho contato com eles, mas a coordenação pode intermediar. }\end{array}$ & \\
\hline
\end{tabular}




\section{Anexo G.5: Entrevista POIE Margarete}

\begin{tabular}{|c|c|c|}
\hline PERGUNTAS & $\begin{array}{l}\text { ENTREVISTA } \\
\text { MARGARETE }\end{array}$ & INDICADORES \\
\hline $\begin{array}{l}\text { Falei para a Cris... } \\
\text { primeiro, porque eu } \\
\text { parto do programa POIE } \\
2012 \text {, de formação, que } \\
\text { ela coordenou... então, } \\
\text { daí eu quero perguntar } \\
\text { como foi essa } \\
\text { formação... como é foi } \\
\text { essa experiência... como } \\
\text { foi a experiência de } \\
\text { trabalhar com } \\
\text { protagonismo, de colocar } \\
\text { rubrica, de criar a } \\
\text { rubrica, como foi isso? }\end{array}$ & 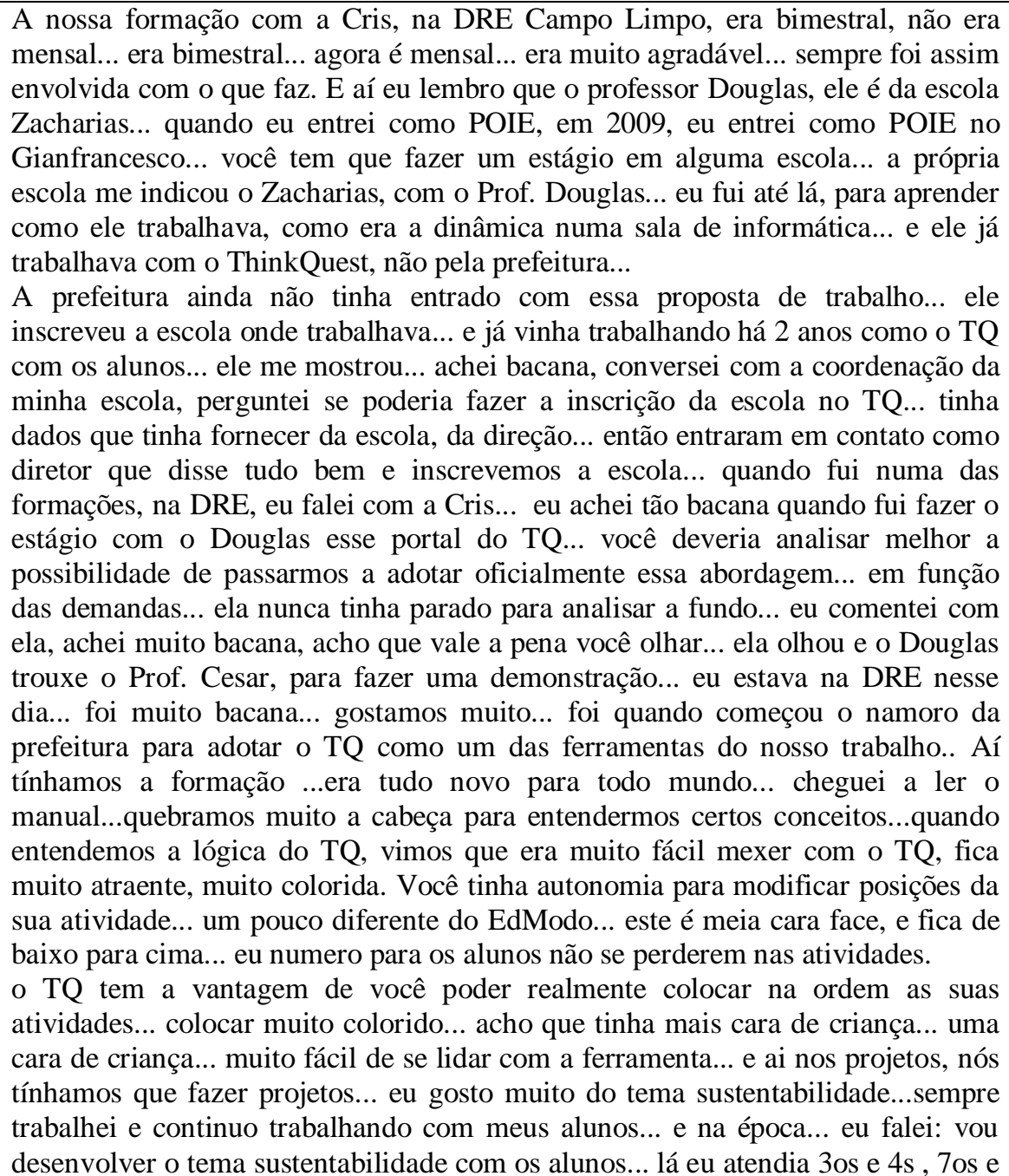 & Perfil do projeto \\
\hline
\end{tabular}




\begin{tabular}{|c|c|c|}
\hline & $\begin{array}{l}\text { 8os e achei melhor trabalhar com } 7 \text { o e } 80 . . . \text { inscrevi todos eles, } 9 \text { turmas... e mais } \\
\text { meus alunos monitores, que fizeram parte desse projetos... e ai como eu fazia? } \\
\text { Aos poucos eu acrescentava as atividades, liberando a visualização para eles de } \\
\text { acordo como andamento de cada sala... sempre respeitando o portal. A } \\
\text { capacidade do portal... você podia só colocar } 10 \text { telas em cada atividade... por } \\
\text { isso tem parte } 1 \text {, parte } 2 \text {, do trabalho... fomos até } 18 \text { ou } 19 . . . \text { e aí começamos foi } \\
\text { paulatinamente crescendo o trabalho, à medida que iam surgindo novas } \\
\text { interações com os alunos, propostas novas, foi caminhando. }\end{array}$ & \\
\hline & $\begin{array}{l}\text { Tanto é que a gente teve um passeio para o SESC... e numa época era falava } \\
\text { sobre o meio e ai nós levamos alguns alunos para participar dessa atividade no } \\
\text { SESC... depois nos trouxemos para a escola um empresário que tem uma empresa } \\
\text { de entulhos lá em Osasco... então, ele recicla o entulho e depois ele faz tijolos } \\
\text { com esse entulho e revende esses tijolos para a prefeitura de Osasco... a um preço } \\
\text { bem mais baixo do que o de mercado...e a prefeitura faz moradias com esses } \\
\text { tijolos... nós levamos esse senhor para fazer uma palestra para que eles } \\
\text { entendessem a importância da reciclagem, como isso faz parte da } \\
\text { sustentabilidade... fizemos também uma entrevista na sala de informática... ai } \\
\text { entrou educom, fizemos uma entrevista com ele, filmamos, foi bacana... e ele } \\
\text { durou } 1 \text { semestre... }\end{array}$ & $\begin{array}{l}\text { A importância de o tema ser trabalhado em um contexto que } \\
\text { tenha correlação com os alunos e em um processo que os } \\
\text { envolva também, de forma ativa e com gestão } \\
\text { compartilhada. } \\
\text { 1. Gestão Compartilhada da Comunicação: a. Ação comunicativa; } \\
\text { b. Apropriação e manejo das linguagens da comunicação; c. Uso } \\
\text { dos recursos da informação para a produção cultural. } \\
\text { 3. Ações de Diálogo: a. Escuta mútua; b. Pensar juntos; c. Apontar } \\
\text { outros pontos de vista; d. Compartilhar e refletir sobre ideias; e. } \\
\text { Fazer emergir ideias / buscar pluralidade de ideias } \\
\text { 4. Relações entre as pessoas nos ambientes do LIE, para criação de } \\
\text { um novo ecossistema comunicativo. }\end{array}$ \\
\hline $\begin{array}{l}\text { Então foi o semestre } \\
\text { todo... sei... isso dá em } \\
\text { torno de quantas aulas } \\
\text { ou semanas? } \\
\text { De } 16 \text { a } 18\end{array}$ & $\begin{array}{l}\text { Era uma aula por semana, de } 45 \text { minutos, } 4 \text { aulas por mês, começamos em } \\
\text { agosto... agosto, setembro, outubro novembro... talvez a primeira semana de } \\
\text { dez... } 16 \text { aulas, mais ou menos. } \\
\text { Mais ou menos... fomos caminhando paulatinamente... eles respondiam sempre } \\
\text { uma ou duas perguntas... dependendo do andamento da aula, da complexidade da } \\
\text { pergunta, fizemos uma rubrica que está publicada no ThinkQuest. }\end{array}$ & Duração \\
\hline $\begin{array}{l}\text { Essa rubrica, que } \\
\text { desenvolveu? Foi você, } \\
\text { foi você, com eles, } \\
\text { foram eles }\end{array}$ & $\begin{array}{l}\text { Essa rubrica, a gente desenvolveu não com eles, sentando com eles... e fazendo..., } \\
\text { mas observando o andar do trabalho... as respostas que eles davam nas } \\
\text { perguntas... então não foi desenvolvida uma rubrica de avaliação do trabalho... } \\
\text { não... então ... acho que por causa da dinâmica da aula, eu não consigo sentar com } \\
\text { os alunos para eles fazerem uma rubrica, para que eles pudessem realmente } \\
\text { entender o que é uma rubrica... }\end{array}$ & $\begin{array}{l}\text { 4. Relações entre as pessoas nos ambientes do LIE, para criação de } \\
\text { um novo ecossistema comunicativo. }\end{array}$ \\
\hline $\begin{array}{l}\text { No caso especifico, da } \\
\text { rubrica, então você não } \\
\text { chega a.... como você } \\
\text { não tem a rubrica logo } \\
\text { de início, você não chega }\end{array}$ & $\begin{array}{l}\text { No final..., mas as vezes é um pouco antes... as vezes fazemos } 3 \text { rubricas, uma no } \\
\text { meio, outra no final... no final é a da avaliação mesmo... }\end{array}$ & $\begin{array}{l}\text { A dificuldade em estruturar a rubrica, para aplica-la no } \\
\text { início do projeto. }\end{array}$ \\
\hline
\end{tabular}




\begin{tabular}{|c|c|c|}
\hline $\begin{array}{l}\text { a apresentar, mas você } \\
\text { desenvolve a rubrica ao } \\
\text { longo do processo e aí } \\
\text { você mostra para eles no } \\
\text { final... }\end{array}$ & & \\
\hline $\begin{array}{l}\text { : ela nasce mesmo do } \\
\text { processo, né? } \\
\text { verdade, ela não nasce lá } \\
\text { no início para eles se } \\
\text { pautarem... ela nasce ao } \\
\text { longo do processo }\end{array}$ & Ao longo do processo... para ficar uma coisa mais natural... & $\begin{array}{l}\text { Apesar de parecer o contrário, há uma reflexão forte sobre } \\
\text { redesenhar o processo de aprendizagem, para adotar a } \\
\text { rubrica. Há uma preocupação em fazer da forma correta, } \\
\text { mas nota-se uma reflexão que nasce da prática com os } \\
\text { alunos. Precisa ser aprimorado, mas é um início de } \\
\text { processo, aparentemente aberto à contribuição dos alunos. } \\
\text { 1. Gestão Compartilhada da Comunicação: a. Ação comunicativa; } \\
\text { b. Apropriação e manejo das linguagens da comunicação; c. Uso } \\
\text { dos recursos da informação para a produção cultural. } \\
\text { 2. Participações de Protagonismo: a. Participação planejadora e } \\
\text { operacional; b. Participação decisória, planejadora e operacional; } \\
\text { c. Participação decisória, planejadora, operacional e avaliadora; d. } \\
\text { Participação colaborativa plena; e. Participação plenamente } \\
\text { autônoma; f. Participação condutora. } \\
\text { 3. Ações de Diálogo: a. Escuta mútua; b. Pensar juntos; c. Apontar } \\
\text { outros pontos de vista; d. Compartilhar e refletir sobre ideias; e. } \\
\text { Fazer emergir ideias / buscar pluralidade de ideias } \\
\text { 4. Relações entre as pessoas nos ambientes do LIE, para criação de } \\
\text { um novo ecossistema comunicativo. }\end{array}$ \\
\hline $\begin{array}{l}\text { Mas eu gostei dessa sua } \\
\text { proposta da rubrica... }\end{array}$ & $\begin{array}{l}\text { Eu achei esquisito fazer no começo se eu não sei o que... quando a gente começa } \\
\text { um projeto, tem uma visão do projeto... eu quero trabalhar sustentabilidade, mas } \\
\text { por onde início? Sustentabilidade é algo amplo, vou afunilar em algum lugar, } \\
\text { fazer o que? Sempre tem um norte, mais ou menos até onde você chegar... só que } \\
\text { para você chegar lá no final às vezes acontecem muitas coisas... que te dão um } \\
\text { novo olhar... é onde começamos a mudar o projeto por conta desse novo olhar,... } \\
\text { por exemplo, estou trabalhando com eles agora a questão do desperdício de água } \\
\text { na escola... é um projeto que já vem desde de } 2013 \text { e a cada ano acrescento algo } \\
\text { diferente... } \\
\text { eu te inscrevi no EdModo quando fiz o cadastro, eu já te inscrevi em projeto de } \\
2014, \text { que fala sobre desperdício de agua, mas ele vem vindo por anos... no ano }\end{array}$ & $\begin{array}{l}\text { Apesar de parecer o contrário, há uma reflexão forte sobre } \\
\text { redesenhar o processo de aprendizagem, para adotar a } \\
\text { rubrica. Há uma preocupação em fazer da forma correta, } \\
\text { mas nota-se uma reflexão que nasce da prática com os } \\
\text { alunos. Precisa ser aprimorado, mas é um início de } \\
\text { processo, aparentemente aberto à contribuição dos alunos. } \\
\text { 1. Gestão Compartilhada da Comunicação: a. Ação comunicativa; } \\
\text { b. Apropriação e manejo das linguagens da comunicação; c. Uso } \\
\text { dos recursos da informação para a produção cultural. } \\
\text { 2. Participações de Protagonismo: a. Participação planejadora e } \\
\text { operacional; b. Participação decisória, planejadora e operacional; }\end{array}$ \\
\hline
\end{tabular}




\begin{tabular}{|c|c|c|}
\hline & $\begin{array}{l}\text { passado eu desenvolvi o mesmo projeto no Scratch... foi desenvolvido por meio } \\
\text { do Scratch a questão do desperdício de agua... este ano u continuei trabalhando } \\
\text { com desperdício de agua... mas eles perceberam e a gente já colheu os frutos do } \\
\text { nosso trabalho de } 2013 \text {, das observações que fizemos em } 2013 \text {, de que forma... } \\
\text { observando as transformações que aconteceram na escola e aquilo que ainda não } \\
\text { aconteceu que ainda dando trabalho, é algo problemático na escola.. Só que eles } \\
\text { descobriram que a escola, além de ter o problema de desperdício de agua, eles } \\
\text { descobriram também o vandalismo... coisa eu eles não estavam observando... e } \\
\text { tiram fotos... e comenta e tal. E eles tiraram fotos do banheiro todo quebrado } \\
\text { porque lá tinha vazamento... não tinha porta, entupimento e etc.... então o nosso } \\
\text { trabalho já deu uma modificada... a gente já começou a trabalhar o vandalismo na } \\
\text { escola... então isso é muito bacana... }\end{array}$ & $\begin{array}{l}\text { c. Participação decisória, planejadora, operacional e avaliadora; d. } \\
\text { Participação colaborativa plena; e. Participação plenamente } \\
\text { autônoma; f. Participação condutora. } \\
\text { 3. Ações de Diálogo: a. Escuta mútua; b. Pensar juntos; c. Apontar } \\
\text { outros pontos de vista; d. Compartilhar e refletir sobre ideias; e. } \\
\text { Fazer emergir ideias / buscar pluralidade de ideias } \\
\text { 4. Relações entre as pessoas nos ambientes do LIE, para criação de } \\
\text { um novo ecossistema comunicativo. }\end{array}$ \\
\hline $\begin{array}{l}\text { Você agora como POIE, } \\
\text { você acha que primeiro } \\
\text { essa metodologia por } \\
\text { projetos, trabalhando } \\
\text { temas assim, quão } \\
\text { eficiente ele é? E o } \\
\text { quanto esse processo de } \\
\text { rubrica e de registro, o } \\
\text { uso do TQ, depois do } \\
\text { EdModo em sala de aula, } \\
\text { auxilia nessa melhoria, } \\
\text { eficiência? }\end{array}$ & $\begin{array}{l}\text { Ele auxiliou bastante por conta do registro... sem o registro você realmente se } \\
\text { perde... por exemplo quando eu olhei ali no material que você me enviou... é que } \\
\text { eu não continuei naquela escola, ne.... no Guarnieri. mas o trabalho que foi feito } \\
\text { de sustentabilidade, se eu tivesse continuado, na escola, eu daria continuidade, eu } \\
\text { saberia exatamente o que eu fiz, saberia quais tinham sido os resultados, né... com } \\
\text { o trabalho... e o que poderíamos ainda atacar em relação a essa problemática... } \\
\text { nesta escola onde estou comecei em } 2013 \text { com o EdModo e fizemos sobre os } \\
\text { desperdício de agua na escola e os meninos saíram fotografando todos os pontos } \\
\text { da escola, cozinha... então o pessoal da cozinha permitiu que eles entrassem para } \\
\text { fotografar, eles tiveram que colocar as roupas, touquinha, avental, para entrar lá } \\
\text { dentro... eles acharam aquilo o máximo ... eles se sentiram muito bem, puseram a } \\
\text { touquinha, avental, entraram na cozinha, tiraram as fotos... delas lavando a louça, } \\
\text { legumes... e as meninas gostaram muito... depois analisaram ... se estava tendo } \\
\text { desperdício... fotografaram também o sr. Jose com a maquininha vap varrendo a } \\
\text { sujeira em vez dele pegar uma vassoura... ele não usava vassoura, usava uma } \\
\text { maquininha vap para varrer ... usando a aguar como vassoura e agua indo para o } \\
\text { ralo... e tudo isso foi registrado... as carteiras... foram também fotografar como } \\
\text { eles limpavam a sala de aula... fotografaram os baldes com agua, as meninas } \\
\text { limpando as carteiras, o quanto de aguar usavam, se ficava limpo ou não... os } \\
\text { corredores , torneiras inteligentes... se elas realmente eram inteligentes ou não ... } \\
\text { se elas estavam desperdiçando agua... as descargas, caixa d’água... tudo que você } \\
\text { possa imaginar, onde vai agua, eles foram atrás, para levantar o desperdício... }\end{array}$ & $\begin{array}{l}\text { 1. Gestão Compartilhada da Comunicação: a. Ação comunicativa; } \\
\text { b. Apropriação e manejo das linguagens da comunicação; c. Uso } \\
\text { dos recursos da informação para a produção cultural. } \\
\text { 2. Participações de Protagonismo: a. Participação planejadora e } \\
\text { operacional; b. Participação decisória, planejadora e operacional; } \\
\text { c. Participação decisória, planejadora, operacional e avaliadora; d. } \\
\text { Participaça colaborativa plena; e. Participação plenamente } \\
\text { autônoma; f. Participação condutora. } \\
\text { 3. Ações de Diálogo: a. Escuta mútua; b. Pensar juntos; c. Apontar } \\
\text { outros pontos de vista; d. Compartilhar e refletir sobre ideias; e. } \\
\text { Fazer emergir ideias / buscar pluralidade de ideias } \\
\text { 4. Relações entre as pessoas nos ambientes do LIE, para criação de } \\
\text { um novo ecossistema comunicativo. }\end{array}$ \\
\hline
\end{tabular}




\begin{tabular}{|c|c|c|}
\hline & $\begin{array}{l}\text { para apurar se estava tendo ou não o desperdício de agua... e tudo isso a gente } \\
\text { registrou... ficou um registro bem detalhado, longo... e ai a gente pode perceber a } \\
\text { máquina vap não foi mais utilizada par afazer esse tipo de serviço de varredura... } \\
\text { ele varre agora toda a escola... houve uma conscientização... algumas torneiras } \\
\text { do pátio das crianças, que estavam desreguladas, foram reguladas... a DRE } \\
\text { forneceu par anos a conta de agua da escola e pudemos analisar com gráficos... } \\
\text { está la no EdModo... o quanto a gente gastou de agua e a razão da conta ir la para } \\
\text { cima por } 2 \text { meses... quer mais? }\end{array}$ & \\
\hline $\begin{array}{l}\text { Quando você faz esse } \\
\text { tipo de coisa, você chega } \\
\text { a fazer uma relação, por } \\
\text { exemplo, você falou da } \\
\text { conta e valores, com } \\
\text { matemática, por } \\
\text { exemplo? No sentido de } \\
\text { uma relação }\end{array}$ & 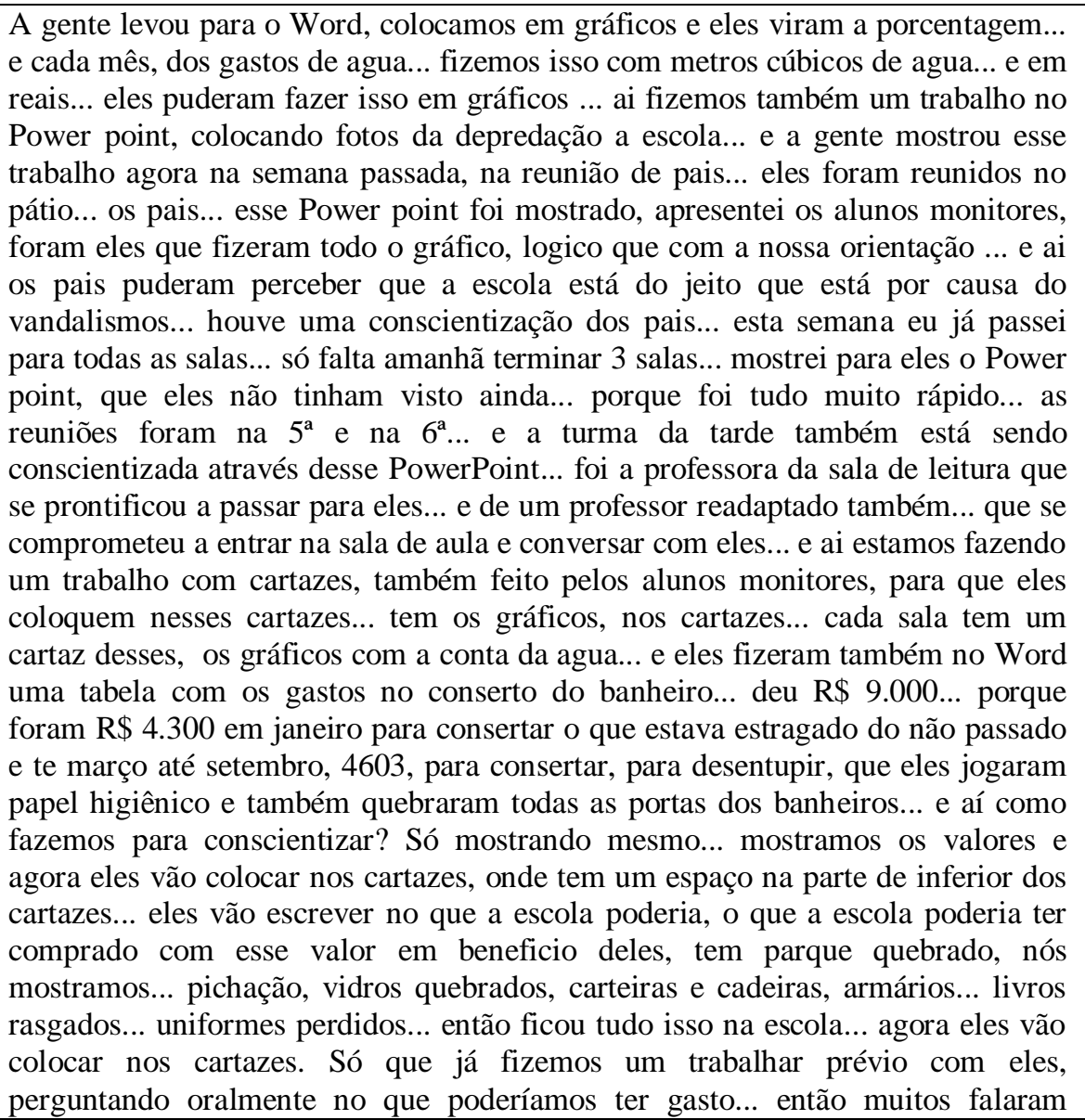 & $\begin{array}{l}\text { 1. Gestão Compartilhada da Comunicação: a. Ação comunicativa; } \\
\text { b. Apropriação e manejo das linguagens da comunicação; c. Uso } \\
\text { dos recursos da informação para a produção cultural. } \\
\text { 2. Participações de Protagonismo: a. Participação planejadora e } \\
\text { operacional; b. Participação decisória, planejadora e operacional; } \\
\text { c. Participação decisória, planejadora, operacional e avaliadora; d. } \\
\text { Participação colaborativa plena; e. Participação plenamente } \\
\text { autônoma; f. Participação condutora. } \\
\text { 3. Ações de Diálogo: a. Escuta mútua; b. Pensar juntos; c. Apontar } \\
\text { outros pontos de vista; d. Compartilhar e refletir sobre ideias; e. } \\
\text { Fazer emergir ideias / buscar pluralidade de ideias } \\
\text { 4. Relações entre as pessoas nos ambientes do LIE, para criação de } \\
\text { um novo ecossistema comunicativo. }\end{array}$ \\
\hline
\end{tabular}




\begin{tabular}{|c|c|c|}
\hline & $\begin{array}{l}\text { assim... "poderia ter comprado uma mesa de ping-pong"... é verdade. Jogos para } \\
\text { brincar na roa do intervalo... aí sugeriram também televisores, parquinho, } \\
\text { piscina... eles querem até uma piscina na escola... eles coloquem tudo que vocês } \\
\text { puderem imaginar... depois faremos uma tabulação... e depois dar um retorno... } \\
\text { tudo isso para que eles se conscientizem que não pode estragar a escola, que tem } \\
\text { que ser um lugar bacana }\end{array}$ & \\
\hline $\begin{array}{l}\text { Então, na verdade, os } \\
\text { temas você decide? Você } \\
\text { tem autonomia para } \\
\text { definir isso também? } \\
\text { Como isso é definido? }\end{array}$ & $\begin{array}{l}\text { Esse tema do vandalismo surgiu no meio do projeto sobre sustentabilidade, de } \\
\text { desperdício de agua... você acredita? }\end{array}$ & $\begin{array}{l}\text { 1. Gestão Compartilhada da Comunicação: a. Ação comunicativa; } \\
\text { b. Apropriação e manejo das linguagens da comunicação; c. Uso } \\
\text { dos recursos da informação para a produção cultural. } \\
\text { 2. Participações de Protagonismo: a. Participação planejadora e } \\
\text { operacional; b. Participação decisória, planejadora e operacional; } \\
\text { c. Participação decisória, planejadora, operacional e avaliadora; d. } \\
\text { Participação colaborativa plena; e. Participação plenamente } \\
\text { autônoma; f. Participação condutora. } \\
\text { 3. Açães de Diálogo: a. Escuta mútua; b. Pensar juntos; c. Apontar } \\
\text { outros pontos de vista; d. Compartilhar e refletir sobre ideias; e. } \\
\text { Fazer emergir ideias / buscar pluralidade de ideias } \\
\text { 4. Relações entre as pessoas nos ambientes do LIE, para criação de } \\
\text { um novo ecossistema comunicativo. }\end{array}$ \\
\hline
\end{tabular}


Aí você permite que eles falem, que eles deem retorno deles..

E quando eles montam assim os projetos, eles vão em grupos, e aí eles dividem as atividades entre eles ou é você quem define a divisão das atividades entres eles?

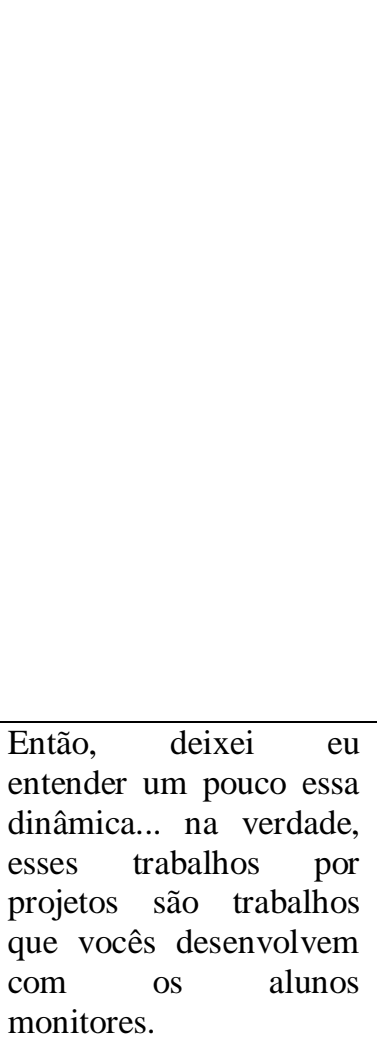

não, a gente faz assim... porque depende muito da nossa dinâmica de encontro, né... então eu trabalho só na parte da manhã... o meu aluno monitor eu atendo dentro do projeto... eles ficam comigo na sala, ajudando nas aulas... e naquele nosso horário de projeto... é a hora que sento com eles para fazer projetos, para fazer com que pesquisem as atividades dos alunos... as vezes eu quero um jogo de alfabetização para os alunos mais novos... então eu peço para eles pesquisarem, testarem... depois eles me dão o retorno, se é bacana, se não é, o que eles acharam... então a gente trabalha assim... E durante eu trabalho com eles 4 vezes por semana... e cada dia, vai 2 ou 3... a nossa frequência é no máximo 3 porque 4 aluninhos monitores no mesmo dia, pela minha experiência de sala, fica meio tumultuado... no máximo 3 está ótimo para trabalhar na sala com aluno monitor.. e como eles não podem se encontrar... eles escolhem o dia que podem estar conosco na escola... porque eles tem cursos extracurriculares, e outras atividades... quando reúno os alunos já pergunto que dia que você pode... Ahn, eu posso na $3^{\mathrm{a}}$, eu posso na $4^{\mathrm{a}}$...e ai a gente já monta os grupos de cada dia... e ai nesse horário que eu tenho de projeto, eu sento com aqueles aluninhos que estão ali e a gente estipula o que a gente vai fazer... essa questão dos cartazes, foram eles que deram a sugestão... como a gente vai falar com a escola que precisa acabar com o vandalismo... vai ser um vídeo? Vai ser o quê? Ahn poderia ser cartazes... eu acho bacana... então tudo bem? Então está... aí pego o material e a gente vê o que vai fazer e cada um faz uma parte, ne.... uns digitam o conteúdo, outros que tem uma letra melhor, se precisar escrever o cartaz, é esse que vai escrever, os outros recortam, ou colam no cartaz... depois que está tudo pronto, os aluninhos daquele dia são os que vão colar pela escola... vai sendo assim, conforme vai andando o trabalho e a disponibilidade do aluno, a gente vai fazendo essa atividade.

Então, depende... aquele do TQ, eu desenvolvi com os alunos monitores, mas eu desenvolvi com os 7 os e 8 os anos... tem 224 aluninhhos... que participaram do projeto... esses projetos do EdModo, nós temos um problema na escola... o EdModo não entra em todos os computadores... ao contrário do TQ, que entrava...
1. Gestão Compartilhada da Comunicação: a. Ação comunicativa; b. Apropriação e manejo das linguagens da comunicação; c. Uso dos recursos da informação para a produção cultural.

2. Participações de Protagonismo: a. Participação planejadora e operacional; b. Participação decisória, planejadora e operacional; c. Participação decisória, planejadora, operacional e avaliadora; d. Participação colaborativa plena; e. Participação plenamente autônoma; f. Participação condutora.

3. Ações de Diálogo: a. Escuta mútua; b. Pensar juntos; c. Apontar outros pontos de vista; d. Compartilhar e refletir sobre ideias; e. Fazer emergir ideias / buscar pluralidade de ideias

4. Relações entre as pessoas nos ambientes do LIE, para criação de um novo ecossistema comunicativo. 


\begin{tabular}{|c|c|c|}
\hline para processar. & $\begin{array}{l}\text { para trabalhar com a escola toda. O EdModo ele entra no máximo em } 4 \text { a } 5 \\
\text { máquina... não entra em mais nenhuma... ele trava... entendeu? Então uma } \\
\text { ferramenta bacana ... eu gosto dele já me acostumei, só que ele limita... então não } \\
\text { dá para trabalhar com uma sala se ele não entra... principalmente na primeira } \\
\text { aula... primeira aula na escola temos muita dificuldade de estudo... de entrar na } \\
\text { internet, em determinados sites, não entra... se vai pedir para visualizar um vídeo, } \\
\text { tem que baixar do Youtube, para que todos possam visualizar porque não dá para } \\
\text { acessar o Youtube em todas as maquinas... então o trabalho fica assim bastante } \\
\text { comprometido... o EdModo, eu só desenvolvo com aluno monitor... e o trabalho } \\
\text { que eu passei para você, ele foi feito também com aluno mediador ... que são os } \\
\text { aluninhos que ajudam na sala de leitura... nós fizemos... um bem bolado... ai eles } \\
\text { traziam as pesquisas assim mais da área de leitura e de escrita...e os alunos } \\
\text { monitores faziam o trabalho mais na área tecnologias... depois juntamos tudo... } \\
\text { tanto é que eles fizeram... os aluninhos da sala de leitura fizeram sobre cordel, } \\
\text { falando sobre a agua... depois eles foram e digitaram... foi muito bacana.. }\end{array}$ & $\begin{array}{l}\text { b. Apropriação e manejo das linguagens da comunicação; c. Uso } \\
\text { dos recursos da informação para a produção cultural. }\end{array}$ \\
\hline & $\begin{array}{l}\text { Eles são os cartazes são todos iguais... desse trabalho... o que eles fizeram como } \\
\text { aluno monitor., é assim... nesse dia... nós conseguimos imprimir... na } 3^{\mathrm{a}} \text { feira } \\
\text { precisávamos produzir o conteúdo do cartaz... então os alunos que estão lá na } 3^{\mathrm{a}} \\
\text { feira, vão digitar o conteúdo que nós precisamos que seja digitado e impresso... se } \\
\text { por um acaso, eles não terminaram, o da } 4^{\mathrm{a}} \text { feira vão lá e terminam o trabalho... }\end{array}$ & $\begin{array}{l}\text { Muitas vezes, para viabilizar o projeto, abandona-se as } \\
\text { tecnologias digitais e opta-se pelo mais simples e viável. } \\
\text { 1. Gestão Compartilhada da Comunicação: a. Ação comunicativa; } \\
\text { b. Apropriação e manejo das linguagens da comunicação; c. Uso } \\
\text { dos recursos da informação para a produção cultural. }\end{array}$ \\
\hline $\begin{array}{l}\text { Eu quero ver, até porque } \\
\text { o jornal mural é uma } \\
\text { coisa que inclusive a } \\
\text { gente trabalha muito ... }\end{array}$ & $\begin{array}{l}\text { É a mesma coisa, jornal mural vamos fazendo as pesquisas... então eles } \\
\text { levantavam os assuntos... esporte saúde... eu sento com eles e conversamos sobre } \\
\text { o que eles querem pesquisar para publicar... ai a gente faz o registro... quem } \\
\text { gostaria de trabalhar com este tema... você fica responsável pelo esporte, saúde } \\
\text { beleza culinária... e eles vão fazendo pesquisando... e no dia que está tudo pronto } \\
\text { a gente monta o jornal mural lá embaixo... via trocando as notícias... é um } \\
\text { trabalho bem interativo... }\end{array}$ & \\
\hline $\begin{array}{l}\text { Quanto tempo fica o } \\
\text { aluno monitor com } \\
\text { você? Por quanto tempo? }\end{array}$ & $\begin{array}{l}\text { O aluno monitor tem um tempo que pode ficar na escola... não pode ficar um } \\
\text { período todo na escola... eles ficam } 5 \text { horas na aula. Mas eles podem ficar na } \\
\text { escola até } 6 \text { horas... ou } 7 \ldots \text { então em } 2013 \text {, quando saiu essa nova lei, da portaria, } \\
\text { nós tínhamos acho que uns } 19 \text { alunos monitores porque eu atendia assim, da s7 as } \\
\text { 9:51 eram 3...ai eles tomavam lanche e iam embora e vinham mais } 3 \ldots \text { era muito }\end{array}$ & $\begin{array}{l}\text { Práticas pedagógico-comunicacional (rubrica e práticas } \\
\text { reflexivas entre os alunos) } \\
\text { Gestão da comunicação (rubrica e práticas reflexivas entre } \\
\text { os alunos) }\end{array}$ \\
\hline
\end{tabular}




\begin{tabular}{|c|c|c|}
\hline & $\begin{array}{l}\text { complicado... sabe monitorar tudo isso e ai a coordenadora, falou assim, quem } \\
\text { tiver a disponibilidade de ficar a manha toda, tudo bem, você pega... quem tiver a } \\
\text { oportunidade de ficar só } 2 \text { ou } 3 \text { horas você pega também... então hoje eu trabalho } \\
\text { assim, tenho alunos que ficam comigo uma parte do período da manhã e vão } \\
\text { embora e tem outros que querem ficar a manha toda e a gente permite... }\end{array}$ & $\begin{array}{l}\text { Leitura crítica dos meios (práticas reflexivas mediadas por } \\
\text { tecnologias) }\end{array}$ \\
\hline $\begin{array}{l}\text { Ele pode } \text { ser aluno } \\
\text { monitor? } 6 \text { meses? } 1 \\
\text { ano? }\end{array}$ & $\begin{array}{l}\text { Ele fica o ano todo... ele pode sair a hora que quiser... ele também pode ser } \\
\text { retirado se não estiver dando bom exemplo... na sala de aula dele, se ele estiver } \\
\text { dando trabalho, o professor questiona... porque ele é aluno monitor se na sala } \\
\text { dele, ele dá tanto trabalho? Às vezes eu nem sei... e nessa semana mesmo veio } \\
\text { uma professora me falar que minha aluninha monitora na minha aula é uma } \\
\text { graça, na aula dela, ninguém aguenta... nessa aula dela... aí eu converso com } \\
\text { aluno, não pode, você tem que dar bom exemplo... aluno monitor aqui todo } \\
\text { mundo quer ser....então você precisa prezar por você ter sido escolhido... } \\
\text { geralmente eles ouvem eles mudam de comportamento mas tem alguns que não } \\
\text { tem jeito, eles não mudam. }\end{array}$ & $\begin{array}{l}\text { Práticas pedagógico-comunicacional (rubrica e práticas } \\
\text { reflexivas entre os alunos) } \\
\text { Gestão da comunicação (rubrica e práticas reflexivas entre } \\
\text { os alunos) } \\
\text { Leitura crítica dos meios (práticas reflexivas mediadas por } \\
\text { tecnologias) } \\
\text { Avaliação estética do vídeo..., mas não há destaque real para } \\
\text { a leitura crítica dos meios... }\end{array}$ \\
\hline $\begin{array}{l}\text { Assim... o perfil do } \\
\text { aluno monitor, do ponto } \\
\text { de vista... ele } \\
\text { normalmente ele é o } \\
\text { aluno referência ou ele } \\
\text { muitas vezes tem } \\
\text { dificuldade de ficar } \\
\text { tranquilo dentro da sala } \\
\text { de aula normal, mas ele } \\
\text { é muito bom em } \\
\text { informática }\end{array}$ & 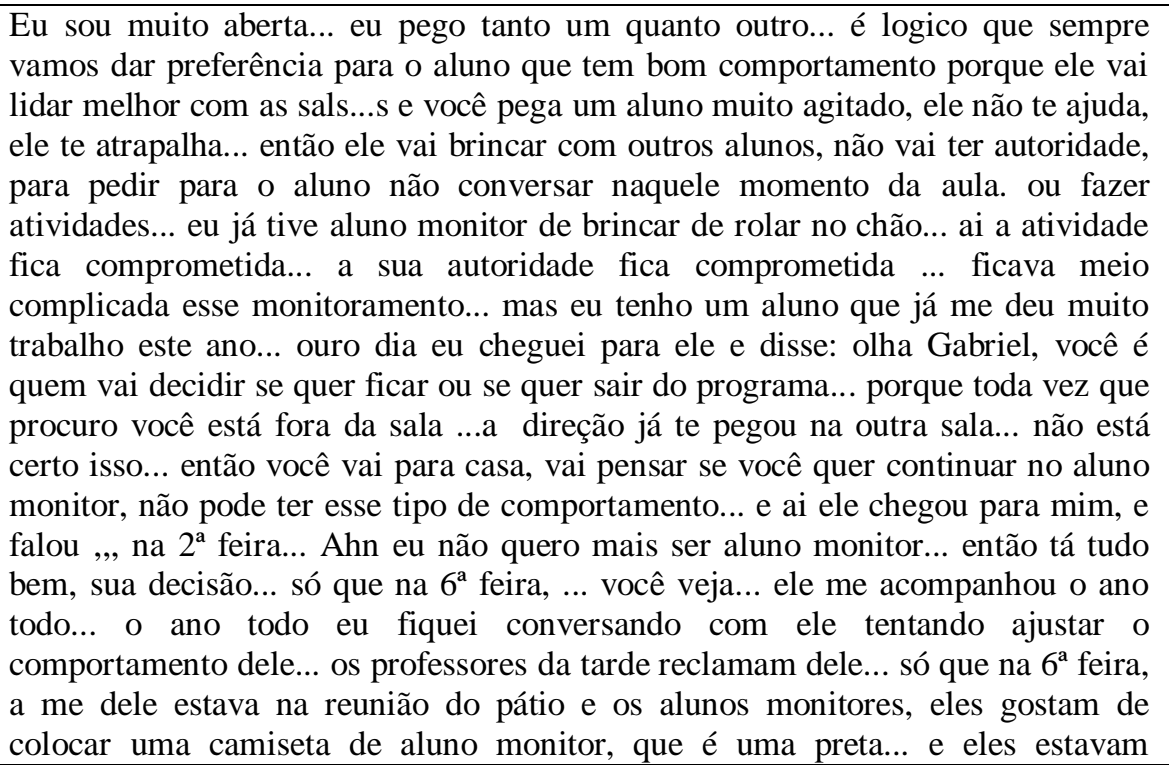 & $\begin{array}{l}\text { Práticas pedagógico-comunicacional (rubrica e práticas } \\
\text { reflexivas entre os alunos) } \\
\text { Gestão da comunicação (rubrica e práticas reflexivas entre } \\
\text { os alunos) } \\
\text { Leitura crítica dos meios (práticas reflexivas mediadas por } \\
\text { tecnologias) }\end{array}$ \\
\hline
\end{tabular}




\begin{tabular}{|c|c|c|}
\hline & $\begin{array}{l}\text { comigo, la na apresentação e eu avistei ele la embaixo com a mãe... ai eu fiz sinal } \\
\text { para ele, para ele vim falar comigo.. Eu falei assim... olha Gabriel... você sabe } \\
\text { que eu gosto de você... ele é bom na informática... eu gosto de você, mas seu } \\
\text { comportamento você mesmo concorda que não é adequado... olha só, seus } \\
\text { colegas estão todos aqui, você fez tanta coisa boa bacana na informática e agora } \\
\text { você não quer vestir esta camiseta... o que você me fala? Aí ele olhou para a } \\
\text { camiseta e falou assim... Ahn eu topo, professora... então toma... veste esta } \\
\text { camiseta aqui e pronto... entendi... então a gente trabalha com eles para tentar } \\
\text { mudar comportamento porque realmente eles têm interesse na informática, são } \\
\text { bons, você percebe que tem futuro, ... só que às vezes os comportamentos são } \\
\text { inadequados... }\end{array}$ & \\
\hline $\begin{array}{l}\text { Uma questão de ele } \\
\text { entender u lugar... e é } \\
\text { um trabalho que tem que } \\
\text { ser feito... você está } \\
\text { certa... não é algo que } \\
\text { muda do dia para a } \\
\text { noite...então eles além de } \\
\text { fazer o projeto, eles } \\
\text { também apoiam você, } \\
\text { monitoram o os } \\
\text { projetinhos que você faz } \\
\text { com as salas de aula. }\end{array}$ & $\begin{array}{l}\text { Sem eles hoje fica difícil... hoje, por exemplo, as vezes acontece de você ter } 1 \text { ou } \\
\text { nenhum... hoje eu tinha } 2 \ldots \text { e eles não puderam vir... eles ajudam demais... } \\
\text { enquanto você está ajudando com um aluninho, eles já estão atendendo outros } 2 .\end{array}$ & $\begin{array}{l}\text { Práticas pedagógico-comunicacional (rubrica e práticas } \\
\text { reflexivas entre os alunos) } \\
\text { Gestão da comunicação (rubrica e práticas reflexivas entre } \\
\text { os alunos) } \\
\text { Autoavaliação permite que o aluno se manifeste, perceba } \\
\text { como foi seu desempenho e o quanto lucrou ou não com } \\
\text { isso... }\end{array}$ \\
\hline Rubrica & $\begin{array}{l}\text { Eles não fazem a rubrica, né... tem professores que sentam e fazem com eles... } \\
\text { por causa da minha dinâmica de aula, eu não consigo. }\end{array}$ & $\begin{array}{l}\text { Aqui é curioso porque a POIE demonstra adotar uma } \\
\text { dinâmica intensa e participativa, apesar do não uso da } \\
\text { rubrica. Uma coisa não invalida a outra, mas nos sinaliza } \\
\text { que as práticas já apresentam aspectos educomunicativos } \\
\text { mesmo sem as ações estratégicas todas da avaliação } \\
\text { formativa. No caso, ela utiliza a reflexão e feedback intenso. }\end{array}$ \\
\hline
\end{tabular}




\section{Anexo G.6: Entrevista POIE Maria Helena}

\begin{tabular}{|c|c|c|}
\hline PERGUNTAS & $\begin{array}{c}\text { ENTREVISTA } \\
\text { MARIA HELENA }\end{array}$ & INDICADORES \\
\hline $\begin{array}{l}\text { Qual foi a duração do } \\
\text { projeto (aulas e meses)? }\end{array}$ & $\begin{array}{l}\text { O projeto foi realizado durante o ano letivo. Teve início em março e finalização } \\
\text { em novembro. Foi desenvolvido por duas professoras, eu, que na época era } \\
\text { POIE (Professora Orientadora de Informática Educativa) e a Prof. Nágila } \\
\text { Polido, POSL (Professora Orientadora de Sala de Leitura). A ideia do projeto } \\
\text { era a divulgação científica, estudo da astronomia e ampliação do repertório } \\
\text { cultural dos alunos. }\end{array}$ & Perfil do projeto \\
\hline $\begin{array}{l}\text { Qual o perfil dos alunos } \\
\text { que participantes (idade, } \\
\text { sexo, serie)? }\end{array}$ & $\begin{array}{l}\text { Nessa turma eram } 24 \text { alunos do } 5^{\circ} \text { ano (antiga } 4^{\text {a }} \text { série), turma mista de meninos } \\
\text { e meninas, por volta de } 9 \text { ou } 10 \text { anos. A entrada no grupo foi feita por inscrição } \\
\text { de acordo com o interesse das crianças no assunto. }\end{array}$ & Perfil do projeto \\
\hline $\begin{array}{l}\text { Só aluno monitor ou } \\
\text { demais alunos, das } \\
\text { turmas que você atendia? }\end{array}$ & $\begin{array}{l}\text { O projeto foi realizado dentro do Programa Ampliar, no período pós aula. Não } \\
\text { eram } \\
\text { alunos }\end{array}$ & Perfil do projeto \\
\hline $\begin{array}{l}\text { Quantos alunos mais ou } \\
\text { menos tinham no } \\
\text { projeto, no total? }\end{array}$ & $\begin{array}{l}24 \text { alunos nessa turma. Existia mais uma turma de Clube de Astronomia, com } \\
\text { alunos do } 6^{\circ} \text { ao } 9^{\circ} \text { ano, onde a abordagem era um pouco diferente, mas o } \\
\text { mesmo } \quad \text { conteúdo, } \quad \text { com } \quad \text { pouquíssimas }\end{array}$ & Perfil do projeto \\
\hline $\begin{array}{l}\text { Qual o(s) produto(s) } \\
\text { finais? Houve } \\
\text { compartilhamento com a } \\
\text { escola ou comunidade de } \\
\text { entorno? }\end{array}$ & $\begin{array}{l}\text { Além do aprendizado dos alunos, respostas aos questionamentos nas aulas que } \\
\text { foram registrados em ambiente colaborativo, houve produções de textos e } \\
\text { jogos. A produção de texto envolveu um estudo de etnoastronomia, onde os } \\
\text { alunos entraram em contato com as lendas envolvendo as constelações por } \\
\text { diversas etnias, além da cultura ocidental. A atividade consistia em observar as } \\
\text { estrelas no céu, imaginar um desenho e criar sua própria lenda. Quanto aos } \\
\text { jogos, a atividade consistia em criar jogos de tabuleiros, memórias, entre outros, } \\
\text { envolvendo os temas de astronomia, sistema solar, galáxias, nascimento e morte } \\
\text { de estrelas, onde o aluno/jogador tivesse acesso aos conceitos relacionados com } \\
\text { o tema. Na outra turma, de } 6^{\circ} \text { ao } 9^{\circ} \text { ano, houve a produção de um conto de } \\
\text { ficção científica, após um processo de melhorias de ideias. }\end{array}$ & $\begin{array}{l}\text { Descritivo geral do projeto indica para a presença de práticas } \\
\text { colaborativas e reflexivas, em conjunto. } \\
\text { Indica também o desenvolvimento de atividades com uso de } \\
\text { TIC, para reflexão sobre o tema Astronomia. } \\
\text { O conto de ficção científica como construção conjunta implica } \\
\text { nas trocas entre as crianças, e colaboração. } \\
\text { Práticas de diálogo e de diversos tipos de participação. } \\
\text { Trabalha as relações entre eles e com as TIC. }\end{array}$ \\
\hline
\end{tabular}




\begin{tabular}{|c|c|c|}
\hline $\begin{array}{l}\text { Como é o protagonismo } \\
\text { dos alunos nesse } \\
\text { projeto? Eles dão ideias } \\
\text { de temas, planejam e } \\
\text { dividem tarefas, definem } \\
\text { as tecnologias de registro } \\
\text { da atividade, avaliam os } \\
\text { resultados em conjunto? } \\
\text { Como é esse processo } \\
\text { dialógico? Há conflitos? } \\
\text { Quem faz essa mediação } \\
\text { nos casos de conflito? }\end{array}$ & $\begin{array}{l}\text { O protagonismo acabou aparecendo na criação dos jogos, onde não houve } \\
\text { influência dos professores, além da própria correção. As aulas eram } \\
\text { programadas por roteiros de aula, com sequência de conteúdos, envolvendo } \\
\text { literatura, música e divulgação científica. Os alunos seguiam o roteiro e } \\
\text { interagiam no ambiente colaborativo na construção das suas respostas. O nosso } \\
\text { objetivo é que eles influenciassem as respostas uns dos outros criando um } \\
\text { diálogo sobre o assunto. Isso não aconteceu, segundo a nossa avaliação, por não } \\
\text { terem o hábito desse tipo de abordagem. O processo dialógico dava-se no } \\
\text { desenvolvimento do roteiro, conforme os alunos traziam suas dúvidas, seu } \\
\text { conhecimento de senso comum que acabava por ser diferente do conhecimento } \\
\text { científico, o que algumas vezes gerava alguns conflitos. Nós, as professoras, } \\
\text { sempre tentávamos mostrar que esses conhecimentos não eram contrários e sim } \\
\text { complementares. }\end{array}$ & $\begin{array}{l}\text { Descritivo geral do projeto indica para a presença de práticas } \\
\text { colaborativas e reflexivas, em conjunto. } \\
\text { Destaque direto para o protagonismo e seus diversos tipos de } \\
\text { participação. } \\
\text { Práticas de diálogo e de diversos tipos de participação. } \\
\text { Trabalha as relações entre eles e com as TIC, quando fala da } \\
\text { criação de jogos. }\end{array}$ \\
\hline $\begin{array}{l}\text { Quem elaborou as } \\
\text { rubricas: você (ou você } \\
\text { com outros POIE) ou } \\
\text { eles ou vocês em } \\
\text { conjunto? }\end{array}$ & $\begin{array}{l}\text { As rubricas foram elaboradas pelos professores. Numa continuidade do projeto, } \\
\text { imaginávamos aperfeiçoá-las com a ajuda dos alunos. Como o projeto não teve } \\
\text { continuidade, não tivemos essa oportunidade }\end{array}$ & $\begin{array}{l}\text { Práticas pedagógico-comunicacional (rubrica e práticas } \\
\text { reflexivas entre os alunos): não é refletida com os alunos, é } \\
\text { apenas apresentada, para eles se autoavaliarem }\end{array}$ \\
\hline $\begin{array}{l}\text { Quando as rubricas } \\
\text { foram elaboradas: início } \\
\text { meio ou fim? }\end{array}$ & No fim do projeto. & $\begin{array}{l}\text { Momento de definição dos critérios: não atendeu às orientações } \\
\text { de apresentar logo no início. }\end{array}$ \\
\hline $\begin{array}{l}\text { Quando elas foram } \\
\text { informadas a eles (caso } \\
\text { os alunos não tenham } \\
\text { tido participação no } \\
\text { processo)? }\end{array}$ & $\mathrm{Na}$ autoavaliação dos alunos no fim de cada semestre. & $\begin{array}{l}\text { Momento de informar critérios: não informou antes ou durante } \\
\text { o processo. Só informou no final, no momento deles se } \\
\text { avaliarem }\end{array}$ \\
\hline $\begin{array}{l}\text { Qual a dificuldade ou } \\
\text { desafio de utilizar as } \\
\text { rubricas? }\end{array}$ & $\begin{array}{l}\text { Acredito que o maior desafio em utilizar as rubricas, seja na reflexão entre uma } \\
\text { avaliação e outra. O aluno ter que refletir onde ele deve melhorar, o que ele } \\
\text { deixou de fazer para não avançar um nível. Como esse tipo de avaliação nunca } \\
\text { havia sido feita com eles, nós simplificamos a rubrica utilizada, para que ele se } \\
\text { habituasse } \quad \text { com } \quad \text { esse } \\
\text { tipo }\end{array}$ & $\begin{array}{l}\text { Indicador 4, sobre relações nos espaços educacionais, para } \\
\text { criação de ecossistemas comunicativos: pela fala da POIE, } \\
\text { parece que o aluno queria se estender, mas ela queria caminhar. } \\
\text { Aqui lembramos dos tempos adequados para comunicação em } \\
\text { cada atividade, o que muitas vezes não ocorre. O que pode } \\
\text { comprometer todo o processo. }\end{array}$ \\
\hline $\begin{array}{l}\text { Há diálogo } \\
\text { aprofundamento }\end{array}$ & $\begin{array}{l}\text { Tentamos propor questões que permitiam um envolvimento dos alunos, mas } \\
\text { percebemos que eles } \text { se limitavam } \begin{array}{llllll}\text { a } & \text { fazer } & \text { o } & \text { registro. }\end{array}\end{array}$ & $\begin{array}{l}\text { Aqui indica a falta de domínio do aluno sobre a atividade, que } \\
\text { ainda não se sentiu estimulado a fazer mais e se dedicar mais. }\end{array}$ \\
\hline
\end{tabular}




\begin{tabular}{|c|c|c|}
\hline $\begin{array}{l}\text { reflexão no AVA? Ou } \\
\text { ele se limita a permitir } \\
\text { um número maior de } \\
\text { registros? }\end{array}$ & & Foca no registro. Não há indicativo de mudança na relação. \\
\hline $\begin{array}{l}\text { Quais as principais } \\
\text { funções do ThinkQuest? }\end{array}$ & Permitir todo o registro do processo, além de permitir um debate dos assuntos. & $\begin{array}{l}\text { Práticas pedagógico-comunicacional (rubrica e práticas } \\
\text { reflexivas entre os alunos): trocas foram feitas no ambiente } \\
\text { virtual de aprendizagem o que gerou registros interessantes das } \\
\text { práticas. }\end{array}$ \\
\hline $\begin{array}{l}\text { Você segue utilizando o } \\
\text { EdModo ou } \text { outra } \\
\text { plataforma, com essa } \\
\text { abordagem? }\end{array}$ & $\begin{array}{l}\text { Utilizei o Edmodo em alguns projetos posteriormente, mas hoje como estou em } \\
\text { sala de aula, a utilização do Laboratório de Informática é um pouco esporádica. } \\
\text { A outra professora que participava do projeto, também não seguiu com a } \\
\text { utilização por não ter mais o apoio do POIE. Mas, nós deixamos de utilizar o } \\
\text { recurso por problemas pessoais e de organização, não pela diferença nas } \\
\text { plataformas. Nós achávamos o ThinkQuest mais organizado, mas o Edmodo } \\
\text { mais atrativo para os alunos. Não tivemos a oportunidade de adequar o projeto } \\
\text { para o Edmodo, afim de melhorar alguns pontos. }\end{array}$ & $\begin{array}{l}\text { Práticas pedagógico-comunicacional (rubrica e práticas } \\
\text { reflexivas entre os alunos): o comentário dos POIE nos indicam } \\
\text { que o ThinkQuest parecia ser bem mais adequado às práticas } \\
\text { dos LIE e ainda permitia uma bora organização das aulas do } \\
\text { projeto. }\end{array}$ \\
\hline $\begin{array}{l}\text { Como foi feita a } \\
\text { avaliação final - foi com } \\
\text { base nas rubricas? Foi } \\
\text { uma autoavaliação } \\
\text { individual - você e o } \\
\text { aluno? Ou foi uma } \\
\text { autoavaliação de cada } \\
\text { aluno, mas para todos os } \\
\text { participantes? Ou foi } \\
\text { uma avaliação entre } \\
\text { pares? }\end{array}$ & $\begin{array}{l}\text { A avaliação foi de acordo com a participação dos alunos e levou-se em conta a } \\
\text { autoavaliação } \quad \text { realizada por } \quad \text { eles através } \quad \text { da }\end{array}$ & $\begin{array}{l}\text { Práticas pedagógico-comunicacional (rubrica e práticas } \\
\text { reflexivas entre os alunos): houve autoavaliação e reflexão a } \\
\text { partir da rubrica }\end{array}$ \\
\hline & $\begin{array}{l}\text { Se tiver mais algum questionamento, estou à disposição. O outro projeto de } \\
\text { Clube de Astronomia era semelhante a esse, com a diferença na faixa etária e, } \\
\text { portanto, na abordagem de alguns assuntos, devido aos interesses. Já o dos } \\
\text { Mediadores de Leitura tinha objetivos diferentes e o produto final eram os } \\
\text { próprios alunos que se tornariam mediadores de leitura. Mas, o nosso objetivo } \\
\text { principal nos três projetos era a ampliação do repertório cultural e científico dos } \\
\text { alunos. } \\
\text { Hoje à noite eu respondo ao questionário no Google Docs. }\end{array}$ & $\begin{array}{l}\text { Práticas pedagógico-comunicacional (rubrica e práticas } \\
\text { reflexivas entre os alunos) } \\
\text { Gestão da comunicação (rubrica e práticas reflexivas entre os } \\
\text { alunos) } \\
\text { Leitura crítica dos meios (práticas reflexivas mediadas por } \\
\text { tecnologias): não é feita }\end{array}$ \\
\hline
\end{tabular}




\section{Anexo G.6: Entrevista POIE Nádia}

\begin{tabular}{|c|c|c|}
\hline PERGUNTAS & $\begin{array}{c}\text { ENTREVISTA } \\
\text { NADIA } \\
\end{array}$ & INDICADORES \\
\hline $\begin{array}{l}\text { (01) qual foi a duração do projeto } \\
\text { (aulas e meses)? }\end{array}$ & $\begin{array}{l}\text { Esse da sustentabilidade foi mais ou menos } 2 \text { meses, } 2 \text { meses e meio. Temos } \\
\text { uma aula por semana então sim tinha uma aula semanal. Então foram de } 8 \text { a } \\
10 \text { aulas mesmo. }\end{array}$ & Duração \\
\hline $\begin{array}{l}\text { (02) qual o perfil dos alunos que } \\
\text { participantes? Só aluno monitor } \\
\text { ou demais alunos, das turmas que } \\
\text { você atendia? }\end{array}$ & $\begin{array}{l}\text { Foram alunos de três nonos anos que tínhamos em 2012. Eram alunos que eu } \\
\text { acompanhava desde a quarta série. Era o quinto ano que eu estava dando aula } \\
\text { para eles. Foi a primeira turma que nós trabalhamos com o TQ. É uma turma } \\
\text { que trabalhou com o TQ por pelo menos } 2-3 \text { anos. }\end{array}$ & Perfil dos alunos \\
\hline $\begin{array}{l}\text { (04) quantos alunos mais ou } \\
\text { menos, no total? }\end{array}$ & $\begin{array}{l}\text { Mais ou menos } 35 \text { em cada uma das três turmas. Então, nesses projetos não } \\
\text { trabalhei apenas com aluno monitor. Nesses projetos eu trabalhei a sala toda. } \\
\text { Nessa época, eu já estava trabalhando com projetos na sexta, sétima e oitava } \\
\text { series. Ou seja, é sétima, oitava e nona séries. }\end{array}$ & Número de alunos \\
\hline (05) qual o(s) produto(s) finais? & $\begin{array}{l}\text { Eles trabalhavam em duplas. Esse projeto sobre a sustentabilidade por } \\
\text { exemplo tinha uma parte individual, para melhoria das ideias e reflexão sobre } \\
\text { o tema que estava sendo tratado, com o registro individual no AVA. Os } \\
\text { projetos de registro em PowerPoint e desenvolvimento em Movie Maker } \\
\text { eram feitos em duplas, porque nós não tínhamos computador para todos. E o } \\
\text { produto final dele o que foi então esse projeto, esses vídeos - foram cerca de } \\
15 \text { vídeos. O material que você me enviou está um pouco fora de ordem. E } \\
\text { como ele já faz um tempo, eu não lembro exatamente. Eu acho que o produto } \\
\text { final dele foi a construção de um vídeo mostrando passo a passo para se } \\
\text { utilizar a sucata para poder produzir alguma coisa. Eu não sei, eu não me } \\
\text { lembro se teve algo além disso. Eu vou dar uma pesquisada pois aquelas } \\
\text { páginas que você me enviou estão fora da ordem do projeto. Bem, foram } \\
\text { feitos mais ou menos } 15 \text { vídeos, pois nem todos frequentavam assiduamente. } \\
\text { E sempre tem algumas duplas que não fazem. Então foram feitos de } 10 \text { a } 15 \\
\text { vídeos. }\end{array}$ & $\begin{array}{l}\text { 1. Gestão Compartilhada da Comunicação: a. Ação } \\
\text { comunicativa; b. Apropriação e manejo das linguagens } \\
\text { da comunicação; c. Uso dos recursos da informação } \\
\text { para a produção cultural. } \\
\text { 2. Participações de Protagonismo: a. Participação planejadora } \\
\text { e operacional; b. Participação decisória, planejadora e } \\
\text { operacional; c. Participação decisória, planejadora, } \\
\text { operacional e avaliadora; d. Participação colaborativa plena; } \\
\text { e. Participação plenamente autônoma; f. Participação } \\
\text { condutora. } \\
\text { 3. Ações de Diálogo: a. Escuta mútua; b. Pensar juntos; } \\
\text { c. Apontar outros pontos de vista; d. Compartilhar e } \\
\text { refletir sobre ideias; e. Fazer emergir ideias / buscar } \\
\text { pluralidade de ideias } \\
\text { 4. Relações entre as pessoas nos ambientes do LIE, } \\
\text { para criação de um novo ecossistema comunicativo. }\end{array}$ \\
\hline (06) quando fui informada que o & Está quase tudo lá. Então como faz anos eu fiquei um pouco perdida, mas & \\
\hline
\end{tabular}




\begin{tabular}{|c|c|c|}
\hline $\begin{array}{l}\text { TQ sairia do ar, eu ainda } \\
\text { precisava estruturar pesquisa. } \\
\text { Então o Cesar e a Jane me } \\
\text { pediram para baixar e depois eu } \\
\text { tinha que organizar. O que eu fiz } \\
\text { foi fotografar as telas, para } \\
\text { manter os registros. }\end{array}$ & $\begin{array}{l}\text { está tudo lá ou pelo menos quase tudo. Eu particularmente não sabia onde era } \\
\text { o começo. Eu fiz isso para vários projetos e eu não sabia que projeto eu ia } \\
\text { pegar. }\end{array}$ & \\
\hline $\begin{array}{l}\text { (07) houve compartilhamento } \\
\text { com a escola ou comunidade de } \\
\text { entorno? }\end{array}$ & $\begin{array}{l}\text { Não foi divulgada, mas eu não me lembro se eu publiquei em um blog da } \\
\text { escola. Se eu não me engano, esse projeto foi feito no final do ano. O que } \\
\text { acontece é que já temos toda uma programação, mas chega no final do ano e } \\
\text { algumas aulas acabam sendo comprometidas. Acaba não dando para fazer } \\
\text { essas finalizações por causa de reunião e outras atividades de final de curso. } \\
\text { Por isso eu não lembro se eu cheguei a postar alguma coisa no blog da escola. } \\
\text { Eu preciso procurar. A escola ainda tem um blog antigo, mas não tenho } \\
\text { certeza. }\end{array}$ & $\begin{array}{l}\text { Contexto com muitas dificuldades para o } \\
\text { desenvolvimento do processo como um todo e POIE } \\
\text { não consegue finalizar o projeto. }\end{array}$ \\
\hline $\begin{array}{l}\text { (08) como é o protagonismo dos } \\
\text { alunos nesse projeto? }\end{array}$ & $\begin{array}{l}\text { Então esse tema foi um tema que surgiu na época da DRE campo limpo... não } \\
\text { sei se foi da DRE campo limpo ou se foi da secretaria municipal que era o } \\
\text { objetivo para trabalhar em sustentabilidade. } \\
\text { Aí eu iniciei o projeto. O TQ era bom por isso. A gente conseguia ir } \\
\text { acrescentando informações e essas informações apareciam na ordem } \\
\text { cronológica. Então eu comecei a montar esse projeto buscando ideias deles. } \\
\text { Então ele começava definindo o que era sustentabilidade, começava com um } \\
\text { texto, uma definição, um processo de melhoria de ideais, até chegarmos no } \\
\text { que era sustentabilidade. Aí fomos construindo assim: vindo deles, a gente } \\
\text { construiu uma definição nossa. }\end{array}$ & $\begin{array}{l}\text { 1. Gestão Compartilhada da Comunicação: a. Ação } \\
\text { comunicativa; b. Apropriação e manejo das linguagens } \\
\text { da comunicação; c. Uso dos recursos da informação } \\
\text { para a produção cultural. }\end{array}$ \\
\hline $\begin{array}{l}\text { (09) eles dão ideias de temas, } \\
\text { planejam e dividem tarefas, } \\
\text { definem as tecnologias de registro } \\
\text { da atividade, avaliam os } \\
\text { resultados em conjunto? }\end{array}$ & $\begin{array}{l}\text { É, eu dava um tempo para eles responderem e geralmente eu estipulava em } \\
45 \text { minutos a minha ideia eram } 2 \text { a } 3 \text { questões do TQ respondidas. Então eu } \\
\text { dividia essa aula, por exemplo: Então vocês têm } 10-15 \text { minutos. Ou então eu } \\
\text { fazia um bloco de coisas que eles podiam fazer sem a minha interferência e } \\
\text { deixava uma questão dessas por último para que eu tivesse o dia todo para } \\
\text { analisar e construir uma definição ou algo que eles pudessem melhorar. Isso } \\
\text { para mim durante a aula era um pouco difícil. Por exemplo dar } 10 \text { minutos, } \\
\text { ler tudo e sintetizar. }\end{array}$ & $\begin{array}{l}\text { 1. Gestão Compartilhada da Comunicação: a. Ação } \\
\text { comunicativa; b. Apropriação e manejo das linguagens } \\
\text { da comunicação; c. Uso dos recursos da informação } \\
\text { para a produção cultural. } \\
\text { 2. Participações de Protagonismo: a. Participação planejadora } \\
\text { e operacional; b. Participação decisória, planejadora e } \\
\text { operacional; c. Participação decisória, planejadora, } \\
\text { operacional e avaliadora; d. Participação colaborativa plena; } \\
\text { e. Participação plenamente autônoma; f. Participação } \\
\text { condutora. }\end{array}$ \\
\hline
\end{tabular}




\begin{tabular}{|c|c|c|}
\hline & & $\begin{array}{l}\text { 3. Ações de Diálogo: a. Escuta mútua; b. Pensar juntos; } \\
\text { c. Apontar outros pontos de vista; d. Compartilhar e } \\
\text { refletir sobre ideias; e. Fazer emergir ideias / buscar } \\
\text { pluralidade de ideias } \\
\text { 4. Relações entre as pessoas nos ambientes do LIE, } \\
\text { para criação de um novo ecossistema comunicativo. }\end{array}$ \\
\hline $\begin{array}{l}\text { (10) Ahn, sei... então você } \\
\text { deixava eles fazerem e depois } \\
\text { você ia analisando e depois dava } \\
\text { a devolutiva para eles. }\end{array}$ & $\begin{array}{l}\text { Geralmente eu colocava um texto, alguma coisa assim, e aí por último era: } \\
\text { para você, o que é sustentabilidade? Aí terminava a aula com essa resposta. } \\
\text { Eu lia e no dia seguinte ou semana seguinte a gente fazia a melhoria dessas } \\
\text { ideias. }\end{array}$ & $\begin{array}{l}\text { 1. Gestão Compartilhada da Comunicação: a. Ação } \\
\text { comunicativa; b. Apropriação e manejo das linguagen } \\
\text { da comunicação; c. Uso dos recursos da informação } \\
\text { para a produção cultural. } \\
\text { 2. Participações de Protagonismo: a. Participação planejadora } \\
\text { e operacional; b. Participação decisória, planejadora e } \\
\text { operacional; c. Participação decisória, planejadora, } \\
\text { operacional e avaliadora; d. Participação colaborativa plena; } \\
\text { e. Participação plenamente autônoma; f. Participação } \\
\text { condutora. } \\
\text { 3. Ações de Diálogo: a. Escuta mútua; b. Pensar juntos; } \\
\text { c. Apontar outros pontos de vista; d. Compartilhar e } \\
\text { refletir sobre ideias; e. Fazer emergir ideias / buscar } \\
\text { pluralidade de ideias }\end{array}$ \\
\hline
\end{tabular}




\begin{tabular}{|c|c|c|}
\hline & & $\begin{array}{l}\text { 4. Relações entre as pessoas nos ambientes do LIE, } \\
\text { para criação de um novo ecossistema comunicativo. }\end{array}$ \\
\hline $\begin{array}{l}\text { (12) então, depois, quando era } \\
\text { para ir para o projeto, para eles } \\
\text { desenvolverem a ideia, como eles } \\
\text { faziam o planejamento, as tarefas. } \\
\text { Por exemplo, você falou do } \\
\text { vídeo: como é que eles fizeram } \\
\text { isso daí? }\end{array}$ & $\begin{array}{l}\text { Esse vídeo saiu mais deles do que de mim, porque eu estruturei o projeto, } \\
\text { trabalhei, defini sustentabilidade e aí tem uma parte do projeto que eu pedia } \\
\text { para eles pesquisarem o que seriam atitudes sustentáveis. E aí a maior parte } \\
\text { deles respondeu algo relacionado com reciclagem e reaproveitamento. Então } \\
\text { isso apareceu muito. Foi aí que a gente pensou: isso. Bom, o que gente pode } \\
\text { reaproveitar? Lixo? Lixo? E aí veio a de construir alguma coisa com o lixo. } \\
\text { Então isso acabou surgindo mais deles. Ou seja, eu não sabia bem o que eu } \\
\text { iria fazer no projeto. Mas como eles falaram muito e reaproveitar, de } \\
\text { reutilizar, de coisas que eles jogavam fora e nunca mais servia para nada... aí } \\
\text { a gente pensou nisso. Aí eles começaram a fazer a construção de brinquedos, } \\
\text { objetos de decoração. Cada dupla escolheu alguma coisa. }\end{array}$ & $\begin{array}{l}\text { 1. Gestão Compartilhada da Comunicação: a. Ação } \\
\text { comunicativa; b. Apropriação e manejo das linguagens da } \\
\text { comunicação; c. Uso dos recursos da informação para a } \\
\text { produção cultural. } \\
\text { 2. Participações de Protagonismo: a. Participação planejadora } \\
\text { e operacional; b. Participação decisória, planejadora e } \\
\text { operacional; c. Participação decisória, planejadora, } \\
\text { operacional e avaliadora; d. Participação colaborativa plena; } \\
\text { e. Participação plenamente autônoma; f. Participação } \\
\text { condutora. } \\
\text { 3. Ações de Diálogo: a. Escuta mútua; b. Pensar juntos; c. } \\
\text { Apontar outros pontos de vista; d. Compartilhar e refletir } \\
\text { sobre ideias; e. Fazer emergir ideias / buscar pluralidade de } \\
\text { ideias } \\
\text { 4. Relações entre as pessoas nos ambientes do LIE, para } \\
\text { criação de um novo ecossistema comunicativo. }\end{array}$ \\
\hline $\begin{array}{l}\text { (13) Ahn... aí então eles foram } \\
\text { trabalhando quase que com eles } \\
\text { estruturando para desenvolverem } \\
\text { novos produtos a partir da sucata. } \\
\text { E foi aí que se originou os vídeos. } \\
\text { Porque [e quase um documentário } \\
\text { do que eles estavam fazendo. }\end{array}$ & $\begin{array}{l}\text { É... esse projeto específico da sustentabilidade foi uma coisa que nasceu } \\
\text { mais deles do que minha. Porque até esse momento eu trabalhava com o } \\
\text { ThinkQuest, mas eu tinha um projeto pronto já e aí eu sabia de onde eu partia } \\
\text { e onde eu queria chegar. E nesse projeto da sustentabilidade, não. Eu parti } \\
\text { sem saber onde eu chegaria. }\end{array}$ & \\
\hline $\begin{array}{l}\text { (14) há conflitos? Quem faz essa } \\
\text { mediação nos casos de conflito? }\end{array}$ & $\begin{array}{l}\text { : então, no começo teve um pouco de uma desorganização ... de ideias... eles } \\
\text { estavam um pouco perdidos até eles entrarem num consenso, essa parte toda } \\
\ldots \text { aí na hora que definimos... bom, então faremos isso... aí eu delimitei... } \\
\text { brinquedos, objetos de decoração, utensílios, tudo a partir da sucata. } \\
\text { Procurem algo e vamos construir. Aí eles conseguiram um foco maior e } \\
\text { começou a parte mais pratica. Aí eles deslancharam }\end{array}$ & O início do processo... sempre o mais difícil. :) \\
\hline $\begin{array}{l}\text { (15) quem elaborou as rubricas: } \\
\text { você (ou você com outros POIE) } \\
\text { ou eles ou vocês em conjunto? }\end{array}$ & $\begin{array}{l}\text { Fui eu... a rubrica eu já estava com ela pronta, é uma coisa que a gente } \\
\text { também trabalhou bastante na informática. Só que eu nunca me senti tão à } \\
\text { vontade de trabalhar... então assim, eu construía, pensando sempre em } \\
\text { valores do que cada um tinha feito e um degrau acima do outro, quem fez um } \\
\text { pouco mais, um pouco mais, mas eu que criava as rubricas e eles se }\end{array}$ & $\begin{array}{l}\text { As reflexões causadas pela rubrica iniciam quando da } \\
\text { sua elaboração, pelos próprios POIE. }\end{array}$ \\
\hline
\end{tabular}




\begin{tabular}{|c|c|c|}
\hline & encaixavam na minha rubrica. & \\
\hline $\begin{array}{l}\text { (16) quando a rubricas foram } \\
\text { elaboradas: início meio ou fim? }\end{array}$ & $\begin{array}{l}\text { Só quando chegasse na parte da avaliação } \\
\ldots\end{array}$ & \\
\hline $\begin{array}{l}\text { (17) quando elas foram } \\
\text { informadas a eles (caso os alunos } \\
\text { não tenham tido participação no } \\
\text { processo)? }\end{array}$ & $\begin{array}{l}\text { Não o deles foi bem no final, quando acho que eles já tinham terminado o } \\
\text { vídeo e salvo. Acho que aí tinha uma rubrica. Não tenho certeza se o deles } \\
\text { tinha mais de uma... mas acho que era apenas uma. }\end{array}$ & \\
\hline $\begin{array}{l}\text { (18) qual a dificuldade ou desafio } \\
\text { de utilizar as rubricas? }\end{array}$ & $\begin{array}{l}\text { Porque na época que eu trabalhava como POIE, tinha muita coisa pronta, né! } \\
\text { Acho que a gente se considera muito detentor do saber, onde quero chegar. } \\
\text { Para mim era fácil avaliar se eu tinha atingido os objetivos ou não. Eu estava } \\
\text { visualizando. Então essa era a dificuldade da rubrica, porque a rubrica é uma } \\
\text { avaliação que acaba não sendo feita por mim. É uma avaliação feita por eles. } \\
\text { Dele mesmo então acho é essa coisa, a gente sair do conforto. }\end{array}$ & Refletindo sobre posturas antigas, controladoras. \\
\hline $\begin{array}{l}\text { (20) ele era mais amigável, né? A } \\
\text { navegação dele? }\end{array}$ & $\begin{array}{l}\text { O EdModo eu acho que ela já partia de uma confusão até pela cor dele, } \\
\text { porque ele tinha cara de Facebook. Então o aluno ali dentro eu tinha a } \\
\text { impressão de que ele achava que podia tudo. E no TQ ele visualizava aquilo } \\
\text { como uma plataforma educacional. Então eu já senti aí essa diferença. Ele } \\
\text { achava que o EdModo era o Facebook. }\end{array}$ & \\
\hline $\begin{array}{l}\text { (21) e você acha que assim o } \\
\text { registro no ava, independente de } \\
\text { qualquer que seja, ele realmente } \\
\text { ajuda na hora de compilar as } \\
\text { ideias, ele tem um ganho nisso e } \\
\text { qual seria esse ganho? }\end{array}$ & $\begin{array}{l}\text { Eu acho que ele tem vantagens e desvantagens, como qualquer coisa. Eu } \\
\text { tinha muitos alunos que trabalhando no ThinkQuest ou Edmodo, eles liam } \\
\text { tudo que os outros faziam e então eles sabiam o que cada um estava } \\
\text { pensando... então tinha essa coisa de olhar para a opinião do outro, de pensar } \\
\text { "nossa, de repente, ele está pensando assim e eu... será que é assim??" Que a } \\
\text { gente não tem isso no físico na sala de aula e, mas também eu acho que o } \\
\text { AVA, ainda mais trabalhando com } 30 \text { alunos, todos juntos, ajuda também a } \\
\text { dispersar. Então muitas vezes eu tinha foco pequeno, } 3 \text { questões de alunos } \\
\text { que demoravam a aula inteira e não conseguiam porque estavam ou } \\
\text { interessados em tocar a foto do ambiente virtual, ver o que o outro respondeu } \\
\text { e não fazia aquilo que pedia. Mas eu acho que tem mais ganhos do que ... }\end{array}$ & $\begin{array}{l}\text { 1. Gestão Compartilhada da Comunicação: a. Ação } \\
\text { comunicativa; b. Apropriação e manejo das linguagens } \\
\text { da comunicação; c. Uso dos recursos da informação } \\
\text { para a produção cultural. } \\
\text { 4. Relações entre as pessoas nos ambientes do LIE, } \\
\text { para criação de um novo ecossistema comunicativo. }\end{array}$ \\
\hline $\begin{array}{l}\text { (23) e você acha, assim... o } \\
\text { registro no AVA, então, } \\
\text { enriquece o processo até reflexivo } \\
\text { e dialógico entre eles? Como? }\end{array}$ & $\begin{array}{l}\text { Eu acho que enriquece porque é uma coisa que eu hoje em dia em sala de } \\
\text { aula não vejo. Porque cada um faz a sua atividade, ninguém sabe o que o } \\
\text { outro está fazendo, ninguém troca informação, por mais que vê monte } \\
\text { grupos, sente em dupla, é cada um fazendo o seu e isso no ava gerava uma } \\
\text { curiosidade... todo mundo sabia o que o outro estava fazendo... então, eu acho } \\
\text { muito mais positivo. }\end{array}$ & $\begin{array}{l}\text { 1. Gestão Compartilhada da Comunicação: a. Ação } \\
\text { comunicativa; b. Apropriação e manejo das linguagens } \\
\text { da comunicação; c. Uso dos recursos da informação } \\
\text { para a produção cultural. } \\
\text { 2. Participações de Protagonismo: a. Participação planejadora }\end{array}$ \\
\hline
\end{tabular}




\begin{tabular}{|c|c|c|}
\hline & & $\begin{array}{l}\text { e operacional; b. Participação decisória, planejadora e } \\
\text { operacional; c. Participação decisória, planejadora, } \\
\text { operacional e avaliadora; d. Participação colaborativa plena; } \\
\text { e. Participação plenamente autônoma; f. Participação } \\
\text { condutora. } \\
\text { 3. Ações de Diálogo: a. Escuta mútua; b. Pensar juntos; } \\
\text { c. Apontar outros pontos de vista; d. Compartilhar e } \\
\text { refletir sobre ideias; e. Fazer emergir ideias / buscar } \\
\text { pluralidade de ideias } \\
\text { 4. Relações entre as pessoas nos ambientes do LIE, } \\
\text { para criação de um novo ecossistema comunicativo. }\end{array}$ \\
\hline $\begin{array}{l}\text { (24) e quando chegava na } \\
\text { avaliação final, como era? Você } \\
\text { que fazia ou eles faziam a } \\
\text { autoavaliação em cima da rubrica } \\
\text { que você apresentava? }\end{array}$ & $\begin{array}{l}\text { Geralmente esses projetos que tinham como produto final vídeo ou } \\
\text { apresentação em Power point, eu gostava de marcar um dia com eles e } \\
\text { mostrar num telão para todos eles os vídeos de cada dupla e fazia os } \\
\text { comentários: "olha poderia estar melhor aqui..." a ideia foi boa... isso aqui } \\
\text { está ótimo... isso não está tanto..." então marcava um dia, fazia essa } \\
\text { avaliação, se o projeto permitisse, se o tempo hábil permitisse, pedia que } \\
\text { consertassem as coisas que levantamos, indicamos... e nesse dia, talvez até } \\
\text { alguns outros alunos de outras duplas, até opinavam, " Ahn... gostei daquilo, } \\
\text { Ahn, aquilo podia melhorar... e ai terminando esse processo, fazia a } \\
\text { autoavaliação através das rubricas... }\end{array}$ & $\begin{array}{l}\text { 1. Gestão Compartilhada da Comunicação: a. Ação } \\
\text { comunicativa; b. Apropriação e manejo das linguagens } \\
\text { da comunicação; c. Uso dos recursos da informação } \\
\text { para a produção cultural. } \\
\text { 2. Participações de Protagonismo: a. Participação planejadora } \\
\text { e operacional; b. Participação decisória, planejadora e } \\
\text { operacional; c. Participação decisória, planejadora, } \\
\text { operacional e avaliadora; d. Participação colaborativa plena; } \\
\text { e. Participação plenamente autônoma; f. Participação } \\
\text { condutora. } \\
\text { 3. Ações de Diálogo: a. Escuta mútua; b. Pensar juntos; } \\
\text { c. Apontar outros pontos de vista; d. Compartilhar e } \\
\text { refletir sobre ideias; e. Fazer emergir ideias / buscar } \\
\text { pluralidade de ideias } \\
\text { 4. Relações entre as pessoas nos ambientes do LIE, } \\
\text { para criação de um novo ecossistema comunicativo. }\end{array}$ \\
\hline $\begin{array}{l}\text { (25) então primeiro vocês } \\
\text { olhavam o produto tanto em } \\
\text { termos do conteúdo trabalhado, } \\
\text { como em termos da própria } \\
\text { qualidade do vídeo, parte } \\
\text { estética? }\end{array}$ & $\begin{array}{l}\text { Isso... em termos de ideia... corrigia erros de português que às vezes eles } \\
\text { cometem... e erros também do trabalho do software... porque também fazia } \\
\text { parte da disciplina eu dava, parava o projeto e dava uma aula só sobre Movie } \\
\text { Maker... então, tinham algumas coisas que eles precisavam ter no vídeo } \\
\text { deles... como por exemplo os créditos... a gente combinava desde o início... } \\
\text { no final vocês tem que inserir os créditos...tem que ter esse texto. Aí era uma } \\
\text { coisa que eu cobrava. }\end{array}$ & $\begin{array}{l}\text { 1. Gestão Compartilhada da Comunicação: a. Ação } \\
\text { comunicativa; b. Apropriação e manejo das linguagens } \\
\text { da comunicação; c. Uso dos recursos da informação } \\
\text { para a produção cultural. }\end{array}$ \\
\hline
\end{tabular}


(26) Ahn.. Ok... então primeiro você fazia toda essa avaliação e aí eles faziam a autoavaliação. E normalmente qual era o critério da autoavaliação, o que eles iam avaliar ali nessa autoavaliação?

$(28)$

dando

informação, dando opinião, trocando?

Veja, eu estou dizendo assim... dentro do universo deles, com certeza...
Eles avaliavam o desempenho deles durante todas as aulas desse projeto. Então nesse dia da autoavaliação, eu relembrava com eles todas as etapas do projeto... começamos aqui, fizemos isso, lemos o texto, definimos sustentabilidade, fizemos uma pesquisa, aí produzimos o vídeo e apresentamos... agora leiam as rubricas que escrevemos e vejam em qual delas cada um de vocês se encaixa... e as vezes também pedia para eles comentarem algo... pedia para eles explicarem o porquê, a razão deles se inserirem naquela rubrica, (naquele degrau, ou nível) ...

Olha... era parte... se o projeto fosse ... esse da sustentabilidade andou muito bem... as turmas eram boas... ele se desenvolveu bem... então uma autoavaliação foi o que esperava...a maior parte dos alunos participou e participou ativamente... então

Produzindo

dentro do que foi esperado do projeto, que era... a minha esperança dentro desse projeto de sustentabilidade era que eles percebessem o que poderiam fazer... para melhorar, para ter uma vida melhor em relação ao meio ambiente e tudo mais... então eu queria uma atitude deles... como isso partiu deles, foi interessante, porque aí chegou no final do projeto, tinha um menino que fez um porta lápis e ele deu ele para mim... esse porta lápis ficou anos na minha mesa... ele estava até lá, ele fez, ele me deu... ele falou "oh, professora, toma para você... “... e ele ficou lá... virou um objeto útil porque não tinha porta lápis em cima da mesa... e aí ele me deu esse todo de garrafa pet.. Tampinha... era um palhaço... então achei que foi legal e toda vez que entravam outros alunos, eles diziam... "o Iuri te deu, foi que ele fez e deu para você"... eu sempre falava... " estão vendo... projeto de vocês!!!"
1. Gestão Compartilhada da Comunicação: a. Ação comunicativa; b. Apropriação e manejo das linguagens da comunicação; c. Uso dos recursos da informação para a produção cultural.

2. Participações de Protagonismo: a. Participação planejadora e operacional; b. Participação decisória, planejadora e operacional; c. Participação decisória, planejadora, operacional e avaliadora; d. Participação colaborativa plena e. Participação plenamente autônoma; f. Participação condutora.

3. Ações de Diálogo: a. Escuta mútua; b. Pensar juntos c. Apontar outros pontos de vista; d. Compartilhar e refletir sobre ideias; e. Fazer emergir ideias / buscar pluralidade de ideias

4. Relações entre as pessoas nos ambientes do LIE, para criação de um novo ecossistema comunicativo.

1. Gestão Compartilhada da Comunicação: a. Ação comunicativa; b. Apropriação e manejo das linguagens da comunicação; c. Uso dos recursos da informação para a produção cultural.

2. Participações de Protagonismo: a. Participação planejadora e operacional; b. Participação decisória, planejadora e operacional; c. Participação decisória, planejadora, operacional e avaliadora; d. Participação colaborativa plena; e. Participação plenamente autônoma; f. Participação condutora

3. Ações de Diálogo: a. Escuta mútua; b. Pensar juntos; 


\begin{tabular}{|c|c|c|}
\hline & & $\begin{array}{l}\text { c. Apontar outros pontos de vista; d. Compartilhar e } \\
\text { refletir sobre ideias; e. Fazer emergir ideias / buscar } \\
\text { pluralidade de ideias } \\
\text { 4. Relações entre as pessoas nos ambientes do LIE, } \\
\text { para criação de um novo ecossistema comunicativo. }\end{array}$ \\
\hline $\begin{array}{l}\text { Agora, tem um aspecto que eu } \\
\text { quero te perguntar... você para } \\
\text { fazer o seu projeto, esse projeto, } \\
\text { na verdade foi escolhido? Porque } \\
\text { ele fez parte de uma formação } \\
\text { que foi coordenada pela Cristina, } \\
\text { via DRE que teve a formação de } \\
\text { vocês e a partir disso vocês foram } \\
\text { desenvolvendo esse projeto, cada } \\
\text { um foi desenvolvendo o seu... } \\
\text { como foi essa formação? Você se } \\
\text { lembra como foi? Você se lembra } \\
\text { como foi essa construção de } \\
\text { rubricas, fazerem essas } \\
\text { autoavaliações de vocês... }\end{array}$ & $\begin{array}{l}\text { eu sou muito suspeita para falar, porque eu admiro muito o trabalho da } \\
\text { Cristina... tanto que eu estava há oito anos trabalhando na informática... e } \\
\text { como todo mundo na prefeitura, cheguei sem saber nada e assim acho que } \\
\text { todas as formações dela no geral são ótimos, ela sempre incentivou muito a } \\
\text { gente... assim... ela percebia a dificuldade que a gente tinha porque além da } \\
\text { dificuldade de trabalhar com uma coisa nova, a gente ainda tinha a } \\
\text { dificuldade estrutural que era uma rede de internet que não funciona bem, } \\
\text { você chega para dar aula e seu laboratório está quebrado porque resolveram } \\
\text { fazer uma reforma... então a Cris sempre trabalhou muito com a gente essa } \\
\text { parte... vamos ter o foco no aluno ... precisamos em prol do aluno... construir } \\
\text { coisas boas para ele... e ai ela sempre incentivou muito e o que a gente não } \\
\text { sabia... ela ensinava... ou se ela não podia ensinar, ela mostrava onde buscar... }\end{array}$ & Avaliação do Programa POIE 2012 \\
\hline $\begin{array}{l}\text { Ela é fora de série... ela é ponto } \\
\text { fora da curva... o que eu quero } \\
\text { entender... como foi o processo... } \\
\text { por exemplo... até onde eu } \\
\text { entendi, posso ter entendido } \\
\text { errado... por exemplo, quando } \\
\text { estavam fazendo a formação em } \\
\text { rubrica, vocês tiveram que entre } \\
\text { vocês, fazerem rubrica... então } \\
\text { como é esse processo de } \\
\text { negociação entre vocês, e depois } \\
\text { como foi o processo de } \\
\text { autoavaliação e vocês em termos } \\
\text { da aplicação de processo? Essa } \\
\text { apresentação entre vocês? Como } \\
\text { foi isso? Você se lembra? }\end{array}$ & $\begin{array}{l}\text { Então essa construção da rubrica... eu não me lembro de ter construído... eu } \\
\text { me lembro dela chegar pronta no final do projeto... e aí a gente se encaixar ... } \\
\text { como foi seu desenvolvimento... tínhamos também o ambiente virtual que } \\
\text { tínhamos o nosso projeto montado e já tinha uma rubrica pronta ali... }\end{array}$ & Rubrica chega pronto para o POIE podes aplicar. \\
\hline
\end{tabular}




\begin{tabular}{|c|c|c|}
\hline $\begin{array}{l}\text { Então a rubrica veio pronta, ela } \\
\text { não foi discutida e elaborada por } \\
\text { vocês? }\end{array}$ & $\begin{array}{l}\text { Aquela especificamente do projeto, não..., mas sempre foi mostrado como } \\
\text { construir. Mas aquela da avaliação do projeto estava pronta... }\end{array}$ & \\
\hline $\begin{array}{lrr}\text { Então... no final vocês } & \text { se } \\
\text { autoavaliarem } & \text { quanto } & \text { à } \\
\text { participação ao longo } & \text { do } \\
\text { processo? Na aplicação } & \text { do } \\
\text { projeto com seus alunos... } & \end{array}$ & $\begin{array}{l}\text { : foi uma autoavaliação também... eu acabei reproduzindo com os alunos o } \\
\text { que tínhamos feito na formação... por isso eu usei as rubricas dessa maneira... } \\
\text { Então, foi assim que eu achei que a coisa deveria caminhar, para mim era } \\
\text { assim... eu faço as rubricas, preparo... e os alunos se autoavaliar... }\end{array}$ & \\
\hline No final & $\begin{array}{l}\text { Ahn... eu nunca imaginei que poderia ser utilizado de outra maneira... agora } \\
\text { que você está colocando }\end{array}$ & Revendo orientações \\
\hline $\begin{array}{l}\text { Eu estou te } \\
\text { perguntando... } \\
\text { porque... bem agora posso } \\
\text { explicar... pela proposta da } \\
\text { avaliação formativa... para } \\
\text { aprendizagem...o aluno sabe } \\
\text { exatamente o que está sendo } \\
\text { esperado dele... os critérios não } \\
\text { estão claros para os alunos... } \\
\text { então ele não caminha tanto } \\
\text { porque ele acha que é aquilo que } \\
\text { se espera dele... em alguns casos, } \\
\text { você até valida as rubricas que } \\
\text { pautarão a atividade... }\end{array}$ & $\begin{array}{l}\text { É, os meus faziam isso em alguns momentos porque mesmo antes de colocar } \\
\text { a rubrica... eu dava uma orientação... como eles já tinham trabalhado no TQ } \\
\text { antes... eles já sabiam que tinha uma avaliação no final e aí eles já } \\
\text { perguntavam... professora, como será a avaliação no final? E eu respondia... } \\
\text { serão avaliados esses, esses e esses pontos... e um dos passos vai ser ajudar o } \\
\text { outro... ou as vezes eu acabava colocando as questões já com antecedência e } \\
\text { eles já viam as rubricas... então tinha esse surto do "deixa que eu te ajudo"... }\end{array}$ & A prática vai aprimorando \\
\hline $\begin{array}{l}\text { Normalmente esse é o papel da } \\
\text { rubrica... e é o que quero trazer } \\
\text { para a educom..., mas eu também } \\
\text { não acho que você não deve } \\
\text { trabalhar por causa da rubrica... } \\
\text { porque tem alguns autores que } \\
\text { falam que tem que pautar tudo em } \\
\text { cima da rubrica... você tem uma } \\
\text { rubrica que vai nortear, mas não } \\
\text { quer dizer que para cada passo } \\
\text { que for dar tem de ficar olhando } \\
\text { para rubrica, senão fica refém } \\
\text { dela... }\end{array}$ & $\begin{array}{l}\text { Senão ficamos muito amarrados também... e não consegue produzir nada... } \\
\text { pensando só no produto final e no que vai ser avaliado }\end{array}$ & O medo da rubrica engessar o processo. \\
\hline
\end{tabular}




\section{Anexo H - CATEGORIAS TEMÁTICAS E RESPECTIVOS SUBTEMAS: APROXIMAÇÕES CONCEITUAIS POSSÍVEIS}

\begin{tabular}{|c|c|c|c|}
\hline $\begin{array}{c}\text { INDICADORES } \\
\text { A PARTIR DO } \\
\text { PARADIGMA DA } \\
\text { EDUCOMUNICAÇÃO } \\
\text { (SOARES, 1999; 2011) }\end{array}$ & $\begin{array}{c}\text { INDICADORES } \\
\text { A PARTIR DA } \\
\text { AVALIAÇÃO } \\
\text { DIALÓGICA } \\
\text { (ROMÃO, 2011) } \\
\end{array}$ & $\begin{array}{l}\text { INDICADORES } \\
\text { A PARTIR DA } \\
\text { AVALIAÇÃO } \\
\text { FORMATIVA } \\
\text { (WILIAM, 2011) } \\
\end{array}$ & $\begin{array}{l}\text { CONSIDERAÇÕES SOBRE AS POSSÍVEIS APROXIMAÇÕES } \\
\text { CONCEITUAIS }\end{array}$ \\
\hline $\begin{array}{l}\text { FINALIDADE PRINCIPAL } \\
\text { 1. Empoderamento do aluno enquanto } \\
\text { cidadão responsável } \\
\text { 2. Apoio à construção do conhecimento } \\
\text { 3. Acompanhamento do desenvolvimento } \\
\text { das competências educomunicativas no } \\
\text { contexto de ecossistemas comunicacionais }\end{array}$ & $\begin{array}{l}\text { FINALIDADE } \\
\quad \text { PRINCIPAL } \\
\text { 1. Empoderamento do } \\
\text { aluno enquanto responsável } \\
\text { 2. Apoio à construção do } \\
\text { conhecimento }\end{array}$ & 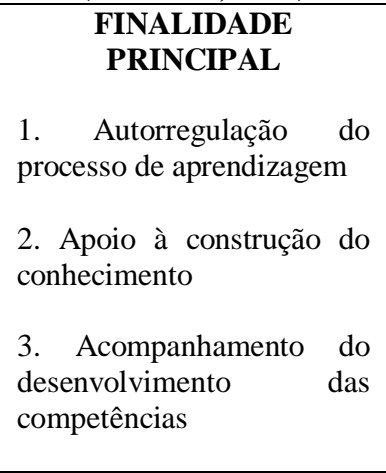 & $\begin{array}{l}\text { FINALIDADE PRINCIPAL } \\
\text { O paradigma da Educomunicação tem como sua finalidade o } \\
\text { empoderamento, e consequentemente o apoio à construção do } \\
\text { conhecimento, o que demanda um acompanhamento do desenvolvimento } \\
\text { das práticas nos ecossistemas comunicacionais. } \\
\text { A avaliação dialógica destaca esses aspectos todos. } \\
\text { Já a avaliação formativa não fala em empoderamento, mas em } \\
\text { autorregulação. } \\
\text { Contudo estamos considerando convergentes, pois a autorregulação } \\
\text { implica que a criança e jovem compreenda e se aproprie de seu processo } \\
\text { de aprendizagem, o que, a nosso ver, é convergente e complementar com a } \\
\text { questão do empoderamento. }\end{array}$ \\
\hline $\begin{array}{l}\text { MOMENTO DE AVALIAÇÃO } \\
\text { 1. Acompanhamento ao longo do processo; } \\
\text { 2. Viabilização de intervenções e } \\
\text { orientações ao longo de todo o processo, e } \\
\text { não apenas no início ou final do mesmo. }\end{array}$ & $\begin{array}{l}\text { 1. Acompanhamento ao } \\
\text { longo do processo; } \\
\text { 2. Viabilização de } \\
\text { intervenções e orientações } \\
\text { ao longo de todo o } \\
\text { processo, e não apenas no } \\
\text { início ou final do mesmo. }\end{array}$ & $\begin{array}{l}\text { 1. Acompanhamento ao } \\
\text { longo do processo; } \\
\text { 2. Viabilização de } \\
\text { intervenções e orientações } \\
\text { ao longo de todo o } \\
\text { processo, e não apenas no } \\
\text { início ou final do mesmo. }\end{array}$ & $\begin{array}{l}\text { MOMENTO DE AVALIAÇÃO } \\
\text { Dada a finalidade principal ser o empoderamento, uma proposta de } \\
\text { abordagem educomunicativa deve ser viável DURANTE o } \\
\text { desenvolvimento das práticas, sendo que ambas as abordagens aqui } \\
\text { analisadas apresentam essa característica. }\end{array}$ \\
\hline $\begin{array}{l}\text { DINÂMICA ENCERRAMENTO } \\
\text { 1. Rodas de conversas, ao final do } \\
\text { processo, para desenvolvimento de } \\
\text { reflexões analíticas e reflexivas pelos } \\
\text { alunos, de forma individual e/ou grupal. }\end{array}$ & $\begin{array}{l}\text { DINÂMICA } \\
\text { ENCERRAMENTO } \\
\text { 1. Rodas de conversas, ao } \\
\text { final do processo, para } \\
\text { desenvolvimento de } \\
\text { reflexões analíticas e } \\
\text { reflexivas pelos alunos, de }\end{array}$ & $\begin{array}{l}\text { DINÂMICA } \\
\text { ENCERRAMENTO } \\
\text { 1. Avaliação entre pares } \\
\text { (duplas ou grupos } \\
\text { pequenos, equipes) e/ou } \\
\text { autoavaliação. }\end{array}$ & $\begin{array}{l}\text { DINÂMICA ENCERRAMENTO } \\
\text { Esta premissa educomunicativa também é atendida nas duas propostas de } \\
\text { avaliação dialógica e formativa. } \\
\text { Vale destacar, que apesar da adoção de outra terminologia - avaliação } \\
\text { entre pares ou autoavaliação individual - a avaliação formativa detalha } \\
\text { mais objetivamente as ações que seriam desenvolvidas nessa roda de } \\
\text { conversa. }\end{array}$ \\
\hline
\end{tabular}




\begin{tabular}{|c|c|c|c|}
\hline & $\begin{array}{l}\text { forma individual e/ou } \\
\text { grupal. }\end{array}$ & & \\
\hline $\begin{array}{l}\text { 2. Participações de Protagonismo [Degraus } \\
\text { de Participação: } 5 \text { a } 10 \text { (HART, 1992; } \\
\text { COSTA,2006) ]: } \\
\text { a. Participação planejadora e operacional. } \\
\text { b. Participação decisória, planejadora e } \\
\text { operacional. } \\
\text { c. Participação decisória, planejadora, } \\
\text { operacional e avaliadora. } \\
\text { d. Participação colaborativa plena. } \\
\text { e. Participação plenamente autônoma. } \\
\text { f. Participação condutora. } \\
\text { 3. Ações de Diálogo } \\
\text { a. Escuta mútua } \\
\text { b. Pensar juntos } \\
\text { c. Apontar outros pontos de vista } \\
\text { d. Compartilhar e refletir sobre ideias, } \\
\text { e. Fazer emergir ideias / buscar pluralidade } \\
\text { de ideias }\end{array}$ & $\begin{array}{l}\text { AÇÕES DIALÓGICAS } \\
\text { 1. Gestão da Comunicação: } \\
\text { definição dos } \\
\text { procedimentos de ao longo } \\
\text { de todo o processo de } \\
\text { avaliação, para definição } \\
\text { dos pontos de intervenção, } \\
\text { negociação } \\
\text { estabelecimento de padrões } \\
\text { a serem trabalhados; } \\
\text { 2. Planejamento dos } \\
\text { instrumentos de verificação } \\
\text { e dos pontos onde eles } \\
\text { serão aplicados; } \\
\text { 3. Ações estratégicas de } \\
\text { verificação do desempenho } \\
\text { e aplicação dos critérios } \\
\text { previamente definidos. } \\
\text { 4. Procedimentos de } \\
\text { análises dos resultados, } \\
\text { descrição das formas de } \\
\text { feedback e definição das } \\
\text { próximas ações, } \\
\text { considerando esses } \\
\text { resultados. }\end{array}$ & \begin{tabular}{l} 
AÇÕES \\
\multicolumn{1}{c}{ ESTRATÉGICAS } \\
1. Criação colaborativa de \\
Rubrica: elaboração \\
coletiva; construção \\
conjunta por meio de trocas \\
dialógicas para definição \\
dos critérios e respectivos \\
níveis; elaboração no início \\
do projeto ou dinâmica; \\
validação com alunos e \\
professores. \\
2. Práticas de diálogo e \\
reflexão: tipos de \\
participação dos alunos \\
(degraus de Hart e Costa); \\
alunos enquanto recursos \\
de aprendizagem \\
(aprendendo ensinando) e o \\
protagonismo no processo \\
de aprendizagem \\
3. Feedback propositivo, \\
com base na rubrica. \\
4. Avaliação entre pares e \\
autoavaliação reflexiva, \\
com base na rubrica.
\end{tabular} & $\begin{array}{l}\text { Aqui observamos que há vários tipos de ações passíveis de serem } \\
\text { consideradas como praticas pedagógico comunicacionais, sendo que para o } \\
\text { caso da avaliação dialógica, a gestão da comunicação tem forte aderência } \\
\text { com as premissas educomunicativas, bem como suas demais dinâmicas. } \\
\text { O próprio fato de ser uma proposta derivada das ideias de Paulo Freire } \\
\text { confirma que as suas premissas são convergentes com as da } \\
\text { Educomunicação. E então esta proposta valida as premissas que definimos } \\
\text { como sendo necessárias a uma proposta de avalição de abordagem } \\
\text { educomunicativa. } \\
\text { Quanto às ações estratégicas da avaliação formativa, elas indicam também } \\
\text { a convergência, e parecem se estruturar principalmente nas ações } \\
\text { dialógicas e protagonistas, como estamos considerando como uma das } \\
\text { nossas hipóteses norteadoras. } \\
\text { Contudo, por todas as ações estratégicas listadas e possibilidades de } \\
\text { ocorrência de cada uma delas, entendemos que os comentários acerca da } \\
\text { estrutura desta abordagem terem ou não fortes características dialógicas } \\
\text { serão melhor estruturados a partir dos dados da pesquisa empírica. }\end{array}$ \\
\hline $\begin{array}{l}\text { COMPETÊNCIAS } \\
\text { EDUCOMUNICATIVAS } \\
\text { 1. Diálogo (Pensar e construir } \\
\text { conjuntamente) } \\
\text { 2. Escuta mútua } \\
\text { 3. Organização e expressão do pensamento } \\
\text { (reflexão) }\end{array}$ & $\begin{array}{l}\text { COMPETÊNCIAS } \\
\text { DIALÓGICAS } \\
\text { Não foi especificado } \\
\text { claramente. }\end{array}$ & $\begin{array}{l}\text { COMPETÊNCIAS } \\
\text { TRABALHADAS } \\
\text { Não foi especificado } \\
\text { claramente. }\end{array}$ & $\begin{array}{l}\text { Para este tema e respectivos subtemas, os autores de ambas as propostas } \\
\text { de avaliação indicam a possiblidade de trabalharmos inúmeras } \\
\text { competências com a adoção dessas abordagens avaliativas, mas não } \\
\text { mencionam competências específicas, como as que definimos aqui como } \\
\text { sendo educomunicativas. }\end{array}$ \\
\hline
\end{tabular}




\begin{tabular}{|l|l|l|l|}
\hline 4. Colaboração & & $\begin{array}{l}\text { Na verdade, este tema foi definido principalmente para verificarmos se há } \\
\text { competências educomunicativas sendo trabalhadas nas atividades dos } \\
\text { projetos, quando analisamos seus quadros de rubricas. }\end{array}$ \\
5. Compartilhamento (de experiências e de \\
ideias)
\end{tabular}




\section{Anexo I - AUTORIZAÇÕES}

I.1 - Autorização Secretaria Municipal de Educação de São Paulo

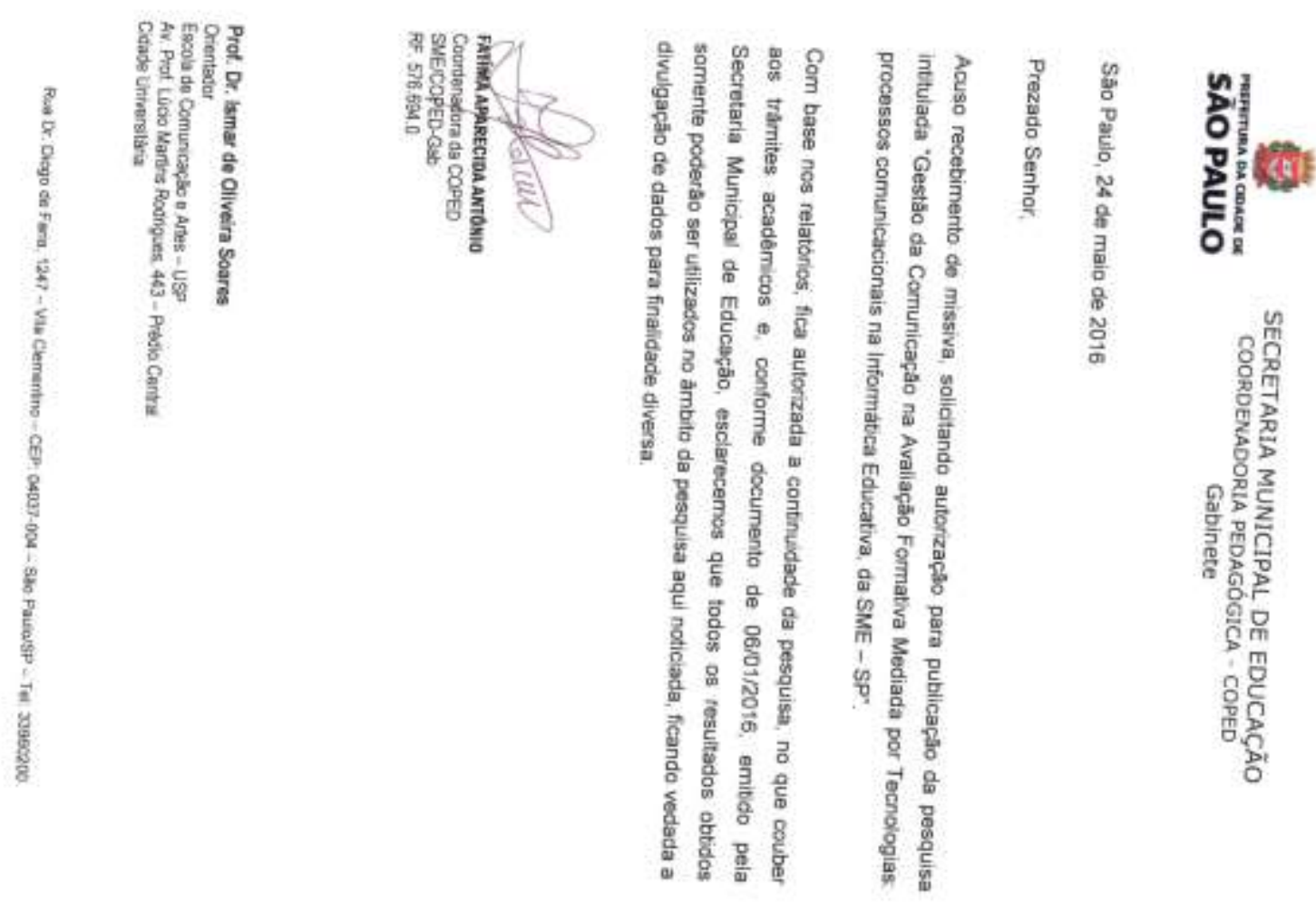

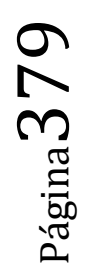



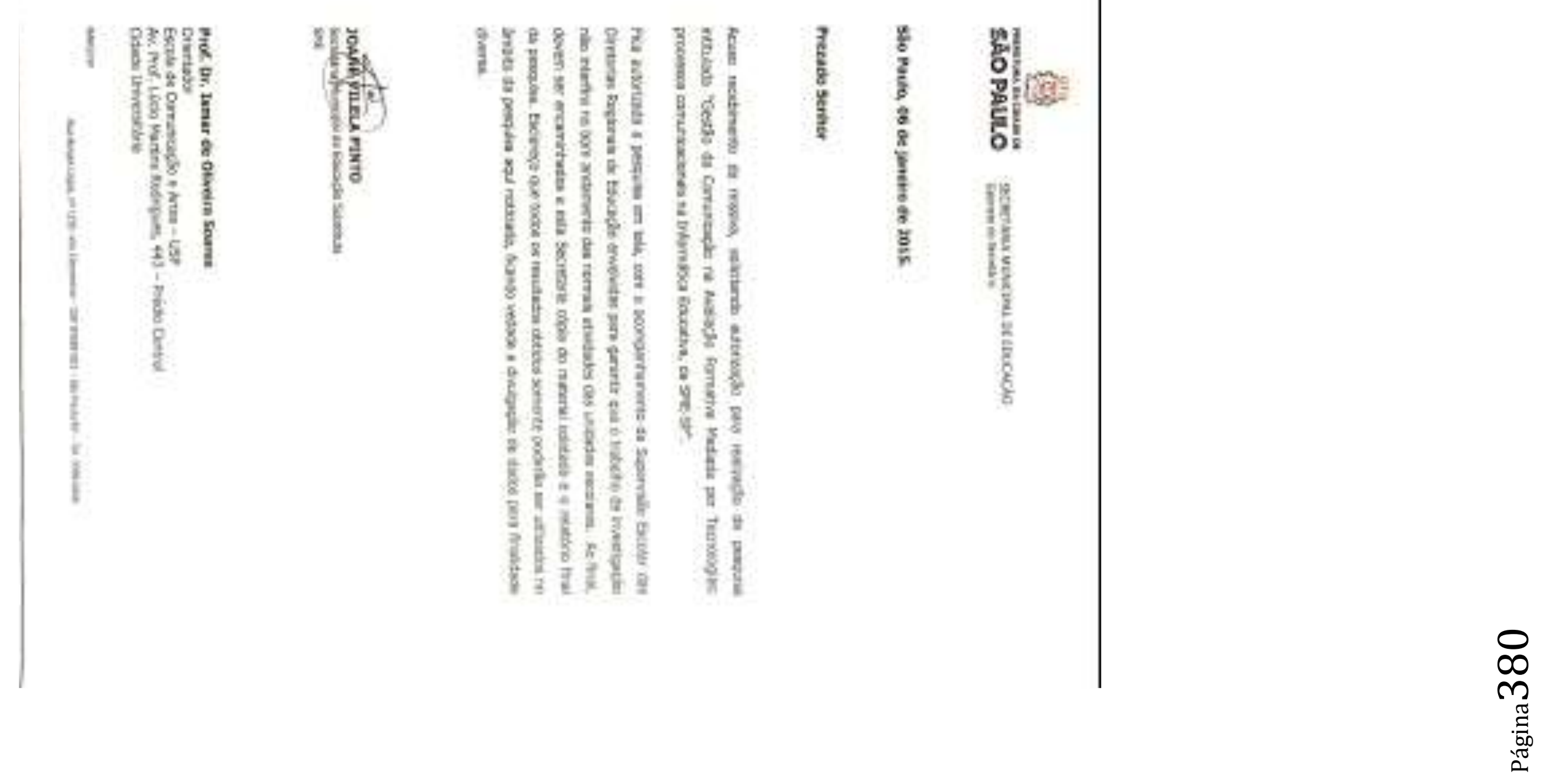

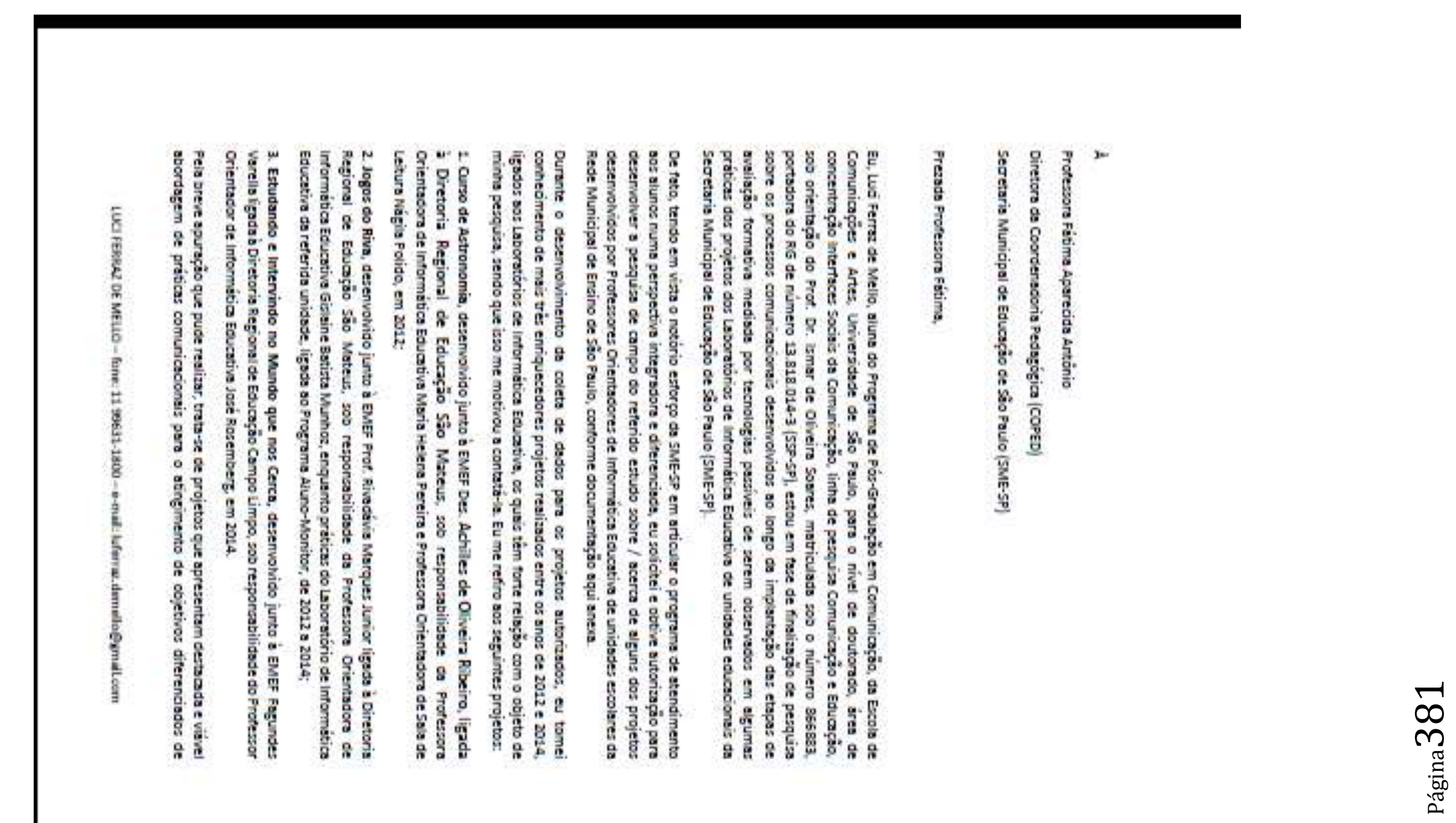


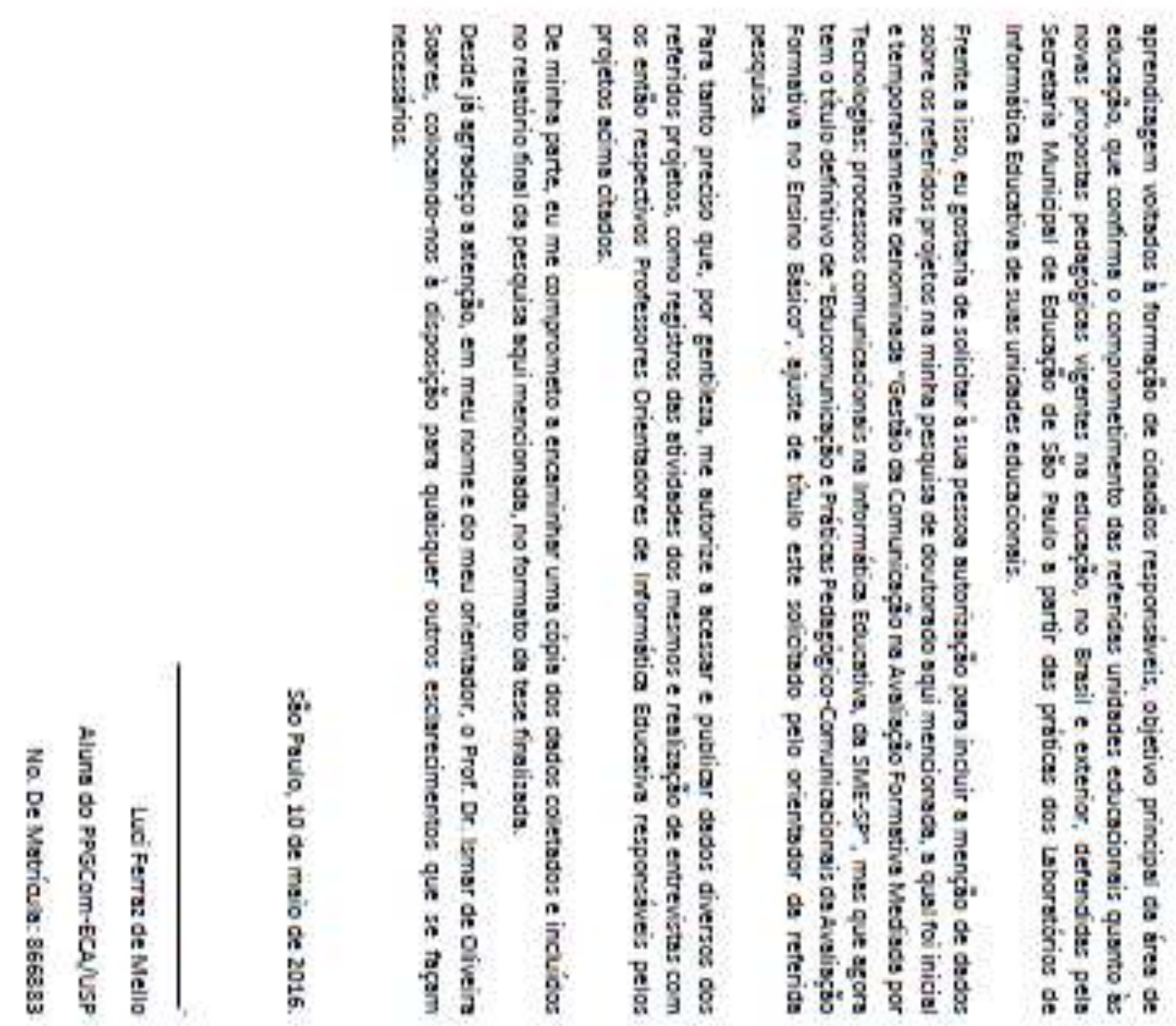




\section{I.2 - Autorização EMEF Prof. Rivadávia Marques Junior}

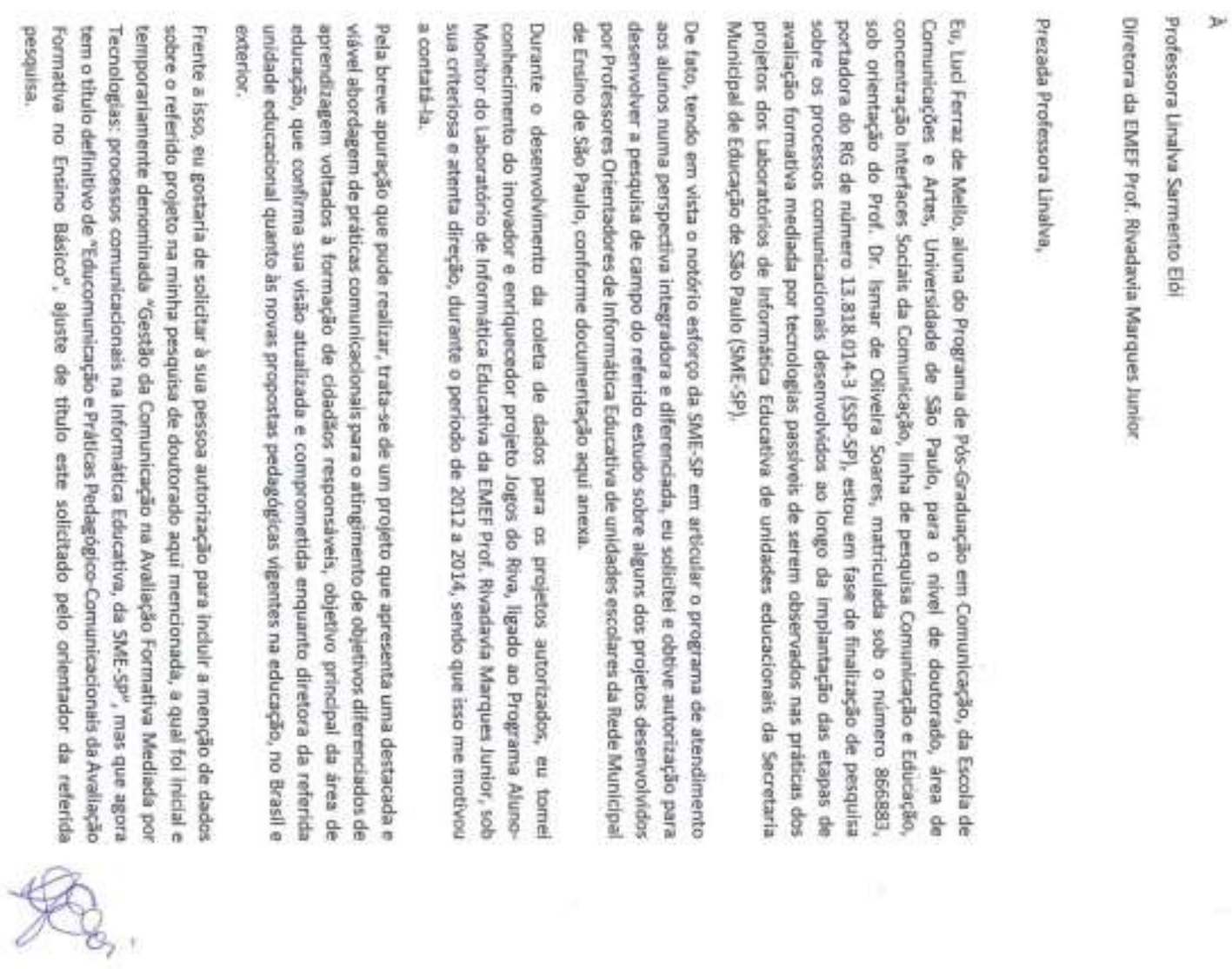




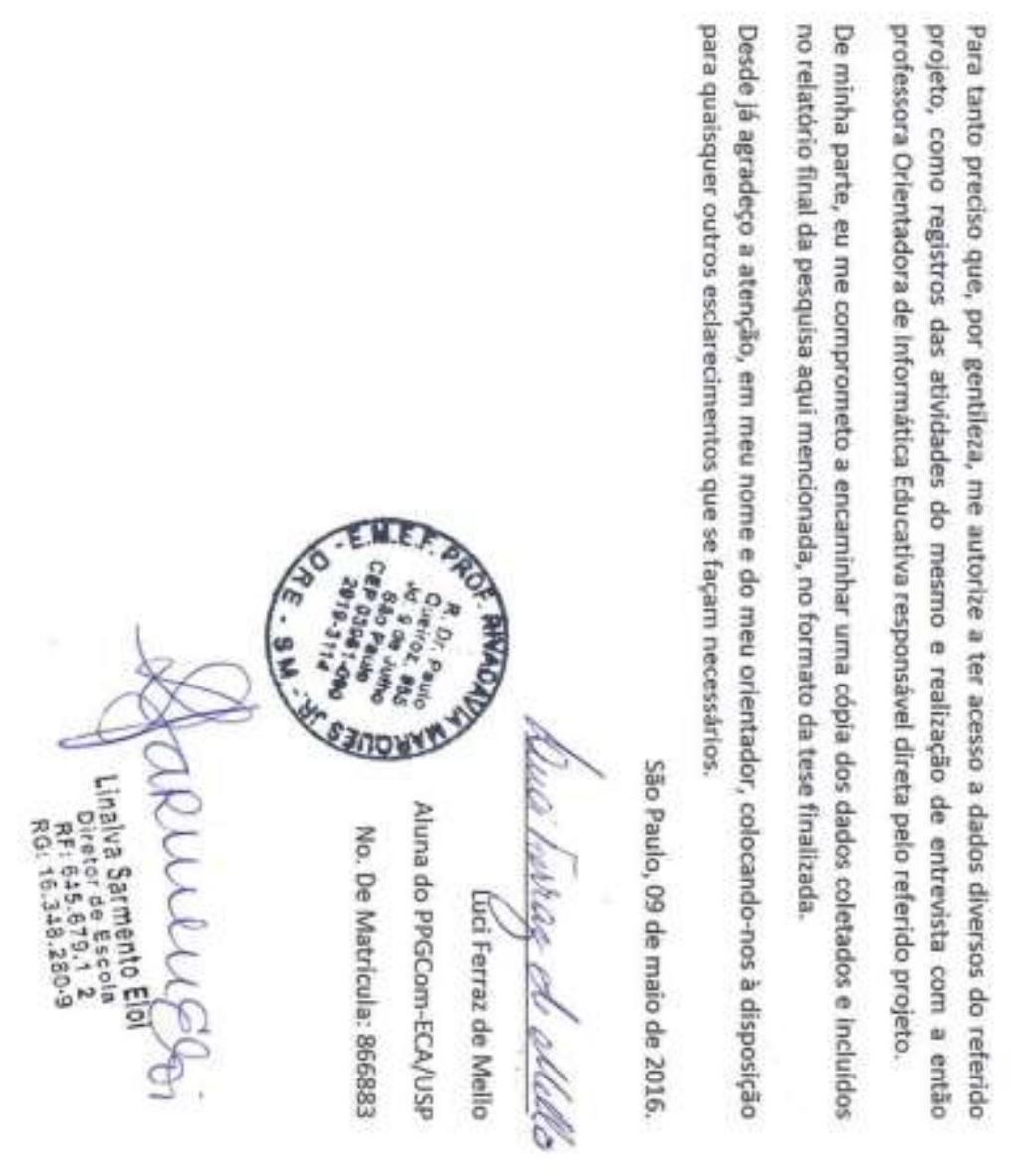

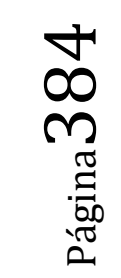




\section{I.3 - Autorização EMEF Des. Achilles de Oliveira Ribeiro}

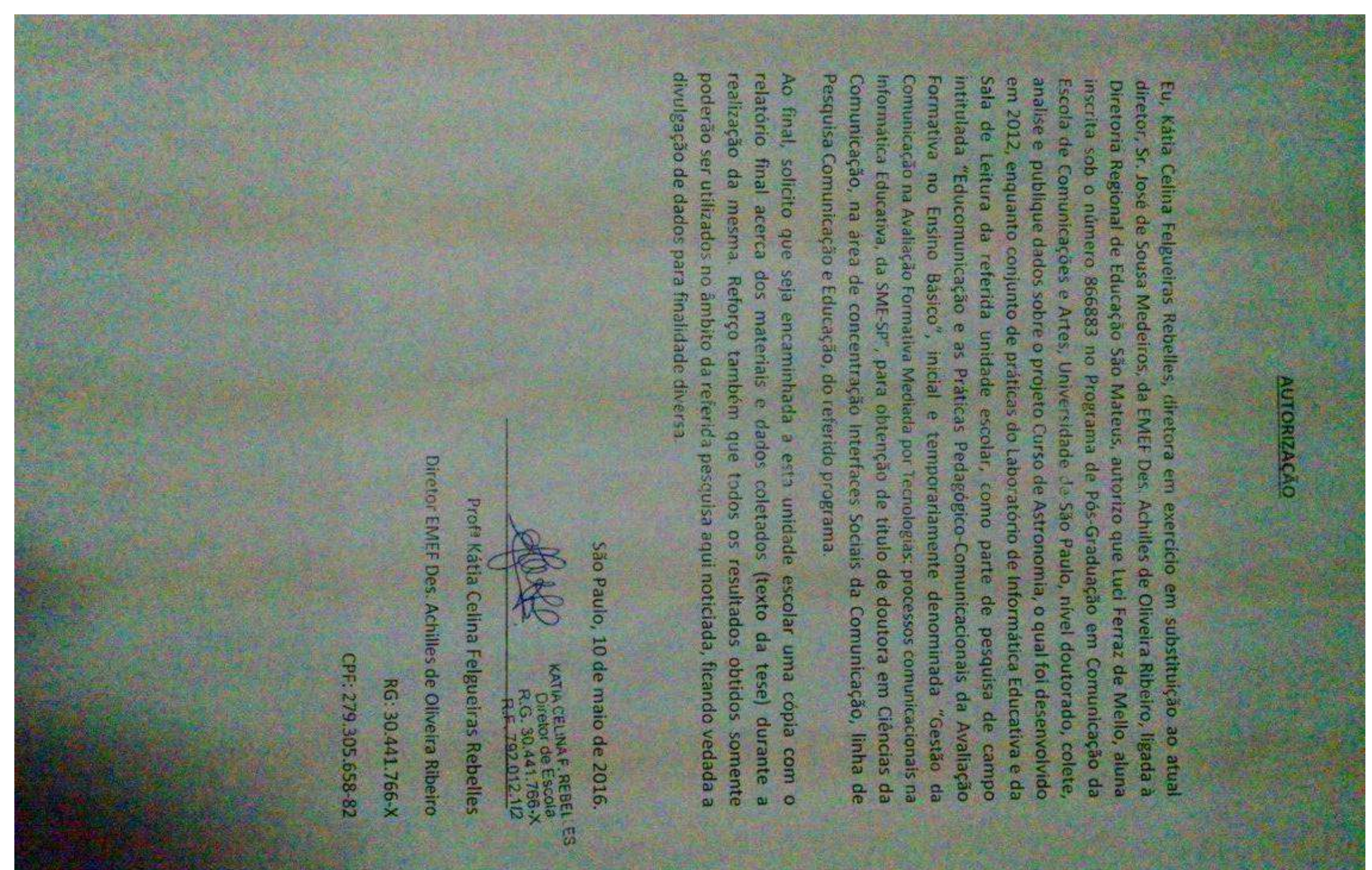

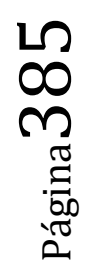




\section{I.4 - Autorização Cristina Barroco Massei Fernandes}

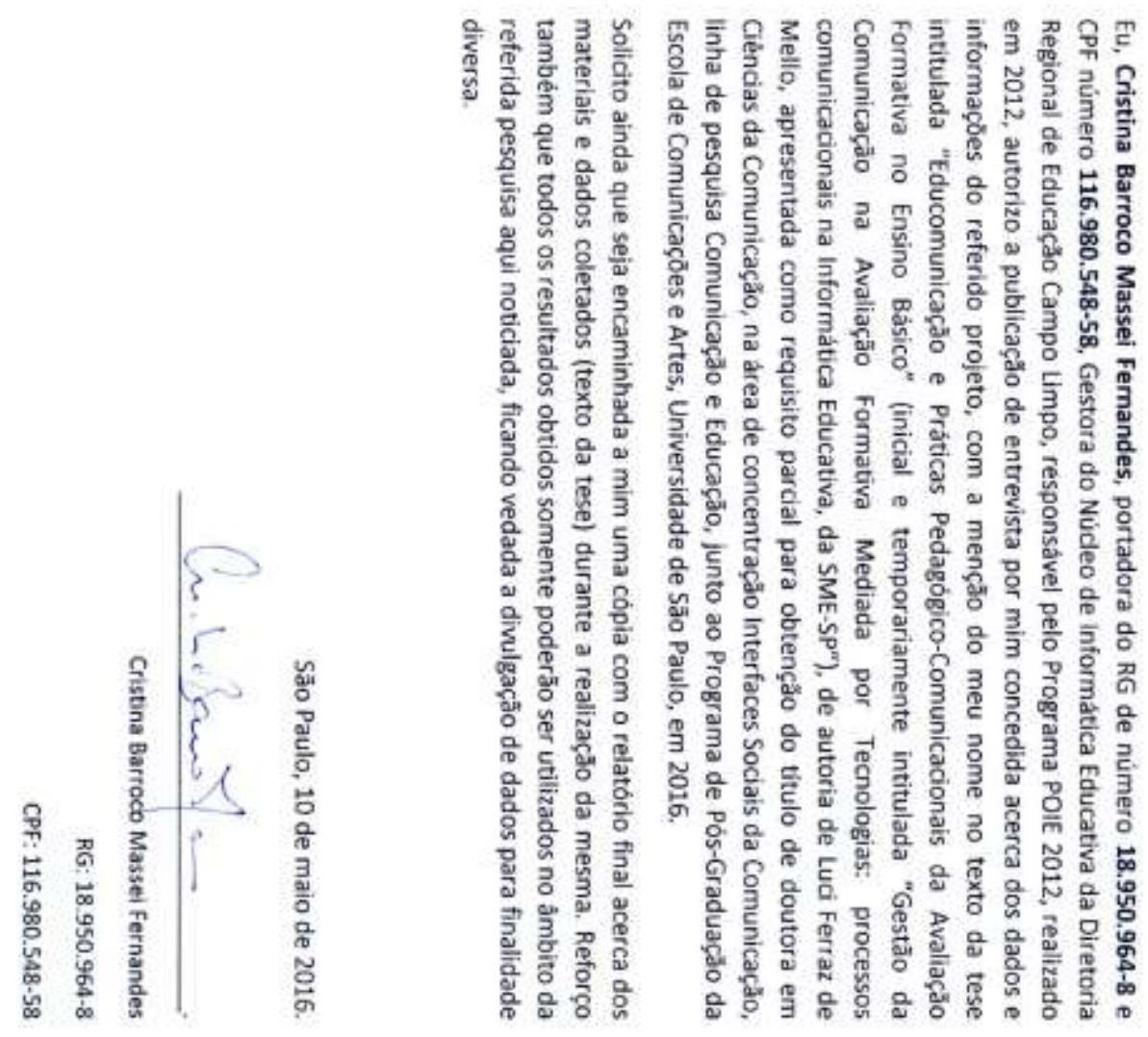




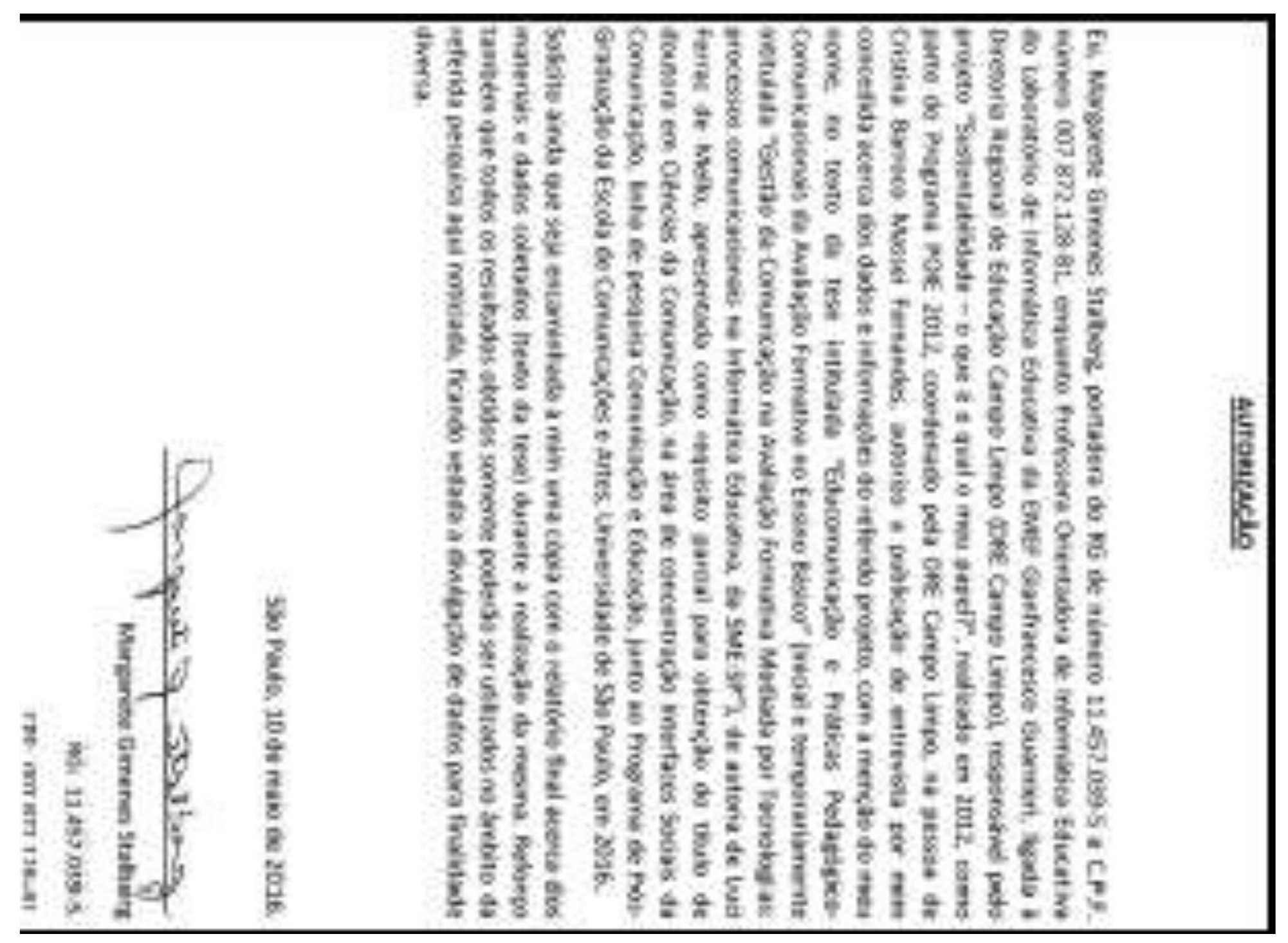




\section{I.6 - Autorização José Rosemberg}
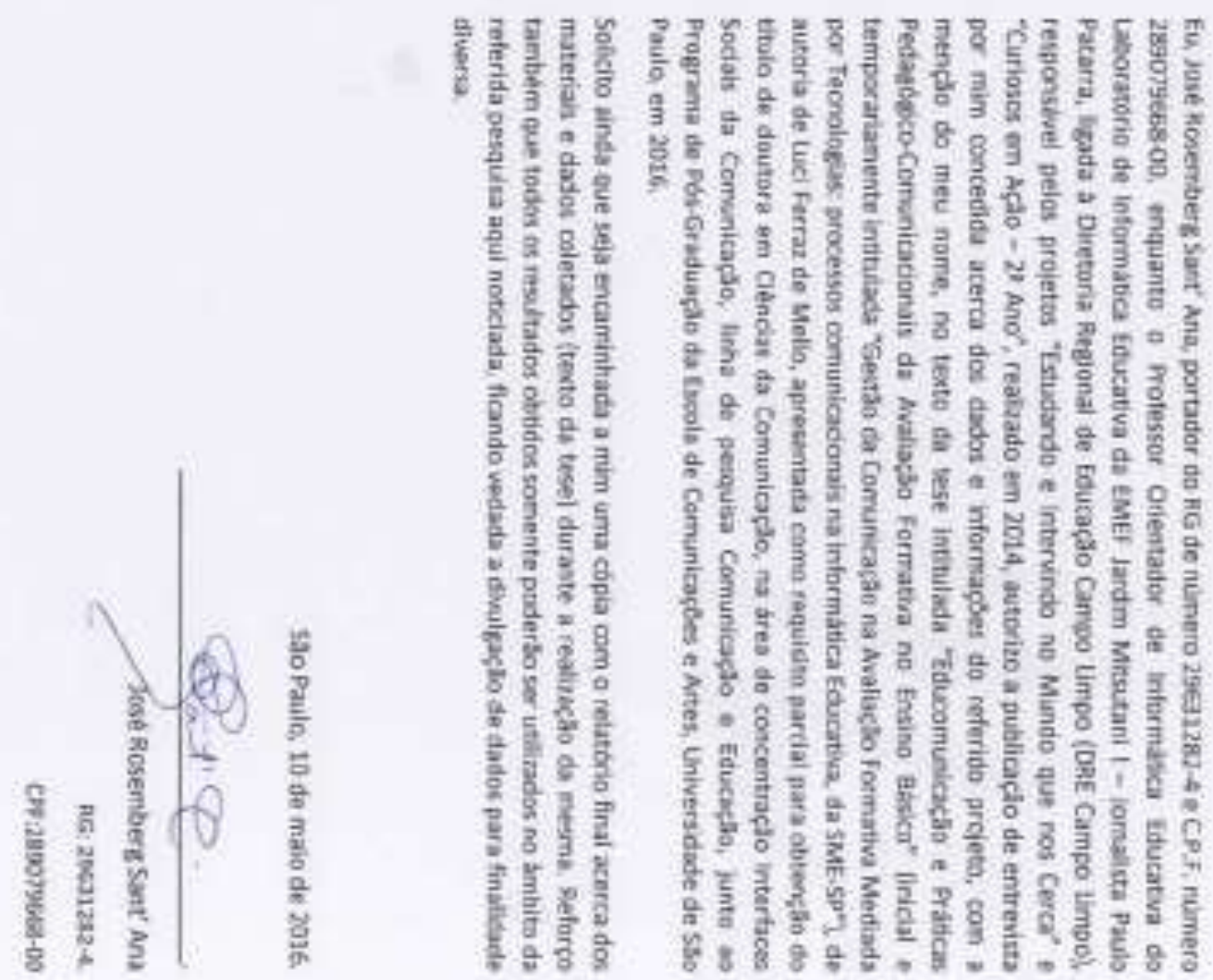


\section{I.7 - Autorização Douglas Ferreira Tomé}

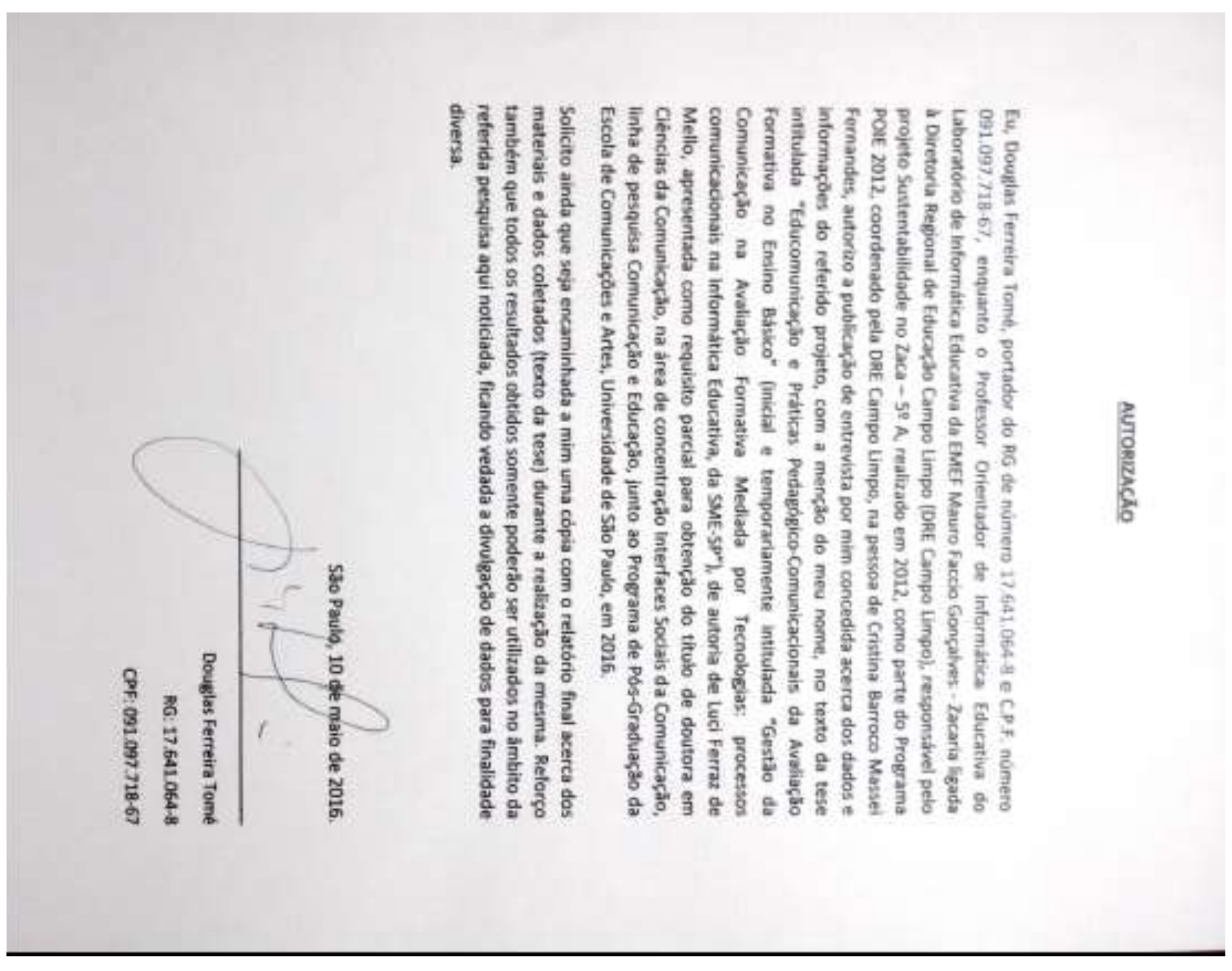

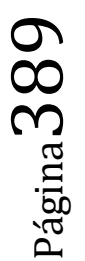




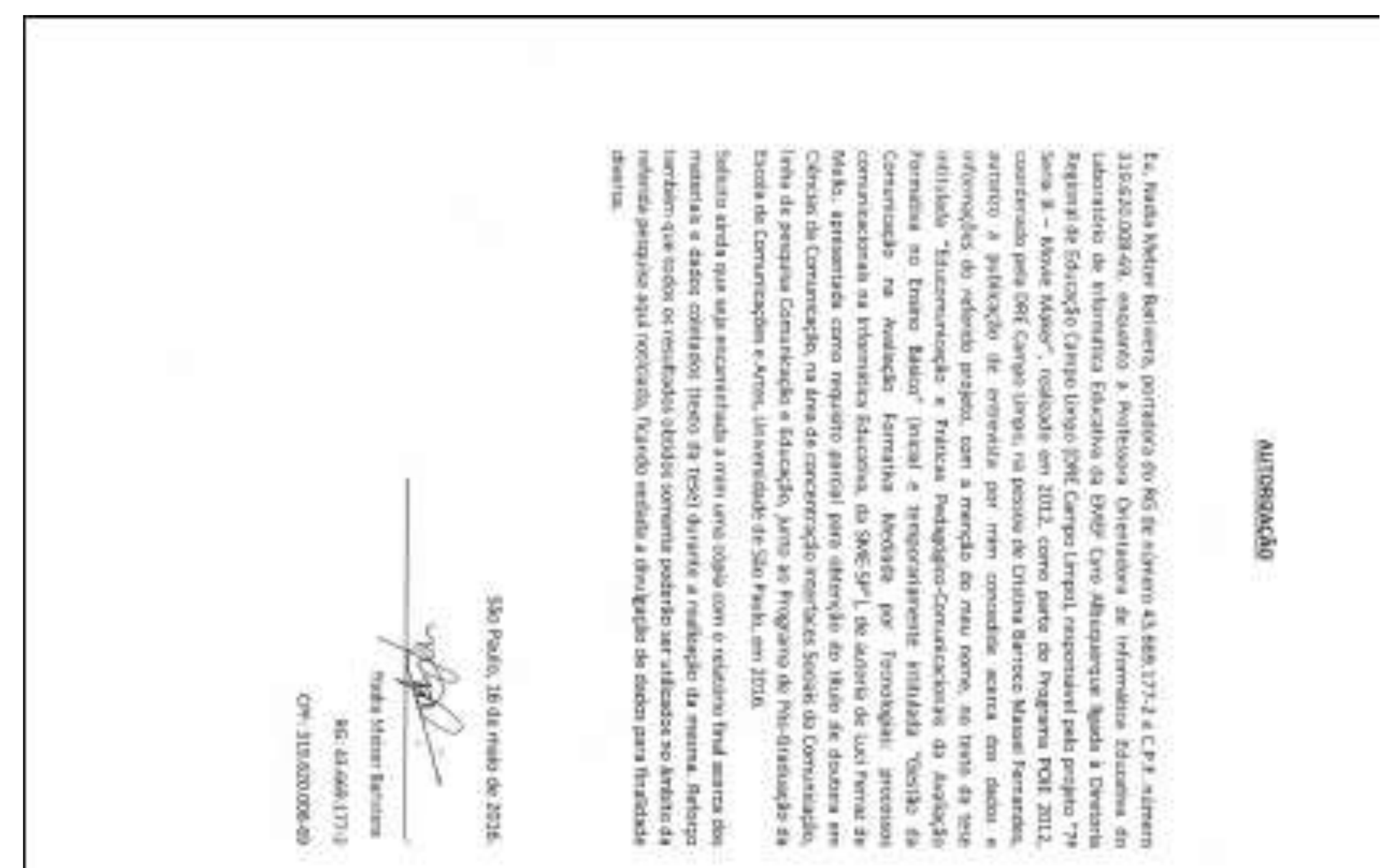

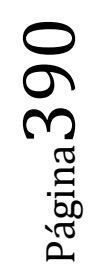




\section{I.9 - Autorização José Rosemberg (Projetos B.1 e B.2)}
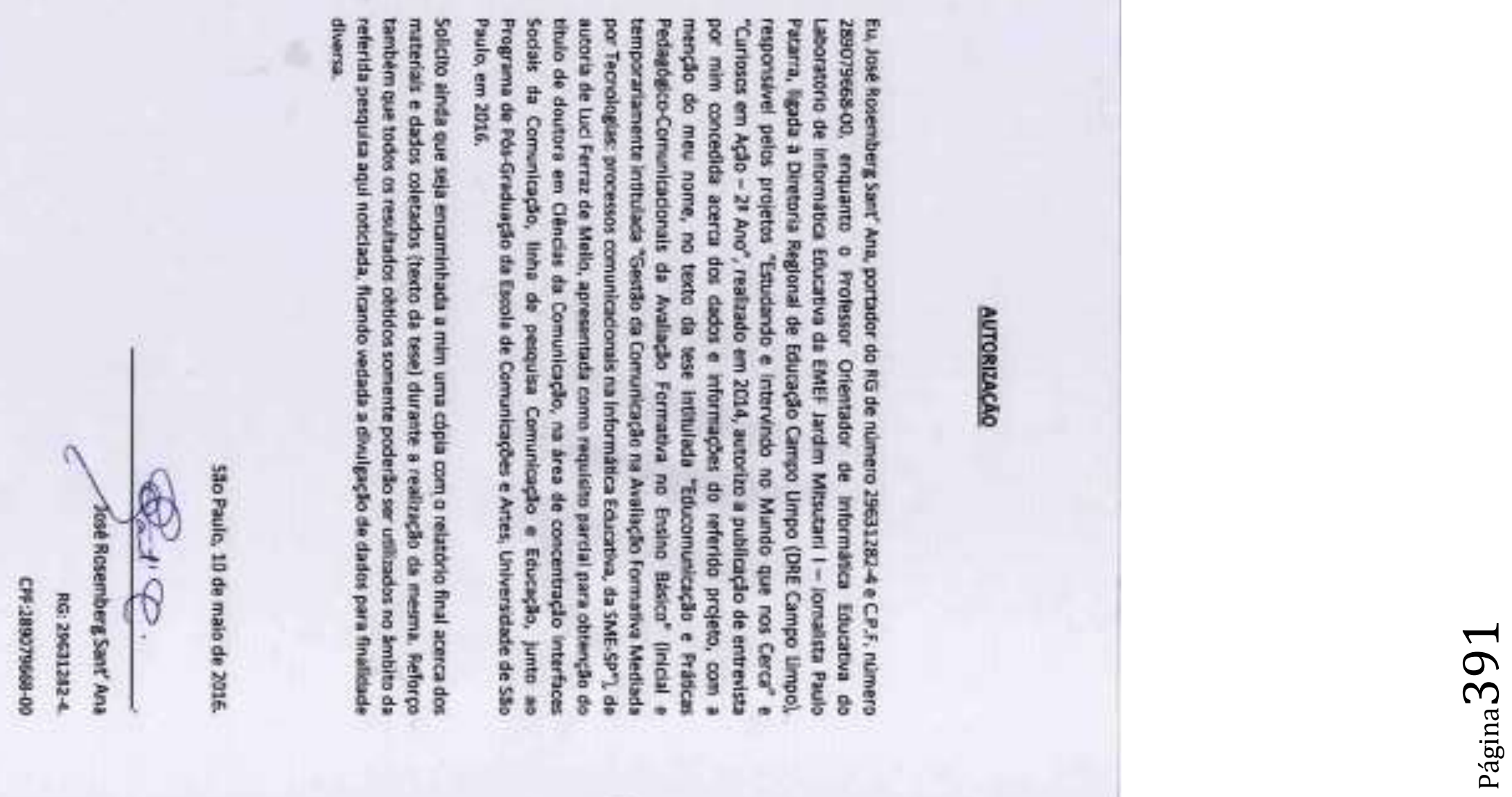


\section{I.10 - Autorização Maria Helena Pereira (Projeto B.3)}

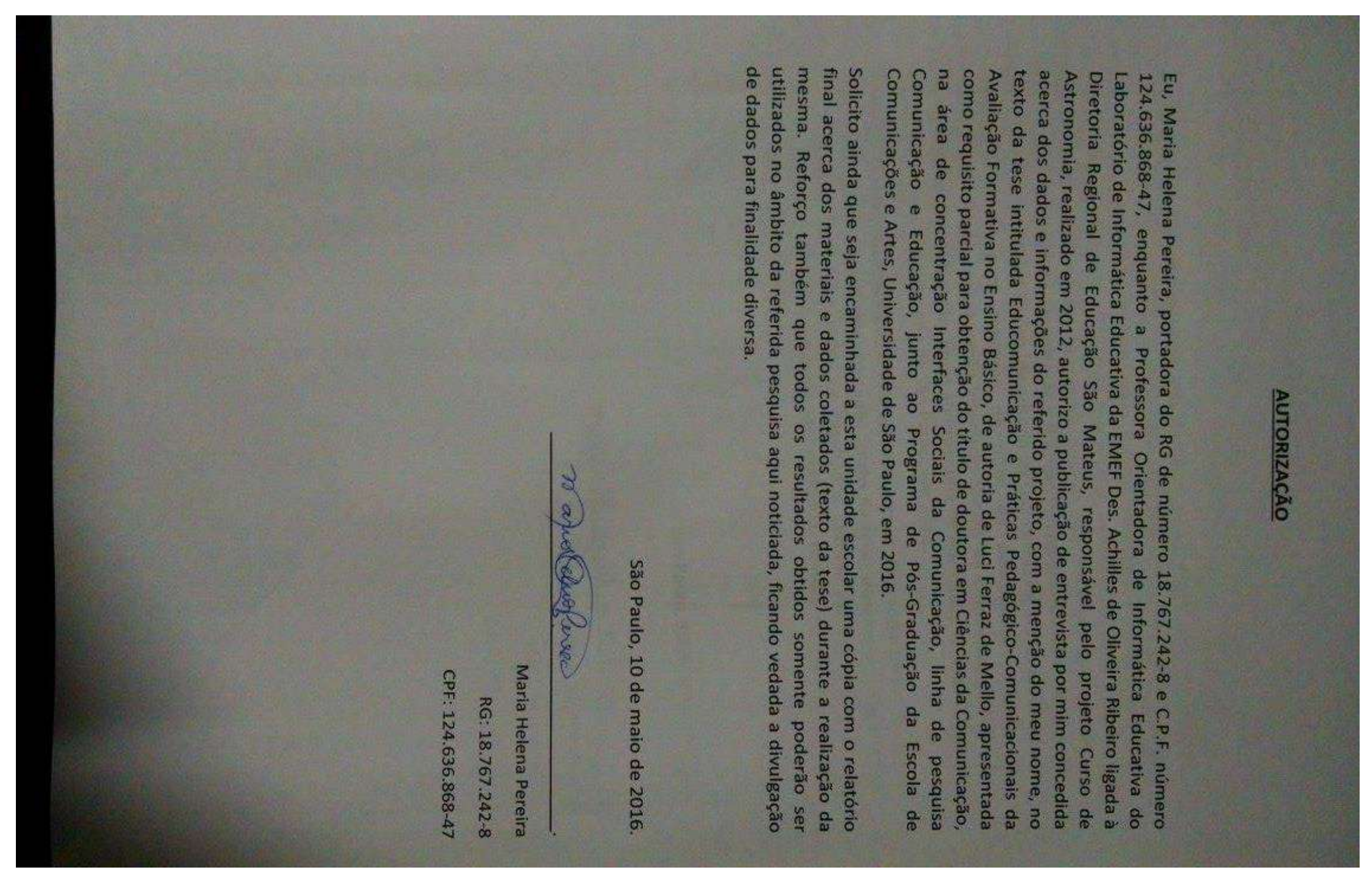

స్ 


\section{I.11 - Autorização Nágila Polido (Projeto B.3)}

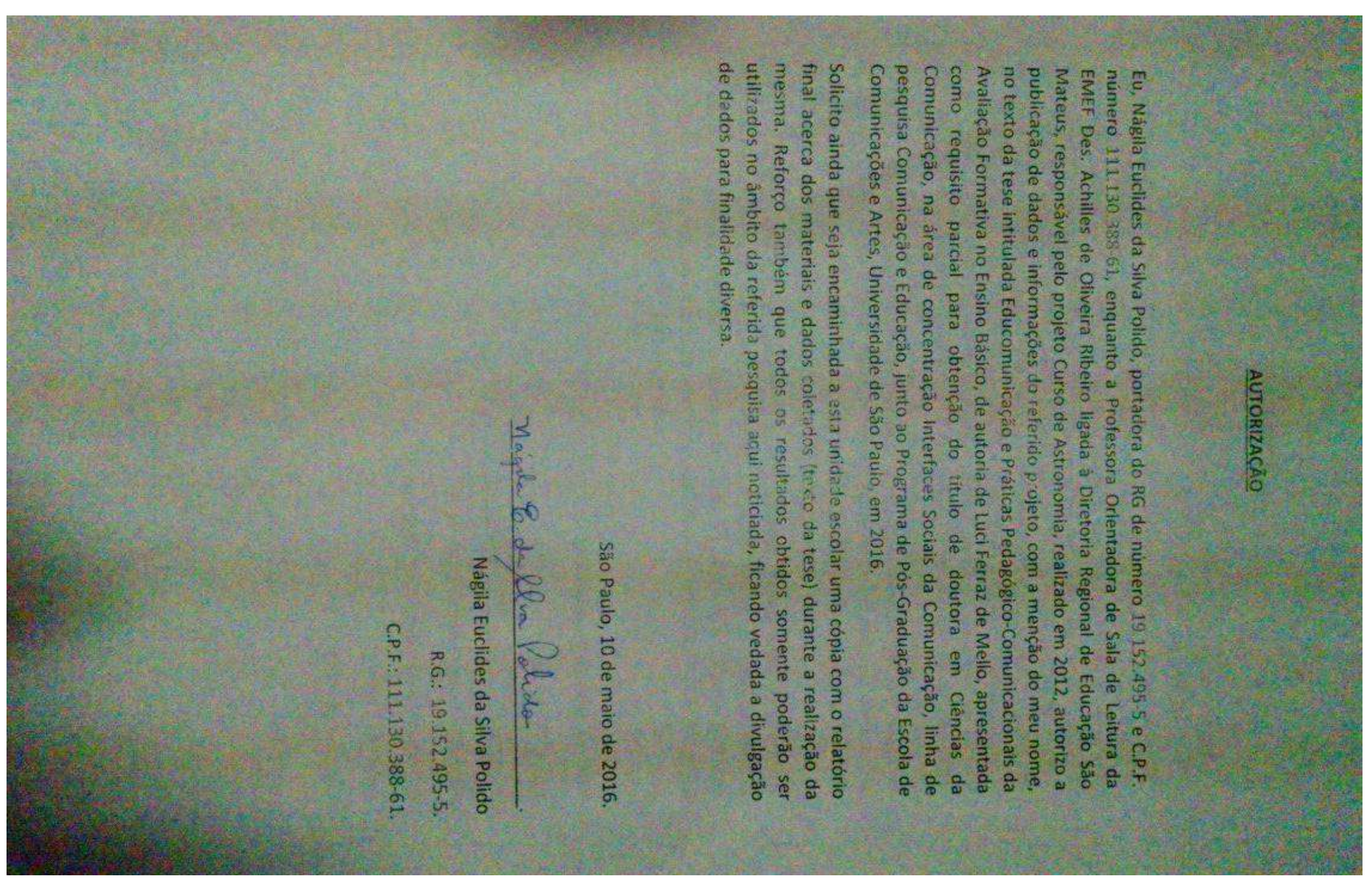




\section{I.12 - Autorização Gislaine Batista Munhoz (Projeto B.4)}

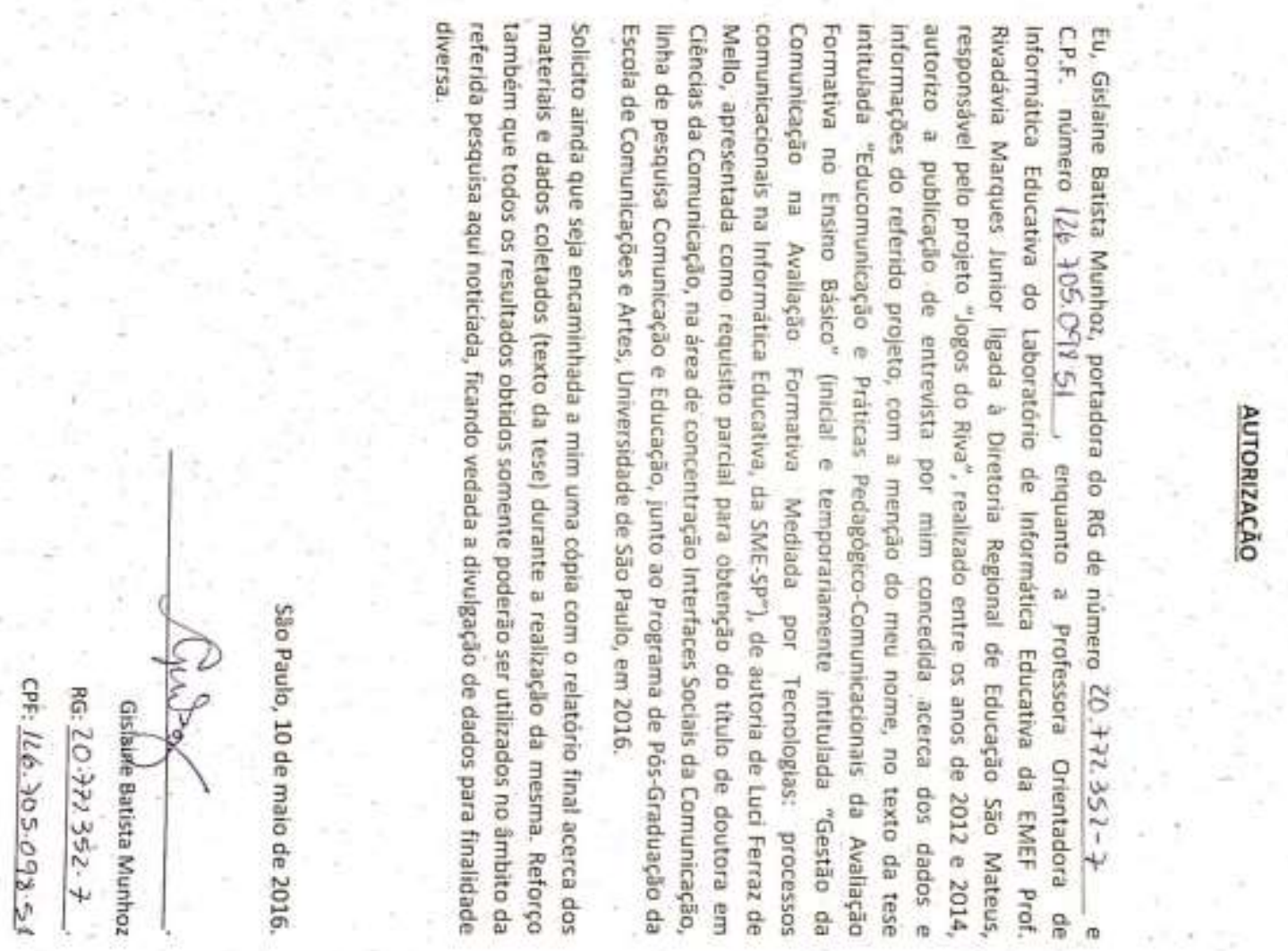


I.13 - Autorização Jane Reolo Silva (Gestora Núcleo de Informática Educativa 2012 a 2014)

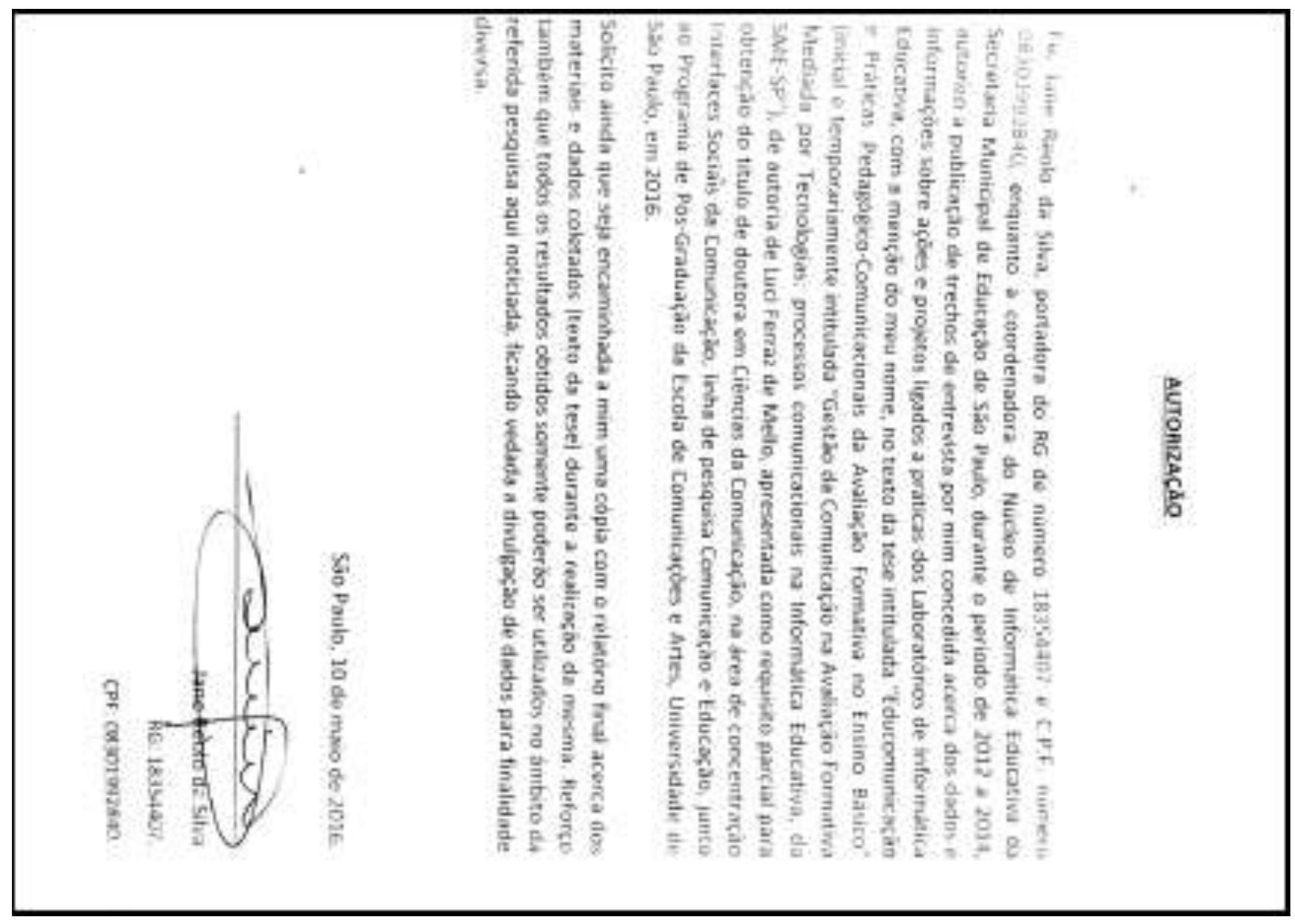

노ำ 